
ALHERT $R$ MANN

LIBRARY

AT

CORNELL UNIVERSII: 


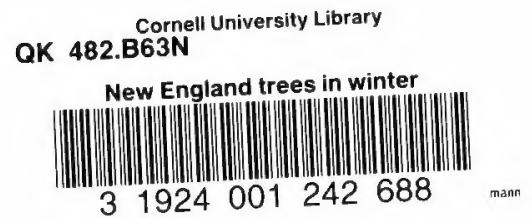




\section{Cornell University Library}

The original of this book is in the Cornell University Library.

There are no known copyright restrictions in the United States on the use of the text. 




\section{STORRS}

\section{Agricultural Experiment Station}

\section{S'TORRS, CONN.}

BULLETIN No. 69, JUNE, 1911

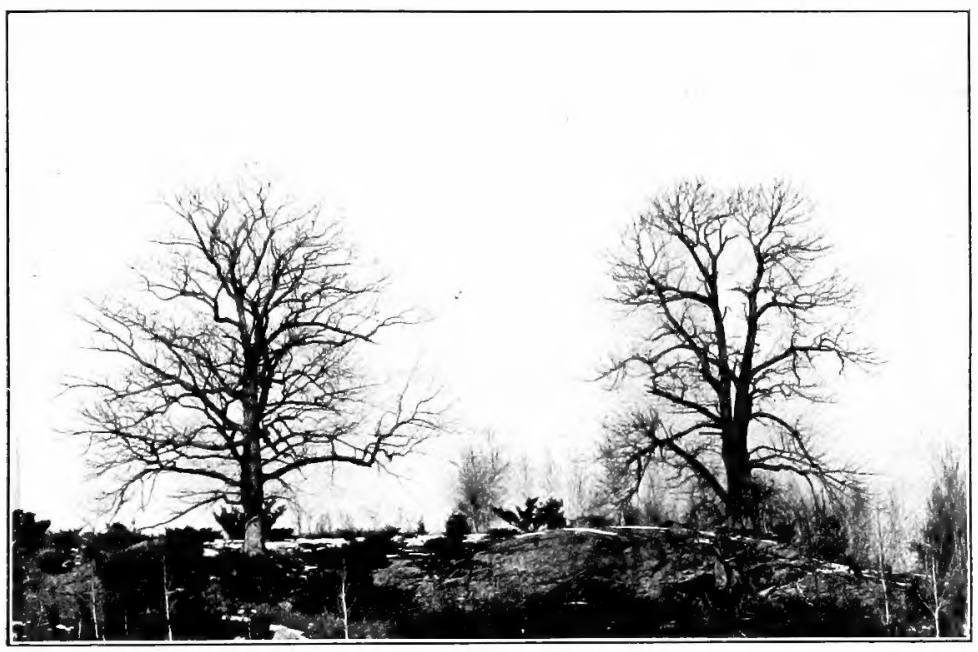

White OAK and Cinestare

\section{NEW ENGLAND TREES IN WINTER}

A. F. BLAKESLEE and C. D. JARVIS 


\title{
BOARD OF CONTROL
}

\author{
THE BOARD OF TRUSTEES
}

- OF THE-

\section{CONNECTICUT AGRICULTURAL COLLEGE}

\section{Governor Sumeon E. Baldwix}

H. G. Manohester

E. H. JENKINS

George A. Horson

L. J. STORRS

Charles A. Capen
E. Stevens Henry

D. Walter Patten

A. J. Pierpont

J. W. Alsop

Cimarles M. Jarvis

C. I. Beacr B.S.A., President Conn. Agricultural College

\section{STATION STAFF}

L. A. Chinton, M. S.

J. M. Trueman, B. S. Agr.

F. H. Stoneburn,

W. M. Esten, M. S.

C. D. Jaryis, Ph. D.

Charlies Thom, Ph. D.

G. H. Lumson, M. S.

H. D. Edmond, B. S.

L. F. Rettger, Ph. D.

Cinristie J. Mason, B. Agr.

E. B. Fit's,

Kennetil J. Matiewson, B. S.

P. A. Wrigitt, B. A.
Director and Agronomist Dairy Husbandman Poultry Husbandman Bacteriologist IIorticulturist

Cheese Investigations, Mycologist Economic Zoologist Chemist

Bacteriologist, Poultry Diseases Assistant Bacteriologist Assistant Dairy II usbandry Cheese Maker Chemist, Cheese Investigations

A. F. Blakeslee, Pl.. D., Professor of Botany, Conn. Agr'l College 


\section{TABLE OF CONTENTS}

PAGL

PREFACE

LITERATURE, ACKNOWLEDGEMENTS

INTRODUCTION

NAMES, HABIT, BARK, TWIGS, LEAF-SCARS, BUDS,

FRUIT, COMPARISONS, DISTRIBUTION, WOOD.

ANALYTICAL KEY

METHOD OF LSE, KEY TO GENERA AND SPECIES.

DESCRIPTION OF SPECIES

The Pines (p. 34t-355); the Larch (p. 356); the Spruces (p. 358-36\%); the Douglas Fir (p. 368): the Balsam Fir (p. 3\%0); the Hemlock (p. 3\%2): the Coast White Cedar (p. 3\%t); the Arbor Vitae (p. 3\%6); the Junipers and Red Cedar (p. 378-381); the Ginkgo (p. 382); the Willows (p. 384); the Poplars (p. 386-39\%); the Walnuts and Hickories (p. 398-409); the Hornbeams (p. 410-113); the Birches (p.+14-425); the Alders (p. 426); the Beech (p. 428); the Chestnut (p. 430 ); the Oaks (p. 432-455); the Elms (p. 456-463); the Hackberry (p. 464); the Mulberries (p. 466-469); the Magnolias (p. 4i0473 ); the Tulip Tree (p. 471); the Sassafras (p. $4 \% 6$ ); the Witch Hazel (p. $4 \% 8$ ); the Sweet Gum (p. 480); the Sycamore (p. 482); the Pear p. 48t); the Apple (p. 486); the Mountain Ash (p. 488); the Quince (p. 490); the Shadbush (p. 492); the Hawthorns (p. 49t); the Cherries (p. 496-505); the Plums (p. 506-511); the Peach (p. 512); the Kentucky Coffee Tree (p. 514); the Honey Locust (p. 516); the Redbud (p. 518); the Yellow Wood (p. 520); the Locusts (p. 522); the Ailanthus (p. 52t); the Sumachs (p. 526-529); the Holly (p. 530); the Maples (p. 532-54\%); the Horse-chestnut (p. 548 ); the Linden (p. 550); the Dogwoods (p. 552); the Tupelo (p. 554); the Ashes (p. 556-561); the Catalpas (p. 562). 



\section{PREFACE}

So much has been written popularly and in a seientific way on trees that no book on the subject would be warranted unless it was designed to meet a decided need. At present there is no general work upon American trees which combines illustrations of the individual forms with keys for their identification based upon winter characters. The forester and lumberman, however, are more called upon to distinguish trees in winter when leaves and flowers are fallen than in summer. 'Trees, as the most conspicuous elements in the winter landscape, must also appeal to the student of out door life. The interest shown by classes of school teachers in the summer School in identifying specimens of twigs collected the previous winter indicated that the winter study of trees can be taken up with enthusiasm by teachers in their schools. In our experience, the winter identification of trees has proven to students one of the most interesting subjects of their course. It is of decicled ralue for its training in the power of accurate obserration. The work comes at a time when material for natural history study seems scanty and might therefore be used to bridge over the periorl between fall and spring which are unfortunately considered ly many the only seasons when study of out door life is possible in the schools. A tree in winter is far from being the characterless olject many believe. Freed from its covering of leares, the skeleton of the tree is revealer and with the method of branching thus clearly discernible, the species may generally be more readily identified at a distance than in its summer garb. There are many forms, moreover, that are diffucult to distinguish from summer features alone but which in winter have twig, bud or other characters which make their separation comparatively easy. It is believed that the combination of keys, text, and illustrations from photographs will furnish the assistance which the current texts fail to supply and render the identification of our common trees in winter a relatively simple task.

The text with keys is an outgrowth of outlines that one of the authors has developed and used with rarinus modifications for the last four years in his college classes in Botany and Forestry. 
The photographic illustrations are all originals, most of them by the other anthor. Although one of us is responsible for the text and for the selection of the material photographed and the other for the photographs, we have frecly consulted and the bulletin is therefore to be considered a joint publication.

The order of arrangement of the species in the text and the scientific names follow the dusage of the seventh edition of Gray's Manual and the latter are in accord with the rules laid down in the Vienna Congress. The figures and deseriptions given are of trees for the most part growing wild in New England. A few rarer species which occur in New England only very locally or in isolated instances have been omitted from jllustration. In their places, however, some of the more frequently cultirated trees, have been included because of their value for forestry planting in New England or because of their familiarity in city ornamental plantings. The rarieties of cultivated forms are so numerous that it is obviously possible to take account of only the most common types. Their inclusion, it is believed, will add to the value of the publication especially for its use in cities. The keys can be absolntely relied upon only for the species just mentioned from New England. New England, including as it does the meeting ground between the northern and southern floras, is extremely rich in the species of trees represented. The bulletin, therefore, especially in its descriptive text and illustrations should prove of service outside of the geographically restricted region described.

The final keys to the genera and to the species as well as the descriptive text in galley were placed in the hands of the present year's classes in Botany and Forestry. A student after finding the species by the keys, read the twig characters in the galley and signed his name opposite the species if the description corresponded with the twigs supplied. All of the trees described and illustrated have thus been cherked up by students and some of them by as many as seventy different persons. In this way limitations to the use of certain of the characters employed as means of separating allied species have been discovered and the constancy of other characters has been confirmed in so far as the material arailable could allow. The greatest assistance rendered by the students, however, has been in disclosing difficulties in the use of the keys, due to unfortunate choice of contrasted characters or of 
terms used in their description. The keys in consequence have been considerably modificd before final paging. Many of the explanatory phrases which may appear to be unnecessary have been inserted at the demand of the students. Where possible the most obvious characters have been employed and though the keys in consequence have become somewhat more cumbersome it is hoped they will prove more usahle. Errors and omissions have no doubt crept in despite the efforts to avoid them. We would be grateful for any additions or corrections that may be suggested in the descriptions or leys in view of a possible revision of the text.

The photographs of the twigs and of the fruit of the deciduous trees are very nearly natural size. They liave been slightly reduced in production but all of them to the same scale, except the fruits of the Catalpa, the Chestnut, and the Honey Locust as indicated under these species. Line drawings or touchedup photographs would no doubt show important details more clearly by emphasizing certain of the minute markings. Since, however, these details are often obscure, and moreover receive full recognition in the accompanying text, it has been thought that a truer idea of the twigs would be gained if they were left as they appeared in the plotographs. Accordingly, they have not been "doctored" in preparation or reproduction. "The leafy twigs of the conc-bearing evergreens have been more or less reduced as indicated under the descriptions of the genera in the kroy. All the twigs of a single genus, however, are on the same scale.

\section{LITERATURE}

The following is a list of books which will be found useful to the student of New England trees. They have been freely consulted, as well as others not listed, and have been of valne in determining the ranges and wood characteristics of the individual species, in confirmation of bark and habit characters, and to a less degree of the other winter features. The dimensions of the trees in the hearling "Halsit" and the information under the heading "Distribution" have been taken with little change from Dame \& Brooks' Handbook, except what is given in the subheading "In Connecticut" which was obtained from the catalog of the flowering plants and ferns of Connecticut; Bulletin No. 1t, 
Conn. Geol, and Nat. Hist. Surrey, 1910. The characters under the heading "Wrood" were taken chiefly from Sargent's Manual. 'To obtain information in regard to the dimensions, the distribution and the wood characters of cultivated species, Bailey's Cyclopadia of Horticulture and various European works have been freely consulted.

\section{Generit Morks on Trees.}

Sargent, C. S.-Manual of the trees of North America, $826 \mathrm{pp}$. IFoughton Miltlin Co., Boston, 1905. The best general book on the sulject. The text and illustrative drawings are taken chiefly from summer characters, but winter characters receive some attention.

Sargent, C. S.-Silva of North America in 1t quarto volumes. Houghton Mifflin Co., Boston, 1902. The most extensive work of its kincl. Except for the more elaborate clrawings, of less general ralue than the Manmal, the text of which is practically the same but more conveniently arranged.

Britton, N. L.-North American Trees, $89 t$ pp. Henry Holt \& C'o., New York, 1908. Of the same general seope as Sargent's Mamual. Contains occasional hatsit photographs.

IIough, R. B.-Hanthook of the trees of the northern states and Canada, 470 pp. Lowville, N. Y., 190\%. A most valuable pulication, without hal,it illustrations, but with exeellent photographs of leaves, fruit and loark and less suecessful photographs of winter twigs. The keys and the text are based npon smmmer characters. This is onr only book giving bark photographs for each species treated.

Dame, L.L. \& Brooks, H.-Flandbook of the Trees of New England, 196 pp. Gimn \& Co., Boston, 1901. The hest manual for the region covered.

Emerson, G. B.-Report on the trees and shrubs of Massachusetts, $621 \mathrm{p}$. in two volumes. Little, Brown \& Co., Boston, 1815. Especially valuable for its habit deseriptions.

Collins, J. F. and Preston, H. W.-Key to New England Trees, 42 p). Preston \& Rounds Co., Providence, 1909. A useful little book. Contains key's only, baserl on summer characters. Inclutes cultivated forms.

Rogers, Julia E.-The Tree Book, 589 1)" Doubleday, Page \& Co., New York, 1908. The hest of the popular books on trees. 
Contains habit and twig photographs of some of the species treated and occasional photographs of the bark taken chiefly from musemm specimens.

Works Dealing With tile Wixter Coxdition of T'rees.

Schneider, C. K.-Dendrologische Winterstudien. 290 pp.; 224 fig. Gustar Fischer, Jena 1903. A very extensive work giving descriptions and drawings of twigs of $43 t$ individual species cultivated and native in Europe, together with keys and an introductory text.

Huntington, Miss A. L.-Studies of Trees in Minter, $198 \mathrm{pp}$. Knight \& Millet, Boston, 1902. A popular book excellent as far as it goes. Figures at least the winter twig, the halsit, or the bark of 65 species. Has descriptive text with habit notes and poetical quotations.

Wiegand, K. M., and Foxworthy, F. W.-A key to the genera of woody plants in winter, $33 \mathrm{pp}$. Ithaca, N. Y. 1904. Treats of wild and cultivated plants of New Iork state, including shrubs as well as trees, contains keys only. Scientific names alone used, a valuable key to genera, has passed through several editions.

Trelease, Wm.-Winter synopsis of North American Maples, Rep't Mo. Bot. Gard., rol. 5, pp. 88-106, 1894. A critical treatment of the Maples based upon winter characters with keys and twig figures.

Trelease, Wm.-Juglandaceae of the United States. Rep't Mo. Bot. Gard., vol. $r$, pp. $25-46$. A critical treatment of the genera C'arya \& Juglans with keys, twig figures and bark photographs.

Schaffner, J. H.-Key to the Ohio woody plants in the winter condition. The Ohio Naturalist vol. 5, no. 4, pp. 27\%-286, 1905. Keys only, limited to genera, shrubs as well as trees treated.

Hitchoock, A. S.- Keys to Kansas Trees in their winter condition, 6 pp. Keys only, leading to species. 


\section{ACKNOWLEDGMENTS}

Acknowledgnents are due to Prof. C. S. Sargent, Prof. J. G. Jack, Mr. Jackson Dawson, and Mr. R. W. Curtis for courtesies in the museum and grounds of the Arnold Arboretum where many of the photographs were taken; to Prof. B. I. Robinson for assistance in checking up the scientific names; to the Connecticut State Forester S. II. Spring, for snggestions as to what cultivated trees are of sufficient valne in New England forestry to be included in this pullication; to Mr. $\mathrm{T}$. F. Rady, for supplying the additional galley sheets used by the students; to Mr. Robert Weller for his painstaking care in the reproduction of the photographs; to Mr. A. F. Schulze for compiling the index; to Miss F. M. Whituey for reading the proof; to the Station Director, I. A. Clinton, for the generous way in which the undertaking has been supported; and especially to the students whose interest in trees in winter first suggested this publication and whose co-operation in its production has given it its finished form.

Albert Francis Blakeslee. Chester Deicon Jarvis.

Storrs, Conn., June, 1911. 


\section{IXTRODUCTION}

Before considering the individual trees in detail it seems desirable to give a general discussion of the different terms used as headings in the description of the species.

NAILE- I common English name heads the description of each tree and this name is used throughout the book as the designation of a particular species. The same form may be known in different localities by several entirely different common nanes. Thus the Tupelo in some places is called only Pepperidge, in others, Sour Gum or Black Gum. After consultation with the literature the name 'Tupelo was chosen as being somewhat more desirable for the whole of New England than the other names giren in smaller type as symonyms. Often several common names may be in alout equally frequent use. There is, however, only one scientific name at present sanctioned by botanical authorities and this is placed first, followed by the Latin synonyms in italics.

HABIT-By the word habit, we denote the general appearance of a tree seen as a whole. A tree strictly speaking is generally considered as a woody growth having an undivided trunk at the base and rising to at least twice the height of a man. A shrub on the other hand is low-growing and may branch from the very base. No hard and fast line, however, can be drawn luetween a tree and a shrub. Many trees at the limit of their range or under unfavorable conditions are redued to the form and dimensions of a shrub and some forms growing as shrulss in New England become trees in states outside this gromp. A young tree sometimes resembles a shrub, but is more rapich in growth and generally does not bear fruit until it has reached a considerable size. Of the forms on the horderline between trees and shrubs only those have been treated that have demanded recognition on account of their commonness or their relationship with other forms.

The information regarding the dimensions of a tree are of minor importance for purposes of identification, but are of considerable value to the woodsman. The diameter of the trunk may be best measured directly by calipers at breast height from the ground or indirectly obtained by dividing the circumference by 3 (more accurately by $\pi=3.1416$ ). A number of rough methods of estimating height are given in books on forestry. For example, 
from a distance equal to several times the length of the tree, the height of a $10 \mathrm{ft}$. pole lxaside the trunk or a mark on the trunk of known height may be compared with the height of the whole tree. Instruments for more accurate measurment are on the market under the name of hypsometers. I home-made instrument may readily be constructed which has been found to compare favorably in accuracy with the expensive Faustmann hypsometer of which it is a modification. A rectangular board alsout a foot in length is ruled in squares or more conveniently has squared coordinate paper pasted on one side (fig. 1). Care should be

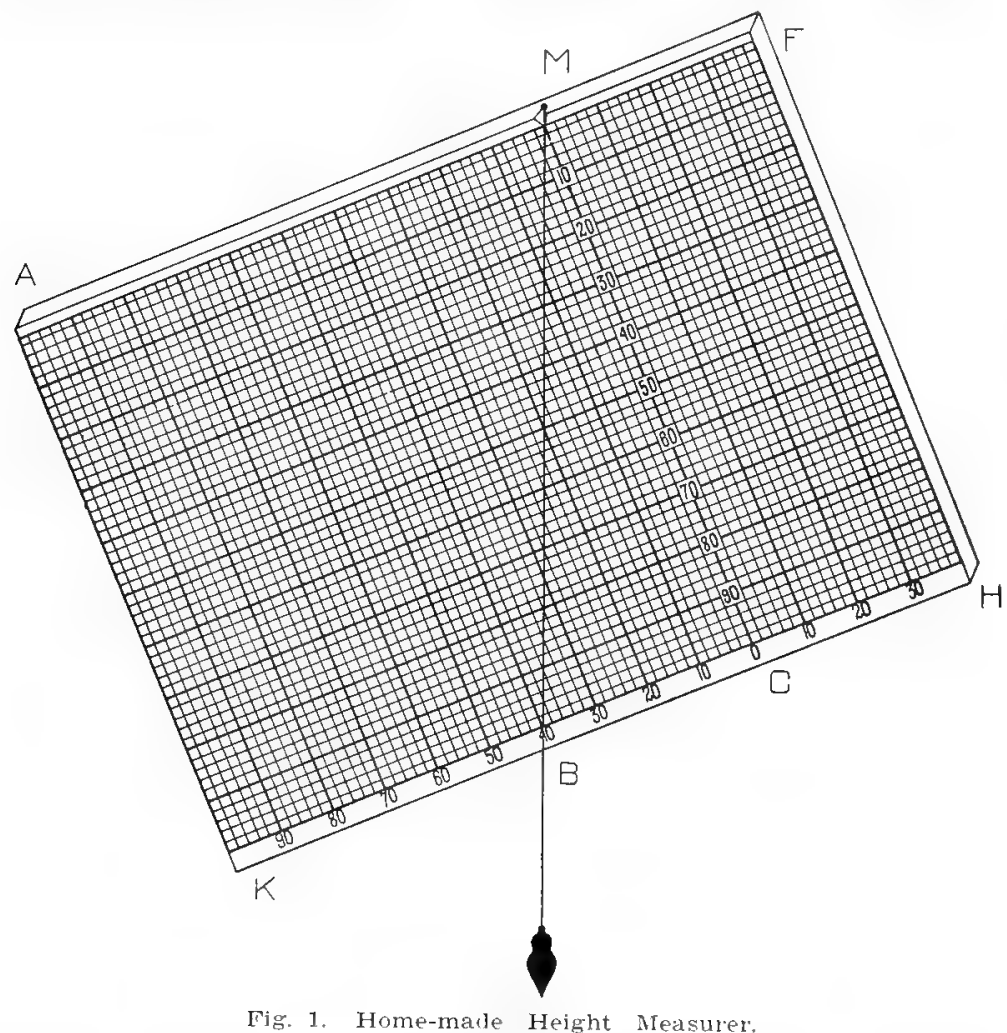

observed that the top of the board $\mathrm{AF}$ is straight and accurately parallel to the lines running lengthwise of the paper. The line MC is numbered from M in any convenient unit, say up to 100 , and using the same unit, the line $\mathrm{HK}$ is numbered in both direc- 
tions begiming at C. A thread with a weight is attached at M and hangs free from the zero point of the top of MC. In use a convenient distance, say $100 \mathrm{ft}$. from the tree, is first measured off as a base line, and upon this measurement largely depends the accuracy of the height estimation. At the 100 ft. mark the top of the tree is sighted along the straight edge $\lambda F$ which may more conveniently be fitted with some simple form of sights. At the point $B$, where the plumb line crosses the line CK the height of the tree above the eye is indieated in feet. The height of the eye alove the ground is added to this reading if the measurentent is on the level, or a second sight may be made to the base of the tree and the reading noted on ${ }^{1} \mathrm{H}$ arded or sulstracted, according to whether the base of the tree is below or abore the ere level. If in the instrument as figurerl, the base line had been $100 \mathrm{ft}$. as suggested, the height of the tree above the eye is given as $10 \mathrm{ft}$. If, however, the base line hat been 50 ft. the height is given as $20 \mathrm{ft}$, the reading being taken at the intersection of the threarl with the line running lengthwise through whatever number on MC' has been used to represent the base line. The two smaller diagrams show the instrument in position for sighting to top and hase of tree

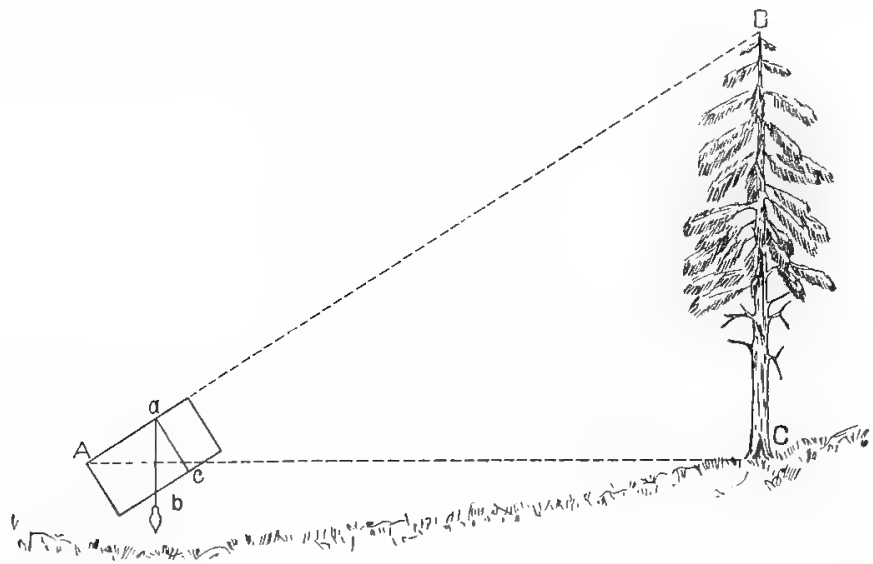

Hig. 2. Height Measurer in position for sighting to top of tree. 


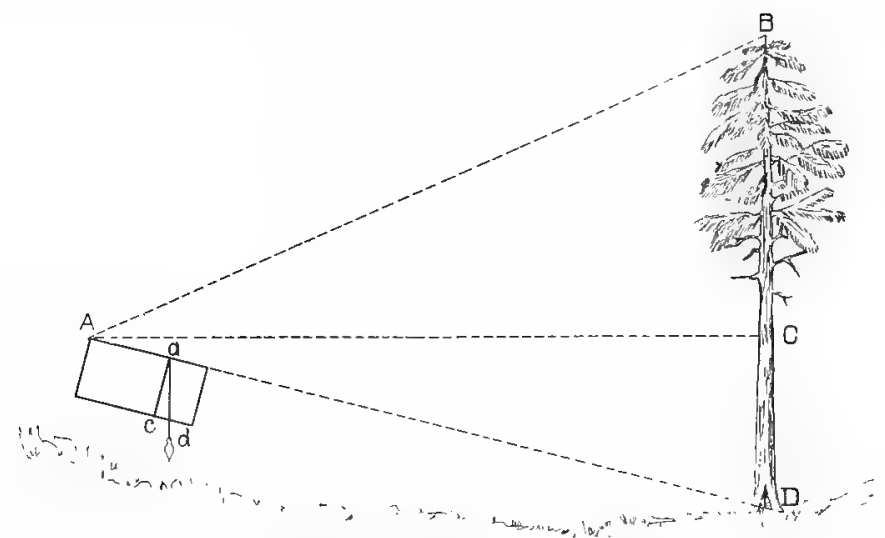

Fig. 3. Height Measurer in position for sighting to base of tree.

respectively. In figure 2 , the eye is assumed to be on the level with the base of the tree and only a single sight is necessary. In figure 3, the base of tree is below eye level and the distance CD must be found by a downward sight and added to the reading obtained for $\mathrm{BC}$. It ean be readily seen from inspection of the figures that the method is based upon the similarity of the triangles $\mathrm{ABC}$ and $\mathrm{ACD}$ with the smaller triangles abe and acd.

Two general habit types are recognized-the spreading and the erect-often termed deliquescent and excurrent respectively. The former is well represented by the Apple (p. 487) and White Elm (p. 461) and the latter by the Evergreens and those of the Poplars that form narrow conical heads ( $p .395-39 \%)$. By its more erect habit of growth the Sweet Cherry (p.503) is readily distinguished from the Sour Cherry (p. 505) and in like manner the Pear (p. 485) from the Apple (p. 48\%). It is these habit differences that form the most ready means of separating the contrasted trees just mentioned which may closely resemble each other in twig characters. The angle which the branches make with the trunk is frequently a diagnostic character of considerable value. For example, the ascending and gracefully outward curving limbs of the American White Elm (p. 461) stand in contrast with the sharply divergent limbs of the English Elm (p. 459). Jikewise the lugrizuntal branches of the Tupclo (p. 55.j) amt the strongly pendant lower limbs of the Swamp White Oak (p.439) are characteristic of these species. The relative thickness of the branchlets contrasted 
in the Sweet Cherry (p. 503) and the Black Birch (p. 415) and the arrangement of the branchlets whether opposite or alternate and whether erect or drooping, may further be mentioned as habit characters.

As one becones more familiar with trees in their winter aspect, the number that camnot be recognized at a distance becomes greatly diminished. We come to know trees by hardly definable traits, much as we recognize our friends at a distance by some peculiarity of form or gait. Watching the trees from a car window is a great help in acquiring this familiarity with the habit characters. The method of branching and other features included in the habit, however, do not furnish such precise marks as do the twigs, and cannot therefore be of much value in a descriptive key. In fact the habit varies considerably among individual trees of the same species, no two trees having exactly the same method of branching. Moreover trees grown in woods in company with other trees are prevented by lateral shading from developing their normal form and produce tall trunks with but little branching. On the other hand trees apart from other trees have usually been planted for ornament or have originally grown in wools but have been left isolated by the cutting down of their neighbors. In the latter case the halit will be more or less that of a forest-grown tree dependent upon the age at which the conditions of light and shade were altered (see lower habit picture p. 463). In the former case the top of the young tree may have been cut in the process of transplanting causing an increased branching at the point of cutting and the lower limbs may have been trimmed off, giving a greater show of trunk. These mutilations, however, have less influence upon the outline of the head or crown than might be imagined since the tree is generally able to accommodate itself to such accidents as those mentioned and express its individuality despite them. The age of the tree is also an important factor in the outline, young specimens being in general narrower and more conical than in later life while those in old age may have lost shape through ice storms, high winds and the attacks of fungi.

So far as possible the photographs have been taken from mature specimens growing in the open and only those have been chosen which have been considered to present an appearance typical of the species. They will help one to form a mental picture of those 
generalized features of a tree in the landscape which may be recognized at a distance, but which are difficult of analysis.

BARK-Although it is upon the appearance of the bark more than upon any other character that the woodsman depends in his recognition of timker trees. the bark shares with the habit the misfortune of being dittivult of precise description. A study of the photographs, however, in connection with the description of the color and texture will enable one to recognize a large proportion of our trees by the appearance of the bark alone. They have been taken from mature trees of molerate size which have developed the characteristic sculpturing of the bark rather than from those of larger size which are less frequently seen. A tape measule surrounding the trunk or in some instances a penknife stuck into the bark mar serve to gire an idea of the relative size of the markings on the trunk. The heading "Bark" is used throughout the descriptions in reference to the trunk and larger limbs and not to the twigs which are described under another heading.

The color of the outer bark is an important mark of distinction and is the chief means of separating the different species of the Birches (1) $415-425)$. The color and taste of the inner layers of the bark are in some cases also characteristic. The Black Oak for example is luest distinguished from other Oaks by the yellow and intensely bitter inner bark. Similarly, the Black Birch, the Sassafras and the genus Prunus including the Cherries have barks with characteristic flavors. The swamploving Poison Sumach (p. 529) is the only poisonous tree in New England so that after this shrubby form is known there need be $\mathrm{n}$ o fear of tasting bark and twigs of any unknown treelike species.

The bark varies in character according to the age of the tree. In the young tree the bark is smooth, but, as the trunk expands from the growth of the wood within, the corering of dead bark outside is forced to crack in a variety of ways giving rise to characteristic fissures and ridges which become more prominent as the tree grows older. The hark of few trees such as the Beech (1). 429$)$ and the American Hornbeam (p. +13) remain smooth, their outer layers expancling with the growth of the tree. The barks of other's as the Paper and Yellow Birch (p. $41 ;$ ) stretch and peel 
off in thin papery layers. In the Birches (1).423) and Cherries (p. 503) the breathing pores (lenticels) become horizontally elongated to form narrow transverse streals which are characteristic for these forms. When riclges or scales are formed they may be close and firm and with difficulty removed from the trunk as is the case with the bark in the Black Oak group or, on the other hand, they nay be easily rubled off as are the scales of the bark of the White Oak and of most members of the White Oak group. Barki of this latter type is called flaky in our descriptions and this distinction between barks that are flaky and those that are not flaky is of considerable importance in classification. To aroid confusion little notice is taken of the minute scales that are likely to occur on the surface of both types of bark. The bark may come off in large sheets as in the Shag-bark Hickory (p. 403) and the Sycamore (p. 483), and the ridges may be long as in the Chestnut (p. 431) or short and run together to form more or less perfect diamond-shaped areas as in the White Ash (p.557) but these as well as other differences in the sculpturing are shown in the photographs and do not require further discussion in the introduction.

TWIGS-The unqualified word twig refers in the descriptions to the growth of the past season only. Older twigs and branchlets are the designations employed for the small growth of several seasons. The Horse-chestnut (fig. 4) may be taken as a convenient form to illustrate the various markings found on the twig. The large triangular patches resembling somewhat closed horse-shoes in shape are the leaf-scars showing where the bases of the leafstalks were attached to the twig before their fall. The little dots corresponding to the nail holes in a horse-shoe are the bundle-scars and mark the location of the so-called fibro-rascular bundles that run up through the leaf-stalks and connect with the veins of the leaf acting thus as the channels for the transference of raw material and manufactured food to and from the leaf. The leaf-scars are located at the nodes and the portion between the nodes is called the internode. Scattered along the twig are little dots, the lenticels, which are openings that function to a certain extent like breathing pores. Above each leaf-scar is normally produced an axillary bud so called because located in the axil or angle made between the twig and the leaf-stalk when the latter was present. The lateral 


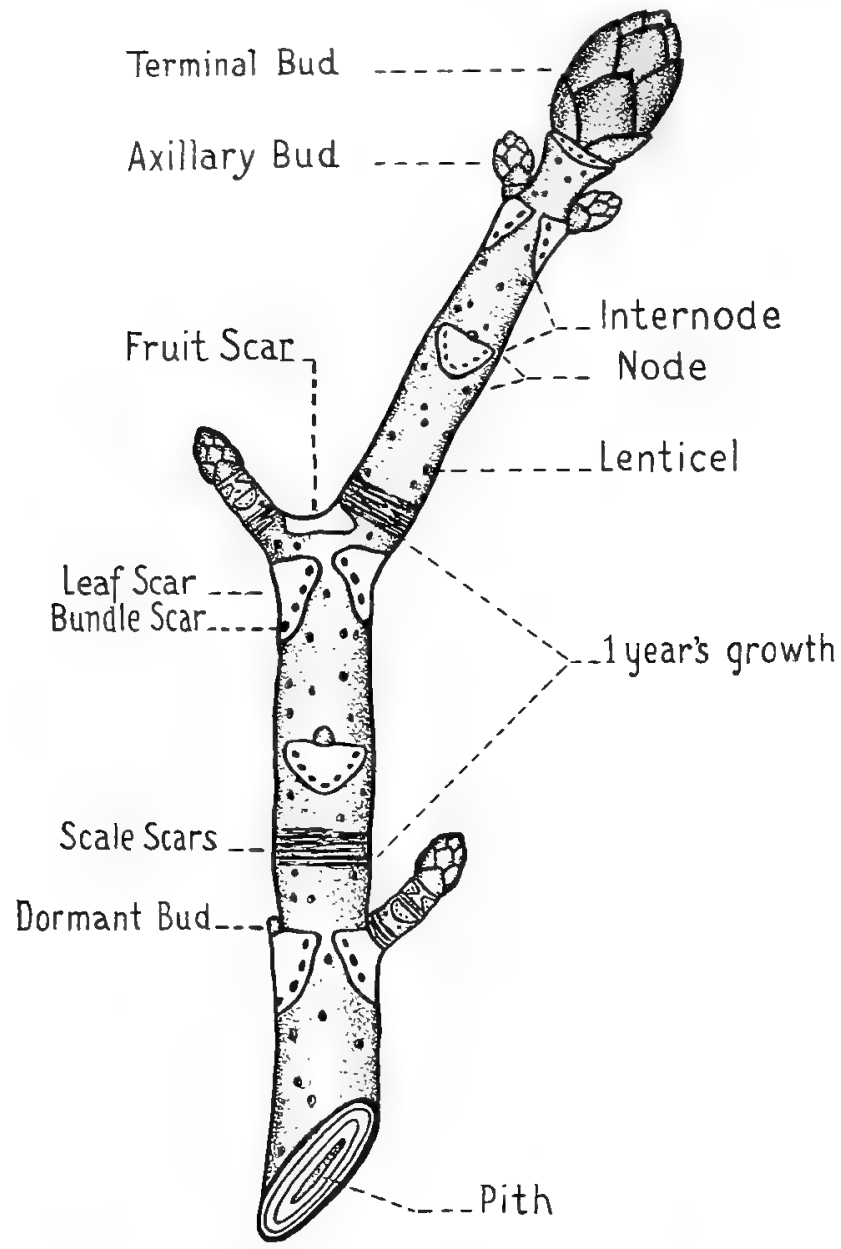

Fig 4. 'rwig of Horse-chesinut.

buds are in distinction to the terminal buds at the ends of the twigs. Each bud contains the rudiments of next year's growth with shortened internodes and minute leaves folded together like a fan and packed away within the protective covering of the bud-scales. Growth in the spring consists for the most part of a rapid elongation of the-internodes and an enlargement of the parts which are already formed in the bud but which remain during winter 
in a condensed condition. The bud-scales are modified leaves which protect the parts within from mechanical injury and from loss of noisture, but are of little value as a protection against coll as is often supposed. At falling they leave a ring or band of scalescars marking the linit of each year's growth. These bands often rmain distinct for nany years (see twig of Buckl p. 4.9.) and by counting their number the age of the branchlet may be estimated. Thus it can be readily seen that the figure of the Horse-chestnut represents growth made during three rears. Each year a ring of new wood is formed just underneath the bark, and a count of the number of these anmal rings between the central pith and the bark, as seen in a cross section of a branch or trumk, will likewise give the age of the part investigated. The uppermost buds of a year's growth are generally the largest and most likely to derelop into branches the following spring. In some species, such as many of the Evergreens, and the ('arolina l'oplar (13.395) for example, the branches coning from these more vigorous buds form regular whorls along the trunk at the uplex part of each year's growth and afford for such species a third means of estimating the age. Certain of the buds do not continue the growth of the twig but form flowers which develop into fruit. Where the individual fruit (in the Horse-chestnut the fruit (luster) was attached, a fruit-setr is left and these fruit-scars furnish evidence of the amount of fruit produced in previous vear's.

In some species, such as the Black Birch (1) 415) and the cultivated Cherry (p. 503), a sharp distinction can be drawn between rapidly-grown long shoots which have clongated internodes and continue the growth of the twig and slowly grown short spurs which have greatly ablireviated internodes and crowded leaf-scars. The fruit-spurs of the Apple (p. 48\%) and Pear (p. 485) are of this latter type.

Of the distinctive characters given under the heading twigs may be mentioned the relative thickness, whether stout or slender, the presence or absence of thorns or prickles, the color, the taste as indicated under the discussion of the bark, and the character of the surface, whether smooth or more or less covered with hairs. Twigs are called hairy when the hairs are individually distinct, downy when they are fine and numerous, and woolly or cottony 
when they are twisted together into a more or less felt-like mass, lut these distinctions cannot be alwars sharply drawn. A twig if smooth may be dull or shiny in appearance. The lenticels are of most distinctive value in those forms like the Birches ( $1 .+23$ ), in which they become horizontally elongated with age. 'The color, size and shape of the pith are often characteristic as seen in the wille salmon-colored pith of the Kentucky Coffee Tree (p. 515) and the star-shaped pith of the Oaks and to a less degree in the Poplars (fig. 5). Some few trees have their pith seprarated by hollow chambers snch as the Hacklorry and the Butternut (fig. (6) or have solid pith but with woody cross partitions such as the 'Tupelo.

ILAF-SCARS-The arrangement of the leaf-scars form primary divisions in the classification. They may be opposite with two scars at a node as in the Horse-chestnut, or alternate with only one scar at the node as in the majority of species. Alternate leafscars may be arranged along the twig in two longitudinal rows when they are said to be z-ranked, as in the Mulleery (fig. 8), or in several rows when they are more than 2-ranked as in the Poplars (fig. 5). Twigs sometimes if rapidly gromn have the leaf-scars which are normally opposite pulled apart to appear alternate, but the typical condition will be found on other parts of the tree. A few species like the Chestnut sometimes take the 2-ranked, an:l sometimes the more than 2-ranked position, and the number of ranks in other forms may be at times somewhat obsenred by a twisting of the twig. The distinctions in the main, however, hold good and where a doubt is likely to oceur in regard to the arrangement, a place has been made in the key for the species in both the 2-ranked and the more than 2-ranked groups.

The size and shape of leaf-scars are important factors in identification. They may be very narrow as in the Pear and their upper margins may be flat or convex as in the Black Ash (p. 561) or deeply notched as in the White Ash (p. 557) or form a band nearly surrounding the bud as in the sycamore (p. 483). Ther may become dingy and inconspicuous or be sharply distinct by color contrast with the rest of the twig. Thus the Elms and the Poplars have their leaf-sears covered with a light-rolored cork-like layer which makes them conspicuous 
irrespective of their size. Teaf-scars may be level with the twig on: more or less raised with their surfaces parallel with the twig or making various angles with it up to a light angle. IRidges in some cases run down the twig from the hase and cornes's of the leaf-scar.

At the bases of the leares of some species a pair of small leaflets called stipules are regularly formed and leave, at the fall of the leaf, more or less definite stipule-ser's at either sirle of the leaf-

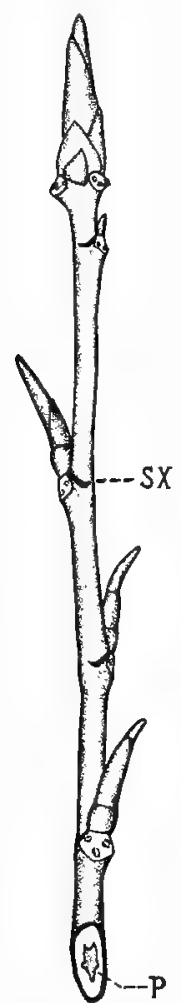
seal as shown in the ('arolina lopplar (fig. n).

T'he number, the size, the relation to the surlace of the leaf-scal whether sunken or projecting, and the distribution of the loumlle-sears lorm important points of clistinction. When they are inclistinct, as is fore(puently the case, they may be revealed if a thin slice is taken off the surface of the leaf-scart. This surface section must be very thin, howerer, since the number of bunclle-scars exposed ly a leep cut is often different from that on the surface, and this latter number is the one used in the keys and descriptions. I distinction is male between a group in which the hundle-scars form a single line ank a second group in which they are rarionsly seattered and gromped or in a donble line.

BLDS-In legald to their position luds are terminal or lateral. Buts produced at or near the nodes but not in the axil of a leaf-scar are callert accessory buts. Of these there are two kints: superposed buds located above the axillary burls and colluterel buts locaterl at wither sirle of the axillary buts. The former are shom in the Buttemut (fig. 6) and the latter in the Red Maple (fig. ‘). ('lassified according to what they proluce there are fouce buds which contain the rudiments of flowers, leaf buds Fig. 5 . Twig of which contain the rop which contain ructiments of leaves, and mixed buds
car.

sx-Stipule p-star-shaped Pith. which produce both flowers and leaves. Flower buds are generally stouter than leaf buds. 
Wost species by the end of the growing season have formed terminal huds which remain through the winter and are destined

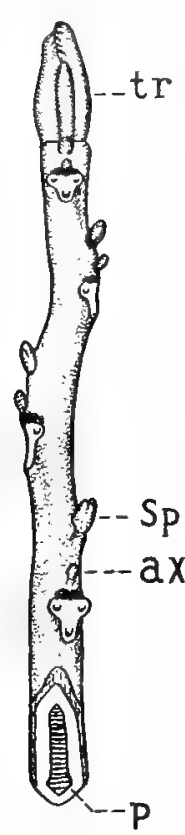
to continue the growth the following spring. In some species, however, such as the Hulberry (fig. 8) the terminal bud together with the tip of the twig dies away and drops off before the beginning of winter leaving a small sear at the end of the twig. The presence or alssence of the terminal bud is a very raluable point of distinction and is used throughout in the keys. Unfortunately it is not always possible at a cursory glance to say whether the teminal bud is present or absent and a hand-lens must generally be used for an accurate determination of this point. In the Mulber'ry figured, the self-pruning scar formed by the dropping off of the terminal Fig. 6-Twig of Butternut. tr-terminal bud. ax-axillary bud.
s p-superposed s p-superposed p-chambered pith. bud is perched on the tip of the twig with the topmost lateral bud obviously in the axil of the last leaf-scar. Frequently, howerer, the self-pruning sear may be nearer the lateral bud which bends in and gives the appearance of being terminal. The

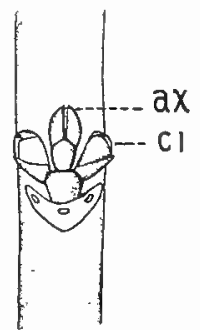
presence of a leaf-sear below it Fig. 7-Twig of Red shows that it is in fact axillary, but since leaf-scars are sometimes Iraple. ax-axillary bud. c1-collateral accessory bud. present toward the end of twigs without buls in their axils the presence of the self-pruning sear at the twig end must be used as the decisive sign that the terminal bud is really absent.

Aside from the color, the presence or absence of hairs, stickiness, fragrance and other such surface characters, the position of the buds in relation to the twig may be of importance. Buds that lie close up against the twig as those of the Small-toothed Aspen (p. 389) are called appressed, while those that project more or less away from the twig as those of the Carolina Poplar (fig. 5) are called divergent. In the Common Locust and a few other forms the buds are sunken below the surface of the twig, and can be found only by cutting the twig lengthwise through the leaf-scar. 
The characters of the bud-scales of most importance are the shape, the number visible in the unmutilated bud, their arrangement-whether alternate or opposite-and the number of ranks they form on the bud.

FRUTT-The fruit generally forms a good means of identification when it can be found. Unfortunately there are a number of limitations to its use for this purpose. In the first place many species of trees do not fruit every year, and it may happen that the ax--89-SC species under examination is not in its fruiting period and consequently all the trees of the region will fail to show fruit. Again, in some species such as the Ash the sexes are separate and consequently only female trees an ever be expected to bear fruit. 'The fruit generally does not remain on the tree throughout the winter but if the tree is sufficiently isolated from other species, a careful search on the ground will often be rewarded by the finding of specimens of fruit that one can feel sure came from the tree in question. However, some species such as the Poplars and

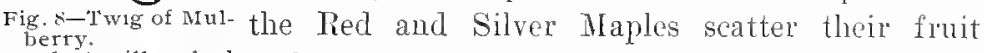
ax-last axillary bud often mistaken for a terminal bud.

sc-self-pruning scar left by fall of real terminal bud and tip of twig.

early in spring, and fruiting material of such forms in consequence is not to be looked for in winter. The immature fruit of some species may be found on the tree in winter and be of value in identification. Thus the presence of young acorns on an Oak in winter shows that it belongs to the Black Oak group.

The staminate flowering clusters are of similar diagnostic value in certain groups, their presence or absence, for example, separating the American Hornbeam from the Hop Hornbeam.

COMPARISONS-Under this heading are contrasted the different species that are considered likely to be confused. It is believed that the information in this section will prove more valualle to one with some knowledge of trees than the more detailed descriptions first given.

DISTRIBUTION-The habitat first discussed under this heading shows in what kind of locations as to soil, moisture and exposure the species normally grows. The information may be of identificational ralue by elimination. 'Thus if one finds a cedar-like 
tree on a hillside pasture one can be sure it is not a coast White Cedar since this latter species grows only in swamps. In like manuer the geographical limits may assist in identification; a Pine found growing wild in Phode Island or Connecticut, for example. could not be the Jack Pine since this is a northern form found native only in the northern New England states. Althongh some cultirated trees hare escaped from cultiration, an introcluced tree is generally characterized by the places in which it is found growing.

WOOD-Under this heading the information giren in regard to the characters of the wood and the economic ralue of the species is of practically no value for purposes of identification of standing timber, but may prove of general interest to the student of trees. 


\section{ANALITICAL KEI \\ METIIOD OF T'SE}

Despite the fact that the appearance of the bark and the nethorl of branching are almost exclusively depended upon by the experienced roodsman in recognition of species, these character's are difficult of precise description and not adapted to use in a key. The twigs therefore with the scaly buds and leat-scars are used, as a basis of the following keys. The word "twig" in the sense here used, it should be remembered, denotes the growth of the past season only, and the word "bark" refers to the bark of the trunk and older limbs and not of the twigs or loranchlets. The student should read the introduction and note the limitation of terms aml characters used in the following pages.

Before attempting to identify an unknown tree it is necessaly to have good material to work with. Care should be taken that the twigs selected are normal in aprearance, being neither almormally stunter in growth nor unusually elongated as are twigs on young sprouts. Frequently the species may be determined by an inspection of the twigs alone but notes on the character of the hark and the halit of growth as well as specinens of the fruit will generally be found useful and sometimes necessary.

In the key a choice is given between two paragraplus preceded ly the same number. This choice leads to a new mumber or to the name of the species followed ly the page where a detailed description of the tree may be found. The White Asl may be used to show the method of procedure. Starting with fo. 1 we have the choice between trees with "leaves persistent and green thronghont winter" and trees with "leaves not persistent and green throughout winter." We choose the latter and this takes us to No. 11 where the decision must be made between "leaf-scars opposite or in 3's" and "leaf-scars alternate." The leaf-scars on the Ish are opposite and we take the first 11 and are led to No. 12. At 12 we have the alternative between "leaf-scar's, or some of them, 3 at a node" and "leaf-scars always 2 at a node." The first pair of contrasting characters mentioned are always the most important. The constant presence in the Ash of two leaf-scars at a norle is sufficient to cause us to choose the second 12 , and our choice is corroboraterl by the position of the bundle-sears ancl by the presence of a terminal burl, so we pass to 13 . The upper lateral buts of 
the Ash are not covered by persistent bases of leaf-stalks and there are 2 or more pairs of scales to the leaf buds, we therefore pass to 14 . The relatively small size of the buds and their freedom from stickiness takes us to 15 where the number of the bundlescars and the other characters given show us that we have in hand a twig of one of the Ashes. Ne now turn to No. $16 \pm$ and confirm our determination of the genus by reading the general description of the Ashes. To find out which Ash we are dealing with we procede with the key of the Ashes and, knowing that the leaf-scars in our specimens are deeply concave on their upper margins, we conclude that we have the Thite Ash (Fraxinus americana). It page 556 we find a detailed description with photographic illustrations of this species and may learn the winter characters of the tree not already given in the key. If the description and photographs do not correspond to the tree under investigation, we know that we have gone astray at some point in the key, and turning back we repeat the analysis taking if need be the other alteruative of a pair where the choice had been doulstful.

Sometimes a tree is rariable in the characters nsed in the key. Thus the Chestnut has terminal buds sometimes present on the trigs though they are generally absent. In such cases, howerer, and where there is a legitimate doubt as to whether the tree should be placed in the first or the second group, it has generally been placed in both so that either of the two choices should lead to the correct name. The determination of the presence or absence of the terminal but is perhaps the greatest pitfall like? to be found in the use of the liey, but should give little difficulty if the discussion in the introduction is understood and the terminal scar is looked for with the aid of a hand-lens. 


\section{KEY TO GENERA AND SPECIES}

1. Leaves persistent and green thronghout winter (Evergreens) ...2

1. Leaves not persistent and green throughout winter (dead leares often persistent in the vaks and Beeches)................. 11

2. Leaves broad, prominently spiny-margined. Iolly (Ilex opaca)p.niso

2. Leaves narrow, often minute and scale-like; Conifers (i.e. cone-

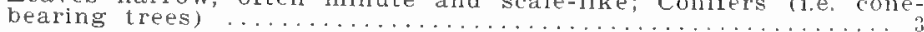

3. Leaves, except scale-leares, needle-shaped, in definite, generally sheathed clusters on the sides of the branches. .....Ine (Pinus) 85

3. Leaves, not in definite clusters ...................... 4

4. Leaves opposite or in 3's, therefore 2 or 3 at a node ........ 5

4. Leaves alternate, scattered, therefore only 1 at a node.......

5. Leaves whorled in 3 's, all alike, whitened above and green below, awl-shaped, sharp-pointed and spreading; fruit bluish, berry-like; a shrub or low tree. (See also juvenile condition of Red Cedar)...

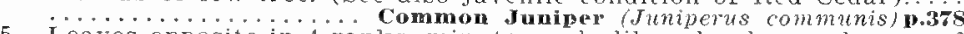

5. Leaves opposite in 4 ranks, minute, scale-like, closely overlapping 6

6. Young twigs prominently flattened and forming a flat, 2-ranked, fan-shaped spray often mistaken for the true leaves which are minute and of two shapes, those on edges of twig being narrower. those on flat sides being broader and more abruptly pointed with each leaf generally showing a conspicuous raised glandular dot: fruit a thin-scaled, oblong, woody cone.

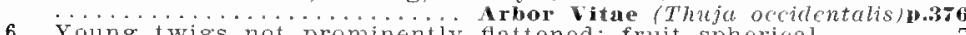

6. Young twigs not prominently flattened; fruit spherical ....... .

7. Spray somewhat fan-shaped; young twigs not prominently 4 -angled; leaves all alike in shape, some of them with prominent raised glandular dot on back: fruit a spherical woody cone.

7. Siray not fan-shaped, young twigs with typical leares and prominently 4-angled: leaves without conspicuous glandular dots, of two kinds: (a) the juvenile form-awl-shaped, spiny-pointed and spreading, in 2's or 3's at a node and resembling leaves of Common Juniper, the usual leaf form on young trees but generally to be found on some parts of older trees; (b) the typical form-smaller, scale-like and closely appressed; fruit bluish, berry-like. ......

8. Leares distinctly lattened ...................... 9

8. Leares not distinctly lattened, needle-shaped, 4 -angled, sessile on projections of the bark. .............. Spruce (Picca) 91

9. Leaf about $1 \mathrm{~cm}$. long with definite leaf-stalk, leaving prominently projecting scar when detached. Hemlock (T'suga canadensis) p.nz2

9. Leaf about $2 \mathrm{~cm}$. or more long, without leaf-stalk, leaving a flat or only slightly raised scar when detached $\ldots \ldots \ldots \ldots \ldots \ldots \ldots$

10. Buds small, nearly spherical to broadly ovate, their scales covered and glued together by resinous coating; leaf-scars flat. .........

10. Buds läger, narrow conical, without resinous coating; leaf-scars slightly raised......... Dourlas Fir (Psendotsuga taxifolia) p.36s

11. Leaf-scars opposite or in 3's, therefore 2 or 3 at a node ...... 12

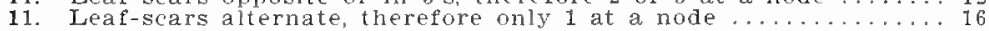

12. Leaf-scars or some of them 3 at a node: bundle-scars in an ellipse; terminal bud absent ............ Catalpa (Catalpa) p.562

12. Leaf-scars always 2 at a node; bundle-scars not in an ellipse;

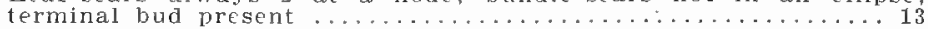

13. Lateral buds, at least the upper ones, covered by persistent bases of leaf-stalks; leaf buds with only a single pair of scales.

Flowering Dorwood (Cornus forida)ivisa

13. Lateral buds not covered by persistent bases of leaf-stalks: leaf buds with 2 or more pairs of seales ...................... 
14. Terminal buds large, oter $1.5 \mathrm{~cm}$. long, sticky or varnished; leafsuar large, inversely triangular; bundle-scars $3-9$, conspicuous.

1. .................. Horse-chestnut (Aesculus Hippocastanum) p.s4s

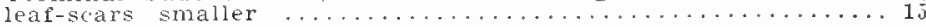

15. Bundle-scars. minute, numerous in a U-shaped line often more or

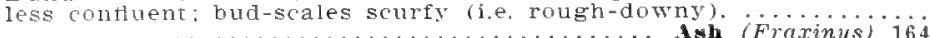

1. Bunde-scars definitely 3 in number; bud-scales not scurfy. .....

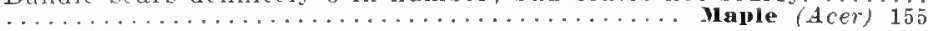

16. Stipule-scars entirely encircling the twig .............. 17

16. Stipule-scars when present not encircling the twig .......... 19

17. Terminal bud absent; (the last lateral bud may appear to be terminal but absence of terminal bud is shown by small scar at end of twig); leaf-scar almost completely surrounding the bud......

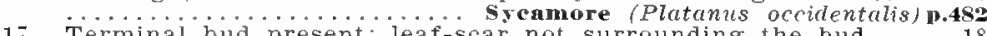

esent; leaf-scar not surrounding the bud .....18

18. Scar of rudimentary leaf sumounting decurrent ridge on side of bud; buds ovate to conical, hairy at least within.

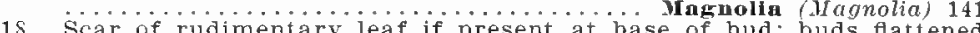
base of bud; buds flattened

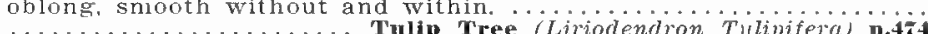

19. Twigs with thorns, spines, or prickles, or branches ending in

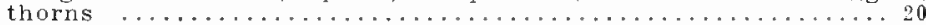

19. Twigs without thorns, spines, or prickles ....................

20. Spines in pairs at the nodes, or twigs covered with weak hair-

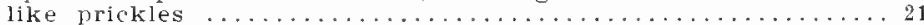

20. Spines not in pairs at the nodes, twigs not covered with weak

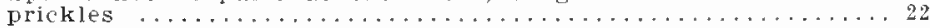

21. Buds rusty-hairy, more or less covered by bark; terminal bud absent. ............................. Loeust (Robinia) p.inge

21. Buds, red, exposed; terminal bud present; a shrub. .... Prickly Ash (Zanthoxylon americanum) under Comparisonsp.i2:

22. Thorns lateral, regularly placed on the twig at or near the

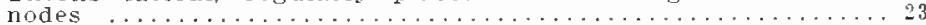

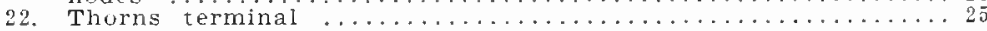

23. Thorns generally branched, situated above the nodes; buds sereral in a longitudinal row, the lower ones covered by the bark. ....... ....................... Hones Locust (Gleditsia triacanthus)p.ỉí

23. Thorns generally unbranched on twigs, situated at the nodes; sometimes branched thorns on trunk; buds exposed .........24

21. Thorns generally present at all the nodes: bundle-scar single.

...... osage orange (Harlura pomifera) under comparisonsp.494

21. Thorns generally absent from many of the nodes; bundle-scars 3 $\ldots \ldots \ldots \ldots \ldots \ldots$ Hawthorn (Cratacgus) p.494

25. Terminal bud absent but leaving a terminal scar on twig. ......

25. Terminal bud present, at least on spineless branches......... 26

26. Tree with bushy habit of growth: twigs with characteristic licorice-like taste, generally reddish-brown, more or less palewolly at least toward apex; lateral buds blunt, flattish, appressed and more or less pale-woolly .......... Ipple (Pyrus Walus) p.486

26. Tree with upright habit of growth; twigs without characteristic taste, generally yellowish green and generally smooth; lateral buds sharr-fininted, smooth or sometimes slightly downy, generally not flatened nor appressed. ......... Pen (Pyrus commanis) p.4v4

27. Pith in section lengthwise of twig seen to be interrupted by hollow

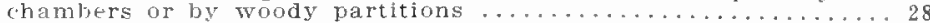

27. Pith continuous; i.e. without hollow chambers or woody parti-

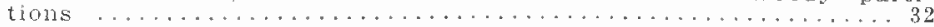

$\because$ Pith chambered but with chambers confined to the nodes

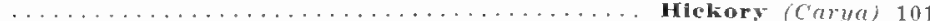

25. Pith when chambered with chambers not confined to the nodes.. 29 
29. Pith wide, brown, with hollow chambers; fruit a nut ........30

29. Pith narrow, light colored; fruit a small stone-fruit ..............

30. Downy patch present above leaf-scar; nut elongated. ...........

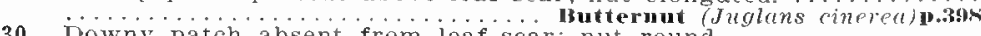

30. Downy patch absent from leaf-scar; nut round. $\ldots \ldots \ldots \ldots \ldots \ldots \ldots \ldots \ldots$ Black Walnut (Juglans nigra)p.400

31. Pith with hollow chambers; buds brown, terminal bud absent, lateral buds appressed. ...... Hackberry (Celtis occidentalis) 1 .4.44

31. Pith with woody partitions in the solid ground-mass; buds reddish, terminal bud present, lateral buds divergent.

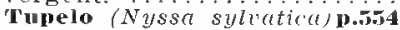

32. Leaf-scars regularly 2-ranked, i.e. arranged in 2 longitudinal rows

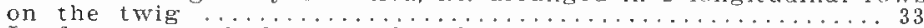

32. Leaf-scars reguiarly more than 2 -ranked, i.e. in more than 2 rows on the twig ................................ 49

33. Terminal bud absent (the last lateral bud may appear to be terminal but absence of terminal bud is shown by small scar at

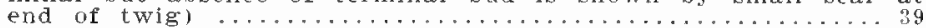

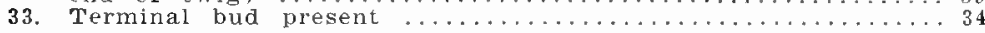

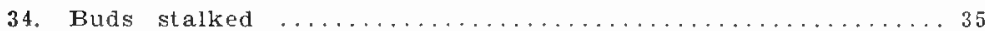

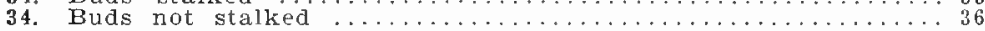

35. Buds, for the most part naked, i.e. with undeveloped leares serving the function of scales; woody, 4-parted fruits and the remains of last season's flowers generally present. Buds covered with bud-scales; fruit a woody cone-like catkin

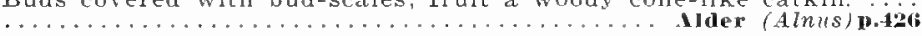

36. Stipule-scars nearly encircling twig; buds long and narrow, generally over 5 times as long as wide, divergent; bud-scales in pairs, 4-ranked, 10 or more scales visible; bundle-scars 5.

............................ Beech (Fugus) p.428

36. Stipuie-scars when present relatively short; buds stouter, generally not over 4 times as long as wide; bud-scales less numerous.... 37

37. Leaf-scars very narrow, V-shaped, swollen at the 3 bundle-scars; buds long, appressed; bud-scale tipped with dark point; stipulescars absent. ......... Shad Bush (Amelanchier canadensis) p.492

37. Leaf-scars relatively broad; buds shorter; bud-scale without conspicuous dark point; stipule-scars present though often incon-

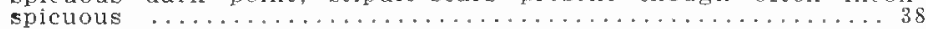

38. Bundle-scars 3; bark of young stem and branches with horizontally elongated lenticels, often peeling into papery layers; pith generally elliptical often with irregularly toothed edges; fruit a catkin, immature catkins generally present on tree in winter. ${ }_{10}$

38. Bundie-scars several; lenticels not horizontaily elongated bark never peeling in papery layers; pith more or less 5 -rointed. starshaped; fruit a bur............. Chestuut (Castaned rentata) .430

39. Leaf-scar almost entirely surrounding the buds; buds brown, hairy, several massed together to form a bud-like cone; bundescars raised, generally 5 in a single curved line.

rellow wood (cladirastis lutealponet

39. Leaf-scar not more than half surrounding the bud; buds not massed

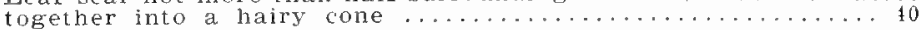

40. Bundle-scars 3 or more in a single curved line ..........43 40. Bundle-scars more than 3 in a closed ellipse double line, variously clustered or irregularly scattered . ............... 41

41. 2-3 scales visible to a bud; bundie-srars not prominently pro-

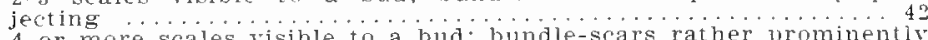

41. 4 or more scales visible to a bud; bunde-scars rather prominentiv

42. Twigs usually zigzag: pith roundish: buds and twigs mucilaginous when chewed; fruit spherical, woody, about size of pea, attarieal to a leafy bract. ......................................... (Tilia) po 
4.'. Trigs nearly straight; pith more or less 5-pointed. star-shaped; buds and twigs not mucilaginous when chewed; fruit a large bur.

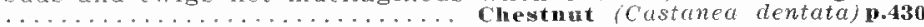

4.. Buds superposed. at least at some of the nodes; stipule-scurs absent; older pith with reddish streaks. bucs nerer superposed; stipule-scars Iresent; pith without reddish streaks ..................................... 44

44. $2-3$ scales visible to a bud ....................... 45

4 4. 4 or more scales visible to a bud ..................... 46

4). Buds stout; buds and twigs mucilaginous when chewed; Ienticels not horizontally elongated; fruit spherical, woody, about size of

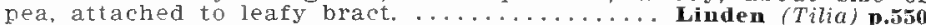

45. Buds narrower, buds and twigs not mucilaginous when chewed; lenticels on stems and branches horizontally elongated; bark often peeling in papery layers; fruit a winged seed-like body borne in

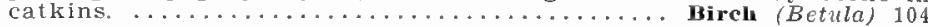

46. Bud-scales 2-ranked (i.e, arranged on the bud in 2 longitudinal rows); leaf-scars covered with a smooth corky layer; bundlescars typically sunken; bark ridged; catkins absent.

46. Bud-scales more than 2-ranked "........ EIm (Ulmus) 137

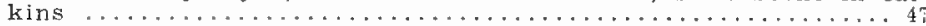

47. Lenticels horizontally elongated with age; bark on young trunks and branches smooth, not becoming fluted, often peeling into papery layers but not flaky; fruit a flat seed-like body borne in catkins; catkins generally present on tree in winter. Birch (Betula) 104

47. Lenticels not horizontally elongated; bark flaky or fluted; budscales 4 -ranked; fruit a nutlet attached to a bract ........... 48

48. Bark flaky; thigs $1-2 \mathrm{~mm}$, thick; buds usually $3-7 \mathrm{~mm}$. long; nutlet enclosed by a sac-like bract; staminate catkins generally abundantly present in winter.

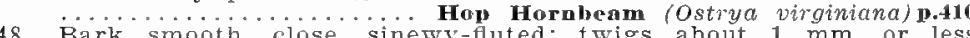
Bark smooth, close, sinewy-fluted; twigs about $1 \mathrm{~mm}$. or less thick; buds usually 2-4 mm. long: nutlet attached to flattish, toothed bract; staminate catkins enclosed in enlarged scaly buds, therefore no catkins visible on tree in winter.

American Hornbeam (Carpinus caroliniana) p.412

49. Buds clustered at tips of vigorous shoots; terminal bud not greatly larger than others of the cluster ......................50

49. Buds not clustered at tips of vigorous shoots, or if slightly clustered, then terminal bud much larger than others of the cluster 53

50. Bunde-scars numerous, scattered; pith regularly 5-pointed, star-

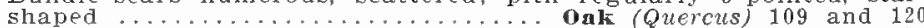

50. Bundle-scars 3 ; pith not 5 -pointed, star-shaped ...........51

51. Terminal bud absent, but leaving a terminal scar on twig.

Tlum (Prunus) 150

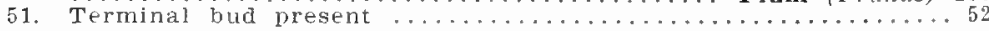

52. Buds woolly at least at tip; collateral buds generally present. ...

52. Bu............................................... (Prunus Persica)

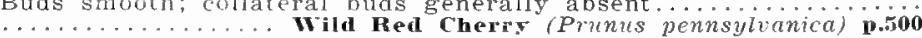
(See also other cherries 144.)

53. Buds stalked ............................. 54

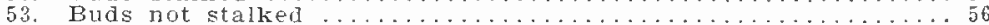

54. Buds bright yellow dotted, often superposed.

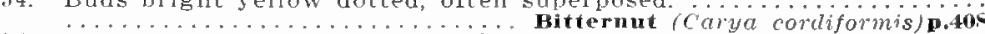

54. Buds not bright jeliow doted, not superposed .............55

55. Buds always stalked, blunt; stipule-scars present; catkins present in winter. ............................. (Alnus) p.420

5.5. Buds, except occasionaliy on rapidy grown twigs, generally not stalked, pointed: corky ridges generally present on branchlets: stipule-scars and catkins absent.

sweet Gum (Liquidambar styrarifuajp.4so 
56. Buds sunken, partially or completely covered by the bark, for the most part minute and superposed; best seen in a section lengthwise of the twig, through the node at right angles to the surface

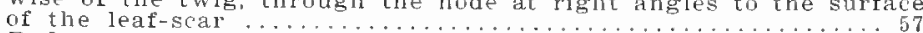

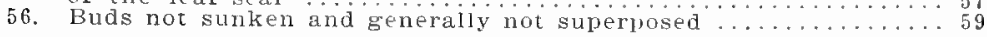

57. Twigs very stout, generally $1 \mathrm{~cm}$ or more thick; pith salmoncolored; buds bronze-silky, exposed but surrounded by an incurved downy rim of the bark; bundle-scars generally more than $3 . . . .$.

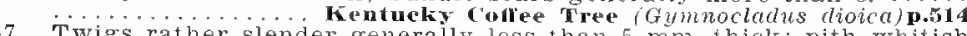
Twigs rather slender generally less than $5 \mathrm{~mm}$. thick; pith whitish

58. Buds smooth, distant, the uppermost breaking through the bark above the leaf-scar, the lower ones submerged, appearing in section of twig as separate green dots.

58.

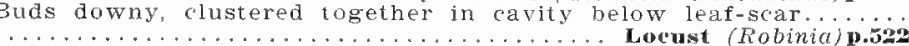

59. Bud-scale one, large cap-like, terminal bud absent. ..........

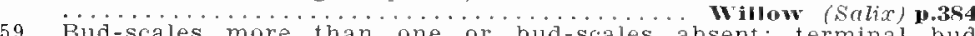

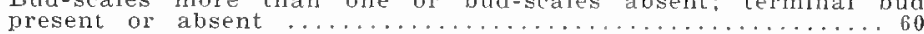

60. First scale of lateral bud directly in front (i.e. facing directly out away from twig); leaf-scar covered with a light-corky layer, large inversely triangular; bundle-scars 3; often compound; pith more or less 5-pointed star-shaped. .............. Poplar (Populus) 96

60. First scale of lateral bud not directly in front ..............61

61. Twigs branching freely the first season, the branches surpassing

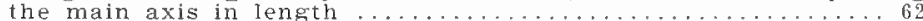

61. Twigs generally not branching the first season or if branching then branches not surpassing main axis in length ............63

62. Bundle-scar one; twigs greenish, spicy. mucilaginous when chewed.

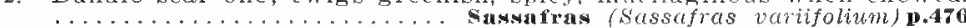

62. Bundle-scars 3 , twigs not mucilaginous. .............. Miternate-leaved Domwood (Connus alternifolia) under Comparisonsp.s5a

63. Bundle-scars 1 or 2; leaf-scars, except on young shoots, mainly dellsely clustered on short, stout, wart-like branches ........64

63. Bundle-scars 3 or more ......................... 65

64. Bundle-scar single; leaf-scars minute, scattered leaf-scars also present on twigs, very numerous and strongly decurrent; twigs slender; fruit a cone, generally present........ Larch (Larix) 90

64. Bundle-scars 2; leaf-scars larger, seattered leaf-scars if present relatively far apart and not decurrent; twios stouter; fruit a stonefruit generally absent. ............... Ginkso (Ginkjo triloba) p.sk2

65. Bundle-scars 3 or more in a single curved line ........... 69 65. Bundle-scars more than 3, variously grouped or seatered, but not

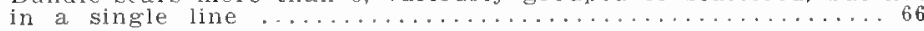

66. Stipule-scars absent; terminal bud present .............. 68

66. Stipule-scars present; terminal bud present or absent .........6. 67

67. 2-3 bud-scales visible; bundle-scars not projecting; terminal bud present or generally absent. Chestunt (Castanea dentata) p.430

67. 4 or more bud-scales visible; bundle-scars projecting; terminal

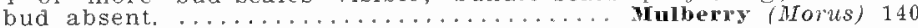

68. Buds large; twigs without resinous juice; fruit a nut; a tree.

$\ldots \ldots \ldots$ Hickory (Carya) 101

68. Buds small; twigs with resinous juice; fruit a small white drupe; a shrub growing in swamps. Poison Sumach ( $R$ hus Vernix) p.528

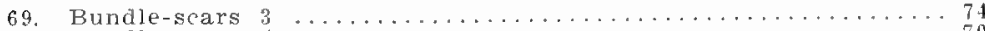

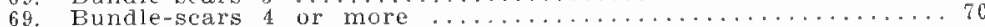

70. Terminal bud absent, but leaving a terminal scar on twig .... 72

70. Terminal bud present ......................... 71

71. Lateral buds mostly large, twig without resinous juice; fruit red, berry-like; a small tree............. Mountain Ash (Pyrus)p.4k8 
71. Lateral buds small, cut twig exuding watery, resinous juice; fruit

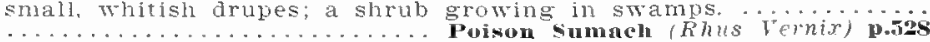

7:- Leaf-suas deelly $\mathbf{r}^{-}$-shaped, almost entirely surrounding the buds 73

7 Leaf-scars, 1 versely triangular to heart-sliaped, large not more than half surrounding the bud; twigs stout; pith chocolate-brown.

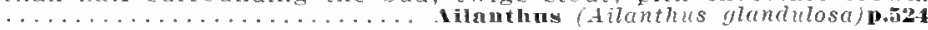

73. Pith yellowish-brown; twigs stout, exuding a milky juice when

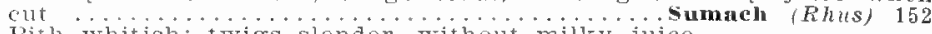

73. Pith whitish; twigs slender, without milky juice. ...................... Tellow wood (Cladrastis lutea) p.ña

it. Terminal buds on rapidy grown shoots absent, but learing a ter-

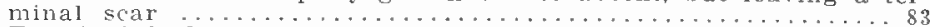

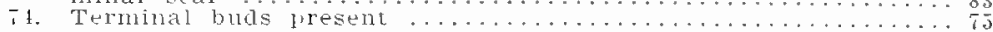

75 Lateral buds flattened, appressed, ahout as hruad as $10 m g \ldots . . .76$

75. Lateral buds not distinctly flattened and appressed, nustiy ionger

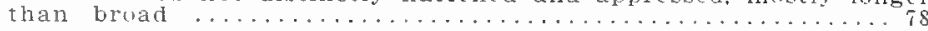

76. Terminal bud large, generally $12 \mathrm{~mm}$. or more long; some of the lateral buds generally long, nearly equalling terminal bud; leafscars raised on dark red, polished ridges of the bark.

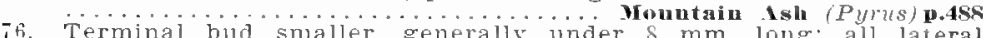
buds small; leaf-scars not on specially colored ridges of the bark 77

77. Tree with bushy habit of growth; twigs with eharacteristic licoricelike taste, generally redaish-brown, more or less pale-woolly at least tomard apex; lateral buds blunt, more or less pale-woolly.

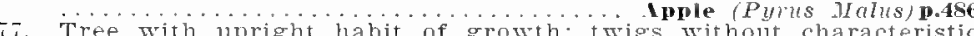
Tree with lipright habit of growth; twigs without characteristic taste, generally yellowish-green and generally smooth; lateral buds

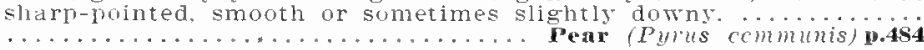

7s. Buds spherical or nearly so, seldom pointed; bud-scales thick, shining; leaf-scars narrow; twigs more or less zigzag, branches generally thorny; fruit a small pome; small trees or sirubs......

7s. Buds not spherical; bud-scales thinner .................. 79

79. Leaf-scars narrow crescent-shaped, several times as broad as

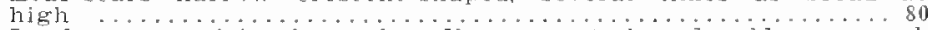

79. Leaf-scars semicircular to broady crescent-shaped, seldom as much

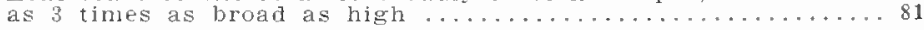

s. Buds long, narrow, elliptical. 3-t times as long as wide

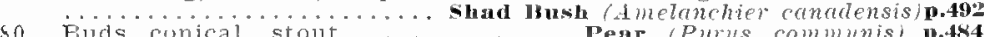

41. Twigs densely speckled with rery minute pale dots, brightly colored, generally green-yellow below and more or less reddish above and highly polished; buds generally densely downy at least toward apex; collateral buds usually present.

61. Twigs not densely speckled with minute dots buds not densely downy, collateral buds generally not present............... 82

82. Twigs without bitter taste; branchlets generally becoming corky. ridged; bud-scales downy-margined; leaf-scars large with conspicucius bunde-scars; fruit a spherical bur-like head generally liresent in winter..... Sweet Gum (Liquidambar styracifua) p.4so

82. Twigs with bitter taste often resenbling bitter almonds: branches without corky ridges: bud-scales not downy-margined; fruit a

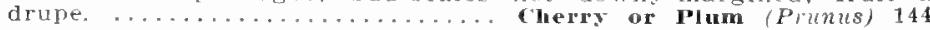

s3. Buds spherical or nearly so: bud-scales thick, shining; twigs more or less zigzag, often thorny: fruit a small pome.

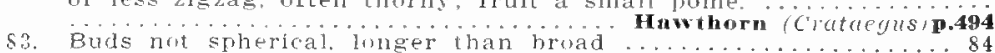

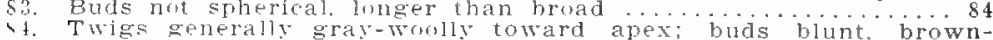
hairy at till: stimulf-scars at the sides of leaf-scar 
84. Twigs smooth or downy but not woolly; buds printed, generally smocith or somewhat downy; stipule-suars more or less behind

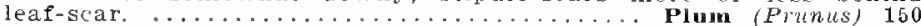

\section{THE PINES} Pinus.

Needle-shaped leaves in many small clusters of 5 or less, each cluster surrounded by a persistent or deciduous sheath and borne on a rudimentary branch which is subtended by a scale-like primary leaf: fruit a cone with woody scales, maturing at the end of the second or third season; seeds winged. The position of the resin-ducts in the leaves is a distinctive character of some value and may be observed if a thin cross section is made with a sharp knife and viewed toward the light with a hand-lens. Twig photographs are about $1 / 4$ natural size.

85. 5 needles in a cluster. .......... White Pine (Pinus Strobus)p.344

85. Less than 5 needles in a ciuster......................86

86. 3 needles in a cluster. ........... Pitch Pine (Pinus riguda)p.346

86. 2 needles in a cluster .......................... 87

87. Needles 3-6 in. long, cones at right angles to branch .......88

87. Needles $1 / 2-3 \frac{1}{2}$ in. long, cones pointing eitlier backward or for-

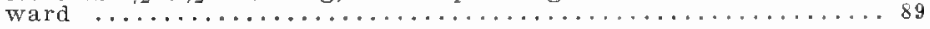

88. Twigs reddish-brown, leaves slender and flexible, resin-ducts peripheral; native species. ............. Red Pine (Pinus resinosa p.3no

88. Twigs yellowish-brown, leaves thicker and stiff, resin-ducts between

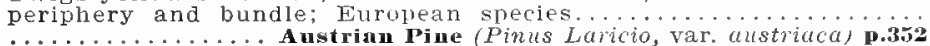

89. Cones pointing forward, leaves $1 / 2-1 \frac{1}{2}$ in. long, dark yellowishgreen, resin-ducts between periphery and bundle; native species.

89. Cones pointing backward leaves $11 / 2-31 / 2$ in. long, bluish-green, resin-ducts peripheral; European species.

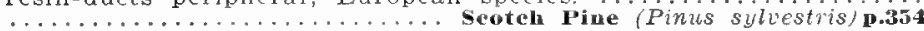

\section{THE LARCHES Larix.}

Pyramidal deciduous-leaved cone-bearing trees; twigs with resinous taste; rapidly-grown shoots with numerous scattered strongly decurrent leaf-scars with single bundle-scars; short stout wart-like branches with densely clustered leaf-scars abundant.

90. Cones 1/2-8/1 inch long with few scales; twigs pale redish-brown;

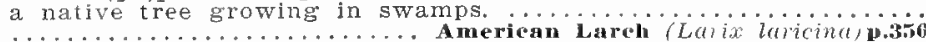
90. Cones 1 inch or more long with many scales; twigs yellowish, stouter; a European tree

..........European Lareh (Larix decidua) under Comparisons

p.356

\section{THE SPRUCES Picea.}

Evergreen pyramidal trees with scaly bark, alternate scattered, 4angled leaves without proper leaf-stalks but perched on persistent decurrent projections from the bark and ovate to cylindrical pendant cones which fall of the tree entire. The Spruces are distinguished from the Balsam Fir by the 4-sided scattered leaves, the projecting leaf-scars and the scaly bark. Twig photographs are about $1 / 3$ natural size.

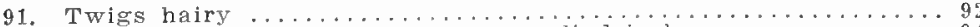

91. Twigs smooth or nearly so, cones cylindrical .............. 94

92. Cones cylindrical, more than 3 inches long; cultivated species. ....

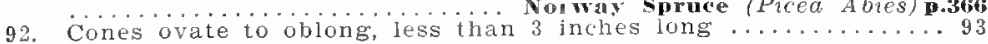

93. Leaves dark yellowish green, $1 / 3-3 / 4$ inch long. Cones ovate-oblong $11 / 4-2$ inches long; a tree growing on urlands, rarely in wet places, reaching $40 \mathrm{ft}$. or more in height. .... Red spince (Picea mubra)p.360 
93. Leates bluish green, $1 / 4-1 / 2$ inch long, cones orate, $1 / 1 / 2-1 / 2$ inches long, persistent on tree for more than a year; a tree growing chiefly in swamps or lowlands, generally under $30 \mathrm{ft}$. in height,

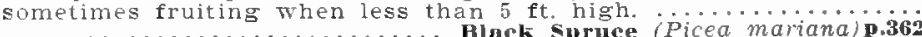

94. Leares green, cones $4-7$ inches long, cultivated species. \#....... .......................... Norwas Spruce (Picea Abies)p.366

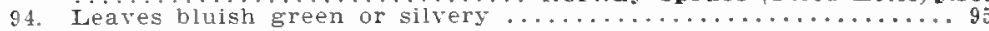

95. Cones 21,-4 inches long, cone scales distinctly longer than broad with narrowed, ragged, blunt apex; cultivated western species.

Blue Spruce (Picea Mensiesii) p.364

95. Cones $11 / 2-2$ inches long, cone scales rounded, not ragged; leaves generally with unpleasant odor, native in northern New England but cultivated further south. White spruce (Picea canadensis) p.35s

\section{THE POPLARS Populus.}

Rapldly growing trees generally with erect more or less continuous trunk forming generally distinct whorls of branches at top of each year's growth by which the age of the tree may be estimated: branchlets brittle easily separating at point of attachment; young bark smooth. generally light colored; pith. F-pointed star-shaped, upon drying generally turning brown or black; leaf-scars large, 3-lobed, inverted triangular, covered with a light colored corky layer; stipule-scars generally distinct, narrow; bundle-scars 3, simple or compound in 3 groups; buds with the first scale anterior (facing outward), the first pair of scales small and opposite; scale-scars marking annual growth persisting for several years; seeds downy, produced from catkins in spring, the tree often spreading widely by formation of root suckers. The Poplars resemble the Tillows but are easily distinguished by the numerous scales to the bud. In addition to the native species here described a rare form. the Downy Poplar. [Populus heterophylla L.] occurs locally in stvamps in southern New England.

96. Twigs of past season more or less slender, covered at least at apex with white cottony felt which may be readily rubbed off exposing the greenish bark below. ...... Silver Poplar (Populus alba)p.340

96. Twigs smooth, not at all covered with white felt ..........97

97. Twigs yellowish . . . . . . . . . . . . . . . . . . . . 98

97. Twigs not yellowish (generally reddish-brown). ...........99

98. Lateral buds for the most part divergent, large, about $10 \mathrm{~mm}$. or more in length. tree nith more or less pyramidal head, but not narrowly spire-shaped. ... Carolina Poplar (Populus deltoides).394

98. Lateral buds for the most part appressed, smaller, generally under

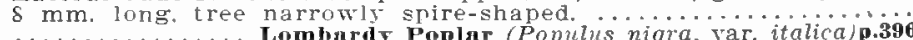

99. Buds more or less pale dusty-downy. ..........................

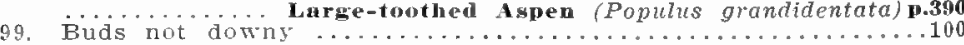

100. Buds large, over $15 \mathrm{~mm}$. long. covered with fragrant sticky gum.

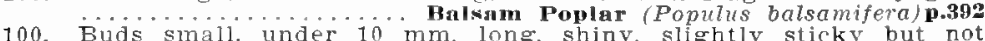
fragrant. .......... Smnll-toothed Ispen (Populus tremuloides)p.38s THE HICKORIES Carya.

Trees with smooth gray tough bark in young trees, becoming roughened with age; twigs in the main stout, tough, flexible, but with difficulty broken, dark, sharply outlined agalnst the sky; buds more or less naked to evidently scaly, frequently superposed, the lateral sometimes enclosed in a sac soon spliting at the top and often stalked: lear-scars alternate, more than 2-ranked, large, conspicuous, more or less 3-lobed inversely triangular; bundle-scars conspicuous, more than 3 , irregularly scattered or collected in 3 more or less regular groups, rarely in a straight line; pith not chambered except at nodes, sometimes somewhat star-shaped in cross section; lenticels oblong. consplcuous; frult an unsculptured nut, inclosed in a husk which splits into four valves at least at the apex. 
101. Buds conspicuously bright yellow with minute glandular dots; terminal buds elongated, flattened; bud-scales $4-6$, valvate in pairs.

101. $\ldots \ldots \ldots \ldots \ldots \ldots \ldots \ldots \ldots \ldots \ldots$ Hiternut (Carya cordiformis) p.40s Buds not conspicuously bright yellow-dotted; terminal buds uvate; bud-scales, 10 or more, overlapping, or the outermost on lateral buds usually forming a closed sac soon splitting from the top; inner scales hairy. ............................. 102

102. Buds small, terminal buds $5-10 \mathrm{~mm}$. long, their outer darker scales generally somewhat glandular dotted, but not conspicuously yellow; outer scales often falling and exposing downy scales beneath; twigs smooth, comparatively slender; bark not at all or but slightly shaggy. ................ Pigmut (Carya glabra)p.406

102. Buds large, the terminal buds $8-15$ mm. long, ovate, nearly or quite glandless; twigs stout, often downy toward tip .......103

103. Bark not shaggy; terminal buds broadly ovate to spherical, outer scales soon falling off entire, expusing pale yellowish-gray silky

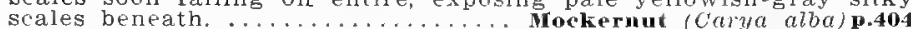

103. Bark distinety shaggy; terminal buds elongated ovate, outer scales persisting through winter but shagging oft in pieces from their apex down ward. ...... Shas-bark Hickory (Curya ovata)p.doz

\section{THE BIRCHES}

\section{Betula.}

Bark smooth, in some species peeling into papery layers but not flaky; lenticels becoming conspicuously horizontally elongated with age; leai-scars alternate, 2 -ranked, semi-oval to crescent-shaped; stipulescars narrow, often inconspicuous; bundle-scars 3 rather inconspicuous: fruit a flat seed-like body borne in catkins, staminate catkins generally present on the tree in winter.

104. Bark close, not easily separated into thin papery layers .... 105 104. Bark easily separated into thin papery layers and generally peel-

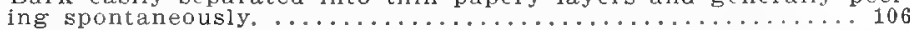

105. Bark dark redish brown; twigs with strong wintergreen taste.

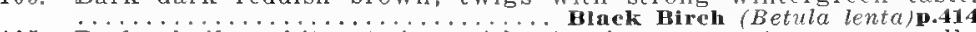
105. Bark chalky-white; twigs without wintergreen taste, generally roughened with resinous dots. Gray Birch (Betula populifolia)p.4\%

106. Outer layers of bark chalky-white ................. 107

106. Outer layers of bark not chalky-white $\ldots \ldots \ldots \ldots \ldots \ldots \ldots \ldots \ldots$

107. Native species. ..... Paper Bireh (Betula alba, var. papyrifera)p.422

107. European species. ...... European White Birch (Betula alba) p.tz4

108. Bark reddish-brown to light pink; rare and local in New Hampshire and Massachusetts, occasionally cultivated, ...................

108. Bark dirty-yellow; common throughout New England.

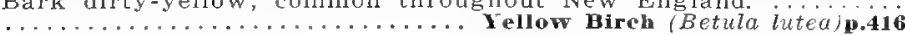

\section{THE OAKS Quercus.}

The Oaks form a large genus, of which 52 are North American, Of these, 12 are native to New England. Buds clustered at ends of twigs, nuore or less 5-sided pyramidal, covered with 5 rows of closely overlapping brownish scales. Leaf-scars concave to rounded above, rounded at base, generally broader than high and raised with a ridge more or less well marked, decurrent from lower edge, the ridges from the 5 ranks of leaf-scars causing twig to be more or less 5-angled especially when dried. Bundle-scars irregularly scattered. inconspicuous. Stipulescars inconspicuous. Pith of cut twig 5-pointed, star-shaped. Crosssection of branch or trunk showing layers of large, porous spring wood alternating with dense layers of summer wood. Medullary rays of wood very prominent, showing as radial lines in cross section of a log, also generally showing prominently, especially through a hand-lens, on cut end of stout branchlet of several years growth. Fruit an acorn inclosed in a scaly cup. Dead leaves often persistent on the tree during winter. 


\section{Key to Oaks based upon fruiting material.}

109. Fruit maturing in a utumn of second year, ripe acorns therefore burne upun parts of twig two years old; immature acorns to be Found in winter on twigs of the past season's growth; shell of nut hairy inside; abortive ovules at the top of the nut; scales of acorn-cup broad and thin; lobes of leares bristle-pointed. ....

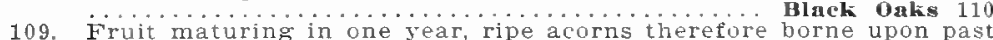
seasons growth; no immature acorns to be found upon twigs in winter; shell of nut smooth inside; abortive orules at base of nut: lower scales at least of acorn cup more or less thickened at base giving a knubby appearance to surface of cup; scales more or less densely woolly; kernel commonly sweetish; lobes of leaves not bristle-pointed; bark flaky except in Chestnut Oak. ........... $\ldots \ldots \ldots \ldots \ldots \ldots \ldots \ldots \ldots \ldots \ldots \ldots \ldots \ldots \ldots \ldots \ldots \ldots$ hite Oaks 114

110. Cup of acorn shallow saucer-shaped ..................... 111

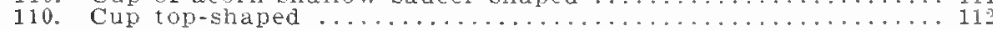

111. Cup thin. $15 \mathrm{~mm}$. or less wide; buds $4 \mathrm{~mm}$. or less long. .......

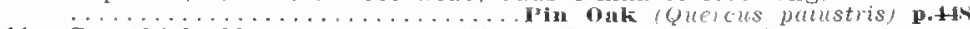

111. Cup thick, $20 \mathrm{~mm}$ or more nide; buds urer t mm. long. ......

112. Buds under $4 \mathrm{~mm}$. long; twigs slender; slirubs. .................

112. Buds ơer $4.5 \mathrm{~mm}$. long; twigs rather stout; trees .......... 113

113. Upper scales of cup loosely overlapping; buds pointed, whole surface woolly; inner bark yellow. Black onk /Quercus relutina, p.4ma

113. L'pper scales of cup closely overlapping; buds blunt, downy above midde; inner bark pale red. Scarlet onk (Quercus coccinea) p.450

114. Liper scales of cup with thread-like outgrowths forming a fringe to cup; branchlets often with corky ridges; lateral buds frequentiy appressed. ....... Bur onk (Quercus macrocurpa) p.43t

114. Cup without distinct fringe; branchlets without corky ridges:

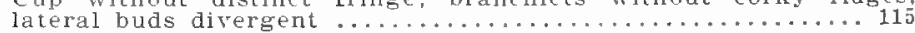

115. Bark on branchlets peeling back in dark stiff-papery layers: marginal scales of cup narrow awn-pointed; acorns long-stalked.

115. Bark on branchie...... Swamp white oak (Qucrcus bicolor)p.43s acurns sessile or short-stalked cat times long-stalked in White

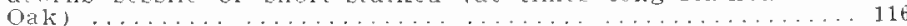

116. Buds sharp-pointed ............................. 117

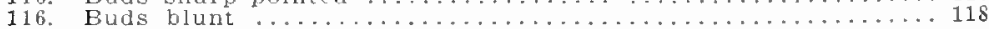

117. Nut 20-35 mm. long; buds $4-10 \mathrm{~mm}$. long; bark thick, furrowed,

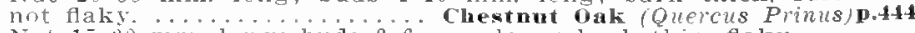

117. Nut $15-30 \mathrm{~mm}$. ling; buds $3-6$ nm. lnng; bark thin, flakt. $\cdots$.

118. Twigs slender, generally not over $2 \mathrm{~mm}$, thick; shrubs.

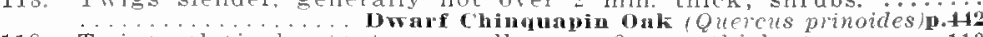

118. Twigs relatively stout, generally over $2 \mathrm{~mm}$. thick; trees ... 119

119. Twigs, at least in part, covered with very fine close olive-green dowll buds, generally nearly hemispherical, about as broad as long: scales of cup only slightly knobby, apex of nut generally duwny. ................ Post onk (Quercus stellata) p.434

119. Twigs smooth; buds distinctly longer than broad, broady ovate; scales of cup thick-knobby at base, apex of nut generally smooth. $\ldots \ldots \ldots \ldots \ldots \ldots . . . \ldots \ldots$ White onk (quercus alba) p.432

\section{Key to Oaks without fruit.}

NOTE. ( $T$ ) after name indicates that the tree belongs to the Mhite Oak Group.

( $B)$ after name indicates that the tree belongs to the Black rak Group.

Immature acorns therefore may often be found on winter twigs of species marked with (E) but not on those marked with (W).

120. Buds large, those at tip of twig $4,5 \mathrm{~mm}$. or more long ..... 121 


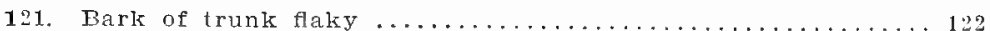

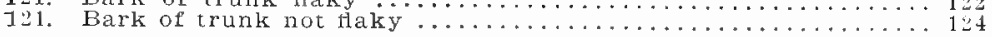

122. Lateral buds generally appressed, buds downy; older twigs often with corky ridges. ..... Bur onk (W) (Quercus macrocarpalp.43t

122. Lateral buds divergent, buds smooth; twigs without corky ridges

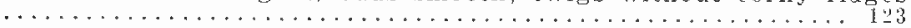

123. Buds narrow conical, pointed.

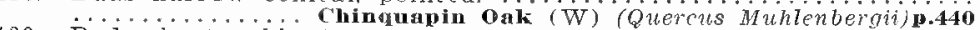
123. Buds shorter, blunt. .......... White oak (W) (Quercus alba)p.432

124. Surface of buds pale-woolly. ..........................

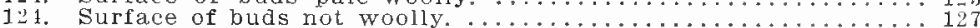

125. Inner bark of trunk orange-yellow; whole surface of bud woolly; buds large, ovate-conical. Biack Oak (B) (Quercus velutina) p.45

125. Inner bark of trunk not yellow; not more than upper half of bud

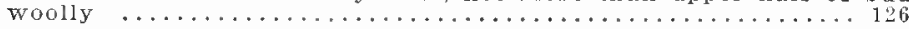

126. Buds sharp-pointed; ovate, the widest part about $1 / 1 / 16$ above

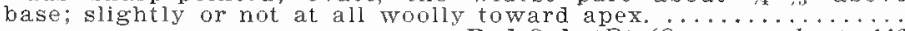

726. Buds blunt-pointed; oval-oväe. ped oak (B) (Quercts rubralp.446 below middle; distinctly woolly above middle. $\ldots \ldots \ldots \ldots \ldots \ldots \ldots$ Searlet oak (B) (Querchs coccinea) p.450

127. Fissures of bark separated by long fat ridges; buds ovate, more or less constricted at base; twigs not bitter.

Red Oak (B) "ivercus mibraip.446

127. Fissures of bark separated by long romated ridges; buds narrower, conical, seldom constricted at base; twigs more or less bitter when

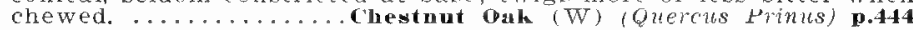

128. Buds narrow, conical ....................... 129

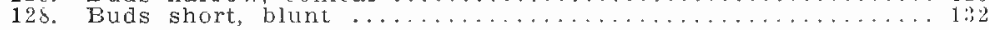

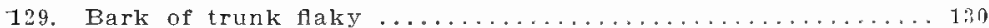

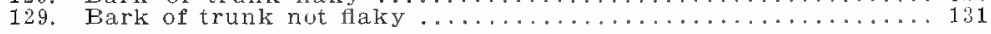

130. Buds downy, lateral buds generally appressed; older twigs often with corky ridges...... Bü oak (W) (Quevers macrocarpa) p.436

130. Buds smooth. lateral buds divergent, twigs without corky ridges ................hinqupin Oak (W) (Quercus Muhlenbergii) p.440

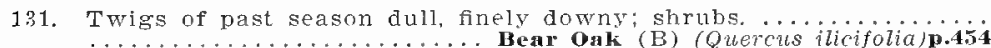

131. Twigs smooth. shining; slender pin-like twigs numerous, arising at nearly a right angle with the branchlets; trees. . . . . . . . .

132. Bark on branchlets peeling into long, dark, stiff-papery layers.

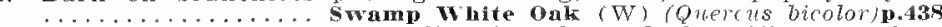

132. Bark on branchlets not peeling into long, dark, stiff-papery lay-

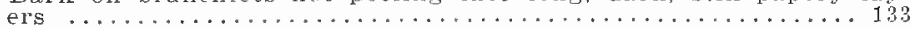

1.33. Twigs slender, generally not over $2 \mathrm{~mm}$, thick; shrubs .... 1.44

133. Twigs stout, generally over $2 \mathrm{~mm}$ thick; trees ........... 135

134. Bark of trunk smooth; young acorns generally found on winter twigs; buds more generally conical.

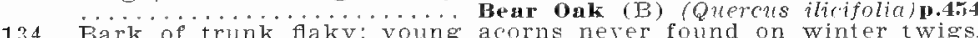
Bark of trunk flaky; young acorns never found on winter twigs. .............. Inare Chinquapin onk (W) (Quercus prinoides)p.142

135. Lateral buds generally appressed; buds densely downy; older

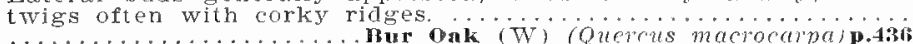

135. Lateral buds divergent; buds not densely downy; twigs without

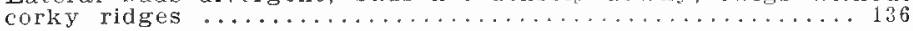

136. Twigs at least in part covered with very fine close orange-brown down; buds generally nearly hemispherical and about as broad as

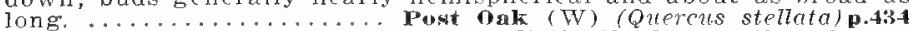

136. Twigs smooth: buds broady orate, distinctly innger than broad. White oak (W) (Quercus alba)p.43\% 


\section{THE ELMS Ulmus.}

Leaf-scars alternate, 2-ranked, semi-circular, small, but conspicuous, covered with a light corky layer; bundle-scars prominent, 3 to several. sunken; terminal bud absent, lateral buds medium sized with 2 ranks of over-lapping bud-scales; twigs slender; bark ridged; fruit small, flat, winged, ripening in spring.

137. Twigs gray and rough and strongly mucilaginous; tips of buds conspicuous with long rusty hairs. Sippery Eim (I'lmus fulva) p.4n

137. Trigs neither gray and rough nor strongly mucilaginous; buds

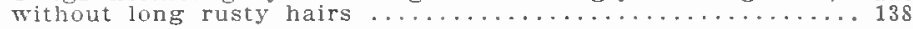

13S. Buds chestnut brown; bud-scales with darker margins; bark

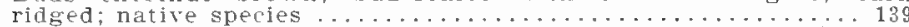

13S. Buds smoky brown to almost black; bud-scales nearly uniform in color, bark firmer, roughened into dark oblong biocks; trunk mostiy continuous into crown with stout limbs arising at a broad angle; head, "Oak-like;" European species. .................

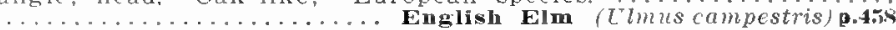

139. Twigs often with corky ridges; trunk generally continuous into crown with stiff dependent lower branches; head narrow, "Hickorylike." ................. Cork Elm (L'linus racemosa)p.462

139. Twigs without corky ridges; trunk dividing into several limbs, spreading gradually upward and gracefully recurving: head broad, "Elm like.".............. White EIm (L lmus americana) p.460

\section{THE MULBERRIES Morus.}

Leaf-scars alternate, 2-ranked, nearly circular; stipule-scars narrow; bundle-scars projecting in a closed ring or irregularly scattered; terminal bud absent; bud-scales 2-ranked; twigs with milky juice.

140. Buds about as broad as long. more or less flattened and appressed, generally under $4 \mathrm{~mm}$. long; bud-scales reddish brown without darker margins. ........... White Irulberry (Morus alba) p.46s 140. Buds longer than broad. not at all or but slightly flattened, divergent, generally over $5 \mathrm{~mm}$. long; bud-scales greenish brown with darker margins. .............. Red Mulberry (1) Morus rubra)p.466

\section{THE MAGNOLIAS Magnolia.}

Terminal bud much larger than lateral buds; bud-scales valvate, united in pairs to form a cap, corresponding to stipules, each pair enclosing in succession an erect folded leaf connected with the next inner pair of scales; the unmatured leaf which belongs to the outer pair of stipular scales falling off in autumn and leaving a scar on side of bud with a decurrent ridge below, representing its leaf stalk; stipule-scar narrow, encircling the twig; leaf-scars alternate, more than 2-ranked, broad, oval to narrow crescent-shaped, bunde-scars numerous, irregularly scattered or in a double row; twigs aromatlc; fruit a cone made up of numerous follicles which split open in the autumn and let out the large flattish seeds.

141. Buds large 25-50 $\mathrm{mm}$. long, twigs stout, leaf-scars large .... 142 141. Buds small 10-20 mm. long; twigs slender; leaf-scars smail ... 143

142. Buds densely pale-downy; twigs light yellowish to bluish-green, more or less downy, fruit nearly spherical. Large-leaved Ingnolia, Large-leaved Cucumber Tree, Large-leaved Umbrella Tree...... ......... (Magnolia macrophylla Michx.) under Comparisons p.47o

142. Buds smooth; twigs brown fruit elongated

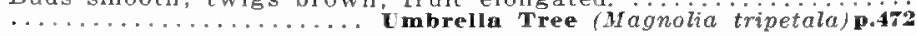

143. Twigs brown; leaf-scars narrow, creseent to U-shaped; buds blunt, densely downy: bark flaky; a tree; in New England found only in

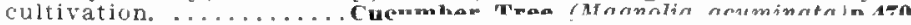


143. Twigs and buds bright green; leaf-scars oval to broadly crescentshaped; buds pointed, with long, silky hairs, often nearly smooth; pith with more or less distinct transverse woody partitions in the ground mass; bark smooth; in New England usually a shrub, growing wild in deep swamps in Eastern Massachusetts, also extensively cultivated. Sweet Bay, Swamp Bay, Laurel Magnolia, Beaver Tree. (Magnolia virginiana L.; M. glauca L.) .............

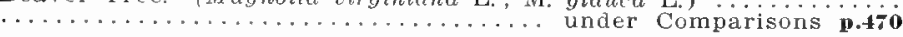

\section{THE CHERRIES, PLUMS AND PEACH}

\section{Prunus.}

Leaf-scars alternate, more than 2 -ranked; bundle-scars 3 ; stipule-scars present, inconspicuous, or absent; buds with scales overlapping in several rows; terminal bud present or absent; fruit a drupe.

144. Terminal bud present ....................... 145

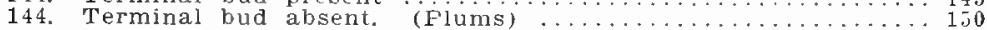

145. Twigs densely speckled with very minute pale dots, brightly colored, generally green-yellow below and more or less reddish above and highly polished; buds generally densely downy at least

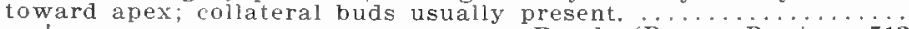

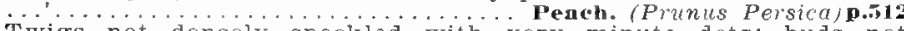
Twigs not densely speckled with very minute dots; buds not densely downy; collateral buds absent (occasionally present in Wild Red Cherry) ............................ 146

146. Buds clustered at tips of all shoots; twigs under $2.5 \mathrm{~mm}$. thick.

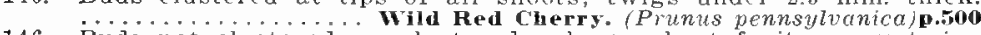

146. Buds not clustered, or clustered only on short fruit spurs; twigs over $2.5 \mathrm{~mm}$ thick ........................... 147

147. Short stout slow-growing fruit spurs present with buds clustered

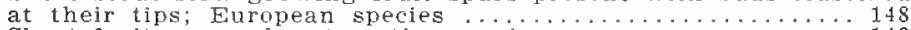

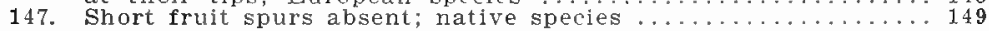

148. Habit erect, generally with a central leader.

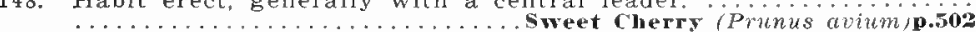

148. Habit spreading, without central leader; buds smaller; twigs more

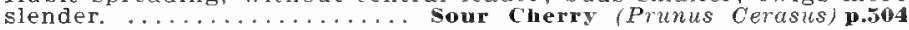

149. Buds generally over $5 \mathrm{~mm}$. Iong; bud-scales gray-margined; bark

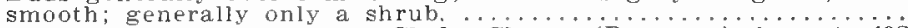

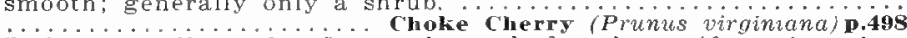

149. Buds generally under $5 \mathrm{~mm}$, long; bud-scales uniform in color: bark becoming rough-scaly; a small to large tree. ............ .................... Wild Black Cherry (Prunus serotina)p.496

150. Native species, growing wild .................... 151

150. CuItivated species. Varieties chiefly of the American, European, $\ldots \ldots \ldots \ldots \ldots . \ldots . \ldots . \ldots$ or Japanese type of Plum. p.50s

151. Buds generally under $4 \mathrm{~mm}$ long. .......................... 151. Büs generaliy over $4 \mathrm{~mm}$. long. Canada Plum (Prunus nigra)p.506

\section{THE SUMACHS}

\section{Rhus.}

Shrubs or small trees with pithy twigs and milky or watery juice; leaf-scars alternate, more than 2-ranked; bundle-scars numerous scattered or in a single curved line; stipule-scars absent; terminal bud present or absent; fruit a small drupe borne on erect or drooping clusters.

152. Terminal bud present; fruit smooth white in loose drooping clusters. ....................... Poison Sumach (Rhus Vernix) p.528

152. Terminal bud absent; fruit more or less hairy, red, in dense erect

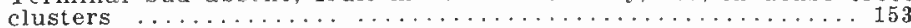


153. Leaf-scars narrow, V-shaped, nearly encircling the buds; cut twig

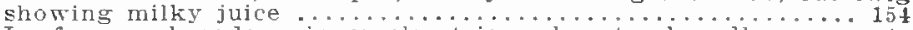

153. Leaf-scars broader; infersely triangular to broady crescentshaped; twig with watery juice and resinous taste. . ............. Dwari Summeh

154. Twigs densely hairs. ....... Staghorn Sumach (Rhus typhina) p.526

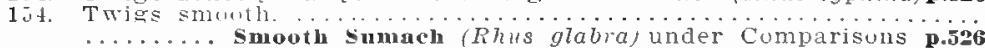

\section{THE MAPLES}

\section{Acer.}

Leaf-scars opposite, narrow U or V-shaped; bundle-scars conspicuous, typically 3, eutidistant, though sonetimes each of these becomes compounded; fruit winged, in pairs.

155. Adjacent edges of leaf-scars meeting and prolonged upward into

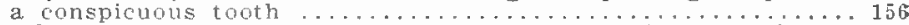

155. Adjacent edges not meeting, therefore not forming a tooth .... 15s

156. Buds white-downy, collateral buds generally present, twigs generally with a bloom. ............... Box Elder (Acer Negundo/p.546

156. Buds smooth, collateral buds never present, twigs without

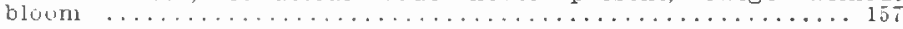

157. Buds with only one pair of scales visible, older branchlets whitestreaked. ............. Striped Taple (Acer pennsylvanicum/p.ñz

15i. Buds with sereral pairs of scales visible, branchlets not whitestreaked. ................ Norway Maple (Acer platanoides) p.juz

158. Outer single pair of bud-scales equalling the bud in length, their edges meeting and enclosing the bud, therefore generally only one pair of scales visible: pith brown; shrubs or at the most small

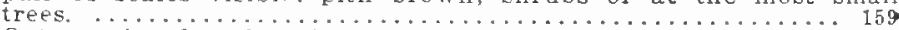

158. Outer pair of scales shorter than bud, their edges not meeting, therefore several pairs of scales visible; trees .............160

159. Buds and twigs stout, smooth: young bark with longitudinal white lines. .................. Striped Inple (Acer pennsylianicum, p.n3z

159. Buds and twigs more slender, both buds and twigs white-donny, white lines absent from bark. Mountain Maple (Acer spicatum)p.54t

160. Buds bromn, narrow, sharp-pointed, generally $4-8$ pairs of closely over-lapping scales risible, collateral buds absent. ....................

160. Buds red or green, bruader, blunt-pointed, fewer scales risible 161

161. Terminal buds small, red, generally under $5 \mathrm{~mm}$. long and not distinctly larger than lateral buds; collateral buds generally

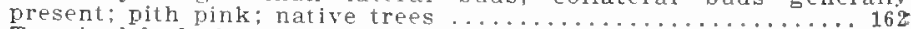

161. Terminal buds large, stout generalis over 5 mm. iong and generally distinctly larger than lateral buds; collateral buds never

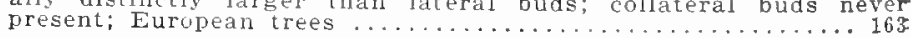

162. Broken twigs with rank odor, bark falling away in large, thin flakes on old trees. ........... silver Maple (Acer saccharinum) p.53s

162. Broken twigs without rank odnr, bark rough on old trees but generally not flaking in large thin scales.

Red Inple (Acer rubrum) p.5to

163. Buds red. inner scales covered with rusty wonl; anjacent edges of leaf-scars meeting and forming a slight projection; bark closeridged, not flaks........... Norway Maple (Acer platanoides) p.54z 163. Buds green. inne scales mhite-wonlly edges of leaf-scars not
meting; bark flaking off in squarish scales. . . .

$\ldots . . . . . . . . . . .5$ s. .... 


\section{THE ASHES \\ Fraxinus.}

Leaf-scars opposite, large, conspicuous, bundle-scars minute, forming a curved line often more or less confluent; buds stout, scurfy, brown or black with ovale bud-seales opposite in pairs; twigs stout and brittle; fruit winged.

164. Leat-scars deeply concave on upper margin. ..................

164. Leaf-scars not deeply concave on upper margin, semicircular to

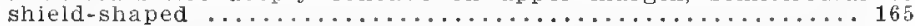

165. Bark soft-scaly; buds generally black; last pair of leaf-scars generally some distance below end of twig giving a stalked-like

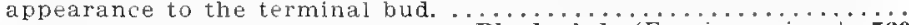

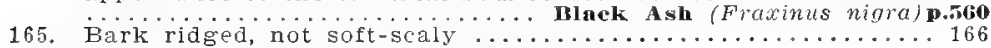

166. Euds black; trees found only in cultivation. ................

166. Buds dark brown; trees native ......................... 167

167. Twigs downy,........... Red Ash (Fraxinus pennsylranica)p.ñs

167. Twigs smooth. Green Asin (Fraxinus pennsylvanica, var. lanceolata)

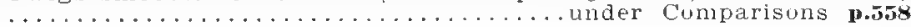




\section{WHITE PINE \\ Soft Pine, Weymouth Pine.}

Pinus Strobus L.

HIBIT-The tallest conifer of New England, 50-80 ft. high with a trunk diameter of $2-4 \mathrm{ft}$.. in virgin forests of northern New England trees have been found over $150 \mathrm{ft}$. in height with a trunk diameter of 7 ft.; trunk straight, tapering gradually, normally continuous into the crown, with wide-spreading, horizontal limbs, in young trees generally arising in whorls of five, and with secondary branches in the same plane, producing characteristic horizontal layers; head broadly conical, spray delicate, bluish-green.

BARI-On young trunks and branches, smooth, greenish-brown, becoming fissured into comparatively shallow, broad, flat-topped, longitudinal ridges.

TWIGS-Slender, light brown smooth or slightly hairy, resinous.

LEAVES-In clusters of 5, without sheaths in winter, soft, bluishgreen flexible, $3-5$ inches long, slender, 3 -sided. MICROSCOPIC SECTION-showing a single fibro-vascular bundle, 1 or 2 peripheral resin-ducts, a single layer of strengthening cells only beneath the epidermis, stomata only on the two inner sides.

BLDS-Ovate to oblong, about $1 \mathrm{~cm}$. long, sharp-pointed, bud-scales long, pointed, yellowish-brown.

FRITT-Cones, 4-10 inches long, stalked, drooping, cylindrical and more or less curved. SCALES-thin, not thickened at apex and without spines. Seeds winged.

CoMp.IRIsoxs-The White Pine is the only Pine of New England that has 5 needles in a cluster. The latered arrangement of its secondary branches enables it to be recognized as far as it can be seen. Young trees can be further distinguished from the Pitch or Red Pines by the greater delicacy and bluer color of the leafage. Frequently the terminal bud of the central leader is killed by an insect, the Pine Tieevil, thus interrupting the growth and causing one or more of the young lateral branches to grow erect to take its place. Gnarled old specimens which have many times in their lifetime suffered these insect injuries may present a rather picturesque appearance but are of little value for lumber. The tree photographed perhaps had its leader killed when young but despite the three erect limbs which have taken the place of the single leader it still shows the outline characteristic of the species.

DISTRIALTION-In fertile soils; moist woodlands or dry uplands; often planted for ornament. Wind-breaks and for reforestation. Newfouniland and Nova Scotia, through Quebec and Ontario to Lake Winnipeg; south along the mountains to Georgia, ascending to 2.500 feet in the Adirondacks and to 4,300 feet in North Carolina; west to Minnesuta and Iowa.

IN NET ENGLAND-Common, from the vicinity of the sea coast to altitudes of 2.500 feet, forming extensive forests.

IN CONNECTICUT-Occasional near the coast becoming frequent northward and common in northeastern Connecticut.

woOD-Light, not strong. straight-grained, easily worked, light brown often slightly tinged with red, largely manufactured into lumber, shingles and lathes, used in construction, for cabinet-making, the interior finish of buildings, woodenware, matches and the masts of vessels. 

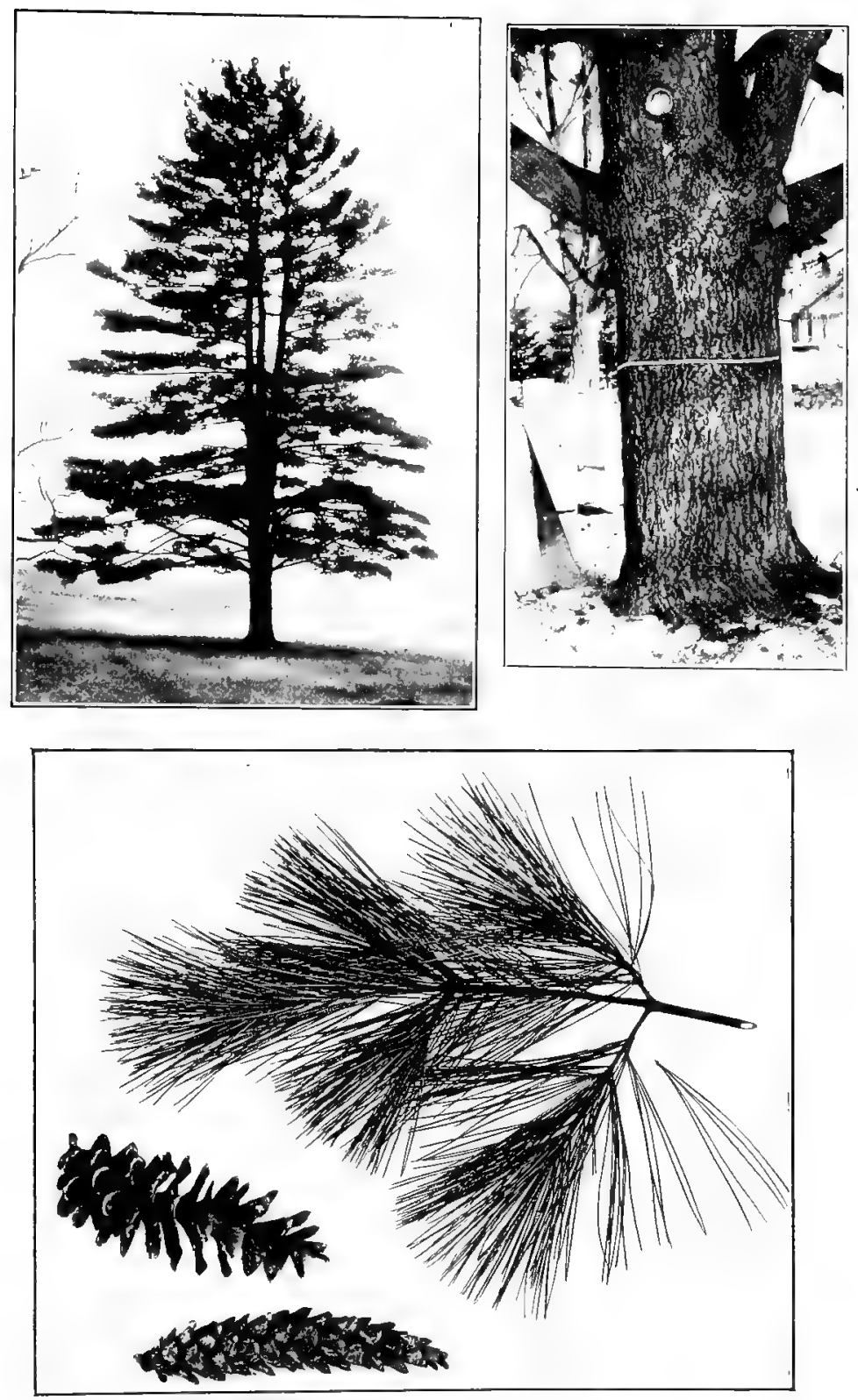

White Pine 


\section{PITCH PINE Hard Pine, Yellow Pine.}

Pinus rigida Mill.

HABIT-Generally a low tree $30-50$ ft, in height with a trunk diameter of $1-2 \mathrm{ft}$. occasionally $70-80 \mathrm{ft}$. in height with trunk diameter of $2-4$ ft.; trunk more or less tapering, branches thick, gnarled, often drooping. forming an open pyramidal or oblong head; foliage in coarse rigid, yellowish-green tufts. Dead branches and old persistent cones are frequent and the tree has generally a decidedly scraggly appearance.

B.RK-On young trunks and branches rough, broken into reddish brown scales, with age becoming deeply furrowed into broad flattopped ridges separating on the surface into rather loose dark reddishbrown scales. Clusters of leaves and short branches are not infrequently formed directly from the old trunk (see in photograph above the tape measure.)

TWIGS-Stout, light brown, not downy, roughened especially after the fall of the leares by the decurrent bases of scales subtending the leafclusters.

LENVS-In clusters of 3 , with persistent sheaths, yellowishgreen. -5 inches long. stout, stiff, spreading. with pointed tips. MICFUSCOPIC \$ECTIUS-3-sided, showing 2 fibro-vascular bundles, resin-ducts located intermediate between bundles and periphery, strengthening cells beneath the epidermis in patches several layers thick. generally surrounding the resin-ducts and at one side of the vascular bundles, stomata on all three sides.

IB LDS-Cylindrical to orate, pointed, resin-coated, scales reddishbruwn.

FRI IT-Cones $11 / 2-4$ inches long. Without stalks, ovate becoming more or less spherical when opened, borne laterally, singly or in clusters at abut a right angle to the twig. often remaining on the branches fur ten or a dwzen years and freluently found on trees only a few feet high. SCALES-thickened at tip and with a stiff recurved prickle.

CoMP.risoxs-The Pitch Pine is the only native Pine in New England that has three needles in a cluster. Its ragged appearance with frequent dead branches, persistent cones, and yellowish-green stiff foliage renders it easily distinguished from the White and Red Pines without examination of the needles.

DISTRIBLTIOV-Most common in dry, sterile soils, occasional in swamps. New Brunswick to Lake Ontario; south to Virginia and along the mountains to northern Georgia; west to western New York, Ohio, Kentuck $y^{\circ}$, and Tennessee.

IN NEW ENGLAND-Maine-mostly in the southwestern section near the seacoast; as far north as Chesterville. Franklin county: scarcely more than a shrub near its northern limits: New Hampshire-most. common along the Merrimac valley to the White Mountains and up the Connecticut valley to the mouth of the Passumpsic, reaching an altitude of 1,000 feet above the sea level; Vermont-common in the northern Champlain valley, less frequent in the Connecticut valley; common in the other New England states, often forming large tracts of woodland, sometimes exclusively oceupying extensive areas.

IN CONNECTICLT-Fare or local in Litchfield county, frequent elsewhere.

wooD-Light, soft, not strong, brittle, coarse-grained, very durable, light brown or red, with thick yellow or often white sapwood; largely used for fuel and in the manufacture of charcoal; occasionally sawed. into lumber. 


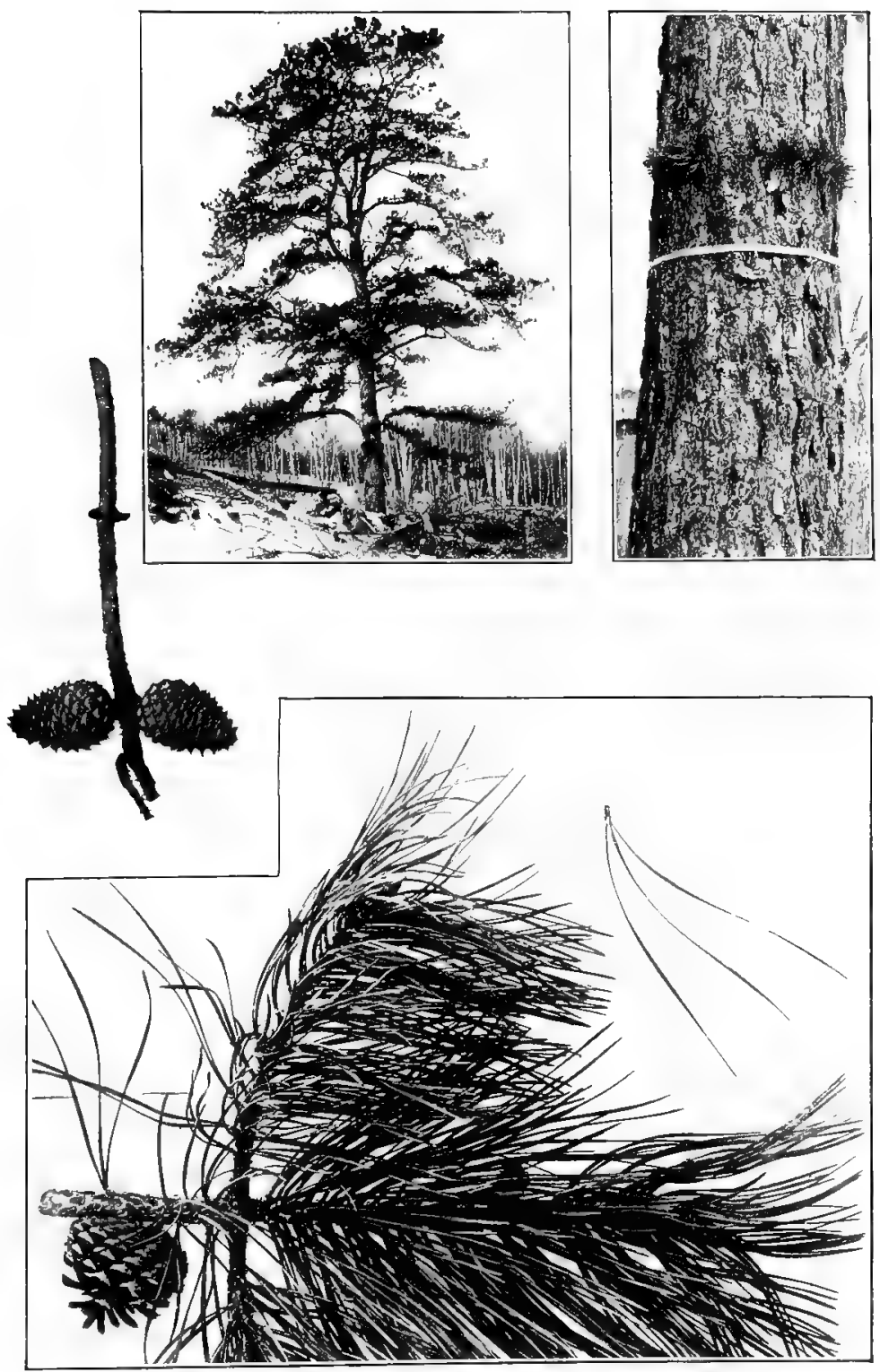

Pitch Pine 


\section{JACK PINE \\ Northern Scrub Pine, Gray Pine, Spruce Pine. \\ Pinus Banksiana Lamb. \\ $P$. divaricata auth.}

H. BIT-L'sually a low tree 15-30 ft, in height with a trunk diameter of $6-\delta$ inches, under farorable conditions becoming $50-60 \mathrm{ft}$. high with a trunk diameter of 10-15 inches; with large spreading branches forming an open symmetrical head resembling somewhat the spruce in regularity of outline or on exposed windy situations and in poor soil becoming stunted with gnarled stem and irregular seraggly distorted head.

BIF-Dark reddish-brown with irregular rounded ridges roughened with close scales.

TWIfis-Rather slender, reddish to purplish brown, not downy, roughenel by scales subtending leaf-clusters.

LEAVES-In clusters of 2 , with short persistent sheaths, dark yellowish-green, $1 / 2-1 \frac{1 / 2}{3}$ inches long. stout, stiff, generally curved and tristed, flattened or concave on one side, rounded on the other, tip puinted. MICROSCOPIC SECTION-Showing 2 widely separated fibro-vascular bundles, resin-ducts located intermediate between bundles and periphery, a single layer of strengthening cells around the resinducts and one or more layers beneath the epidermis.

BCDS-Orate, short-pointed, coated more or less thickly with resin.

FRI IT-Cones 1-2 inches long. without stalks, conic-oblong usually curved and pointing formard, appearing between or sometimes at the whorls of lateral branches, more or less distorted. remaining closed for several years, persisting on the tree often for a dozen years. SCALES-in young cones with an incurved prickle, when mature thickened at the apex rithout spines or prickles.

COMPIRISONS-The short yellowish-green needles of the Jack Pine will distinguish this species from other Pines. The longest needles sometimes approach in size short needles of the Scotch Pine, but those of the scotch Pine are of a bluish-green color and moreover their cones point backward instead of forward as in the Jack Pine.

DISTRIH TIOY-Sterile, sandy soil; lowlands, boggy plains, rocky slupes. Nova Scotia, northwesterly to the Athabasca river, and northerly down the Mackenzie to the Arctic circle; west through northern New York, northern Illinois, and Michigan to MIinnesota.

IN NEW ENGLAND-Maine-Traveller Mountain and Grand Lake; Beal's Island on Washington county coast, Harrington, Orland, and Cape Rosier; Schoodic peninsula in Gouldsboro, a forest $30 \mathrm{ft}$, high; Flagstaff; east branch of Penobscot; the Forks; Lake Umbagog; New Iampshire-around the shores of Lake Lmbagog, on points extending into the lake, rare: Welch mountains: Vermont-rare but few trees at each station; Monkton in Addison county; Fairfax, Franklin county; Starkesboro.

IN CONNECTICLT-Not reported.

wooD-Light, soft, not strong. close-grained clear pale brown or rarely orange color with a thick nearly white sapwood; used for fuel and occasionally for railroad ties and posts; occasionally manufactured into lumber. 

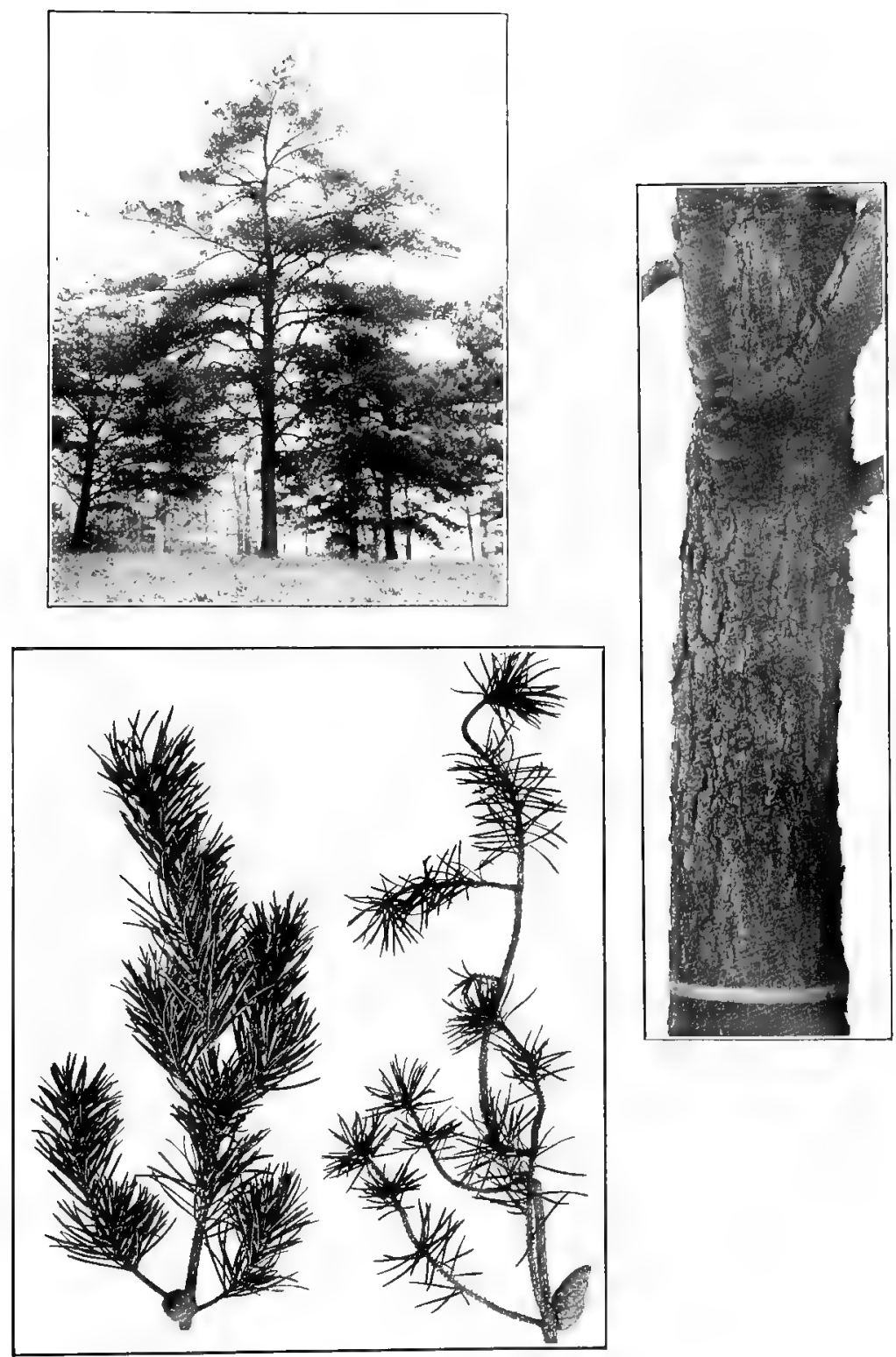

$J_{\text {ACK }}$ PINE 


\section{RED PINE Norway Pine.}

Pinus resinosa Ait.

HABIT-A tree $50-75 \mathrm{ft}$. in height with a trunk diameter of $2-3 \mathrm{ft}$, in Maine, reaching a height of ofer $100 \mathrm{ft}$; trunk erect, continuous into the crown with stout streading branches often dependent and ascending at their tips, more distinctly ${ }^{* h o r l e d ~ t h a n ~ i n ~ t h e ~ P i t c h ~ P i n e, ~ i n ~ y o u n g ~ t r e e s ~}$ clothing the trunk to the ground, furming a broadly pyramidal head becoming irregularly ruund-topped with age. Foliage in long flexible dark green tufts.

BARK-Feddish-brown, with shallow flat ridges, separating off in irregular thin flaky scales.

TWIGs-stout, light reddish brown, not downy, roughened by decurrent scales subtending leaf clusters especially toward base of each year's growth.

LEIVF- In clusters of 2, With long persistent sheaths, dark green, shining, 3-6 inches long, slender, suft, flexible, flattened on one side, rounded on the other, with pointed tip. MICFOSCOPIC SECTION -showing 2 fibro-vascular bundles, peripheral resin-ducts, a single layer of strengthening cells beneath the epidermis and around the resin-ducts, stomata all aruund.

BCDS-Oblong to conical, pointed; scales reddish-brown.

FRUIT-Cones about 2 inches long, without stalks, ovate-conical, when opened more or less spherical, making a right angle with the stem, ripened cones remaining on the tree during winter. SLLILES-thickened at apex but without spines or prickers.

comp.risovs-The Fied Pine with two long needles in a cluster is not to be confused with our native New England Pines, It resembles however, the Austrian Pine, but may be distinguished from this species by its more slender flexible needles (see under Austrian Pine).

DISTRIBITIO $\mathbf{x}$ - In poor soils; sandy plains, dry woods. Newfoundland and New Brunswick, throughout quebee and Ontario, to the southern end of Lake $W^{*}$ innipeg: south to Pennsylvania; west through Michigan and Wisconsin to Minnesota.

IN NETW ENGLAND-MIaine-commnn, plains, Brunswick, (Cumberland county); woods, Bristol (Lincoln county); from Amherst (western part of Hancock county) and Clifton (southeastern part of Fenobscot county) northward just east of the Penobscot river the predominant tree, generally on dry ridges and eskers. but in Greenbush, and Passadunkeag growing abundantly on peat bogs with Black Spruce: hillsides and lower mountains about Mroosehead, scattered: New Hampsire-ranges with the Pitch Pine as far north as the White Mountains, but is less common, usually in grotes of a few to several hundred acres in extent; Fermont-less common than the White or the Pitch Pine, but nut rare; Massachusetts-still more local, in stations widely separated, single trees or small groups; Rhode Island-oceasional.

IN CONNECTICLT-Rare or local; Granby, Salisbury.

wooD-Light, hard, very close-grained, pale red, with thin yellnw often nearly white sapwood; largely used in the construction of bridges and buildings, for piles, masts and spars. The bark is occasionally used for tanning leather. 

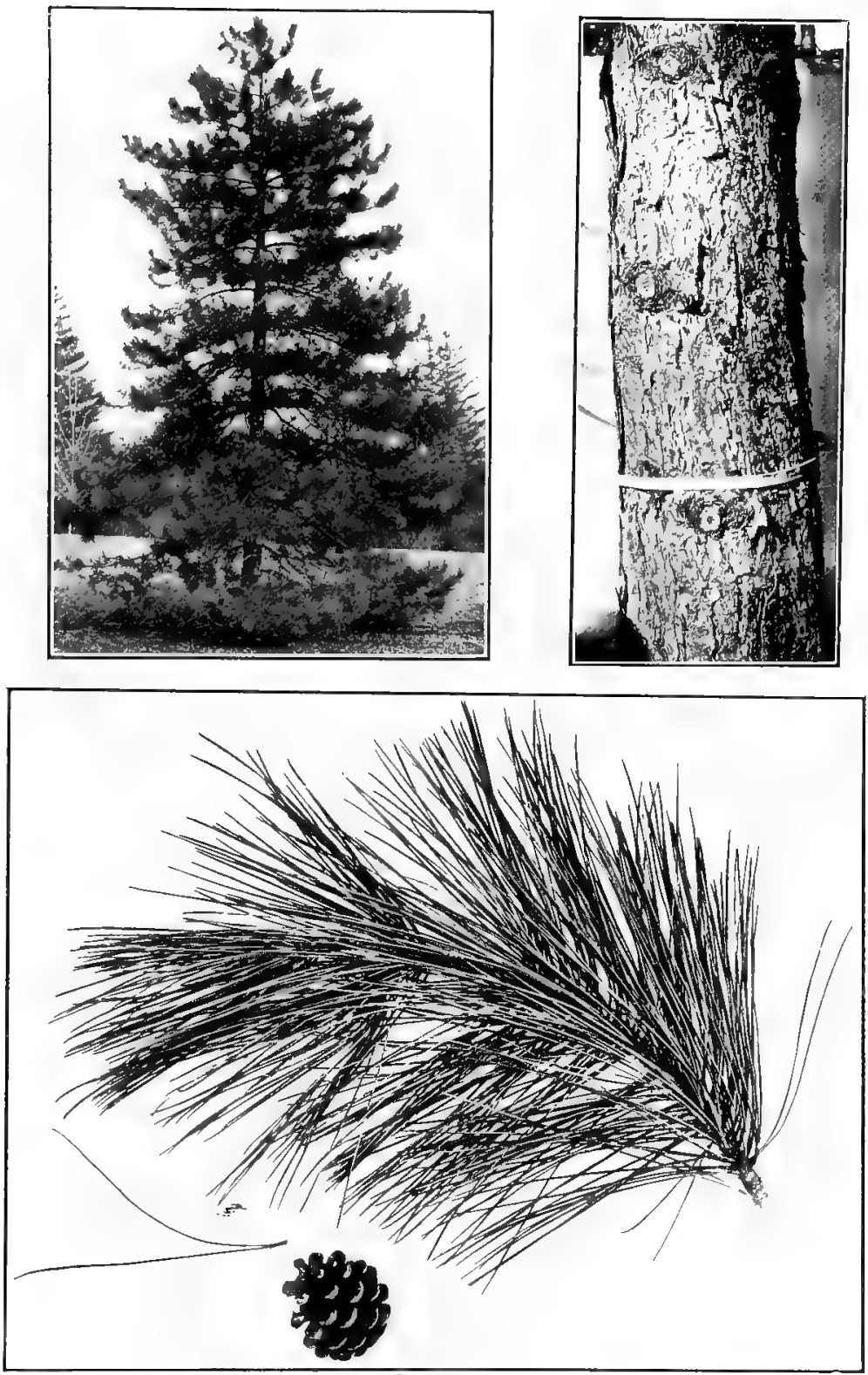

Red Pine 


\section{AUSTRIAN PINE Black Pine. \\ Pinus Laricio, var. austriaca Endl.}

H.ABIT-A tall tree reaching 60-80 ft. in height; trunk erect continuous into the crown, branches in young trees regularly whorled, foliage in rigid dark green tufts.

BıRK-Grayish-brown, roughened with scaly ridges, reddish-brown within.

TWIGS-Stout, yellowish-brown, not downy, roughened by decurrent scales subtending leaf-clusters especially toward base of each year's growth.

LFAVES-In clusters of 2, with relatively short persistent shedths, dark dullish green, 3-5 inches long, rigid, flattened on one side, rounded on the other. sharp-pointed. MICFOSCOPIC SECTION-showing 2 fibro-vascular bundles, resin-ducts located intermediate between bundles and periphery, strengthening cells beneath the epidermis in patches several layers thick also surrounding the resin-ducts and on one side of the fibro-vascular bundles, stomata all around.

BUDS-Oblong-conical, pointed, sometimes covered with a white resin.

FR I IT-Cones $2 \frac{1}{4}-3$ inches Iong, without stalks, ovate-conical, becomIng broadly ovate when opened, making about a right angle with the stem. SCALES-thickened at apex, generally with a short dull spine.

Compinisoxs-The Austrian Pine resembles most closely the Red Pine among our New England snecies. The stiff character of its sharp-pointed leaves in distinction to the soft flexible leaves of the Red Pine may be observed by striking the open hand against a tuft of the needles. The winter twigs of the Austrian Pine are yellowishbrown. those of the Red Pine are bright red. The microscopic sections of the leaves of the two species are very distinct.

DISTRIBI TION-A native of Europe but frequently cultivated in this country as an ornamental tree and to some extent used in forest planting.

woon-Light, soft, rich in turpentine and very durable. In Europe the wood is used as a building timber and turpentine is obtained from the tree. 

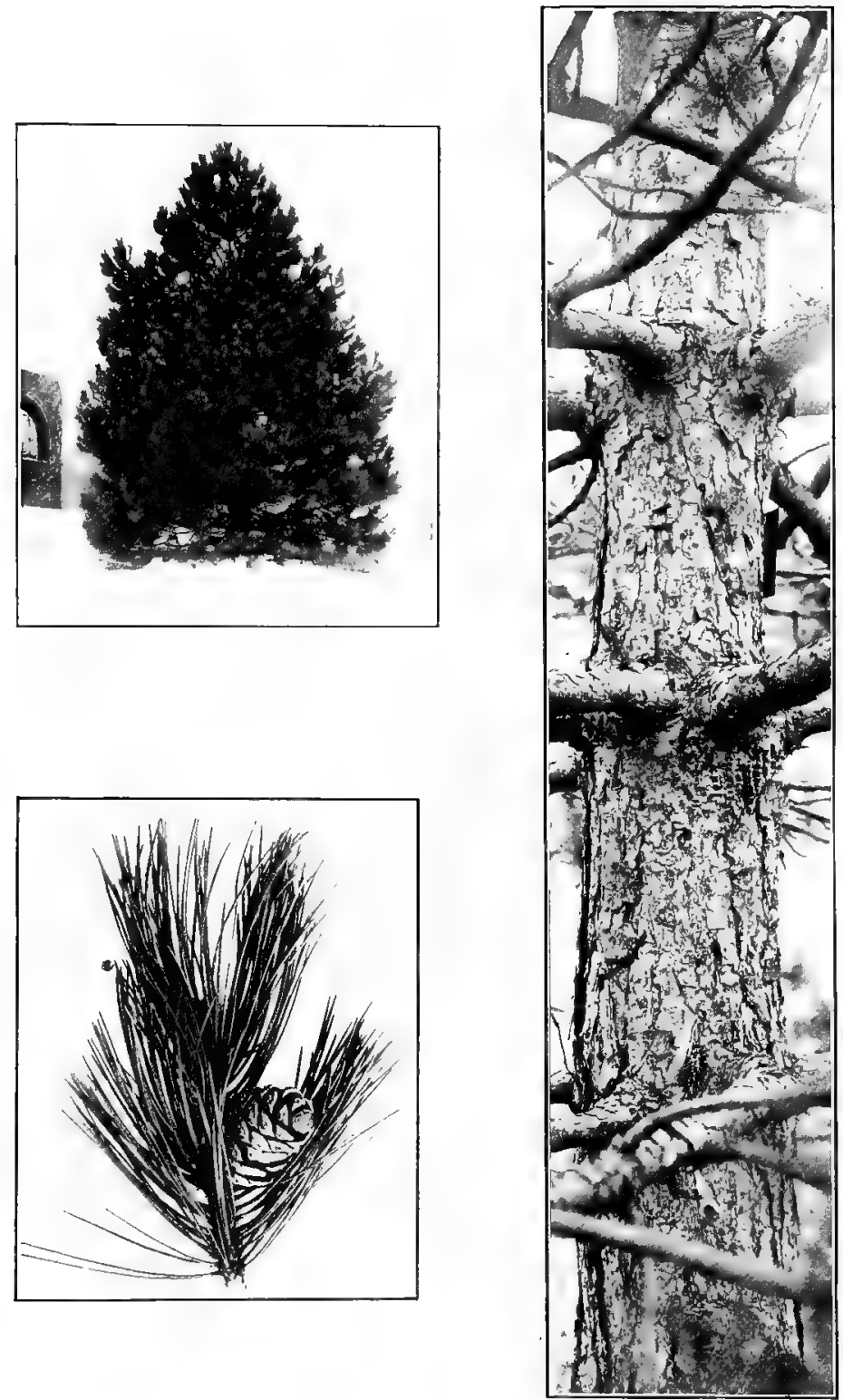

Austrian Pine 


\section{SCOTCH PINE \\ Scotch "Fir."}

Pinus sylvestris $\mathrm{L}$.

HIBYT-A tree up to 70 ft. or occasionally $120 \mathrm{ft}$. in height; as cultirated in this country in the open, often a low branching tree with nore or less pendant limbs and inclined trunk presenting a rather straggling unkempt appearance; frequently of more erect habit, especially in company with other trees.

BNRK-Grayish-brown, scaly, upper part of trunk and branches characteristically smoothish in appearance by flaking off of the outer bark in thin papery light-reddish layered scales.

TWIGs-Of medium thickness, dull grayish-yellow, not downy, roughened by scales subtending leaf clusters.

LEAVES-In clusters of 2, persistent, sheaths becoming lacerated, dull bluish-green $1 \frac{1}{2}-3 \frac{1}{2}$ inches long, stiff, generally twisted, flat or concave on one side, rounded on the other, pointed. MICROSCOPIC SECTION-showing 2 fibro-vascular bundles, peripheral resin-ducts, strengthening cells around resin-ducts, at one side of the bundles and beneath the epidermis, stomata all around.

BCUS-Oblong-conical, brown, often somewhat resinous-coated.

FRIIT-Cones 11/2-21/2 inches long, short-stalked, grayish or reddish brown, conic-oblong, generally appearing with the whorls of lateral branches, usually pointing backward. SCALES-in young cones with a short projection which when mature may persist as a short weak inconspicuous point or is deciduous, apex of scale thickened with a more or less prominent four-sided boss often recurved especially toward base of cone.

COMPARISONs-The Scotch Pine often Improperly called Scotch "Fir" may be distinguished from the other Pines native or cultivated in New England by the bald reddish appearance of the upper part of trunk and branches, the short bluish-green leaves and the backward-pointing cones.

DISTRIBCTION-A European tree cultivated abroad in extensive forests for its timber. In this country more or less planted as an ornamental tree, and sparingly escaped from cultivation. In Connecticut rare or local as an escape; New London, Lyme, Southington, Bridgeport.

wOOD-Light, soft, reddish-brown with thick light yellowish or reddish sapwood, easily split and durable, corresponding in importance abroad to the White Pine in this country. 

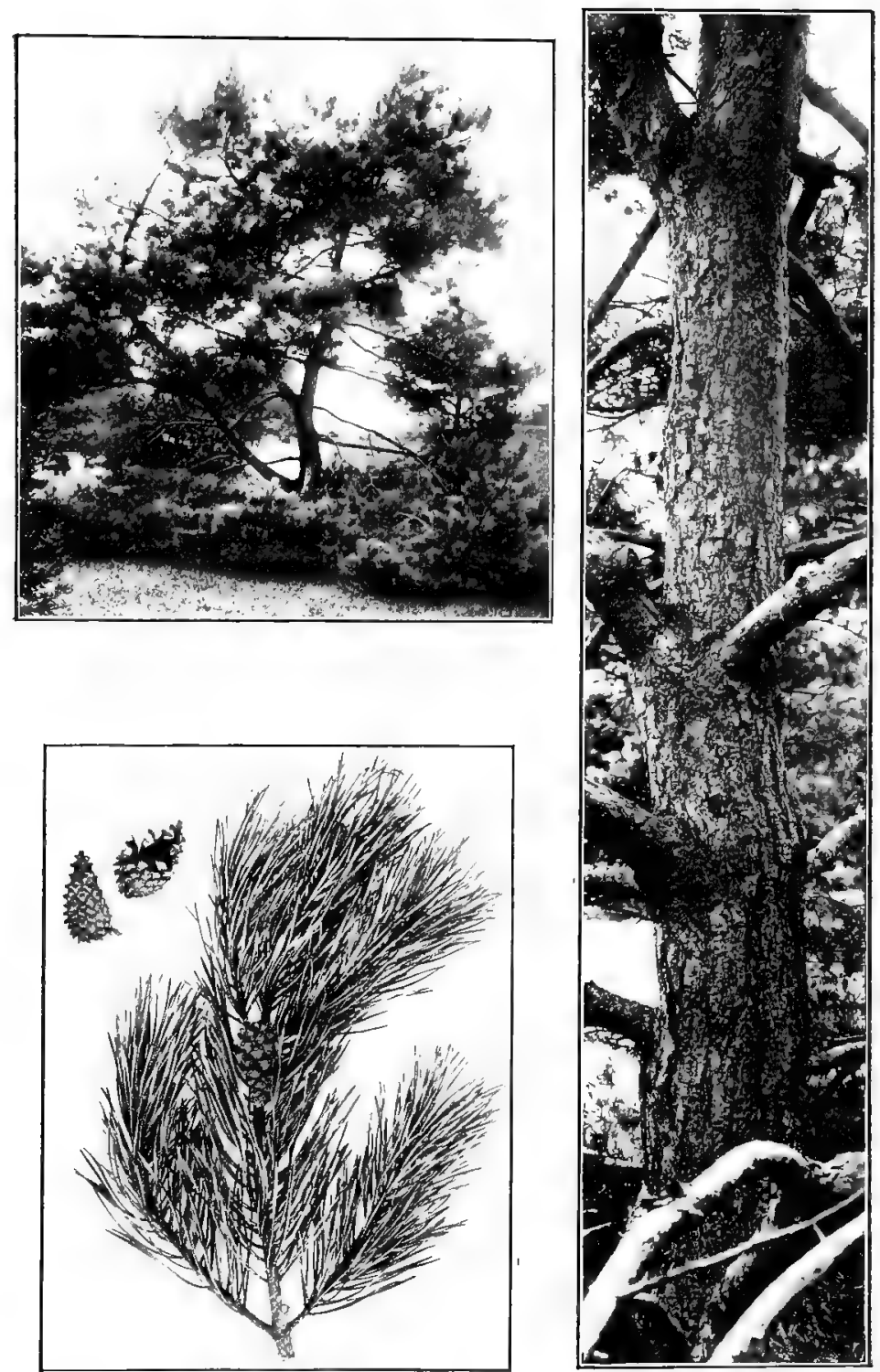

Scotch Pine 


\section{AMERICAN LARCH \\ Tamarack, Hackmatack, Black Larch, "Juniper." Larix laricina (Du Roi) Koch.}

L. anericana $\mathrm{Mich} \mathbf{x}$.

HARIT-A tree $30-70 \mathrm{ft}$. in height, with a trunk diameter of 1-3 ft., at high altitudes reduced to $1-2 \mathrm{ft}$. in height: trunk erect continuous into the crown, branches irregular or indistinctly whorled, in young age and when crowded and in swamps forming a narrow symmetrical pyramidal head, in old age becoming broader and of irregular form. The Larch is the only New England cone-bearing tree that sheds its leaves in the fall; specimens in winter consequently are frequently mistaken for dead trees.

BIRK-On young trunks smooth. With age becoming roughened with thin, close, reddish-brown, roundish scales,

TWras-Slender, smooth, pale orange colored to reddish-brown with short lateral wart-like branches, with resinous taste.

LFIF-sCIRS-Scattered on rapidly grown shoots, very numerous and strongly decurrent, minute, triangular, with a single bundle-scar; also on shurt wart-like branches, smaller and densely clustered.

BCDS-Scattered along last season's twigs, on older growth at the ends of the short lateral branches, small, about $1 \mathrm{~mm}$ long, spherical, reddish, shining.

FRI IT-Orate, oblong cones, about $1 / 2-3 / 4$ inch long on short, stout, incurved stalks, persistent on trees throughout winter. SCALES-thin, about a dozen or fewer in number.

COMPIRIsoxs-The American Larch or Tamarack as it is more commonly called by woodsmen is hardly to be confused with any other tree except the European Larch [Larix decidua Mill, $L$. europaea DC.]. The European Larch is a species adapted to dryer situations than the American form. It is readily distinguished by its stouter, yellower twigs. larger cones, about 1 inch long, with numerous cone scales (see lower twig in plate).

DISTRIBITION-Low lands, shaded hillsides, borders of ponds; in New England preferring cold swamps; sometimes far up mountain slopes. Labrador. Newfoundland, and Nova Scotia, west to the Rocky mountains; from the Rockies through British columbia, northward along the Yukon and Mackenzie systems, to the limit of tree growth beyond the Arctic circle: south along the mountains to New Jersey and Pennsylvania; west to Minnesota.

IN NEW ENGLAND-Maine, New Hampshire and Vermont-abundant, filling swamps acres in extent, alone or associated with other trees, mostly Black Spruce: growing depressed and scattered on Katahdin at an altitude of $4,000 \mathrm{ft}$.; Massachusetts-rather common at least northward; Rhode Island-not reported.

IN CONNECTICUT-Absent near the coast; rare in the eastern part of the state; Union. Tolland; becoming occasional westward and frequent in Litchfield county.

WoOD-Very heavy, hard and strong, rather coarse-grained, very durable in contact with soil, bright light red with thin nearly white sapwood; largely used for the upper knees of small vessels, fence posts, telegraph poles, railroad ties, in cabinet making and for interior finish of buildings. 

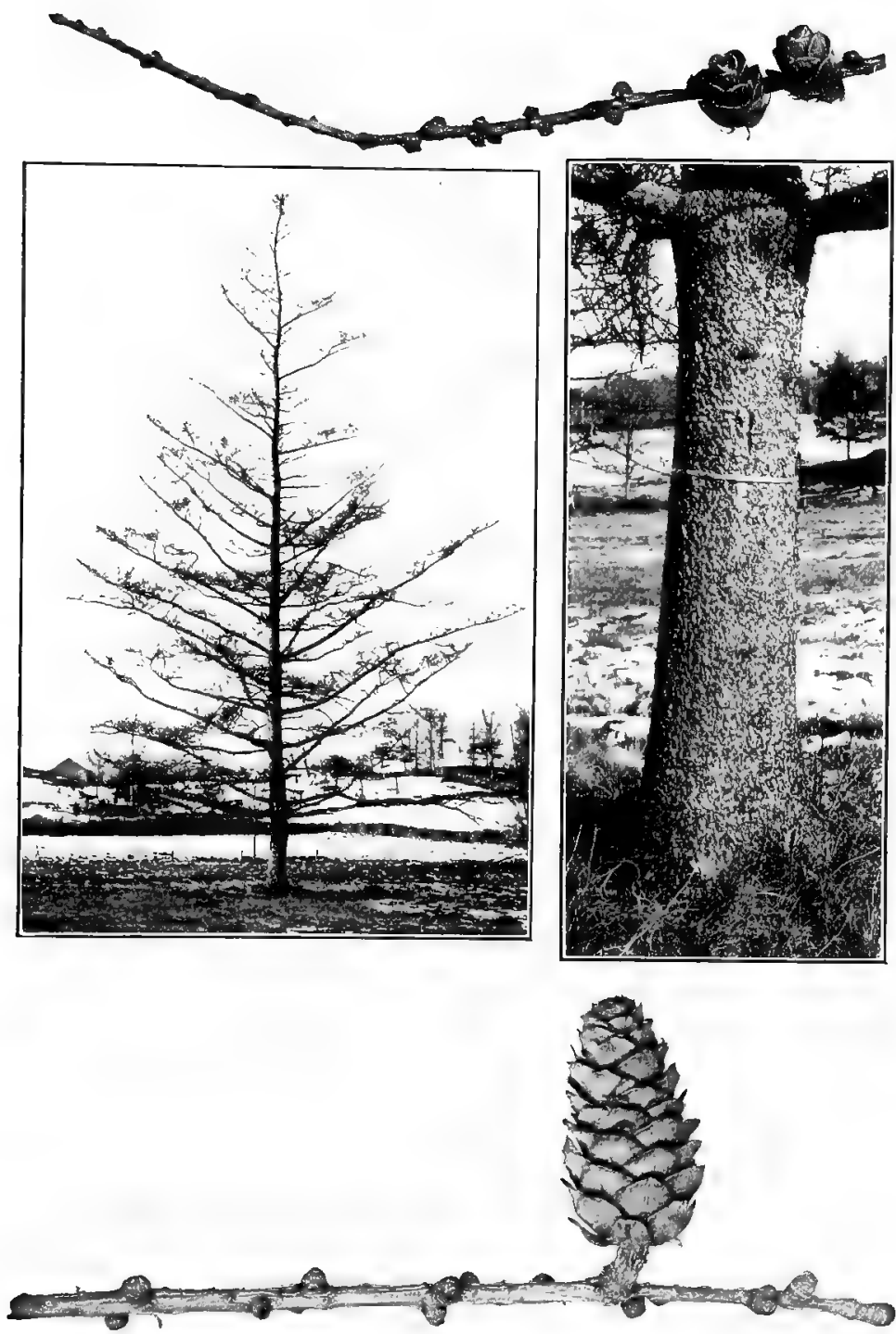

American Larcil

Furopean Larch (lower twig only) 


\section{WHITE SPRUCE \\ Cat, Skunk or Labrador Spruce. Picea canadensis (Mill.) BSP. \\ P. alba Link.}

H.IIT-A tree 40-55 feet in height with a trunk diameter of $1-2 \mathrm{ft}$; trunk straight, slowly tapering, branches numerous, slightly ascending or nearly horizontal. with numerous lateral, generally somewhat pendant branchlets, spread in more or less well marked dense planes, forming a broad-based pyramidal head; foliage bluish-green.

BARK-Grayish to pale reddish-brown; on young trunks and branches smoothish or slightly roughened becoming in a relatively late stage flaky with small closely appressed scales.

TWIGS-Light, yellowish-brown, smooth.

LEAF-SCARS-Alternate, more than 2-ranked, on strongly projecting, decurrent ridges of the bark. BLNDLE-SCARS-single.

LEAVES-Bluish-green, 4-angled, 10-25 $\mathrm{mm}$. long, blunt or sharppointed, straight or incurved, without proper leaf-stalks with a strong rank odor when bruised which is respunsible for some of the common nanies.

BIDS-Orate, blunt-pointed, light brown.

FRIIT-Oblong-cylindrical cones, 11/2-21/2 inches long, generally falling the first winter. SCALES-thin, flexible and elastic; margin rounded or straight-topped, generally entire.

Comp.IRIsoys-The Thite Spruce differs from our other native Spruces, the Red and the Black, by its smooth twigs, less scaly bark, rather longer and mure nearly cylindrical cones and usually by the rank odor of its leares; from the fied Spruce further by its biuishgreen foliage. From the smooth-twigged Blue Spruce it is distinguished by its smaller cones and less distinctly layered arrangement of branches.

DISTRIBC TION-Low, damp, but not wet woods; dry, sandy soils, high, rocky slopes and exposed hillops, often in scanty soil. Newfoundland and Nora Scotia, through the provinces of Quebec and Ontario to Manitoba and British Columbia, northward beyond all other trees. within 20 miles of the Arctic sea; west through the northern sections of the northern tier of states to the Rocky mountains. Sometimes cultivated as an ornamental tree.

IN NEW ENGLAND-Maine-frequent in sandy soils, often more common than the Fed spruce, as far south as the shores of Casco bay; New Hampshire-abundant around the shores of the Connecticut river, disappearing southward at Fifteen-sile falls; Termont-restricted mainly to the nurthern sections, more commun in the northeast; Massachusettsoccasional in the mountainous regions of Berkshire county: a few trees in Hancock; as far soutl as imherst, and Northampton, probably about the southern limit of the species; Rhode Island-not reported.

IN CONNECTICLT-Rare. Waterford, a few trees in a pasture as an escape from cultivation.

wOOD-Light, snft, not strong, stralght-grained, light yellow, with hardiy distinguishable sapwood; manufactured into lumber in the eastern provinces of Canada and used in construction for the interior finish of bulldings and fur paper pulp. 

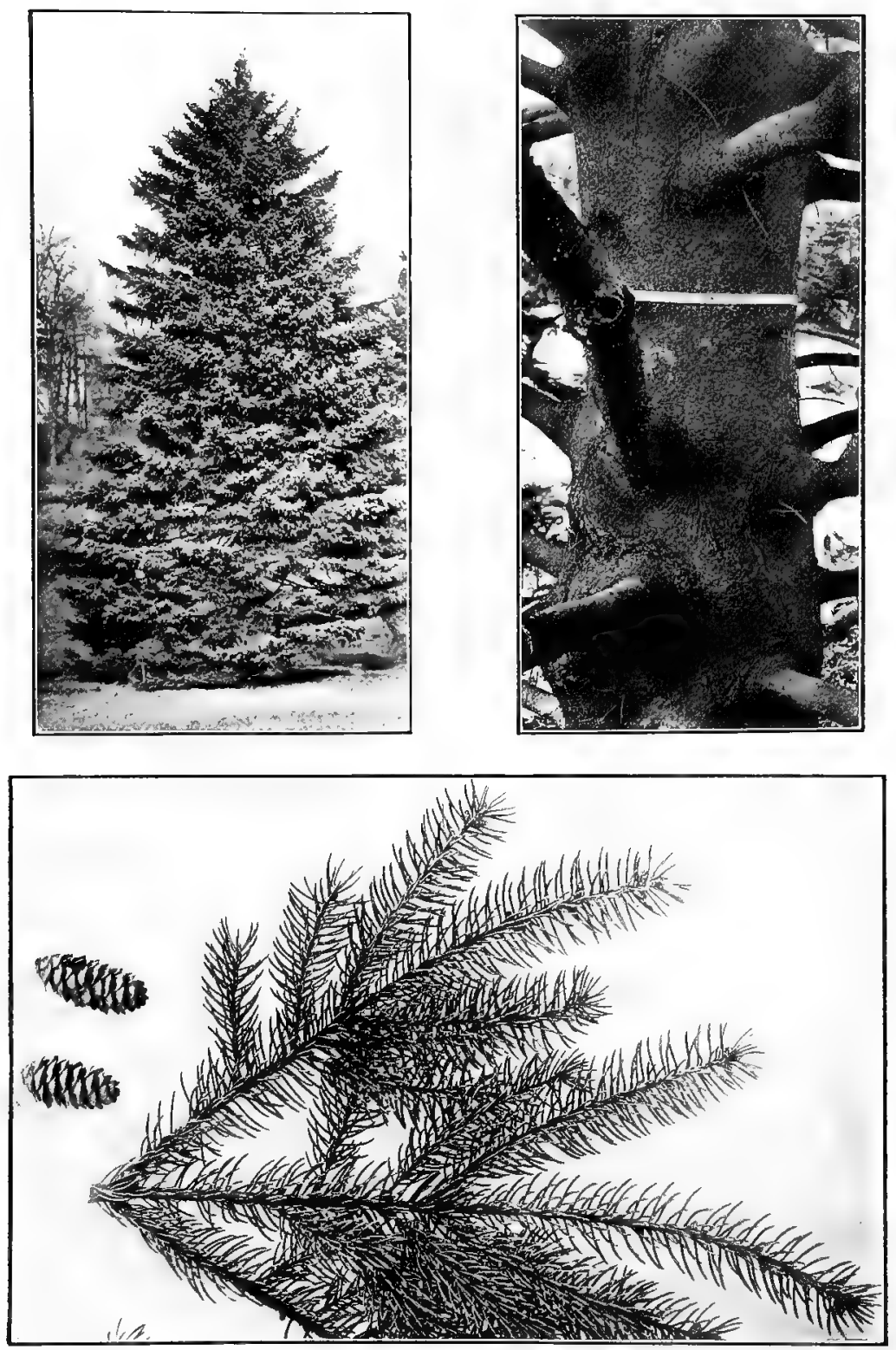

Winite Spruce 


\title{
RED SPRUCE
}

\author{
Picea rubra (Du Roi) Dietr. \\ P. nigra, rar. rubra Engelm. ; P. rubens Sarg.
}

H ABIT-A tree $40-75 \mathrm{ft}$. in height with a trunk diameter of 1-21/2 ft.: trunk straight, slowly tapering; branches toward the middle of the tree horizontal with upward tips, more or less strongly declined toward the base forming a narrow conical head somewhat broader than that of the Black Spruce; foliage dark yellowish-green.

B.ARK-Reddish-brown, flaky with thin scales.

TwIGS-Brown, more or less densely covered with short rusty to black hairs.

LEAF-SCARS-Aiternate, more than 2-ranked, on strongly projecting decurrent ridges of the bark. BUNDLE-SCARS-single.

LEAVES-Dark yellowish-green, 4-angled, 10-20 $\mathrm{mm}$, long, bluntpointed, straight or curved, without proper leaf-stalks.

BIDS-Ovate, pointed, reddish-brown.

FRI IT-Orate-oblong cones, 11/4-2 inches long, with short stalks not at all or but slightly recurved, falling the first autumn or sometimes remaining on the tree a year longer. SCALES-stiff, thin; margin ruunded, entire or slightly toothed.

CoMp IRIsons-The Red Spruce from its close resemblance to the Black spruce is considered by some authors as merely a variety of this latter species (see Black Spruce under Comparisons). It differs from the White and the Blue Spruce by its hairy twigs and yellowish-green fuliage and from the Norway Spruce by its shorter cones.

DISTRIBCTIOX-Cool, rich woods, well-drained ralless. slopes of mountains not infrequently extending down to the borders of swamps. Prince Edward Island and Nova Scotia along the valley of the St. Lawrence; south along the Alleghanies to Georgia. ascending to an altitude of 4.500 feet in the Adirondacks, and $4.000-5,000$ feet in West Virginia; west through the northern tier of states to Minnesota.

IN NET ENGLAND-Maine-throughout; most common towards the coast and in the extreme north, thus forming a belt around the central area. where it is often quite wanting except on cool or elevated slopes; New Hampshire-throughout; the most abundant conifer of upper Cuos, the White Anuntain region where it climbs to the alpine area, and the higher parts of the Connecticut-Merrimac watershed; Vermont -throughout; the common spruce of the Green mountains, often in dense groves on rocky slopes with thin soil; Massachusetts-common in the mountainous regions of Berkshire county and on uplands in the northern sections, occasional southward; Rhode Island-not reported.

IN CONNECTICUT-Rare. Litchfield. Canaan, Salisbury.

woon-Light, soft, close-grained, not strong, pale, slightly tinged with red, with paler sapwood generally about 2 inches thick; largely manufactured into lumber in the northeastern states and used for the flooring and construction of houses, for the sounding-boards of musical instruments and in the manufacture of paper pulp. 

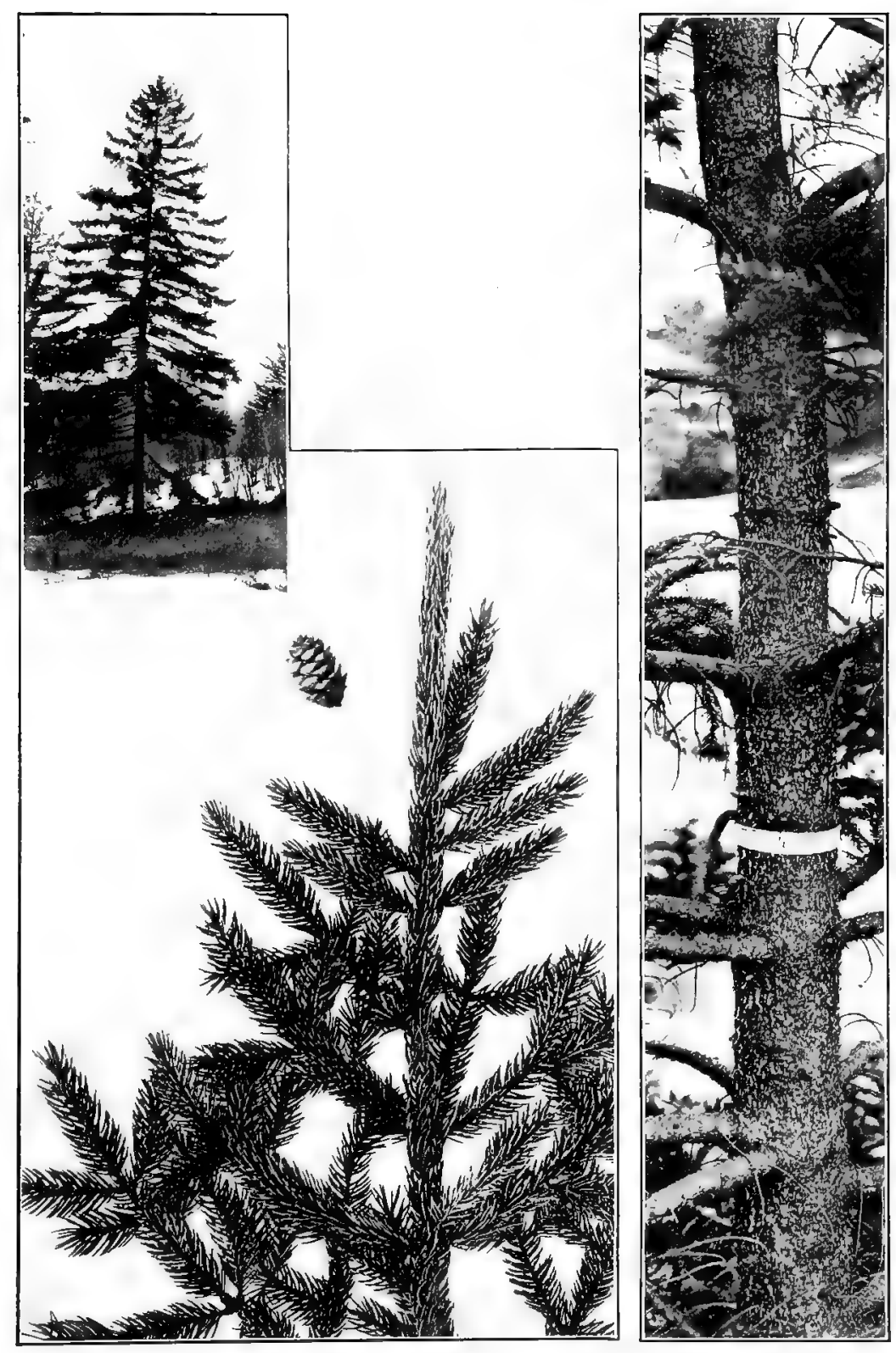

Red Spruce 


\section{BLACK SPRUCE \\ Swamp, Bog, Water or Double Spruce. \\ Picea mariana (Mill.) BSP. \\ $P$. nigra Link; P. brerifolia Peck.}

HIBIT-In New England usually a small slender tree $10-30$ ft. in height with a trunk diameter of $5-\delta$ inches, much larger northward and westward, reduced to a shrub $2-5$ ft. in height at high altitudes; with relatively short, generally scattered branches, horizontal or usually declined and curring upward at the ends; in open-grown trees, basal branclies frequently resting on the ground, taking root and sending up shoots; crown an irregular open narrow-based cone; foliage bluishgreen.

BIRK-Grayish-brown, flaky. With thin scales.

TWIGs-Brown or yellowish-brown, more or less densely covered with short rusty to black hairs.

LEAF-SC、RS-Alternate, more than 2-ranked on strongly projecting decurrent ridges of the bark. BUNDLE-SCARS-single.

LEAVES-Bluish-green, 4-angled, 5-15 mm. long, blunt-pointed, straight or slightly incurved, without proper leaf-stalks.

BLDS-Ovate, pointed, reddish-brown.

FRIIT-Ovate cones, $1 / 2$ to $1 \frac{1 / 2}{2}$ inches long becoming nearly spherical when open, on short strongly recurved stalks generally remaining on the tree for many years. SCALES-stiff, thin; margin rounded, uneven, ragged, toothed or rarely entire.

COMP.RIsoNs-The Black Spruce closely resembles the Red Spruce from which it may be distinguished by its shorter, more nearly spherical cones which generally remain for many years on the tree, by the more ragged edging of the cone-scales, by the bluish-green color of its foliage and by its habitat in swampy land. Extreme forms of the two species are sufficiently distinct but they are often difficult to distinguish even in the fruiting condition.

DISTRIIITIOX-Swamps, sphagnum bogs, shores of rivers and ponds, wet, rocky hillsides; not uncommon, especially northward, on dry uplands and mountain slopes. Labrador. Newfoundland, and Nova. Scotia, westward beyond the Focky mountains, extending northward along the tributaries of the Iukon in Alaska.

IN NEW ENGLAND-Maine-common throughout, covering extensive areas almost to the exclusion of other trees in the central and northern sections, occasional on the top of Katahdin $(5.215 \mathrm{ft}$.); New Hampshire and Termont -common in sphagnum swamps of low and high altitudes: the dwarf form. var. semiprostrata, occurs on the summit of Mt. Mansfield; Massachusetts-frequent; Rhode Island-not reported.

IN CONNECTTCET-SWamps and sphagnum bogs. Rare or local over most of the state but absent near the coast. Usually a small stunted tree 5 to $1.1 \mathrm{ft}$. high but growing much larger in the cool swamps of Litehfield county. In open bogs the trees often produce cones when not more than $5 \mathrm{ft}$. high, and the cones persist on the tree for many years.

WOOD-Light. soft, not strong, pale yellowish-white, with thin sapwood probably rarely used outside of Manitoba and Saskatchewan except in the manufarture of paper pulp. Spruce gum is gathered from this and the other New England spruces. Spruce beer is made by boiling the branches of the Black and Fied spruces. 


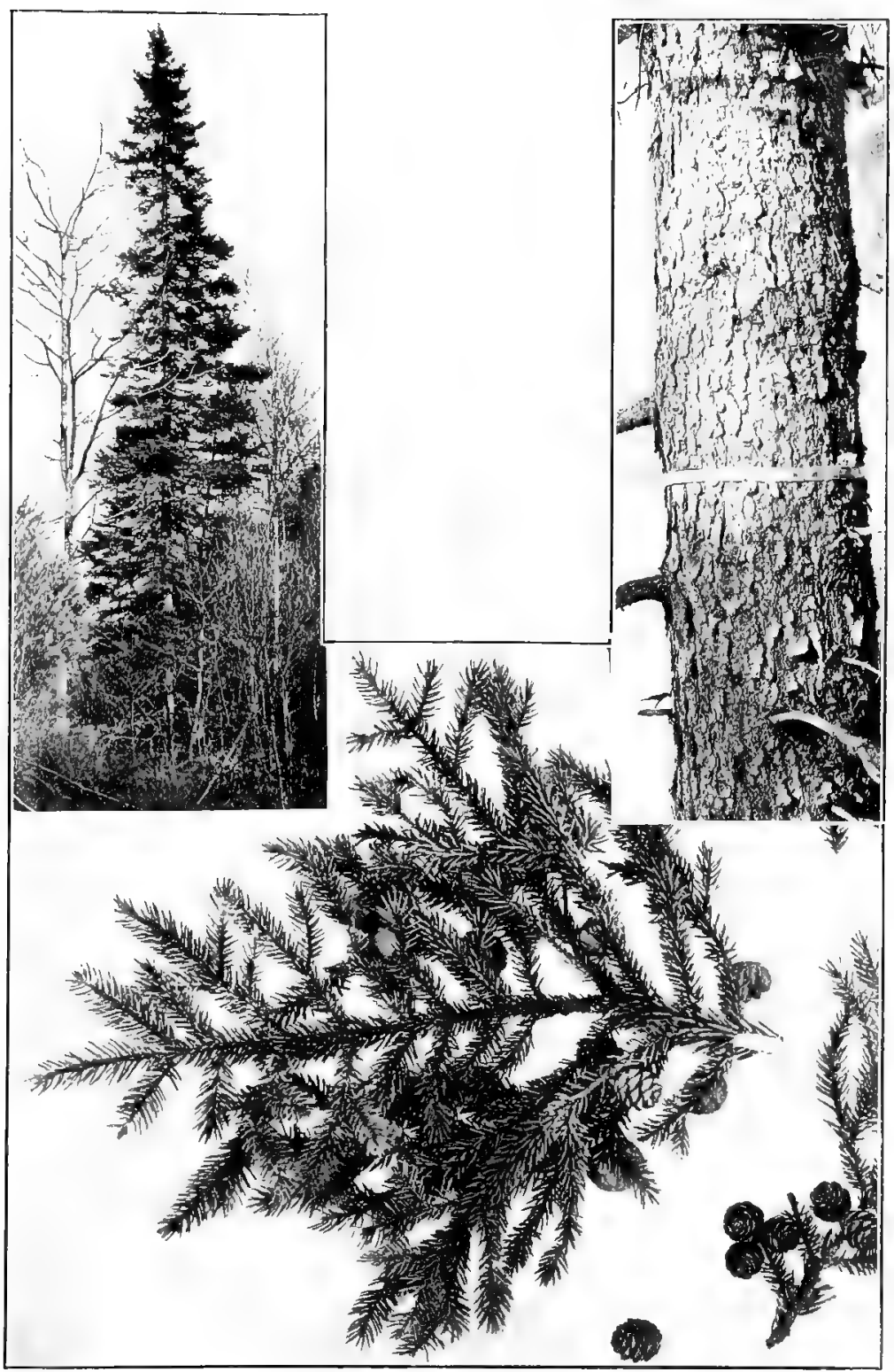

Black Spruce 


\section{BLUE SPRUCE \\ Colorado Blue Spruce, Silver Spruce. \\ Picea Menziesii Engelm. \\ P. Paryana (Andre) Sarg.; P. pungens Engelm.}

HAHT-A tree reaching in Colnrado a height of $100 \mathrm{ft}$, and a trunk diameter uf -3 ft. much smaller in cullitation; branches rigid, horizontal with short, stout, stiff, lateral branchlets arranged in horizontal planes giving a layered effect to the tree, especially in the young stages; older trees becoming less regular with a thin. ragged, pyramidal crown; foliage bluish-green to silvery-white or rarely dull green.

B IRk-Grayish-brown. scaly beconing deeply ridged toward the base.

TW IGs-Bright gellowish to reddish-brown, smooth.

LEAF-SCARS-Alternate, more than 2-ranked, on strongly projecting decurrent ridges of the bark. BUNDLE-SCARS-single.

LEAVES-Bluish-green to silvery-white or rarely dull green, 4-angled, 25-30 mm. long on sterile branches, often not over half as long on fruiting branches, stout, stiff, sharp-pointed, incurved, without proper leaf-stalks, with a pungent somewhat disagreeable odor when bruised.

BCDS-Ovate, blunt-pointed, light brown.

FRIIT-Oblong-cylintrical cones $2 \frac{1}{2}$ to $t$ inches long, generally not remaining on the tree after the second winter. SCALES - thin, distinctly longer than broad with narrowed, flexible, ragged, blunt tips.

COMp ARISoxs-The Blue spruce as cultivated as an ornamental tree is strikingly distinct from other Spruces in its bluish-green or silvery foliage and the horizontally layered arrangement of its branchlets. The long stiff sharp-pointed needles and the narrowed elongated scales of the large cones are further characteristic.

DISTHIBITIOx- Along or near streams. Colorado and eastern Utah, northward to the Tind River mountains of Wyoming. Often planted as an ornamental tree in the eastern and northern states and also in Europe, especially individuals with blue foliage.

wood-Light, soft, clnse-grained, weak. pale brown, or often nearly white with hardy distinguishable sapwood. 

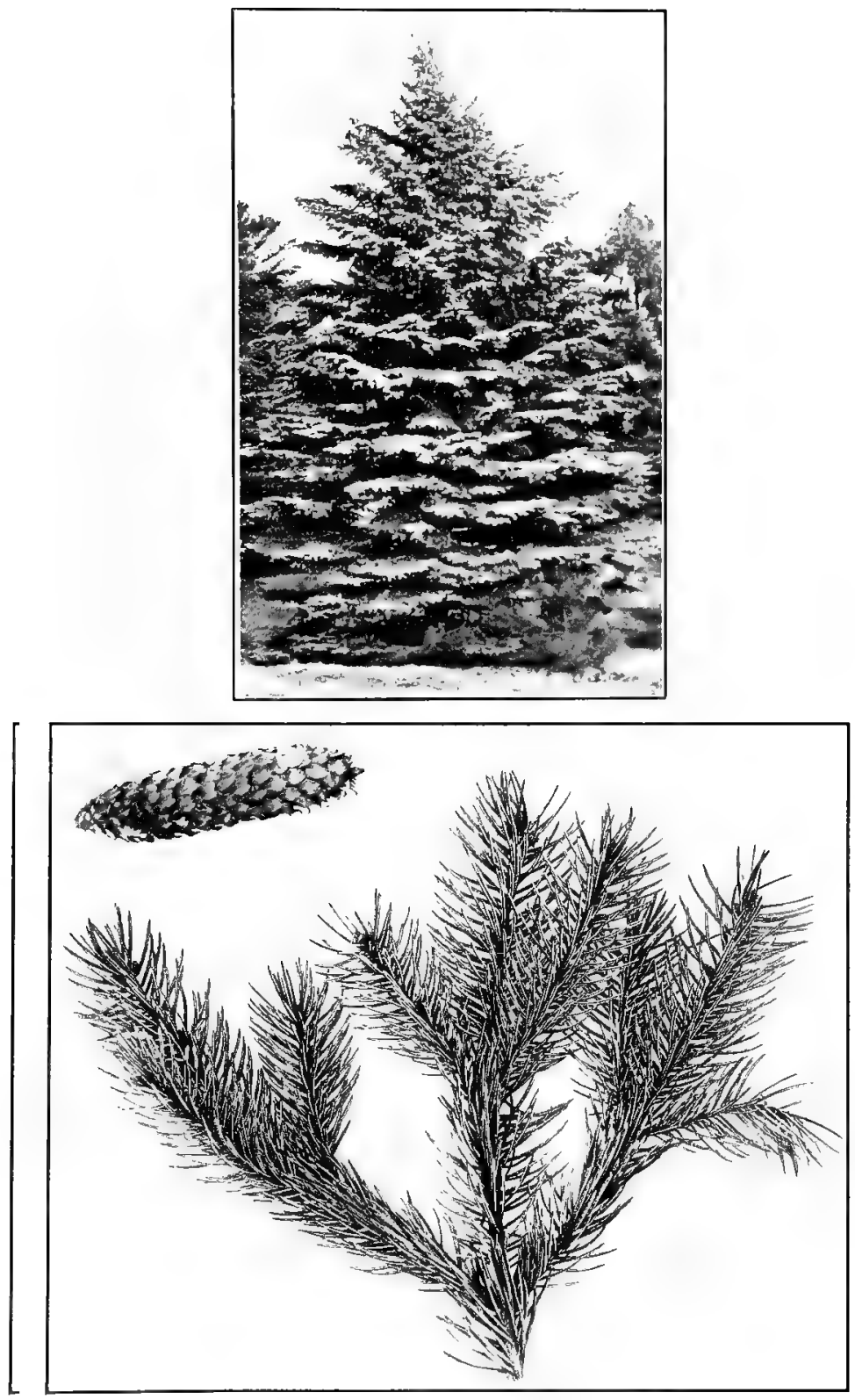

Bute Spruce 


\title{
NORWAY SPRUCE
}

\author{
Picea Abies (L.) Karst. \\ $P$. excelsa Link.
}

HIBIT-A large rapidly growing tree, $50-100 \mathrm{ft}$. or more in height with a trunk diameter up to $2 \mathrm{ft}$.; with spreading horizontal or ascending branches and in mature trees generally with strongly drooping lateral branchlets, forming a rather broad pyramidal head; foliage dark green. The tree usually has a single erect trunk continuous into the crown but although the tree photographed shows a double stem it is typical in general outline.

BARI-Feddish-brown, on young trunks and branches smoothish with very fine flaky scales becoming with age roughened with larger thicker flaky scales.

TWIGS-Bromn, smooth or hairy.

LEAF-SCARS-Alternate, more than 2-ranked, on strongly projecting decurrent ridges of the bark.

LEAVE-Dark green and usually shining, 4-angled, 15-25 mm. Iong, sharp-pointed, without proper leaf-stalks.

BLDS-Ovate, pointed, light brown.

FRI IT-Cylindrical-oblong. pendant cones, 4-7 inches long, light reddish-brown, falling after the first winter. SCALES-thin, stiff. generally broader than long, margin more or less irregular and finely toothed.

COMP.AISONS-The large cones form the most distinctive character of the Norway Spruce, and when present easily separate this species from all others with which it might be confused. The pendant lateral branches generally strikingly noticeable on the older trees together with the vigor of growth furnish good habit characters of distinction.

OISTRIBI TION-A large tree of Europe especially abundant in Norway: largely cultirated in this country as ornamental individual trees, in hedges and for windbreaks.

WoOD-Light, soft, close-grained, reddish to yellowish-white; used for spars, oars and masts to small vessels. 

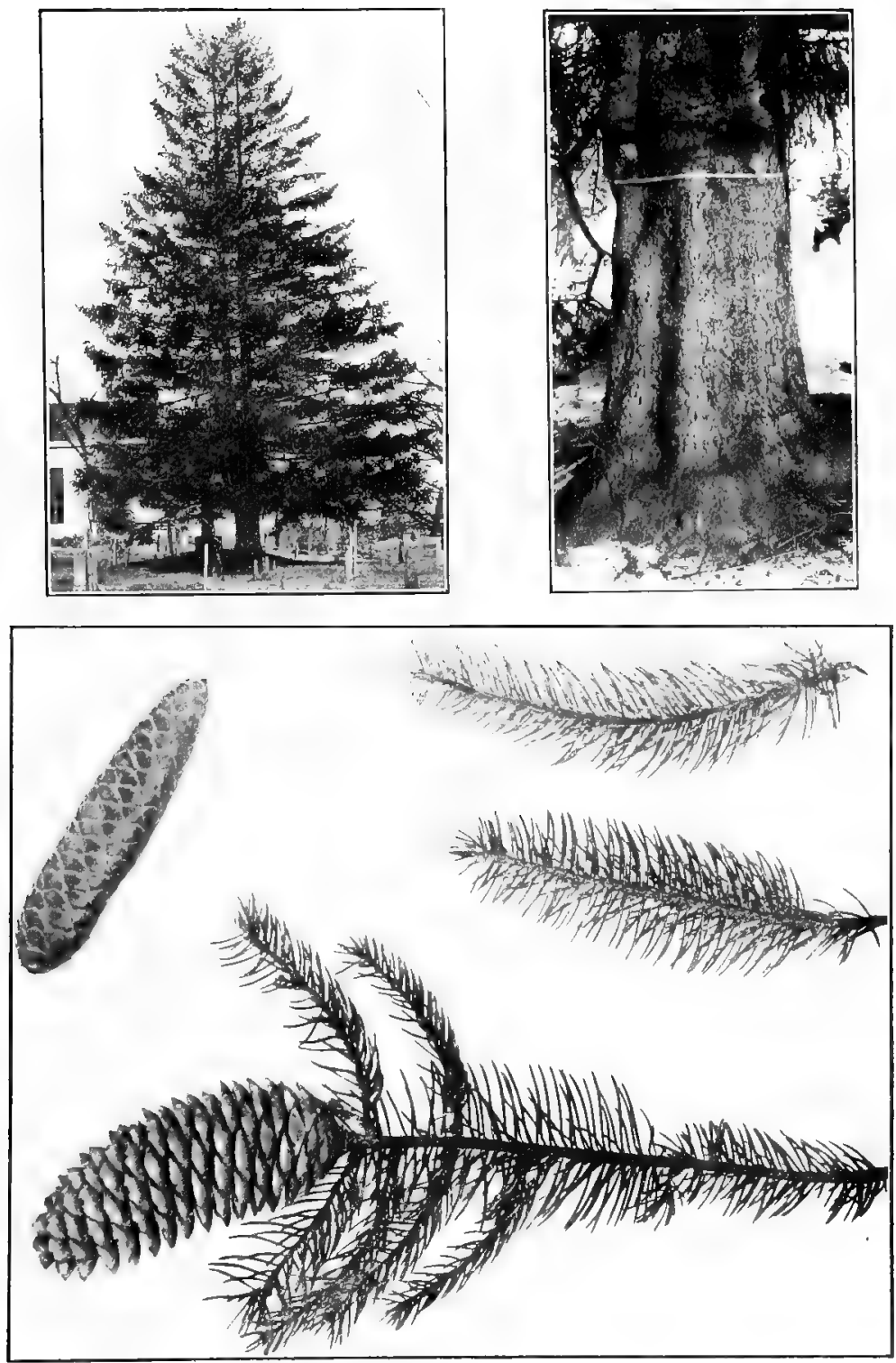

NoRWhy SIRLCE 


\section{DOUGLAS FIR Red Fir, Douglas Spruce. \\ Pseudotsuga taxifolia (Lam.) Britton. \\ P. mucronata (Raf.) Sudw.; P. Douglasii (Lind1.) Carr.}

H.NB'T-A tree under favorable conditions in the west reaching a height of $200 \mathrm{ft}$. wr over and a trunk diameter up to 10 or $12 \mathbf{f t}$; branches horizontal with more or less pendulous branchlets forming a pyramidal head. A number of varieties are in cultivation varying somewhat in habit and color of foliage.

B WRK-On young trunks dark gray, smooth, with few resin blisters, soon becoming roughened, with reddish-brown scales and eventually deeply ridged.

Twis-Reddish to yellowish-brown, more or less downy, becoming with age smooth and dark grayish-brown. Photograph of twig is about 1,3 natural size.

LEMIS-Scattered, sometimes appearing somewhat 2-ranked but less distinctly so than leares of the Balsam Fir, dark green above, pale below with grayish lines of minute dots, flattened, generally blunt, $z_{4}$ inch or more long. slightly narrowed at base but not distinctly stalked, arising at about a right angle to the $t$ wig and leaving in falling a round sear slightly raised at the base, and slightly fragrant and aromatic when crushed. MICROSCOPIC SECTION-showing a single fibrovascular bundle, 2 resin-ducts next to the epidermis, strengthening cells beneath the epidermis and generally around the resin-ducts, giant thick walled irregularly lobed cells frequently appearing in crosssections of the leaf un either side of the bundle, stomata on the under side.

BIDS-Comparatively large, narrowly ovate to conical, sharp pointed, reddish.brown, $i-1$ ․ $\mathrm{mm}$. lung, lonsely clustered at tips of twigs; budscales not resinous-cuated, often with reflexed tips.

FRI I'T-A cone maturing in one season, pendant, stalked, $2-4 \frac{1 / 3}{3}$ inches long. SCALES-persistent, rounded on edges with conspicuous protruding bracts which are long-pointed and laterally winged like the feathering on an arrow.

Compirisoxs-The Douglas Fir resembles the Balsam Fir but may be readily distinguished by its large dark bruwn buds, free from resin, by the slightly projecting leaf-scars and especially by the cones with persistent scales and lobed bracts. Further a thin knife section held toward the light and looked at with a hand-lens shows the two resin-ducts on the edge of the leaf while those of the Balsam Fir are located between the edge and the bundle.

DISTRIBITION-Throughout the Rocky mountain system south of latitudes 55 degrees north to the Pacific coast, forming extensive forests. Planted for ornament in the eastern states where, however, only plants grown from seed obtained from the interior of the continent are successful.

wooD-Light red or yellow, with nearly white sapwood, very variable in density, quality and in the thickness of the sapwood: largely manufactured into lumber in British Columbia, western WashIngton and Oregon and used for all kinds of construction, fuel, railroad ties and piles. The bark is sometimes used in tanning leather. 

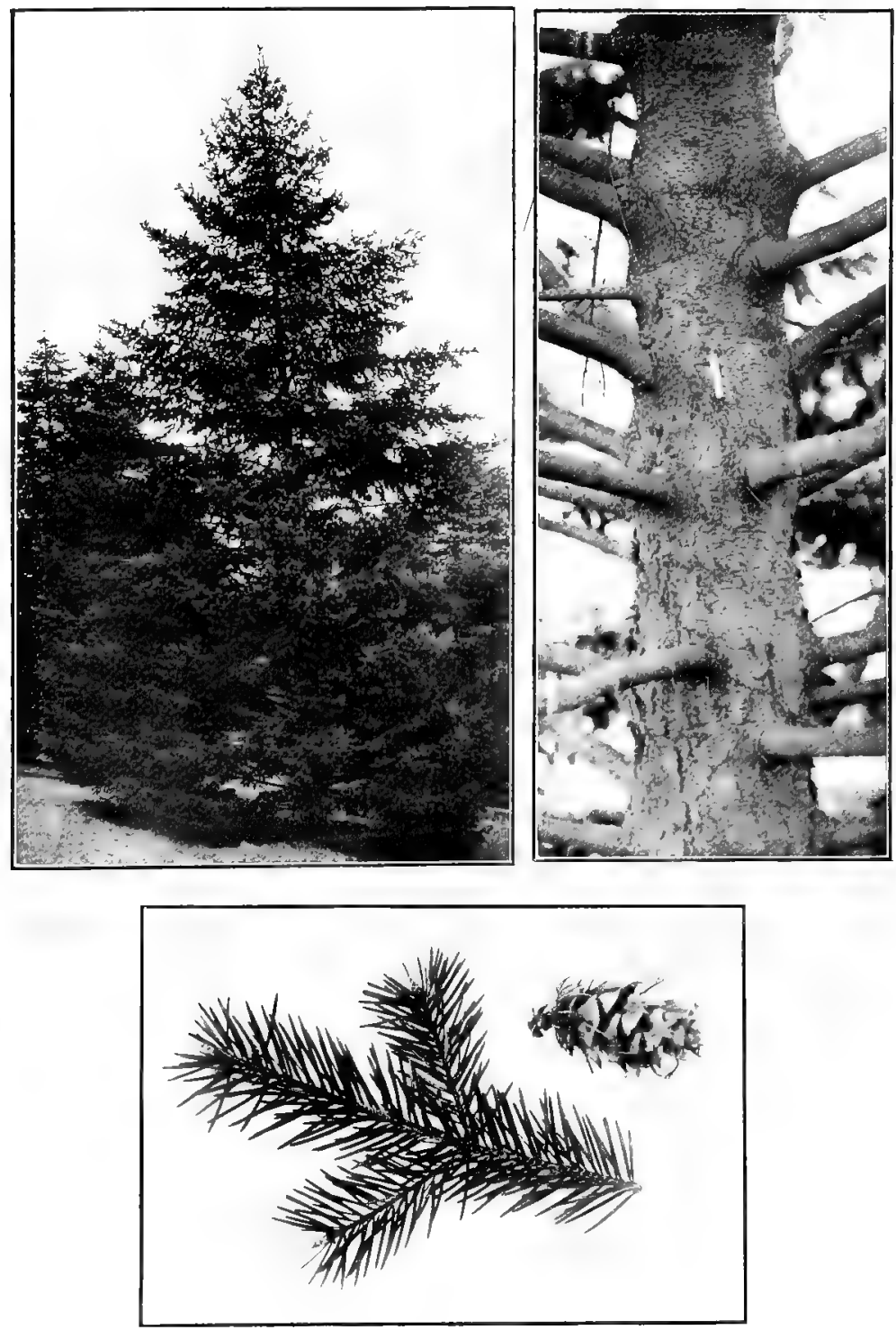

DOUGLAS Fir 


\section{BALSAM FIR Balsam, Fir, Balm of Gilead Fir.}

Abies balsamea (L.) Mill.

HABIT-A medium sized tree, 25-60 ft. in height with a trunk diameter of $1-2$ ft.. becoming a shrub toward the tops of high mountains: branuthes usually arising in distinct whorls and throughout horizontal, ascending or declining, or declining toward the base horizontal in the middle and ascending toward the top of the tree forming a symmetrical broad-based conical head. A rapidly growing comparatively short-lived tree losing its lower branches at an early period.

B MFE-Grayish-brown. smooth with raised blisters containing a fragrant oily resin; in old trees becoming somewhat roughened with small scales at base of trunk.

TIIrS-Grayish and more or less downy, becoming with age grayish. krown and smooth, branchlets mostly opposite arising at a wide angle. J'hotograph of twig is about ${ }_{13}$ natural size.

LEIVIS-Scattered, on young trees and sterile twigs generally twisting so as to appear 2-ranked as in the Hemlock, on upper fruiting branches and leading shoots generally covering the upper side of the twos: dark green and shining on upper side, pale below with grayish lines of minute dots. flattened, generally blunt about $3 / t$ inch or more lung. slightly narruwed at base but not stalked, arising at about a right angle to the twig, leaving after falling a flat, round scar, fratgrant, aromatic when crushed. MICROSCOPIC SECTION-showing 2 fibru-vascular bundles closely adjacent and appearing as one in a knife section, 2 resin-ducts between the bundles and the epidemis with stumata chiefly on the under side.

WTDS-Small, broadly ovate to spherical, generally less than $5 \mathrm{~mm}$. Inng, clusely grouped at tips of main twigs; bud-suales varnished and glued together by resinous coating.

FRIT-Frect cones ripening in the autumn of the first season. SCALES-falling and leaving only the erect central axes to which they were attached persistent through winter.

COMPIRISONS-The Balsam Fir is distinguished from our native New England evergreens by its smooth blistery bark and by its leaves which are attached directly to the twig and leave a round, flat scar on falling. From the Hemlock it is further distinguished by the absence of leaf stalks and from the Spruce by the flattened apparently 2-ranked leares. See under Douglas Fir for Comparisons with this species.

DISTRIBCTON-Rich, damp, cool woods, deep swamps, mountain slupes. Occasionally cultisated as an ornamental tree. Labrador. Newfoundland. and Nova Scotia, northwest to the Great Bear Lake region: suth to Pennsylvania and along high mountains to Virginia; west to Minnesota.

IN NEW ENGLAND-Maine-very generally distributed, ordinarily associated with White Pine, Black Spruce, Red Spruce, and a few deciduous trees. growing at an altitude of 4.500 feet upon Katahdin: New Hampshire-common in upper cons county and in the white Mnuntains, where it climbs up to the alpine area; in the southern part of the state, in the extensire swamps around the sources of the Contoncook and Miller's rivers it is the prevailing timber; Vermontcommon; nut rare on mountain slopes and even summits; Massachusetts - not untomimon on mountain slopes in the northwestern and central portions of the state, ranging above the Red Spruces upon Graylock; a fen trees here and there in damp woods or cold swamps in the southern and eastern sections, where it has probably been accidentally introduced: Rhode Island-not reported.

IN CONNECTICLT-Rare. Cold swamps and woods. Middlebury, Goshen. Curnwall. Salisbury. Also occurs as an escape from cultivation at Woodstock, Andover and Farmington.

woOD-Light, solt, not strong, coarse-grained, perishable, pale brown. streaked with yellow. with thick lighter colored sapwood, occasionally made into lumber, principally used for packing cases, used largely in manufacture of wood pulp. From the blisters in the bark Canada balsam is obtained which is used in medicine and as a medium for mounting microscopic preparations. The fragrant leaves and small twigs are used to stuff balsam or so-called "pine"-pillows. 

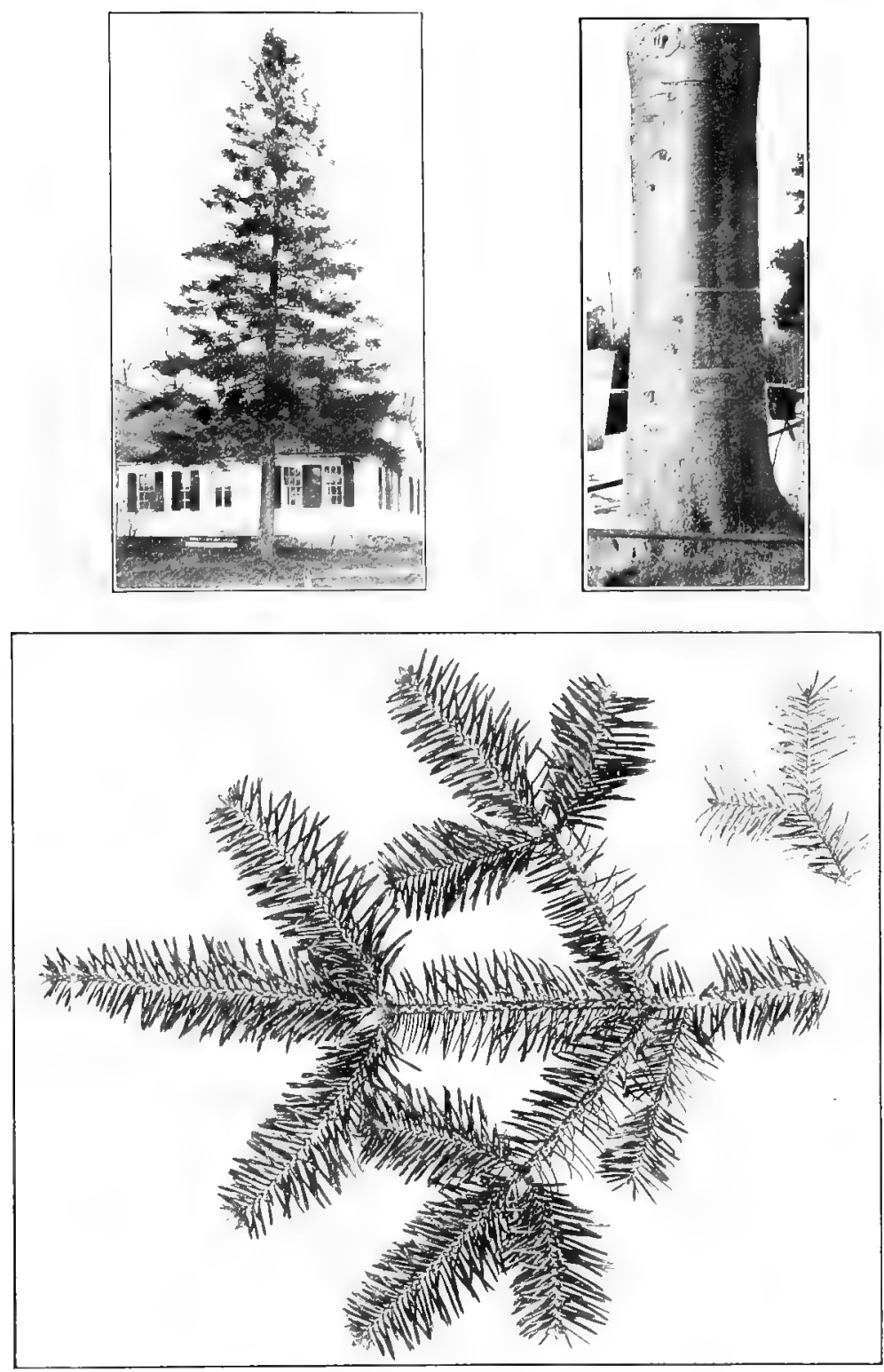

Balsam Fir 


\section{HEMLOCK \\ Hemlock Spruce.}

Tsuga canadensis (L.) Carr.

HInIT-A large tree 50-s0 ft. in height with a trunk diameter of 2-4 ft, branches long, slender, horizontal or drooping at base, ascending above, forning a bruad-based pyramidal head with fine feathery suray giving a delicate airy appearance to the tree. The apex is plumelike and generally bent to one side indicating, so woodsmen claim, the direction of prevailing winds.

BARk-Reddish to grayish-brown, with shallow broad connecting ridges sumewhat scaly on the surface.

TwIGs-slender, gellowish-bruwn, more or less downy, branchlets generally not coposite and arising at less than a right angle. Photograph of twig is about $x_{3}$ natural size.

LEIVES-Scattered but generally twisting so as to appear 2-ranked, dark, slightly yellowish-green above, pale green below with grayish lines of minute dots on either side of midrib, flattened generally blunt at the apex, about 1/2 ineh long with a distinct short stalk, borne upon a reddish-brown decurrent projextion of the bark which is left as a raised scar at the fall of the leaf. MICFOSCOPIC SECTION-showing a single fibru-rascular bundle and a large resin-duct filling the space between the bundle and the epidernis.

BI DS-Small, abuut $2 \mathrm{~mm}$, long, ovate, reddish-brown, not resinouscoated.

FR I IT-Small, stalked, pendant cones, ripening the first season, and generally persistent thrutoh winter, about 3 it inch long.

COMPIRIsM N-In its flattened, apparenty g-ranked leaves the Henlock resembles the Balsam Fir, but aside from the difference in hahit and bark, the leares of the Hemlock are shorter, distinctly stalked and leave projecting scars when they fall off. From the Spruces it is distinguislied by its distinctly flattened and stalked leares and flattened spras.

DISTRIHI 'IOX-CoId soils, horlers of swamps, deep woods, ravines, mountain slowes, and also cultivated as an ornamental tree. Nora Scotia. New Brunswick, thrugh Quebec and Ontario: south to Delaware and along the mountains to Geurgia and Alabama, ascending to an altitude of 2000 feet in the Adirondacks; west to Michigan and Minnesuta.

IN NET FNGLAXT-Naine-abundant, generally distributed in the southern and central purtions, becuming rare northward, disappearing entirely in must of truustook county and the northern Penobscot region: New Hampshire-abundant, frum the sea to a height of 2,000 feet in the Thite Munntains, disappearing in upper Coos county; Termont-common especially in mountain forests; Massachusetts and Rhode Islandcompon. tion.

IN CONXECTICLT-USually frequent but rather local in its distribu-

WooD-light, soft, not strong, brittle, coarse-grained, difficult to work. liable to wind-sluake and splinter, not durable when exposed to the air. light brown tinged with red, with thin somewhat darker sapwood: largely manufactured into coarse lumber, employed for the outside finish of buildings. The astringent inner bark furnishes the largest part of the material used in the northeastern states and canada in tanning leather. Oil of Hemlock is distilled from the young branches. 

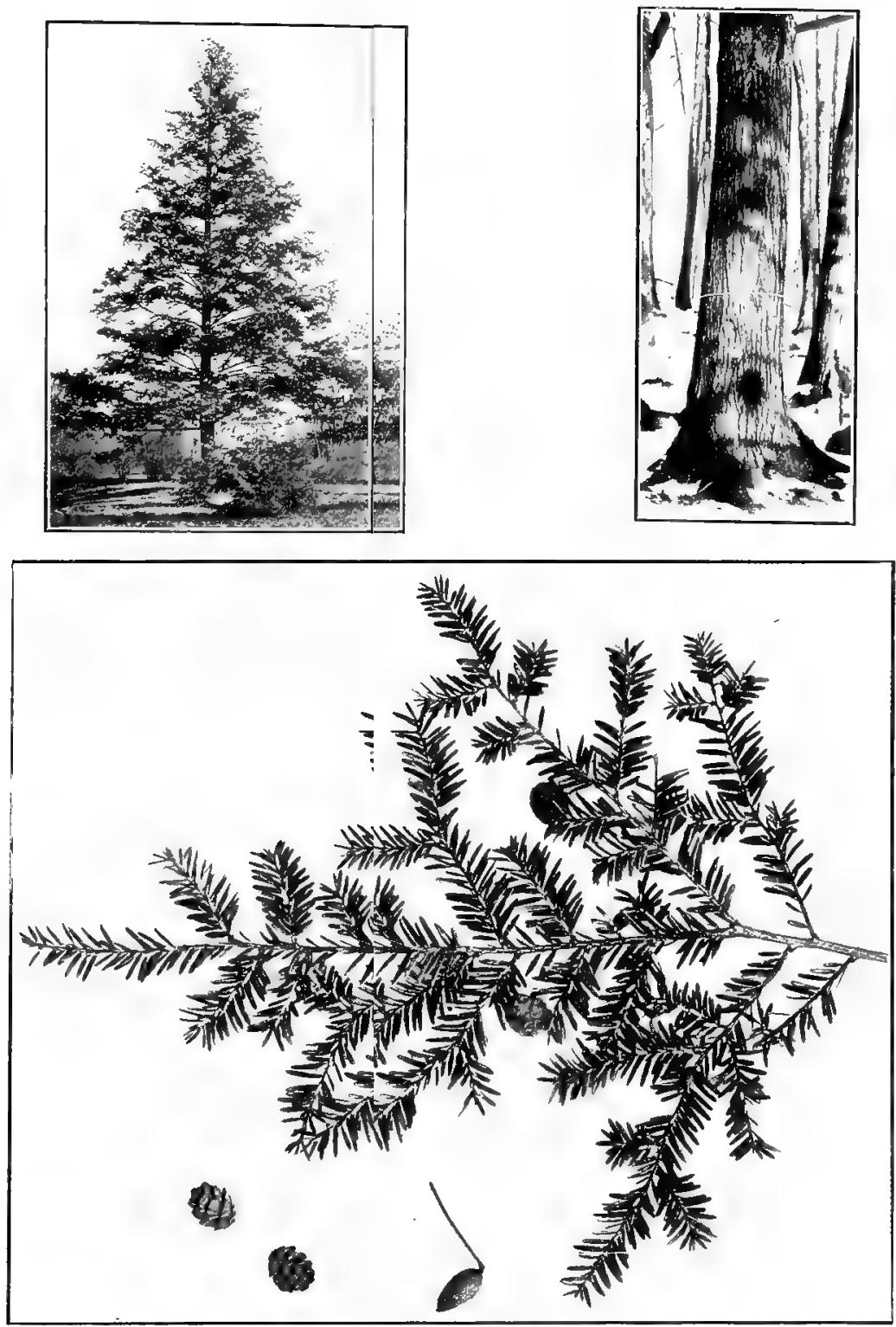

IIEMLOCK 


\section{COAST WHITE CEDAR White Cedar, Cedar.}

Chamaecyparis thyoides (L.) BSP.

C. sphaeroiden Spach; Cupressus thyoides L.

HABIT-A small tree, $20-50 \mathrm{ft}$. in height with a trunk diameter of 1 - $\mathrm{ft}$., further south reaching $90 \mathrm{ft}$, in height and a trunk diameter of $4 \mathrm{ft}$. t tunk tall, erect, tapering gradually, branches short, slender, more or less horizontal. with delicate feathery secondary branches and branchlets lonsely enveloping the narrow conical head and surmounted by an airy, pliant, plume-like terminal shoot.

B.IRK-Grayish-brown, separating off in narrow shreddy strips, more or less spirally twisted; on younger and sometimes also on older trunks the bark separates off in broader reddish-brown strips, (see photograph of young trunk).

TwIGs-Generally less than $1.5 \mathrm{~mm}$. thick, slightly but not prominently flattened, arranged in more or less fan-shaped clusters in vlanes at varims angles, the last season's growth bluish-green from the cumplete covering of minute leaves, with death of leares the second season becoming reddish-brown, older growth slowly losing its leaves and marked by scars of deciduous branchlets. Photograph of twig is about $4 / 5$ natural size.

LFIVES-Minute, scale-like, 1-2 $\mathrm{mm}$. long, appressed and closely overlatping, opposite in 4 ranks. but not giving a conspicuously 4 -sided appearance to the $t w i g s$, more or less keeled and with a raised glandular dot at least on leaves of rapidy grown shoots, with spicy aromatic odor when crushed.

FRI IT-Small, spherical cones, $5-8 \mathrm{~mm}$. in diameter, inconspicuous in winter, opening toward the center never toward the base maturing the first season and persistent through the winter. SCALES-thickened, woody, shield-shaped, with a slight projection in middle, each perched on a stalk connecting it with the center of the cone; seeds winged.

COMP.IRISOxS-The Coast White Cedar resembles the Arbor Vitae as indicated under this species but its twigs are only slightly flattened. the clusters of twigs are less distinctly fan-shaped, the twigs and leaves are smaller and the leaves are of a bluish rather than of a yellowishgreen. The cones are distinctive being spherical and with thickened shield-shaped scales perched on stalks connecting them with the center. Aside from the fruit characters which separate them, the Coast White Cedar is distinguished from the Red Cedar by the more or less distinct fan-shaped arrangement of its twigs, the absence of two kinds of leaves, the more distinct glandular dot generally present on the leaf and by the fact that the twigs are round or slightly compressed in section and not distinctly 4 -sided as are those of the Red Cedar.

DISTRIBITION-In deep swamps and marshes, which it often fills to the exclusion of other trees. mostly near the seacoast. Cape Breton island and near Halifax, Nova Scotia, perhaps introduced in both: southward, coast region to Florida and west to Mississippi.

IN NETW ENGLAND-Maine-reported from the southern part of York county: New Hampshire-limited to Rockingham county near the coast; Termont-no station known: Massachusetts-occasional in central and eastern parts, very common in the southeast; Rhode Island-common.

IN CONNECTICUT-Rare in western and central districts; Danbury and New Fairfield, becoming occasional or frequent eastward.

woOD-Light, soft, not strong, close-grained, slightly fragrant, light brown, tinged with red, largely used in boat building, and cooperage and for woodenware, shingles, the interior finish of houses, fence posts and railroad ties. 

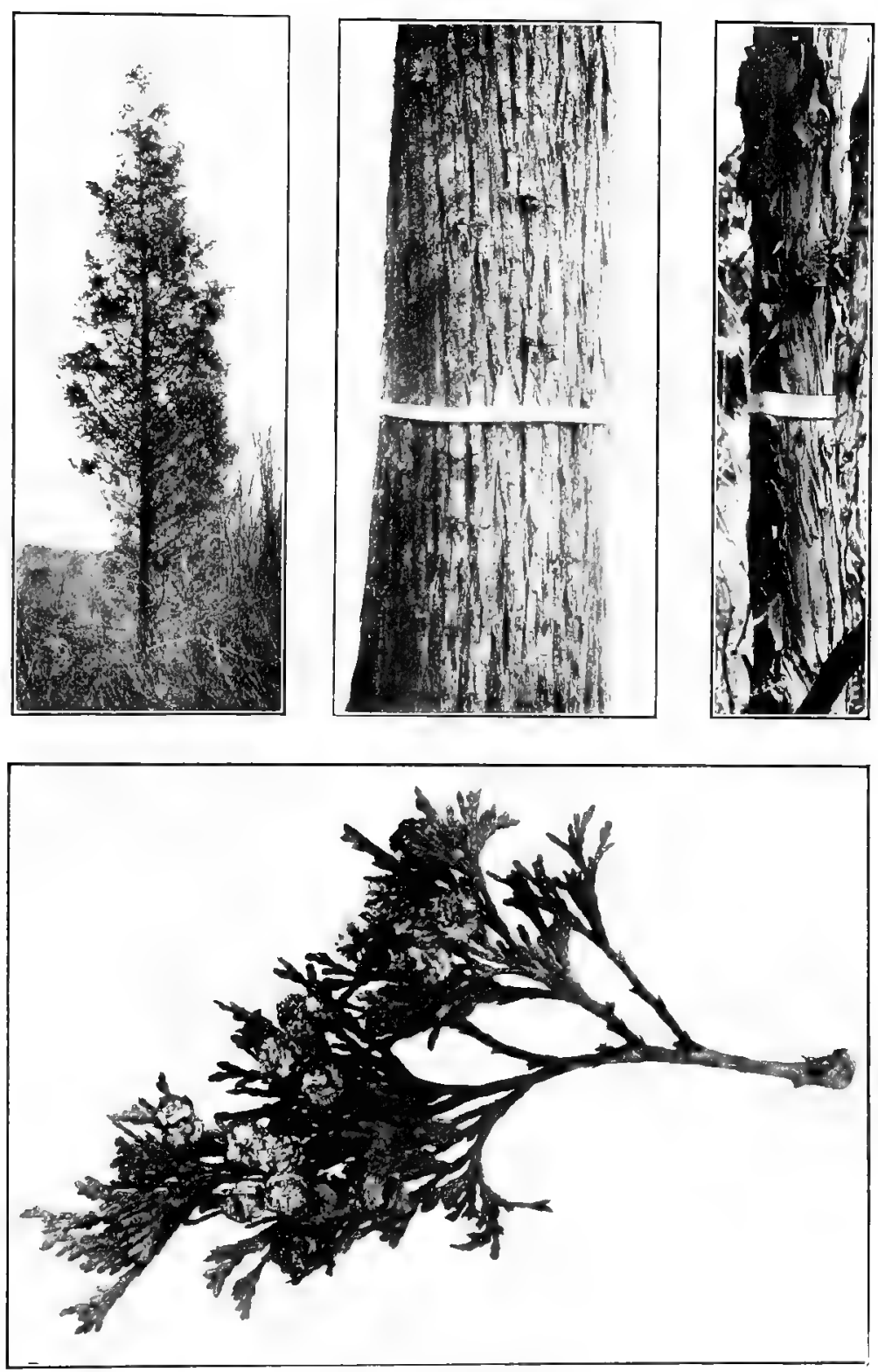

Coast White Cedar 


\section{ARBOR VITAE White Cedar, Cedar.}

Thuja occidentalis $\mathrm{L}$.

H IBIT-Common] y $25-50$ ft, in height with trunk diameter of $1-2$ ft., in northern Maine occasionally reaching a height of $70 \mathrm{ft}$. and a trunk dianieter of $3-\overline{f t}$; trunk more or less lobed and buttressed at base, often inclined and tristed, frequently dividing into two or more stout erect stems; branches short, horizontal, lower branches often strongly declined, branchlets numerous, forming a dense, conical head clothed with foliage to near the base.

B IRK-Ashy-gray to light reddish-brown, separating off in long. narrow, flat, shreddy strips, often more or less spirally twisted.

TWIGS-Generally more than $2 \mathrm{~mm}$. wide, decidedly flattened arranged in fan-shaped clusters, placed vertically or in planes at rarious angles, often mistaken for the true leaves which are minute and completely cover the last season's growth, dark yellowish-green. paler on the underside. with the death of the leaves in the second season becoming pale cinnamon brown and later shining reddish-brown, round in section. swollen at place of attachment to main branch, and marked by scars of deciduous branchlets. Photograph of twig is about $z$ natural size.

LIMES-Minute, 3-6 mm. Iong, scale-like, appressed and closely overlapping, opposite in 4 ranks; on the flattened spray those in the side pairs keeled, those in the uther pair flat, ovate, each with a single raised glandular spot especially conspicuous on leaves of leading shoots; with a characteristic camplor-like aromatic odor when crushed.

FRI IT-Small, oblong cones, about $1 / 2$ inch long, pale reddish-brown, opening to the base when mature. maturing the first season and persistent through the winter. SCALES-6-12, thin, oblong, dry with margins mustly entire.

conpIRIsoys-The Arbor Titae is often called White Cedar and resembles the Coast White Cedar. which likewise is often known as White Cedar, in its bark, its habit of growth and its flattened fanshaped spray. The twigs of the Arbor Vitae are much more flattened and larger and the clusters of twigs more decidedly fan-shaped; the leaves are also larger and of a vellowish-green color. The cones of the two species are decidedly different, those of the Arbor Vitae being nblong with thin scales opening to the base of the cone, those of the Cuast White Cedar being spherical with thickened shield-shaped scales, perched on stalks attached to the center of the cone.

DISTRIBITIOX-Lnw, swampy lands, rocky borders of rivers and ponds. Often cultivated as single ornamental trees and in hedges. Southern Labrador to Nova Scotia: west to Manitoba; south along the mountains to North Carolina and East Tennessee; west to Minnesota.

IN NEW FNGLAND-Maine-throughout the state: most abundant in the central and northern portions, forming extensive areas known as "Cedar Swamps": sometimes bordering a growth of Black Spruce at a lower level; New Hampshire-mostly confined to the upper part of Coos county, disappearing at the White river narrows near Han"ver: seen only in isolated localities south of the White Mountains; Vermont-common in swamps at levels below $1.000 \mathrm{ft}$.: MassachusettsBerkshire county; occasional in the northern sections of the Connecticut river valley; Rhode Island-not reported.

IN CONNECTICUT-Rare; Canaan, on a limestone ridge and in a nearby swamp. Salisbury, rocky hillsides and at another locality in a deep swamp; apparently native at these three localities. Fscaped from cultivation to fields and roadsides at Norwich, East Hartford, Killingly and Windsor.

WOOD-Light, soft, brittle, very coarse-grained, durable, fragrant. pale yellowish-brown, largely used in Canada and the northern states for fence posts, rails, railroad ties, spools and shingles. 

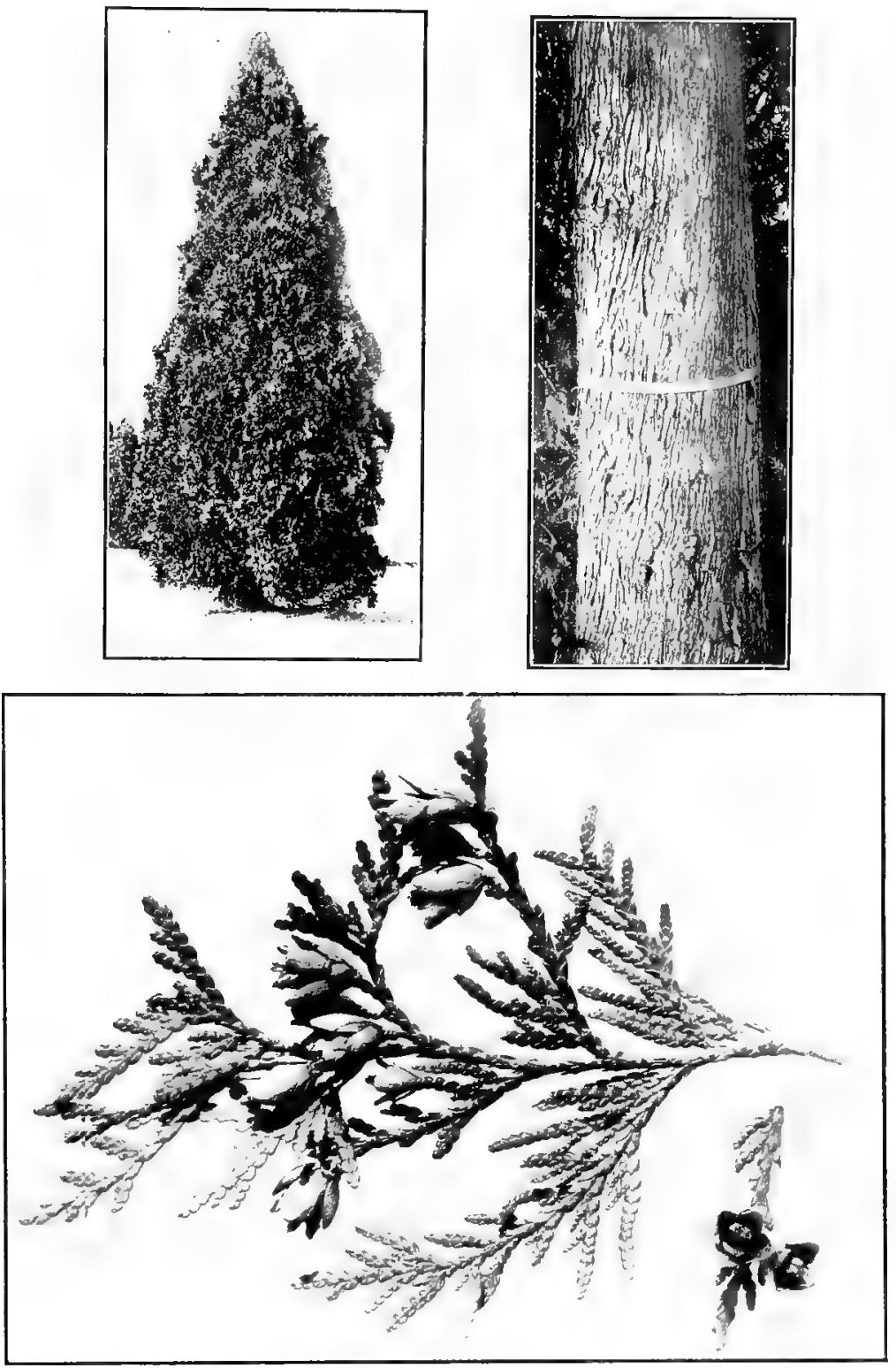

Arbor Vitae 


\title{
COMMON JUNIPER Dwarf Juniper. Juniperus communis $\mathbf{L}$.
}

\begin{abstract}
HABIT-A shrub or small tree $5-15 \mathrm{ft}$, high: in the type form with generally sereral erect stems, bearing erect branches densely clothed with foliage, forming a narrow or rather broad compact plume-like erect growth (habit picture at the right); in the more common dwarf variety; [Juniperus communis, var. depressa Pursh; S. nana or Britton's Manual in part: J. communis, var. canadensis Loud.; J. communis, var. alyina Grar's Manual ed. 6 in part] with low-lying branches, frequently rooting below, radiating from the center and curving upwards to form low broad, round mats resembling gigantic birds' nests 1 to 3 $\mathrm{ft}$. high and often 10 to $20 \mathrm{ft}$. in diameter (habit picture at the left).
\end{abstract}

AIPI-Gravish-brown, breaking on the surface into thin papery shreddy longitudinal layers, which lift at the ends and edges exposing the reddish bark below.

TWIGs-Smooth, light yellow, turning to red, prominently 3-angled the first two years by decurrent ridges from below the leaves. Photograph of twig is about $1 / 5$ natural size.

LFIVFS-All alike in whorls of 3, separated by short internodes, spreading from the twigs at a broad angle, $7-20 \mathrm{~mm}$. long, awl-shaped, stiff and sharp-pointed, free from glandular dots, compressed, the upper side concave and conspicuously streaked with a broad white line, the dark green under side appearing uppermost by the bending over of the twigs and leaves; persistent for several seasons.

BUDS-Distinct, scaly.

FRITT-About the size of a pea, fleshy, berry-like, dark blue, covered with a bloom, sweetish with a resinous flavor, remaining on the plant during winter, but as the species is dioecious, to be found only on a part of the plants.

CoMP.MISONS-The Common Juniper is distinguished from its near relative the Fed Cedar by its lower habit of growth, by the fact that its leaves are all alike and without glandular dots; in distinction from the typically appressed leaves of the Red Cedar, the leaves of the Common Juniper are spreading at a wide angle. They thus resemble the juvenile type of leaves found on young specimens of the Red Cedar and on rapid-growing twigs of older trees of the same species but may be distinguished by being almost always in 3"s wider and longer, more distinctly whitened above, with a greater separation between the nodes and by the presence of distinct scaly buds. A number of forms are described but not always recognized. The dware variety (var. depressa) is described as having leaves $8-13 \mathrm{~mm}$. long, and the trpe as having leaves 12-21 $\mathrm{mm}$. long but they are best distinguished by their different habits of growth as shown in the photographs.

DISTRIRITIOY-In poor rocky soil, pastures and waste open places. Widely distributed through the colder regions and mountains of the northern part of the $U$. S. in a broad band extending westward from Newfoundland on the north and New Jersey and Pennsylvania on the south. The dwarf form (var. depressa) occurs throughout New England. The type is reported as less common and as occurring in Massachusetts and southward.

IN CONNECTICUT-The type is listed as rare and is reported only from Norwich. It is not uncommon, however, about Storrs. The variety depressa is frequent throughout this state.

woOD-Hard, close-grained, very durable in contact with soll, light brown. with pale sapwond. In northern Eurnpe the fruit is extensively used in giving its peculiar flavor to Holland gin. 

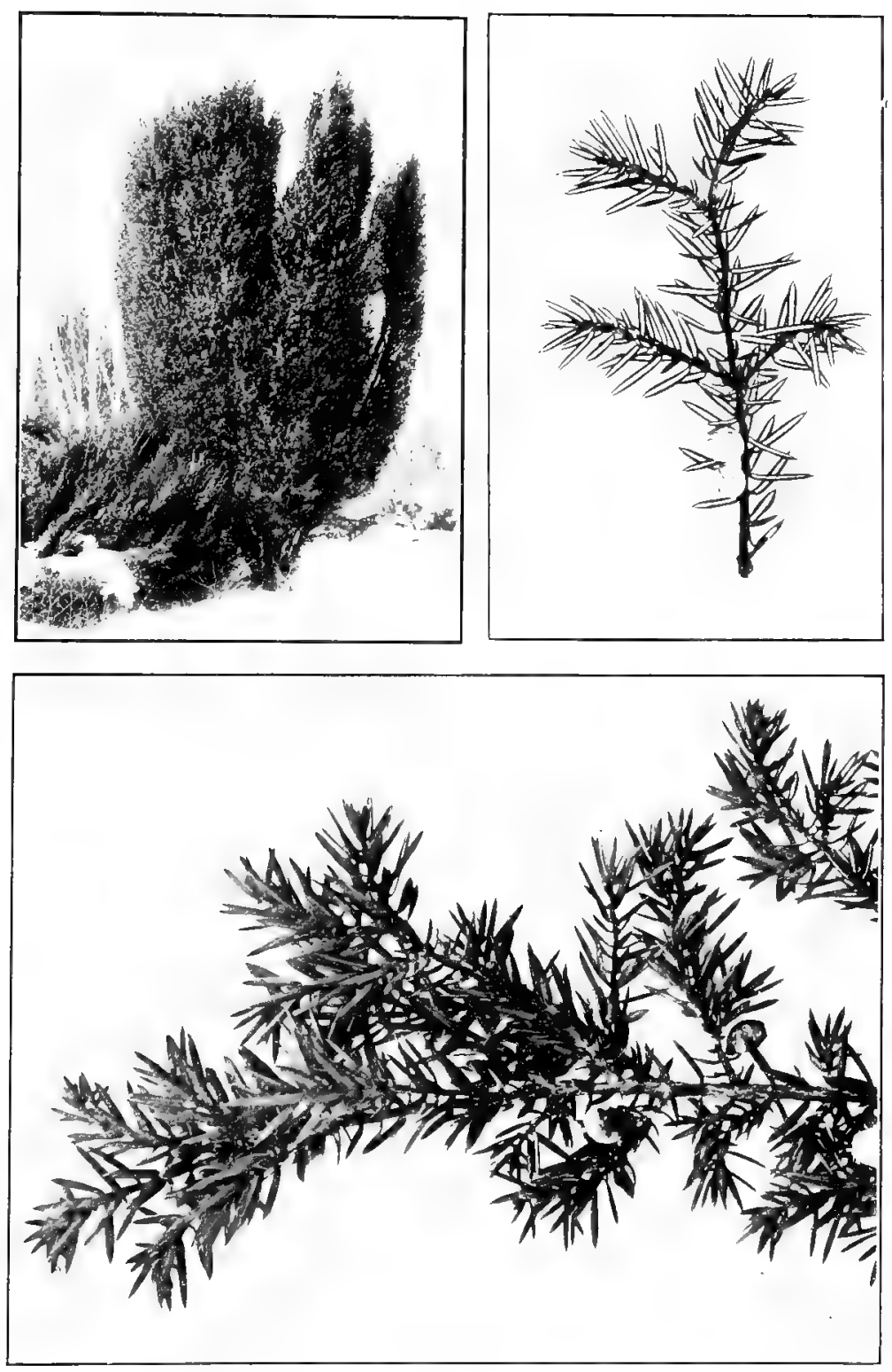

COMMON JINIHER 


\section{RED CEDAR \\ Savin, Cedar, Red Juniper.}

Juniperus virginiana L.

H. BIT-A medium sized tree $25-40 \mathrm{ft}$, in height with trunk diameter of $\delta-20$ inches, much larger in the southern states; trunk more or less ridged and buttressed at base, with slender branches horizontal below erect above, forming in young trees a narrow, conical head, becoming in old age wider, spreading, orate, round-topped, or on bleak situations especially near the sea shore more or less irregularly distorted.

B IRK-Light reddish-brown separating off in long narrow shreddy strips more or less fringed at the edges, frequently somewhat spirally twisted.

Tw1GS-Generally 4-sided in mature trees, green from covering of minute leaves, not flattened nor arranged in fan-shaped clusters, becoming reddish-brown after the fall of the leaves. Photograph of twig is about $4 / 5$ natural size.

LE IVES-Dark green or redish-brown with aromatic odor when crushed, persistent for several years, of two kinds:-

1. The form typical of the species; about $2 \mathrm{~mm}$. or less long, scalelike, opposite in pairs, forming 4 ranks, closely overlapping and appressed, rounded, with or without an inconspicuous glandular dot on the back, ovate, sharp or blunt-pointed. (See left hand twig.)

2. The juvenile furm; occurring often exclusively on very young trees and also frequently together with the typical form on older trees: narrow, awl-shaped to needle-shaped, sharp-pointed without glands, spreading, scattered and not overlapping, opposite or in 3 's, 5-20 mm. long. (See right hand twig.)

BLDS-Inconspicuous.

FRIIT-About the size of a small pea, fleshy, berry-like, dark blue, covered with a bloom, sweetish with a resinous flavor, containing generally 1-2 bony seeds. The fruit remains on the tree during winter but the species is dioecious and consequently not all the trees bear fruit.

compurisons-The Fed Cedar resembles the Coast White Cedar but it fails to show a flattened fan-shaped arrangement of its twigs, its twigs further are generally 4 -sided when bearing typical leaves and on young trees and generally on some twigs of older trees leaves of the juvenile type may be found. The berry-like fruit of the Red Cedar when present is the most distinctive character separating this species from the Coast White Cedar. The Common Juniper is not to be confused with Fied Cedar trees that have typical leaves. It resembles somewhat the juvenile leaved form of the Red Cedar, however, but the growth of the former is generally less upright, the leares always in 3 's and generally more whitened above and the buds are more conspicuous.

DISTRIBITIOX-Dry, rocky hills but not at great altitudes, borders of lakes and streams, sterile plains, peaty swamps. Nova Scotia and New Brunswick to Ontario; south to Florida; west to Dakota, Nebraska, Kansas and Indian Territory.

IN NEW ENGLAND-MIaine-rare, though it extends northward to the middle Kennebec valley. reduced almost to a shrub: New Hampshire -most frequent in the southeast part of the state; sparingly in the Connecticut valley, as far north as Haverhill, found also in Hart's location in the White Mountain region; Termont--not abundant; occurs here and there on hills at levels less than 1.000 feet; frequent in the Champlain and lower Connecticut ralleys; Massachusets - west and center occasional, eastward common; Rhode Island-common.

\section{IN CONNECTICUT-Common.}

WoOD-Light, close-grained, brittle, not strong, dull red with thin nearly white sapmood, very fragrant, easily worked; largely used for posts, the sills of buildings, the interior finish of houses, the lining of chests and closets as a protection of woolen garments against attacks of moths, and for pails and other small articles of wooden-ware. A decoction of the fruit and leaves is used medicinally and oil of Red Cedar is distilled from the leaves and wood as a perfume. 

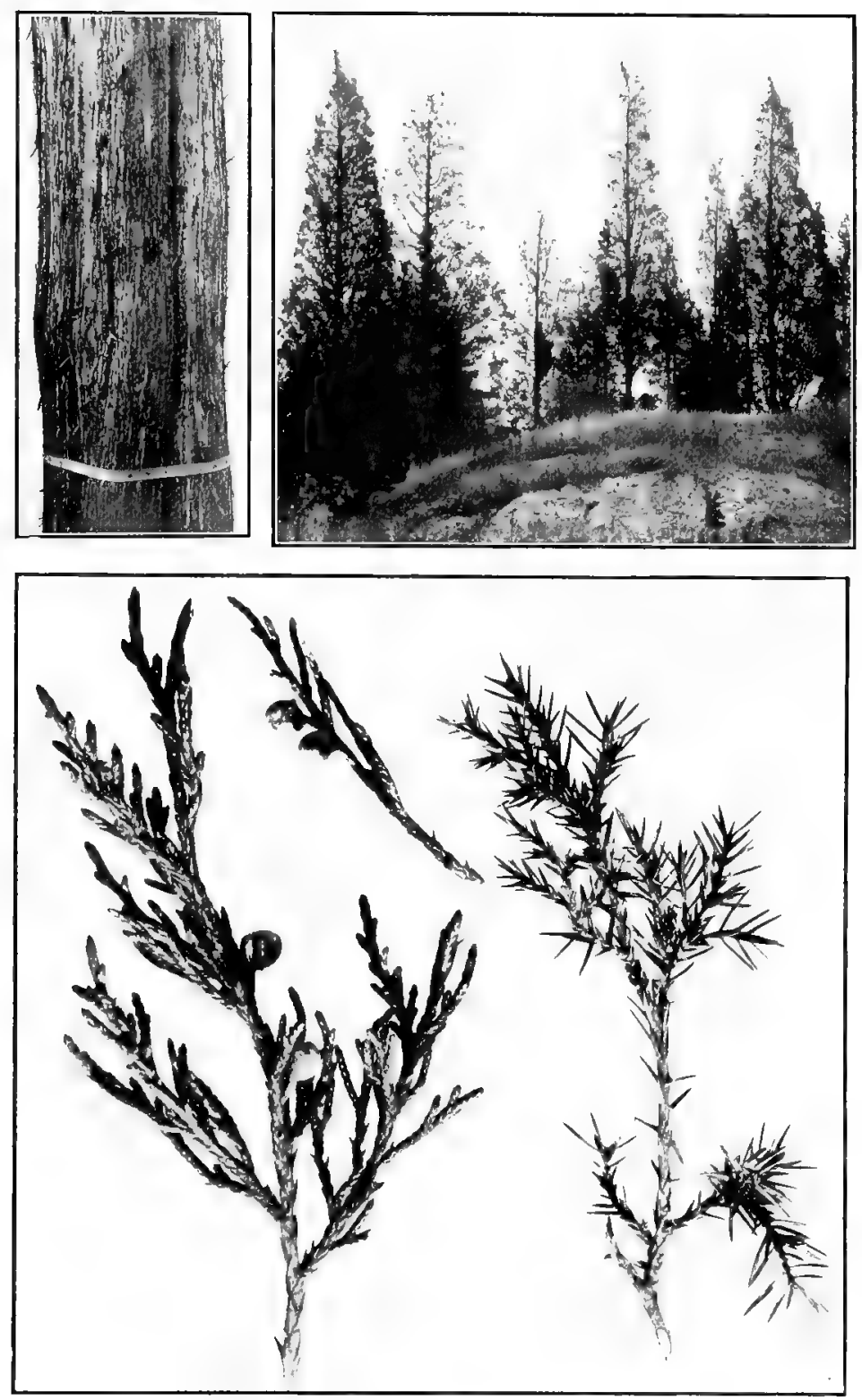

Red Cedar 


\section{GINKGO \\ Maidenhair Tree. \\ Ginkgo biloba L. \\ Salisburia adiantifolia Smith.}

H.IBIT-A tree reaching a height of $60-\delta 0 \mathrm{ft}$., with generally a single erect trunk (a double trunk in tree photographed) continuous into the crown with straight, slender branches, making an angle of about 45 degrees with the trunk and regularly parallel except those below which are more or less declined, forming in mature specimens a very regular symmetrical broadly ovate to pyramidal head. There are several horticultural varieties including one weeping form.

BIRK- - shy gray, on younger trunks and branches smooth, becoming with age seamy and longitudinally roughened.

TWIGS-Rather stout, smooth, yellowish-brown, shining, a thin grayish skin separating off in narrow shreds on older twigs; rapidiygrown twigs of one year's growth, comparatively rare, with scattered leaf-scars; stout lateral or terminal spurs with thickly crowded leafscars common. PITH-pale yellowish, with ragged outline.

LEIF-SCIRS-Alternate, 2-ranked or more than 2-ranked, semf-oval, raised. upper margin generally fringed. STIPULE-SCARS-absent. BLNLLE-SCAFS-2, often most distinct in recent leaf-scars on short spurs.

BI DS-Light chestnut brown, short, conical, generally under $4 \mathrm{~mm}$. long, isolated lateral buds on rapidly grown shoots divergent, on short spurs generally only terminal buds developed. BUD-SCALES-about 5 visible, bruader than long, thickened and dotted toward the midule with small reddish transparent lumps.

FRI IT-A stone-fruit with a sweet ill-smelling flesh. The tree is dioevious, there being separate male and female individual trees. On account of the disagreeable odor of the fruit the male trees are more frequently planted. The two sexes are said to differ in their growth forms, the male tree being more narrowly pyramidal while the female forms a broad head.

comp.risoxs-The Ginkgo belongs to the Gymnosperms, an order of plants which are mostly cone-bearing like the Pines and Spruces. It has a peculiarity with the Larch in that it is not evergreen as are most of its relatives but sheds its leaves in the fall. Like the Larch. too, it has numerous stubby spurs with crowded leaf-scars. It differs from the Larch in that its large leaf-scars are not strongly decurrent and are relatively far apart on the rapidy grown shoots and further have 2 bundle-scars.

DISTRIMC TION-A native of northern China, introduced into America early in the century and generally successful in the eastern states as far north as eastern Massachusetts and central Michigan and along the St. Lawrence River in parts of Canada. 

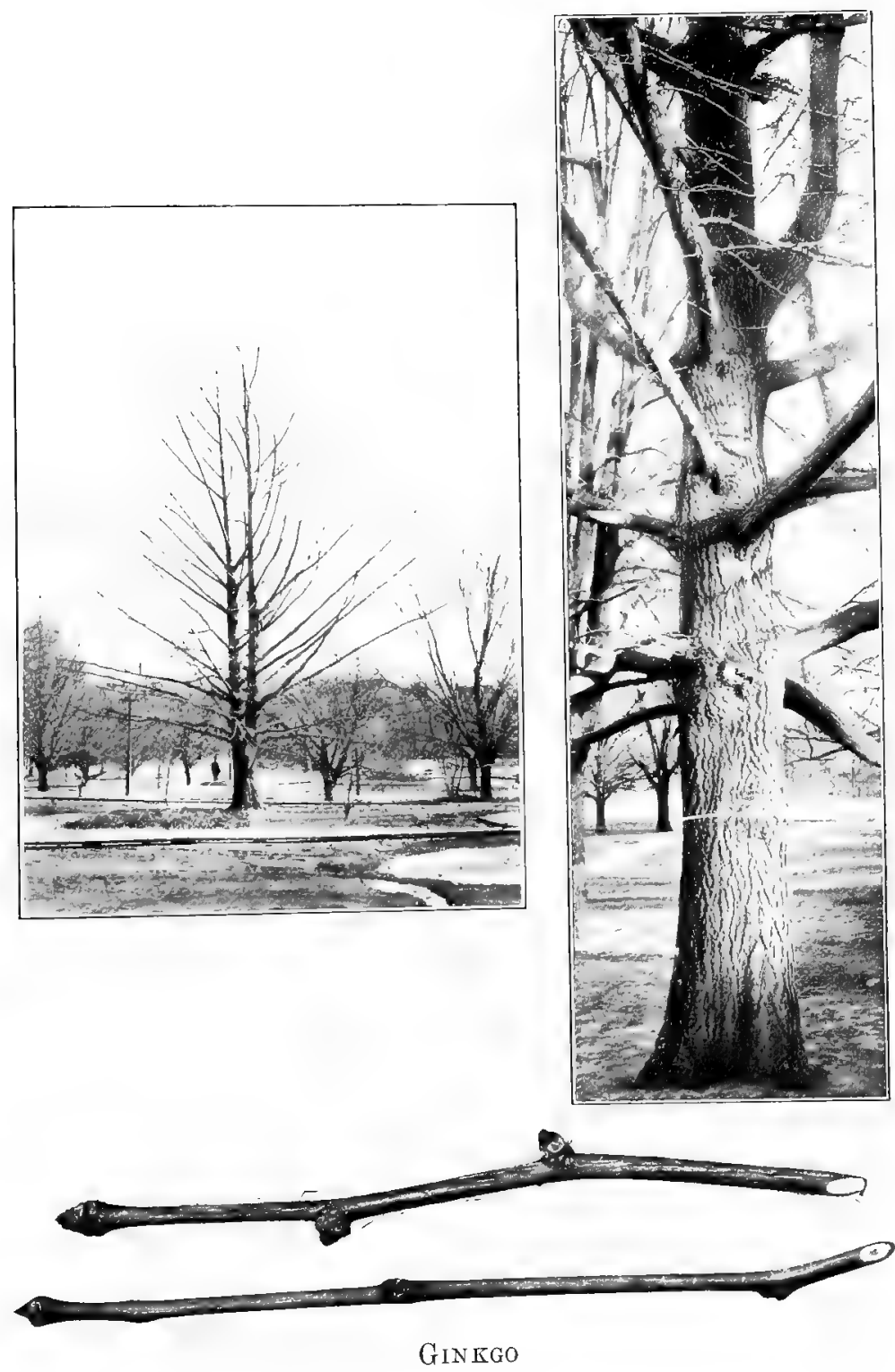


\section{YELLOW WILLOW Golden Osier.}

Salix alba, var, vitellina (L.) Koch.

S. ritellina Koch.

HIBIT-A large tree reaching $50-80 \mathrm{ft}$. in height with a trunk diameter of $3-5 \mathrm{ft}$; trunk short, rarely erect, generally inclining to one side, dividing low down into a number of stout spreading limbs, forming an irregular broad rounded head.

BARK-On young stems smooth, becoming with age dark gray and deeply furrowed.

TwIGs-Rather slender, bright yellow, smooth and shining or dull with more or less dense covering of fine silky hairs, bitter to taste. LENTICELS-scattered, inconspicuous. PITH-more or less 5-pointed.

LEAF-SC IRS-Alternate, more than 2-ranked, narrow, raised, broadly $\mathrm{V}$-shaped, more or less swoolen at the bundle-scars. STIPULE-SCARSoblique, close to leaf-scars and often appearing connected with them. BUNLLE-SCARS-3.

RuDs-Terminal bud absent, lateral buds about $5 \mathrm{~mm}$. long, oblong. rounded at apex, smooth or more or less silky-downy, flattened and appressed against twig. BUD-SCALES-a single bud-scale visible, rounded on back, flattened toward the twig, forming a cap to silkyhairy green leaves within.

FR LIT-A catkin of small capsules, containing numerous hairy seeds ripening in spring. The willows are dioecious and the male trees of the Yellow Willow are seldom planted in this country.

COMPARIsons-The species of Willows are closely related and have hybridized abundantly. Their classification is based largely upon differences in the pistils and stamens but since the Willows are dioecious and therefore bear the male and female flowers upon separate trees their determination even when in flower is often a matter of considerable difficulty. The Yellow Willow here described, a yellow twigged variety of the less common European White Willow [Salix alba L.1, is one of the most common tree Willows in New England. The European Weeping Willow [Salix babylonica L.] was formerly much planted for ornament especially in cemeteries and may be distinguished by the drooping habit of its branches. The Black Willow [Salix nigra Marsh.], a small-budded species is the one sizable native Willow in New England. The Willows may be most readily separated from the other trees by the single cap-like scale to the bud in connection with the 3 bundle-scars in the narrow leaf-scar.

DISTRYBITION-A European tree much planted in this country for ornament. It has become naturalized throughout the populated regions of New England, in moist places, near streams and ponds.

woon-Very light, soft, tough, light brown in color with thick nearly white sapwood, easily worked and taking a beautiful polish: used in this country for charcoal and for fuel. 


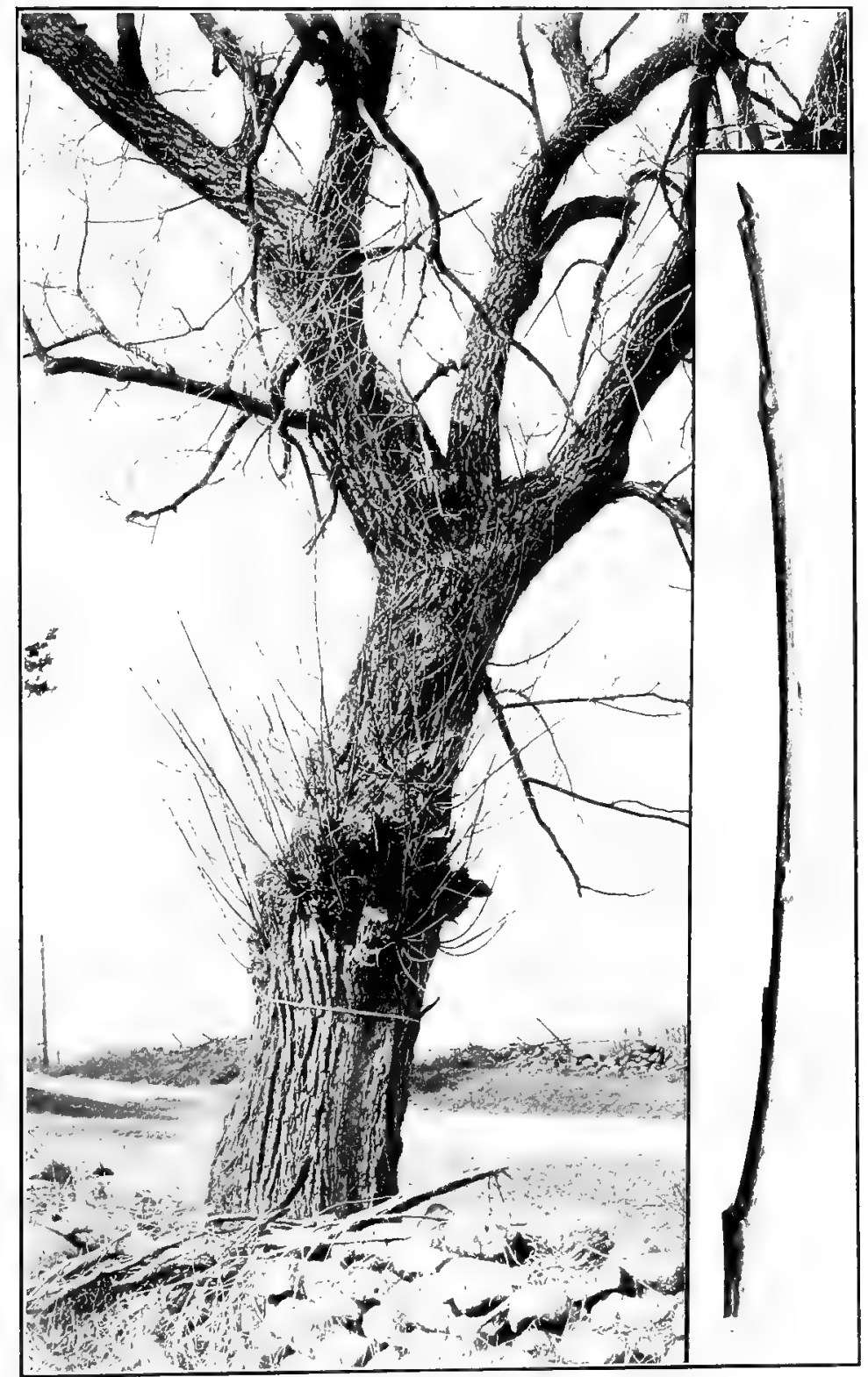

YELLOW MTLLOW 


\section{SILVER POPLAR White Poplar, Silver-leaf Poplar, Abele. Populus alba L.}

H IBIT-A good sized tree $40-75 \mathrm{ft}$. high, with a trunk diameter of 2-t ft.; branches wide-spreading, developing a large, irregular, open, briad, round-topped head; spreading abundantly by means of root suckers.

B IRF-On young trunks and limbs smooth, characteristically light greenish-gray or whitish, often with dark blotches; base of older trunk at length deeply furrowed into firm dark ridges. The Silver Poplar retains its smooth light colored bark longer than our other members of the genus.

TWIGS-Slender or sometimes stout, greenish-gray, densely covered with thick whitish-cottony wool which can be readily rubbed off and often renains throughout the winter only toward the apex; where wool is reninved the surface is shing; short spurs numerous with conspicuus raised leaf-scars and with terminal buds only. LENTICELS-pale, round, raised dots. PITH-5-pointed, star-shaped.

LEIF-sCIRS-Alternate, more than 2-ranked, semi-circular to inversely triangular; on short spurs narrower. STIPULE-SCARS-distinct. BLNDLE-SCAFS-3, simple or compound.

RI DS_-Small, ovate to conical, light chestnut brown; neither sticky nor fragrant; shining or more or less covered especially toward base with cottony wool; lateral buds $5-7 \mathrm{~mm}$. long, terminal buds somewhat larger, thicker. BUD-SCALES-margined with very minute hairs; the first scale of lateral buds anterior. This first scale in front has a scale directly above it, the edges of the two being essentially parallel; likewise the first scale in back generally has a scale directly above it with similarly parallel edges. The first four scales therefore form two ranks facing respectively front and back. This condition seems constant for typical buds, but does not hold for abnormally small buds.

COMPARISONS-The Silver Poplar, acquires a roughened trunk later than the other Poplars, retaining the smooth whitish-green appearance of its bark as a distinctive character. Its generally delicate twigs, greenish-gray when not covered with cottony wool which generally can be found at least at the apex, furnish further characters that distinguish this species from the other poplars. The two rows of scales with parallel edges in the lateral buds are found to a less striking degree in the larger buds of the Small-toothed Aspen and the Large-tootheu Aspen.

DISTRIBL TION-Tidely distributed in the old World. Introduced from England by the early settlers and soon established in the colonial towns on the western shore of Massachusetts Bay. Planted or spontaneous over a wide area. New Brunswick and Nova Scotia, occasional; southward to Virginia.

IN NEW ENGLAND-Occasional throughout, local, sometimes common.

IN CONNECTICUT-OCcasional, escaped from cultivation to roadsides and waste places.

wooD-Light, soft, weak, reddish-yellow with nearly white sapwood; difficult to split and to ignite; used in Europe for rollers, packing cases and flooring. 

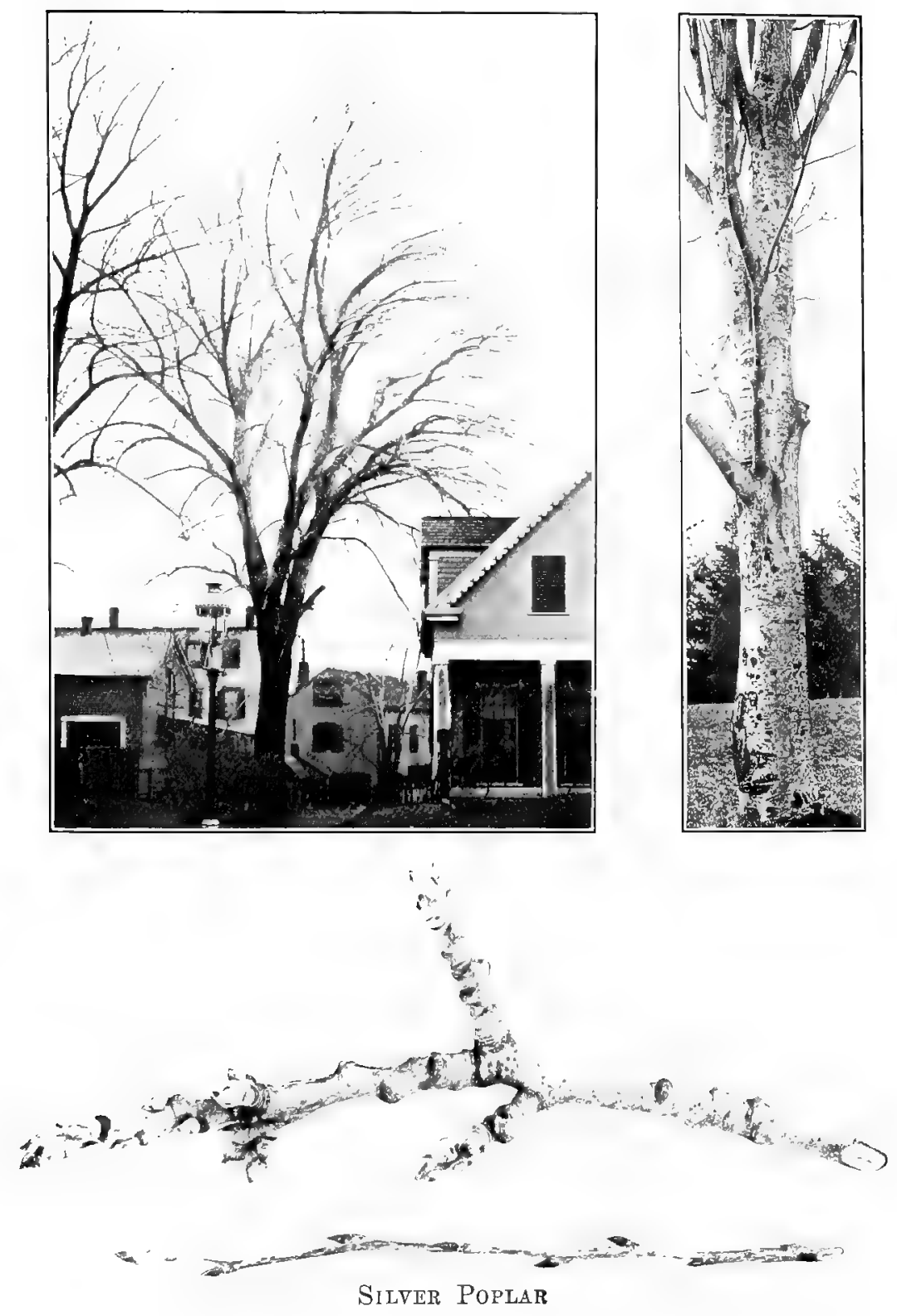


\section{SMALL-TOOTHED ASPEN American or Quaking Aspen, Popple, Poplar, Aspen.}

Populus tremuloides Michx.

HABIT-As generally found a small tree $35-40 \mathrm{ft}$. high though not infrequently reaching 50-60 ft. in height with a trunk diameter of $11 / 2$ ft. or more; trunk tapering, continuous into top of tree; main branches slender, scattered, often drooping at the ends forming an open, narrow, round-topped head; spreading by means of root suckers.

HARK-On young trunks and branches thin, pale yellowish-brown, orange-green or nearly white with dark blotches below the branches, smooth with horizontal raised ridges (often encircling limbs); on older trunks especially toward the base, thick, furrowed and nearly black.

TWIGS-Slender, round, bright reddish-brown, smooth, shining. Older twigs grayish-brown. roughened by elevated leaf-scars and by swollen bases of detached branchlets. LENTICELS-light reddish-orange, scattered, oblong. PITH-5-pointed, star-shaped.

LEAF-SCARS-Alternate, more than 2-ranked, large, inversely triangular, covered with light colored corky layer, upper edge of scar more or less depressed. STIPULE-SCARS-blackish, more or less conspicuous. BUNDLE-SCAPS-3, simple or each compunded.

BCDS-Narrowly conical, sharp-pointed, generally appressed especially toward apex of twig or incurved, about $5-7 \mathrm{~mm}$. long, shining, slightly sticky but not fragrant; flower buds larger, ovate. BUD: SCALES-6 or 7 in number, smooth, reddish-brown, shining, scarious along the margins; the first scale of lateral buds anterior (i.e, facing outward), reaching about $1 / 3$ of the way to the apex, often splitting at the top.

COMPARISONS-In general habit and bark characters the Smalltoothed resembles the Large-toothed Aspen. It is readily distinguished from the latter by its shining reddish-brown, often slightly sticky, mostly appressed buds which are free from down. Those of the Largetoothed Aspen are thicker, dull dusty-looking. more or less gray-downy, and for the most part divergent. The bark of the Small-toothed Aspen is generally somewhat lighter in color, often nearly white and generally earlier and more deeply roughened at the base; the larger branches of the Large-toothed Aspen have a tendency to grow out at a wider angle with the trunk than those of the Small-toothed Aspen. The buds resemble somewhat those of the Balsam Poplar but are much smaller, only slightly sticky and not fragrant. It is separated from the Carolina Poplar and Lombardy Poplar by its reddish twigs, those of the latter two species being Jellow; from the Silver Poplar by absence of down on twigs.

DISTRIHUTION-In practically all soils and situations except in deep swamps though more often in dry ground; one of the first trees to take possession of clearings or burnt lands. Newfoundland, Labrador, and Nova Scotia to the Hudson Bay region and Alaska; south to New Jersey, along the mountains in Pennsylvania and Kentucky, ascending 3.000 feet in the Adirondacks; West to the slopes of the Rocky mountains, along which it extends to Mexico and lower California.

IN NEW ENGLAND-Common, reaching in the White Mountain region, an altitude of $3.000 \mathrm{ft}$.

IN CONNECTICUT-Frequent.

wooD-Light brown, with nearly white sapwood of $25-30$ layers of annual growth, soft, weak and soon decaying; used in great quantities for paper pulp and in the manufacture of excelsior. 

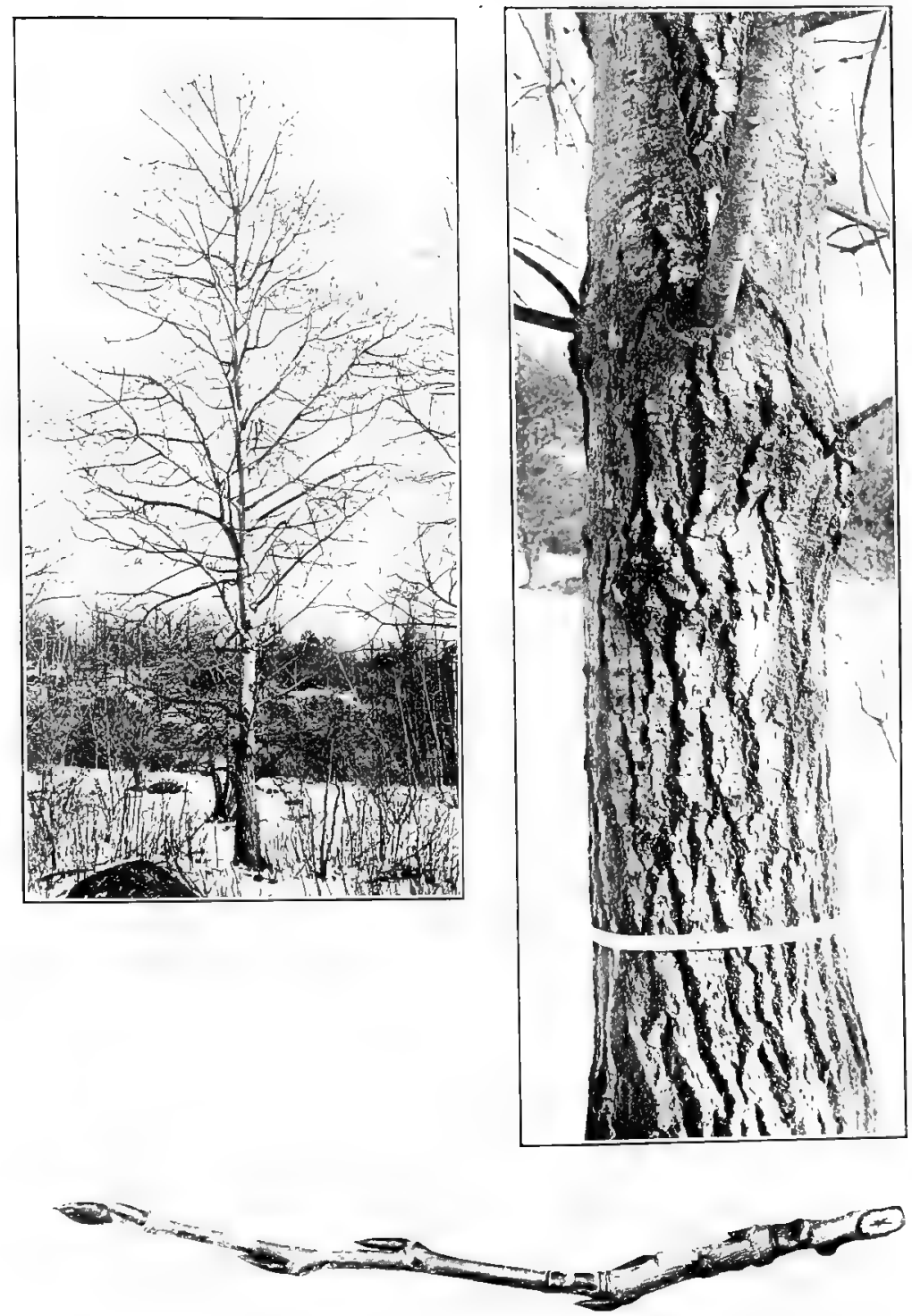

SMall-toothed Aspex 


\section{LARGE-TOOTHED ASPEN Popple, Poplar. \\ Populus grandidentata Michx.}

H IBIT-Generally a small tree $30-45 \mathrm{ft}$. in height with trunk diameter of up to ${ }^{1}{ }^{1} \mathbf{2} \mathrm{ft}$. at times reaching much greater dimensions: resembling the Snall-touthed Aspen; spreading by means of root suckers.

BIRI- Resembling that of Small-toothed Aspen though generally with more yellow or buff color to young trunks and limbs. The older trunks seem to be rather less deeply furrowed.

TW IGs-Stout, round, reddish-brown or somewhat yellomish-bromn, In early winter often more or less pale-downy in protected portions, older twigs greenish-gray, otherwise resembling Small-toothed Aspen.

LEIF-sCARS-Fesembling Small-toothed Aspen though the rather larger stipule-scars are often indistinct or absent.

BCDS-Averaging larger than those of Small-toothed Aspen, ovate to conical, pointed, generally divergent, dull, dusty-looking, due to fine, close, pale wool, especially at margins of scales; flower buds larger and thicker. BUD-SCALES-light chestnut brown with scarious margins; first scale of bud anterior.

Compinisons-The Large-toothed Aspen resembles the Smalltoothed Aspen with which it is frequently confused. For points of distinction see under the latter species. The Lombardy and Carolina Poplars are distinguished by their yellow twigs and smooth buds; the Balsam Poplar by its shining fragrant resinous buds; the Silver Poplar by its generally more delicate, greenish twigs which are cottonynoolly at least toward the apex.

DISTRIBLTIOX-In rich or poor soils; woods, hillsides, borders of streams. Nova Scotia, New Brunswick, southern Quebec, and Ontario; south to Pennsylrania and Delaware, along the mountains to IEntucky, North Carolina, and Tennessee; west to Minnesota.

IN NEW ENGLAND-Common, occasional at altitudes of 2.000 feet or nore.

IN CONXECTICUT-Frequent.

woOD-Light brown, with thin nearly white sapwood of $20-30$ layers of annual growth, weak and soft, used in manufacture of paper, excelsiur, and to a small extent for woodenware. 

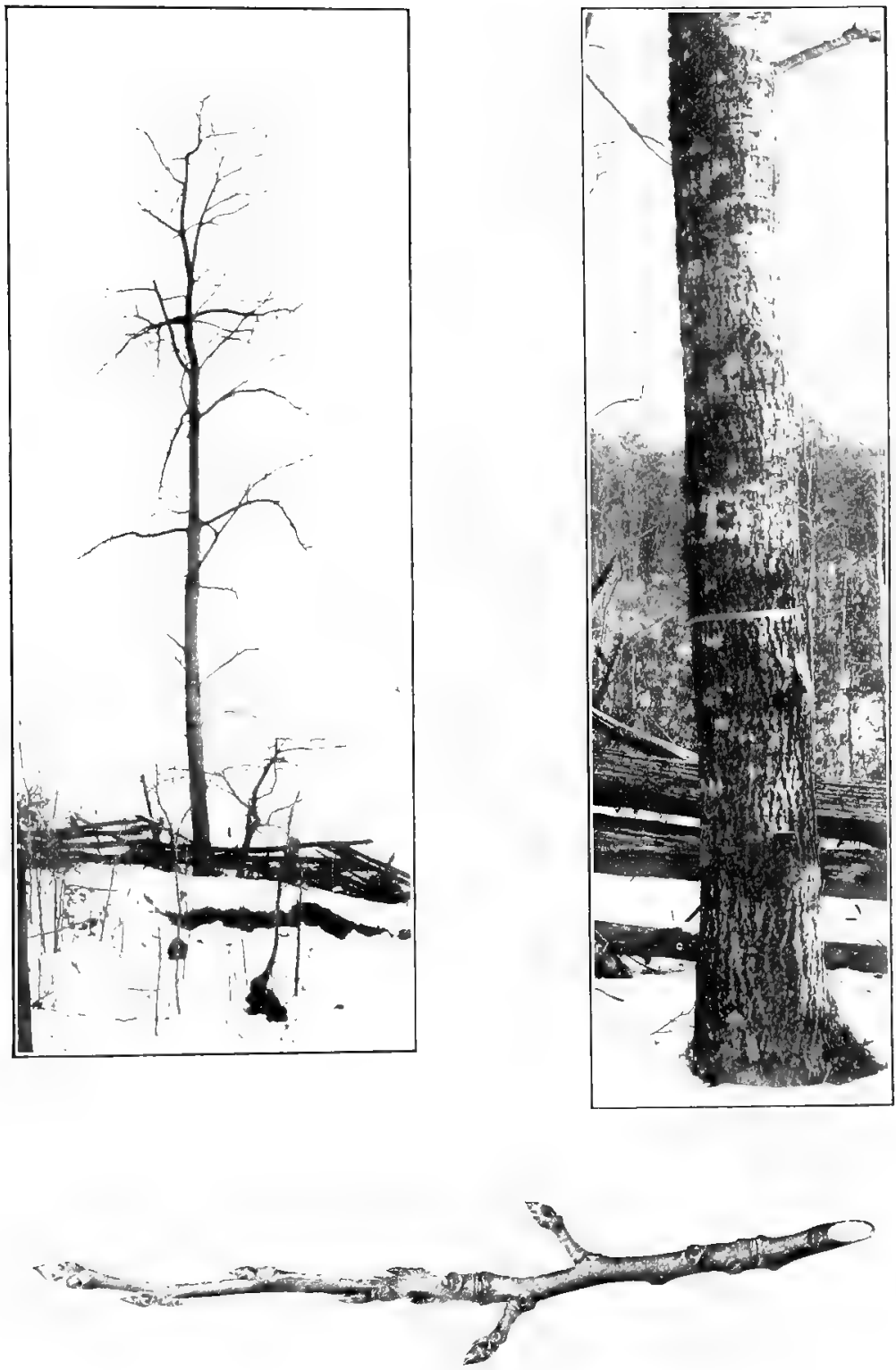

IARGE-Tootiled AsPEN 


\section{BALSAM POPLAR \\ Balsam, Tacamahac, Balm of Gilead. \\ Populus balsamifera $\mathrm{L}$.}

H IBIT-A medium sized tree, $30-75 \mathrm{ft}$, in height with trunk diameter of 1-3 ft.; head open. comparatively narrow, with spire-like tendency; spreading by means of root suckers.

B.IR-On young trunks and branches smooth. light brown tinged with red, on older trunks dark gray tinged with red, broken into broad, firm, rounded ridges.

TWIGs-Stout, round, bright reddish-brown, smooth, shining; older twigs dark orange colored becoming gray tinged with yellowish-green, rughened by thickened leaf-scars; short spurs numerous with terminal but without lateral buds. LENTICELS-oblong, light reddish-orange, scattered. PITH-i-ponted, star-shaped.

LEIF-sC. IRS-Alternate, more than 2-ranked, large, 3-lobed, inversely triangular, rather narrow for the group. STIPULE-SCAFS-distinct. BEXDLE-SCARS-3, simple or compound.

BX DS-Large, dark red, resinous, sticky, fragrant especially if crushed, narrowly ovate to conical long-pointed. $15-25 \mathrm{~mm}$. long. terminal larger and relatively wider than lateral buds. BUD-SCALES-thick, smooth, oblong, pointed, red or green, saturated with fragrant ambercolored resin which on the outside, where exposed to the air, forms a dark reddish, shining varnish to the bud; the first scale of lateral bud anterior.

CoMP IRISONS-The Balsam Poplar with its rarieties is distinguished from all other forms by the fragrance of its large resinous buds. Twigs and buds resemble those of the Small-toothed Aspen in color but are much larger and are distinctly fragrant especially if crushed. The Balm of Gilead [Populus candicans Ait.] is considered a distinct species by some and by others only a variety. It is extensively planted. It differs from the typical Balsam Poplar in its more spreading branches forming a broader and more open head but the twig characters are closely similar. The photogranhs were all taken from this latter variety, the descriptions from the type.

DISTRIBC TION-Alluvial soils; river banks, valleys, borders of swamps, woods. Newfoundland and Nova Scotia; west to Manitoba; northward to the coast of Alaska and along the Mackenzie Fiver to the Artic circle; west through northern New York. Michigan, Minnesota, Dakota (Black Hills), Montana, beyond the Rockies to the Pacific coast.

IN NEW ENGLAND-Maine-common; New Hampshire-Connecticut river valley, generally near the river, becoming more plentiful northward; Vermont-frequent; Massachusetts and Rhode Island-not reported.

IN CONNECTICUT-Local. River banks, wet woods and roadsides, usually as an escape from cultivation; Southington, Milford, Wilton, Sherman. New Milford and Kent. Apparently native at Norfolk.

W00D-Light. soft and weak; light brown. with thick nearly white saprood; used for pails, boxes and paper pulp. 

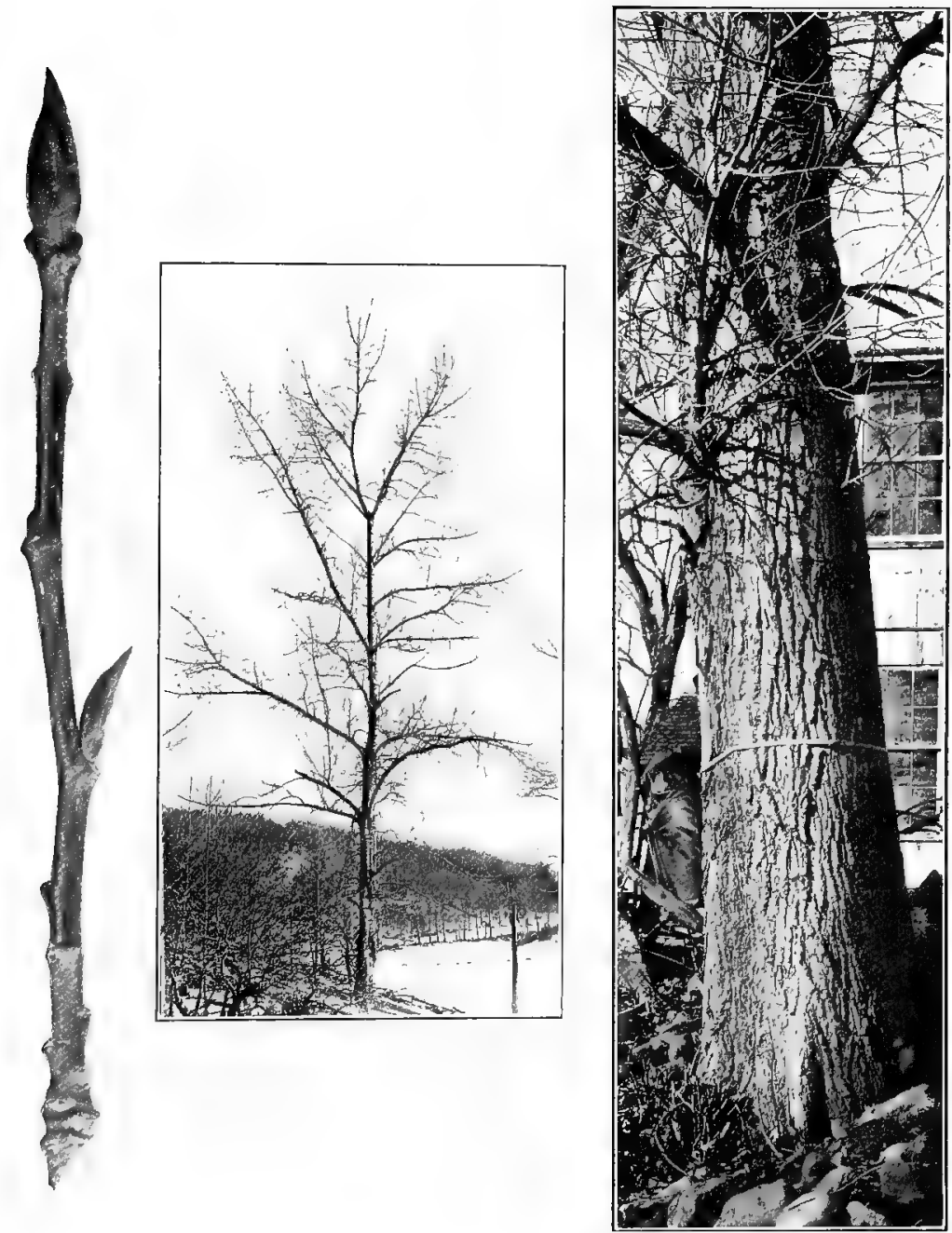

Balsam Poplar 


\section{CAROLINA POPLAR Cottonwood, Necklace Poplar.}

Populus deltoides Marsh.

$P$. monilifera Ait. ; $P$. canadensis Moench.

HIBIT-A large tree, the largest of the Poplars, 75-100 ft. in height with $\mathrm{a}$ trunk diameter of $3-5 \mathrm{ft}$; lower branches massive nearly horizon. tal, those abure arising at a sharper angle and forming altogether in old trees a broad-spreading, rather open head, often as bruad as high; in younger individuals forming a more pyramidal head; of very rapid grumth hence much planted for quick effects. The form cultivated under the name Carolina Poplar and considered by some distinct from the Cottonwood, is of pyramidal habit of growth with erect tapering trunk continuous to the top of the tree and producing branches in whorls at the upper limit of each year's growth. The figures in the plate were all taken from the more commonly cultivated form.

BIRI-On young trunks and branches thin. smooth, light yellowishgreen. On older trunks thick, ashy-gray, deeply divided into long. broad, flattish or eventually rounded ridges of characteristic appearance in native-grown trees.

TW IGS-Stout, yellowish to greenish-yellow, smooth, round or marked especially on vigurous trees with more or less prominent wings running down frum the two sides and bases of the leaf-scars. LENTICELSlarge, pale, elongated longitudinally.

LEIF-sC IRS-Alternate, more than 2-ranked, large, 3-lobed, inversely triangular. STIPLLE-SCARS-generally conspicuous, blackish. BUNDLE-SCAFS-3, simple or compound.

BCDS-Conical, large, the lateral buds reaching $15 \mathrm{~mm}$. and the terminal buds reaching $20 \mathrm{~mm}$. in length, frequently much smaller; lateral buds, especially the larger flower buds, generally divergent and cften strongly recurved; terminal bud more or less distinctly $5-$ sided. BUD-SCALES-smooth, light chestnut brown, shining; first scale of lateral bud anterior; outer scales slightly resinous-sticky, inner scales thickly coated with a light yellow sticky resin which is scarcely fragrant.

Covm InIsoxs-The Carolina Poplar is distinguished from our other Poplars except the Lombardy Poplar by its light yellow twigs. The Lombardy has somewhat similar twigs but they are more slender. the buds are generally much smaller and typically appressed. Appressed buds do occur on the Carolina Poplar and divergent buds on the Lombardy but they are more typical on each tree as indicated. The distinet habit of the Lombardy Poplar is however a suffieient criterion of this latter species.

DISTRIBCTYOX-In moist soil, river banks and basins, shores of lakes, not uncommon in drier locations, often cultivated. Throughnut Quebec and Ontario to the base of the Rocky mountains; south to Florida; west to the Rocky mountains.

IN NETV ENGLAND-Maine-not reported; New Hampshire-restricted to the immediate vicinity of the Connecticut river, disappearing near the northern part of Westmoreland; Termont-western sections, abundant along the shores of the Hoosac river in Pownal and along Lake champlain; in the Connecticut valley as far north as Brattleboro; Massachusetts-along the Connecticut and its tributaries; Rhode Island Loccasional.

IN CONNECTICUT-Frequent in the valleys of the Connecticut, Farmington, and Housatonic rivers; rare or occasional elsewhere.

wooD-Dark brown. with thick nearly white sapwood, light and soft. warping badly in drying and difficult to season, used for paper pulp and in the manufacture of boxes. 

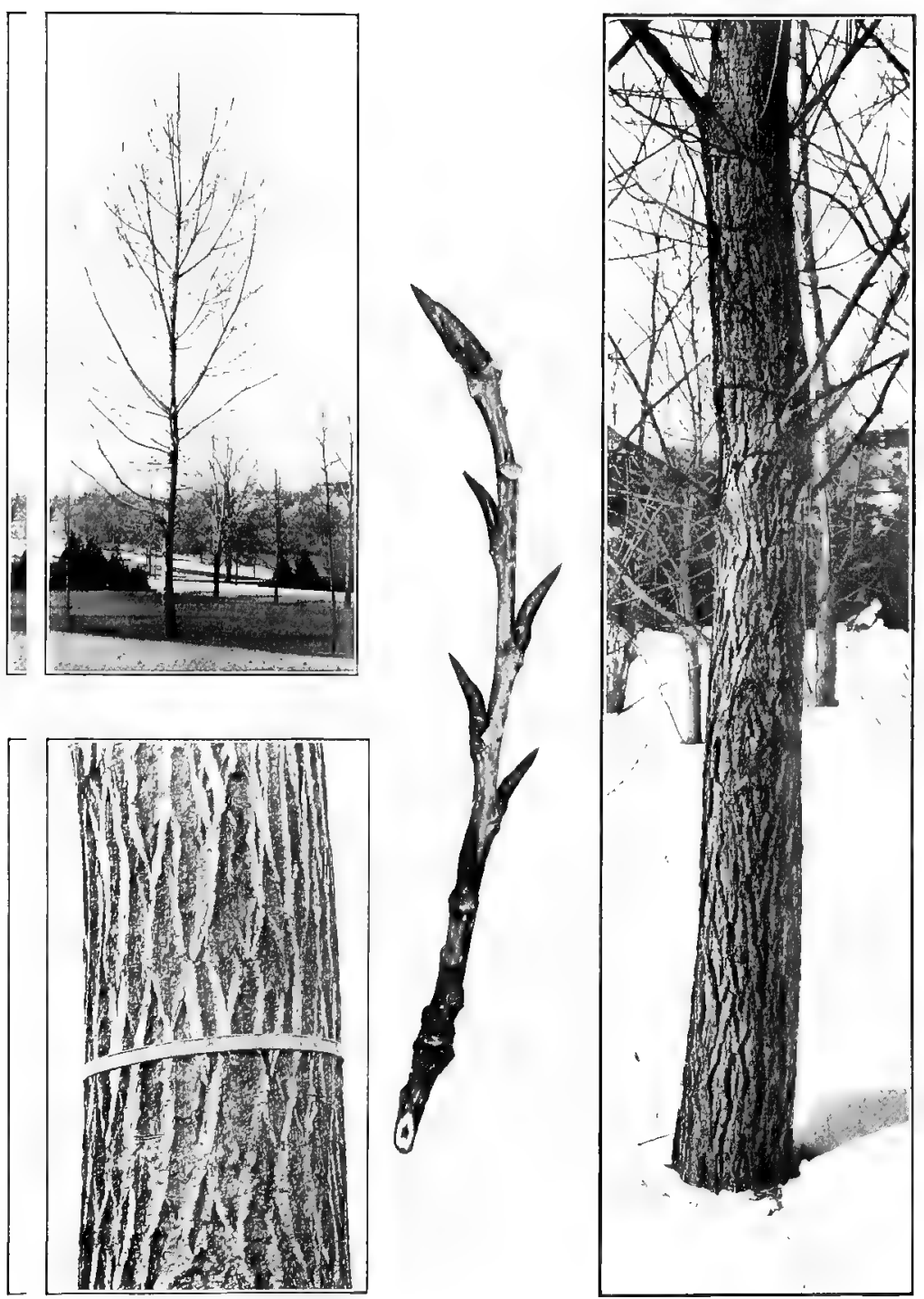

Carolina Poplar 


\section{LOMBARDY POPLAR \\ Populus nigra, var. italica. Du Roi. \\ P. dilatata Ait.; P. pyramialis Rozier; P. fastigiata Desf.}

H I BIT-A tall tree reaching over $100 \mathrm{ft}$. in height with a buttressed tapering, continuous trunk. sometimes as much as $6-8 \mathrm{ft}$. in diameter at base; branches numerous, arising low on the trunk, bending upward at a sharp angle with numerous branchlets also sharply ascending to furm a very narrow spire-shaped tree of decidedy characteristic appearance; spreading by means of root suckers. It tends to retain its leaves on the lower part of the tree. (See bark picture.)

I3 In-On old trees gray to bromn, deeply furrowed.

TW ICt-Resembling those of Carolina Poplar but slender, round and appressed.

I.FAF-sC.IRs-Fesembling those of Carolina Poplar but smaller.

BCDs-Resembling those of Carolina Ponlar but for the most part appressed, distinetly smaller, terminal buds seldom over $10 \mathrm{~mm}$. long and lateral buds generally under 8 mm. in length.

COMPIRIsoxs-The Lombardy Poplar is readily distinguished from all our other trees by its striking spire-shaped habit of growth. In twig characters it resembles the Carulina Puplar but the twigs are slender and the buds average smaller and are more characteristically arinressed.

UITRIBL TIOx-A European tree much planted in this country for ornament, escaping to a certain extent to roadsides and river banks.

w OOD-Light, soft, weak, close-grained, reddish-brown with thlck nearly white sammol, used to a slight extent in the manufacture of buxts and wouden ware 

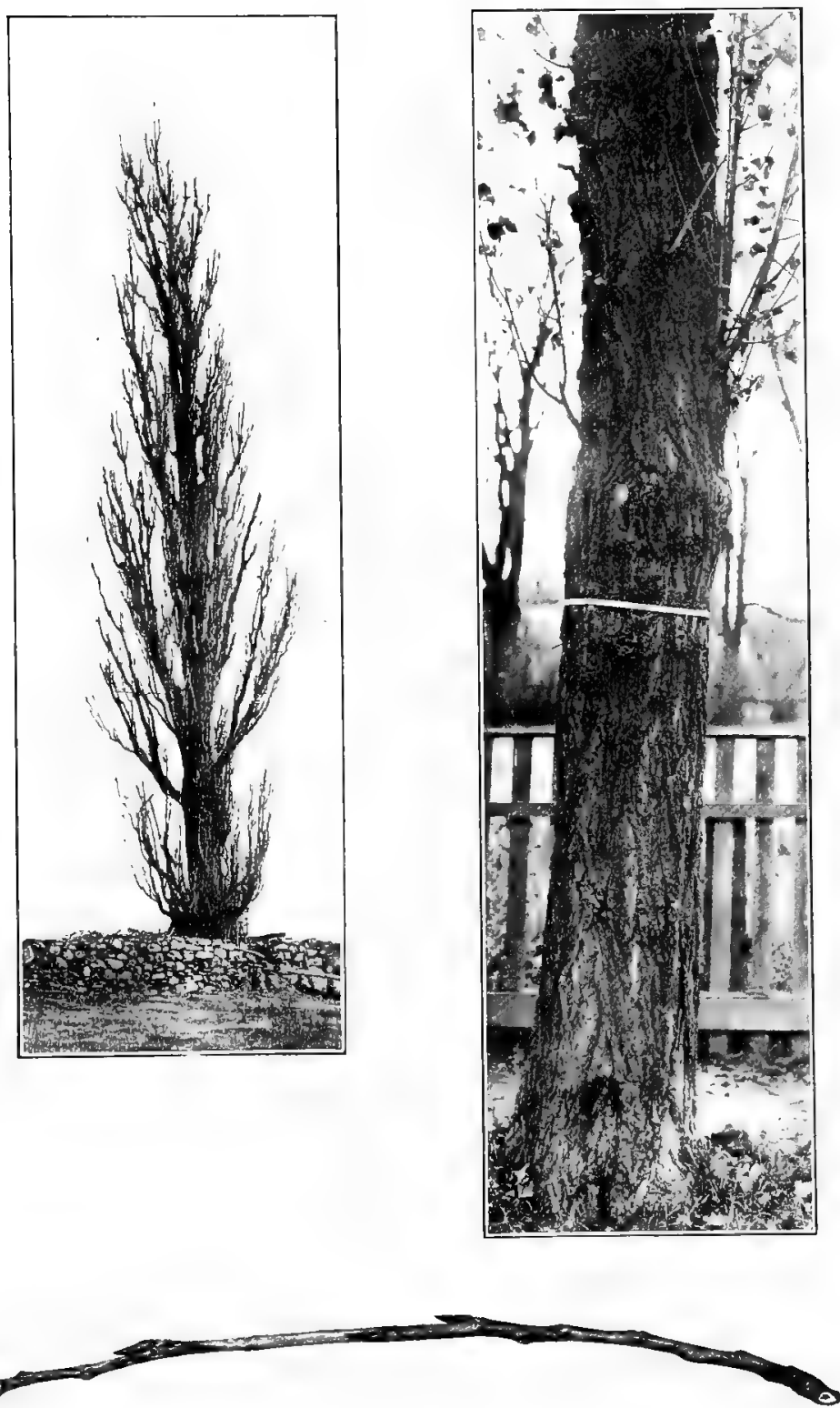

Lombardy Poplat 


\section{BUTTERNUT Oilnut, White Walnut. Juglans cinerea L.}

II I BIT-A small to medium-sized tree $20-45$ ft. in helght, with trunk diameter of 1-4 ft.; comparatively large for the height; soon dividing into a few stout spreading branches with lower branches somewhat drooping forming a symmetrical, broad, low, round-topped head of inversely pyramidal outline.

RARK-On young trunks and branches smooth, light gray, on older trunks deeply divided into long, rather broad, flat-topped, whitish ridges separated by smoothish, broader fissures, which are likewise gray or frequently become black in striking contrast to the whitish ridges; inner bark becoming yellow on exposure to air, bitter.

TWIGS-Stout, reddish-buff to greenish-gray, downy or nearly smooth, round or somewhat angled from lobes of leaf-scars, bitter to taste, and coloring saliva yellow when chewed. LENTICELS-small, pale, raised dots. PITH-somewhat 5-pointed, star-shaped, dark brown, chambered, the narrow chambers a little wider than the intervening diaphragms.

1.EA-SCARS-Large, conspicuous, 3-lobed, inversely triangular; margins flevated, upper margin generally convex seldom slightly notched, surmounted by a raised, downy pad. BUNDLE-SCARS-dark, conspicuous in $3 \mathrm{U}$-shaped clusters.

BIDs-Densely pale-downy; terminal buds large, conical-oblong, 10$20 \mathrm{~mm}$. long, longer than broad, flattened oblong to conical, obliquely blunt-pointed: lateral buds smaller, ovate, rounded at apex, $1-3$ superposed buds generally present above axillary bud, the uppermost the largest, often far above the leaf-scar and more or less stalked or developing into a twig the first season, especially on rapidly grown shoots; staminate flower buds lateral, rather spherical, protruding the undeveloped catkins like miniature scaly cones from the envelope of short scales. PUD-SCALES-thick, outer scales of terminal bud lobed at apex.

FRUIT-Elongated, 4-10 cm. long, husk thickly covered with sticky hairs, not regularly splitting. NUT-light brown, elongated-ovate, 4ribbed, pointed, rough, deeply sculptured; within, 2-celled at base, 1 celled above; seed sweet, edible, very oily, soon becoming rancid.

COMInISONS-In twig characters the Butternut most nearly resembles the Black Walnut but is easily distinguished from this species (see Comparisons under Black Walnut). Its points of dissimilarity to the Bitternut are given under this latter species.

DISTRIBITION-Roadsides, rich woods, river valleys, fertile, moist hillsides, high up on mountain slopes. New Brunswick, throughout Quebec and eastern Ontario; south to Delaware, along the mountains to Georgia and Alabama; west to Minnesota, Kansas, and Arkansas.

IN NEW ENGLAND-Maine, common, often abundant; New Hampshire-throughout the Connecticut valley, and along the Merrimac and its tributaries, to the base of the White Mountains; Vermont-frequent; Massachusetts-common in the eastern and central portions, frequent westward; Rhode Island-common.

IN CONNECTICUT-Frequent.

woOD-Light, soft, not strong, coarse-grained, light brown, turning darker with exposure, with thin. light-colored sapwood, composed of 5 or 6 layers of annual growth; largely employed in the interior finish of houses and for furniture. The inner bark possesses mild cathartic properties. Sugar is made from the sap and the green husks of the fruit are used to dye cloth yellow or orange color. 

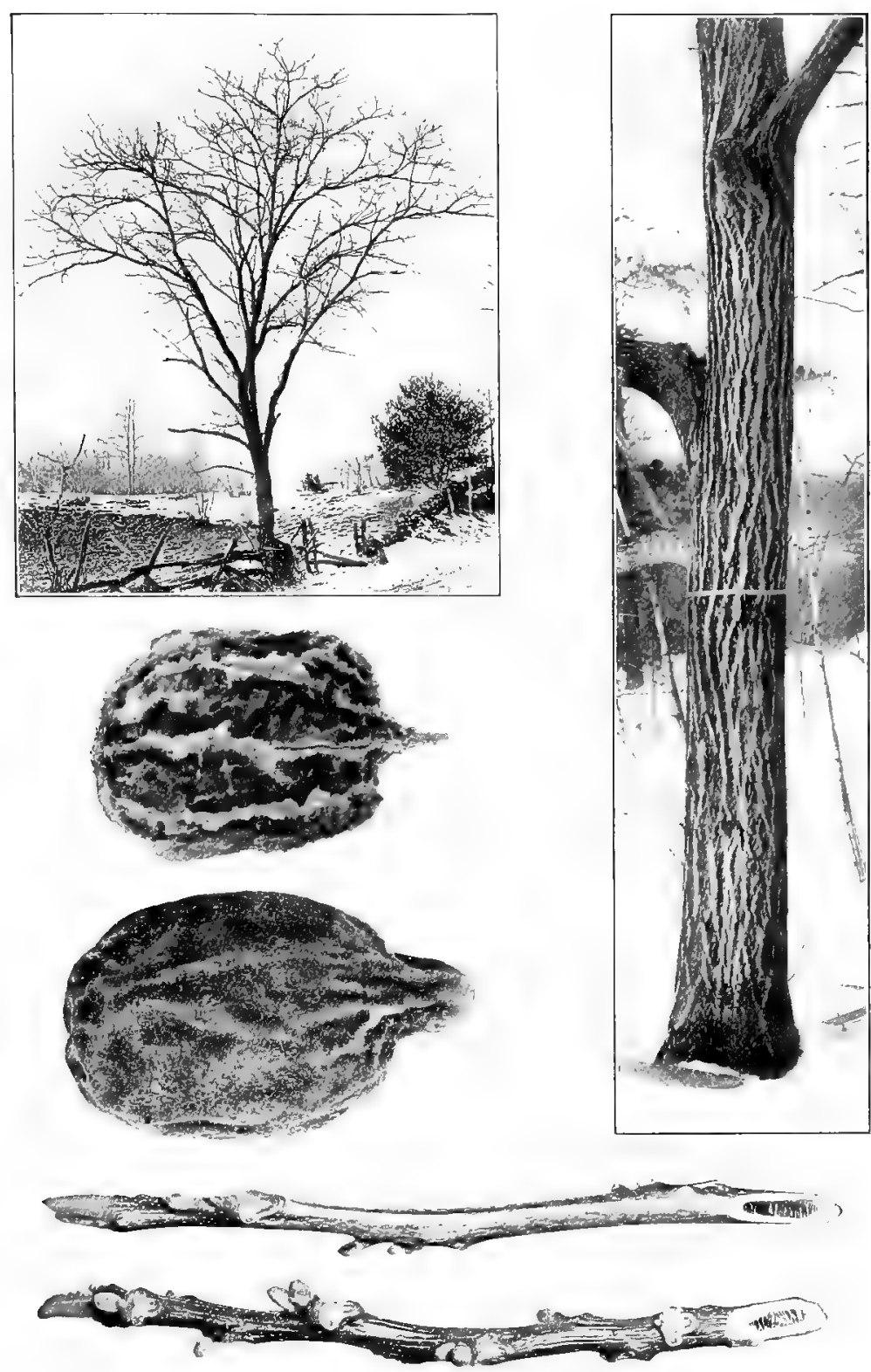

Bitternt? 


\title{
BLACK WALNUT
}

\author{
Juglans nigra L.
}

H IBIT-A large tree, $50-75 \mathrm{ft}$, high with a trunk diameter of 2-5 $\mathrm{ft}$, reaching a height of $150 \mathrm{ft}$. and a trunk diameter of $6-\mathrm{s} \mathrm{ft}$. in the Ohio valley; trunk straight, tapering, giving off stout branches, those below often nearly horizontal or declined, those above arising at a sharper angle, spreading, forming an open, symmetrical, round-topped head.

B IRK-Thick, dark, rough, deeply furrowed into rounded ridges; Inner bark becoming yellow on exposure to air.

TWIG-Stout, densely gray-dorny to smooth and redish-buff; bitter to taste and coloring saliva yellow when chewed. LENTICELS-small, pale, raised dots, rather inconspicuous. PITH-buft, paler than that of Butternut, chambered, the upen chambers several times wider than the intervening diaphragms.

LFAF-sCARs-Large, conspicuous, elerated, 3-lobed inversely triangular to heart-shaped. upper margin distinctly notched enclosing the acillary bud; no downy pad above leaf-sear. BUNDLE-SCARSdark, comspicuous in $3 \mathrm{~L}^{\top}$-shaped clusters.

HI DS-Pale, silky-downy: terminal buds ovate, generally under 10 nim. long and scarcely longer than broad, slightly flattened, obliquely blunt-pointed; lateral buds smaller, their outer scales opening at apex during winter, freguently a single superposed accessory bud above axillary bud. BLL-SCALLS-thick, outer scales of terminal bud generally nut evidently lobed.

FRI IT-Round-oval, 4-10 cm. in diameter, husk smooth not regularly sulitting. NUT-dark brown, ruund-oral, sliohtly flattened, sculptured with interrupted, irregular, thick ridges; within 4-celled below the middle, z-celled above; seed sweet, edible, oily, soon becuming rancid.

COMPIRIso\s-The Black Wralnut is most closely related to the Butternut which it resembles in its chambered pith and the general twig alluearance. The Butternut, however, has terminal buds longer than bruad, downy pads abuse leaf-sears which are not notched as are leaf-scars of the black Talmut and it further has elongated rather than splerical nuts. The pith is dark brown while that of Black Vialnut is pale buff and the chambers are not much wider than the diaphragns. In habit it is a lower, more spreading tree than the Plack Walnut and the light gray color especially of the flat ridges of the barlis further characteristic. The points of dissimilarity to the Bitternut are mentioned under this latter species.

DISTHIHI TION-Rich woods, largely destroyed for its valuable timber and now scarce; occasionally cultirated as an ornamental tree in the eastern United States. Massachusetts; south to Florida; west to Minnesota, Kansas, Arkansas and Texas.

JN X゙EW ENTLAND-Maine, New Hampshire, and Vermont-not reported native; Massachusetts-rare east of the Connecticut river, occasional along the western part of the Connecticut valley to the New Fork line; Rhude Island-doubtfully native, Apponaug, and elsewhere.

IN CONNECTICUT-Rare, Roadsides and rocky hillsides, in most localities derited from planted trees: Norwich, East Hartford, Newington. Southington, Seymour and Southbury, Trumbull and Easton. Probably native at Forth Canaan.

wooD-Heasy, hard, strong, rather coarse-grained, very durable, rich dark brown. with thin lighter colored sapwood of 10-20 layers of annual growth; largely used in cabinet-making, the interior finish of houses, gun-stocks, and in boat and ship building. 

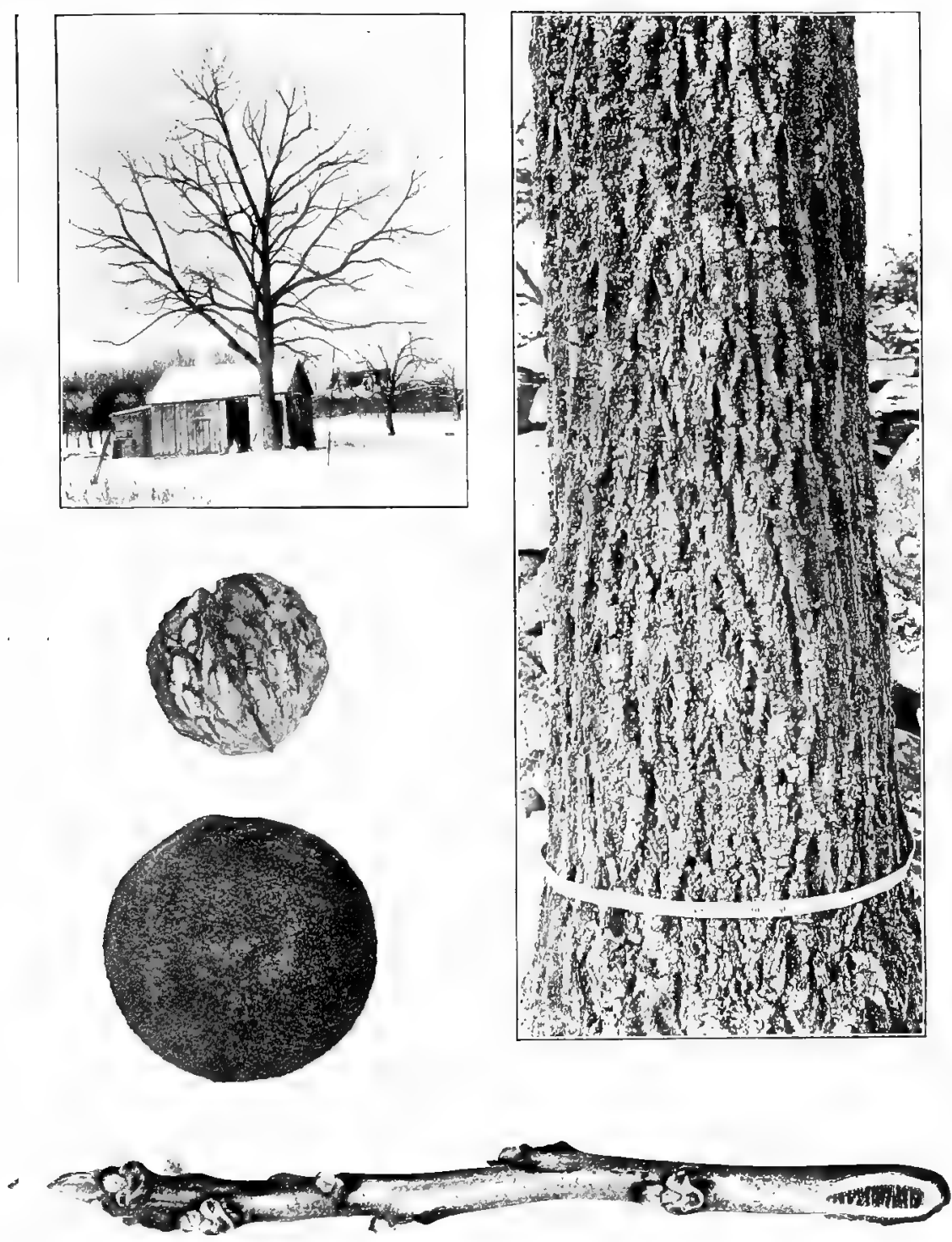

BLACK WALNET 


\author{
SHAG-BARK HICKORY \\ Shell-bark Hickory, Walnut. \\ Carya ovata (Mill.) K. Koch. \\ C. alba Nutt. ; Hickoria ovata Britton.
}

\begin{abstract}
HABIT-A large tree, the tallest of the Hickories 50-75 ft. high, with trunk diameter of less than 2 ft.; in the forest producing a tall, straight trunk often free from branches for $50 \mathrm{ft}$. or more, surmounted by a narrow head of few limbs; in the open generally forking low down or below the middle of the tree into stout ascending limbs forming an irregular open narrow oblong or inversely conical roundtopped head.
\end{abstract}

RARK-On young trunks and limbs smooth, light gray, becoming seamy; on old trunks shagging characteristically into long flat plates which are free at the base or both ends.

TWIGS-Stout, somewhat downy or smooth and shining, reddishbrown to light gray. LENTICELS-numerous, pale, conspicuous, longitudinally elongated. PITH-obscurely 5-pointed, star-shaped.

LEIF-SCARS-Alternate, more than 2-ranked, large, conspicuous, nale, slightly elevated. B-lobed, heart-shaped to semi-circular. STIPULESCAFS-absent. BUNDLE-SCARS-numerous, irregularly scattered or arranged in 3 more or less definite circular groups.

BIDS-Large, terminal bud 10-20 $\mathrm{mm}$ long, broadly ovate, rather blunt-nointed. BUD-SCALES-the 3-4 outer scales dark brown, slightly downy or nearly smooth, fine-hairy on margins, broadly triangular, sharp-pointed, the outermost keted and often with apex prolonged into a long, rigia rount, persistent through winter but cracking and shagging off from the artex duwnward; inner scales yellowish-green, often tinged with red, densely downy on outer surface, shining within.

FRITT-Nearly spherical, 3-5 cm. long, depressed at apex; husk 5-8 mm. tnici. with small pale lenticels, splitting to the base into four pieces. NUT-Whitish, variable in size and shape, generally oblong. flattened, 4-ridged, rounded or pointed at base and apex; seed sweet.

COMPARISOMS-The Shag-bark Hickory is distinguished from other trees by the distinct shayging of its bark. The bark especially of one variety or the Pignut shags to a certain extent but not so extensively. From the Pignut, however, it is distinguished by its larger buds, and scouter twigs. From the Mockernut it is distinguished by its relatively longer buds, the darker, comparatively smooth, outer scalts of which remain throughout the winter though shagging away more or less completely from the tip toward the base.

DISTRIBLTION-In various soils and situations, fertlle slopes, brooksides, rocky hills. Talley of the St. Lawrence; south to Delaware and along the mountains to Florida; west to Minnesota, Kansas, Indian Territory, and Texas.

IN NEW ENGLAND-Maine, along or near the coast as far north as Harpswell; New Hanpshire-common as far north as Lake Winnepesaukee; Termont-occasiunal along the Connecticut to Windsur, rather common in the Champlain valley and along the western slopes of the Green mountains; Massachusetts and Rhode Island-common.

IN CONNECTICUT-Frequent or common.

woon-Heavy, very hard and strong, tough, close-grained, flexible, light brown with thin nearly white sapvood; largely used in the manufacture of agricultural implements, carriages, wagons, and for axehandles, baskets and fuel. The nut is the common hickory nut of commerce. 

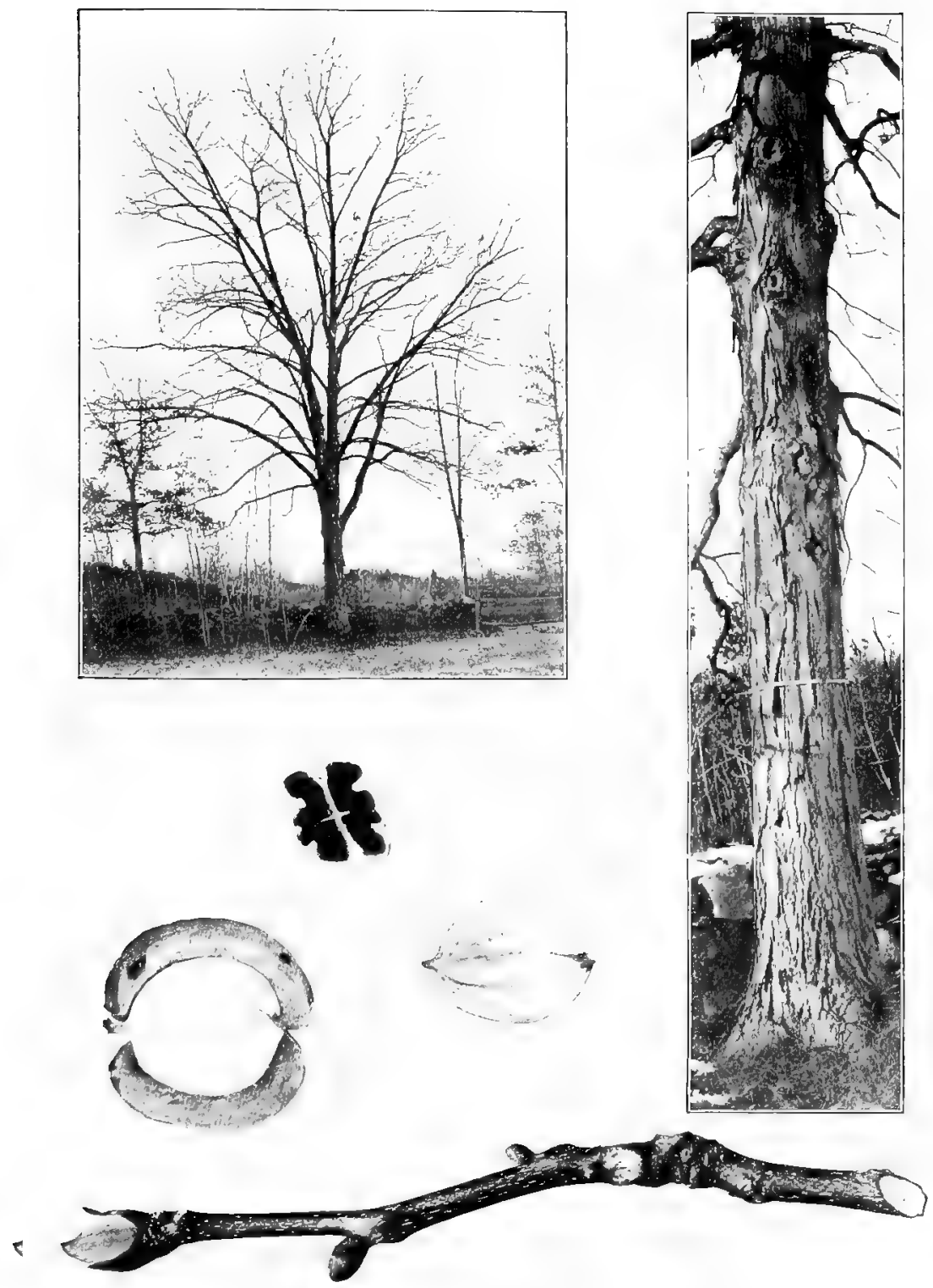

SIIAG-BARK IIICKORY 


\section{MOCKERNUT Big Bud Hickory, White-heart Hickory. \\ Carya alba (L.) K. Koch. \\ C. tomentosa Nutt.; Hickoria alba Britton.}

IIIIT-A tall tree 50-70 ft. high with trunk diameter of 2-3 ft.; lower branches more or less drooping, those above asıending at a sharp angle, forming a narrow oblong or broad round-topped head, trunk sumewhat swollen at base.

HIRI-Light to dark gray, not shaggy, broken by irregular interrupted fissures into shalluw rounded and smooth-tolped ridges which are transversely cracked at intervals; the smonthness of the furrows and of the rounded ridges together with the grayness of the bark is cuite characteristic giving an anpearance as if the roughness of the bark had been sandpapered down or as if a thin veil had been drawn wer the trunk.

TWIA-Tery stout, generally more or less finely-downy, reddishWriwn ta gray. LENTICELS-numerous, pale, conspicuous, iongitudinally elongated. PITH-ubscurely 5-puinted. star-shaped.

I.FIF-SCIRS-Alternate, more than ?-ranked, similar to those of shag-bark Hickury hut rather tending to be more distinctly 3 -lobed with basal love elungated.

HI DS-Terminal buds pale, densely hairy. broady ovate blunt or sharb-pointed, $10-20 \mathrm{~mm}$. long, olitermost scales falling in eariy autumn. expusing the yellowish-gray silky inner scales, some of which fall during the winter.

FII IT-Sinerical to oborate, 4-6 cm. long. more or less narrowed at the ends; husk $3-4 \mathrm{~mm}$. thick, splitting to middle or nearly to base. Nit hrown, variable in size and shape, spluerical to oblong. more or los flattened and angled and generally pointed at both ends; shell very thick; seed comparatively small, sweet.

COMP IRISONs-The Mockernut, so named from the disappointingly small kernel obtained from the relatively large nut. is distinguished by its large. fat. pale, downy buds, which do not retain the outer dark seales as do the narrower buds of the Shag-bark Hickory. The peculiar smoothness of the ridges and furrows of the gray bark is also a distinctive characteristic.

IISTRIMY TIOY-In various soils; woods, dry, rocky ridges, mountain slopes. Niagara peninsula and westward: south to Florida, ascending 3.50n feet in Tirginia; west to Kansas. Nebraska, Missouri, Indian Territory, and Texas.

IN NET ENGLIND-Maine and Vermont not reported; New Hampshire-sparingly along the coast; Massachusetts-rather common eastward: Fhode Island-common.

IN CONNECTICUT-Occasional or frequent.

woon-Tery heaty, hard, tough, strong, close-grained. flexible, rich dark brown, with thick nearly white sapwoud; used for the same Furpose as that of the Shag-bark Hickory. 

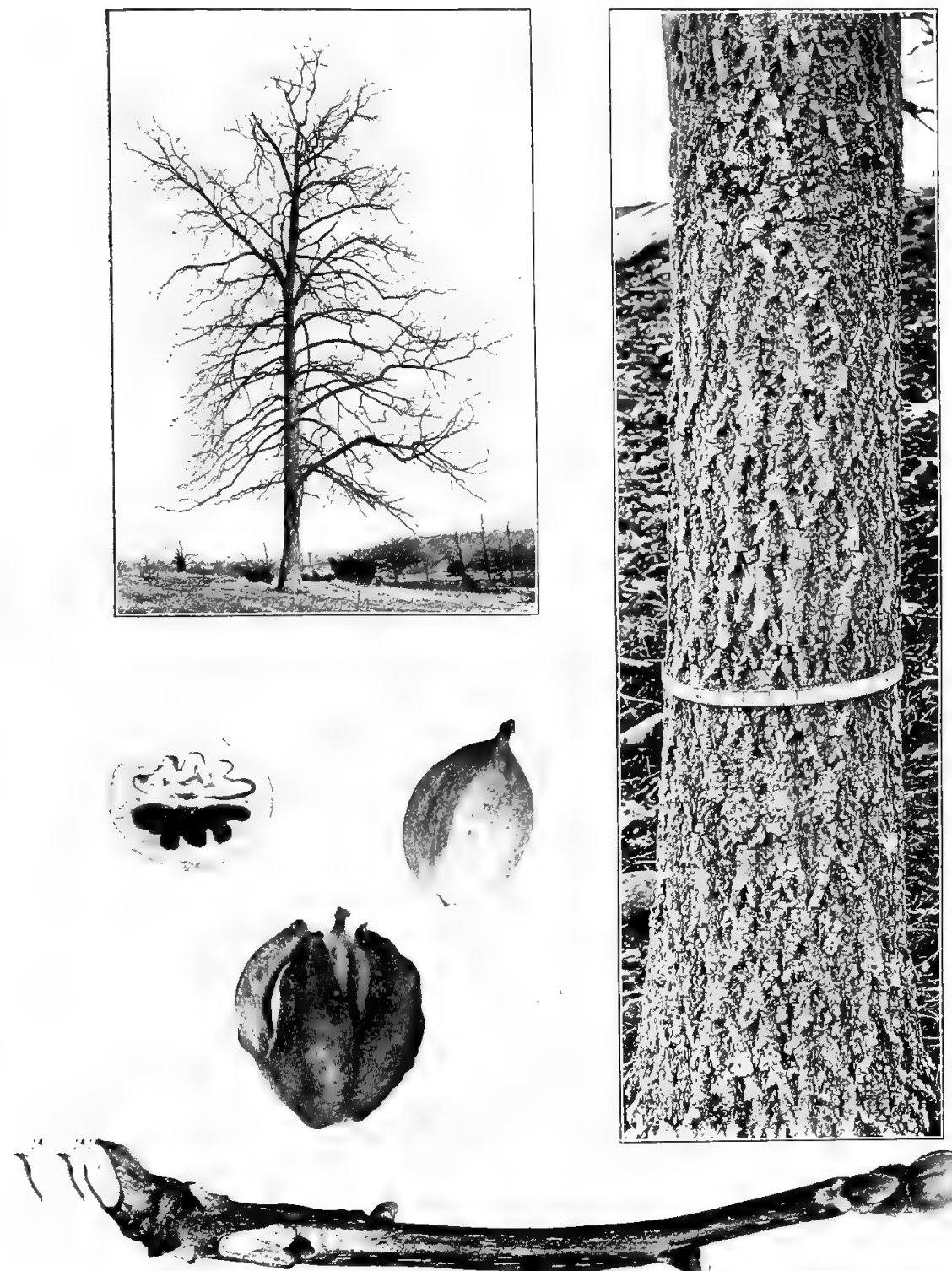


\author{
PIGNUT \\ Pignut or Broom Hickory. \\ Carya glabra (M.ll.) Spach. \\ C. porcina Nutt.; Hickoria glabra Britton.
}

HIBIT-A good sized tree, 50-60 ft, in height with a trunk diameter of 2-5 ft.; branches slender, more or less contorted, the lower ones especially usually strongly pendulous, forming a narrow oblong head, well shown in the tree photographed, or broader in other specimens.

BIRK-Dark gray, fissured into irregular diamond-shaped areas somewhat suggesting bark of White Ash, but narrow ridges flattened, tough, tending to become detached at ends; sometimes somewhat shaggy especially in one of the rarieties mentioned below, which has a bark approaching that of the Shag-bark Hickory.

TWIGs-Comparatively slender for the grenus, smooth, redishbrown, to gray. LENTICELS-numerous, longitudinally elongated, more or less conspicuous. PITH-obscurely 5-pointed, star-shaped.

LFIF-SCIRS-Alternate, more than 2-ranked, obscurely 3-lobed, heart-shaped to semi-circular or oblong. BUNDLE-SCARS-numerous, irregularly scattered or collected in 3 more or less definite groups.

ACDs-Reddish-brown to gray, small. terminal bud under $10 \mathrm{~mm}$. long, oval, blunt or sharp-pointed, becoming subglobuse toward spring. BUI,-SCALES-outer scales dark, smooth or finely downy, generally slightly yellow glandular-dotted, more or less keeled, and sometimes long pointed, often falling before the end of winter and exposing the pale-silky inner scales.

FRI IT-Pear-shaped to oblong to nearly spherical, $3-5 \mathrm{~cm}$. Iong; very variable in size and shape; husk under 2 mm. thick, fu some forms splitting only at the apex and enclosing the nut after it has fallen to the ground, in other forms splitting to the middle or to the base. NIT-thick or rather thin shelled, generally not ridged nor sharppointed; seed sweet or sometimes bitter.

COMPIRISONS-The Pignut is a very varlable species and there are sereral varieties described, some of which have been recognized as distinct species, as for instance Carya microcarpa Nutt.,-the Smallfruited Hickory-which is perhaps the most conspicuous. It has a somewhat shaggy bark and a nearly spherical fruit with the husk splitting to the base. The most distinctive feature of the whole species is the small size of the buds. Which before the uuter dark scales drop off resemble buds of the Shag-bark Hickory except for size, and after these outer scales have been shed may be compared with miniature Mockernut buds. Its bark is not smoothed off like that of the Mockernut nor except in extreme cases shaggy like that of the Shagbark.

DISTRMBTION-Woods, dry hills and uplands. Niagara peninsula and along Lake Erie; south to the Gulf of Mexico; west to Minnesota, Nebraska, Kansas, Indian Territory, and Texas.

IN NEW ENGLAND-Maine-frequent in the southern corner of York county; New Hampshire-common toward the coast and along the lower Merrimac valley; abundant on hills near the Connecticut river, but only occasional above Bellows Falls: Vermont-Marsh Hill, Ferrisburgh, "W. Castleton and Pownal; Massachusetts-common eastward; along the Connecticut river valley and some of the tributary valleys, more common than the Shag-bark; Rhode Island-common.

IN CONNECTICUT-Occasional or frequent.

wooD-Heavy, hard, very strong and tough, flexible, light or dark brown, with thick, lighter colored or often nearly white sapwood; used for the handles of tools and in the manufacture of wagons and agricultural implements, and largely for fuel. 

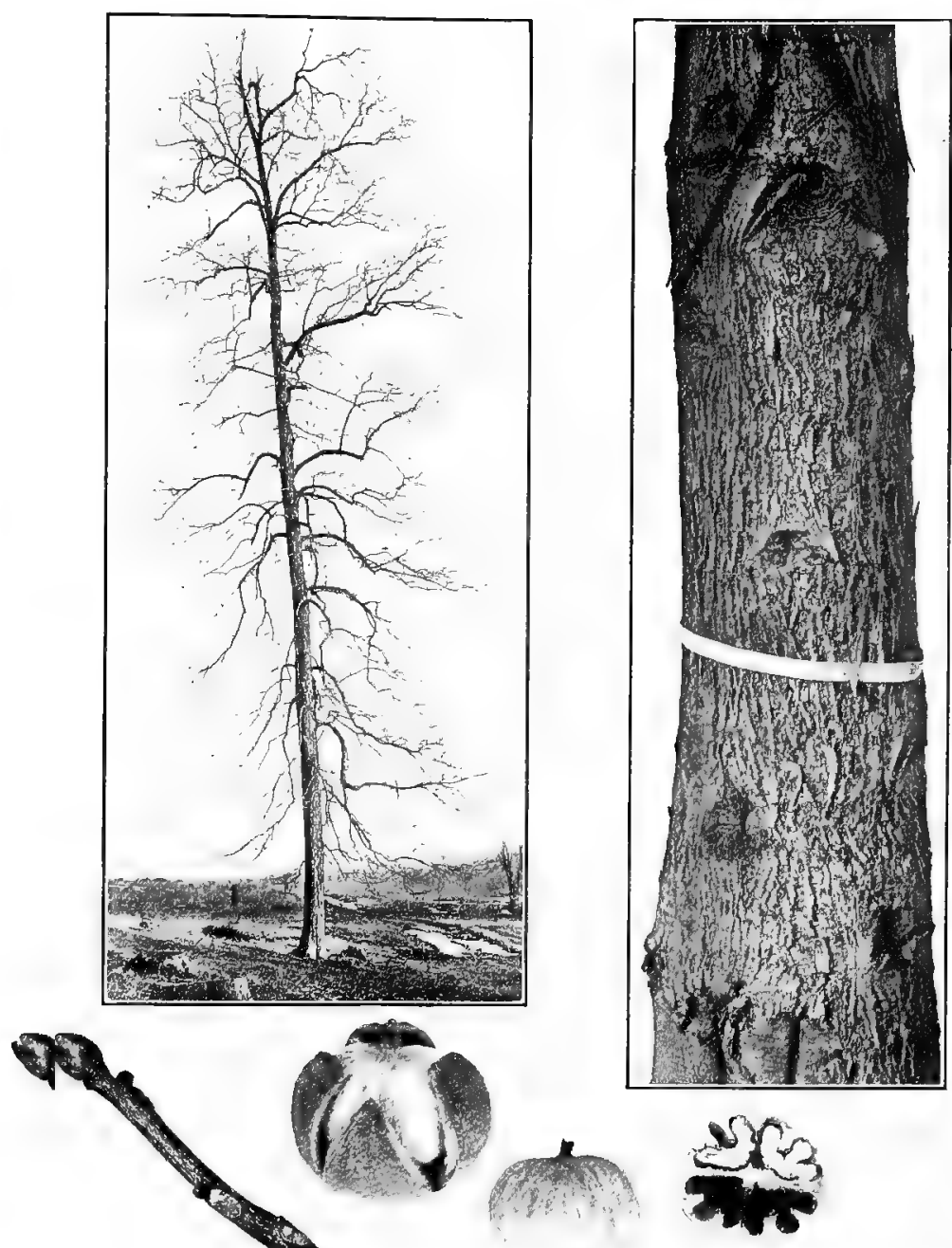

Pignut 


\section{BITTERNUT Swamp Hickory.}

Carya cordiformis (Wang.) K. Koch.

C. amara Nutt. ; Hekoria minima ( Marsh.) Britton.

H IIIT-A tall tree $50-75$ ft. in height, with a trunk diameter of 1-21/2 ft.; trunk generally early developing several stout ascending and somewhat diverging branches to form a broad spreading head generally widest toward the top.

BIRK-Thin, light gray, close, with shallow fissures and narrow ridges rarely thaking off in small thin scales.

TW IGs-slender, buff or gray or reddish, smooth or slightly downy toward apex, generally yellow-glandular above. LENTICELS-more or less distinct. pale, numerous, longitudinally elongated. PITH-infrequently star-shaped, brown.

LEIF-SCIRs-Alternate, more than 2-ranked, obscurely 3-lobed, hedrt-shaped, inversely triangular to elliptical, pale, raised, large, prominent, the upper margin generally rounded, convex to sharpponted, often 2-toothed at apex. BUNDLE-SCAFS-prominent, irregularly scattered or collected into 3 more or less regular groups or somitimes apparently in single curved line.

IB US-Slender, strikingly yellow with crowded glandular dots, slighty hajry between the scales; terminal bud $5-15 \mathrm{~mm}$. long, flattened, (b)lituely blunt-pointed; lateral buds more or less 4-angled, the axillary bud generally minute with one or more larger superposed buds above it often considerably sevarated from each other, the uppermost of the series stalked or developing into a twig the first season. BUD$S C+L E S-4$, valvate in pairs.

FHIIT-Nearly spherical to pear-shaped $2-3.5 \mathrm{~cm}$. long, generally 4-winged from the apex to about the middle: husk about $1 \mathrm{~mm}$. thick, yellow glandular-dotted, tardily splitting to about the middle into 4 valves. NUT-usually thin-shelled, sometimes broader than long", smooth, short-pointed; seed deeply and irregularly roughened, sweetish at first, becoming intensely bitter.

CovI.IRISONS-The Bitternut is not to be confused with any other tree if due notice is taken of the narrow bright yellow, glandulardotted often superposed buds. The Butternut has superposed buds but they are vale greenish-yellow and very downy, not bright yellow nor glandular dotted and the pith though similarly brown is distinctly chambered.

DISTRIBCTIOX-In varring soils and situations: wet woods, low, danp fields, river valleys, along roadsides, occasional upon uplands and hill slopes. From Montreal west to Georgian bay; south to Florida, ascending 3,500 feet in Tirginia; west to Minnesota, Nebraska, Kansas, Indian Territory, and Texas.

IN NEW ENGLAND-Maine-southward, rare; New Hampshireeastern limit in the Connecticut valley, where it ranges farther north than any other of our Hickories, reaching Well's river: Vermontoccasional west of the Green mountains and in the southern connecticut valley; Massachusetts-rather common, abundant in the vicinity of Boston; Rhode Island-common.

IN CONNECTICUT-Occasional.

WooD-Heavy, very hard, strong, tough, close-grained, dark brown, with thick light brown or often nearly white sapwood; largely used for hoops and ox-yokes and for fuel. 

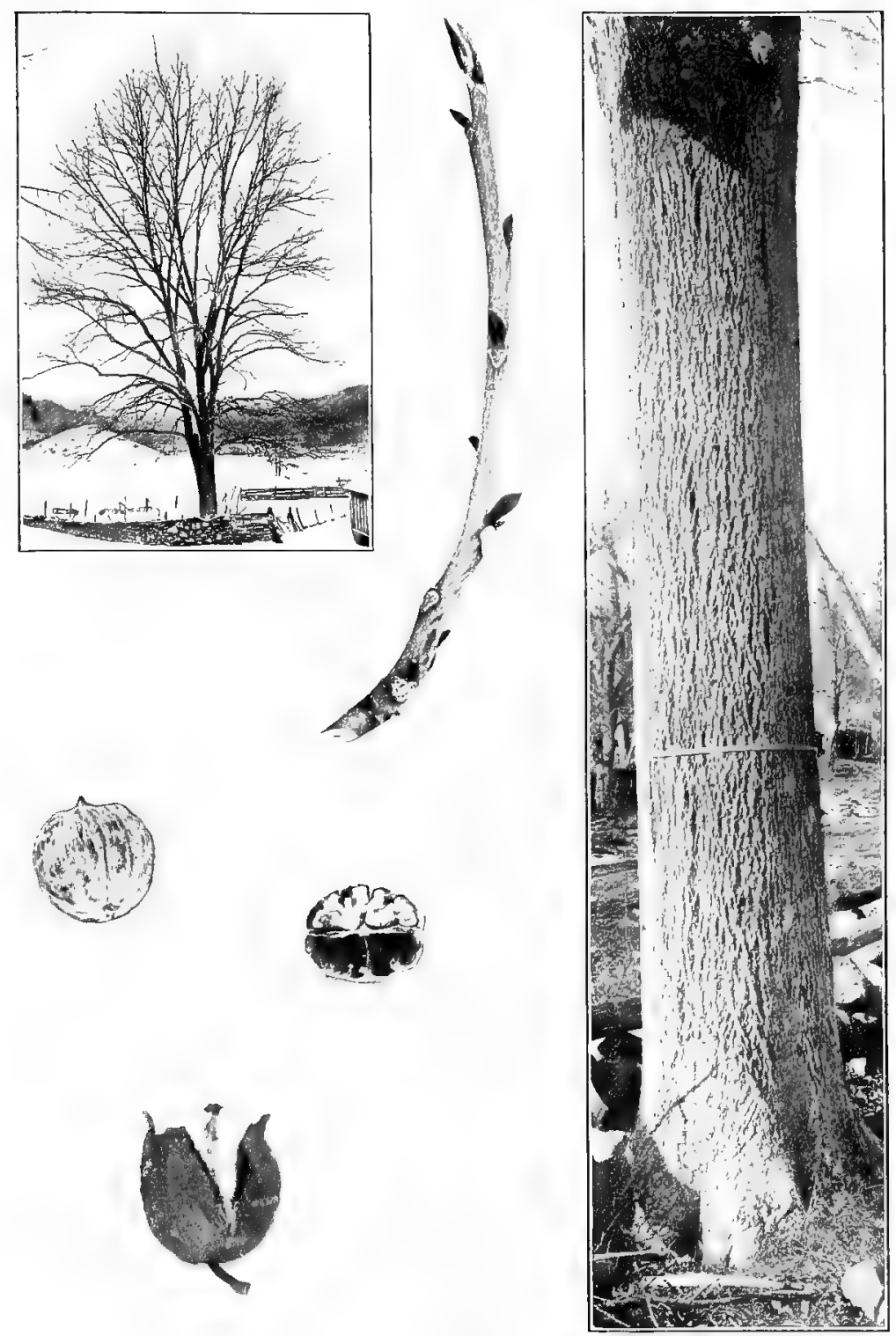

Bitternut 


\section{HOP HORNBEAM Ironwood, Leverwood, Deerwood. \\ Ostrya virginiana (Mill.) K. Koch.}

HIBIT-A small tree $25-40 \mathrm{ft}$. in height with a trunk diameter of generally less than $1 \mathrm{ft}$; branches long, slender, those below widely spreading and often drooping but with branchlets tending upward forming an irregular oblong or broadly ovate head often as broad as tall with slender, stiff spray.

BARK-Thin, flaky, light grayish-brown broken into narrow flatish pieces, loose at the ends.

TWIGs-slender, 1-2 $\mathrm{mm}$, in thickness, dark reddish-brown, often zigzag, for the most part smooth and shining. LENTICELS-scattered, pale.

LEAF-sCARs-Alternate, 2-ranked, minute, $1.75 \mathrm{~mm}$. or less in diameter, flattened, elliptical, projecting. STIPULE-SCARS-triangular, rather inconspicuous. BUNDLE-SCARS-generally 3, inconsplcuous; if scar is surface-sectioned, 5 bundle-scars are evident.

BIDS-Small, 3-7 mm. long, narrowly ovate, pointed, light reddishbrown, smooth or somewhat finely downy, slightly gummy especially within, generally strongly divergent; terminal bud absent. BUD-SCALES -in 4 ranks, about 8 scales visible, increasing in size from below upwards, longitudinally striate if viewed toward light.

FRCIT-A small seed-like nutlet, enclosed in an inflated sac-like, veiny bract, long-hairy at base; the fruits aggregated together in a hop-like cluster about $7 \mathrm{~cm}$. long, with stalks often hairy. generally falling before winter. Young staminate catkins abundantly present, cylindrical, usually in 3 's, their scales bristle-pointed.

COMPARISONS- The Hop Hornbeam from its general appearance and bark character is sometimes mistaken for a young Elm. The scales of the bark, however, are narrower and more flaky, the leaf-scars are smaller and the bundle-scars are not sunken, the bud-scales are in 4 ranks and the staminate flowers are borne in catkins which are generally present on the tree in winter. For differences between the Hop Hornbeam and the American Hornbeam, see under latter species.

DISTRIBUTION-In rather open woods and along highlands. Nova Scotia to Lake Superior, scattered throughout the whole country east of the Mississippl, ranging through western Minnesota to Nebraska. Kansas, Indian Territory and Texas.

IN NEW ENGLAND-Common in all parts.

IN CONNECTICUT-Frequent.

wooD-Strong, hard, tough, durable, light brown and tinged with red or often nearly white, with thick pale sapwood of 40-50 layers of annual growth, used for fence posts, levers, handles of tools, mallets and other small articles. 

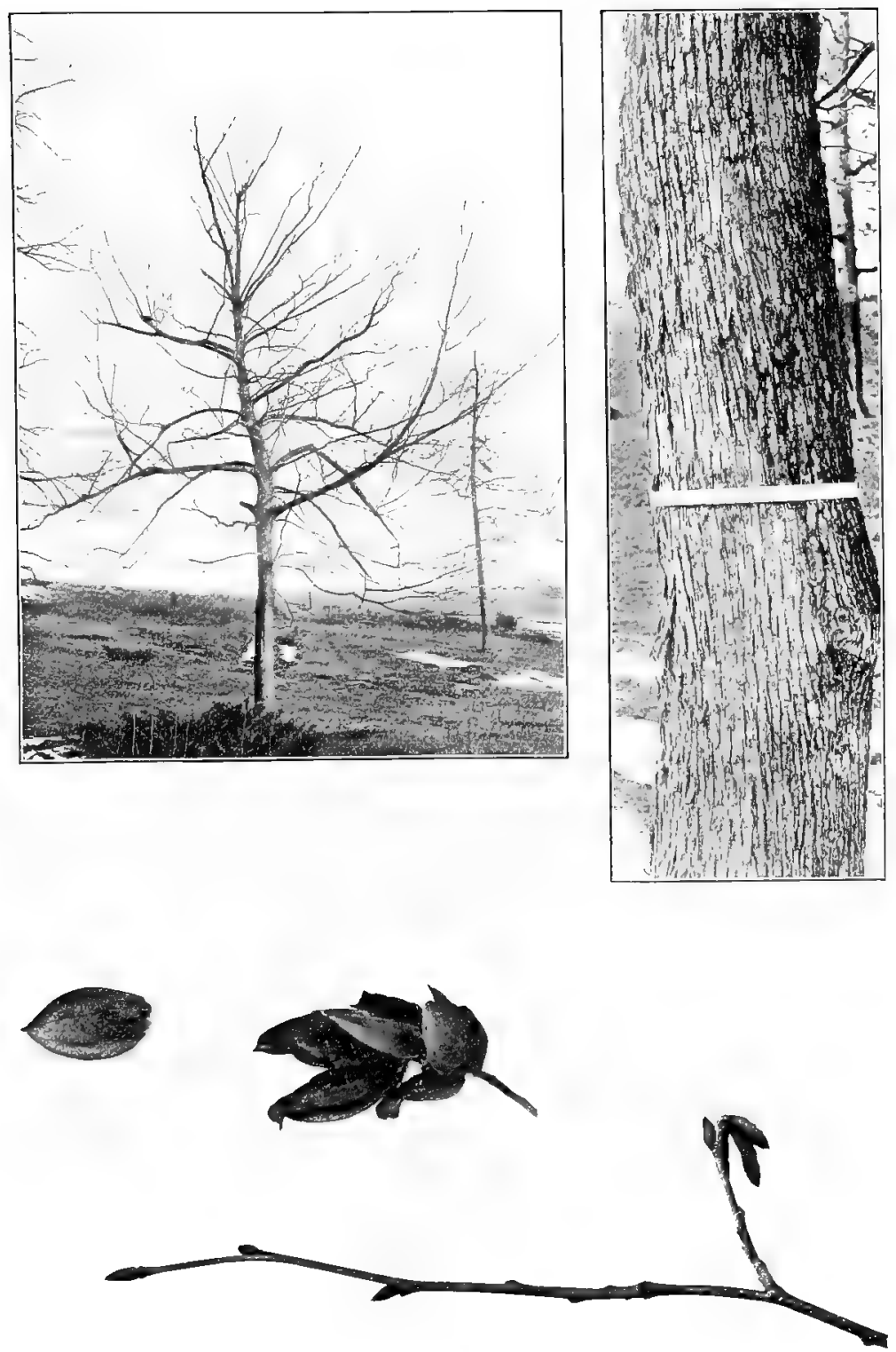

HoP HORNBEAM 


\section{AMERICAN HORNBEAM Hornbeam, Blue Beech, Ironwood, Water Beech. Carpinus caroliniana Walt.}

11 1BIT-A low tree or shrub $10-30$ ft. high with a trunk diameter generally under $1 \mathrm{ft}$; with long. slender, tuugh, more or less zigzag branches not easily broken, which are sumewhat pendulous at ends forming a bushy wide spredding, flat or round-topped head; the trunk is frequently zigzag abuve giving appearance of being forked with broad rounded crotihes.

B.IRli-Smooth, thin, dark bluish-gray, close-fitting, sinewy-fluted with smovth, rounded, longitudinal ridges, The smooth ridges of the bark are rery characteristic and may be compared to the appearance uf the wrist which becomes similarly ridged by the protrusion of the sinews when the hand is clenched.

rw IGS-Slender, about $1 \mathrm{~mm}$, thick or less torard apex, dark red, and shining, smuoth, or uften somewhat hairy. LENTICELS-Scattered, yale, generally conspicuous.

LEIF-SCIRS-Alternate, 2-ranked, minute, flattened, elliptical, prifecting. STIPLLE-SCARS-narruw, triangular, rather inconspicuous. 1:TYILE-SCAFN-generally 3, inconspicuus, up to 5 visible when surface-sectioned.

BUDS-Small, usually 2-4 $\mathrm{mm}$. long, narrowly ovate to oblong, point. ed, reddish-brown. more or less hairs especially the buds containing staminate catkins which are larger and oval to oborate; leaf buds mure or less arpressed or only slightly divergent, terminal bud absent. ELT-SCALES-in 4 ranks about $\delta-12$ scales visible, increasing in size from below unward white-scarious and often downy on edges, frequently with a wolly patch of down on tip; longitudinally striate when viewed tuward light.

FRIrT-A small ribhed seed-like nutlet enclosed by a reiny generally 3-lobed bract abut $2.5 \mathrm{~cm}$. long. which is saw-toothed on one side of larger lube and often has one of lower lobes lacking, usually falling before winter. Staminate catkins entirely enclosed in the larger buds therefore nut visible during winter.

COMP IRISOYs-The Amorican Hornbeam is nften confused with the Hop Hornbeam perhaps chiefly from their unfortunate similarity in conmon names. The smooth, close, bluish-oray bark together with the habitat in which it grows has given it the name of Tater Bepoh. The sinfwy-fluting to the bark is unirue among our trees and readily distinguishes the American Hornbeam from the Hop Hornbeam the bark of which is flaky in narrow scales. Further the American Hornbeam never shuws any catkins in winter while they are generally abundant on the Hop Hornbeam; the buds of the American Hurnbeam are smaller, and have whitish down on the edges; those of the Hop Hornheam are for the most part smooth and slightly gumms. The Feech which the American Hornbeam resembles in its bark has much larger and relatively longer buds.

DISTRIBCTION-LnW, wet woods, and margins of swamps. Province nf Quebec to Georgian bay: south to Flurida; west tu Minnesuta, Nebraska, Kansas, Indian Territory, and Texas.

IN NEW FNGLAND-Rather common throughout, less frequent towards the coast.

IN CONNECTICUT-Frequent or common.

Woon-Light brown with thick, nearly white sapwood, sometimes used for levers, the handles of tools and other small articles. 

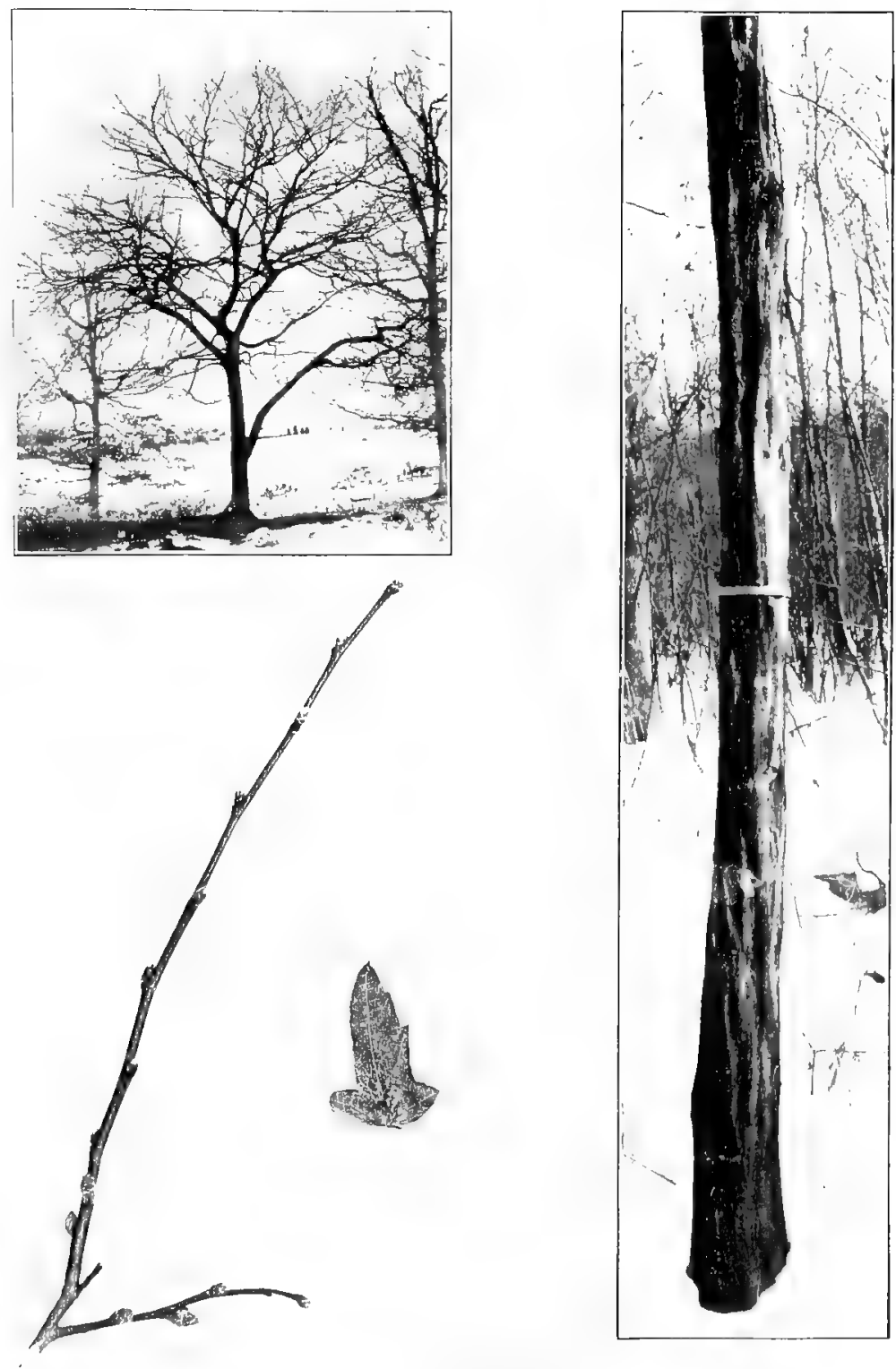

AMERICAN IIORNBEAM 


\section{BLACK BIRCH \\ Cherry Birch; Sweet Birch. \\ Betula lenta L.}

HABIT-A medium to large sized tree 50-75 ft, high, with a trunk diameter of 1-4 ft.; branches long and slender, in young specimens upper branches ascending at sharp angle, lower branches horizontal or drooping with delicate spray forming a narrow head; in older trees becoming wide spreading, ovate in outline.

BIRK-On young trunks and branches smooth, close, not peeling, dark reddish-brown, shining, with horizontally elongated pale lenticels resembling the bark of the cultivated Cherry whence the common name; in older trunks tardily broken into large thick irregular plates; inner bark with distinct wintergreen taste.

TWIGs-Slender, light reddish-brown, smooth, shining, with strong winteroreen flayor when chewed; short spur-like lateral shoots abundant. bearing two leares each season. much roughened by leaf-scars of numerous past seasons. LFNTICELS-pale, raised dots, becoming horizontally elongated with age. PITH-elliptical.

LFIF-SCARS-Alternate, 2-ranked, small, semi-oval to depressed inversely triangular to crescent-shaped, projecting. STIPULE-SCARSpresent, narrow, inconspicuous. BUNDLE-SCAFS-generally 3 and inconspicuous.

BXDS-Medium, 5-10 $\mathrm{mm}$. long, conical, sharp-pointed, reddish-brown, divergent; terminal bud absent on long shoots; buds on short spurs terminal. BUD-SCALES-downy on margins, overlapping with more than 2 ranks; in buds of long shoots 3 scales visible two lateral of equal size reaching half way up and a third with edges rolled around the bud; scales of terminal buds on short spurs more numerous, about 7 visible.

FRIIT-An erect, stalkless, oval-oblong catkin, $2-4 \mathrm{~cm}$. long, with smooth scales about 4-6 mm. Inng, equally 3 -lobed above the middle and with seed-like winged nutlets about as broad as their wings.

COMPARISONS-The Black Birch difers from other Birches in its close dark cherry-like bark. It is most closely related to the Yellow Birch in the character of its fruit and the aromatic flaror of the young: bark. Besides the bark differences, however the twigs of the Black Birch have a more decided wintergreen flavor. It has in general a somewhat less spreading habit of growth, the buds are divergent and the catkins are downy.

DISTRIBTTION-Moist grounds; rich woods, old pastures, fertile hill slopes, banks of rivers. Maine; south to Delaware, along the mountains to Florida; west to Minnesota and Iransas.

IN NEW ENGLAND-Maine-frequent; New Hampshire-in the highlands of the southern section, and along the Connecticut river valley to a short distance north of Windsnr; Yermont-frequent in the western nart of the state, and in the southern connecticut vallev: Massachusetts and Rhode Island-frequent throughout, especially in the highlands, less often near the coast.

IN CONNECTICUT-Widely distributed, especially in the Connecticut river valley, frequent or common.

WoOD-Heavy, very strong and hard, close-grained, dark brown tinged with red, with thin light brown or vellow sapwood of $70-80$ layers of annual growth; largely used in the manufacture of furniture and for fuel, and cccasionally in ship and boat building. Oil of wintergreen. used medicinally and as a flavor. is distilled from the wood, and beer is abtained by fermenting the sugary sap. 

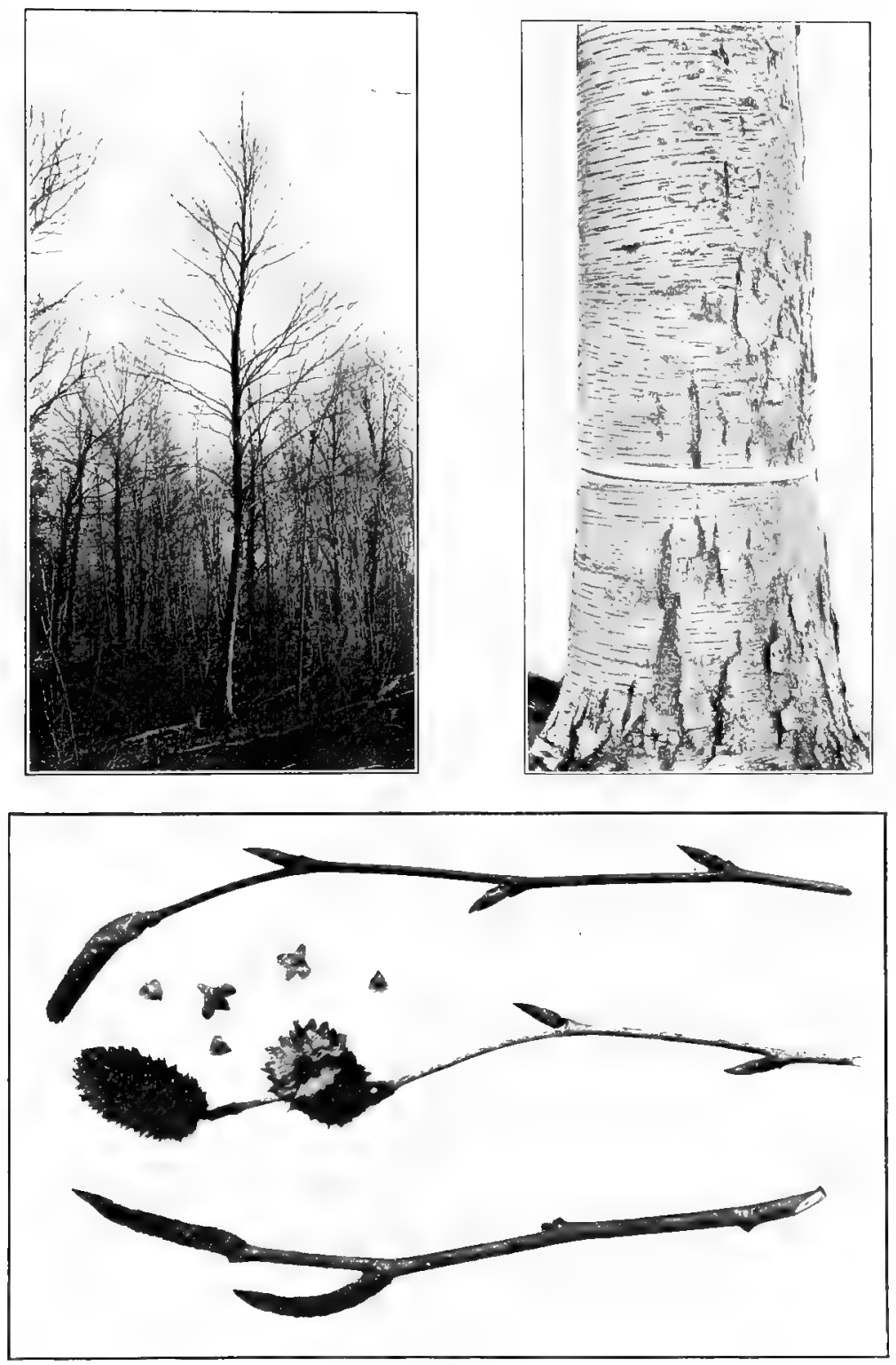

Black BrRch 


\section{YELLOW BIRCH Silver or Gray Birch. \\ Betula lutea Michx. f.}

H.IBIT- -1 large tree $60-90$ ft. in height with trunk diameter of 2- $t$ ft. reaching its largest size in nurthern New England; in the open branching low down with long slender wide spreading somewhat pendulous branches forming a broadly orate to hemispherical head. ulder trees than the one photographed generally show a broader outline with the trunk less conspicuously continuous into the head.

B.IRK-On young trunks and branches cluse, bright, silvery-yellowish gray, generally at length peeling into thin ribbon-like layers which roll back and extend up the trunk in long lines of ragged fringe. There is considerable variation in the amount of peeling of the outer bark. A well marked condition of peeling is shuwn in the bark photographed; the bark uf the tree used fir the habit showed suareely any peeling. On older trunks especially tonard the base the silvery bark is entirely sherl and the bark below shows reddish-brown and becomes rough and fissured into irregular plate-like scales.

TwrGs-Slender, light vellowish-bromn, becoming darker, smooth or somewhat hair: with only slight wintergreen llavor when chewed; short spur-like lateral branches abundant similar to those of Black Birch. LENTICELS-pale, raised dots, inconspicuous, beconing horizontally elongated with age.

LFIF-SCARs-Alternate, 2-ranked, similar to those of Black Birch.

BIDs-Similar to those of Black Birch, more or less appressed. BUL'-SCALES-more or less downy.

FiRI IT-An erect, stalkless or short-stalked downy catkin, ovate to oblong, $2-4 \mathrm{~cm}$. long and about $2 \mathrm{~mm}$. wide and relatively wider than fruit of Black Birch; scales downy on the back and edges, $8-10 \mathrm{~mm}$. long, lunger than bruad, nearly elually v-lubur to the middle; with seed-like winged nutlets about as broad as their wings.

COMP.IISONS-The Yellow Birch differs from the Black Birch as indicated in Comparisons under the latter species. In the peeling of the outer bark it resembles the Paper and the Red Birch. Its outer bark. however, is a dingy yellow and not a chalky white as is that of the exposed layers of the Paper Birch; moreover, in peeling the thin layers tend to curl back to form longitudinal lines of ragged iringe. The fringes of bark are larger and more ragged than in the Red Birch but the color alone is sufficient to distinguish the two forms.

DISTRIBI TION-Low, rich woodlands. mountain slopes. Newfoundland and Nova Scotia to Rainy river; south to the middle states. and along the mountains to Tennessee and North Carolina: west to Minnesuta.

IN NEW ENGLAND-Abundant northward; common throughout, from borders of lowland swamps to 1.000 feet above the sea level; more common at considerable altitudes, where it often occurs in extensive patches or belts.

IN CONNECTICTT-Occasional or frequent.

woOD- Heary, very strong, hard, close-grained, light brown tinged with red. with thin nearly white sapwrod: largely used in the manufacthre of furniture, button and tassel moulds, boxes, the hubs of wheels and for fuel. 

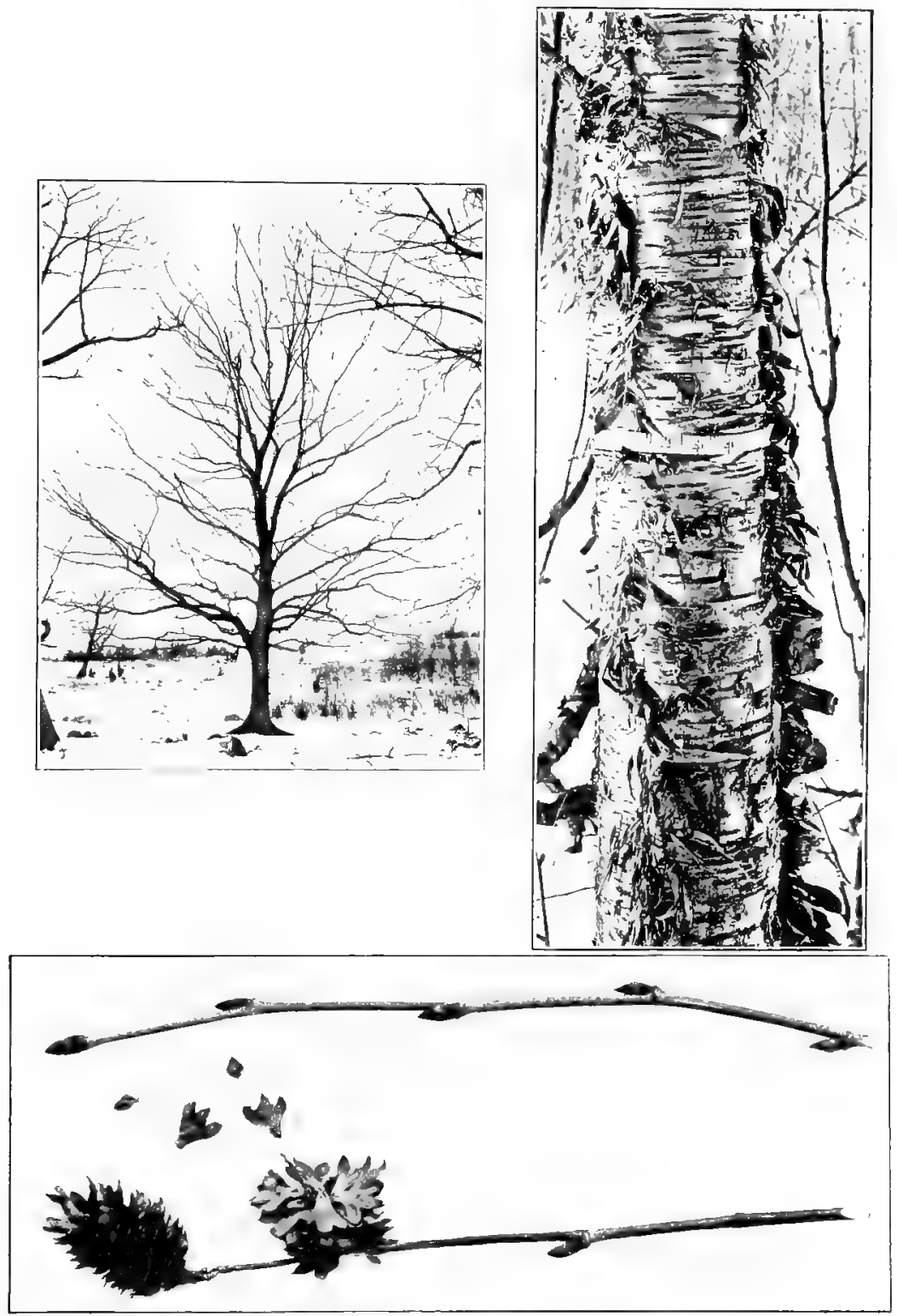

YelLOW Birch 


\section{RED BIRCH River Birch.}

Betula nigra L.

IABIT-A medium sized tree, $30-50$ ft. in height with a trunk diameter of $1-1 \frac{1}{2}$ ft., much larger southward; trunk often divided relatively low down as shown in photographs into a few slightly spreading limbs beset with numerous slender more or less pendulous branchlets, forming a rather narrow oblong head, becoming irregular and broader with age.

R IRK-On young trunks and branches, thin, shining, light reddishbrown, peeling freely into thin papery layers of various shades of red and brown which curl back and remain for several years as ragged fringes and show the light pinkish tints of the freshly exposed inner layers; at base of older trunks, dark reddish-brown, deeply furrowed and broken into thick irregular plate-like scales.

TWIGS-Slender, dark red, for the most part smooth. LENTICELSpale, becoming horizontally elongated.

LEAF-SCARS-Alt ernate, 2-ranked.

BUDS-Small, about $6 \mathrm{~mm}$. long, shining, light chestnut brown, smooth or more or less hairy, ovate, pointed, more or less appressed.

FRITT-Ripening in late spring or summer, a stalked, downy, cylindrical, erect, catkin, 2-5 cm. long; scales downy, with 3 narrow lobes; seed-like nutlet about as wide as the downy margined wings.

COMPARISONS-The Red Birch resembles the Yellow Birch in the more or less persistent ragged fringes of papery layers into which the outer bark peels. Its bark however, is dark reddish to light cinnamon color and is rather less ragged in peeling than that of the Yellow Birch which, moreover, is of a dirty yellowish color. The Black Birch with its dark bark and the white barked species cannot be confused with the tree under discussion. This tree is rare and local in New England and except as planted for ornament is found along river banks.

DISTRIBLTION-Along rivers, ponds, and woodlands inundated a part of the year. Doubtfully and indefinitely reported from Canada; south, east of the Alleghany mountains, to Florida; west, locally through the northern tier of states to Minnesota and along the Gulf states to Texas; western limits, Nebraska, Kansas, Indian Territory, and Missouri.

IN NEW ENGLAND-Not reported in Maine, Vermont, Rhode Island or Connecticut: New Hampshire-found sparingly along streams in the southern yrt of the state; abundant along the banks of Beaver Brook, Pelham; Massachusetts-along the Merrimac river and its tributaries, bordering swamps in Methuen and ponds in North Andover.

IN CONNECTICUTW-Not reported.

woon-Light, rather hard, strong, close-grained, light brown with pale sapwood of 40-50 layers of annual growth; used in the manufacture of furniture, wooden ware, wooden shoes and in turnery. 

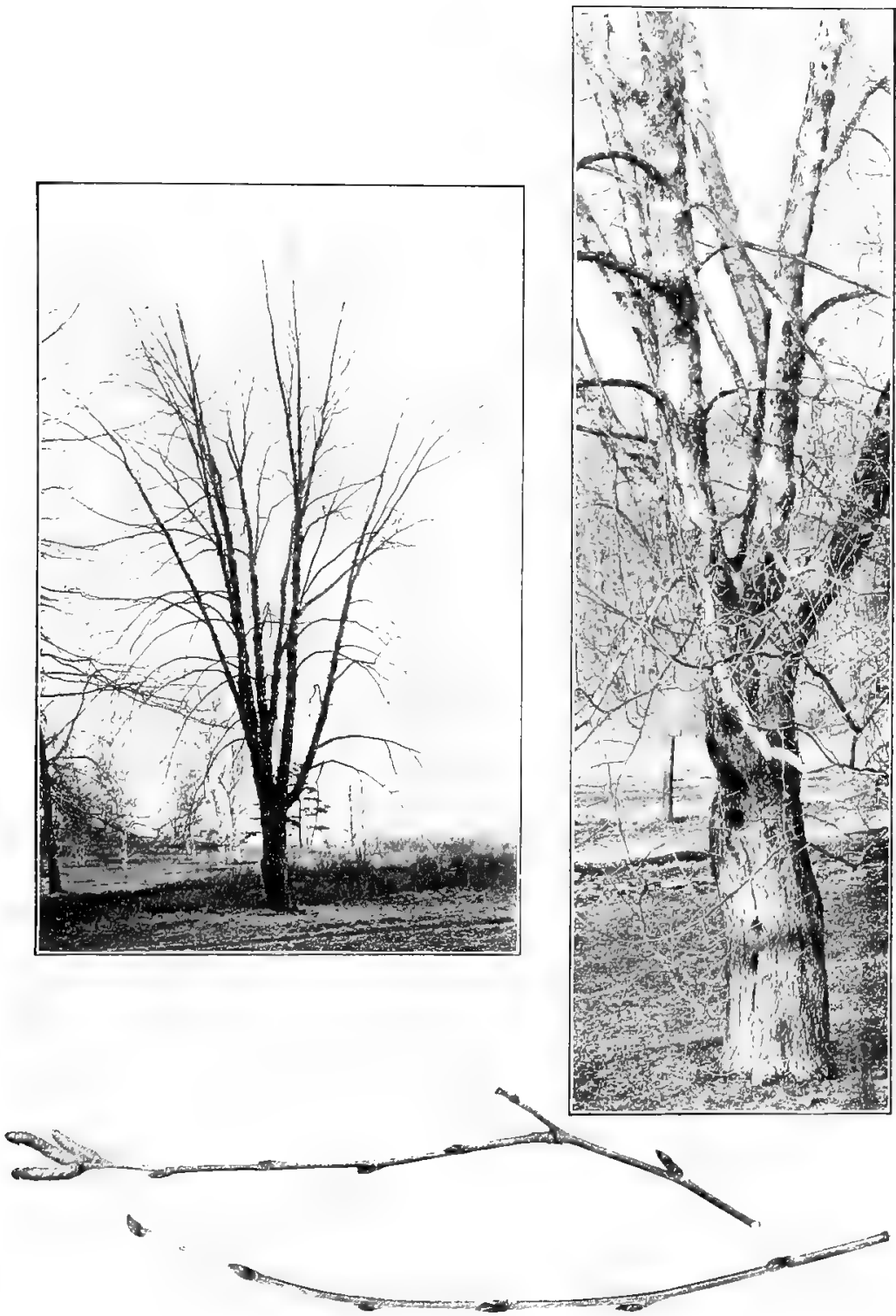

Red Brrci 


\section{GRAY BIRCH \\ Old-field, White, Poverty, Small White or Poplar Birch. Betula populifolia Marsh.}

H 1BIT-A small short-lived tree, 20-35 ft. in height with a trunk diameter of generally less than 1 ft., commonly growing in clumps: trunk slender, generally inelined to one side, continuous into top of tree, with a fringe frum top to buttum of short slender branches which grow upward for a short distance but soon bend downward, with delicate spray forming a narrow, upen, pyramidal, pointed head.

B IRK-Tull chalky-white, close, not peeling, with distinct dark triangular patches below insertion of branches; inner bark reddishorange jellow; base of older trees nearly black and roughened by irregular fissures; young trunks and branches bright reddish-brown.

TW IGS-slender, bright reddish-brown or grayish, becoming with age dull chalky-white, much roughened by warty resinous exudations. LINTICELS-pale, raised duts becuming with age conspicuous and horizontally elongated.

LFIF-SCIRS- Ilernate, 2-ranked, small, with characters of the gerlus.

BบDS-Small, about $5 \mathrm{~mm}$. or generally less in length, smooth, somewhat resinous especially within, orate, pointed, divergent. BUDSCALEs-finely downy on margins, $3-4$ risible.

FRIIT-An erect or pendant, slender-stalked, narrow-cylindriral catkin, 1.5 to $3.5 \mathrm{~cm}$. long; scales minute $-4 \mathrm{~mm}$. long. finely downy with broad lateral recurved lobes, and narrow niddle lobe suggesting the silhmette of a snaring bird: seed-like nutlet, minute, narrower than the wings. Staminate catkin usually solitary.

CoMp IRIsovs-The Gray Birch resembles the Paper Birch in having a whitish outer bark. The bark however is a dingier gray and does not reel into thin panery layers as does that of the paper Birch. A close inspection of its bark sometimes may show a certain breaking away of the outer part in minute inconspicuous scales, but this is not to be confused with a natural peeling. The bark, moreover, cannot be separated into thin papery layers. The slender twigs are generally conspicuously roughened with resinous dots while those of the twigs of the Paper Birch are in general not so roughened except slightly in certain rarieties. The Gray Birch is less inclined to produce large limbs and the numerous small branches are rather strongly pendant after learing the trunk. The species is short lived, never forming a large tree, and is must frequenty met with as a waste-land tree.

DISTRIAT TION-Try, gravelly soils, occasinnal in swamps and frequent along their borlers. of en springing up on burnt lands and usuallv the first tree to take possession of abandoned or neglected fields; often diffemit to eradicate as it sprouts readily from the cut stump. Nova Scotia to Lake Ontario; south, mostly in the coast region, to Delaware; west to Lake Ontario.

TN NEW FNGL.AND-Maine-abundant; New Iampshire-abundant east mard, as far north as Conway and along the Connecticut to Westmoreland: Termont-common in the western and fremuent in the southern sertions: Massachisetts and Fhode Island-common.

IN CONNECTICLT-COMmon.

Woon-Tight, soft, not strong. close-grained, not durable, light hrown. with thick nearly white saprood: used in the manufacture nf spools, shoe pegs and wood pulp, for the hoons of barrels and largely for fuel. 


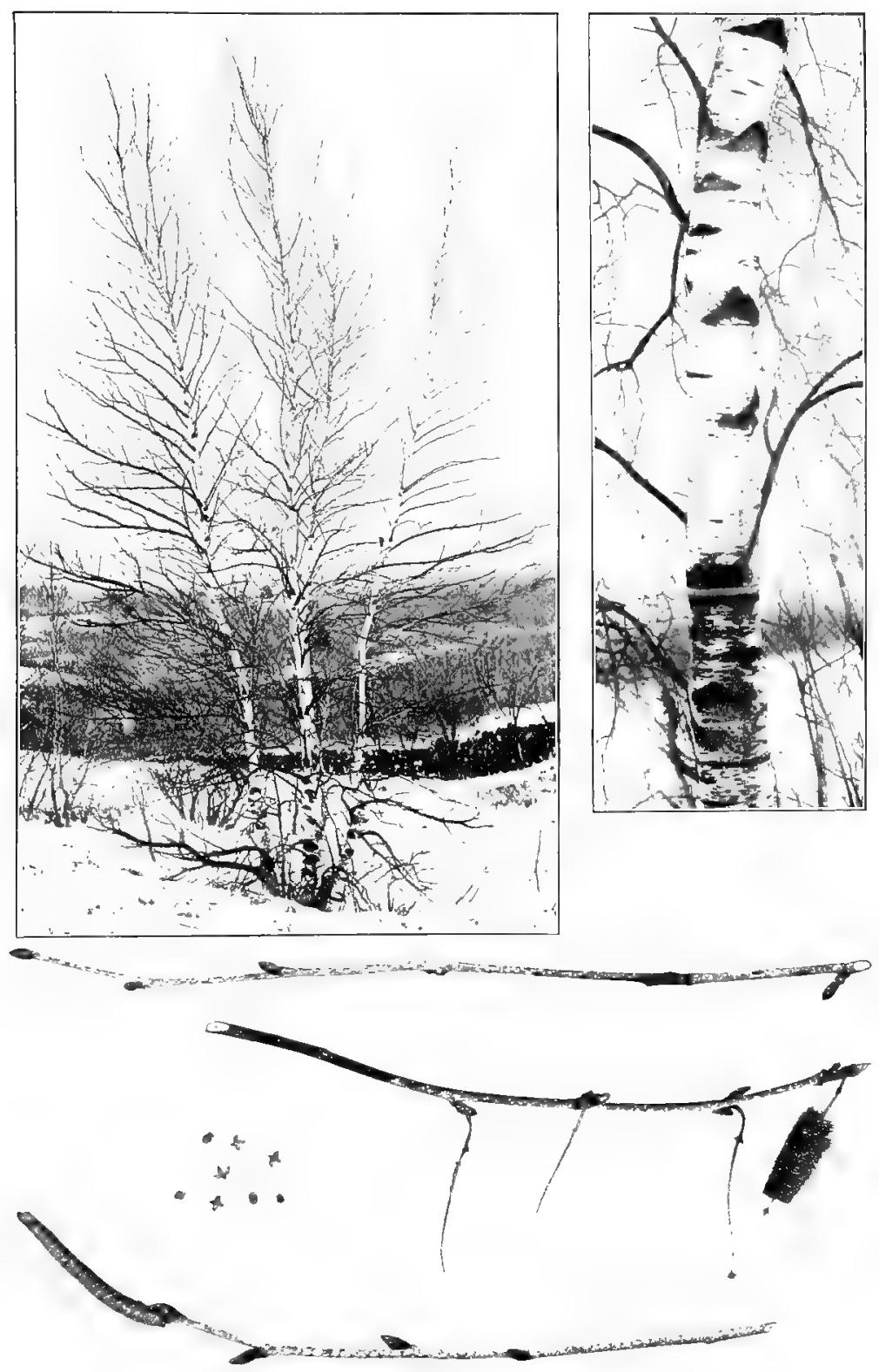

GRAT BrRCH 


\section{PAPER BIRCH Canoe or White Birch.}

Betula alba, var. papyrifera (Marsh.) Spach.

B. papyrifera Marsh.

HABIT-A large tree, $50-75 \mathrm{ft}$, or occasionally more in height with a trunk diameter of 1-3 ft.; developing when not crowded an open, irregular, rounded head, with numerous branches and erect branchlets.

BARK-Trunk and older branches chalky-white, peeling or easily separated into thin paper-like lajers of a delicate pinkish to yellowish tinge where not exposed to the sun, with conspicuous, horizontally elongated, raised lenticels; inner bark reddish-orange yellow. With age the outer bark rolls back in ragged sheets and the trunk becomes more or less black-streaked and blotched and the base ruugh and fissured into large irregular thick scales. The bark of the Paper Birch is much sought after by visitors in the woods for use as letter paper, small picture frames and other souvenis articles. In consequence trees of this species in the neighborhood of picnic grounds generally are despoiled of their bark and even its close-barked relative the Gray Birch is not immune from attacks of those who are ignorant of the difference in bark characters between the two species.

Twics-Stouter than those of the Gray Birch; smooth or somewhat hairy, reddish-brown. LENTICELS-pale, orange colored dots becoming horizontally elongated. LEAF-SCARS-2-ranked, resembling those of the Gray Birch.

BLDS-About 5-10 mm. long, ovate, pointed, divergent. BUD-SCALES - downy on margins.

FIt I'T-A short-stalked, cylindrical, smooth catkin 2-5 cm. long; scales 4-6 mm. long, with thick lateral lobes, hairy-margined; seedlike nutlet, narrower than the wings; staminate catkins in 2 's or usually in 3 's.

Comparisons-The Paper Birch, as known to woodsmen, is distinguished by its chalky-white bark peeling into thin papery layers. A number of botanically more or less distinct separate varieties and species have been recognized but Betula alba, var. papyrifera is the most common. The peeling of its bark distinguishes it from the Gray Birch. The exposed outer bark is more distinctly white and the dark triangular patches noticeable at the insertion of branches in the Gray Birch are often absent especially on older trunks or less distinct. The bark does not typically form the ragged fringe characteristic of the Yellow Birch and while it may not show the characteristic chalky-white where it has peeled, the color is not a dingy yellow but some delicate shade, generally of cinnamon.

DISTRIBCTION-Deep, rich woods, river banks, mountain slopes. Canada, Atlantic to Pacific, northward to Labrador and Alaska to the limit of deciduous trees; south to Pennsylvania and Illinois; west to the Focky mountains and Washington on the Pacific coast.

IN NEW ENGLAND-Maine-abundant; New Hampshire-in all sections. most common on highlands up to the alpine area of the White Mountains, above the range of the Yellow Birch; Termont-common; Massachusetts-common in the western and central sections, rare towards the coast; Rhode Island-not reported.

IN CONNECTICUT-Rare near the coast, Lyme, Huntington, becoming occasional northward and frequent in Litchfield county.

wooD-Llght, strong, hard, tough, very close-grained, light brown, tinged with red, with thick nearly white sapwood; largely used for spools, shoe-lasts, pegs and In turnery, the manufacture of wood pulp and for fuel. The tough resinous durable bark impervious to water is used by all the northern Indians in their canoes, and for baskets, bags, drinking cups and other small articles, and often to cover their wigwams in winter. 

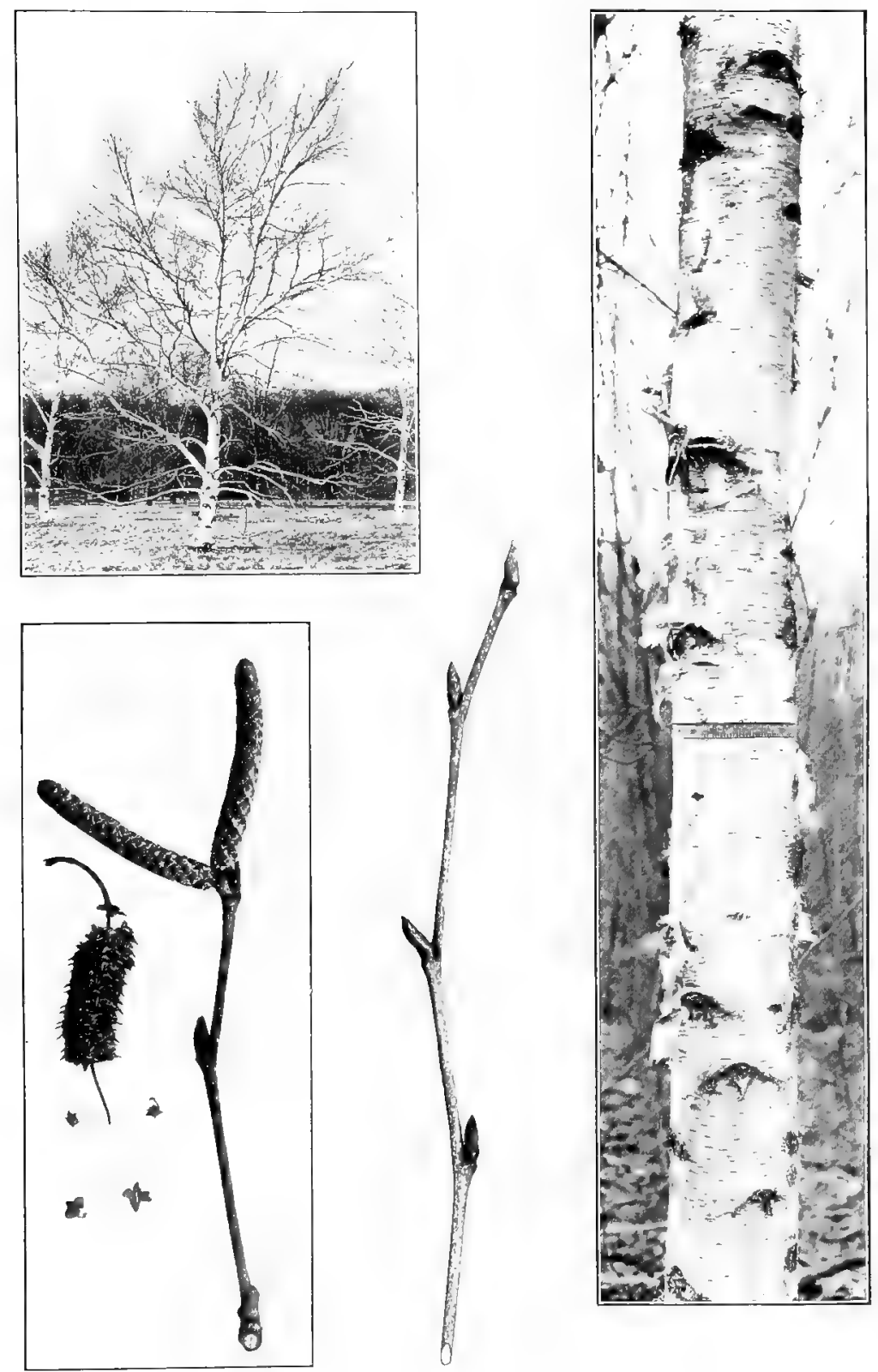


\section{EUROPEAN WHITE BIRCH European Paper Birch.}

Betula alba $\mathrm{L}$.

The Europoan Dirch of which our American Paper Birch is considered a variety is closely related to this latter species. There are many horticultural varieties. Aside from the weeping variety the forms most frequently seen in cultivation are erect with fine drooping spray. The bark is rften slashed at the base of the trunk with deep "gusset"-like furrows exposing the dark inner bark in sharp contrast to the whiteness of the outer layers. The outer bark is separable into thin papery layers but does not seem so inclined to peel spontaneuusly as our native Paper Birch. 

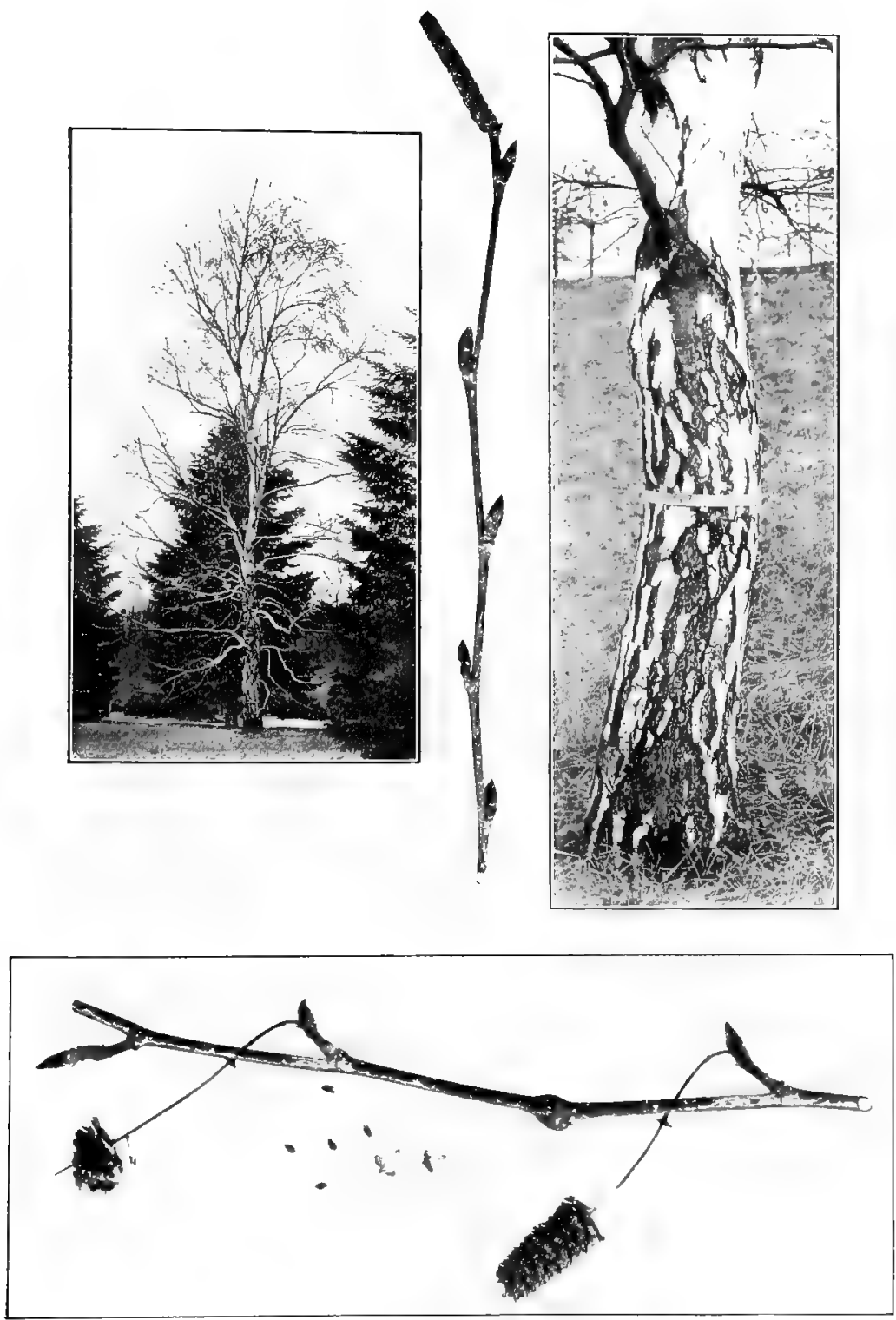

European White Bircin 


\section{SPECKLED ALDER Hoary Alder, Alder.}

Alnus incana (L.) Moench.

H.1BIT-A small tree, or more frequently a shrub 8-25 ft. high with a trunk diameter generally under 5 inches; generally growing in clumps of several stems.

BIRK-Grayish-brown, smooth, with prominent whitish lenticels somewhat elongated horizontally.

TWIGs-Rather slender, more or less zigzag, finely downy, grayishbrown, becoming hoary white toward the tips especially of fruiting twigs. LENTICELS-scattered, whitish, conspicuous. PITH-dark green, 3-cornered.

LEAF-SCIRS-Alternate, 2-ranked, or sometimes apparently more than 2-ranked, conspicuous, inversely triangular, raised, light yellowishbrown. STIPULE-SCARS-narrow, triangular. BUNDLE-SCARS-3, often compounded.

BCDS-Distinctly stalked, about $8 \mathrm{~mm}$. long, reddish, more or less whitened with fine down, slightly sticky within; terminal buds scarcely larger than laterals. BUD-SCALES-3 seales visible, closely stuck together.

FRI IT-A woody cone-like catkin, 6-12 mm. long, remaining on the plant during winter, often distorted by strap-shaped projections caused by a fungus. Staminate catkins of the coming season pendant at the ends of reflexed branchlets with the young fertile catkins appearing lateral and pointing downward; seed-like nutlets, round, flattened.

CoMplRisons-The Speckled Alder is distinguished from its most common relative, the Smooth Alder [Alnus rugosa (Du Roi) Spreng.], by position of the fertile catkins which in the Smooth Alder are erect and seem to be terminal and in the Speckled Alder point downward and seem to be lateral. These two common species occur throughout New England but intermediate forms are found especially near their northern limits. The European Black Alder [Alnus vulgaris Hill.] is somewhat planted for ornament in this country and is repurted in several localities as escaped from cultivation. In contrast to our native Alders it has an erect, distinctly tree-like habit of growth and reaches in Europe a height of $70 \mathrm{ft}$.

DISTRIBI TION-Swamps and borders of streams. Newfoundland to Saskatchewan. south to Pennsylvania and Nebraska.

IN NEW ENGLAND-Throughout, more or less common especially toward the north. local in sections toward the south.

IN CONNECTICUT-Local or occasional except in the southeastern part of the state where it is rare.

WooD-Soft. used as a source of gunpowder charcoal and said to be further valuable because of its durability in water. 

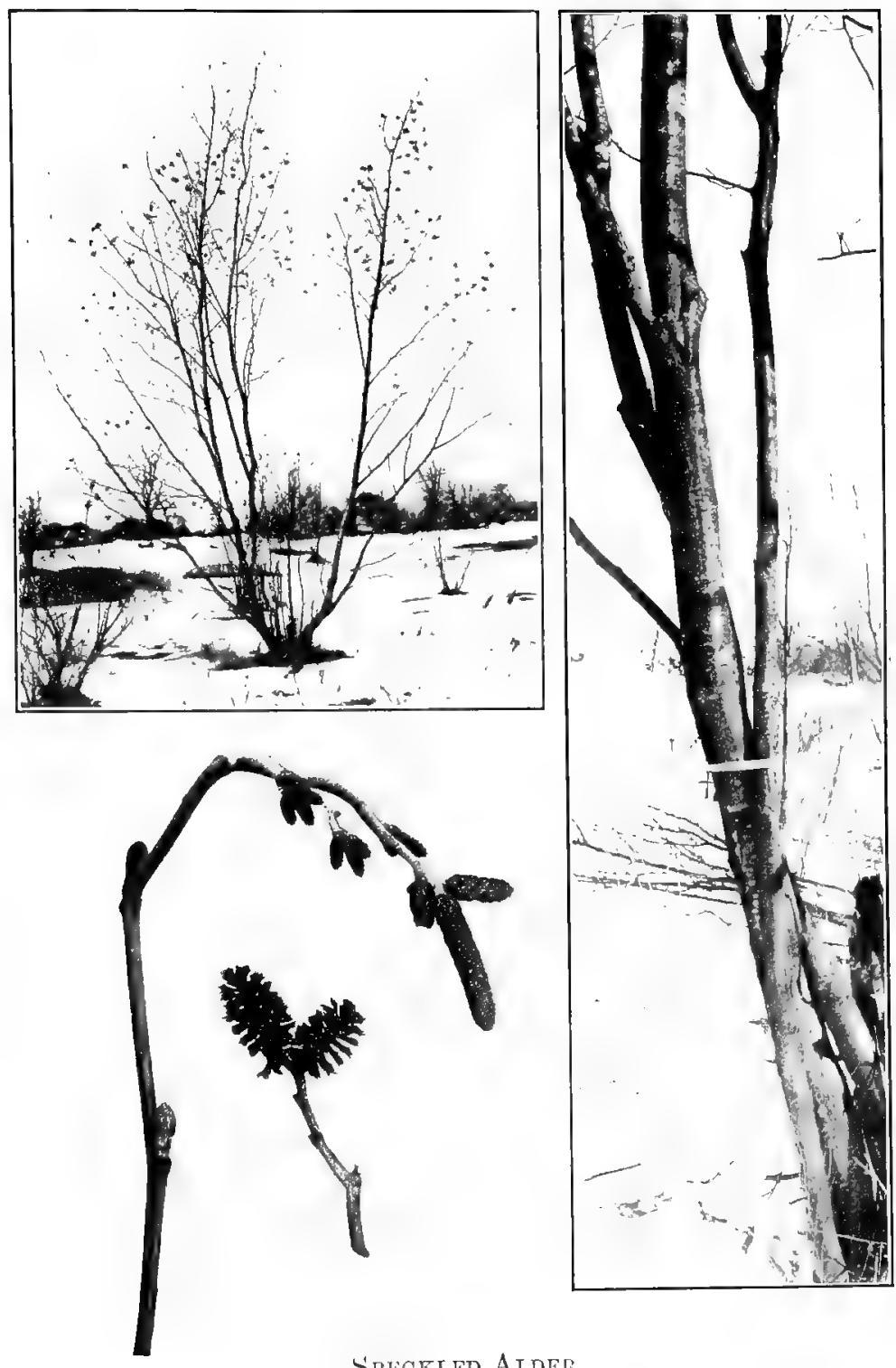

S'prekled Alder 


\section{$\mathrm{BEECH}$ American Beech. \\ Fagus grandifolia Ehrh. \\ F. fermoinia Ait. ; F. americana Sweet; F. atropunicea Sudw.}

H.ABT-A tall tree 50-75 ft. or more in height with a trunk diameter of $11_{2}-4 \mathrm{ft}$; in the forest with a tall slender trunk free of branches for more than half its length; in the open low-branched with numerous long, sleuder, widely spreading or drooping branches, forming a symmetrical, bruad, dense, rounded, oblung or obovate head; roots near the surface, widely spreading and sending up shoots which often surround the parent plant with a thicket of sniall trets.

AIRK-Close, smooth, steel-gray; nore or less dark mottled and covered with lichtns in the comntry in or about citles where lichen gronth is prevented by injuriobs gases in the air, a clear, lighter bluishgray; from the ease with which it is carved, generally adorned with initials and corentunalized outlines of the human heart.

TW16-slender, somewhat zigzag, smooth, shining;, reddish-brown, becuming gray on ulder gruwth. Spiay tlattish from z-ranked position of the kuas; slow-gruwing branchlets numeruus, leafy at tips, elongating each seasun unly a small fraction of an inch, and growing but slightly in thickness; thus one of the twigs in photograph is 29 years old and had grown only $4_{1 / 2}^{1}$ inches in length and acuuired a thickness ot less than $3 \mathrm{~mm}$, during this tinje. LENTICELS-numeruus. conslicuous, urange to gras, elongated longitudinally, LEATEs-frequently renaining on tree in winter, pale jelluw, oval, sharp-pointed, with prominent, straight veins, ending in teeth.

LWIF-ACIRs-small, raised, elliptical to semi-circular. STIPULESCAlis-narrow, distinct, nearly ellcircling twig. BLNDLE-SCARSinconspicuus, best seen by cutting surface section, 5 ur more in double ruw or scattered.

Blos-Conspirnously long and very slender, 10-20 $\mathrm{mm}$. long, about 5 tintes as long as wide, gradually tapering to sharp-pointed apex; terminal bud petsent nut conspicuously larger than laterals. BUD-SCALES -numeruus, $10-20$ in 4 ranks, inereasing in length from base to apex, reddish-bruwn, their margins more or less filely hairy and often with a woolly patch of down at tip, leaving a rather long and distinct set of scale-siars marking each year's growth.

FRIIT-A stalked bur, densely downy and covered with soft spreadIng and more or less recurved prickles, 4-ralred, splitting to near the wase, remaining on the tree into winter, after the nut has fallen. NUTbrown, shining, 1.0-1.5 cm. long;, 3-sided pyramidal; seed sweet, edible.

COMPAnIsoNs-The long narrow buds and the smooth, bluish-gray bark of the Beech make it an easy tree to identify in the winter. The pale persistent dead leares in connection with the habit may frequently be used to distinguish the tree from a distance, the Oaks being about the only other trees that have a similar retention of their withered leaves. The Furopeall Beech [Fums sultatica L.] with weeping and purple-leared varieties is frequenty planted for ornament. It has a darker bark than the Anerican tree but quite closely resembles it.

DISTRIBITIOV-MList, rocky soil. Nova Scotia through Quebec and Ontario: south to Florida; west to Wisconsin, Missouri, and Texas.

IN NEW ENGLAND-Maine-abundant; New Hampshire-throughout the state: common on the Connecticut-Merrimac watershed, enters largely into the composition of the hardwod forests of Coos county; Termont-abindant; Massachusetts-in western sectiuns abundant, conmon eastward; Rhode Island -common. fruit.

IN CONNECTICUT-Occasional or frequent, rarely maturing perfect

wooD-Fard, strong, tnugh, very close-grained, not durable, diffocult to season, dark or often light red. with thin nearly white sapwond of 20-30 lavers of annual vrowth: largely used in the manufacture of chairs, shoe lasts, plane stocks, the handles of tools and for fuel. 

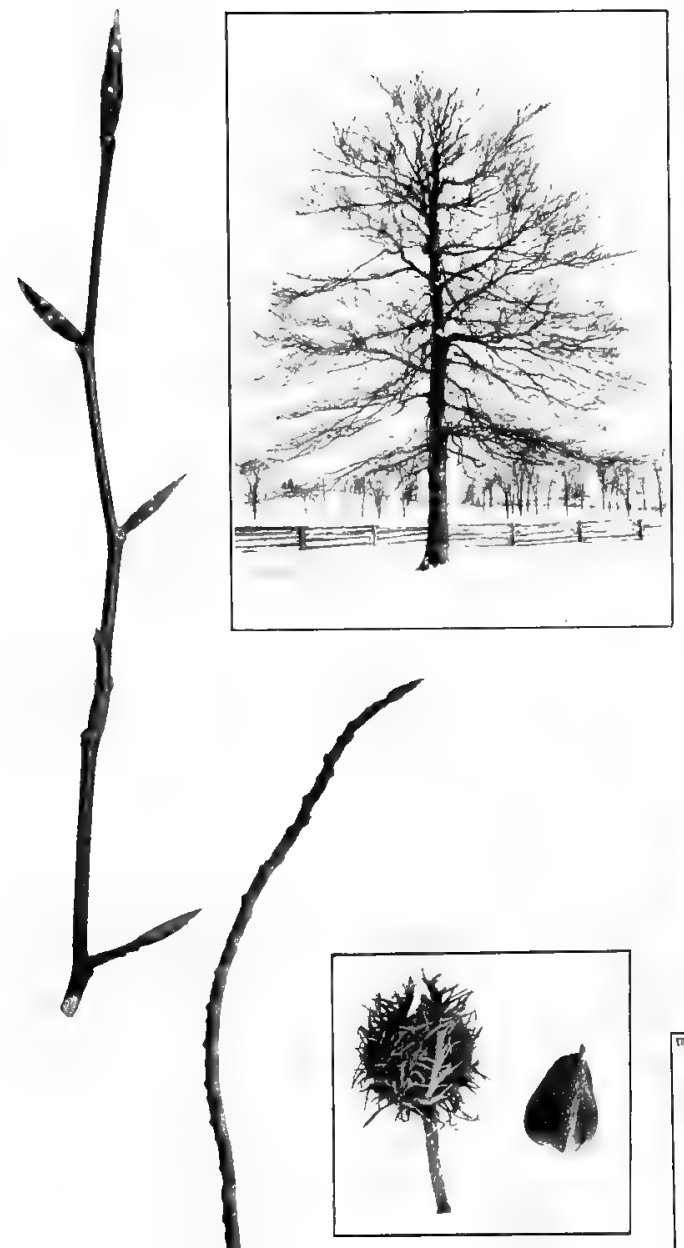

BEECH
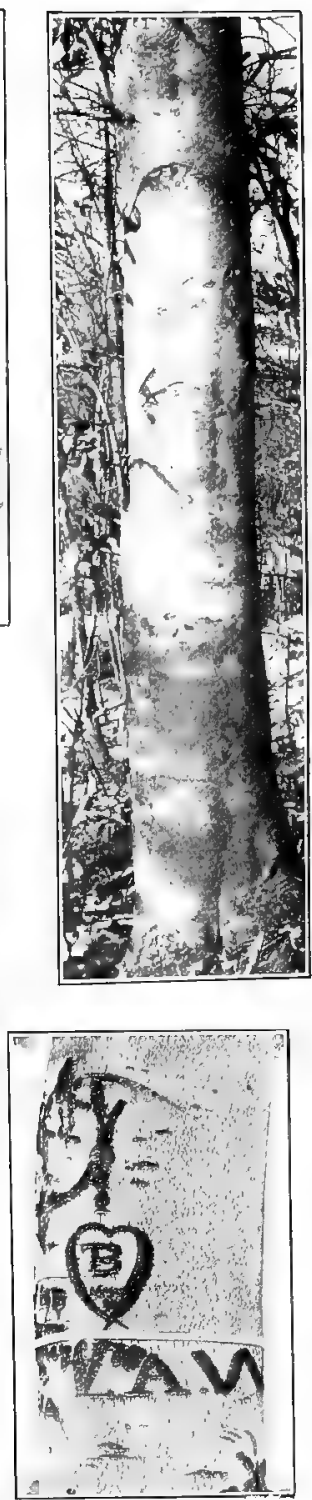


\title{
CHESTNUT
}

\author{
Castanea dentata (Marsh.) Borkh. \\ C. sativa, var. americana Sarg. ; C. vesca, var. americana Michx.
}

HIBIT-A large tree 60-80 ft. In height with trunk diameter of 5-6 ft. or larger; in the forest, trunk tall and slender, in the open trunk short and thick generally tapering rapidly from point of branching into top of tree; lower branches horizontal or declining, often gnarled and twisted, upper branches arising at a sharper angle, forming a low, open, broad, spreading, rounded, ovate head often as broad as high. Young branches tend to bend up from all sides and give an even-edged outline to the tree as if the head had been trimmed like a round. topped hedge. The chestnut when cut sprouts readily from the stump and in consequence in wood-lots Chestnut trees are most commonly to be found in groups of 2-4 or even more surrounding the old stump from which they originally sprouted. (See plate).

HARK-On young trunks and branches smooth, reddish-bronze, often shining; with age broken by shallow fissures into long, broad, flat, more or less oblique ridges.

TWIGS-Stout, generally stralght, greenish-yellow or reddish-brown, smooth, round or somewhat angled from base and outer edges of leafscars: somewhat swollen at nodes. LENTICELS-Numerous, conspicuous, forming minute, raised, white dots. PITH-5-pointed, star-shaped.

LEAF-SCARS-Sometimes distinctly 2-ranked, generally more than 2-ranked, raised, semioval. STIPULE-SCARS-narrow, triangular, often inconspicuous. BUNDLE-SCA ES-scattered, inconspicuous, if leaf-scar is surface-sectioned bundle-scars are found in two small lateral clusters and a large more or less circular basal cluster.

HI Ds-Small, ovate, light to dark chestnut brown, 4-6 mm. long, often oblirue to the leaf-scar; terminal bud generally absent, the end of the twig being marked by a small sear and the bud at end of twig being in the axil of the uppermost leaf-scar. BUD-SCALES-2-3 only visible, thin-margined.

FRUIT-A large, round bur, sharp-spiny without and hairy within, opening by 4 valves. Photograph of bur reduced to about $1 / 2$ natural size. NUTS-generally $3(1-5)$, dark brown, white-downy at apex, ovate, flattened where in contact with other nuts; seed-sweet, edible.

COMPARISONS-From the appearance of gnarled old specimens grown in the open, the chestnut might be taken for one of the Oaks. Its pith. further, is star-shaped but its buds are not clustered at ends of the twigs as in Oaks and have only $2-3$ scales visible. At times the buds of the Chestnut have a 2 -ranked arrangement and in this condition the twigs alone might be confused with those of the Linden (which see under Comparisons). Since the tree begins bearing early and the characteristic burs remain on the ground, the fruit is a valuable winter character. The bark in middle-aged trees resembles somewhat that of the Red oak. If the bark is blazed the wood exposed does not show the short clear lines representing medullary rays in tangential section seen in Oaks under similar treatment.

DISTRIIITION-In strong, well-drained soil; pastures, rocky woods, and hillsides. Ontario, common; south to Delaware, along the mountains to Alabama; west to Michigan. Indiana, and Tennessee.

IN NEW ENGLAND-Maine-southern sections, probably not indigenous north of latitude $44^{\circ} 20^{\prime}$; New Hampshire-Connecticut valley

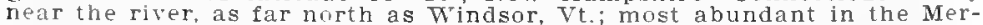
rimac valley south of Concord, but occasional a short distance northward; Vermont-common in the southern sections, especially in the Connecticut valley; occasional as far north as Windsor. West Rutland. Furlington: Massachusetts-rather common throughout the state, but less frequent near the sea: Rhode Island-common.

IN CONNECTICUT-Common.

wooD-Light, soft, not very strong, liable to check and warp in drying, easily split, durable in contact with the soil, reddish-brown with thin lighter colored sapwood of 3 or 4 layers of annual growth: used largely in the manufacture of cheap furniture and in the interinr finish of houses, for railroad ties, piling, fence posts, and rails, The nuts which are superior to those of the old Wrild Chestnut in havor and sweetness are gathered in great quantities in the forest and sold in the cities. 

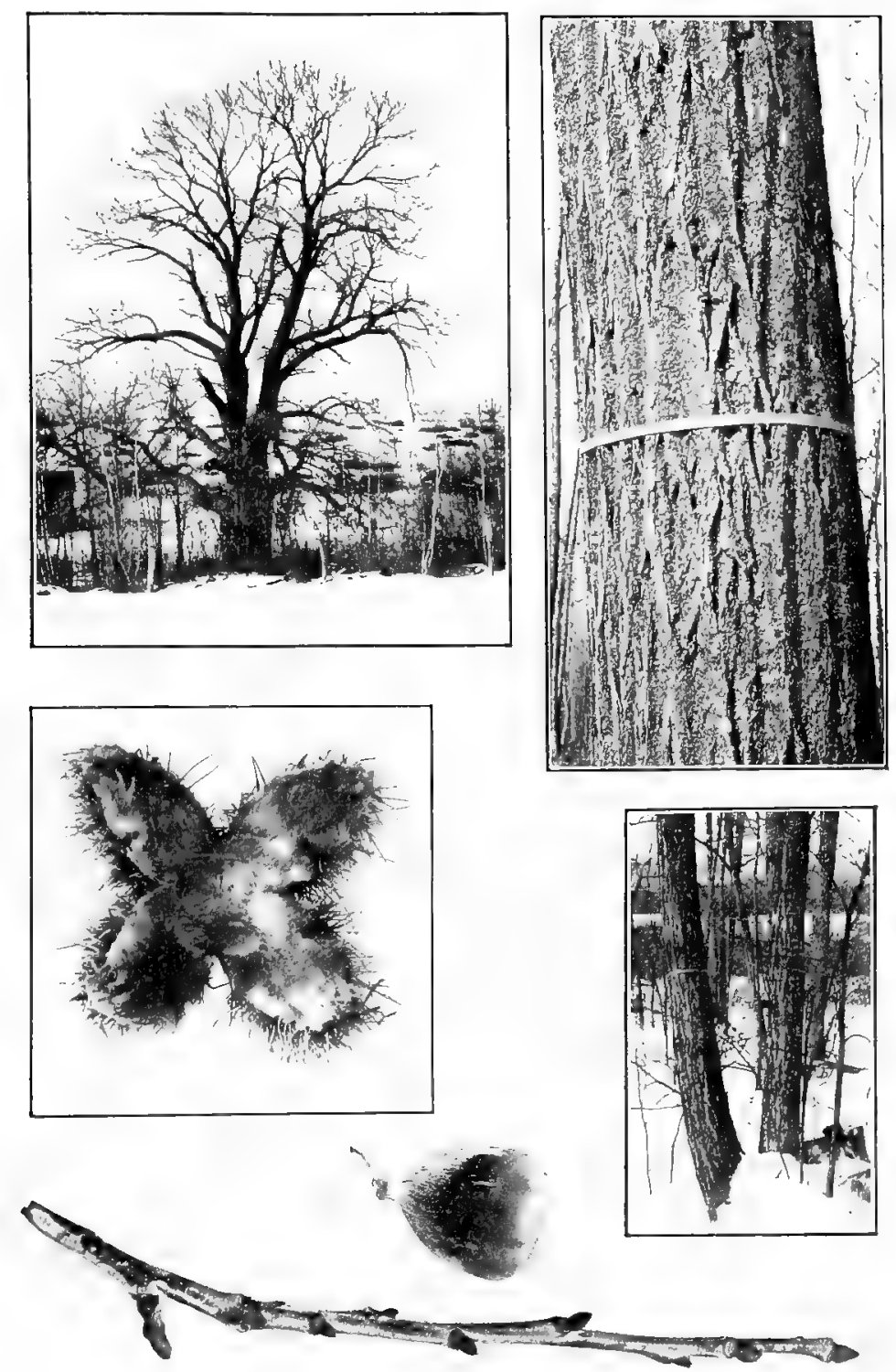

Chestnut

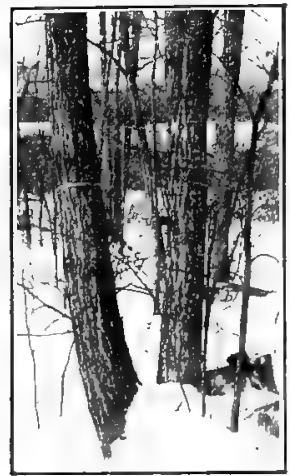




\title{
WHITE OAK
}

\author{
Quercus alba L.
}

HIBIT-A large tree with arerage height of $50-75 \mathrm{ft}$ and trunk diameter of $1-6$ ft. somewhat rarious in habit, tending in the open tu shuw a broad outline, sometinies 2-3 times as broad as high, with short trunk and lower limbs hurizontal or declined, characteristically gnarled and twisted.

HARI-Light gray or nearly white, whence its name; broken by shallow fissures into long, irregular, thin scales which readily flake off. On some trees ridges broken into short oblongs giving a rougher appearance to bark. Bark up to 2 inches thick in older trees: inner bark light. The bark is rich in tannin, is of medicinal value and is used in tanning.

TwIGs-of medium thickness, greenish-reddish to gray, smooth, sometimes covered with a bloom. LENTICELS-forming conspicuous, light-colored, minute, rounded, raised dots. LEAVES-frecuently remaining on tree throughout winter, oblong to obovate with generally 7 large blunt lobes. PITH-5-pointed, star-shaped.

BIDs-Broadly ovate, blunt, about $3 \mathrm{~mm}$. long (2-6 $\mathrm{mm}$.), reddishbrown, sometimes slightly hairy.

FRIIT-Maturing in autumn of first year singly or in pairs, sessile or sometimes on slender stalks. NUT-ovoid to oblong, rounded at apex, shiny, light chestnut brown, $1.5-2.5$ em. long, enclosed $1 / 3-1 / 4$ of its length by deep saucer-shaped to hemispherical cup. Scales of cup white-woolly, thick-knobby at base, with short, blunt tips becoming thinner and flatter at rim of cup. Meat, sweet edible sumetimes roasted and used as substitute for coffee, or when boiled said to be a good substitute for chestnuts.

COMPARISONS-The White Oak is the most common of the White Oak group. Its light flaky bark resembles that of several other oaks. It is readily distinguished from the swamp White Oak by absence of peeling of bark on young branches and by its larger and more puinted buds; from the Post Oak by absence of greenish down on twigs and by generally larger, narrower buds; from the Chinguapin Oak by its blunt buds; from the Dwarf Chinquapin Oak by its larger stature, larger twigs and buds.

DISTRIITTIOV-On moist or dry ground and in various soils, sometimes forming nearly pure forests. Quebec and Ontario; south to the Gulf of Mexico; west to Minnesota, Nebraska, Kansas, Arkansas and Texas.

IN NEW ENGLAND-Maine-southern sections: New Hampshire-most abundant eastward; in the Connecticut valley confined to the hills in the immediate vicinity of the river, extending up the tributary streams a short distance and disappearing entirely befure reaching the mouth of the Passumpsic: Termont-common west of the Green Mountains. less so in the southern Connecticut valley; Massachusetts, Rhode Island -common.

\section{IN CONNECTICT'T-Common throughout.}

wooD-Strong, Very heavy, hard, tough, close-grained, durable, light brown. With thin lighter colored sapwood; the most valuable of the oaks for timber, used in shipbuilding. for construction and in cooperage, the manufacture of carriages, agricultural implements, baskets, the interior finish of houses, cabinet making, for railroad ties and fences, and largely as fuel. 

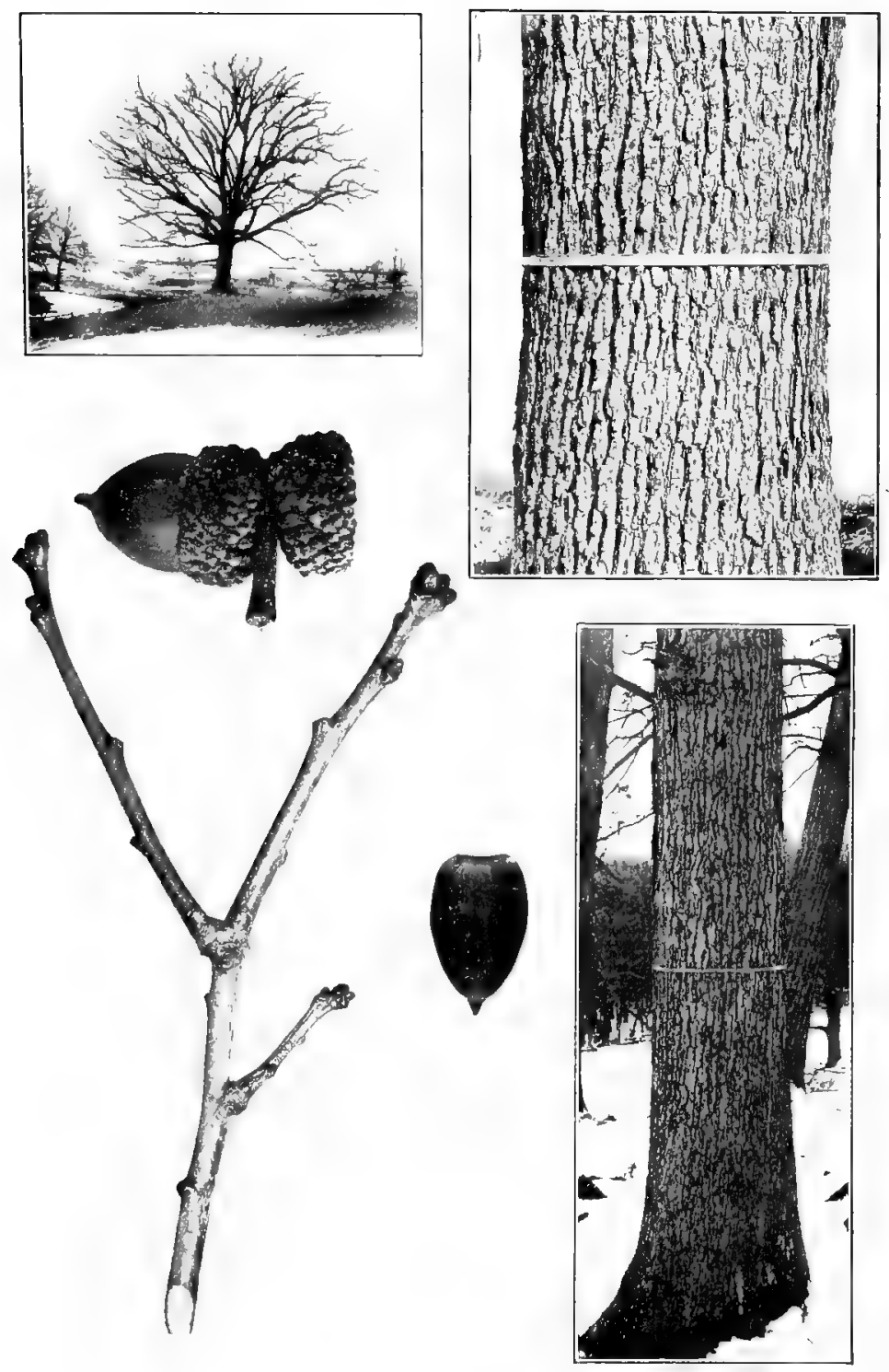

WIIITE O.IK 


\section{POST OAK \\ Box White Oak, Iron Oak.}

Quercus stellata Wang.

Q. minor Sarg.; Q. obtusiloba Michx.

HABIT-In New England a small tree with height in southern section up to $60 \mathrm{ft.}$, with trunk diameter of $3 \mathrm{ft}$; at northern limit a shrub 10-35 ft. high with trunk diameter of $1 / 2-1 \mathrm{ft}$; in the open forming a broad dense, round-topped head with stout spreading branches.

BARK-Flaky; similar to that of White Oak but rather darker, rougher, corresponding more to type of White Oak bark with short oblong ridges: 1/2-1 inch in thickness. Twigs when $1 / 2$ inch to 1 inch in diameter begin to accuire a flaky bark with loose, dark gray scales lifting at sides and ends.

TWIGS-Stout, light orange, redish-brown; the younger growth by its light color, in striling contrast with darker, older growth which is often almost black; young twigs covered, at least in part. with short, dense orange-browr down, rougli to the louch, often not easily noticed without a hand-lens. Late in season down may become almost black and disappear from the more exposed parts of twig. Bass of leafsuars projecting with a sudden curve from the twig. LFNTICELSpale, minute. LEAVES-often persistent, oblong, obovate, thick with generally 5 rounded lobes, the middle pair much the largest. PITH5 -pointed, star-shaped.

BLDS-Broadly ovate, often as broad as long and hemispherical, blunt, rarely acute, generally under $3 \mathrm{~mm}$. long, sometimes up to $6 \mathrm{~mm}$. in length. BUD-SCALES-bright reddish-brown, sparingly downy.

FRIIT-Maturing in autumn of first year, single or in pairs or clustered; sessile or short-stalked. NUT-ovate, to oblong $1.5=2 \mathrm{~cm}$. long, generally covered with pale down at apex. CUP-covering $1 / 4-1 / 2$ the nut, top-shaped or cup-shaped, scales rather thin and flat, only slightly knobby, pale, woolly. Meat sweet.

COMPARISONS-Readily distinguished from White Oak which it most nearly resembles by rough, dirty orange-brown down which is to be found more or less completely covering twigs. Buds are blunter, shorter, generally more nearly hemispherical and of a brighter reddish tinge.

DISTRIBUTION-Doubtfully from southern Ontario; south to Florida; west to Kansas, Indian Territory and Texas.

IN NEW ENGLAND-Mostly in sterile soll near the sea-coast: Alassachusetts- southern Cape Cod from Falmouth to Brewster, the most northern station reported, occasional; the islands of Naushon.Martha's Vineyard where it is rather common, and Nantucket where it is rare; Fhode Island-along the shore of the northern arm of Wickford harbor.

IN CONNECTICUT-Local. Usually in rocky ground on and near the coast: East Lyme and old Lyme, Branford, New Haven, Orange and Milford, and westward extending inland as far as Hamden; on Mt. Carmel and Huntington at $350 \mathrm{ft}$. elevation.

wood-Very heavy, hard, close-grained, durable in contact with soil, difficult to season, light or dark brown. with thick lighter colored sapwood; used for fuel, fencing, ralroad ties and sometimes in the manufacture of carriages, for cooperage and in construction. 

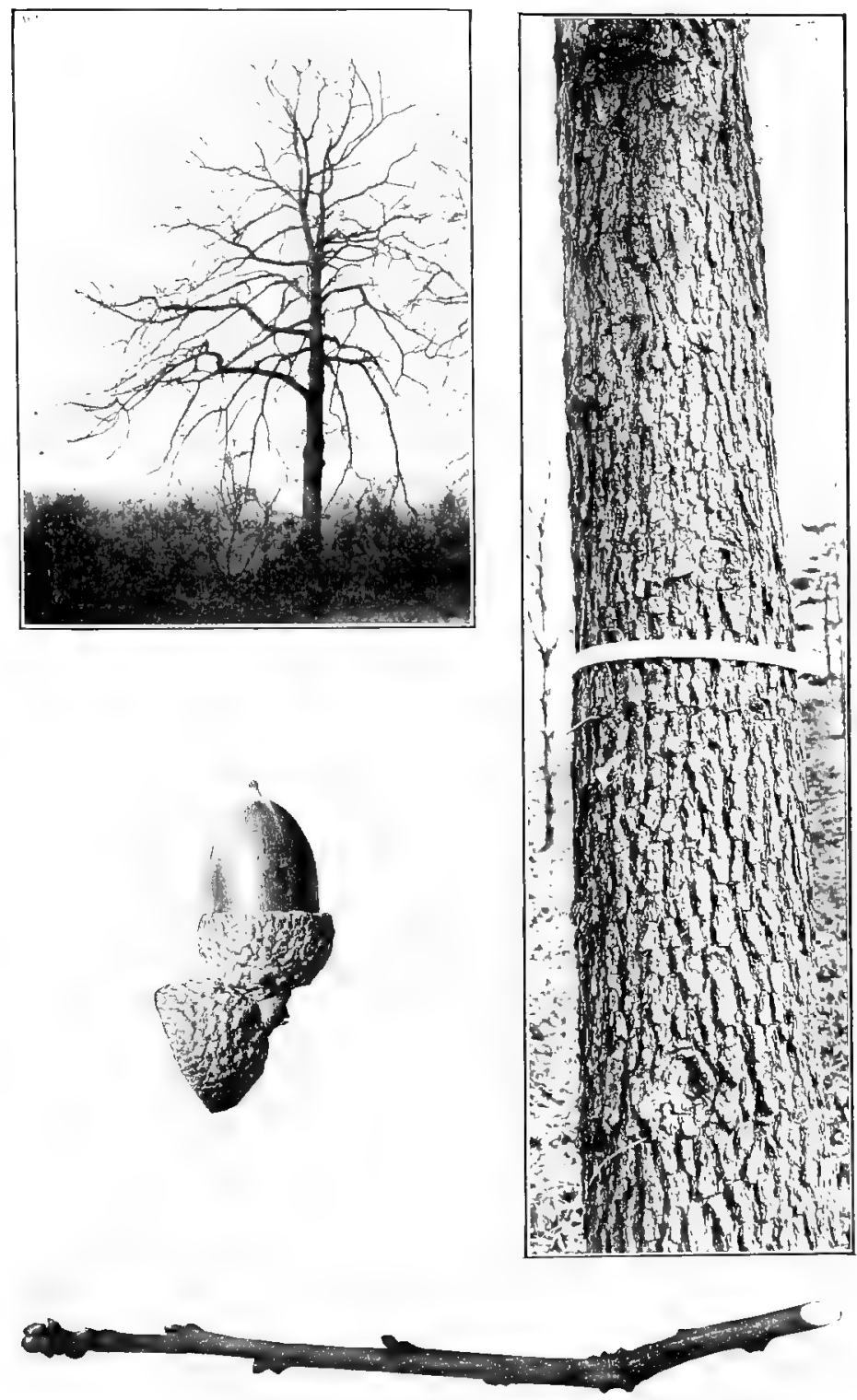

POST OAK 


\section{BUR OAK \\ Mossy-cup or Over-cup Oak.}

Quercus macrocarpa Michx.

H. IBIT-Although one of our largest Oaks in the central states, in New England of medium size only $40-60 \mathrm{ft}$. in height with a trunk dianeter of 1-3 ft.; in the open forming a broad, round top with thick spreading limbs and numeruus often druoping branchlets.

RIRI-Flaky, resembling that of Thite Oak but rather darler and witl ridges rather fimer.

TWIGs-stnut, yellowish-brown, smooth or downy, twigs on some trees after the first jear develouing corky ridges. LENTTCELS-minute. pale, raised duts, inconspicuous. LEATES-which sometimes persist. oburate-ublung: divided by deep indentations into 5-7 rounded lobes, the terminal lobe the largest, PITH-5-pointed, star-shaped.

BL DS-Conical to broadly ovate, sharp-pointed or blunt, $3-5 \mathrm{~mm}$. Iong, reddish-brown, covered with pale wool; lateral buds more or less strongly appressed and flattened against the twig. Stipules often persisting at tips of twigs, long, downy thread-like. BUD-SCALESrelatively few to a bud.

FRI IT-Maturing in autumn of first year, very varlable, sessile or stalked, generally single. NLT-ovate to oval, $2-5 \mathrm{~cm}$. long, apex rounded or depressed covered with pale down. CUP-thick hemispherical to top-shaped enclosing from $1 / 3$ to the entire nut; scales of cup, pale, woolly, thickened at base with pointed tips, tips of upper scales prolonsed into a more or less distinct fringe.

COMPARIsoxs-The Bur Oak is sharply distinguished from our other oaks by a nunber of well-marked characters such as the presence of corky ridges on the young branchlets, the copious fringe to the large acorn. the appressed and downy buds. These characters however are not always present in a given specimen; thus the corky ridges may fail to appear throughout an entire tree: the acorns may be reduced in size and in the distinctness of the fringe; and the lateral buds may be more or less divergent.

DISTRIBITION-Low rich bottom lands. Nova Scotia to Manitoba: south to Pennsylvania and Tennessee; west to Montana, Nebraska, Kansas, Indian Territory and Texas.

IN NEW ENGLAND-Maine-known only in the valleys of the midnle Penobscot and the Kennebec; Yermont lowlands, about Lake Champlain, especially in Addison Count not common: Massachusetts-ralley of the Ware river, Stockbridge and towns south along the Housatonic river; Finode Island-no station reported.

IN CONNECTICUT-Rich bottom lands or swampy places; rare or local and confined to the northwestern part of the state; reported from Canaan and Salisbury.

WOOD-Similar to that of White Oak from which it is not generally distinguished commercially, although superior in strength. 

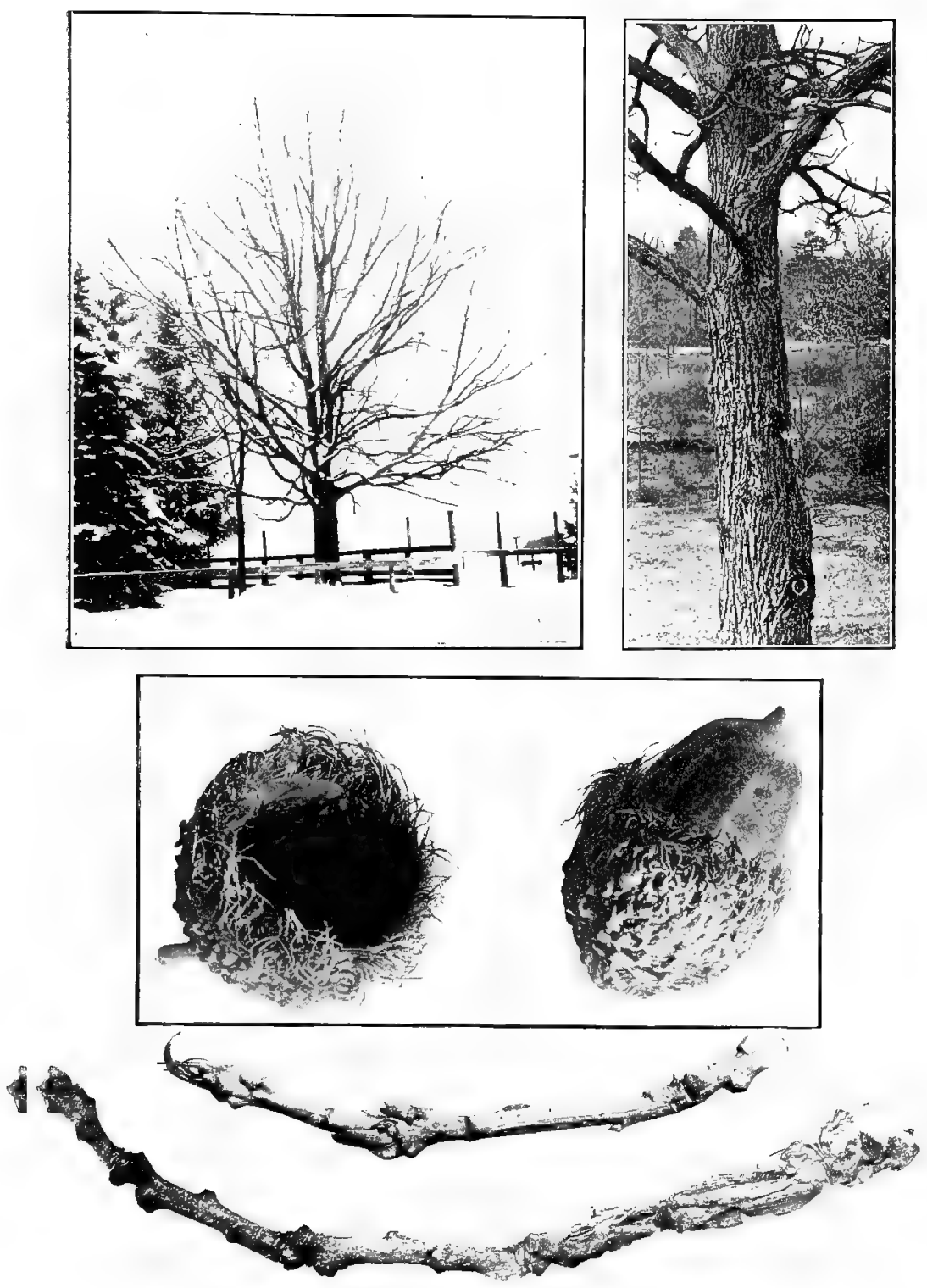

Bur O.K 


\section{SWAMP WHITE OAK \\ Quercus bicolor Willd. \\ Q. platanoides Sudw.}

HABIT-A medium sized tree, 40-60 ft, high, with trunk diameter of 2-3 ft.; in the open with round-topped open head, sometimes broader than high, upper limbs ascending, lower limbs rather small, horizontal or declined even to the ground, with numerous tufted, small, scraggly, lateral, pendant branchlets. The scraggly branchlets in connection with the peeling of the bark give a very rough unkempt appearance to the tree. Trunk erect, generally continuous, sometimes forking above to give somewhat the aspect of an Elm in respect to main limbs.

HARI-Flaky, grayish-brown, divided by deep longitudinal fissures into rather long, flat ridges, Bark on small branchlets, dark reddishbrown to black, peeling into long, persistent, stiff-papery layers, which curl back and expose the lighter bark beneath.

TWIGS-Mediumly stout to slender, yellowish-green to reddishbrown, smooth (seldom slightly downy). Medullary rays generally absent in branchlets even of 6 to 8 years growth. LENTICELS-pale, raised. LEAVES- which may persist obovate-oblong, wedge-shaped at base, wavy-margined to blunt-lobed, with 6-8 pairs of primary veins. PITH5-pointed, star-shaped.

BUDS-Broadly ovate to oval to spherical; biunt-pointed; small, 2-4 mm. long. BUD-SCALES-brown, at times slightly hairy above middle.

FRIIT-Maturing in one year, single or in pairs or groups of $\mathbf{3}$, generally with long stalks, 2.5 to $10 \mathrm{~cm}$. long. NuT-light chestnut ovate to oblong. 2-3 cm. long, apex covered with pale down, rounded or pointed. CUP-thick, cup-shaped, about $1 / 3$ enclosing nut; scales pale woolly, those at base more or less thickened, at rim of cup tips of scales elongated, narrow, awn-pointed, often forming short fringe. Meat sweet, edible.

COMPIRISONS-The sycamore-like peeling of the bark from the young branchlets easily distinguishes this species from all other Oaks. The bark somewhat resembles that of White oak but is somewhat darker and the ridges are longer.

DISTRIIITION-Borders of swamps and streams. Quebec to Ontario where it is known as the Blue Oak: south to Delaware along the mountains to northern Georgia; west to Minnesota, Iowa, East Kansas and Arkansas.

IN NEW ENGLAND-Maine-York county; New IIampshire-Merrimac valley as far as the mouth of the Souhegan, and probably throughout Rockingham county; Vermont-low grounds about Lake Champlain; Massachusetts-frequent in the western and central sections, common eastward-Rhode Island-common.

IN CONNECTICUT-Frequent.

wooD-Similar to that of White oak, and used for same general purposes; sapwood, thin, hardy distinguishable from heartwood. 

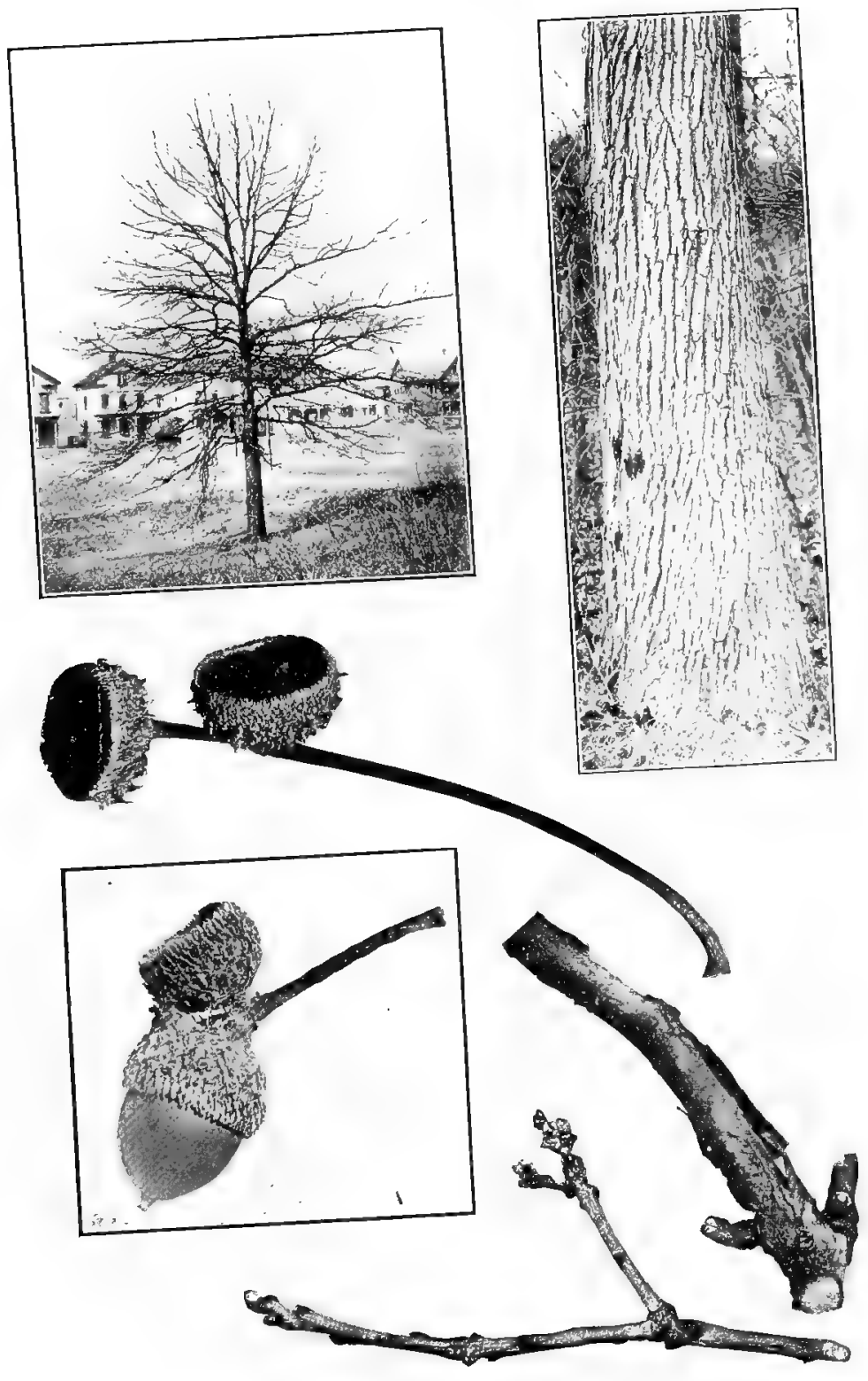

SWamp White OAK 


\section{CHINQUAPIN OAK Chestnut Oak, Yellow Oak. \\ Quercus Muhlenbergii Engelm. \\ Q. acuminata Houba.}

H I IIT-Small to medium sized tree $30-40$ ft. hioh with a trunk diameter of $1-2$ ft.; in basin of the Mississippi reaching an exceptional height of 160 feet; trunk buttressed at base in older specimens, branches comparatively small forming narrow, round-topped head.

BIKK-Thin, flaky, broken into loose grayish or sometimes slightly brownish scales.

TWIGs-Rather slender, light orange to reddish-brown, smooth. LENTICELS-pale, inconspicuous. LEAVES-resembling those of Chestmut with large incurved, glandular-tipped teeth or rarely with wary margin resembling the leaf of the chestnut Oak. PITH5-pointed, star-shaped.

BI DS-Narrowly orate to conical, sharp-pointed, $3-5 \mathrm{~mm}$, long. BUDSCALJS-light chestnut brown, slightly hairy on edges, appearing longitudinally striate if held toward light and viewed with a handlens. Buds similar to those of Chestnut Oak but smaller.

FRI IT-Maturing the first season. sessile or short-stalked, singly or in pairs. NUT-bruadly nvate to oval, $1-29 \mathrm{~mm}$. long, narrowed and rounded at pale downy apex, light chestnut brown. CUP-thin, rather shallow cup-shaped enclosing about $1 / 2$ or less of the nut; scales pale brown, woolly, sligluty knobby at base of cup, the brownish tips of the scales sometimes forming a slight fringe at rim of cup. Meat sweet, edible.

ComInIsoxs-The Chinquapin Oak resembles the Chestnut Oak on the one hand and the Dwarf Chinguapin oak on the other It is distinguished from the former by its flaky, gray bark, and the smaller size of buds and acorns; from the latter by its sharp-pointed buds and larger size.

DISTRIBITIOX-Rare and local in the Atlantic states, usually on limestrine soil, on dry hillsides, rocky ridges and rich bottoms. Ontario: sulth to Trelaware and District of Columbia, along the mountains to northern Alabama; west to Minnesota. Nebraska, Kansas, Indian Territory and Texas.

IN NEW ENGLAND-Vermont-Gardner's Island, Lake Champlain; Ferrisburg.

IN CONNECTICUT-Rare. Calcareous ridges in the northwestern part of the state: Canaan. Salisbury, also along the Housatonic river in Kent, New Milford and bordering tide water in Milford.

woon-Heavy, very hard, strong, close-grained, durable, with thin light-colored sapwood, largely used in cooperage, for wheels, fencing and railroad ties. 

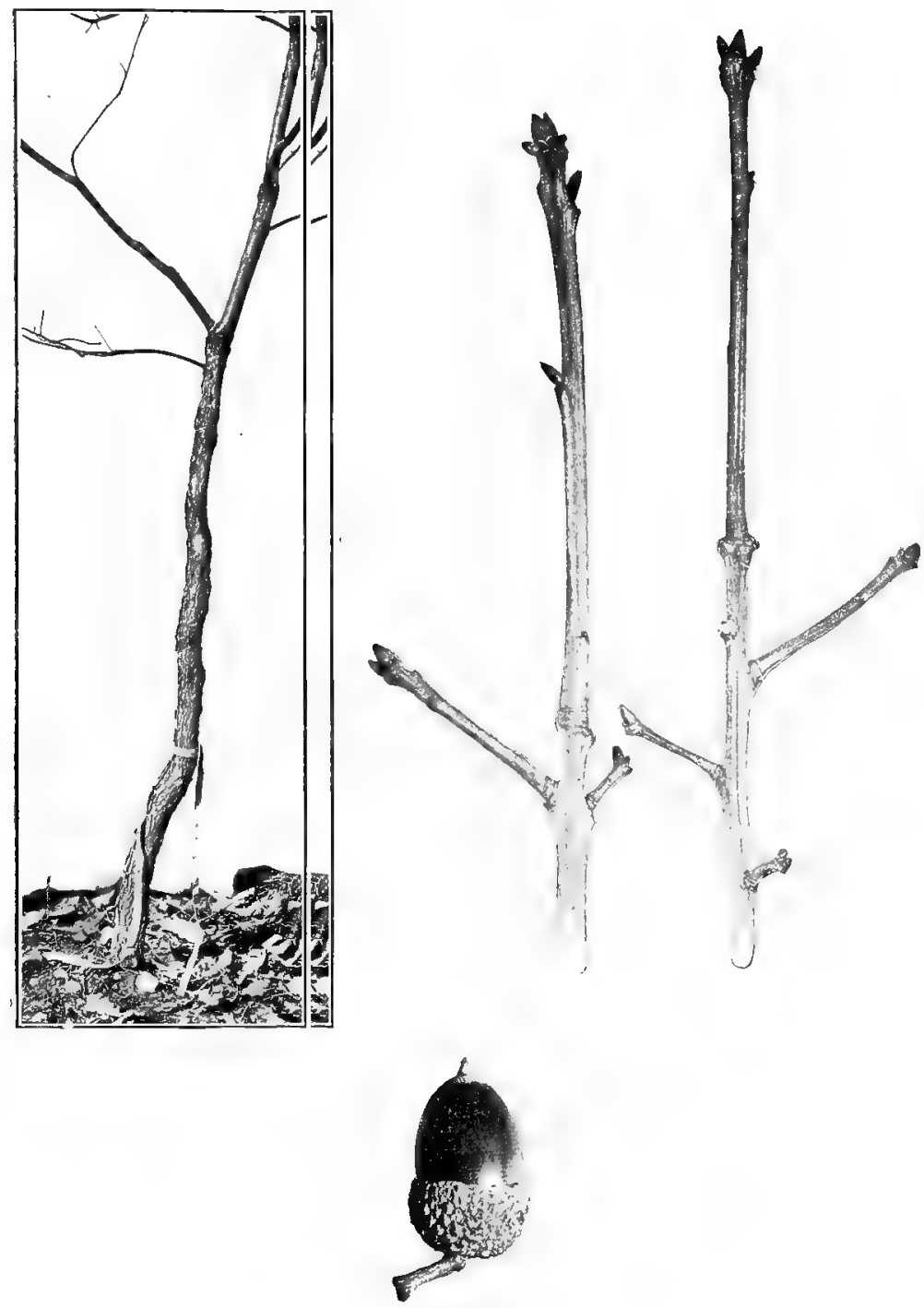

Cinngdatin OAK 


\section{DWARF CHINQUAPIN OAK Scrub Chestnut Oak, Chinquapin Oak, Scrub Oak.}

Quercus prinoides Willd.

HABIT-A low shrub generally 2-4 ft. high or occasionally reaching $15 \mathrm{ft}$. in height, forming broad clumps by prolific stolons.

BARK-Light brown, scaly; scaliness evident when trunk reaches a diameter of $1 \frac{1}{2}$ inches.

TWIGS-Slender; generally not over $2 \mathrm{~mm}$. thick, orange to reddishbrown; generally smooth; a variety, rufescens Rehder with yellowish hairs on twigs. LENTICELS-pale, rather conspicuous. LEAVESoblanceolate to obovate-oblong, coarsely wavy-toothed. PITH5-pointed, star-shaped.

BUDS-Spherical to ovate, rounded or slightly narrowed at apex, about $3 \mathrm{~mm}$. long. SCALES-chestnut brown, thin, scarious and slightly hairy on edges: small collateral buds sometimes present on either side of axillary bud.

FRUTT-Maturing the first season, produced in great abundance, sessile or short-stalked, singly or in pairs. NUT-oval, light chestnut brown and sliny, apex blunt-pointed and covered with pale down, 15 to $25 \mathrm{~mm}$. long. CUP-thin, deep cup-shaped, covering $1 / 2$ or more of nut; scales pale woolly, more or less knobby, thickened at base of cup, thinner toward rim. Meat sweet,

COMPARISONS-In habit the Dwarf Chinquapin Oak most nearly resembles the Bear Oak but is smaller when of the same age; has flaky

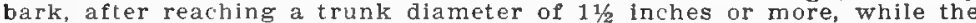
bark of the Bear Oak is close, for the most part smooth, even on old specimens not flaky though developing small close seales. It further belongs to the White Oak group (see page 338 ) and since both these two Scrub Oaks produce fruit in great abundance acorns are generally accessible and easily distinguished. The Bear Oak generally has redder, sharp-pointed buds while those of the Dwarf Chinquapin Oak are blunt with edges of scales ashy with fine wool or mealy scurfiness. Moreover, except in variety rufescens, twigs of the Dwarf Chinquapin Oak are smooth. The Chestnut Oak and the Chinquapin Oak are distinguished by their larger and sharp-pointed buds. The buds of the Swamp White Oak are somewhat similar to those of the Dwarf Chinquapin Oak but the larger size of the tree and peeling of the bark on branchlets of the Swamp White Oak are distinctive. Further west apparently the species inter-grades into the Chinquapin oak.

DISTRIBLTION-Dry woods, rocky slopes and hillside pastures, some. tlmes in open sandy soil. From Maine south to North Carolina, west to Kansas, Nebraska and Texas.

IN NEW ENGLAND-More or less common throughout.

IN CONNECTICUT-Occasional or frequent.

WoOD-From small size of plant, of no economic value except as fuel. 

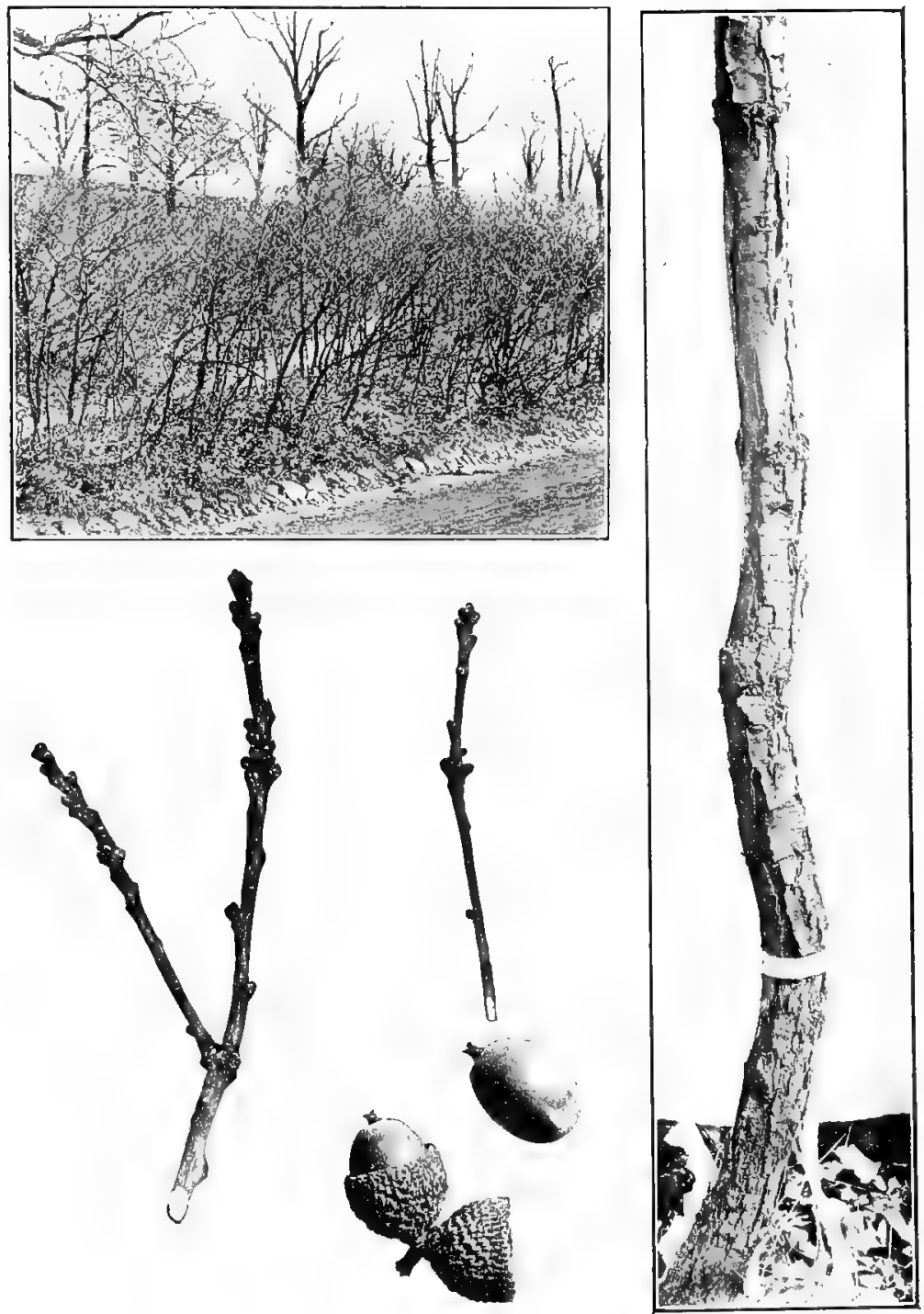

Dwarf Cininquapin Oak 


\section{CHESTNUT OAK \\ Rock Chestnut Oak, Rock Oak. \\ Quercus Prinus L.}

H.IBIT-A medium sized or small tree, 25-50 ft. high with a trunk dianeter of $1-21 / 2$ ft. further south much larger reaching 100 ft. in height; trunk tall, straight, continuous, or divided rather low down into large spreading limbs, forming broad open head, sometimes broader than high.

BARK-Brown to black, deeply fissured into long, more or less continuous, thick, rough ridges which are somewhat flattened on surface or on older trees more characteristically rounded or sharp-edged, a section through one of the ridges forming thus an inverted letter "V" with its apex somewhat rounded or in younger specimens flattened; bark of yuung trees and of smaller branches smooth.

TWIGs-Stout, light orange to reddish-brown, smooth with somewhat bitter taste. LENTICELS-pale, generally inconspicuous. LEAVES -oblong, lanceolate to obovate, wavy-margined with 10-16 pairs of primary veins. PITH-5-pointed, star-shaped.

BCDS-Narrowly ovate-conical, sharp-pointed, 4-10 $\mathrm{mm}$. long. BUDSCALES-light chestnut bruwn, slightly hairy toward apex and on margins, appearing longitudinally striate if viewed toward light with a hand-lens. Margins of scales tend to lose their brown color and to become light or dark gray.

FRCIT-Maturing the first season, short-stalked, singly or in pairs. NUT-shiny, light chestnut brown, oval to ovate to nearly cylindrical, variable in size and relative thickness; $20-35 \mathrm{~mm}$. long; from three times to less than twice as long as broad. CUP-thin, deep, topshaped to hemispherical, covering $1 / 3$ or less of nut; scales reddishbrown, woolly, more or less knobby especially toward base of cup. Meat sweet.

COMPARISONS-The Chestnut Oak is readily distinguished from the other members of the White Oak group by the fact that its bark is not flaky. Its firm, round-ridged bark is definitely characteristic when typically developed. The buds resemble somewhat those of the Fied Oak, but are somewhat lighter in color with edges of scales bleached, are much narrower and for the most part conical, with the widest part at or very near the base, whereas the buds of the Red Oak. when typically developed, are much fatter, with the widest part about a third of the distance from the base. The bark of the Red Oak, moreover, has flat ridges.

DISTRIBUTION-Woods, rocky ridges and hillsides. Along the Canadian shore of Lake Erie; south to Delaware and along the mountains to Georgia, extending nearly to the summit of $\mathbf{M t}$. Pisgah in North Carolina; west to Kentucky, Tennessee, and Alabama.

IN NEW ENGLAND-Maine-Saco river and Mt. Agamenticus, near the southern coast; New Hampshire-belts or patches in the eastern part of the state and along the southern border, Hinsdale, Winchester, Brookline, Manchester, Hudson; Termont-western part of the state throughout, not common; abundant at Smoke mountain at an altitude of 1,300 feet, and along the western flank of the Green mountains, at least in Addison county; Massachusetts-eastern sections, Sterling, Lancaster, Russell, Middleboro, rare in Medford and Sudbury, frequent on the Blue hills; Rhode Island-locally common.

IN CONNECTICUT-Occasional near the coast; frequent or common elsewhere.

woOD-Heavy, hard, strong, rather tough, close grained, durable In contact with the soil, largely used for fencing, railroad ties, ranking next to the White Oak for this purpose, and for fuel. The bark is rich in tannin and is consumed in large quantities in tanning leather. 


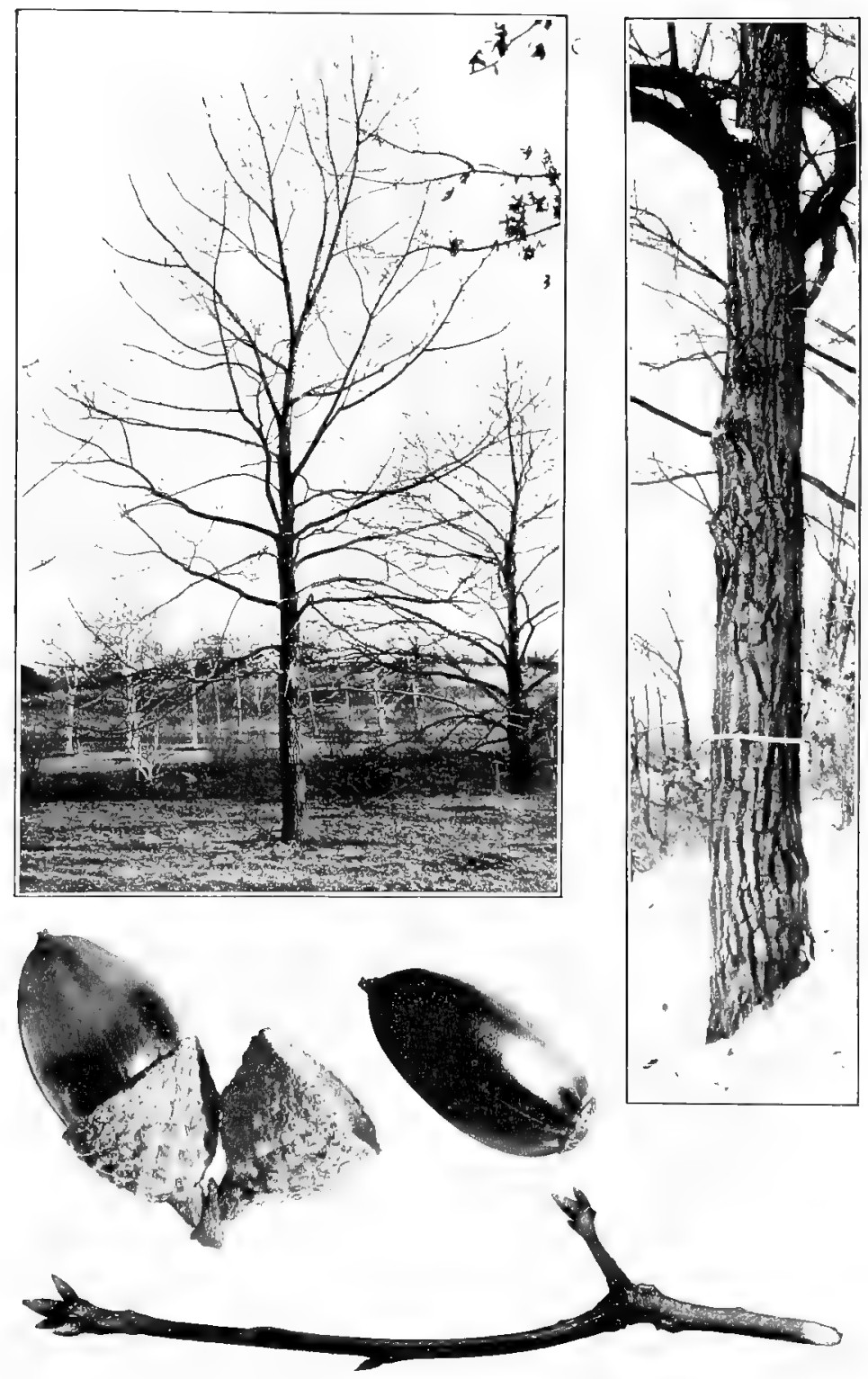

Cinestalt O.h 


\section{RED OAK}

Quercus rubra L.

HA BIT-The largest of our New England oaks, 50-85 ft. high, reaching an exceptional height of $150 \mathrm{ft}$.; with trunk diameter of $2-6 \mathrm{ft}$; trunk branching rather higher up than in the White Oak, often continuous into the top of the tree with ascending branches forming a rather narrow, round-topped head or spreading more widely as shown in the specimen photographed becoming even broader than high. The limbs in"the main are not so horizontal or declined nor so crooked as in the White Oak and the tree in consequence offers a less gnarled aspect.

BIPK-On young trees and upper parts of older trees smooth, graybrown; on trunks of mature trees and on their thicker limbs up to $4 \mathrm{~cm}$. thick, tardily broken by shallow furrows into dark brown, rather regular, elongated, firm. cuarse, flat-topped ridges. The flat ridges which are characteristic of the species are often in older trees roughened up toward the base of the trunk so that the distinctive character of the bark must be sought higher up on the trunk or on the larger limbs. Inner bark, light reddish, not bitter.

TwIrs-Mediumly stout to slender, reddish to greenish-brown. LENTICELS-pale, often inconspicuous. LEAVES-obovate to oblong. with bristle-pointed lobes, often difficult to distinguish from those of Black Oak. PITLI-5-pointed, star-shaped.

BCDS-Oval to nvate, $4-8 \mathrm{~mm}$. long, with widest part typically $1 / 4$ to $1 / 3$ above base suggesting appearance of a short stalk to the bud: sharp pointed with more or less distinct development of rusty hairs at the extreme apex, otherwise smooth or sometimes slightly pale-woolly on upper half. BUD-SCALES-numerous, light chestnut brown seen to be longitudinally striate with darker lines when viewed toward light with a hand-lens, margins slightly hairy.

FRUTT-Maturing in autumn of second season, singly or in pairs, sessile or on a short, thick stalk NUT-ovate to cylindrical with broad base and narrowed, rounded apex, dark chestnut brown, large, $2-3 \mathrm{~cm}$. long. CUP-flat, shallow, thick, saucer-shaped (rarely somewhat top-shaped). rim somewhat coltstricted, enclosing about $1 / 5$ of the nut, $2 .-3.5 \mathrm{~cm}$ across. Scales thin. reddish-brown, shining. not at all or but slightly hairy, closely overlapping. Meat pale yellow, slightly bitter. Immature acorns generally divergent or but slightly appressed, with basal scales reaching about half way ur, giving appearance of 3 rows of scales.

COMPARISONS- if the acorns are obtainable the Fed Oak is not to be confused with any of our other species, the large flat cup being distinctive. The flat flutings of the bark arid the fat, basally constricted, sharp-pointed buds are further characteristic. See Black Oak for comparison with Red and Black and Searlet Oak, and Chestnut Oak for comparison with latter species.

DISTRIBLTIOX-Woods, widely adapted to varlous condilions of soll and situation except distinctly wet lands, rances further north than our other Oaks and is most planted of the American Oaks in Europe. Nova Scotia and New Brunswick to divide west of Lake Superior; south to Tennessee, Virginia, and along mountain ranges to Georgia; reported from Florida; west to Minnesota, Nebraska, Kansas and Texas.

IN NEVV ENGLAND-Maine-common. at least south of the central portions: New Hampshire-extending into Coos County, far north of the White Mountains; Vermont, Massachusetts, Rhode Island-common: probably in most parts of New England the most common of the genus; found higher up the slopes of mountains than the White Oak.

\section{IN CONNECTICUT-Frequent throughout.}

wooD-Heavy, hard, strong, close-grained, light reddish-brown, wlth thin lighter colored sapwood; used in construction, for the Interior finish of houses, and in furniture. Timber of this species as also of Black and Scarlet Oak is relatively poor but is more used than iormerly on account of scarclty of better. 

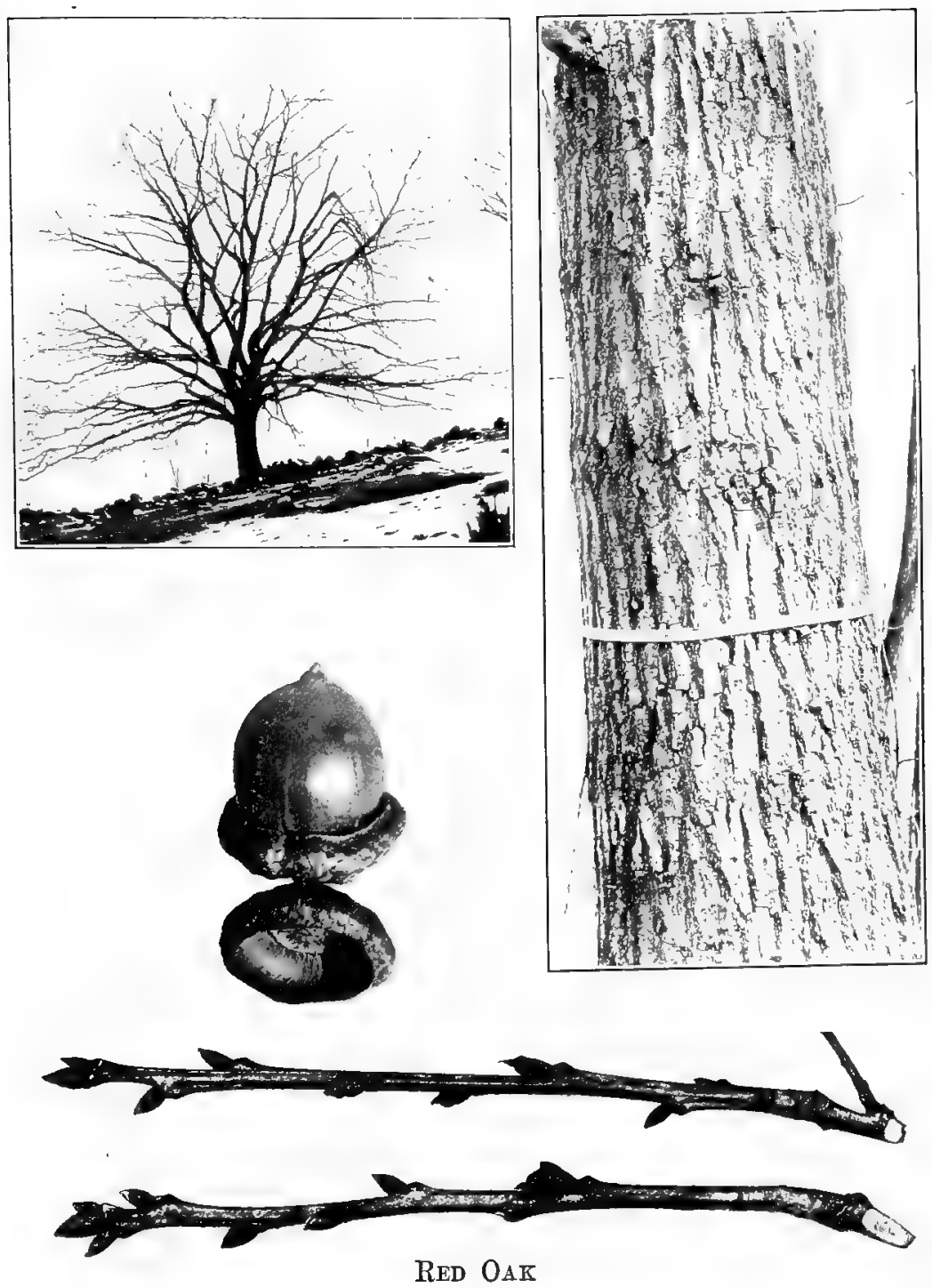


\title{
PIN OAK \\ Swamp Oak, Water Oak. \\ Quercus palustris Muench.
}

\begin{abstract}
H.MIT-A medium sized tree 40-50 ft. high with trunk diameter of $1-2$ ft., reaching a maximum height of over 100 ft. in the lower Ohio basin; trunk tall. straight, continuous up through the pyramidal head; limbs numerous, slender; lower limbs shcirt, dronping, upper limbs longer herizontal or ascending, generally studded with short lateral shoots which give rise to the common name. The habit of this tree is very characteristic and is well shown in the two specimens in the illustration. In older trees the head is more open and irregular.
\end{abstract}

I IRK-Of young trunks and limbs, smooth, shiny, light brown; on older trunks darker, furrowed with close, narrow, frm, low ridges.

TU I6:S-Slender, reddish-brown to orange, shining. LENTICELS-pale. scattered, inconspicuous. LEATES-small, obovate or oblong; lobes bristle-tipped, separated by deep-rounded sinuses, resembling leaves of Scarlet Oak but smaller. PITH-5-pointed, star-shaped.

BIDS-Conical to ovate, generally sharp-nointed, small, 2-4 mm. long. BUD-SCALEs-light chestnut brown, sometimes slightly hairy on the thin margins.

FRIIT-Maturing the second season, abundant, sessile or shortstalked, solitary or in pairs or clusters. NUT-light brown, often striate, nearly hemispherical, 10-15 $\mathrm{mm}$. long, wider than long, and generally wider than the cup. CUP-thin, saucer-shaped, $10-15 \mathrm{~mm}$. across, enclosing only the base of the nut; scales thin, slightly downy, closely overlapping. Meat pale yellow, slightly bitter.

COMPARISONS- When young the Pin Oak is one of the most easily recognized of any of our trees in winter from its general habit of growth. Its continuous trunk, fringed with slender branches and its romparatively smooth bark roughened only slightly by narrow, low ridges are alone distinctive. Further characteristics are the small sharp-pointed buds and the small acorns with saucer-shaped cup.

DISTRIBCTION-Borders of swamps and river bottoms in deep moist rich soll. Ontario; south to the valley of the lower Potomac in Virginia: west to Minnesota, east Kansas, Missouri, Arkansas, and Indian Territory.

IN NETV ENGLAND-Massachusetts-Amherst; Springfield, south to Connecticut, rare; Rhode Island-southern portions, bordering the great kingston swamp and on the margin of the Pawcatuck River.

IN CONXECTICLT-Common in the Connecticut river valley and near the coast in southwestern Connecticut; occasional or local elsewhere.

woOD-Heaty, hard, coarse-grained, but liable to warp and check in drying; light brown, with thin rather darker colored sapwood; sometimes used in construction and for shingles and clapboards. 

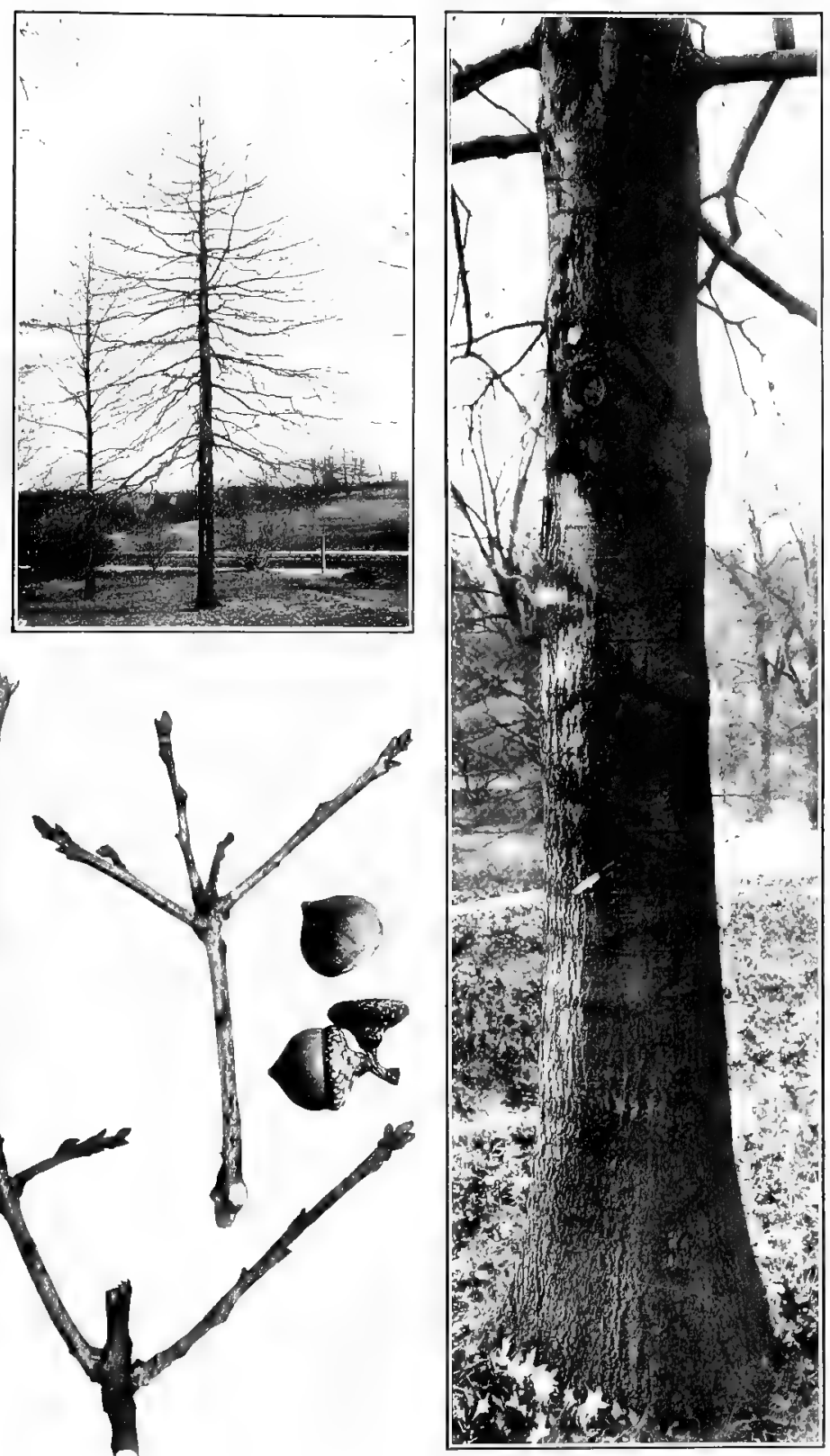

P'IN OLK 


\title{
SCARLET OAK
}

\author{
Quercus coccinea Muench.
}

HABIT-A tree of medium size, $30-50 \mathrm{ft}$. high with trunk diameter of 1-3 ft., larger further south; trunk tends to be continuous into the crown, narrowed and giving off ascending branches above and horizontal, often terminally declined branches below; limbs long and comparatively slender for an Oak, forming a rather narrow, open head.

BARK-Of young trunks and limbs smooth, light brown, on older trunks and limbs up to $2.5 \mathrm{~cm}$. thick, divided by shallow furrows into irregular ridges which in general are neither so regularly flat-topped as the ridges of the Red Oak nor so roughly broken up as those of the Black oak. The bark therefore may be considered as intermediate in character between these two species. Inner bark, reddish not bitter.

TWIGS-Mediumly stout to slender, light red to orange red. LENTICELS-numerous, minute, pale, inconspicuous. LEAVES-broadly oval or obovate, with bristle-tipped lobes separated by deep rounded sinuses. PITH-5-pointed, star-shaped.

BLDS-Broadly oval to ovate, narrowed above to a typically rather blunt apex, widest at or slightly below middle, dark reddish-brown, 4-8 $\mathrm{mm}$. long, pale woolly above middle, lower half mostly free from wool. BUD-SCALES-numerous, free from distinct longitudinal striations.

FRLIT-Maturing in autumn of second season, sessile or short-stalked, singly or in pairs. NUT-oval to oblong, variable in shape, 1 to 2.5 cm. long. light reddish-brown, occasionally striate, CUP-thin, topshaped or cup-sliaped, constricted at base, enclosing $1 / 3$ to $1 / 2$ of nut. Scales, light reddish-brown, thin, closely overlapping, slightly downy, tips of scales at rim typically appressed against the nut-not spreading. Meat pale yellow, slightly bitter. Immature acorns appressed, rather smooth and shiny, light brown, main basal scales generally reaching less than halfway up giving appearance of 2 rows of scales.

COMP.RISONS-The size and shape of the acorn cup as well as the greater woolliness of the upper part of the buds distinguish this species from the Red Oak. From the Black Oak it is distinguished by the appressed scales of acorn cup. by the fatter buds which are less woolly, and that only above the middle, and by the pale inner bark. See also under Black Oak.

DIS RIBLTION-Most common on dry, sandy soll. Ontarlo; south to the middle states and along the mountains to North Carolina and Tennessee; reported from Florida; west to Minnesota, Nebraska and Missourl.

IN NEW ENGLAND-Maine-valley of the Androscoggin, southward; New Hampshire and Vermont-not authoritatively reported by recent observers: Massachusets-more common in the eastern than western sections, sometimes covering considerable areas; Rhode Island-common.

IN CONNECTICUT-Frequent throughout.

noon-Heavy, hard, strong, coarse-gralned. $11 \mathrm{ght}$ or reddish-brown, with thick darker cnlored sapwood, less valuable than wood of Red Oak but used for the same purposes. 

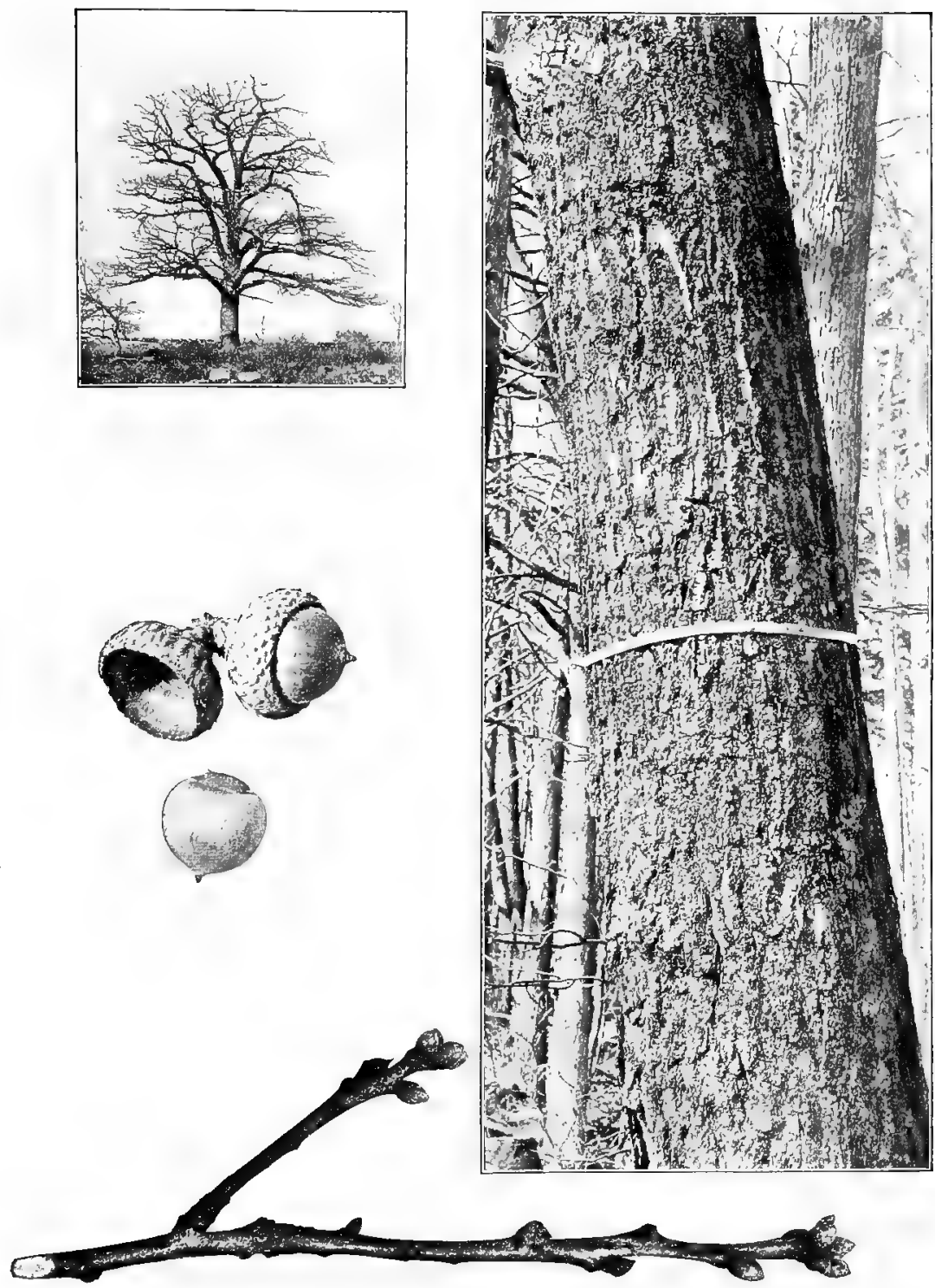

Scarlet OAK 


\section{BLACK OAK \\ Yellow-barked Oak, Quercitron, Yellow Oak. \\ Quercus velutina Lam. \\ Q. coccinea, var. tinctoria A.DC, Q. tinctoria Bartr.}

H. IIT-One of our largest oaks $50-75 \mathrm{ft}$. high with a trunk diameter
of $2-4 \mathrm{ft}$, reaching its greatest develoment in Ohio basin with a
naximum height of 150 ft. somewhat similar in general habit to the
S.arlet Oak; limbs generally somewhat stuuter; head may be wide Suarlet Oak; limbs generally
spreading or narrowed oblong.

IIIRK-Dark gray to blackish often lighter near the seashore, up to $4 \mathrm{~cm}$. thick, very rough, broken by deep furrows into thick ridges which are further divided by cross fissures giving an appearance of irregular block-like strips. The bark is roughened especially at the base of trunk even in quite young trees. The young bark in beginning to fissure for a time may hare flattened ridges resembling those of Red wak but they are suon transversely roughened. Inner bark orangeyellow, intensely bitter; this with the buds forms the most distinctive cliaracter.

TW IGS-Stout, reddish-brown or reddish, mottled with gray; tasting bitter if chewed and coloring saliva yellowish. LENTICELS-scattered, generally large, conspicuous. LEATES-obovate to oblong with broad bristle-pointed lobes sumetimes indistinguishable from those of Scarlet Oak. Large, thin-walled, spherical insect galls formed on leaves seem to be most common on the Black Oak. PITH-5-pointed, star-shaped.

B I DS-Ovate to conical, large, 6-12 $\mathrm{mm}$. long, narrowed above to a rather sharp point, generally 5-sided, strongly angled, covered except basal row of scales with dense, pale yellowish-gray to dirty-white wool. BID-SCALES-numerous, not distinctly longitudinally striate.

HRI IT-Maturing in a utum of second year, singly or in pairs, sessile or short-stalked, deep cup-shaped to top-shaped. NUT-ovate-oblong, variable in shape, $1.2 \mathrm{~cm}$. long, light reddish-brown, frequently coated with soft down, often striate. CUP-thin, deeply cup to topshaped. more or less constricted at base; scales of cup thin, light reddish-brown, finely woolly, closely overlapping at base loosely overlapping above with free tips horizontally wrinkled and forming a lowise more or less spreading fringe-like border to cup. Meat yellower and more bitter than that of the Scarlet Oak. Immature acorns appressed or recurved toward twig, slightly woolly; main scales extending nearly to the top giving the appearance of a single row of scales.

COMP.IRISONS-The three most common trees of the Black Oak group (the Red, the Black and the Scarlet) are readily distinguished by their bud characters. Those of the Black Oak are densely pale woolly over whole surface, those of Scarlet Oak are less densely pale woolly, and the woulliness is confined to upper half. They are more nearly oval than those of the Black Oak, the widest part being toward the middle. The ried Oak buds are generally free from pale woolliness though having often rusty hairs at extreme apex; in distinction from the scarlet oak the widest part is nearer the base. The yellow bitter inner bark and the yellow discoloration of the saliva when the twigs are chewed distinguish the Black Oak from the other two. The Red Oak has flat-topped ridges, these in the Black Oak are broken into rough blocks, while the bark of the Siarlet Oak is intermediate between the two types. The acorns of the Fed Oak are large with large shallow saucer-shaped cups, those of the Red and Black are smaller, and have deeper cups. The cup scales of the Black Oak form a loose fringe at the rim and are wrinkled, those of the Scarlet are closely over-lapping and form no fringe. The acorn characters are distinctive for the Red Oak but are not so good quite in separating the Black and Scarlet Oaks from each other. although when typically developed, the acorns of the two trees can be readily distinguished. The bark characters can be used when typically dereloped in separating the Red from the Black Oak but are not as decisive as bud or inner bark characters.

DISTRIBITION-In poor soils; on dry gravelly plains and ridges. Southern and western ontario: south to the Gulf states; west to Minnesota. Kansas, Indian Territory, and Texas.

IN NET ENGLAND-Maine-York county; New Hampshire-valley of the lower Merrimac and eastward, absent on the highlands, reappearing within three or four miles of the Connecticut, ceasing at North Charles town; Vermont-western and southwestern sections; Massachusettsabundant eastward: Fhode lsland-frequent.

IN CONNECTICLT-Occasional or frequent.

wooD-Heavy, hard, strong though not tough, coarse-gralned and liable to check in drying. bright brown tinged with red, with thin lighter colored sapwood: of little value except as fuel. The bark abounds in tannic acid and is largely used in tanning, as a yellow dye and an astringent in medicine. 

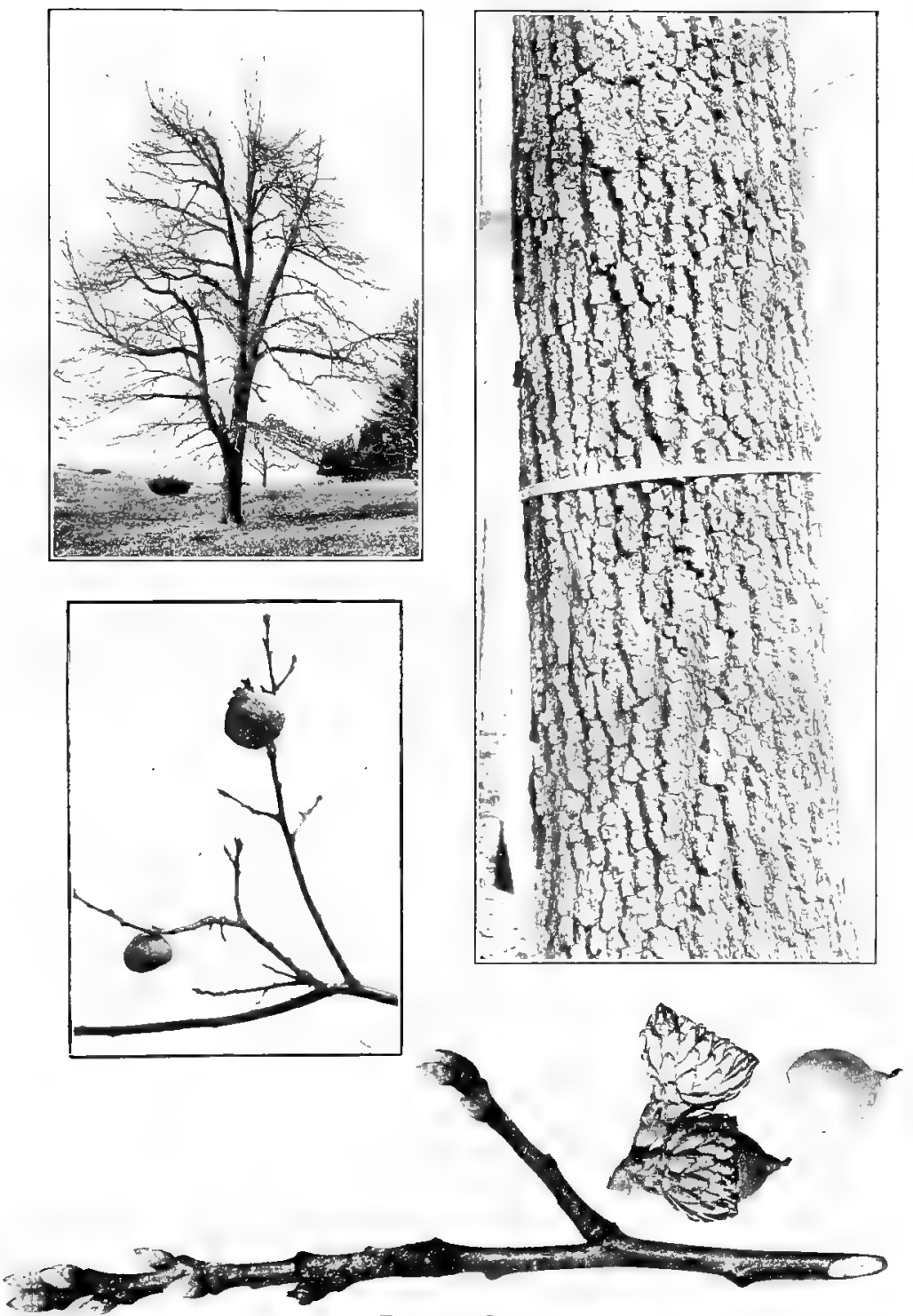

BLACK OAK 


\section{BEAR OAK \\ Black Scrub Oak. \\ Quercus ilicifolia Wang. \\ Q. nana Sarg.; Q. pumila Sudw.}

H.IBIT-Usually a shrub $3-10 \mathrm{ft}$. high, though frequently becoming tree-like and reaching a maximum height of 25 ft. with a trunk diameter of $1 / 2$ to $1 \mathrm{ft}$; trunk short; branches stiff, contorted, slender, spreading and forming a wide flat or round-topped head.

B.IRK-Thin, dark brown, smooth, except for small, close, thin scales on older trunks, never however breaking into large, flaky scales.

TWIGS-Slender, yellowish-green to reddish-brown, covered with greenish-yellowish to reddish down which often disappears from exposed parts of the twig during the winter but which can generally be found in protected parts at the tips, bases or between the ridges of the season's shoots. LENTICELS-minute, pale, inconspicuous on shoots of season. Leaves often breaking off above place of attachment leaving base of leafstalk projecting throughout winter (see illustration). LEAVES-small, obovate, nearly entire or with 3-7 bristle-tipped lobes, downy beneath. PITH-5-pointed, star-shaped.

BUDS-Ovate to conical, sharp or blunt pointed, small, generally not over $3 \mathrm{~mm}$. long. BUD-SCALES-dark chestnut brown, generally minutely hairy on the margins.

Fr'IT-Maturing in second season, produced in great abundance. clustered along the stem, generally in pairs or rarely singly, sessile or generally short stalked. NUT-varying in shape, ovate to sphertcal, 10-15 $\mathrm{mm}$. long, light brown, shining, generally more or less longitudinally striate. CUP-top-shaped to rather deeply saucershaped, more or less constricted at base, thick, enclosing about $1 / 2$ the nut; scales of cup reddish-brown, slightly downy, thin, closely overlapping with free tips of upper scales forming a fringe-like border to cup.

COMPARISONs-The Dryarf Chinquapin Oak is the only one likely to be confused with the Bear Oak. The points of difference between the two species may be found in Comparisons under Dwarf Chinquapin Oak.

DISTRIBUTION-Dry sandy or rocky sterile ground. Maine; south to Ohio and the mountain regions of North Carolina and Kentucky; west to the Allegliany mountains.

IN NEW ENGLAND-Maine-frequent in eastern and southern sections and upon Mount Desert Island; New Hampshire-as far north as Conway, more common near the lower Connecticut; Vermont-in the eastern and southern sections as far north as Bellows Falls; Massachusetts and Rhode Island-abundant, forming in favorable situations, dense thickets, sometimes covering several acres.

IN CONNECTICUT-Rare in northwestern part of the state, local, irequent or common elsewhere.

WooD-Too scant to be of any economic value. 

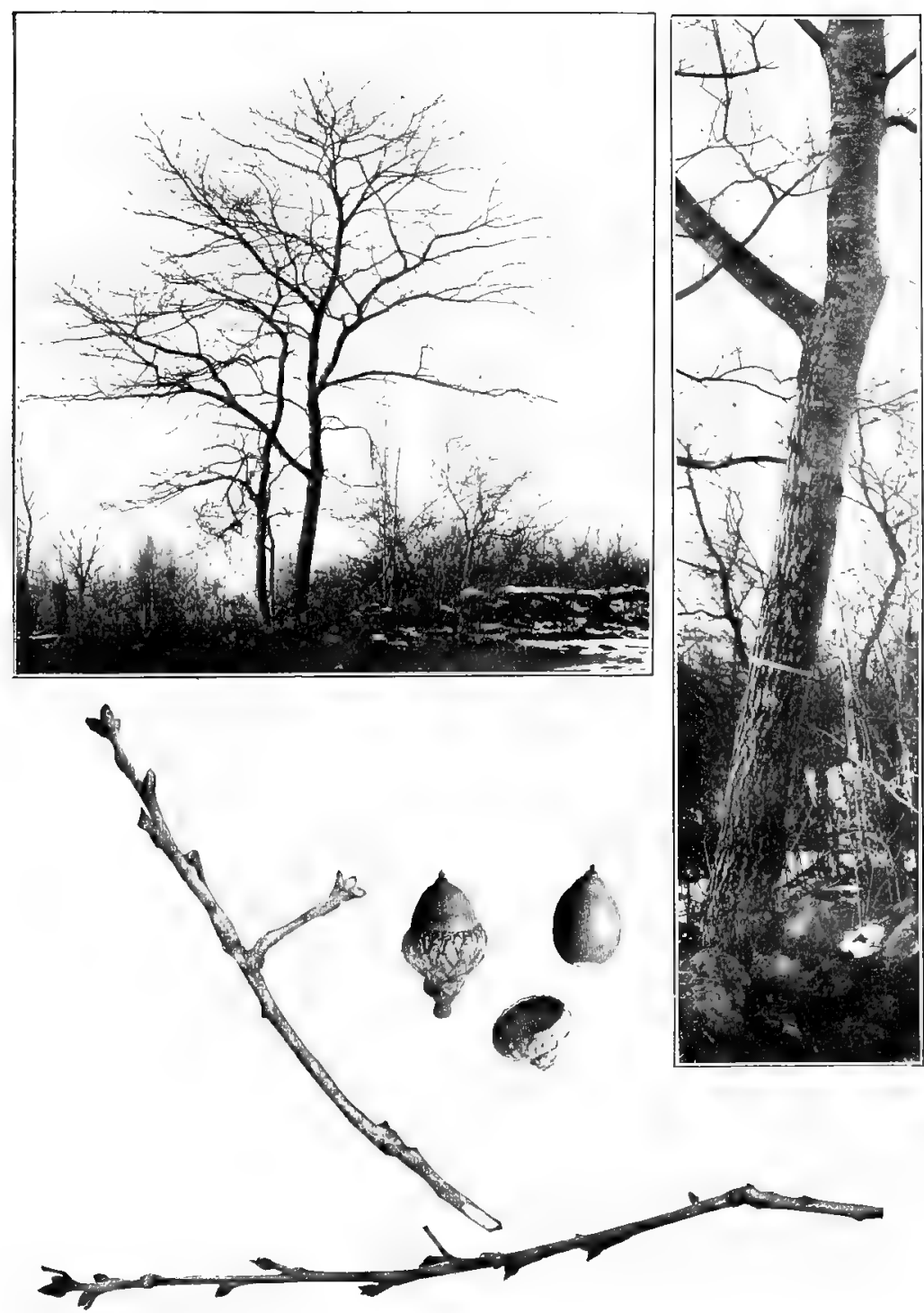

BeAr OAK 


\section{SLIPPERY ELM Red Elm, Moose Elm. \\ T'lmus fulva Michx. L. pubescens Walt.}

H 1BIT-A snall to medium-sized tree, $40-60 \mathrm{ft}$. in height with a trunk diameter of $1-2 \frac{1}{2}$ ft.; forming a broad open rather flat-topped head, resembling the White Elm but with less drooping branches.

B.IRK-Grayish-brown, more or less deeply furrowed, internally reddish-brown without conspicuously whitish layers (see bark section in plate); inner bark next the wood, whitish, strongly mucilaginous, giring the name slippery Elm.

TWIGS-Light, grayish, hairy, roughened by numerous raised lenticels, strongly and characteristically mucilaginous if chewed.

LEAF-SCARS-Alternate, 2-ranked, with generally 3 sunken bundlescars, resembling those of the White Elm.

BCDs-Terminal bud absent; lateral buds about $6 \mathrm{~mm}$. long, dark brown, covered especially at their tips with long rusty hairs; flower buds more or less spherical. BUD-SCALES-in 2 ranks of a nearly uniform color.

FRCIT-A flat round entire-winged fruit withnut hairy fringe, ripening in spring.

Compurisons-The Slippery EIm is easily distinguished from the common White Elm and the rarer Cork Elm by its rough gray twigs, its dark buds covered with long rusty hairs, and by the strongly mucilaginous character of the inner bark of the trunk and even, though to a somewhat less extent, of the twigs, and further from the White Elm by the absence of distinct white layers in the outer bark.

OISTRIBLTION-Rich, low grounds; low, rocky woods and hillsides. Valley of the St. Lawrence, apparently not abundant; south to Florida; west to North Dakota and Texas.

IN NEW ENGLAND-Maine-District of Maine, rare; Waterborough, (York county); New Hampshire-valley of the Connecticut, usually disappearing within ten miles of the river; ranges as far north as the mouth of the Passumpsic; Vermont-frequent; Massachusetts-rare in the eastern sections, frequent westward; Rhode Island-infrequent.

IN CONNECTICUT-Rare to frequent.

woon-Heary, hard, strong, very coarse-grained, durable, easy to split, dark brown or red, with thin lighter colored sapwood; largely used for fence posts, railroad ties, the sills of buildings, the hubs of wheels and in agricultural implements. The thick fragrant mucilaginous inner bark is used in medicine as a demulcent and is somewhat nutritious. 

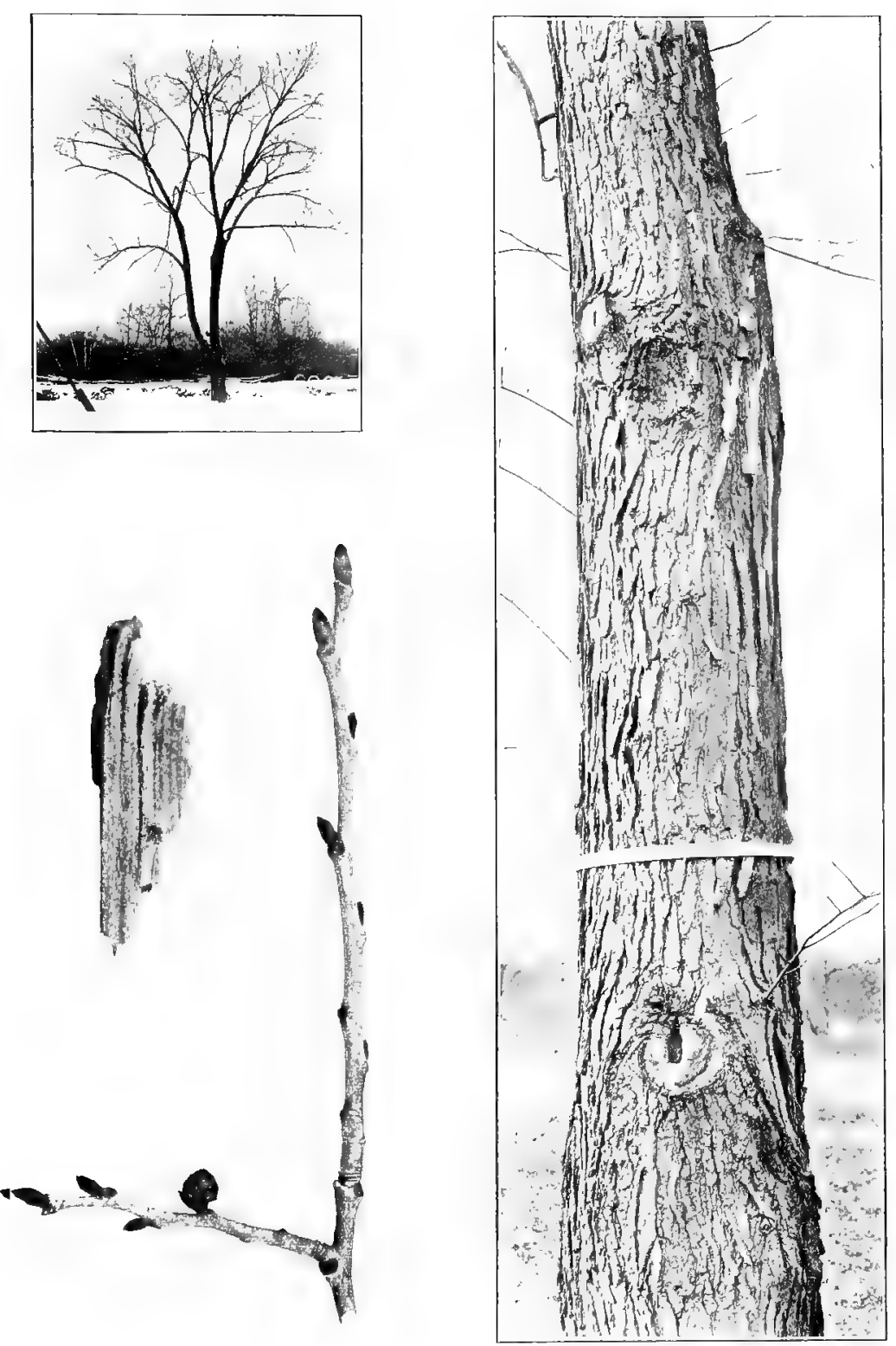


\section{ENGLISH ELM \\ Ulmus campestris $\mathrm{L}$. U. glabra Mill.}

HIBIT-A large tree reaching 100 ft. in height; trunk erect, generally continuous well into the crown, with branches given off at a broad angle and continued horizontally or inclined upward, not drooping at the ends in the graceful curves characteristic of the American White Elm, producing rather an Oak-like appearance with an oblong roundtopped head.

BARIK-Dark, with ridges broken transversely into firm oblong blocks.

TwiGs-Similar to the White Elm but generally a darker reddishbrown. usually smooth or somewhat downy.

LEIF-SCARS-Similar to the White IIm, bundle-scars frequently more than 3 .

BCDS-Similar to the White Eim but of a dark smoky brown color or almost black, smooth or more or less hairy.

FRUIT-A flat, ovate, smooth, entire-winged fruit, ripening in spring.

COMPIRISONS-The erect Oak-like habit, the firm blocked ridges of the bark, and the smoky smoothish buds will serve to distinguish the English Elm from its American cousins. There are a number of varieties of the English Elm differing in habit of growth, one form having corky ridges. We have described the most familiar type.

DISTIIB TION-The English Elm is not confined to England but Iike the English sparrow occurs through Europe. It is not native to America but was considerably planted formerly in the eastern sections especially in Boston and vicinity, where some fine old specimens are to be found. The trees in the plate were taken from Boston Common, the two in the foreground at the right and the one in the background at the left being English Elms while the smaller one, indistinctly outlined in the foreground at the left is an American White Elm. They have all been rather severely pruned on account of insect depredations.

wooD-Heavy, hard, fine-grained, durable in water, not liable to crack when exposed to sun or weather; used in Europe for ships' blocks and other wooden parts of rigging. for the keels of ships, for pumps and water pipes, piles and other construction under water and for the hubs of wheels. 

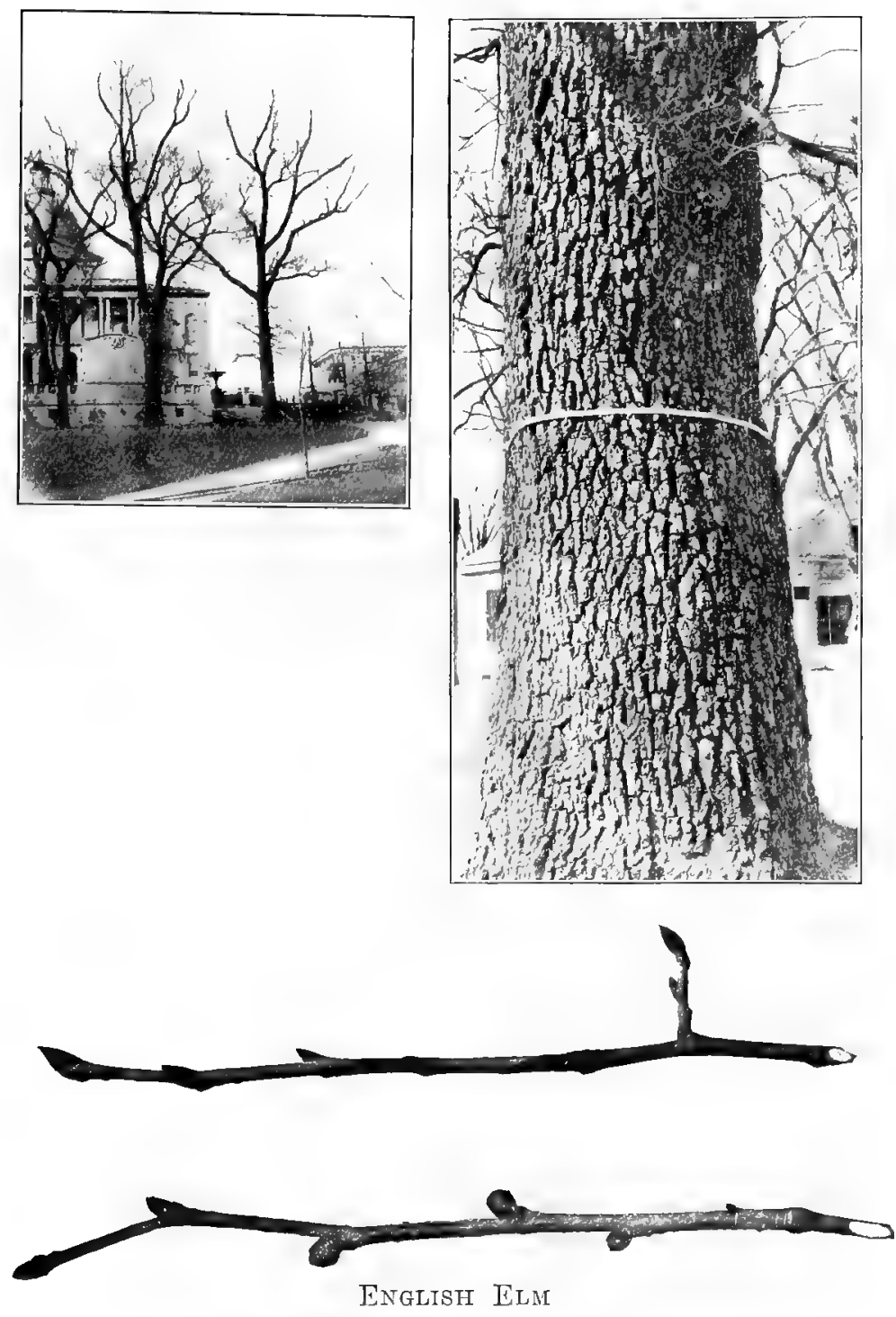


\title{
WHITE ELM American or Water Elm.
}

\author{
Ulmus americana $\mathrm{L}$.
}

HIBIT-A large tree 50-110 ft. in height with a trunk diameter of 1-s ft.; trunk more or less widely buttressed dividing high up into a number of large limbs which grow upward and bend gradually and gracefully outward dividing repeatedy to form a broad round or flat-topped inversely conical head with drooping branchlets. In respect to its general outline various types of the Elm have been distinguished as the "Tase Form" shown in the photograph; the "Umbrella Form" with trunk undivided to near the top with abruptly spreading branches forming a broad shallow arch; the "Plume Form" with a one-sided development of druoping branches from a tall trunk; the "Oak Form" with more tortuous and less arching limbs forming a wide rounded head; the "Feathered Form." a modjication of any of the other types with the trunk fringed with short branches.

BIRK-Dark gray divided by irregular longitudinal fissures into broad flat-topped ridges, rather firm though sometimes in very old trees coming off in hakes; the bark is internally stratified by thick conspicuously whitish layers alternating with layers of a dark brown (see plate for section of a ridge of bark).

TWIG - Slender, smooth or slightly or sometimes densely downy, light reddish-brown, often tinged with yellow, very slightly mucilagin: ous if chewed. LENTICELS-pale, scattered, more or less inconspicuous.

LEII-SCIRS-Alternate, 2-ranked, semi-circular, raised, small but conspicuous because of contrast in color between tle light corky surface of the scar and the darker brown of the twig. STIPULE-SCARSnarrow, minute, sometimes indistinet. BUNDLE-SCARS-relatively large, conspicuous, typically 3 in number though often more by compounding of single scars, generally sunken in depressions of the leaf-scar.

BUDS-Terminal bud absent; lateral buds small, often placed at one side of leaf-scar. ovate-conical, pointed, about $4 \mathrm{~mm}$. long, slightly Hattened and more or less appressed against the twig, light reddishbrown, smooth and shining or slightly pale-downy; flower buds stouter, obovate, appearing as if stalked. BUD-SCALES-about 6-9 to a leafbud in 2 ranks increasing in size from without inward, generally with darker and more or less hairy-edged margins.

FR L $\mathbf{r}$-A flat, oval, terminally deeply notched, winged fruit, hairyfringed on edges, ripening in spring and scarcely to be found in winter.

COMPIRISOM-The White Elm differs from the Slippery Elm in the whitish layers of the bark, the absence of rusty hairs on the buds and the brownish color of its relatively smooth twigs. From the Cork Elm it may be separated by its habit of growth and by the absence of corky ridges on the twigs, The graceful drooping habit of growth of its branches and the light redish brown of its buds are sufficient to distinguish the American from the English Elm.

DISTRIBITION-Low, moist ground; thrives especially on rich intervales. Frequently planted as a street and shade tree. From Cape Bretrin to Saskatchewan, as far north as $54^{\circ} 30^{\prime}$; south to Florida; west to Lakota, Nebraska, Kansas, and Texas.

IN NFW ENGLAND-Maine-common, most abundant in central and southern portions: New Hampshire-common from the southern base of the White Mountains to the sea; in the remaining New England statesvery common, attaining its highest development in the rich alluvium of the Connecticut river valley.

WooD-Heary, hard, strong, tough, diffcult to split, coarse-grained, light brown, with thick somewhat lighter colored sapwood, largely used fur the hubs of wheels. saddle-trees, in flooring and cooperage, and in boat and ship building. 

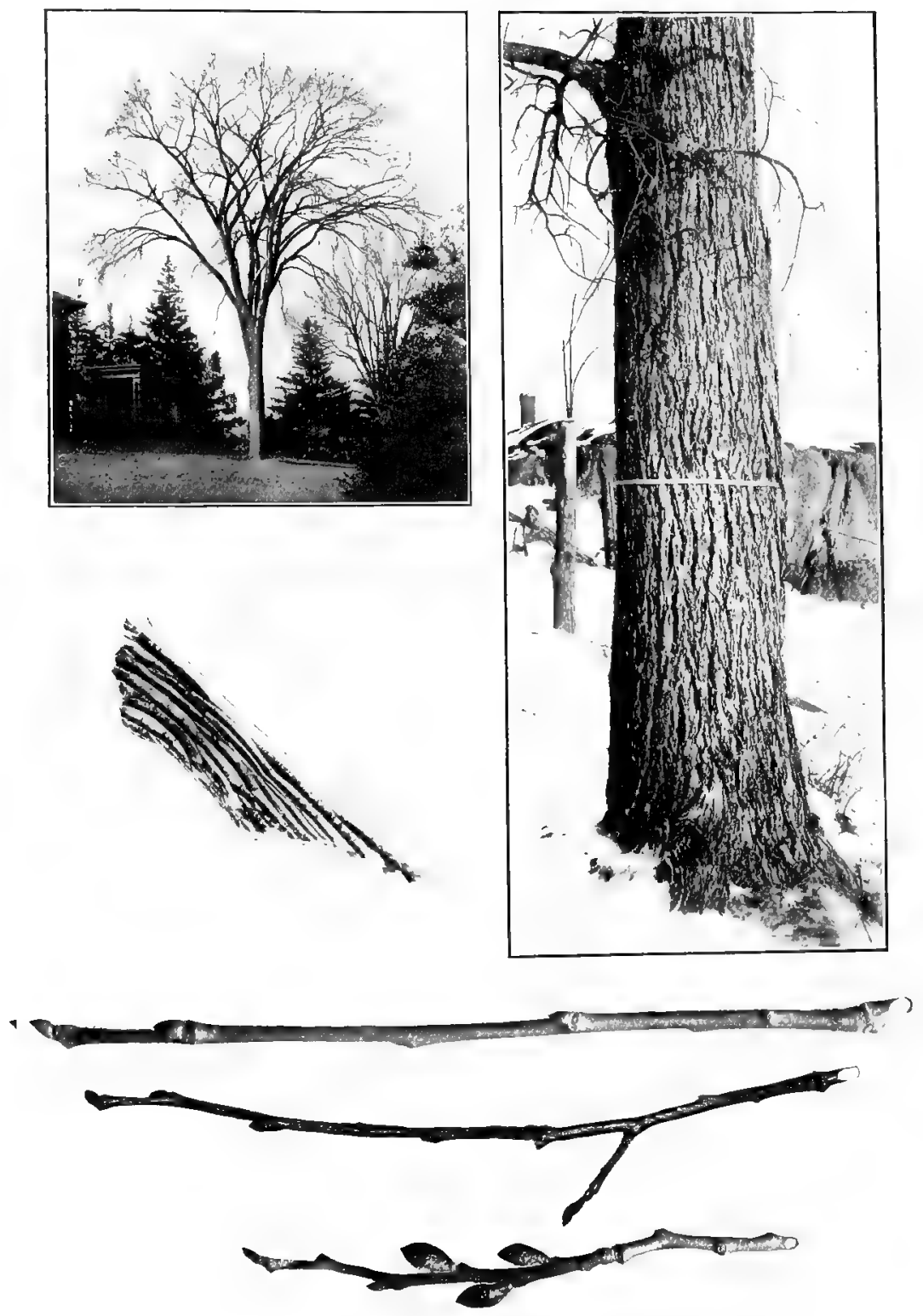

IIIITE FA, F 


\section{CORK ELM \\ Rock Elm, Hickory Elm, Northern Cork Elm. \\ Ulmus racemosa Thomas. \\ U. Thomasi Sarg.}

H.MIT-A large tree 50-75 ft. In height, with a trunk diameter of 2-3 ft., in southern Michigan, reaching $100 \mathrm{ft}$. in height with a trunk diameter of 5 ft, trunk slender, erect, generally continuous into the cromn, develnping numerous slender rigid branches arising at a wide angle, those below generally strongly drooping near the point of origin, forming a narrow, oblong, round-topped head having somewhat the aspect of a Hickory with short twiggy, generally corky-ridged branches in the interior of the tree. A young tree showing corky-ridged branchlets and an old tree showing a more characteristic habit, though with rather long trunk for the open, are shown in the plate.

BARK-On young trunks more deeply furrowed than in the White Elm, becoming with age flat-ridged, resembling the latter species.

TwIGs-More or less downy, resembling twigs of White Elm but generally developing several irregular thick corky ridges not interrupted at the nodes.

LEAF-SCMRS-Alternate, 2-ranked, resembling these of White Elm but with bundle-scars generally more than $3(4-6)$.

חบDS-Terminal bud absent; lateral buds similar to those of White Flm but longer (about $5 \mathrm{~mm}$. long) narrower, sharp-pointed, scarcely flattened, generally downy. BUD-SCALES-with darker and hairy-edged margins.

FRIIT-A flat, oval, downy, shallow-notched, winged frult, with hairy-fringed margins ripening in spring.

COMPARISO vs-In Hirkory-like habit the Cork Elm differs from all our other Elms. The corky ridges on the twigs, morenver, occur on no other native New England Elm. The Winged Elm [Ulmus alata Michx.], a native of the south, is rarely cultivated in southern New England but is not hardy north. It has two opposite thin corky ridges which are abruptly interrupted at the nodes. A variety of the English Elm has sereral corky ridges to the twig which are interrupted at the nodes. The Cork Elm differs further from the White and especially from the slippery Elm in its narrower buds.

DISTRIBITION-Dry, gravelly solls, rich solls, river banks. Quebec through Ontarin: south to Tennessee: vest to Minnesota, Iowa, Nebraska, and Missouri. Occasionally planted as an ornamental shade tree.

IN NEW ENGLAND-Maine-not reported; New Hampshire-rare and extremely local: Meriden and one or two other places: Vermont-rare, Bennington. Pownal. Knnwlton. Highgate; comparatively abundant in Champlain valley and westward; Massachusetts-rare; Khode Islandnot reported native.

IN CONNFCTICUT-Not reported native.

woon-Heavy, hard, very strong and tough, close-grained and difficult to split. light clear brown, often tinged with red with thick, lighter colored saptrod; largely used in the manufacture of many agricultural implements, fnr the framework of chairs hubs of wheels, railroad ties, the sills of bulldings and other purposes demanding toughness, solidity and flexibility. 


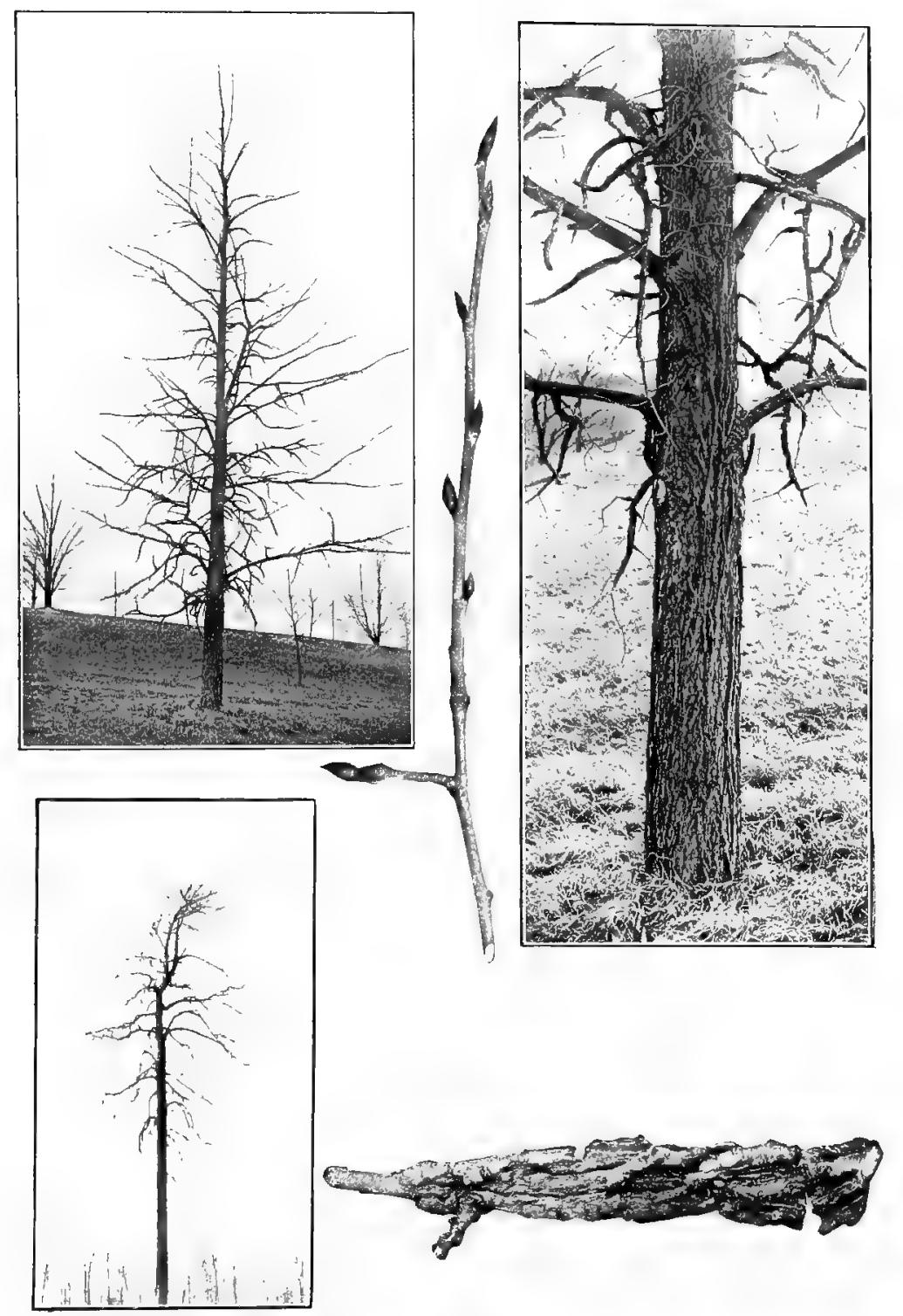

Cork Eln 


\section{HACKBERRY \\ Sugar Berry, Nettle Tree, False Elm, Hoop Ash. Celtis occidentalis $\mathrm{L}$.}

HA BIT-A small to medium sized tree 20-45 ft, in helght with a trunk dianeter up to $2 \mathrm{ft}$, reaching over $100 \mathrm{ft}$. in height further south; rather variable in habit, generally forming a flattish to round-topped wide-spreading, oblong head with somewhat the aspect of an Lim; branches numerous, horizontal or slightly drooping, more or less ziguag: spray slender; berry-like fruit generally persistent throughout the winter.

BIRI-Grayish-brown, on trunk and older limbs roughened with narrow projecting ridges which are sometimes reduced to warts or are almost entirely lacking.

TwiGs-Slender, somewhat zigzag, brownish, more or less shining, more or less downy; wood of twigs light greenish yellow when moistened. LENTICELS-scattered, raised and more or less elongated longitudinally. PITH-white, finely chambered.

LEAF SCARS-Alternate, 2-ranked, small, semi-oval, placed at right angles to the twig on a projecting cushion. STIPULL-SCARS-present, elongated, inconspicuous. BUNDLE-SCAFS-appearing as a single con. fluent scar, evidently 3 in surface section.

BUOS-Small, $6 \mathrm{~mm}$. or generally under in length, downy, chestnut brown, ovate, sharp-pointed, Hattened, appressed; terminal bud absent. Buds frequently transformed into insect galls (swellings on twig photographed). BUD-SCALLS-3-4 visible, closely overlalping in two ranks increasing in size from without inward. longitudinally striate if viewed toward light, generally dark margined.

FRIIT-A small, purplish, more or less spherical stone-frult on long. slender stems, $7-10 \mathrm{~mm}$. in diameter, often remaining on tree throughout winter. Flesh edible, sweet as is also the seed inside the stone.

COMPARISONS-The Hackberry is often taken for an Elm. The warts or narrow ridges on its bark. however. and its rhambered pith readily distinguish it from the Elm if the berry-like fruit which is generally present fails to be found. The twigs are so frequently disfigured by insect galls that their presence might almost be given as a distinguishing character.

DISTRIITTION-In divers situations and solls: woods, river banks, near salt marshes. Province of Quebec to Lake of the Woods, occasional: south to the Gulf states; west to Minnesota and Missouri.

IN NEW ENGLAND-Maine-not reported: New Hampshire-sparingly along the Connecticut valley, as far as Wells river; Vermont-along Lake Champlain, not common: Norwich and Windsor on the Connecticut: Massachusetts-occasional throughout the state; Rhode Islandcommon.

IN CONNECTICLT'-Occasional to frequent, especially in river valleys and along the coast.

woon-Heavy, rather soft, not strong, coarse-grained, clear light yellow, with thick lighter colored sapwood; largely used for fencing and in the manufacture of cheap furniture. 

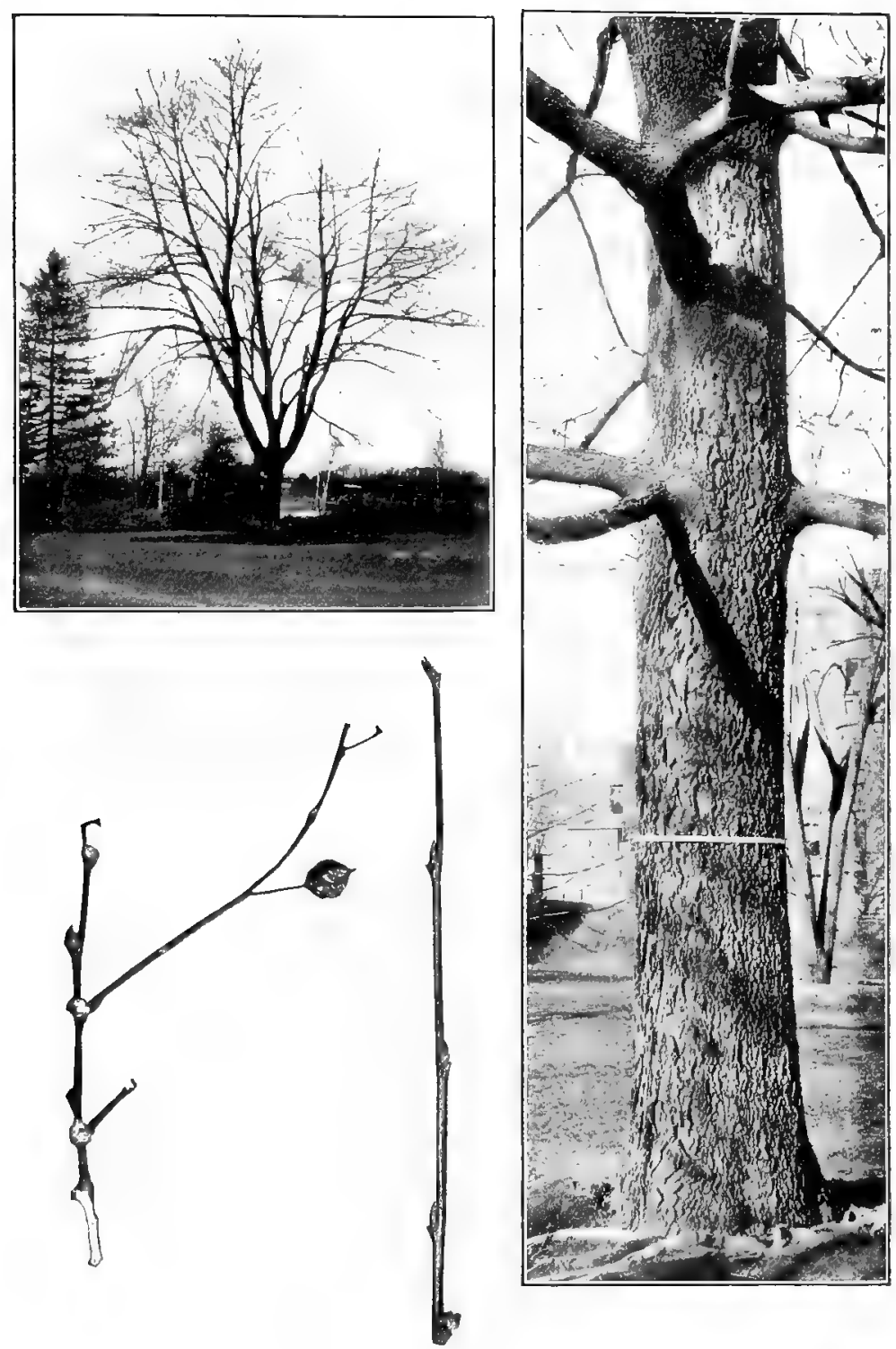

II.ICKBERRY 


\title{
RED MULBERRY
}

\author{
Morus rubra L.
}

HABIT-A small tree 15-25 ft. in helght with trunk diameter of $8-15$ inches, of larger size in the Ohio and Mississippi basins; trunk short, dividing into a number of stout spreading limbs developing a compact, broad, rounded head with numerous small branches in aspect resembling an apple tree, somewhat less scraggly than the White Mulberry. (The tree photographed had been considerably trimmed).

BARK-Dark brown, divided into irregular longitudinal plates which tend to lift at the ends and flake off, sometimes howerer not conspicuously flaky.

TWIGS-Slender though rather stouter than those of the White Mulberry; somewhat zigiag, reddish to greenish-brown, with rather sweetish taste, cut twig showing milky juice. LENTICELS-small, scattered, inconspicuous.

LFAF-SCARS-Alternate, 2-ranked, raised, nearly circular, slightly hollowed in the center. STIPLLE-SCAFS-narrow. BUNDLE-SCARSraised but generally less distinctly so than in the White Mulberry, furming a closed ring or irregularly scattered in the center.

BCDS-Terminal bud absent, lateral buds ovate, pointed. aluot $6 \mathrm{~mm}$. long, stout but longer than broad, not at all or but slightly flattened, divergent, shining, greenish to chestnut brown. BUD-SCALES-2ranked, with thin distinctly darker margins, 4-8 scales visible.

FRIIT-Fied, not to be found in winter.

COMPARISGNS-The Fed is most readily separated from the White Mulberry by its darker twigs, its larger shining. greenish to chestnut bruwn buds with dark-margined bud-scales.

DISTRIBI TION-Banks of rivers, rich woods. Canadian shore of Lake Erie; south to Florida; west to Michigan, South Dakota, and Texas.

IX NEW ENGLAND-A rare tree; Maine-doubtfully reported; New Hampshire-Pemigewasset valley. White Mountains; Vermont-northern extremity of Lake Champlain, banks of the Connecticut, Pownal. North Pownal: Massachusetts-rare; Rhode Island-no station reported.

IN CONNECTICUT-Rare or occasional; Bristol, Plainville, North Guilford, East Rock and Norwich.

WoOD-Light, soft, not strong, rather tough, coarse-grained, very durable, light orange color with thick lighter colored sapwood, used largely for fencing, in cooperage and in ship and boat building. 

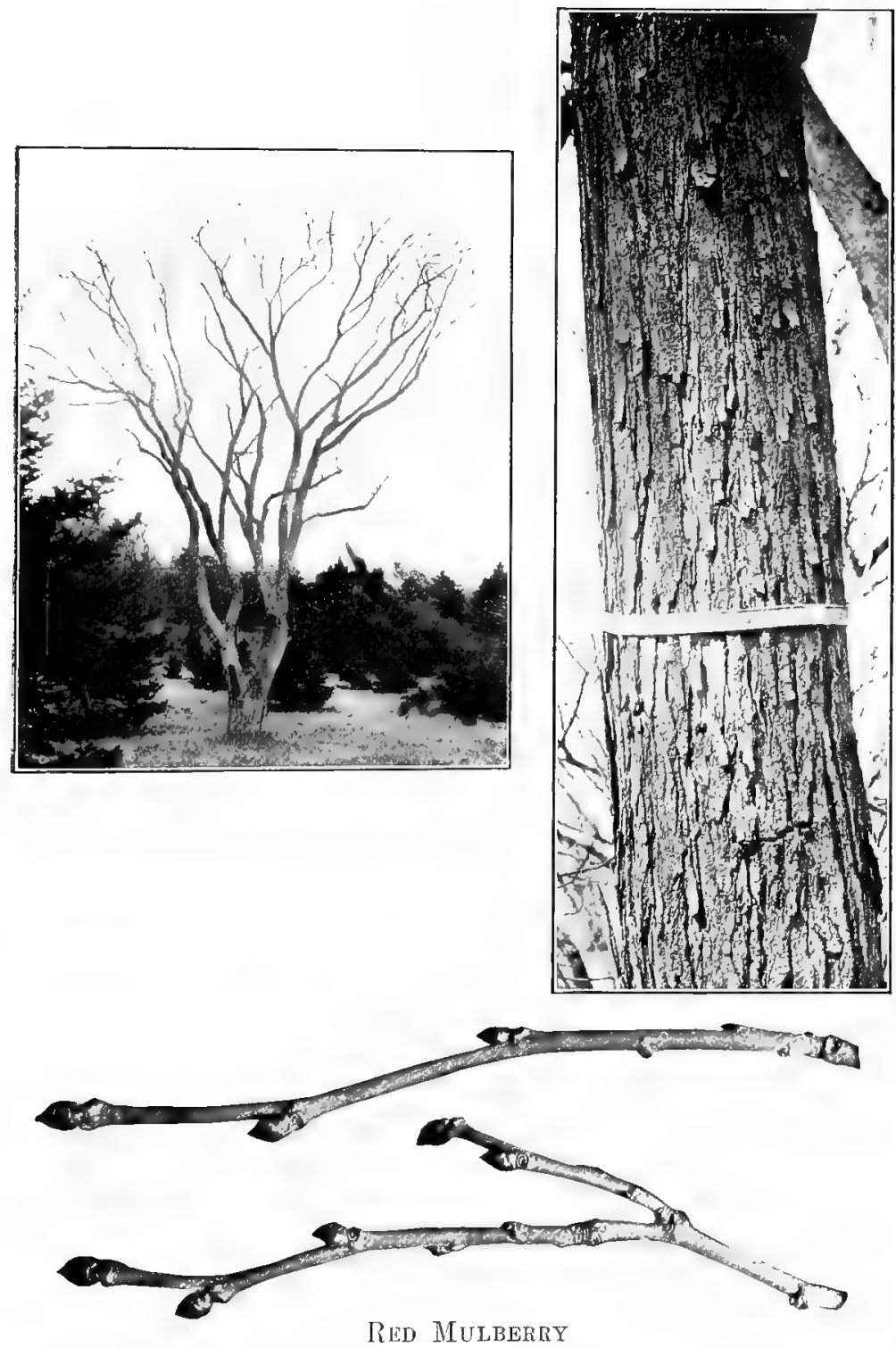


\section{WHITE MULBERRY Silkworm Mulberry. Morus alba $\mathbf{L}$.}

HIDIT-A small tree with a maximum helght of $30-40 \mathrm{ft}$. and with a trunk diameter of less than 3 ft.; branching low with wide spreading limbs forming a low rounded head resembling an apple tree somewhat in labit, but with a characteristic scraggly twigginess to the branchlets.

BIRI-Deeply furrowed into long more or less wavy light yellowish bruwn ridges.

TWIGS-Slender, yellowish-green to brownish-gray, for the most part smooth, round, more or less shining, generally zigzag, swollen at the nodes, shurt branches numerous, often arising at right angles to ranks of previous years and producing a cluaracteristic scraggly complex of branchlets. Twigs slightly siveetish if chewed; bark exuding a white milk if cut on warm das's or tufer being brought into a warm room. LENTICELS-Scattered, similar in color to the twigs and hence inconspicuous. PITH-light, rounded in cross-section.

LEAF-sCARS-Alternate, in 2 ranks, small, projecting, oval to depressed circular. STIPULF-SCARS-narrow, inconspicuous, BUNDLESCARS-conspicuous, 3-10 projecting above leaf-scar; irregularly scattered. If leaf-scar is surface-sectioned leaftraces are reducea to 3 in number.

BI DS-Terminal bud absent; lateral buds small, about $3 \mathrm{~mm}$. long. bright reddish-brown, roundish, generally about as broad as long, sharp or blunt pointed. somewhat flattened against twigs, often set oblique to the leaf-scar, 1 to 2 small collateral accessnry buds sometimes present. BUD-SCALES-in 2 ranks, about 5 scales visible, increasing in size from below upward, margins somewhat finely hairy.

FRIIT-A white, juicy, multiple fruit not to be found in winter.

COIPIRISONS- The projecting bundie-scars are characteristic of the Mulberries; for points of distinction from the Red Mulberry see under this species.

DISTRIBITION-Probably a native of China where its leaves have from time inmemorial furnished fond for silkworms, introduced into the United States and Canada from ontario to Florida and naturalized more or less throughout New England appearing by roadsides or along fences and in waste places, being spread by birds which are very fond of its fruit.

IN CONNECTICUT-Occasional; early in last century extensively planted to furnish food for silkworms and many large trees remain about farm houses.

woon-Moderately hard, close-grained, light yellowish-brown. 

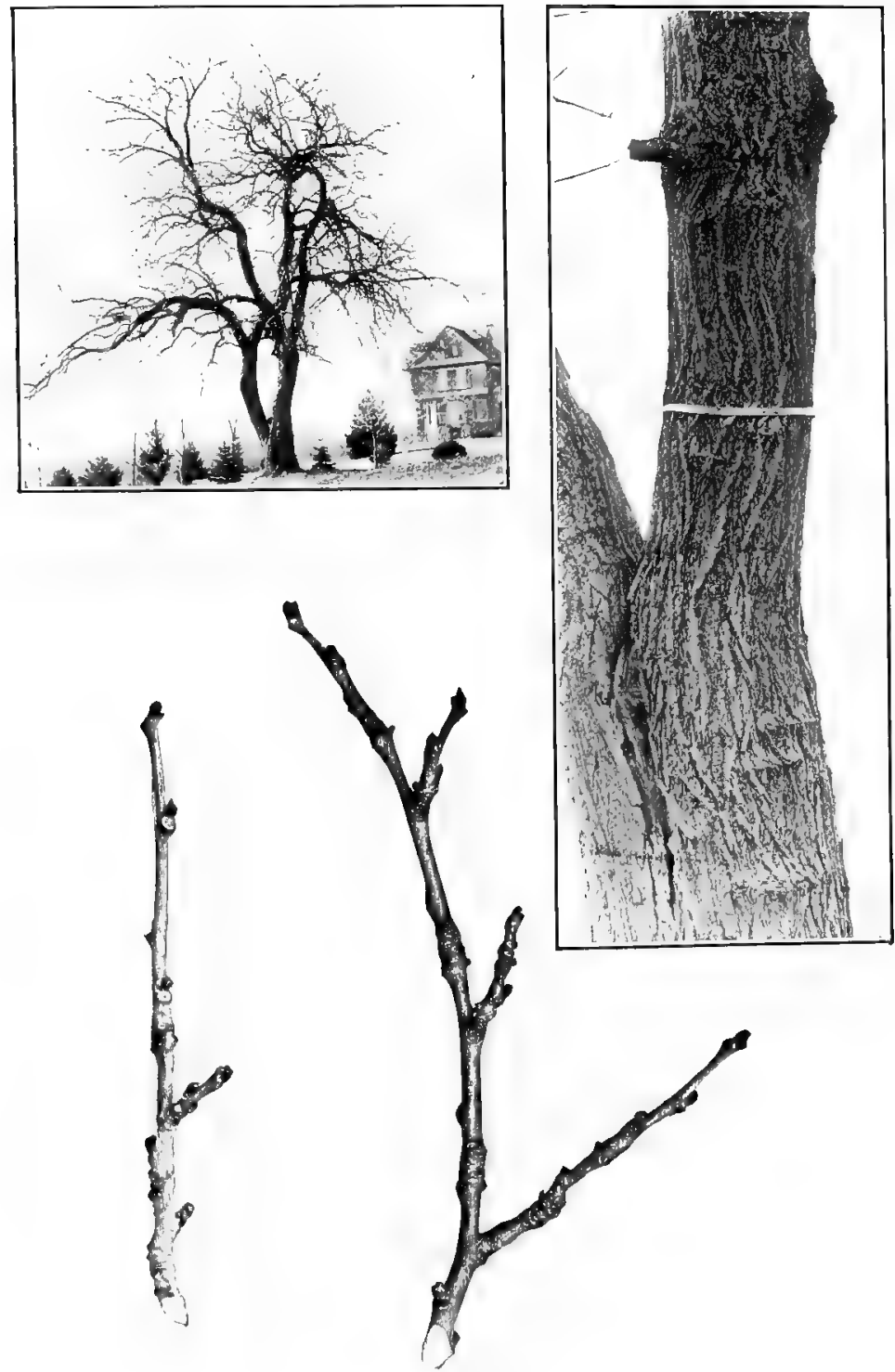

White Mulberry 


\section{CUCUMBER TREE Mountain Magnolia. Magnolia acuminata L.}

H.IBIT- ${ }^{\text {Then }}$ fully developed a tall tree up to $90 \mathrm{ft}$. in height with a trunk diameter of $3-4 \mathrm{ft}$. with comparatively slender branches widely spreading at the base, ascending above, forming a broadly conical head: when young having somewhat the aspect of a Pear Tree.

BARI-Grayish-brown ridged and flaky.

TWIGs-Slender, brown, shining, smooth or at times slightly downy, aromatic, LENTICELS-scattered, inconspicuous, orange colored. PITH -white.

LEAF-SCARS-Alternate, more than 2-ranked, crescent to U-shaped, elevated. STIPULE-SCARS-distinct, arising from upper margins of leaf-scar and encircling twig. BUNDLE-SCARS-large, few to numerous. scattered in an imperfectly double row, more or less raised.

BUDs-Thlckly covered with pale silky halrs; lateral buds blunt, nearly surrounded by leaf-scars, about $1 / 3$ the size of terminal bud: terminal bud oblong, blunt, 10-20 $\mathrm{mm}$. long. BUD-SCALES-valvate and adhering in pairs, with rudmentary leaf-scar and decurrent ridge at side of bud.

FRIIT-An ovate to oblong cone, often curved, generally under $6 \mathrm{~cm}$. long: in the young condition supposedly resembling a cucumber; seed flattish about $1 \mathrm{~cm}$. in diameter.

Comparisons-The Cucumber Tree belongs to the same genus as the Umbrella Tree but differs from it in its smaller, blunt, downy buds. its narrow leaf-scars and its scaly ridged bark; from the Large-leaved Magnolia by the smaller size of its buds, its narrow leaf-scars and its scaly ridged bark; from the Sweet Bay by its larger size, the color of its twigs and the character of its bark. The Chinese Magnolia [Magnolia conspicua Salisb.] is often cultivated and has downy buds resembling those of the Cucumber Tree. The buds, however, are stouter, the bark is smooth and the species is more shrubby than treelike.

DISTRIBCTION-Not native to New England; the hardiest of the Magnolias and extensively planted as an ornamental shade tree. It grows wild from western New York to southern Illinois and southward along the Appalachian mountains to southern Alabama.

wooD-Light, soft, not strong, close-grained and durable, light yellow-brown, with thin lighter colored often nearly white sapwood of usually 25-30 layers of annual growth; occasionally manufactured into lumber used for flooring and cabinet making. 

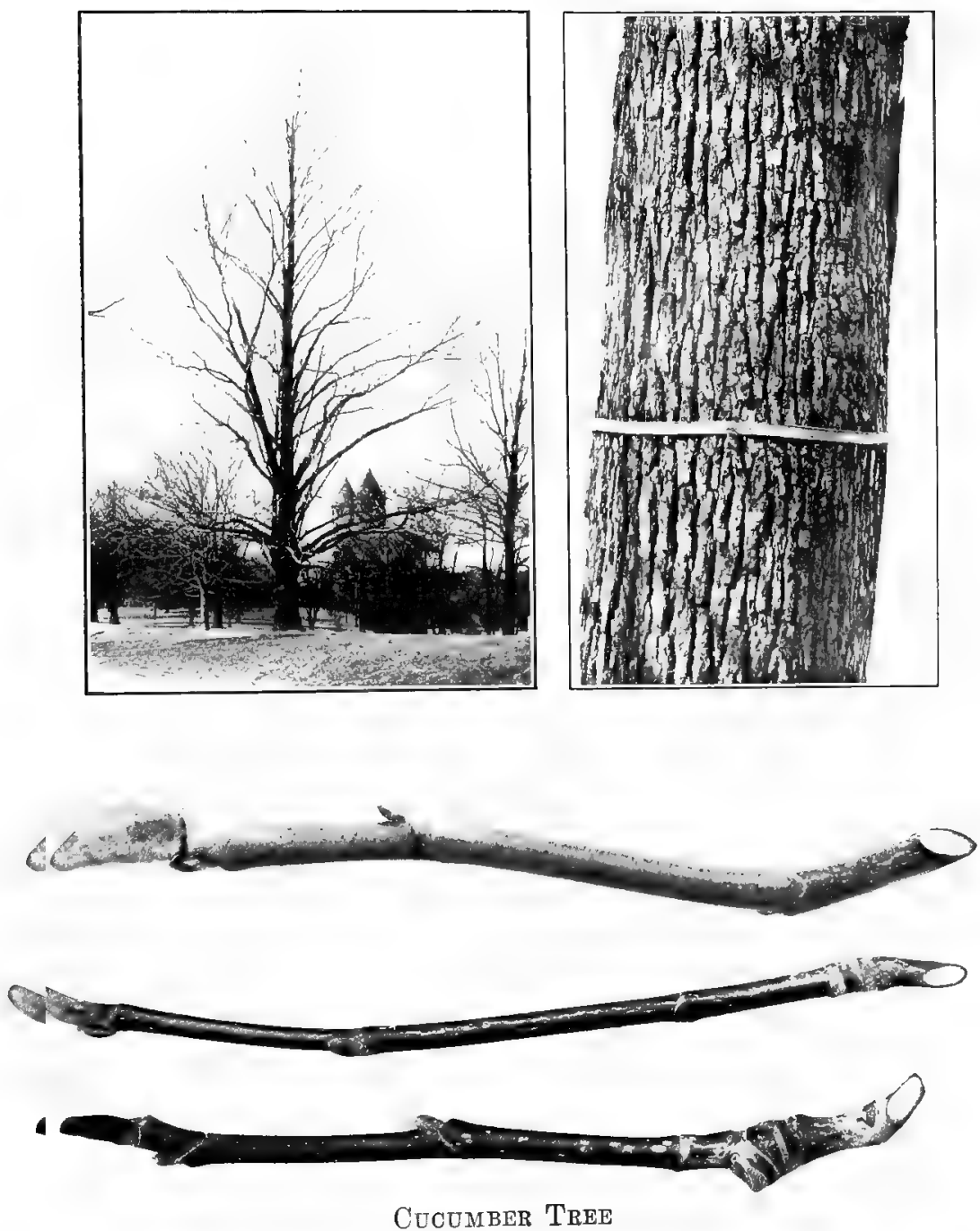


\section{UMBRELLA TREE Elkwood. \\ Magnolia tripetala L. M. Umbrella Lam.}

HADIT-A small tree with a maximum height of about $40 \mathrm{ft}$, and a trunk diameter of $1 \frac{1}{2} \mathrm{ft}$, in New England generally much smaller: trunk erect or inclined with wide-spreading branches which generally bend up at their tips forming a wide spreading irregular open head; at times with several stems springing from near the base of the trunk, forming a bushy growth around the main stem.

BIRK-Light gray, smooth, marked with small excrescences, frequently wrinkled and lumpy at the scars of branches.

Twics-Stout, reddish to greenish-brown, shining, swollen at the base of each year's growth, aromatic. LENTICELS-conspicuous, scattered pale dots. PITH-white, with minute pink dots.

LEAF-SCARS-Alternate, more than 2-ranked, large, conspicuous, oval, slightly raised, mainly clustered at swellings along the twig. STIPULE-SCARS-distinct, arising from the side of leaf-scar and encircling twig. BUNDLE-SCARS-numerous, irregularly scattered, often slightly raised.

BUDS-Lateral buds at best small, conical, divergent, frequently undeveloped or showing as mere bulges of the bark; terminal buds large up to $5 \mathrm{~cm}$. long, conical, with curved pointed apex, purple. with a bloom, with minute pale dots, smooth with patch of rusty hairs at base of leaf-ridge. BUD-SCALES-valvate and adhering in pairs corresponding to stipules, each pair enclosing in succession an erect folded downy leaf, the stalk of which is united with the next inner pair of scales; the leaf connected with the outer pair of scales falls off before maturing, leaving a rudimentary scar on the bud with a decurrent ridge corresponding to its leaf-stalk.

FRUIT-Ovate to oblong cone, 6-10 cm. long, made up of numerous collicles which split open in the fall and let out the red flattsh seeds which are about $1 \mathrm{~cm}$. In diameter.

COMPARISONS-For comparisons with the Tulip Tree see this species. The Umbrella Tree differs from the Cucumber Tree, the Large-leaved Magnolia and the Chinese Magnolia by its smooth buds and from the Sweet Bay by the size and color of its twigs and buds.

DISTRIBUTION-Not native to New England but extensively cultvated as an ornamental tree. It grows wild in the Appalachian mountain region from the valley of the Susquehanna river, Pennsylvania to southern Alabama.

woOD-Light, soft, close-grained, not strong, light brown, with creamy white sapwood of $35-40$ layers of annual growth. 

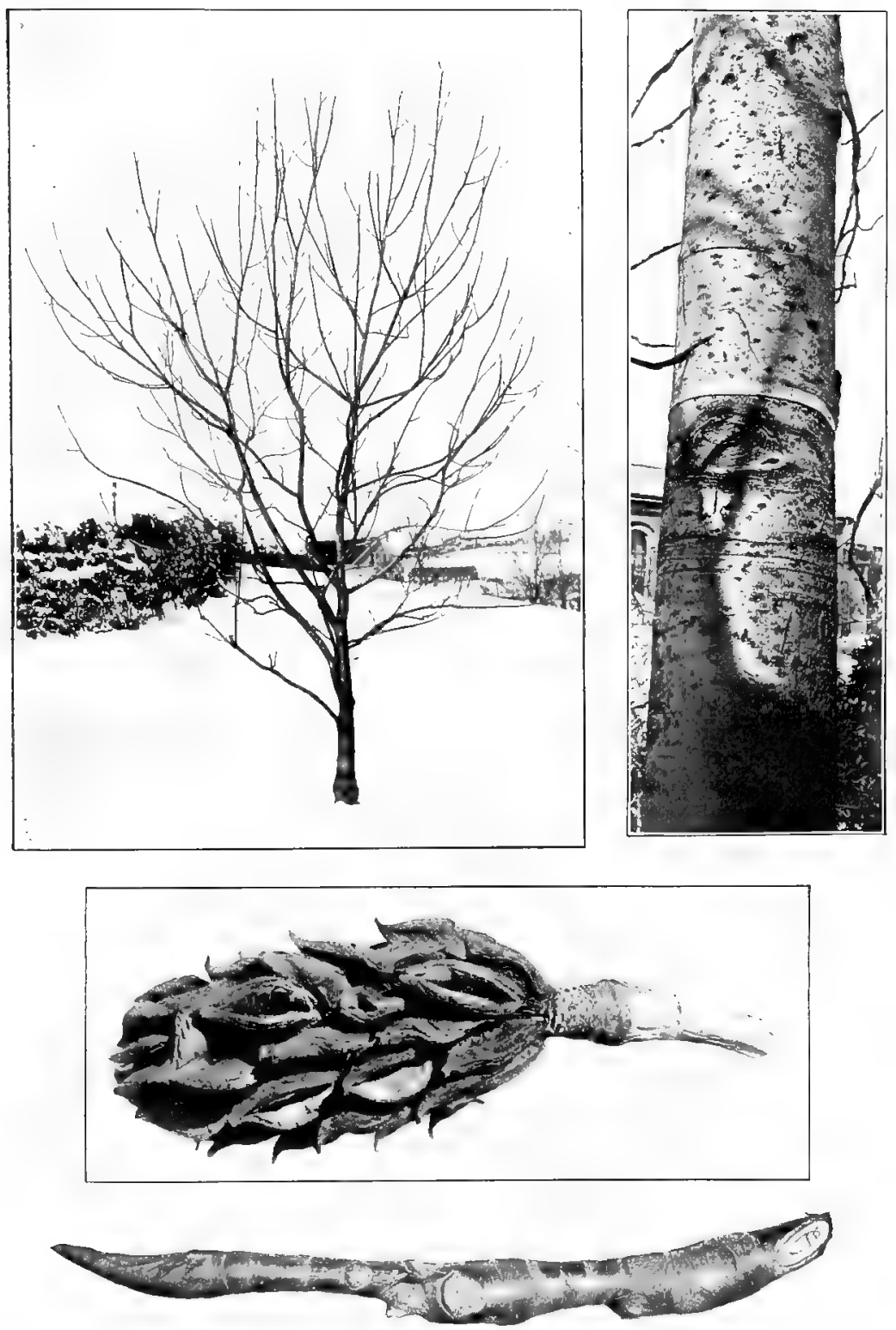

UMBRELLA 'T'REE 


\section{TULIP TREE \\ Whitewood, Yellow Poplar. \\ Liriodendron Tulipifera $L$.}

H.MIT-A good sized tree 50-70 ft. in height with a trunk diameter of 2-3 ft., in the Ohio basin reaching an exceptional height of nearly 200 ft.; trunk tall, straight, continuous into the crown and giving off comparatively short, horizontal, declined or slightly ascending branches with upcurved tips, forming in young trees a pyramidal and in older trees an oblong head. Light yellow fruiting cones or at least their axes conspicuous at ends of twigs.

BARI-Somewhat resembling bark of White Ash but ridges are longer and the furrows are shallower and more rounded and less inclined to form diamond-shaped patches; inner bark bitter; young bark ashygray and smooth, becoming dark with light colored seams.

TWIGS-Slender to somewhat stout, reddish-brown, smooth and shining with more or less evident bloom, with an agreeable aromatic smell when broken but with an intensely bitter taste, not mucilaginous: on vigorous shoots often branching the first season. LENTICELS-conspicuous pale dots. FITH-white with rather inconspicuous transverse woody partitions through the ground-mass.

LEAF-SCARS-Alternate, more than 2-ranked, large, conspicuous, elevated, circular or slightly flattened at the top. STIPULE-SCARSconspicuous, arising from top of leaf-scar, encircling twig. BUNDLESCARS-small, numerous, scattered like perforations in a sleve.

BUDS-Dark reddish-brown, covered with a bloom, white-dotted, blunt, flattish; lateral buds small, on vigorous twlgs superposed acces: sory buds sometimes present which may be stalked or develop into branches the first season; terminal buds large $5-20 \mathrm{~mm}$. long, oblong. blunt. BUD-SCALES-Spoon-shaped, smooth, valvate in pairs corresponding to stipules, each pair enclosing in succession a long-stalked, smooth, reflexed and folded leaf with its 2 scale-like stipules: leafstalk attached only at its base, hence scar of rudimentary leaf when present located at base of bud.

FRUIT-A light brown cone made up of winged seed-like portions, 20-40 mm. long which remain aggregated together into the winter but which are gradually dropped leaving the persistent terminal axis.

COMPARISONS-The Magnollas to which the Tulip Tree is botanically related have likewise aromatic twigs with eircular stipule-scars. Their leaf-scars, however, are not circular; their buds are pointed or hairy and the scar of the rudimentary leaf is considerably above base of bud. The light brown fruiting cones from which the winged seedlike bodies have partially fallen are generally to be found on the Tulip Tree and are distinctive for this species.

DISTRIBITION-Prefers a rich, loamy, moist soll. Is sometimes planted as an ornamental tree. From New England south to the Gulf states; west to Wisconsin; occasional in the eastern sections of Missouri and Arkansas.

IN NEW ENGLAND-Vermont-valley of the Hoosac River in the southwestern corner of the state; Massachusetts-frequent in the Connecticut river valley and westward; reported as far east as Douglas, southeastern corner of Worcester county; Rhode Island-frequent.

IN CONNECTICUT-Occaslonal, local or erequent.

woOD-Light, soft, brittle not strong, easily worked, llght yellow or brown. With thin creamy white sapwood; largely manufactured into lumber generally under the name of "Whitewood"; used in construction. the Interlor finish of houses, boat bullding and for shingles, brooms and woodenware. The intensely acrid bitter inner bark, especlally of the root, is used domestically as a tonic and stimulant and hydrochlorate of tulipterine, an alkaloid, separated from the bark, possesseg the property of stimulating the heart. 

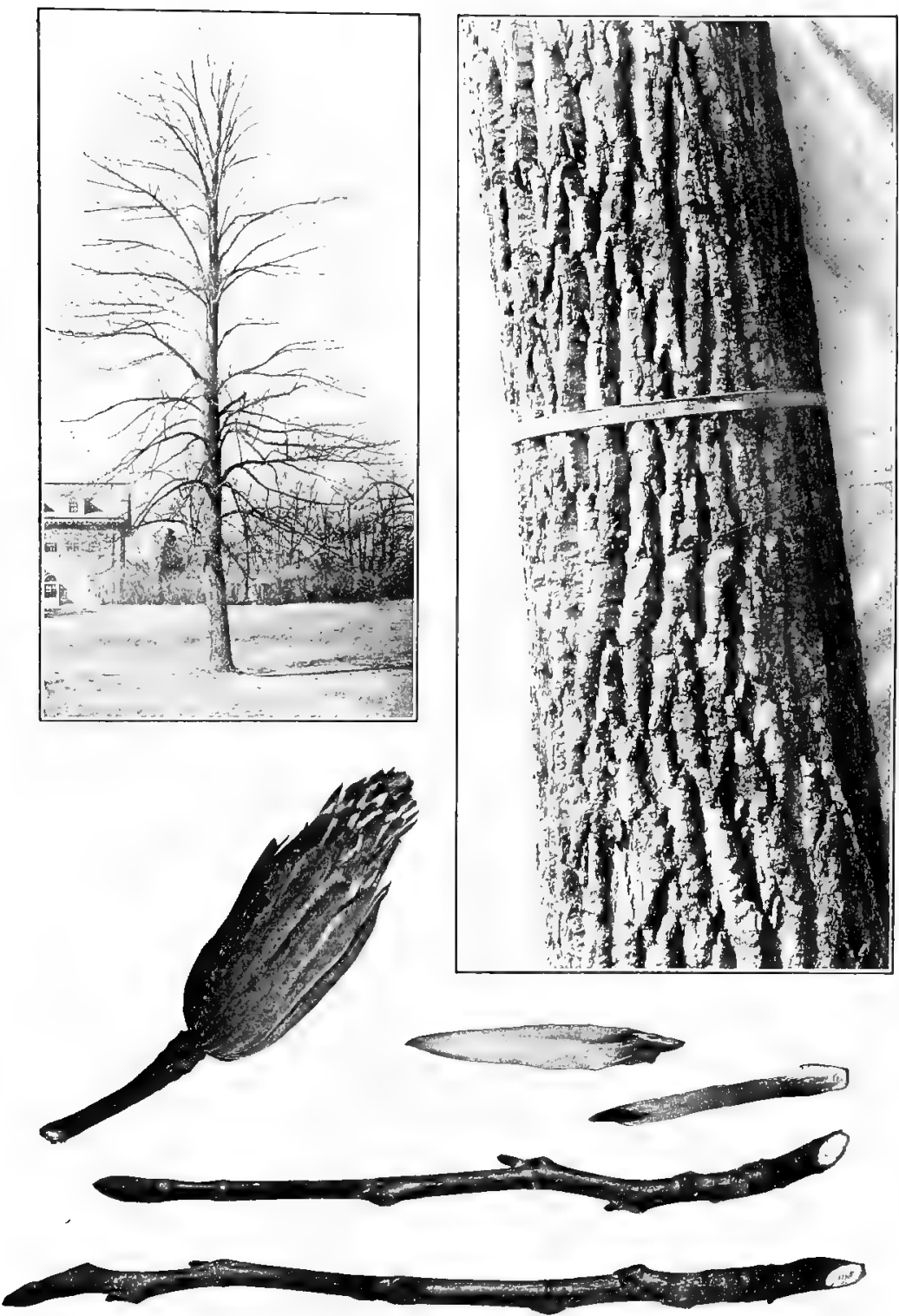

Tulip Tree 


\title{
SASSAFRAS
}

\author{
Sassafras variifolium (Salisb.) Kuntze.
}

S. officinale Nees \& Eberm. ; S. Sassafras Karst.

H.DIT-A small tree at times reaching 40-50 ft. in helght, with a trunk diameter of 2-4 ft.; at the north smaller and often shrubby: in the southern states reaching a height of $100 \mathrm{ft}$; branches numerous, stout, more or less contorted, often distinctly in yearly whorls, horizontal or forming a broad angle with the trunk. subdiriding to produce a bushy spray and forming a flat-topped or slightly rounded oblong head. Limbs brittle and frequently lost through ice storms or other injuries, giting the tree a battered appearance as shown in photograph. The tree sprouts abundantly from the roots often surrounding itself with a thicket of saplings (see those at right in picture).

B IRK-Fieddish-brown, deeply furrowed even in comparatively young trees into broad flat ridges with narrow horizontal cracks running part way around the trunk and dividing the ridges into short blocks.

TWIGS-Slender to stout, bright yellowish-green. often redish where exposed to light, smooth and shining or somewhat downy: internodes very unequal; rapidly grown shoots freely branching the first season, the branches exceeding the main axis; twigs spicy-aromatic to both smell and taste, mucilaginous if chewed. LENTICLLS-scattered, very inconspicuous.

IFIF-SCIRS-Alternate, more than 2-ranked. small, raised. semi. elliptical, with elevated margins. STIPULE-SCARS-absent. BUNDLESCAFS-single, forming horizontal line.

HIJS-Green, more or less tinged with red toward tip: lateral buds small, divergent: terminal buds large, $5-10 \mathrm{~mm}$. long. orate, pointed; flower buds terminal. BUD-SCALES- with thickened reins; generally 3 , narrower, thiclier, shorter scales surrounding terminal bud.

COMIM RISONS-Its bright green aromatic mucilaginous twigs which form branches the first season surpassing the main axis. its single bundle-scar and the transierse cracking of the ridges of the bark render the Sassafras one of the most interesting nf our native trees in winter. It is scarcely to be confused with any other form.

DISTIRIALTION-In various snils and situations: sandy or rich woods, along the borders of peaty swamps, thickets and fence-rows. Provinces of Quebec and Ontario; south to Florida; west to Mlchigan, Iowa, Kansas, and Texas.

IN NEW FNGLAND-Maine-this tree grows not beyond Black Point (Scarboro, Cumberland county) eastward; (Josselyn's New England Rarities, 1672); not reported again by botanists for more than two hundred years; rediscovered at Wolls in 1595 and North Berwick in 1896: New Hampshire-lower Merrimac valley, eastward to the coast and along the Connecticut valley tri Bellows Falls; Vermnnt-occasinnal south of the center; Pownal: Hartland and Brattleboro: Vernon: Massachusetts-common especially in the eastern sections; Rhode Islandcurismon.

\section{IN CONNECTICUT-Frequent.}

woon-Soft, weak, brittle, coarse-grained, very durable in the soll, aromatic, dull orange-brown. With thin light yellow sapwood of $7-8$ layers of annual growth: largely used for fence-posts and rails and in the construction of light boats, ox-yokes, and in conperage. The roots and especially their bark are a mild aromatic stimulant and oll of sassafras used to perfume soaps, flavor candy, etc. and as an ingredient in liniment is distilled from them. 


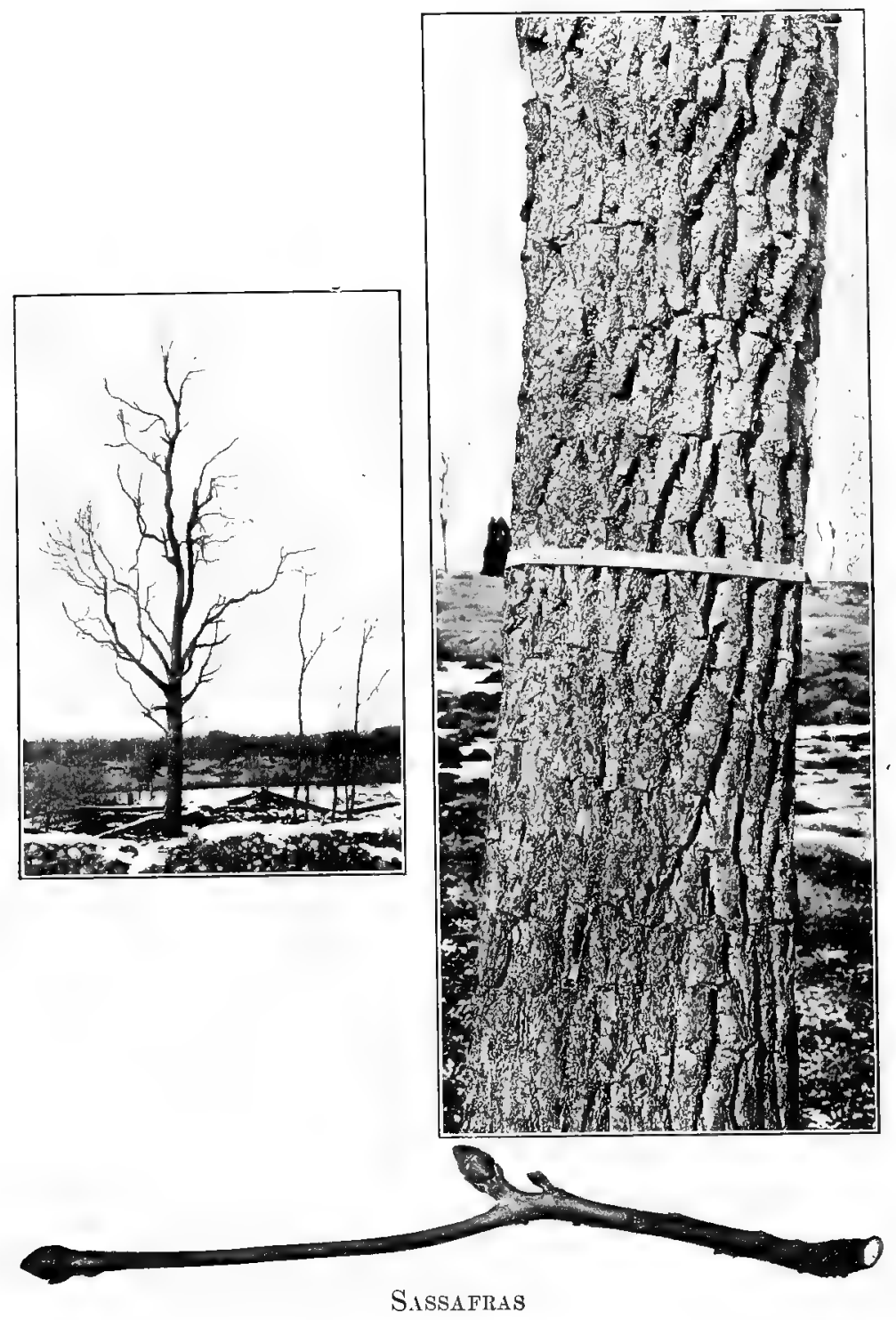




\section{WITCH HAZEL \\ Hamamelis virginiana $\mathrm{L}$.}

HABIT-A large shrub or small tree occasionally 25-30 ft. in height with a trunk diameter of 10-14 inches, with short trunk, spreading crooked branches with conspicuous persistent fruiting capsules, formlng a broad open head.

BARK-Light brown, more or less mottled, generally smooth or minutely scaly.

TWIGS-Rather slender, light orange brown, smooth and shining, or downy especially toward apex, more or less zigzag. LENTICELS-few, scattered, whitish dots.

LEAF-SCARS-Alternate, 2-ranked, small, inversely triangular. STIPULE-SCARS-distinct, narrow, oblong, somewhat separate from leaf-gcar. BUNDLE-SCAFs-whitish in conspicuous contrast to dark brown surface of leaf-scar, generally 3 and separate or these may be compounded or more or less confluent.

BUDS-Stalked, flattish, slightly curved, densely downy with short fine light to dark olive brown hairs; terminal bud larger than laterals, 5-12 mm. long. BUD-SCALES-an outer pair of relatively tbin scales corresponding to stipules and often represented by only a scar accompanying the outermost thick downy laterally folded undeveloped leaf, whlch with smaller leaves within serves the function of bud-scales. The bud is therefore essentially naked.

FRUIT-Produced in abundance, a downy 2-chambered capsule about $15 \mathrm{~mm}$. long, surrounded by the persistent calyx, discharging in autumn 4 shining, brown, oblong seeds and remaining widely gaping on the tree throughout winter (see lower part of twig picture). The plant produces flowers in the autumn at the same time with the ripening of the fruit, and the remains of the flowers, showing the 4 downy sepals with their enclosing bracts, are to be found in clusters on the recent twigs (upper part of twig picture).

COMPARISONS-In habitat and in 1 ts stalked buds the Witch Hazel resembles the Alders. The buds of the latter however are essentially smooth or at most fine-downy, not hairy and their fruit is a woody cone not a capsule.

DISTRXB'TION-In moist or wet often rocky places. Nova Scotia to Ontario and Minnesota; south to Florida and Texas; west to eastern Nebraska.

IN NEW ENGLAND-Common throughout.

wooD-IHeavy, hard, very close-grained, light brown tinged with red, with thick nearly white sapwood of 30-40 layers of annual growth. The bark is slightly astringent and though not known to have essential propertles is largely used in the form of fluid extracts and decoctions a a popular application for sprains and bruises, Pond's Extract being made by distilling the bark in dilute alcohol. Probably equally efficaclous is the use of the twigs as divining rods to locate water and minerals. 

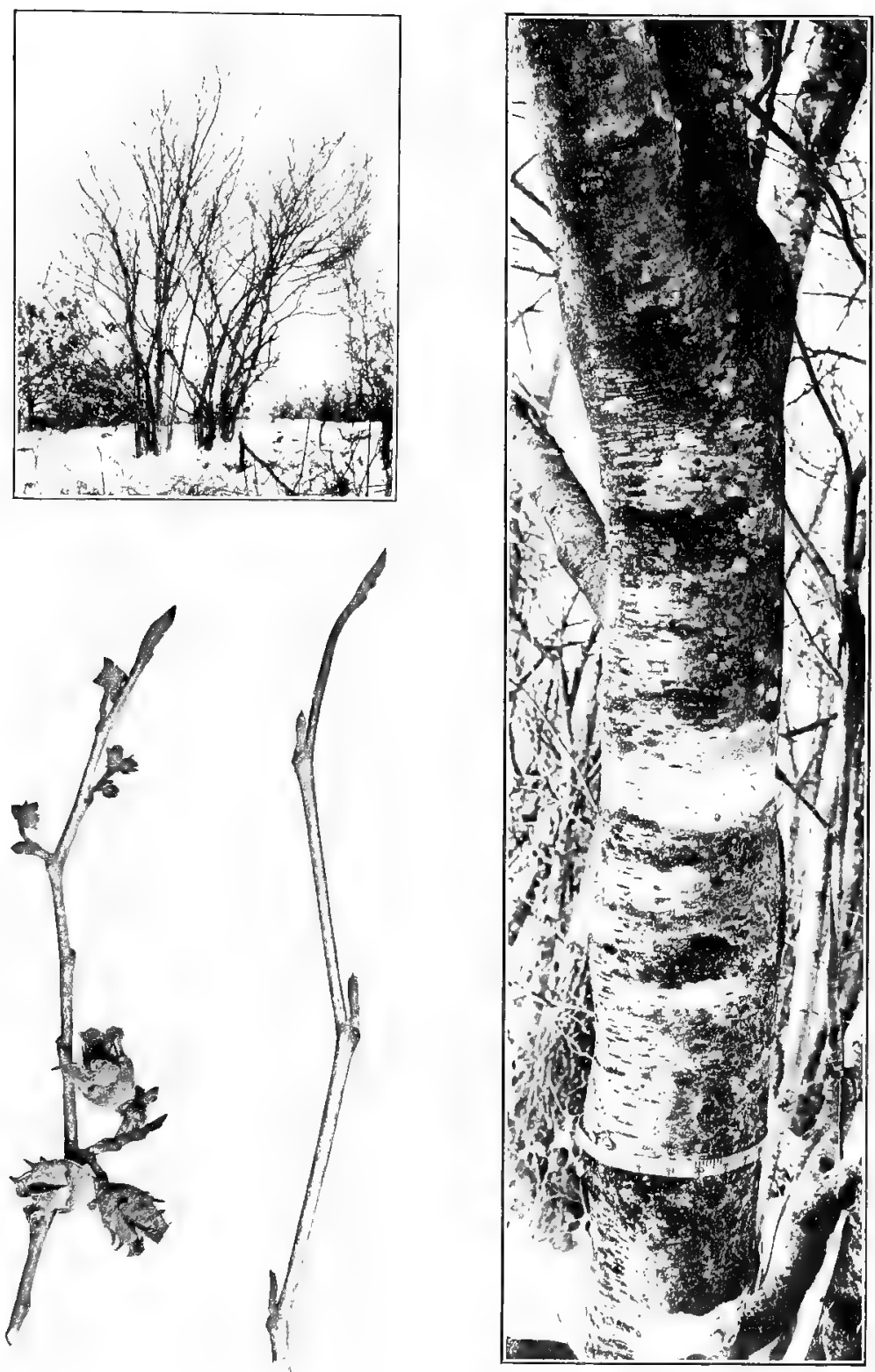

WITCH HAZEL 


\section{SWEET GUM \\ Bilsted, Ret Gurm, Alligator-wood, Liquidambat.}

Liquidambar Styraciflua L.

H.BIT-A tree 40-60 ft. in height with a trunk diameter up to $2 \mathrm{ft}$, reaching $150 \mathrm{ft}$. in height and a trunk diameter of $3-5 \mathrm{ft}$ in the Missis. sippi and Ohio valleys; branches slender, regular and spreading, forming a very symmetrical tree, when young (right hand tree in plate) narrowly oblong-conical. With age (left hand tree in plate) becoming broader and rounded ovate, generally showing persistent stalked spherical fruits.

BARK-Grayish brown, deeply furrowed into broad more or less flaky ridges.

TU IGS-Mediumly stout to slender, light to dark reddish to yellowishbrown, rounded or often somewhat angled, smooth and shiny or seldom slightly hairy; generally developing the second season 3-4 parallel corky ridges on the upper side of horizontal branchlets and on all sides of vertical branchlets (lower twig figure). LENTICELS-scattered, dark. PITH--wide, 5-pointed, star-shaped.

LFAF-SCIRS-Alternate, more than 2-ranked, broadly crescent-shaped to intersely triangular, raised. STIPULE-SCARS-absent. BUNDLESCARS-3, each a circular white ring with dark center conspicuous against the dark surface of leaf-scar.

BIDs-Orate to conical, pointed, shiny, reddish-brown, more or less fragrant when crushed, lateral buds divergent, on rapidly grown shoots sometimes stalked or developing into branches the first season and then frequently with a pair of collateral accessory buds at a node; terminal bud exceeding the laterals, $5-10 \mathrm{~mm}$. long. BUD-SCALESovate, fine-downy on the margins, rounded on the back, generally with a short abrupt point at the apex.

FRTIT-A long stalked spherical spiny aggregate of ovaries, $2-4 \mathrm{~cm}$ in diameter, hanging on the tree through the winter; the mature seeds falling in autumn leaving many minute abortive seeds in the ovaries.

COMPARISONS-The corky ridges on the twigs of the Sweet Gum are striking distinctive characters which are found also in the Cork Elm and the Bur Oak. The Elm, however, has 2-ranked leaf-sears and the buds of the Oak are bunched at the twig ends; neither are shiny reddish-brown between the ridges. The corky ridges may be but sparingly developed upon some trees and may even fail entirely. The spiny fruits which persist through winter form the best single dis: tinctive character.

DISTRIAITION-Low, wet soils, swamps, moist woods, somewhat cultivated as an ornamental tree. Connecticut; south to Florida; west to Missouri and Texas.

IN NEW ENGLAND-Growing native only in Connecticut.

IN CONNFCTICUT-South Norwalk and occasional or frequent westward near the shores of the Sound.

wooD-Heavy, hard, straight, close-grained, not strong, bright brown tinged with red, with rhin almost white sapwood of 60-70 layers of annual growth, inclined to warp and shrink badly; used for the outside finish of houses, in cabinet making, for street pavement, wooden dlshes and fruit boxes. The resinous exudation from the stems (liquidambar) which is more marked in trees grown in the south, is used in the preparation of chewing gum. 


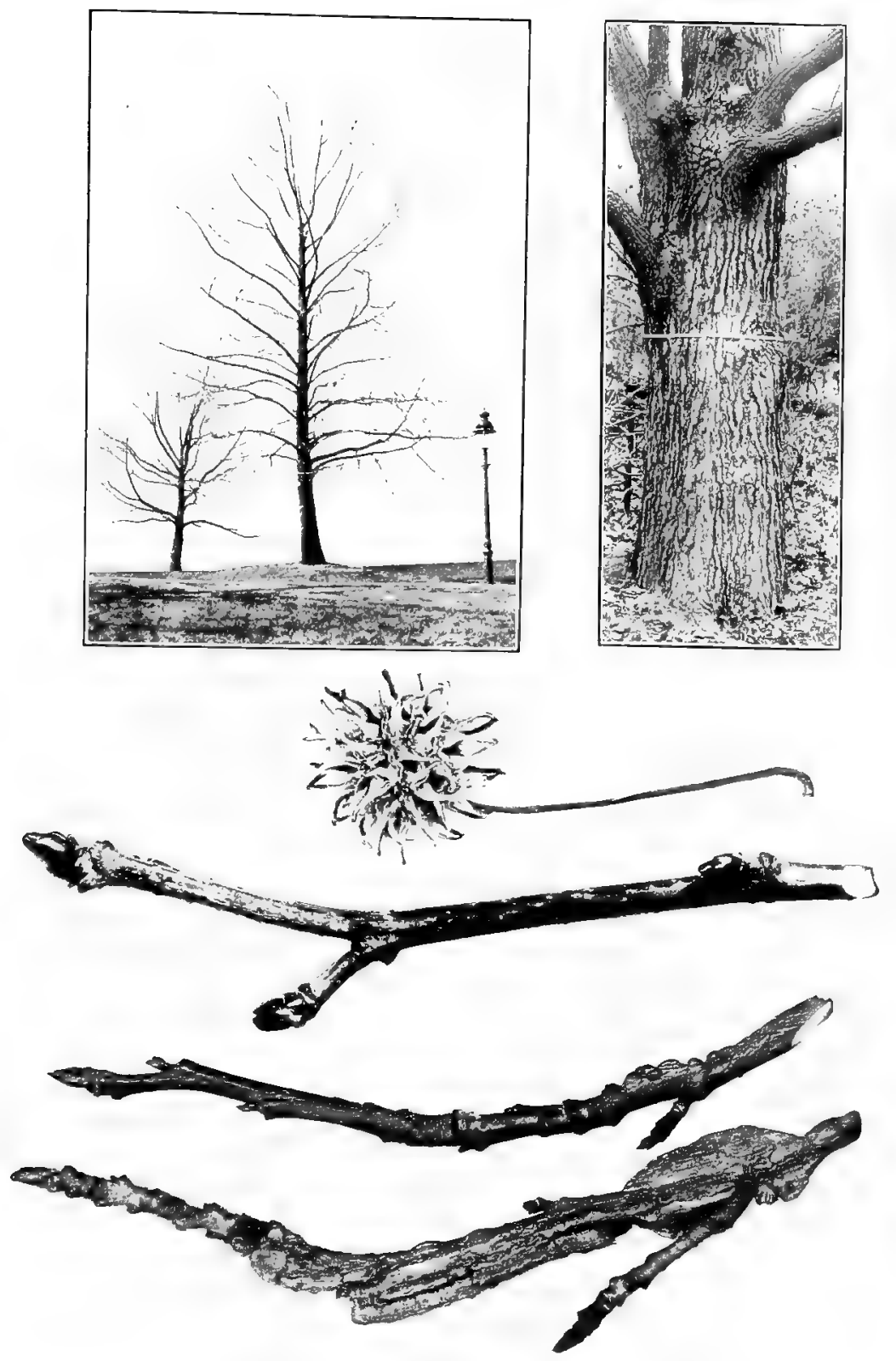

Sweet Gum 


\section{SYCAMORE \\ Buttonwood, Buttonball, Plane Tree. \\ Platanus occidentalis $\mathbf{L}$.}

HABIT-A large tree $50-100 \mathrm{ft}$. in height with a trunk diameter of 3-S ft., in the bottom lands of the lower onio and Mississippi valleys reaching occasionally a height of $170 \mathrm{ft}$. with a trunk diameter of 10-11 ft., the largest tree of the New England forest; with an erect or often declined trunk very gradually tapering and continuous into the top (see habit picture) or hranched near the base into two or three secondary trunks (see bark picture) forming an open, irregular or rounded wide-spreading head; branchlets scraggly, often in tufts with dead twigs not infrequent. (See low cross-branch in bark picture).

BARK-Dark brown, at the base of older trunks shallowly furrowed into broad ridges which are broken into small oblong thick plate-like scales; higher up on the trunk peeling off in large thin plates, exposing conspicuous areas of the whitish, yellowish or greenish inner bark.

TwIGS-Slender, rather shiny, smooth, yellowish-brown, generally zigzag, swollen at the nodes, rounded or with decurrent ridges from the bundle-scars; medulary rays conspicuous in sectioned twig. LENTICELS-pale, minute. PITH-thick.

LEAF-sCARS-Alternate, generally 2-ranked, sometimes appearing more ranked; narrow, projecting, nearly surrounding the bud, more or less swollen at the bundle-scars. STIPULE-SCARS-encircling twig. BUNDLE-SCARS-conspicuous, dark, generally raised, 5-10 or more in single curved line.

BUDS-Terminal bud absent; lateral buds large, contcal, 5-10 mm. long, blunt-pointed, smooth, shiny, dark reddish-brown, divergent. BUD-SCALES-a single scale visible, forming a cap to the bud, second scale green, gummy, innermost scale covered with long rusty halrs.

FRIIT-Spherical heads $2.5 .4 \mathrm{~cm}$. in diameter, on long stalks mostly solitary or seldom in 2's composed of small hairy 1-seeded nutlets. The heads hang on the tree till spring.

COMPARISONS-The native Sycamore [Platanus occidentalis] is closely related to the Oriental sycamore [Platanus orientalis $\mathrm{L}$.] which is extensively planted as an ornamental tree. It bears its fruiting heads singly or rarely in 2 's, while the Orlental Sycamore has its frulting heads in clusters of $2-4$. The whitewashed appearance of the upper limbs, the single cap-like scale of its bud, which is nearly surrounded by the leaf-scar, present characters which prevent the Sycamores from being confused with any other trees.

DISTRIBLTION-Near streams, river bottoms, and low, damp woods: sometimes in dryer places. Ontario; south to Florida; west to Minnesota, Nebraska, Kansas and Texas.

IN NEW ENGLAND-Maine-apparently restricted to York county: New Hampshire-Merrimac valley towards the coast; along the Connectlcut as Iar as Walpole: Vermont-scattering along the river shores, quite abundant along the Hoosac in Pownal; Massachusetts-occasional; Rhode Island-rather common.

IN CONNECTICUT-Frequent.

woOD-Reddish-brown with light somewhat yellowish sapwood, heavy, tough, hard, not very strong, coarse-grained, diffcult to split and work; is used in manufacture of tobacco boxes, crates, butchers'blocks. ox-yokes and when cut quartering is used for inside finishing of bulldings and for furniture. 

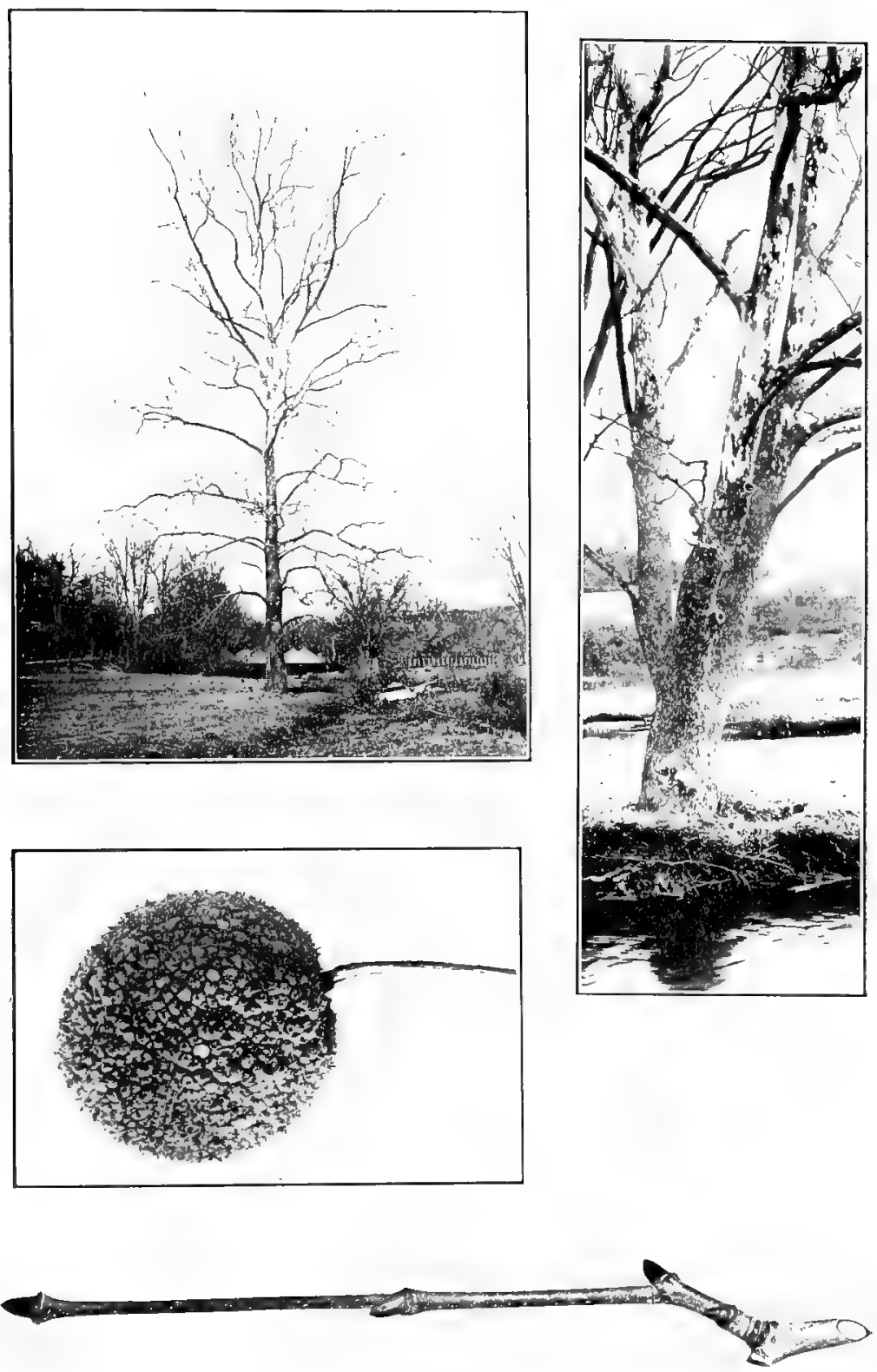

Sycamore 


\section{PEAR}

Pyrus communis L.

HABIT-A tree sometimes $75 \mathrm{ft}$. in height with a trunk diameter of $2 \mathrm{ft}$. or more; trunk erect, more or less continuous into the head, with ascending branches and numerous stubby branchlets forming an upright pyramidal head.

B.IRli-Grayish-brown, on young trunks and branches smooth becomIng with age longitudinally fissured into flat-topped ridges which are further broken by transverse fissures into oblong scales.

Twrcs-Stout, smooth or but slightly downy, yellowish-green or sometimes with tinge of brown. without characteristic taste; short sharp-pointed branches not infrequently present; stubby, branched slow-growing fruit spurs abundant, with prominent fruit scars. LENTICELS-scattered, pale, more or less conspicuous.

I.FAF-SCIRS-Alternate, more than 2-ranked, narrow, crescentshaped, raised. STIPULE-SCARS-absent, BUNDLE-SCARS-3, often indistinet.

IBCDS-Conical, sharp-pointed, smooth or but slightly hairy; terminal bud about $s \mathrm{~mm}$. or less in length, lateral buds smaller, generally divergent and not flattened or at times on vigorous shoots both flattened and appressed. BUD-SCALES-ovate, generally with conspicuous grayish slin on surface, generally 4 or more visible scales to lateral buds, more to terminal bud.

Fritr-A large fleshy pome.

Compinisons-The Pear Tree may be distinguished from the Apple by its erect habit of growth. The twig characters vary somewhat among the different varieties but in general the twigs of the Pear differ from those of the Apple in being smooth, generally of a yellow. ish-green color. devoid of a licorice-like taste and in having polnted, mostly divergent buds the scales of which are more or less covered with a grayish skin.

DISTRJBLTJON-A native of the Old World cultivated in this country for its fruit and escaped from cultivation in waste places.

WOON-Fard, close-grained, reddish-brown; used for drawing instruments, for tools, in imitation of ebony and by the wood engraver. 


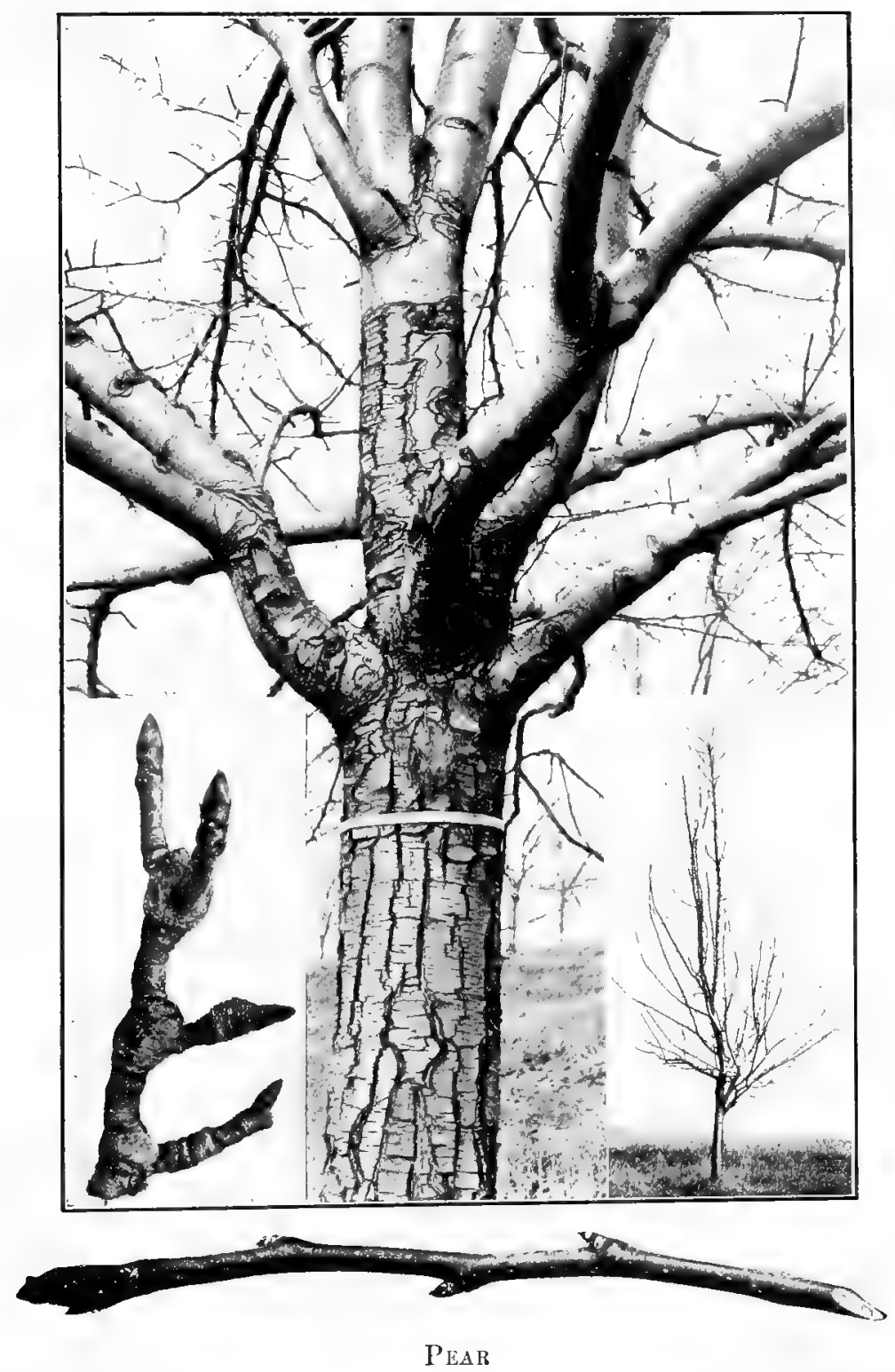




\section{APPLE \\ Pyrus Malus L. \\ Malus Dalus (L.) Brition.}

HABIT-A tree reaching $30-50 \mathrm{ft}$. in height and a trunk diameter of 2-3 ft.; trunk short with wide spreading limbs forming a broad roundtopped head of familiar and very characteristic habit.

BARK-Grayish-brown, scaling off in thin, brittle, flaky plates.

TWIGS-Stout, pale-woolly, at least toward the apex, mostly reddishbrown, rarely yellowish, shining where free from wool, with characteristically slightly bitter and licoricelike taste when chewed; short, stubby, contorted fruit-spurs abundantly present. LENTICELS-Scattered, pale, more or less conspicuous. PITH-white.

LEAF-SCARs-Alternate, more than 2-ranked, narrow, crescentshaped, raised. STIPULE-SCARS-absent. BUNDLE-SCARS-3, often indistinct.

BtDS-Ovate, blunt, bright reddish-brown, more or less densely covered with pale wool; terminal bud $8 \mathrm{~mm}$. or less*long, lateral buds smaller, often triangular, flattened and appressed against twig. BUDSCALES-ovate, abuut 3 scales visible to lateral bud, more to terminal bud.

FRI IT-A large fleshy pome.

Compinisoxs-The Apple Tree resembles the Pear but is readily distinguished from this species by its low spreading habit of growth. The numerous rarieties differ somewhat in the twig characters, some with twigs and buds nearly smooth, others with yellowish rather than reddish-brown twigs. The licorice-like taste of the twigs seems to be a constant character for the Apple. Among its distinguishing characters which in the main hold good, may be mentioned the pale wool on the twigs and buds, the flat appressed lateral buds and the reddish-brown color of the twigs.

DISTRIBCTION-A native of the Old World, cultivated in this country for its fruit and frequently escaped from cultivation in waste places when it assumes a bushier habit of growth with smaller twigs frequently beset with short sharp-pointed thorn-like branches.

WooD-Hard, tough, close-grained, reddish-brown, used for tool handies, shoe makers' lasts, by the cabinet maker and esteemed as a fuel in open grate fires. 

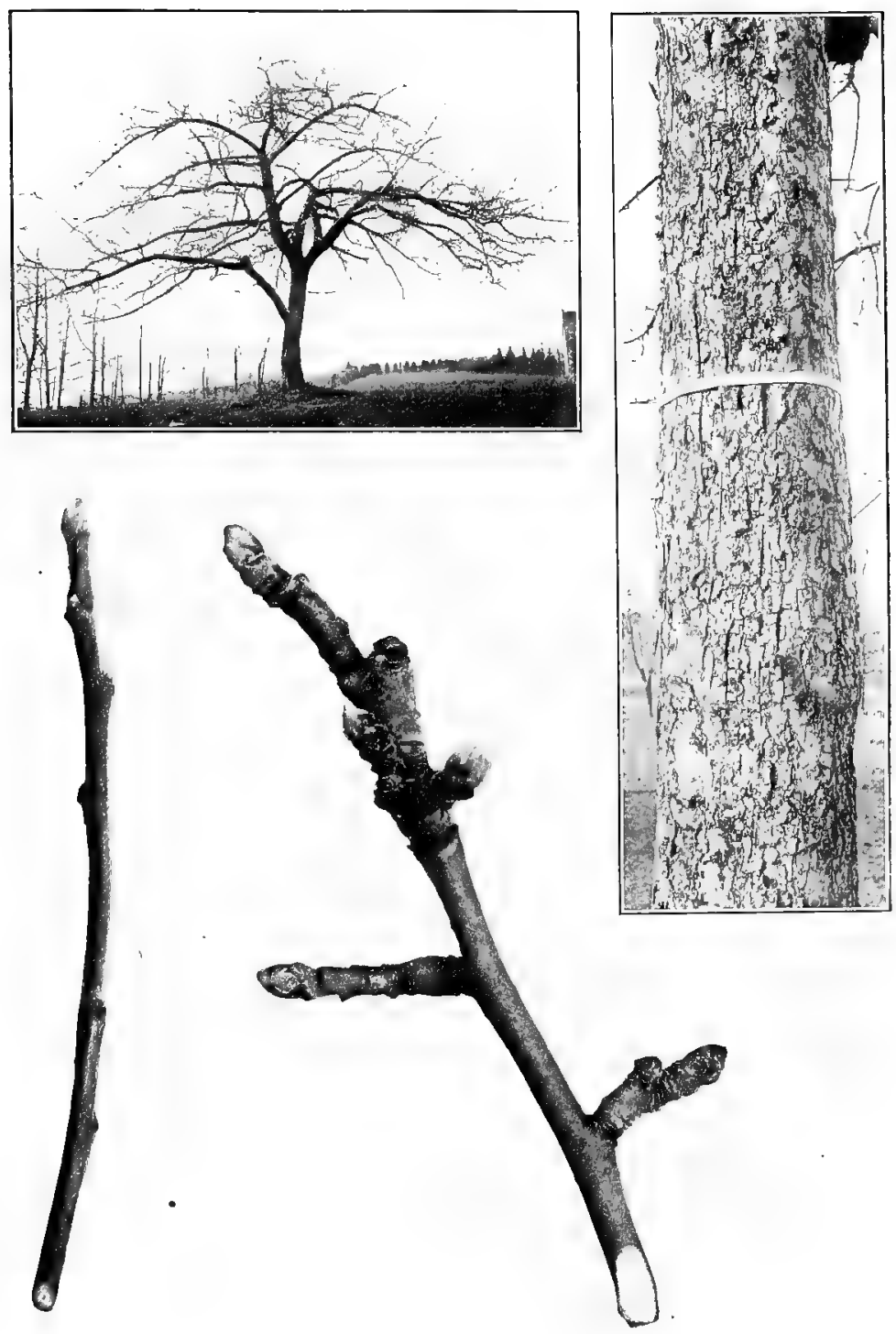

APPLE 


\section{AMERICAN MOUNTAIN ASH Rowan or Service Tree. \\ Pyrus americana (Marsh.) DC. Sorbus americana Marsh.}

HADIT-A shrub or small tree 15-20 ft. high or in northern New England reaching a height of 25-30 ft. with a trunk diameter of 12-15 inches; with slender spreading branches forming a rather narrow round-topped head.

BARK-Grayish-brown, smooth or on older trees somewhat roughish.

TwIGs-Stout, smooth, reddish to grayish-brown. LENTICELS-conspicuous, large, pale, oblong, remotely scattered. PITH-broad, slightly reddish-brown.

LEAF-SCARS-Alternate, more than 2-ranked, large, crescent to broadly $U$ or $V^{T}$-shaped, raised on a projection darker than the $t w i g$. STIPULE-SCARS-absent. BUNDLE-SCARS-regularly 5, often raised, arranged in a single curved line.

BUDS-Terminal buds large, about $13 \mathrm{~mm}$. long, ovate to broadly conical with a curved pointed apex, dark purplish-red, gummy and smooth or whth few hairs on the surface, denselv woolly within; lateral buds smaller, flattened and appressed. BUD-SCALES-2-3 visible to terminal bud; 1 - to lateral bud.

Frit-Berry-like, bright red, strongly acid, round, about the slze of a pea, in flat-topped clusters persistent through the winter.

COMPIIIsOXs-A larger fruited form, the Western Mountain Ash [Pyrus sitchensis (Roem.) Piper], is considered by some a distinct species but by others only a variety of the type described. It is more northerly and westerly in its distribution. The European Mountain Ash [Pyrus Aucuparia (L.) Ehrh.] with many horticultural forms is more frequently cultivated than the American species and has escaped from cultivation in some places. It may be distinguished by the white hairy down present especially on the upper half of the terminal bud and by the larger fruits (about $10 \mathrm{~mm}$. broad) arranged in a rather round-topped cluster. The habit, bark, fruit and lower twig photographs are of the European species.

DISTIIITIOV-River banks, cool woods, swamps, and mountains. Newfoundiand to Manitoba; south, in cold swamps and along the mountains to North Carolina; west to Michigan and Minnesota.

IN NEW ENGLAND-Maine-common; New Hampshire-common along the watersheds of the Connecticut and Merrimac rivers and on the slopes of the White Mountains; Vermont-abundant far up the slopes of the Green mountains; Massachusetts-Graylock, Wachusett, Watatic. and other mountainous reglons; rare eastward; Rhode Islandoccasional in the northern sections.

IN CONNECTICUT-Rare or local. Swamps and about ponds or sometimes on dry ledges or in rocky woods; Stafford, Durham and Meriden, Granby, Winchester, Norfolk, Canaan, Salisbury, Kent.

The variety (Pyrus sitchensis) the Western Mountain Ash, has the following distribution-Mountain slopes, cool woods, along the shores of rivers and ponds, often associated with Pyrus americana, but climbing higher up the mountains. From Labrador and Nova Scotia west to the Rocky mountains, then northward along the mountain ranges to Alaska. In New England, confined to Maine, New Hampshire and Vermont.

woob-Close-grained, light, soft and weak, pale brown with lighter colored sapwood of $15-20$ layers of annual growth; of little economic value. The very astringent bark and berrles are employed medicinally. 

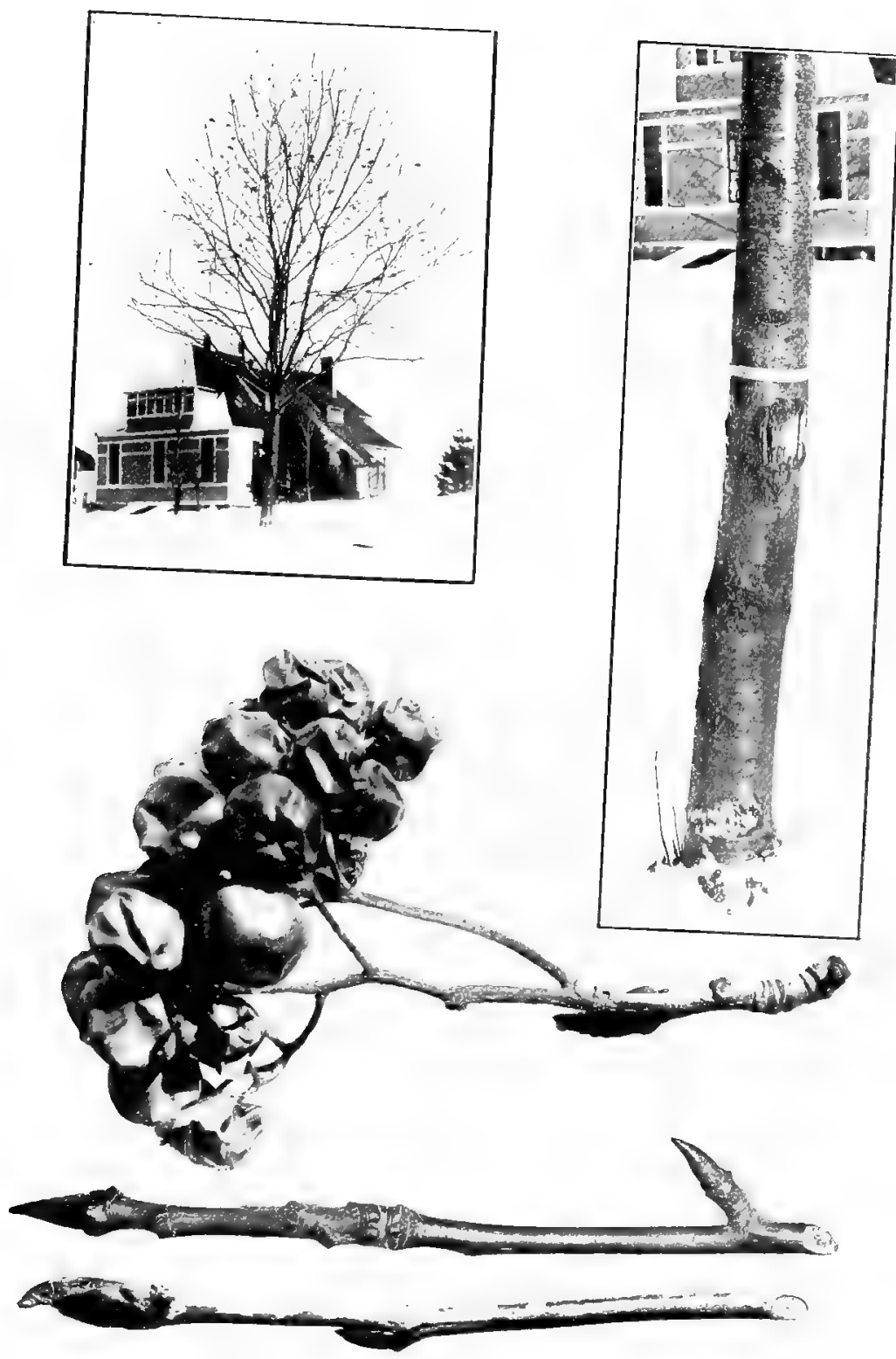

Mocntain Asin 


\section{QUINCE \\ Cydonia vulgaris Pers. \\ Pyrus Cydonia L.}

HABIT-A low bushy straggling rounded shrub or small tree rarely exceeding $15 \mathrm{ft}$. in height with crooked distorted branches.

BARK-Dark gray, finely streaked, becoming with age more or less roughened with large flaky scales.

TwIGS-Slender, dark reddish-brown, often with tinge of green; in protected places and especially toward the tip of the twig generally more or less densely covered with pale wool, bright-shining where smooth; mostly tasteless. LENTICELS-small, numerous, becoming conspicuous brownish dots on older growth. PITH-narrow, greenish.

LEAF-SCARS-AIternate, more than 2-ranked, small, crescent-shaped to inversely triangular, raised on a somewhat shrivelled projection slightly darker than the twig and containing at its outer edges the roundish, rather inconspicuous stipule-scars at either side of the leafscar. BUNDLE-SCARS-3.

BLDS-Terminal bud absent; lateral buds minute, about $3 \mathrm{~mm}$. or often less in length, ovate, blunt, flattened and appressed against twig; smoothish or somewhat hairy at base, with dense pale-rusty hairs within showing through at apex. BUD-SCALES-not easily distinguished, about 2 visible, reddish-brown to light reddish, breaking away at the tip.

FRITT-A large, firm, fleshy, downy pome.

COMPARISons-The twigs and buds of the Quince resemble somewhat those of the Apple but the twigs are much more slender and the buds show a distinctive tuft of rusty hairs. The bushy habit of growth further will distinguish the Quince from the other cultivated fruit trees.

DISTRIBITION-A tree native of Europe, cultivated for the fruit and escaped to a slight extent in some localities.

woon-The wood is of no commercial importance. The fruit is valued for preserving. The raw fruit and mucilaginous seed are used in domestic medicinal practice. 

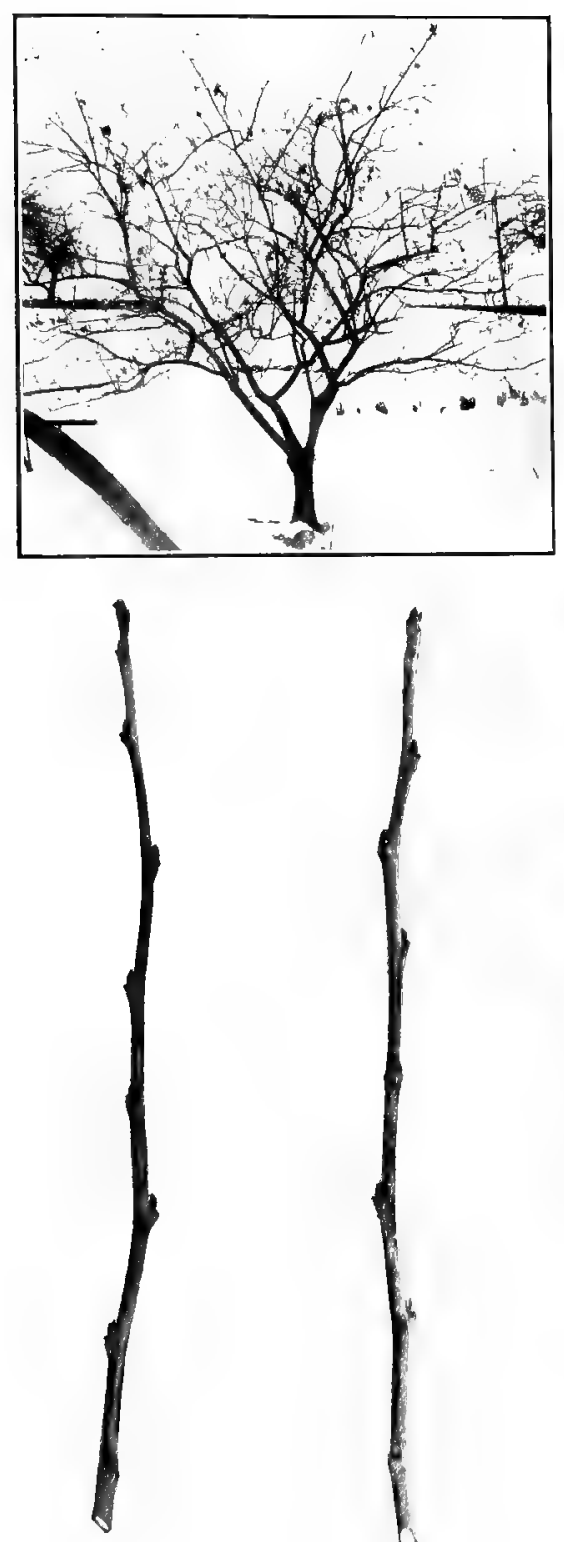

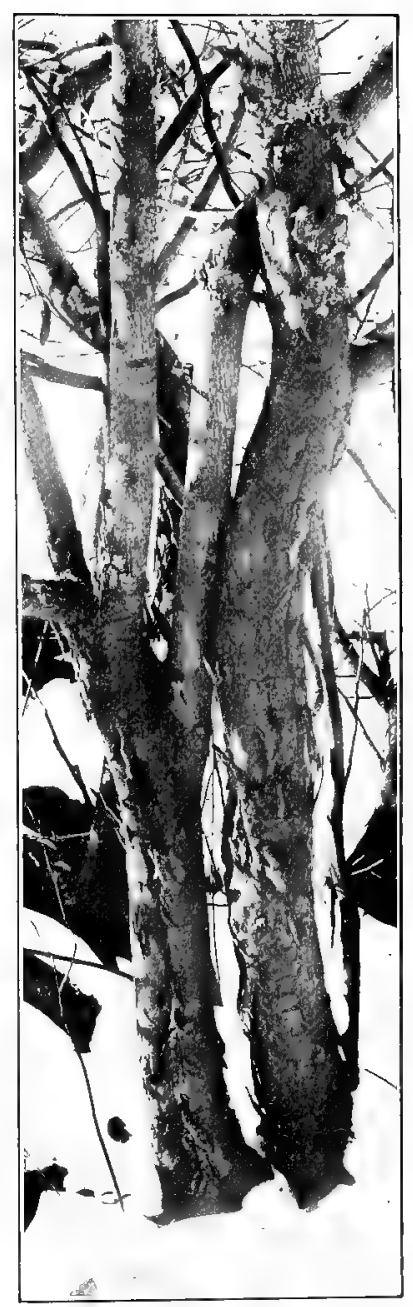

QUINCE 


\section{SHAD BUSH \\ Service Berry, Shadblow, Juneberry.} Amelanchier canadensis (L.) Medic.

H 1 BIT-A shrub or small tree $10-25$ ft. in helght with a trunk diameter of 6-10 inches, sometimes reaching a height of $40 \mathrm{ft}$. with a trunk diameter of $11 / 2 \mathrm{ft}$.; of variable habit, at times a shrub with many stems in a clump (see plate, picture at right) or again a symmetrical tree with a single trunk with many small limbs and fine branchlets forming an oblong or rather widespreading round-topped head (see plate.)

B IRI-Essentially smooth, grayish-brown, older trunks with narrow longitudinal fissures separating off shallow flat ridges which are somewhat scaly at base of trunk; younger trunks and branches smooth, often characteristically streaked witl darker longitudinal lines (see plate).

TWIGs-Slender, grayish, olive-green to redish-brown often covered with a gray skin, generally smooth, with slight taste of bitter almonds. LENTICELS-scattered or numerous, pale, minute dots. PITHgreenish with irregular edges.

LEAF-SCIRS-Alternate, 2-ranked or at times appearing more than 2 -ranked, a raised very narrow flattened V-shaped iine stvollen at the bundle-scars. often with short somewhat decurrent ridges at outer edges. STIPLLE-SCAILS-absent. BUNDLE-SCARS-3, rather large.

BCDS-Terminal buds present, long, narrow, 7-12 $\mathrm{mm}$. long and 3-4 times as long as broad, narrowly ovate to conjcal. sharp-pointed, greenish-yellowish nore or less tinged with reddish-purple, smooth or with White sllky hairs at apex and edges of scales. mostly appressed; lateral buds on rapidly grown shoots normal, on slowly grown spurs, undevel. oped or rudimentary; generally a small lateral bud just below terminal bud. EUD-SCALES-increasing from below upward, the two lowest about 1 , length of the bud more or less keeled and 3 -nerved, dark, margined and with a single short dark spiny tip, lower scales often 3 . tipped, edges from slightly downy on outernost scales to densely silkyhairy on inner scales: on terminal buds about 5 scales visjble. more or less imperfectly 2-ranked; lateral buds on vigorous shoots often with pair of extra lateral scales basally united giving short-stalked appearance to bud.

FRI IT-Berry-like, sometimes if infected by a rust rungus remaining dried on the tree through the winter.

COMPIFISOXS-The long narrow buds of the Shad Bush bear a superficial resentblance to those of the Beech. The Beech buds. however, are divergent, narrower, with 10-20 scales regularly arranged in four rows and have stipule-scars nearly encircling the trig. The Shad Bush is subject to the attacks of a fungus [Dimerosporium Collinsit] which blackens the leaves and causes a profuse branching at the point of infection. The "witches" brooms" thus formed with the persistent blackened leaves often enables the tree to be recognized at a distance.

DISTRIBT-TION-Dry, open woods, hillsides. Newfoundland and Nova Scotia to Lake Superior; south to the Gulf of Mexico; west to Minnesota, IJansas, and Louisiana.

IN NETV ENGLAND-Throughout.

IN CONATETICUT-Frequent.

wo0D-Heary, exreedingly hard, strong, close-gra!ned, dark brown often tinged with red. With thick lighter colored sapwood of $40-i \theta$ layers of annual growth; occasionally used for the handles of tools and other small implements; under the name of "Lancewood" it is used in the manufacture of fish rods. 

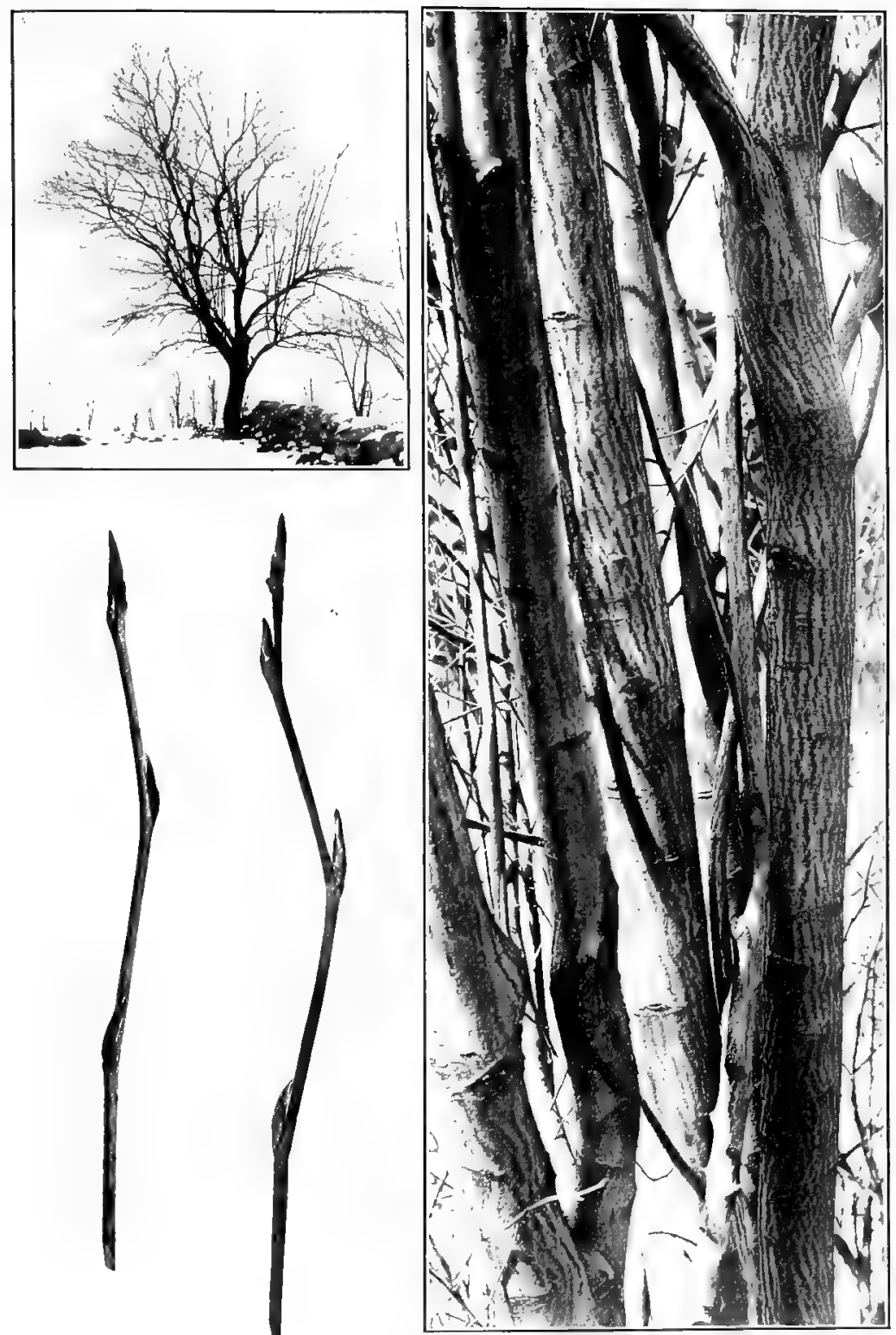

Silad Busit 


\section{THE HAWTHORNS \\ Thorns, Haws, Thorn Apples, White Thorns. Crataegus L.}

Note-The Hawthorns form one of the most complexing genera among flowering plants. Some 600 species have been described and Sargent in his Manual gives descriptions of 132 tree-like forms for North America. The distinctions used are based largely upon flower and fruit characters. They are at best often difficult of application and entirely unavalable in the winter. It seems, therefore, most advisable to give a description which will hold good for the whole group rather than a detailed account of any single species. The twig photographed was taken from the Cockspur Thorn [Crataegus Crus-galli L.]; the habit photograph from an undetermined specimen belonging to the Pruinosa group growing in a deserted pasture.

HADIT-Generally low wide spreading trees or shrubs.

BIRK-Generally dark, scaly.

TWIGS-Rigid, round in section, more or less zigzag, rarely unarmed. generally armed with axillary thorns which are almost always unbranched - not infrequently branched when arising from the trunk and larger branches-generally similar in color to branches from which they grow: thorns generally absent from many of the nodes, LENTICELSoblong. generally pale.

LFAF-SCARS-Alternate, more than 2-ranked, small, narrow, crescent-shaped, slightly raised. STIPULE-SCARS-absent. BUNDLESCARS-3.

BIDS-Small, spherical or nearly so; terminal bud generally present, scarcely larger than lateral buds; a lateral accessory bud on each side of the axillary thorn, frequently only one of the two developed. BUDSCALES- numerous, overlapping, thick, rounded, blunt, bright chestnut brown, shining.

FRIIT-Berry-like, botanically a small drupe-like pome with 1-5 nutlets.

COMPARISONS-The Hawthorns may be distinguished from other gentra by the unbranched axillary thorns usually present on their twigs and by the bright, shining, chestnut brown, generally spherical buds. The thorns of the Honey Locust are branched and situated some distance above the axillary buds. The Osage Orange [Maclura pomifera (RaP.) Schneider]. sometimes grown in hedges, has unbranched thorns generally present at all the nodes, decreasing regularly toward the tip of the greenish-gray twig. With buds lateral to the thorns and a single more or less ring-shaped bundle-scar to the broad leaf-scar.

DISTRIBCTIOX-The Hawthorns are most abundant in eastern North America occurring here from Newfoundland to the mountains of northern Mexico. A few species occur in the Rocky mountains and Pacific coast reginns and in China, Japan, Siberia, central and southern Asia and in Furope.

Woon-Heary, hard, tough, close-grained, reddish-brown, with thick lighter colored usually pale sapwood; useful for the handies of tools, mallets and other smal? articles. 

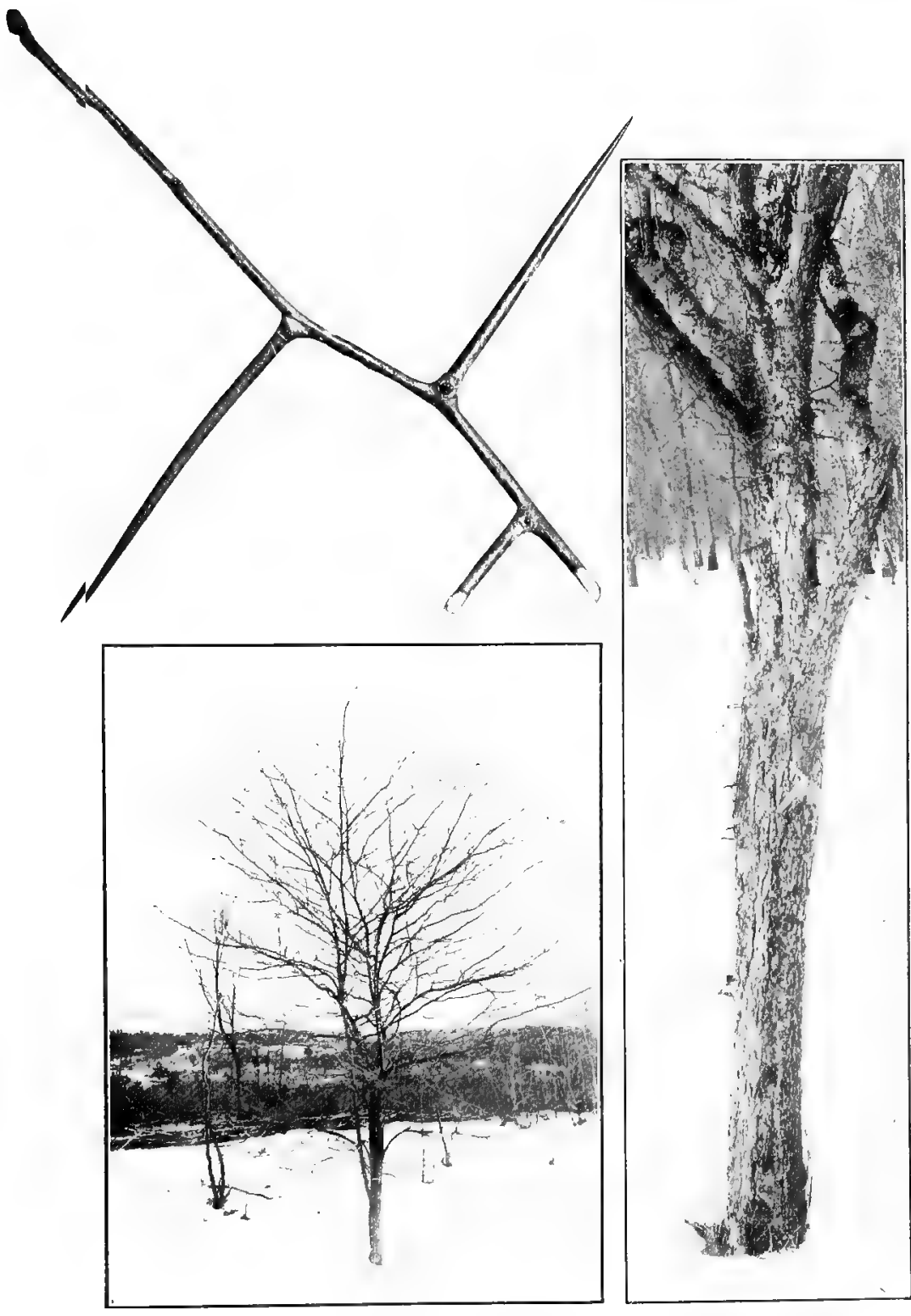

ILAWTIIORN 


\section{WILD BLACK CHERRY Rum, Cabinet or Black Cherry.}

Prunus serotina Ehrh.

Padus serotina (Ehrh.) Agardh.

HABIT-A medium sized tree $30-50 \mathrm{ft}$, in height with a trunk diameter from 8 or 10 inches to 2 feet, becoming much larger in the middle and southern states; branches spreading often more or less zigzag forming an irregular oblong head.

BAfK-On young trunks and branches smooth reddish-brown with conspicuous oblong whitish horizontal lenticels, easily peeled off in thin dark papery layers exposing the bright green bark below, becoming with age very much roughened by irregular, close, dark, scaly plates with upturned edges.

TwiGs-Rather slender, smooth, reddish-brown, more or less covered with a grayish skin easily rubbed off; crushed twigs with odor and taste of bitter almonds. LENTICELS-numerous, pale, minute, rounded dots, becoming horizontally elongated and more conspicuous on later growth. PITH-of recent growth, generally whitish.

LEAF-SCARS-Alternate, more than 2-ranked, small, semi-oval to inversely triangular, raised. STIPULE-SCARS-inconspicuous or apparently absent. BUNDLE-SCARS-3, often inconspicuous.

BCDS-Medium sized, ovate, blunt to sharp-pointed, about $4 \mathrm{~mm}$. long, smooth, bright reddish-brown, divergent or sometimes somewhat Hattened and appressed; terminal bud slightly larger than lateral buds. BUD-SCALES-about 4 visible, broadly ovate, more or less rounded and keeled on the back, of nearly uniform color or with darker edges, sometimes partially covered with a grayish skin, similar to that usual on the twigs.

FRLIT-A drupe about the size of a pea, ripening in summer in drooping elongated clusters.

CompARisons-The Wild Black Cherry in its young growth resembles the Choke Cherry but grows to be a good sized tree and developz a very rough scaly bark. Further the lenticels tend to be whitish and elongate horizontally with age, the buds are smaller and redder and their scales are not white-margined. From the cultivated Sweet and Sour Cherries the Black Cherry is distinguished by absence of fruiting spurs, by smaller buds and by the character of its bark.

DISTRIBCTIOx-In all sorts of soils and exposures; open places and rlch woods. Nova Scotia to Lake Superior; south to Florida; west to North Dakota, Kansas, and Texas, extending through Mexico, along the Pacific coast of Central America to Peru.

IN NEW ENGLAND-Maine-not reported north of Oldtown (Penobscot county); frequent throughout the other New England states.

WOOD-Light, strong, rather hard, close straight-grained, with a satiny surface, light brown or red, with thin yellow sapwood of 10-12 layers of annual growth; largely used in cabinet-making and the interior finish of houses. The bark, especially that of the branches and roots, yields hydrocyanic acid used in medicine as a tontc and sedative. The ripe fruit is used to flavor alcoholic liquors whence one of the common names. 

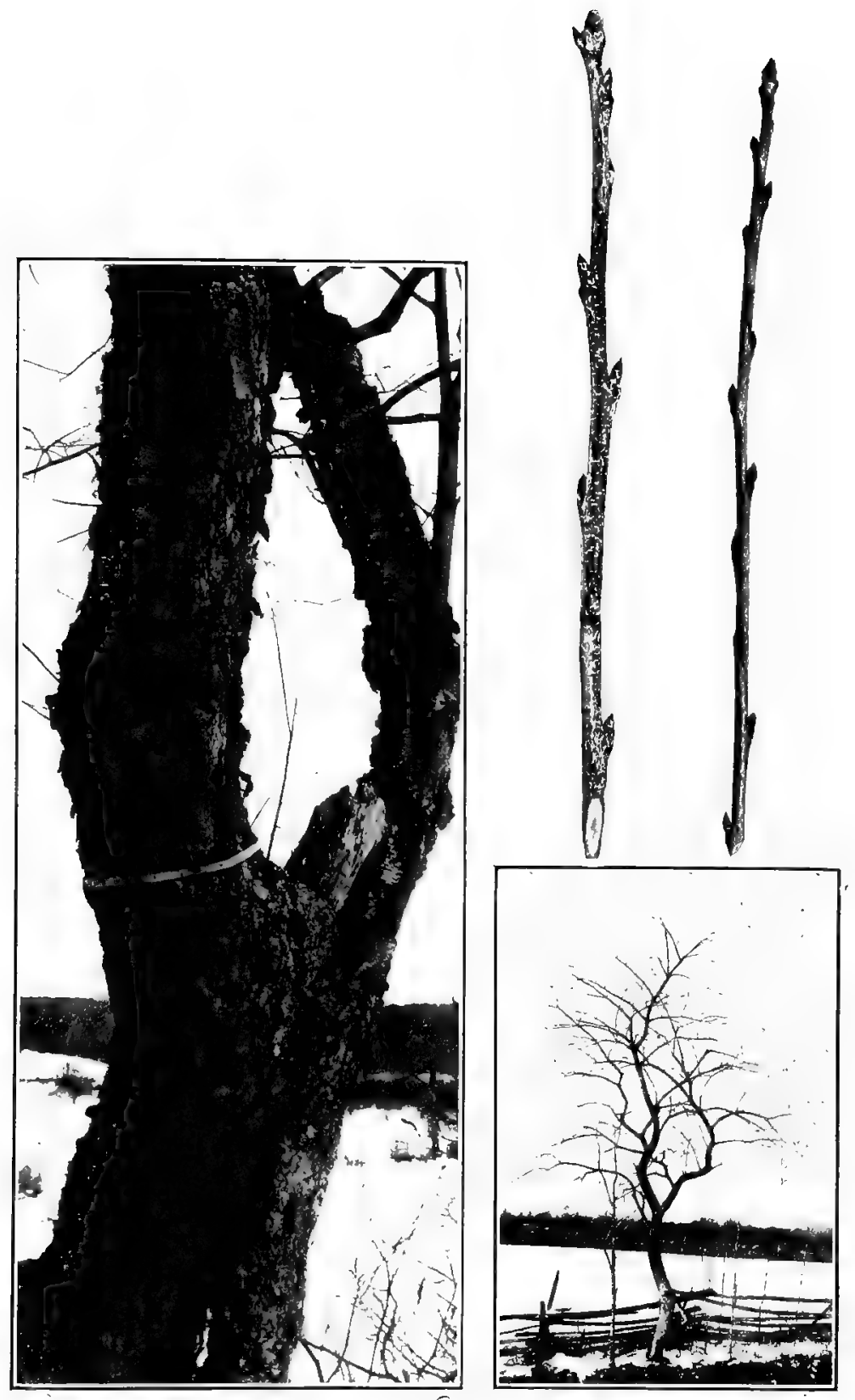

Wild Black Cherry 


\title{
CHOKE CHERRY
}

\author{
Prunus virginiana $\mathrm{L}$.
}

Padus virginiana (L.) Roemer.

H IBIT-Generally a tall shrub or a small tree rarely reaching 20-30 ft. in height with a trunk diameter of $6-8$ inches.

B IRK-Dull grayish-brown, smoothish but slightly roughened with raised buff-orange rounded dots formed by the enlarged lenticels, not becoming rough-scaly with age; on young trunks and branches easily peeled off in thin, dark papery layers exposing the bright green bark below.

TwIGS-Slender to rather stout, averaging stouter than those of the Wild Black Cherry, smooth, reddish to grayish-brown, without grayish skin easily rubbod off, crushed twigs with a rank odor and taste in addition to that of bitter almonds. LENTICELS-numerous, rather conspicuous, buff-orange dots, slightly elongated longitudinally the first year and not becoming distinctly elongated horizontally on later growth. PITH-of recent growth white.

LEAF-SCARS-Alternate, more than 2-ranked, elliptical, raised. STIPLLE-SCARS-inconspicuous or absent. BUNDLE-SCARS-3, frequently sunken.

BLDS-Pather large, narrow, ovate to conical, about $6 \mathrm{~mm}$. or more long, smooth, pale brown, sharp-pointed, generally divergent with more or less strongly curved apex; terminal bud frequently slightly smaller than lateral buds. BUD-SCALES-a half dozen or more scales visible, broadly ovate, mure or less rounded and keeled on the back, with thin grayish margins.

FRIIT-A drupe about the size of a pea, ripening in summer in drooping elongated clusters.

CoMr.RISOxS-The Choke Cherry may be distinguished from the Wild Black Cherry with which it is frequently confused by its smaller size, smoothish bark even in old age, its buff colored lenticels which do not elongate horizontally, the rank odor of its twigs and by its larger and paler buds with whitish-margined bud-scales. From the cultivated Sweet and Sour Cherries the Choke Cherry is distinguished by the absence of short fruit spurs and by its gray-margined bud-scales. The lower twig in the plate is infected by a fungus disease-Black Knot (Plowrightia morbosa) which occurs also upon the Wild Black and Wild Iied Cherries and upon our cultivated Cherries and also upon the Plums.

DISTRIBCTION-In varying solis; along river banks, on dry plains, in woods, common along walls and often in thickets. From Newfoundland arross the continent, as far north on the Mackenzie river as 62 degrees: south to Georgia; west to Minnesota and Texas.

IN NEW ENGLAND-Common throughout; at an altitude of 4,500 feet upon Mit. Katahain.

IN CONNECTICUT-Rare near the coast in the southeastern part of the state but frequent or common elsewhere.

woon-liard, close-grained, weak, light brown; of insuffient size to be of value commerclally. 

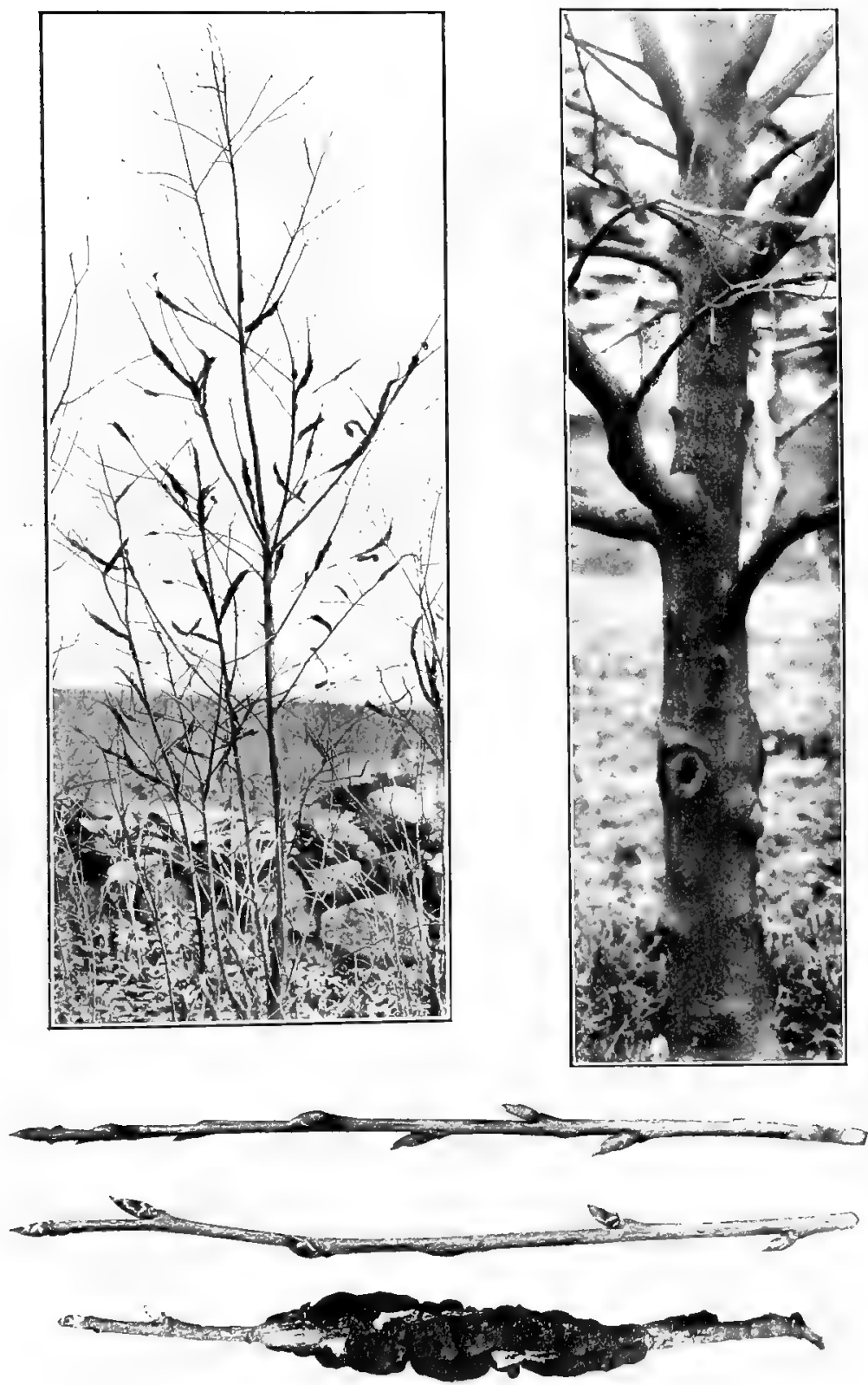

CHOKE CIIERRY 


\section{WILD RED CHERRY Bird, Fire, Pin or Pigeon Cherry.} Prunus pennsylvanica L. $\mathrm{f}$.

HAHIT-A shrub or small tree generally under $30 \mathrm{ft}$. in height with trunk diameter of $8-10$ inches; trunk erect generally continuous into crown with slender branches arising at a rather sharp angle, forming a rather narrow oblong open head. The trees growing in the open about Storrs have in general a narrower outline than the tree photographed.

BARK-Reddish-brown, for the most part smooth, often slightly peeling in transverse strips especially toward the base of the trunk and in old trees somewhat roughened; inner bark on young branches bright green. LENTICELS-conspicuous, horizontally elongated, lensshaped, orange colored and powdery on the surface.

TWIGS-Slender, generally less than $2 \mathrm{~mm}$. thick, often less than $1.5 \mathrm{~mm}$. thick, smooth, bright red and shining, more or less covered with a gray skin easily rubbed off; bitter aromatic. LENTICELS-scattered. pale to bright orange colored, becoming slightly elongated horizontally and more conspicuous on older growth. PITH-brown, narrow.

LEAF-SCARS-Alternate, more than 2-ranked, semi-oval, raised. STIPULE-SCAFiS-back of leaf-scars, generally indistinct or absent. BUNDLE-SCARS-3, the central larger one often alone distinct.

BLDS-Minute, generally under $3 \mathrm{~mm}$. long, blunt-pointed, ovate, reddish-brown, smooth, often partially covered with a grayish skin. divergent, on rapidly grown shoots characteristically clustered at the tips as well as scattered, with the terminal bud present but generally smaller than those in the cluster arouna it: also clustered buds at ends of short fruiting spurs; collateral accessory buds sometimes present. BUD-SCALES - ovate, often notched and short-pointed, not readily distinguished as separate scales with the naked eye.

FRIIT-A drupe about the size of a pea, ripening in summer in short clusters or with stalks arising from a common point on the stem.

COMPARISONS-The appearance of the bark and the taste of the twigs shows the Wild Red Cherry to belong to the Cherry group. It differs from the other Cherries in its very slender twigs and small buds which are constantly clustered at the tips even of rapidly grown shoots. The Wild Black Cherry when tree-like is further distinguished by its scaly bark. The powdery bright reddish-orange lenticels on young and even old trunks form a striking character but a similar color may occur in the lenticels of the other Cherries especlally if the outer surface is rubbed off.

DISTRIBLTION-Foadsides, clearings, burnt lands, hlll slopes, occaslonal in rather low grounds. From Labrador to the Rocky mountains, through British Columbia to the Coast Range; south to North Carolina: west to Minnesota and Missouri.

IN NEW ENGLAND-Throughout; very common in the northern portions, as high up as 4,500 ft. upon Katahdin, less common southward and near the seacoast.

IN CONNECTICUT-OCcasional, Found in various soils and situationg, but especially in rocky woods and clearings.

WoOD-Light, soft, close-grained, light brown, with thin yellow sapwood of little commercial importance. 


$$
\frac{1}{11}
$$




\section{SWEET CHERRY \\ Mazzard Cherry, European Bird Cherry. \\ Prunus avium L.}

II I IT-A good sized tree reaching 50-75 ft. in height with a trunk diameter of $2-3 \mathrm{ft}$; trunk erect continuous into the crown with slender ascending branches forming a narrow pyramidal head; with age becoming broad-spreading.

B IRK-Characteristically reddish-brown with horizontally elongated buff colored lenticels, tardily pefing off in transverse strips which curl back and expose the lighter bark below which on very old trunks may be roughened by scaly ridges; on young branches bark easily peeled off in a thin dark papery layer exposing the bright green bark below.

TWIGS-Stout, bright reddish-brown, smooth and shining, more or less covered with a grayish skin easily rubbed off; crushed twigs with bitter taste. In addition to long rapidly grown shoots, stubby slowly grown fruit spurs with terminally clustered buds are abundant. LENTICELS-rather numerous, pale, becoming horizontally elongated. PITH-brown.

LEIF-SCARS-Alternate, more than 2-ranked, rather broad, semtoval to inversely triangular, raised. STIPULE-SCARS-slightly behind leaf-scars, oblique, often indistinct or absent. BUNDLE-SCARS-3.

BUDS-Clustered at ends of fruiting spurs or scattered on rapidly grown shoots; terminal bud scarcely larger than lateral buds; lateral buds divergent, stout, ovate, pointed, constricted at base, about $7 \mathrm{~mm}$. long, reddish-brown, smooth, often partially covered with a grayish skin. BUD-SCALES-broadly ovate, with edges often lighter colored and more or less frayed and ragged.

FRCIT-A drupe with edible flesh, generally sweet though in some varieties tart, with hard stone or pit enclosing the seed, ripening in summer, with stalks generally several in a cluster arising from a common point on the stem.

COMPARISONS-The two types of cultivated cherries, the Sweet and the Sour are to be distinguished chiefly by habit of growth and relative size of twigs and buds, the Sweet Cherry having a pyramidal outline generally with a central leader and with relatively stout twigs and larger buds. These differences are well shown in the plates. (See Comparisons under Sour Cherry).

DISTRIBCTON-A native of Europe, in this country cultivated for its fruit in several improved varieties such as the Black Tartarian. May Duke. Windsor. Napoleon, etc. and in some places escaped from cultivation.

woon-Strong, rather soft, close-grained, yellowish-red, taking a fine polish; largely used in Europe for fine furniture, inside finishing and fur musical and other instruments. 

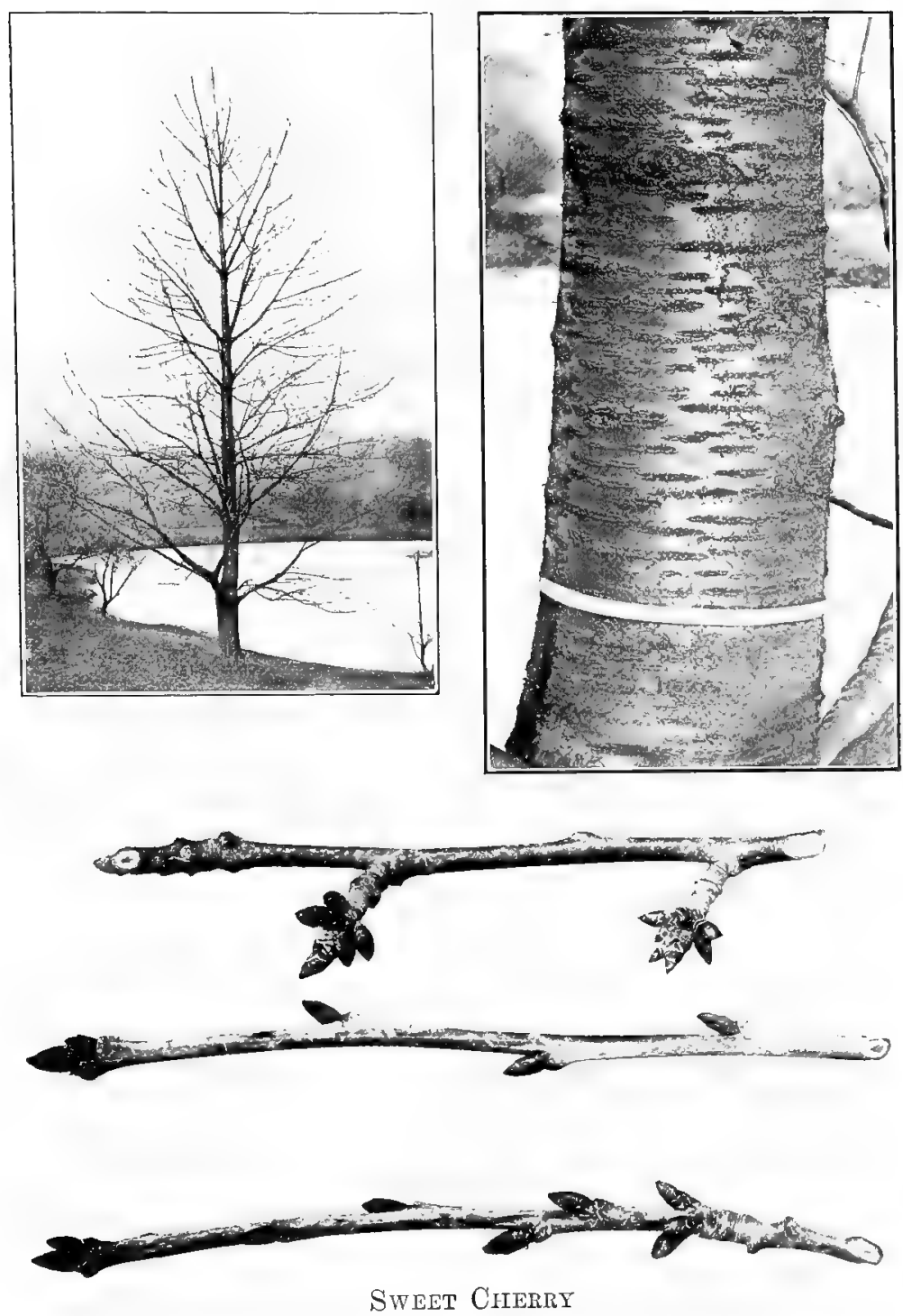


\section{SOUR CHERRY \\ Pie or Morello Cherry. Prunus Cerasus L.}

H.IBT-A small tree 20-30 ft. or less in height with a trunk diameter of 10 or 12 inches; with stout spreading branches and more or less drooping branchlets forming a broad, low, rounded head.

B IRI-Similar to that of the Sweet Cherry, but the outer smooth bark sooner peeling back and exposing the roughened inner bark.

TWIGS-Slender, otherwise resembling twigs of Sweet Cherry.

LEAF-SCARS-Similar to those of the Sweet Cherry.

BIDS-Similar to those of the Sweet Cherry but smaller and apparently more frequently clustered toward the ends of long shoots. Compare the twig photographs of the two species.

FRI IT-Similar to that of Sweet Cherry but flesh tart.

COIrP.1RISONS-The Sour Cherry differs from the Sweet Cherry in Its spreading habit of growth, its more slender twigs and smaller buds. Compare plates of the two species. From the native Wild Black and Choke Cherries the cultivated Sweet and Sour Cherries are distinguished by the short fruit spurs; from the Wild Red Cherry by their stouter twigs and buds and absence of a bud cluster at the tip of long shoots.

DISTRIBI TIOX-A native of Europe, in this country cultivated for 1 ts fruit in several improved varieties such as the Amarelles, Early Rlchmond, Montmorency, etc. and the Morellos, Louis Philippe, etc. and in some places escaped from cultivation.

woOD-Similar in appearance and uses to that of the Sweet Cherry from which it is not distinguished by wood workers. 

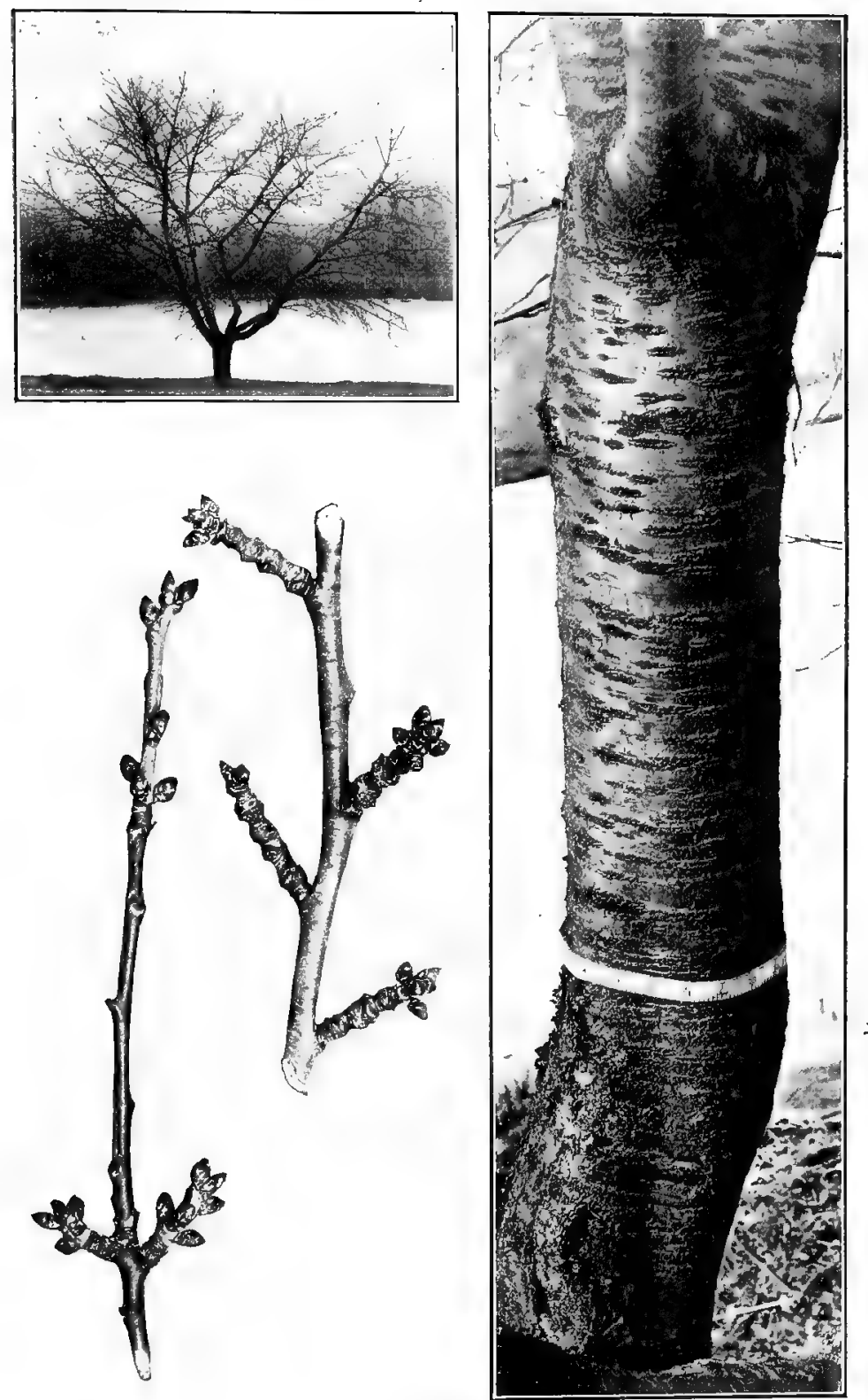

Sour Citeritx 


\author{
CANADA PLUM \\ Red, Horse or Wild Plum. \\ Prunus nigra Ait. \\ $P$. americana, var, nigra Waugh.
}

H1BrT-A shrub or small tree $20-25$ ft. in height with a trunk diameter of $5-8$ inches; with contorted branches and more or less zigzag branchlets forming a low spreading head. It tends to sucker freely forming low thickets.

B IRK-On young trunks and branches dark brown with prominent raised lenticels which are horizontally slightly elongated; at first smooth but soon splitting and curling back in thick grayish-brown layered plates exposing the rough scaly bark below.

TWIGS-Slender, smooth, reddish-brown, often more or less covered with a grayish skin, bitter aromatic, lateral spiny spurs generally present. LENTICELS-scattered, large and rather conspicuous pale dots.

LEAF-sCARS-Alternate, more than 2-ranked, broadly crescentshaped. STIPULE-SCARS-indistinct or absent. BUNDLE-SCARS3 , often inconspicuous.

BLDS-Terminal bud absent, lateral buds about $4-8 \mathrm{~mm}$. long, conical, narrow-pointed, grayish-brown; collateral buds sometimes present. BUD-SCALES-triangular, pale and thin on the margins, generally hairy at the apex.

FRITT-A smooth-skinned drupe with smooth stone.

COMPARISONS-The Plums are distinguished from the other members of the genus Prunus by the absence of a terminal bud. The Canada Plum so far as one can judge from the material investigated is distinguishable by its larger buds from the American Plum, of which it is considered by some only as a variety.

DISTRIBUTION-Native along streams and in thickets, often spontaneous around dwellings and along fences. From Newfoundland through the valley of the St. Lawrence to Lake Manjtoba; rare south of New England; west to Wisconsin. Has given rise to some valuable fruit-bearing varieties in cultivation.

IN NETV ENGLAND-Maine-abundant in the northern sectlons and common throughout; New Hampshire and Vermont-frequent, especially in the northern sections; Massachusetts-occasional; Rhode Island-not reported.

IN CONNECTICUT-Rare. Norfolk, a few trees about an abandoned garden; Oxford.

wooD-Heavy, hard, strong, close-grained, rich bright reddishbrown with thin lighter colored sapwood. 


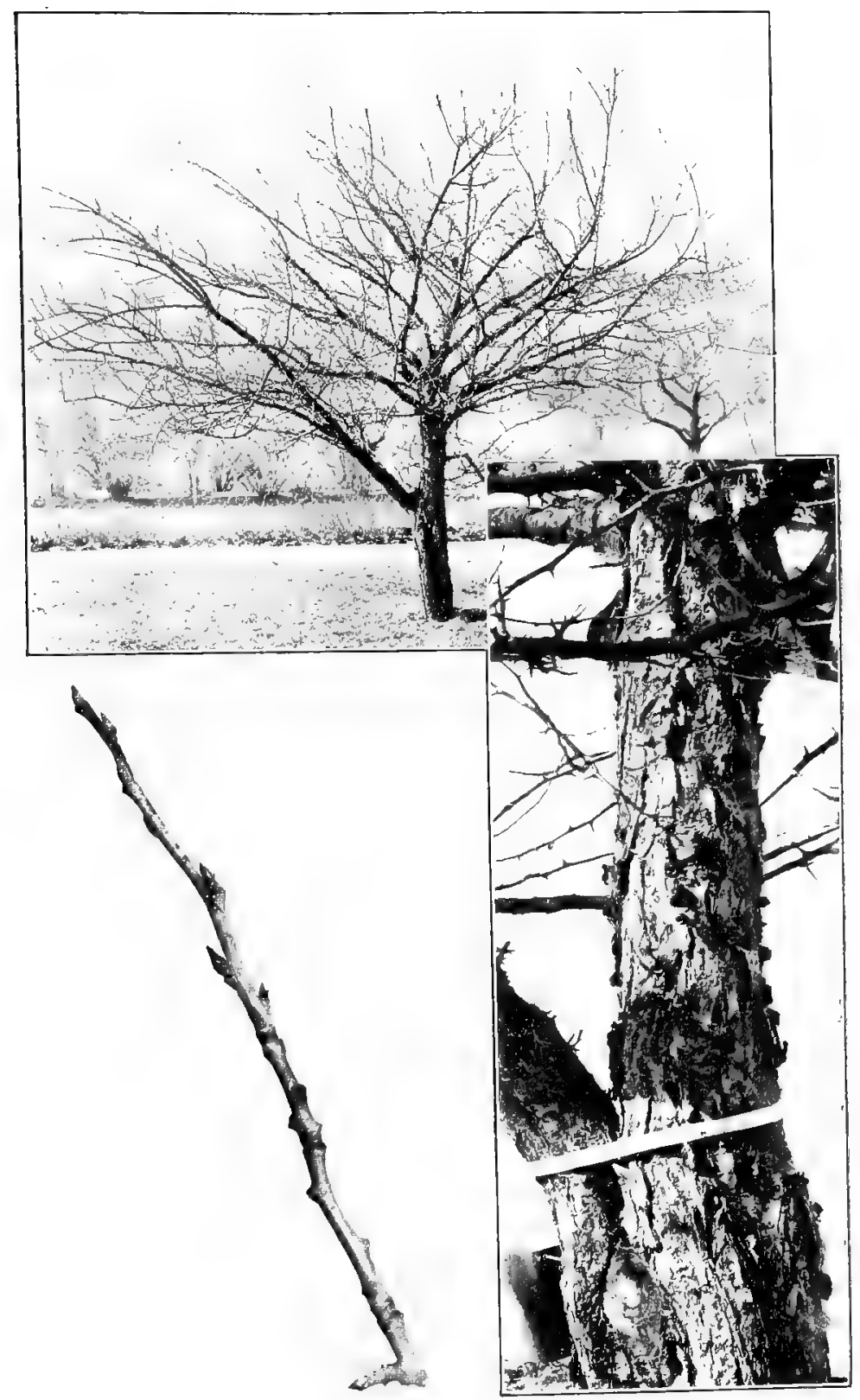

Canada Plum 


\section{CULTIVATED PLUMS}

NOTE-The Cultivated Plums are either improved forms of originally wild species or have been derived by hybridization from a number of such forms. The types most cultivated in the United States are the American (derived from Prunus americana), the European (derived from Prunus domestica) and the Japanese (derived from Prumus triflora). Although the varieties of a given type differ considerably so that without further study it does not seem desirable to try to offer a detailed winter classification of the cultivated plums, still the general characteristics of the unmixed types are recognizable in winter. Certain varieties, the Gold, the Lombard and the Red June have been chosen for the photographs to illustrate respectively the American, the European and the Japanese types.

\section{THE AMERICAN PLUM. VARIETY-GOLD}

Prunus americana Marsh.

Illustrations on page 509 .

The American cultivated type of Plum has very slender grayishbrown twigs and branches which have a decidedly drooping habit of growth. The bark is brown; on young trunks and branches smooth, shining, with prominent, light-colored, horizontally elongated lenticels (see upper part of bark picture). The habit photograph was taken from a specimen of the native form, grown in the Arnold Aboretum. The American Plum, as growing wild, closely resembles the Canada Flum and by some this latter species is considered merely a variety of the former. The material examined shows smaller twigs than the Canada Plum with buds generally under $4 \mathrm{~mm}$. long. The most northern station has been reported to be along the slopes of Graylock. Mass. In Connecticut it is reported as rare in the southern district, becoming occasional nurthward.

\section{THE EUROPEAN PLUM. VARIETY-LOMBARD}

Prunus domestica L.

Illustrations on page 510.

The European Plum has a lighter bark than the other two types without conspicuous horizontal lenticels, with stout, upright, long shoots and an upright habit of growth.

\section{THE JAPANESE PLUM. VARIETY-RED JUNE.}

Prunus triflora Roxbg.

Illustrations on page 511 .

The Japanese Plum has a very dark deeply ridged bark without conspicuous lenticels. The long shoots are rather slender and bright colored and stout fruit spurs are numerous. 

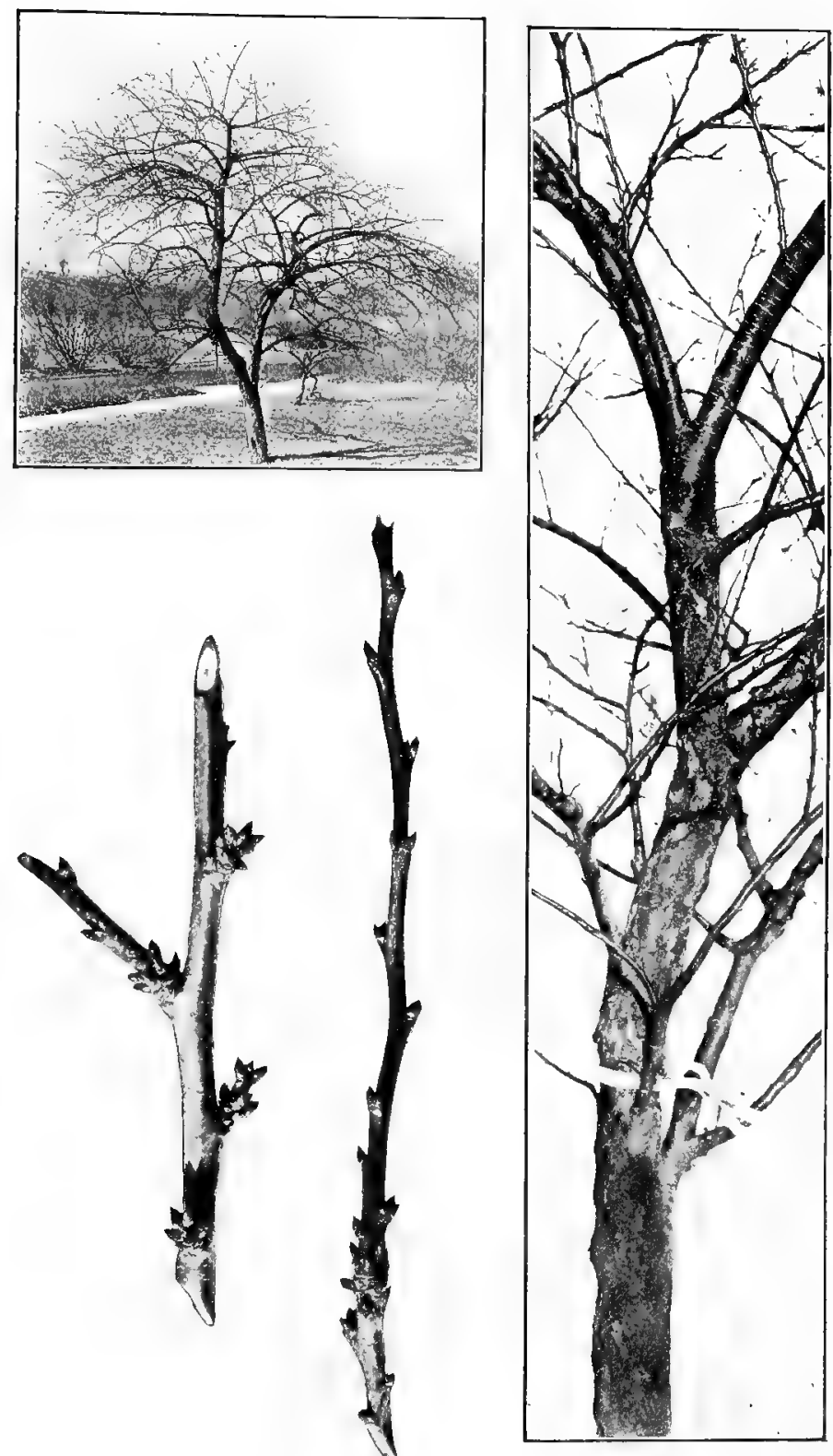

Amerioan Plom 

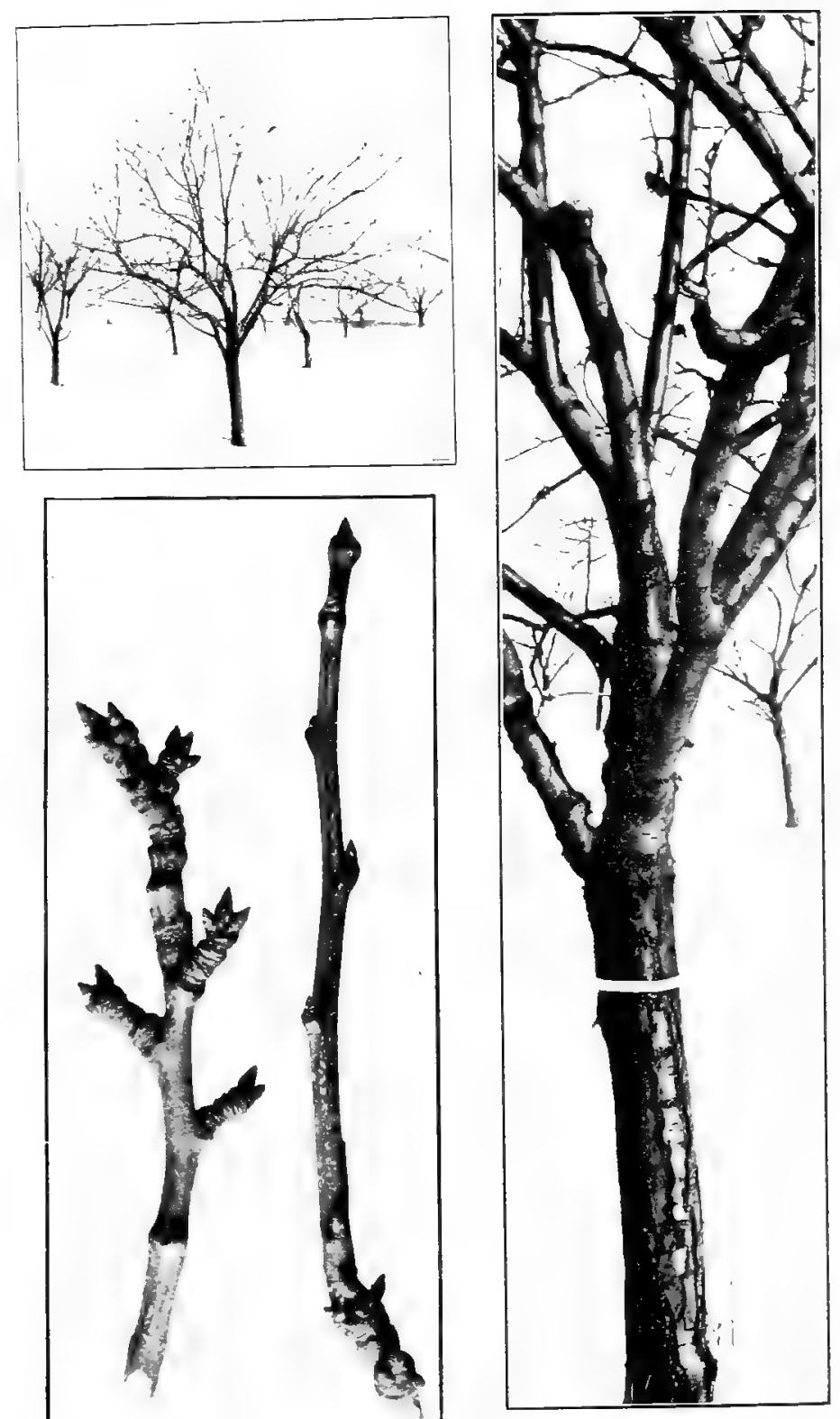

Ecropean Pleas 

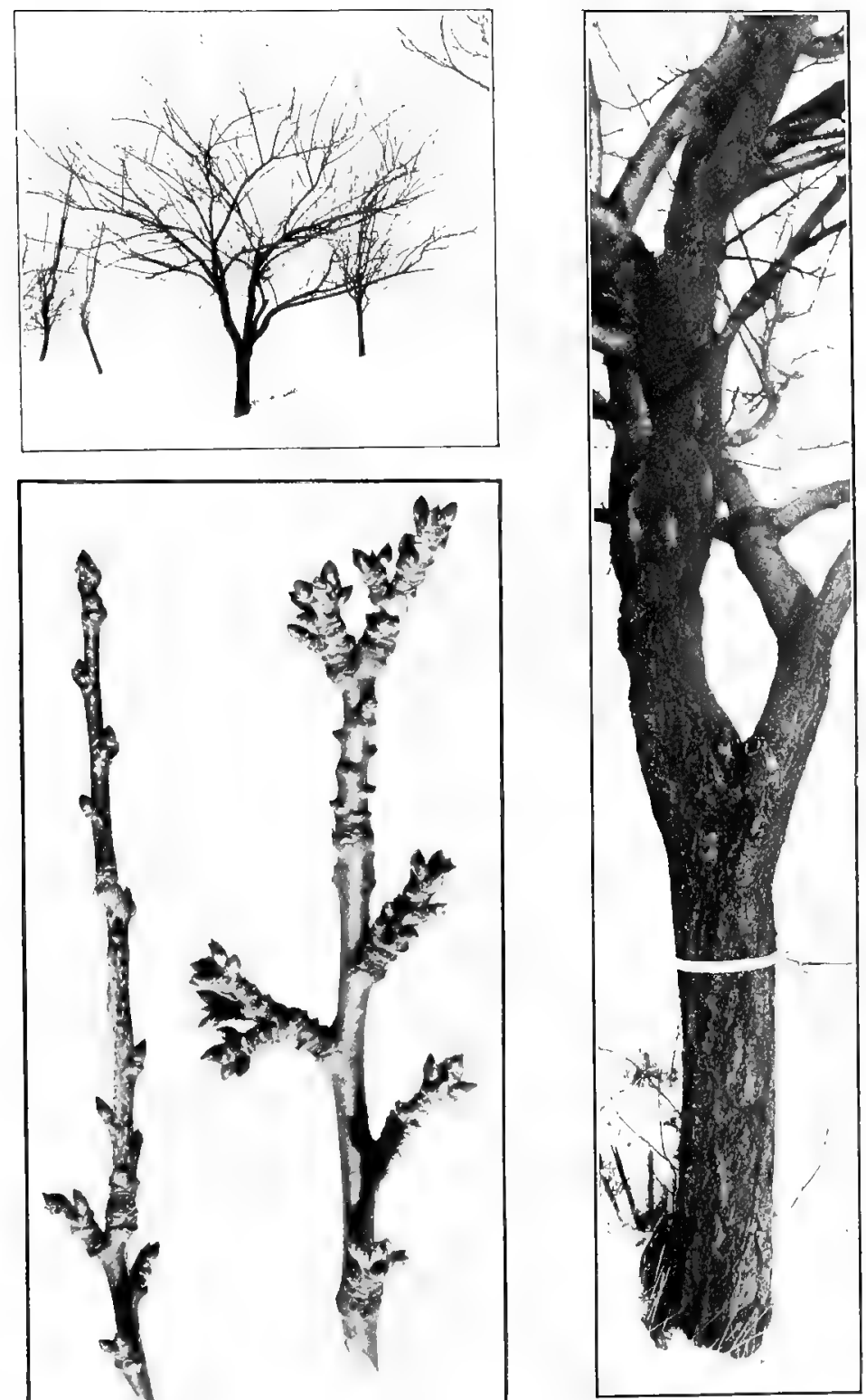

JAPANESE PLUM 


\section{PEACH}

Prunus Persica (L.) Stokes.

A mygdalus Persica L.

H.IBIT-A small tree generally under $20 \mathrm{ft}$. in height with a trunk diameter of about 6 inches; trunk low with spreading limbs and ascending branchlets forming a low broad rounded head.

BARK-Dark reddish-brown, smooth, with prominent horizontally elongated lenticels, becoming roughened and scaly at base.

TwIGS-Of medium thickness, smooth and very shiny, greenish to bright reddish-purple, often green below and red above toward the light. becoming redder as spring approaches; on rapidly grown shoots branches sometimes produced the same season; crushed twigs with odor and taste of bitter almonds. LENTICELS-very numerous and very minute pale dots, in reality stomata, best seen with hand-lens and on reddish portions of twigs, only part of them elongating with age. PITH-rather wide, often somewhat 5-pointed, whitish or tinged with brown.

LEAF-sciRs-Alternate, more than 2-ranked, elliptical to semioval, strongly raised, often more or less decurrent. STIPULE-SCARSbehind and above leaf-scars or raised on persistent bases of stipules, often indistinct and readily confused with broken bud-scales; often a small raised leaf-scar above and on either side of the main leaf-scar in connection with the collateral buds when these are present. BUNDLESCARS-3, often inconspicuous.

BIDS-Orate, rounded at apex or blunt-pointed, generally under $\mathbf{5}$ mm. long, densely pale-woolly at least toward apex and within, more or less appressed, 1 or 2 collateral buds often present at a nodethese generally stout flower buds in sharp contrast to the narrower leaf bud between (in the group of three buds on twig in plate all are Hower buds): terminal bud present often with one or more lateral buds adjacent. BLD-SCALES-reddish-brown, often with ragged edges and generally indistinct and covered with grayish wool.

FRIIT-A large downy drupe with an irregularly pitted stone.

COMPARIsors-The dense woolliness of its stout buds and the very numerous and extremely minute pale dots on its highly colored and polished twigs readily distinguish the Peach from its near relatives.

DISTRIBCTION-A native of Asia, cultivated in this country for its fruit, naturalized throughout the greater portion of the southern states and spontaneous in waste places and on road-sides in the northern states.

wooD-Rather soft, close-grained and light brown. The seeds develop considerable hydrocyanic acid and are used in the manufacture of a substitute for oil of bitter almonds. 

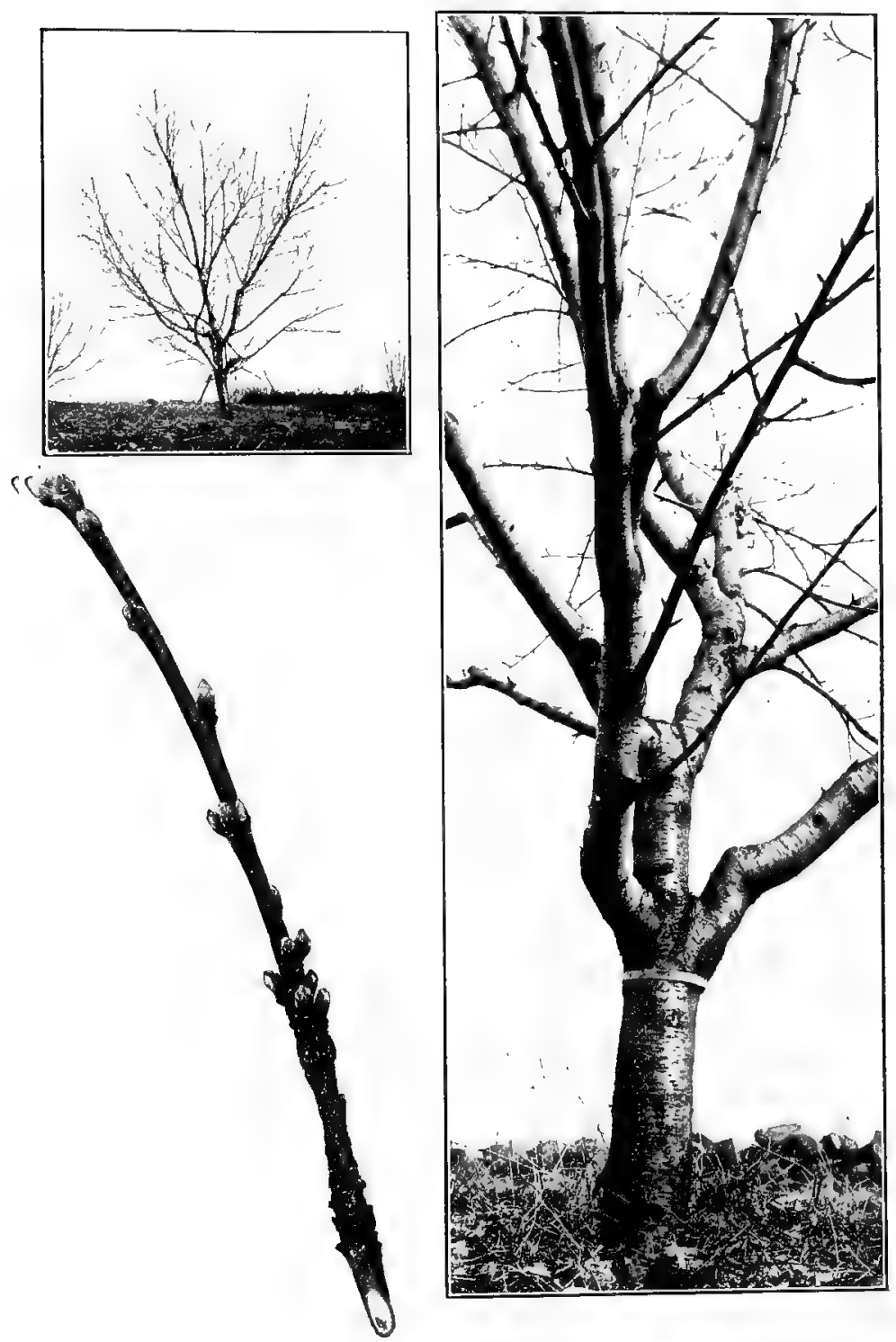

PeaciI 


\title{
KENTUCKY COFFEE TREE \\ Coffee Nut, Coffee Bean, Nicker Tree, Mahogany. Gymnocladus dioica (L.) Koch. \\ G. canadensis Lam.
}

\begin{abstract}
HIBIT-A medium sized tree $30-60 \mathrm{ft}$, in height, trunk generally soon dividing into 3 or $\$$ slightly spreading limbs or less frequently with a continuous trunk, forming a narrow obovate head with thick branchlets devold of spray; the large stout pods often remaining on tree throughout the winter.
\end{abstract}

B.IRK-Dark brown, characteristically roughened with thin tortuous recurved scale-like ridges which are distinct even upon comparatively young branches.

TwIGs-Very stout, more or less contorted, blunt, prown or slightly greenish, generally white-crusted, smooth or often velvety-downy. LENTICELS-rather numerous, large, generally more conspicuous on second year's growth. PITH-wide, salmon-pink to brown.

LEAF-SCARS-Alternate, more than 2-ranked, large, pale, raised, broadiy heart-shaped. STIPULE-SCARS-absent, BUNDLE-SCARSlarge, raised, generally $3-5$.

BLDS-Terminal bud absent, lateral buds small, bronze, silky pubescent, partially sunken, scarcely projecting beyond the surface of the twig, surrounded by an incurved downy rim of the bark; axillary bud in the depression at top of leaf-scar, one or sometimes 2 superposed buds present. BUD-SCALES-sometimes 2 lateral scales visible.

FRIIT-A reddish-brown, large, broad, flat, oblong, abruptly pointed

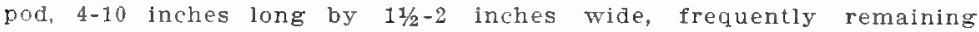
unopened on tree during winter, generally somewhat larger than shown in the photograph. Seed, dark brown, flattish.

COMPIRISOxS-A superficial glance at the habit of the Kentucky Coffee Tree might lead one to mistake its stout branchlets for those of the Ailanthus. Its curious narrow ridged bark, however, should at once prevent any confusion between the two trees. The silky bronze superposed buds partially sunken in downy dimples of the bark in connection with the stout twigs and salmon-colored pith are sufficient characters to distinguish this tree from all other forms.

DISTRIBITION-Not native in New England but frequently cultivated as an ornamental tree; grows wild in rich deep soil from central New Fork and southern Minnesota southward to Tennessee and the Indian Territory.

WooD-Heavy, though not hard, strong, coarse-grained, very durable in contact with soil, rich light brown tinged with red, with thin lighter colored sapwood of 5-6 layers of annual growth; it takes a fine polish and is occasionally used in cabinet-making and for fence-posts, rails and in construction. Its seeds were formerly used as a substitute for coffee. 

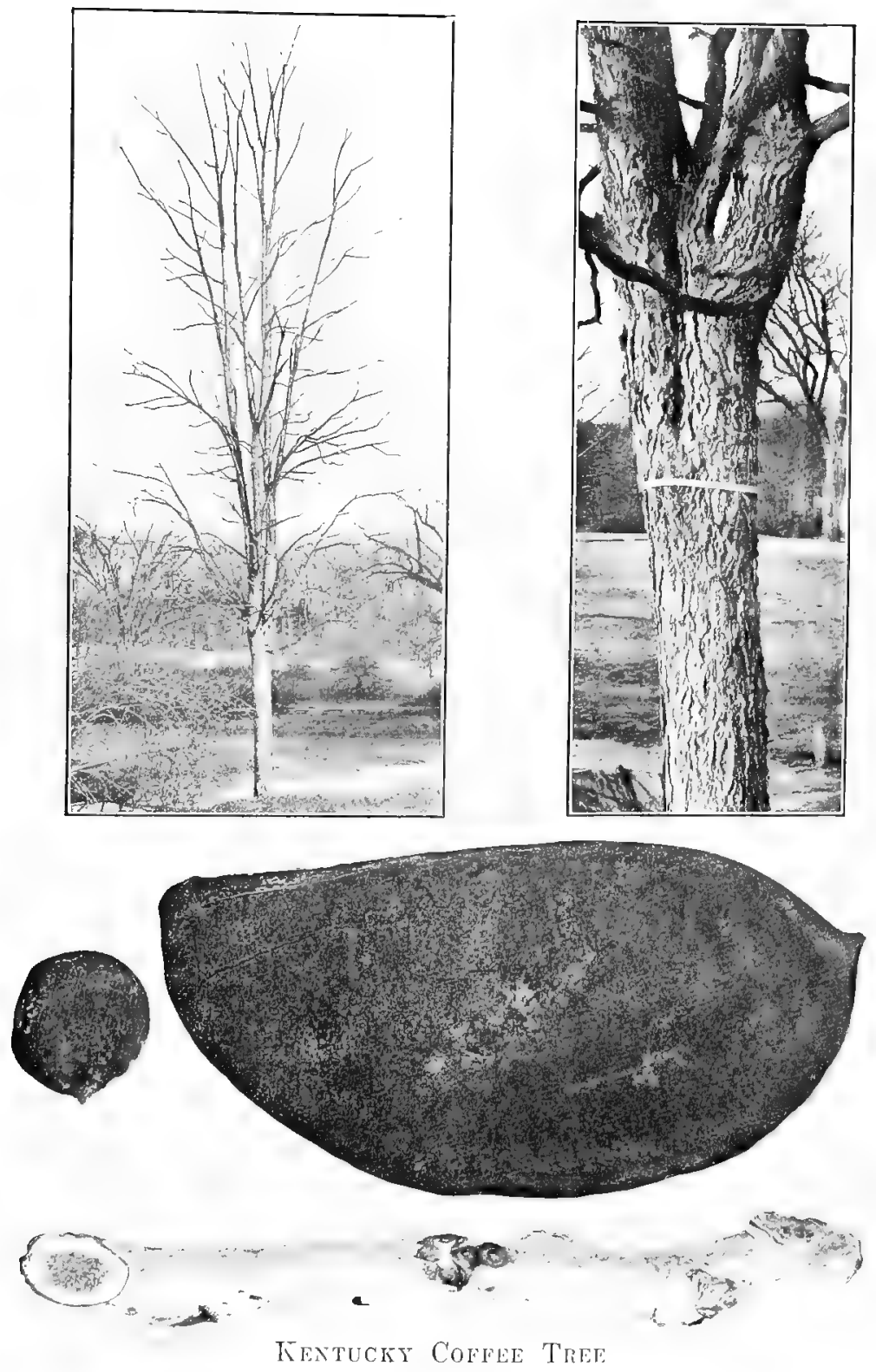


\title{
HONEY LOCUST
}

\section{Three-thorned Acacia, Honey Shucks, Sweet Locust, Thorn Tree.}

\author{
Gleditsia triacanthus L. (Sometimes called Gleditschia.)
}

\begin{abstract}
H. BIT-A medium sized tree 40-60 ft, in height with a trunk diameter of $1-3$ ft.; trunk commonly short diriding into a number of slightly spreading limbs, with somewhat drooping lateral branches, forming a bruad rounded obovate or flat-topped head. Seen against the sky the smaller branches appear zigzag with characteristic swellings at the nodes often surmounted with thorns and rudimentary branchlets developed from the extra buds. (See branches at side of trunk in bark plcture).
\end{abstract}

B.RK-Grayish-brown darkening with age, on young trunks and branches smooth, on older trunks more or less roughened into broad ridges with firm persistent recurved edges. Some trunks have bark practically smooth except for a few deep fissures; some trunks are thickly fringed with dense masses of long branched spines, while others are free frum then.

TWIGs-slender, shining, smooth, reddish to greenish-brown, often light mottled or streaked, zigzag with enlarged nodes; a large branched thorn with pale reddish-brown pith, discontinuous with that of the stem, generally present above nude. LENTICELS-minute, scattered, becoming conspicuous brown raised dots on older growth. PITHthick, whitish.

LE_F-sCARs-Alternate, generally more than 2-ranked, T-shaped with upper margins and apex generally swollen. STIPULE-SCARS -absent or inconspicuous. BLNDLE-SCARS-3, rather inconspicuous.

HUDS-Terminal bud absent, the lateral buds small, generally about 5 more or less distinct at a node, separated one above the other, decreasing in size from above downward, the uppermost a superposed smooth scaly bud breaking through the bark, the next also scaly covered by or breaking through the leaf-scar, the lower buds without scales, covered by bark and seen as minute green dots in a longitudina] section of twig; buds often continue to be produced at the nodes for several years especially when the twigs are trimmed as in hedges and give rise to a bunch of more or less rudimentary branches.

FRIIT-A long, flat, reddish-bromn, more or less twisted, indeniscent pod 10 to 18 inches long. containing numerous flat oval seeds about $10 \mathrm{~mm}$. long. The photograph of the fruit is reduced to about $1 / 3$ natural size.

COMPARISONS-The Honey Locust is at once distinguished from the various other thorny species such as the Hawthorn and common Locust by its large branched thorns situated above the leaf-scar. When the thorns are absent as is sometimes the case the vertical row of separated smooth buds, the unper sealy and superposed, the lower hidden by the bark, are sufficient points of distinction.

DISTRIBI TION-In its native habitat growing in a variety of soils; rich woods, mountain sides, sterile plains. Southern Ontario; spreading by seed southward; indigenous along the western slopes of the Alleghanies in Pennsylvania; south to Georgia and Alabama; west from western New York through southern Ontario and Michigan to Nebraska, Iransas, Indian Territury, and Texas.

IN NET ENGLAND-Not native, but frequently planted as an ornamental tree or for hedges and escaped from cultivation; Maine-young trees in the southern sections said to have been produced from selfsown seed: New Hampshire and Vermont-introduced; Massachusettsoccasional; Rhode Island-introduced and fully at home. Probably sparingly naturalized in many other places in New England.

IN CONNECTICUT-Fare, occasional or local.

wooD-Hard, strong. coarse-gralned, very durable in contact with soils, red or bright red-brown. with thin, pale sapwood of 10-12 layers of annual growth; largely used for fence posts and rails, for the hubs of wheels and in conseruction. 

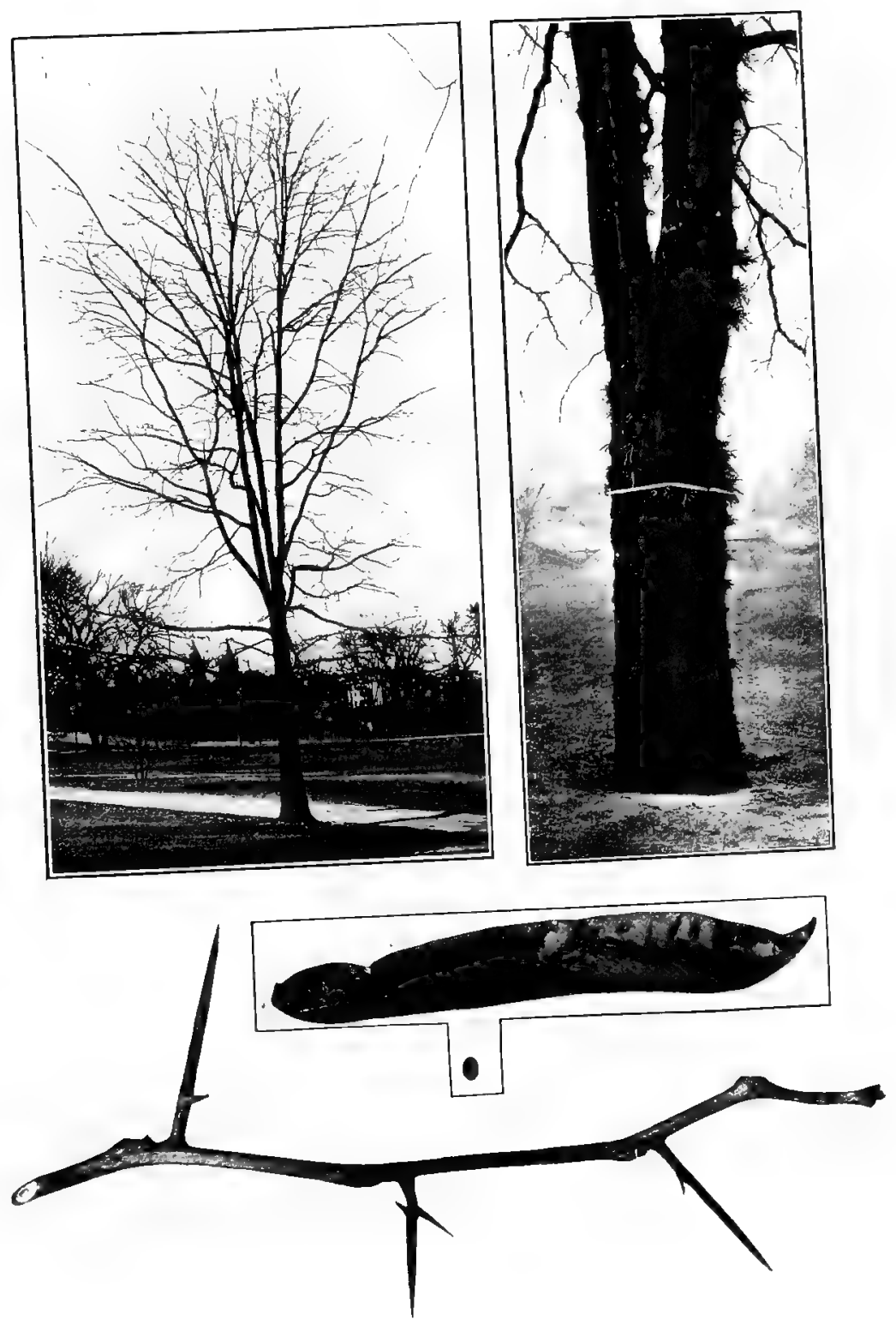

Honey Locust 


\section{REDBUD \\ Judas Tree.}

Cercis canadensis $\mathrm{L}$.

HIBIT-A small tree up to $40 \mathrm{ft}$. in height though generally smaller, develuping an upright or a low, broad, irregular head.

BIRk-Feddish-brown to almost black, somewhat ridged and scaly.

TwiGs-Slender, dark reddish-brown, smooth, more or less zigzag. LENTICELS-very numerous, minute. PITH-especially of older growth, generally with reddish longitudinal streaks.

LEAF-sc.Rs-Alternate, 2-ranked, small, slightly ralsed, inversely triangular, with short, decurrent, spreading, more or less evident ridge from outer edges. STIPULE-SCARS-absent. BUNDLE-SCARS-3, large.

BLDS-Terminal bud absent, lateral buds small, $3 \mathrm{~mm}$. Iong, or generally much smaller, blunt, dark purplish-red, somewhat flattened and appressed, one or more superposed buds often present the uppermost the largest; flower buds conspicuously present on older wood often at the base of a branch (see plate) or even on the trunk itself. BUD-SCALES-overlapping, somewhat hairy on the edges, about 2 visible to a leaf bud, several to a flower bud.

FRIIT-A flat pod about 3 inches long, with small compressed seeds.

COMP.ARISONS-The stout purplish flower buds below the insertion of the branches on the old wood will serve to identify this small tree. The reddish streaks in the older pith seem to be a constant character so far as investigated and if so will be a useful mark of distinction.

DISTRIBLTION-Not native to New England but frequently planted as an ornamental tree. It grows native along the borders of streams and rich bottom land from ontario to New Jersey south to Florida and west to Minnesota and Arkansas.

WooD-Heavy, hard, not strong, close-grained, rich dark brown tinged with red, with thin lighter colored sapwood of $8-10$ layers of annual growth; of little commercial importance. 


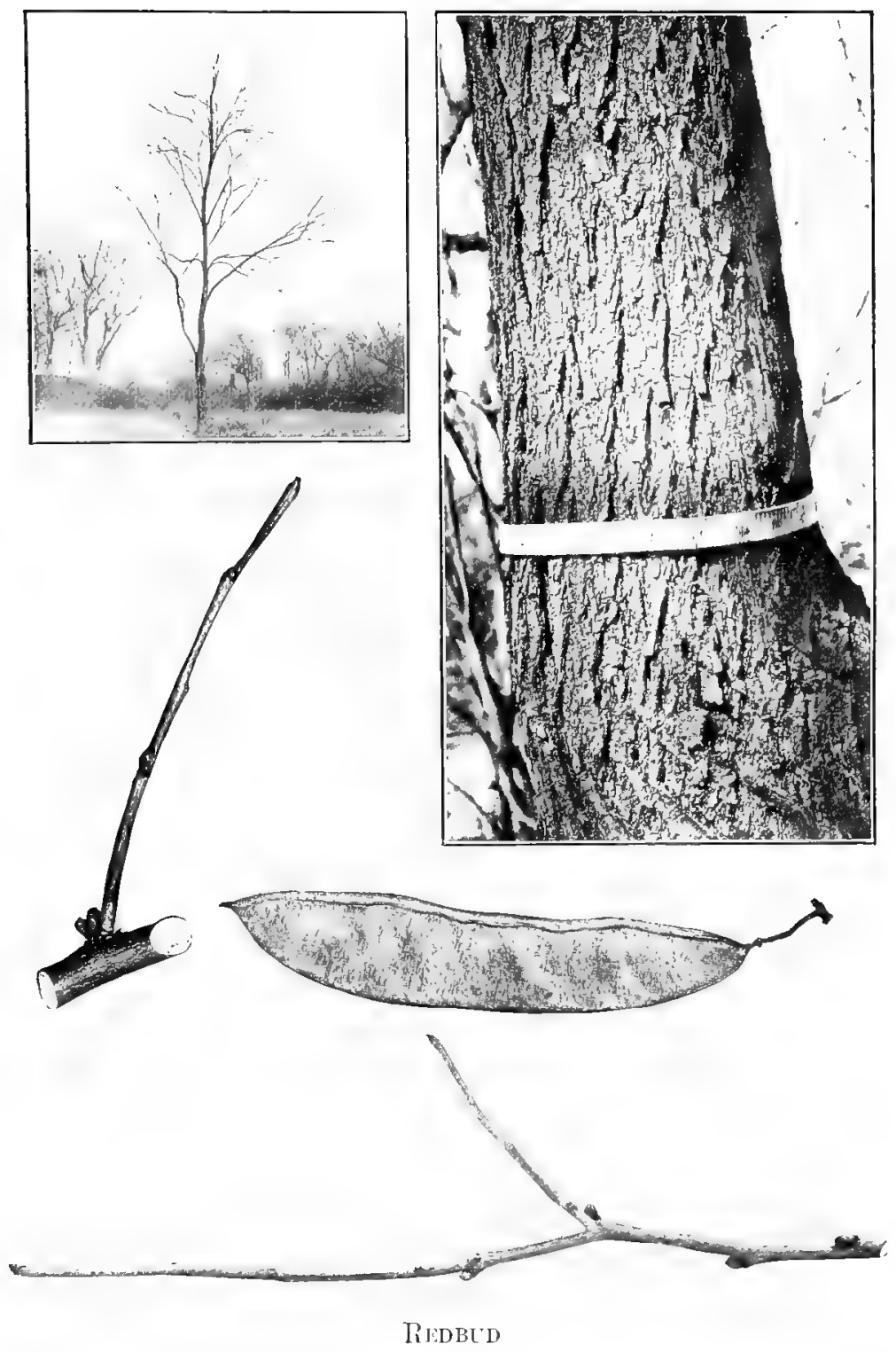




\section{YELLOW WOOD Virgilia, Gopher Wood.}

Cladrastis lutea (Mx. f.) Koch.

HABIT-A small tree under $50 \mathrm{ft}$. in height with trunk diameter or 1-2 ft.; trunk generally dividing low down into several slightly spreading limbs with numerous slender more or less zigzag branches, the lower often strongly declined, forming a broad rounded head.

BIRK-Thin, gray to light brown, in general smooth, resembling bark of the Beech with slight protuberances or ridges and horizontal wrinkles.

TWIGs-Rather slender, more or less zlgzag, brittle, smooth bright reddish-brown, covered often by a grayish skin, odor and taste resembling that of a raw dried pea or bean. LEXTICELS-pale, scattered, generally conspicuous. PITH-wide, white, round in section.

LFIF-SCARS-Alternate, 2-ranked, or more than 2-ranked, raised, pale Jellow, forming a $V$-shaped collar of almost uniform diameter nearly encircling the bud. STIPULE-SCARS-absent. BUNDLE-SCARStypically 5 (4-9) generally regularly spaced and raised or at times some of the five indistinct or lacking.

BIDs-Terminal bud absent, lateral buds naked, superposed, 3-4, the uppermost the largest and generally alone developing, flattened. closely packed together to form a pointed bud-like hairy cone generally under $5 \mathrm{~mm}$. long, nearly surrounded by the leaf-scar. BUD-SCALESabsent, their place taken by the densely hairy immature leaves.

FRLIT-A smooth flat margined pod $5-10 \mathrm{~cm}$. long, containing a few small oblong compressed seeds.

COMPARISONS-The Tellow Wood is well characterized by Its beech-like bark, its slender twigs, and its superposed hairy buds closely clustered into a bud-like cone and practically surrounded by the leafscar and is therefore scarcely to be confused with any other tree.

DISTRIBITION-In rich soil, limestone ridges and often along mountain streams, rare and local. Western Nurth Carolina, Kentucky. Tennessee, Alabama, Missouri; often cultitated in New England as an ornamental tree.

wooD-Heavy, very hard, strong and close-grained, with a smooth, satiny surface, briglit clear yellow changing to light brown on exposure, with thin nearly white sapwood; used fur fuel, occasionally for gun stocks and yielding a clear yellow dye. 

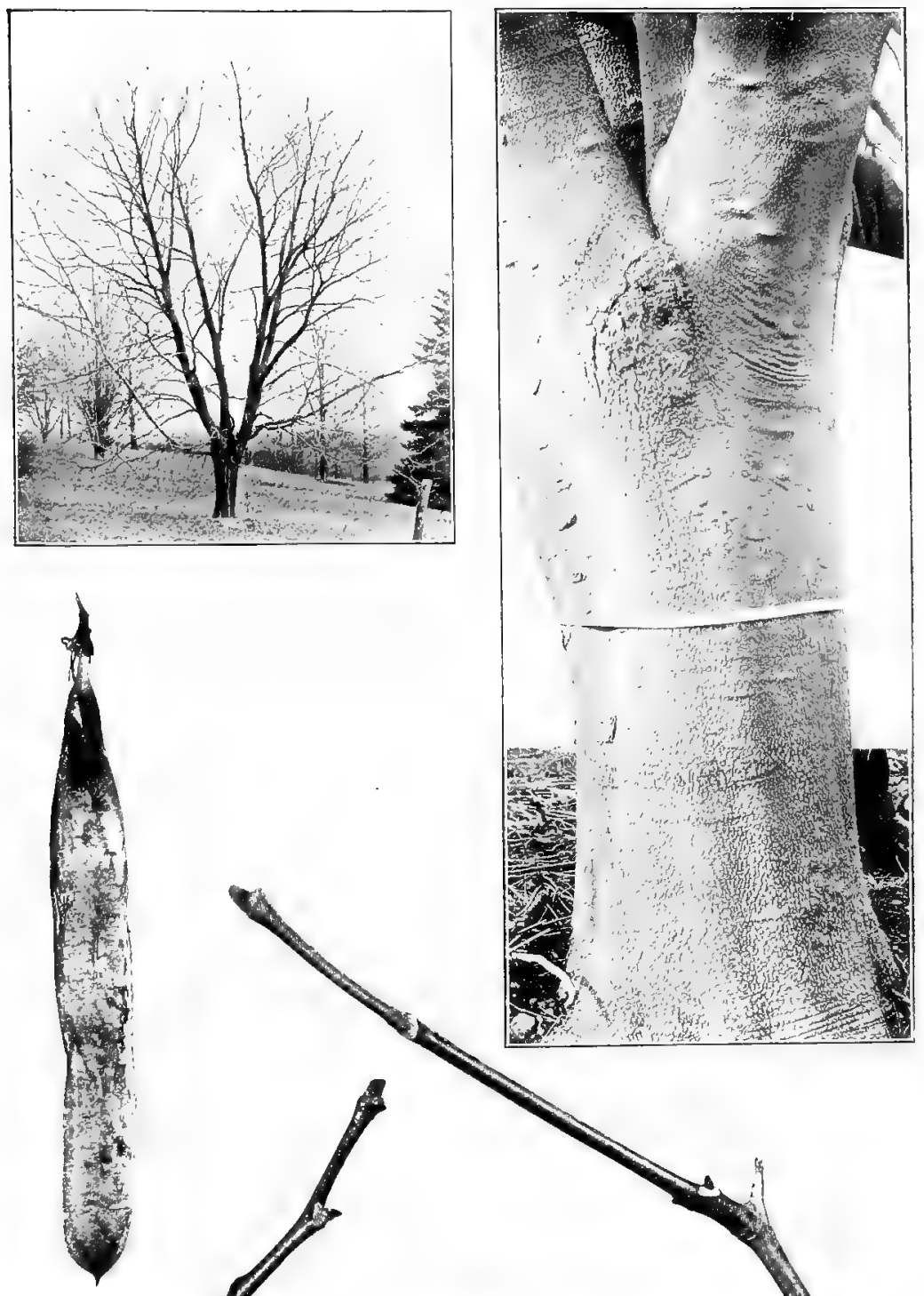


\section{COMMON LOCUST \\ Black, Yellow or White Locust, Locust, Acacia. \\ Robiuia Pseudo-Acacia L.}

H IBIT-Generally a small tree $20-35 \mathrm{ft}$ or occasionally $50-75$ ft. in height with a trunk diameter of eight inches to $21 / 2 \mathrm{ft}$; trunk erect or in rined, frequently dividing into a number of ascending limbs with slender scraggly branches forming a narrow oblong open head; often sireading by underground stems and forming thickets of small trees. A rapidly growing tree but slort lired and subject to the attacks of burers.

H.MF-Rough even on young trunks, dark reddish to yellowishbrown, becoming deeply furrowed into rounded ridges, not flaky.

TWIGs-Rather slender, brittle, often zigzag, light reddish to greenish-brown. smooth or nearly so, more or less angled with decurrent ridges from base and outer angles of leaf-snars, generally spiny with naired stipular prickles at nodes. LENTICELS-pale, scattered. PITHwide, mure or less angled.

LEAF-SCARS-Alternate, more than 2-ranked, generally large and conspicunus, inversely triangular to pentagonal, raised, covering the buds. STIPULES-in the fnrm ne prirklfs, sometimes poorly developed or entirely lacking. BLNDLE-SCAFS-3.

RI DS-Terminal bud absent; lateral buds minute, rusty-downy, 3-4 superposed, generally close together, enclosed in a rusty-downy cavity below the leaf-scar which cracks between the bundle-scars at the development of a branch usually from the uppermost bud exposing the long rusty hairs attached to under side of the three persistent lobes of the leaf-scar: on rapidy gromn shoots, the uppermost bud often develons into a branch the first season. Which may be rudimentary and deciducus, leaving a small scar above leaf-scar.

FRI IT-A dark bromn. flat nod, $5-10 \mathrm{~cm}$. long, containing $4-8$ small bromn mottled flatish seeds, persistent on the tree throughout the winter.

coMPARIsoxs-The paired prickles at the nodes form the most striking character of the Common Locust but since they are absent on sume twigs and entirely lacking on certain ratieties, the hidden closelynqcked downy buds must be taken as the chief distinguishing features. They separate the Common Locust from the Honey Locust when the characteristic branched thorns are not present on the latter species. The Clammy Lomust. [Robmia viscosa Tent] is a small southern tree frequently cultivated and established at many points throughout New Fngland. It has the general characters of the Common Locust but the stipular prickles are less well developed and its twigs are covered with a sticky glandular coating. The Bristly Locust [Robinia hispida L. $]$ is a mere shrub with twigs heset with bristly hairs but without stipular prickles. The Prickly Ash or Toothache Tree [Zanthoxulon americanum L.], a shrub occurring throughout New England resembles the Lncust in its stipular prickles flower twig in plate). It is readily distinguished from the Locusts, howerer, by the red downy exposed clustered huds, the presence of a terminal bud and the pungent flavor (it its twigs.

DISTRIBI TIOY-In its native habitat growing upon mountain slopes. along the borders of forests. in rich soils. Naturalized from Nora S.entia to Ontario. Native from southern Pennsylyania along the mountains to Genrgia: West to Jnwa and southward. Formerly much planted as an ornamental and timber tree; more cultivated in Europe than any other American tree.

IN XET ENGLAND-Maine-thoroughly at home forming wooded hanks along streams: New Hampshire-ahundant enough to be reckoned among the valuable timber trees: Termont-escaped from cultiration in many nlaces: Massarhusetts. Fhnde Jsland-common in patches and thirkets and along the roadsides and fences.

IN CONXECTICUT-Frequent as an escape from cultivation.

wooD-Heary, exceedingly hard and strong, close-grained, very durable in contact with the soil. brown or rarely light green. with rale vellow sapwond of two or three layers of annual growth: extensively used in shiphuilding for all sorts uf prists, in construction and turnery; preferred for tree nalls and ralued as fuel. 

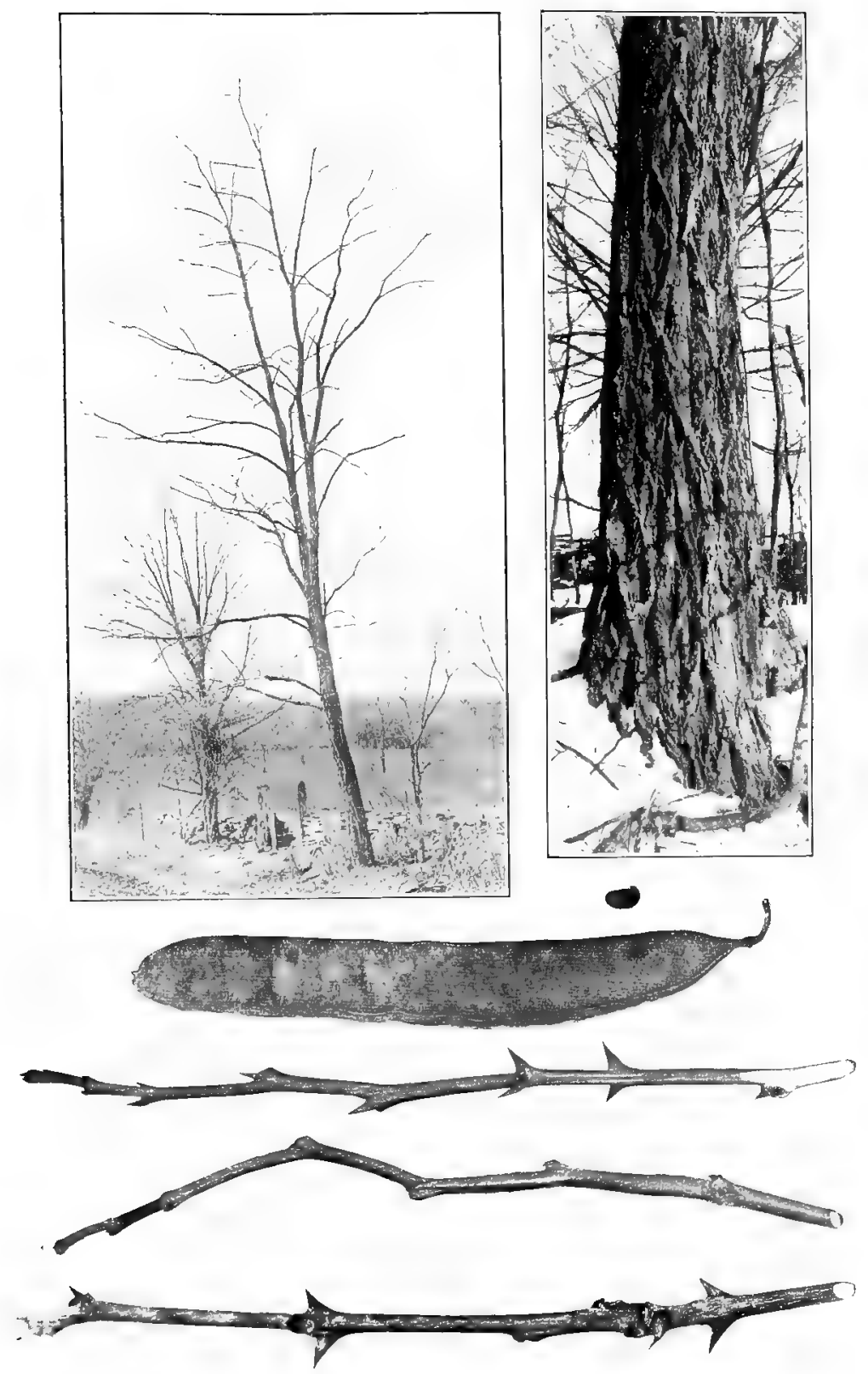

Comaron Locust

Prickly Asf (lower twig only) 


\title{
AILANTHUS \\ Tree of Heaven, Chinese Sumach. \\ Ailanthus glandulosa Desf.
}

\begin{abstract}
H.MFT-A small to good sized tree 50-75 ft, in height with a trunk diameter of $2-3$ ft.; forming a wide flat-topped head with stout branchlets devoid of spray; freely sprouting from the roots; the female trees which are more frequently planted than the male often retaining the clusters of winged fruit throughout the winter.
\end{abstract}

BARK-Grayish, slightly roughened with fine light colored longitudinal streaks in striking contrast to the darker background.

TWIGS-Stout, yellowish to reddish-brown covered with very short fine velvety down, or smooth, rather rank-smelling, when crushed, older twigs often shedding the down in the form of a thin skin and exposing very fine light longitudinal striations below, LENTICELS-scattered, pale, somewhat longitudinally elongated becoming on older growth conspicuous more or less diamond-shaped cracks. PITH-wide, chocolate brown.

LEAF-SCARS-Alternate, more than 2-ranked, large, conspicuous, heart-shaped. STIPLLE-SCAFS-absent. BUNDLE-SCARS-conspicuous, often compound or curved, generally under a dozen in number, forming a curved line.

BUDS-Terminal bud absent, lateral buds relatively small generally under $4 \mathrm{~mm}$. long. half-spherical, reddish-brown, downy. BUD-SCALES -thick, the 2 opposite lateral scales generally alone showing.

FRIIT-About $4 \mathrm{~cm}$. long, winged, spirally twisted, the seed in the center, borne in conspicuous clusters which frequently remain on tree during winter. The species is dioecious, there being male trees bearing only staminate flowers and hence producing no fruit and female trees bearing only pistillate flowers and producing fruit. Owing to the vile smelling character of the staminate flowers, the male trees are now seldom planted.

CoMP.ARISoNs-The Ailanthus in its stout twigs resembles somewhat the Kentucky Coffee Tree but its buds are solitary and not sunken, its pith is brown rather than salmon-colored and its bark is not ridged as is the bark of the Kentucky Coffee Tree. From the stout-twigged Black Walnut and Butternut it is distinguished by its solitary buds and continuous pith; from the Staghorn and Smooth Sumachs by its broad leat-scars.

DISTRIBI'TION-A native of China sparsely and locally naturalized in southern Ontario, New England and southward; a very rapid grower, thriving under the most unfavorable conditions of city existence.

wooD-Light brownish-yellow, with lighter sapwood, soft, weak, rather open-grained; in Europe used in the manufacture of woodenware and charcoal, little used in this country. 

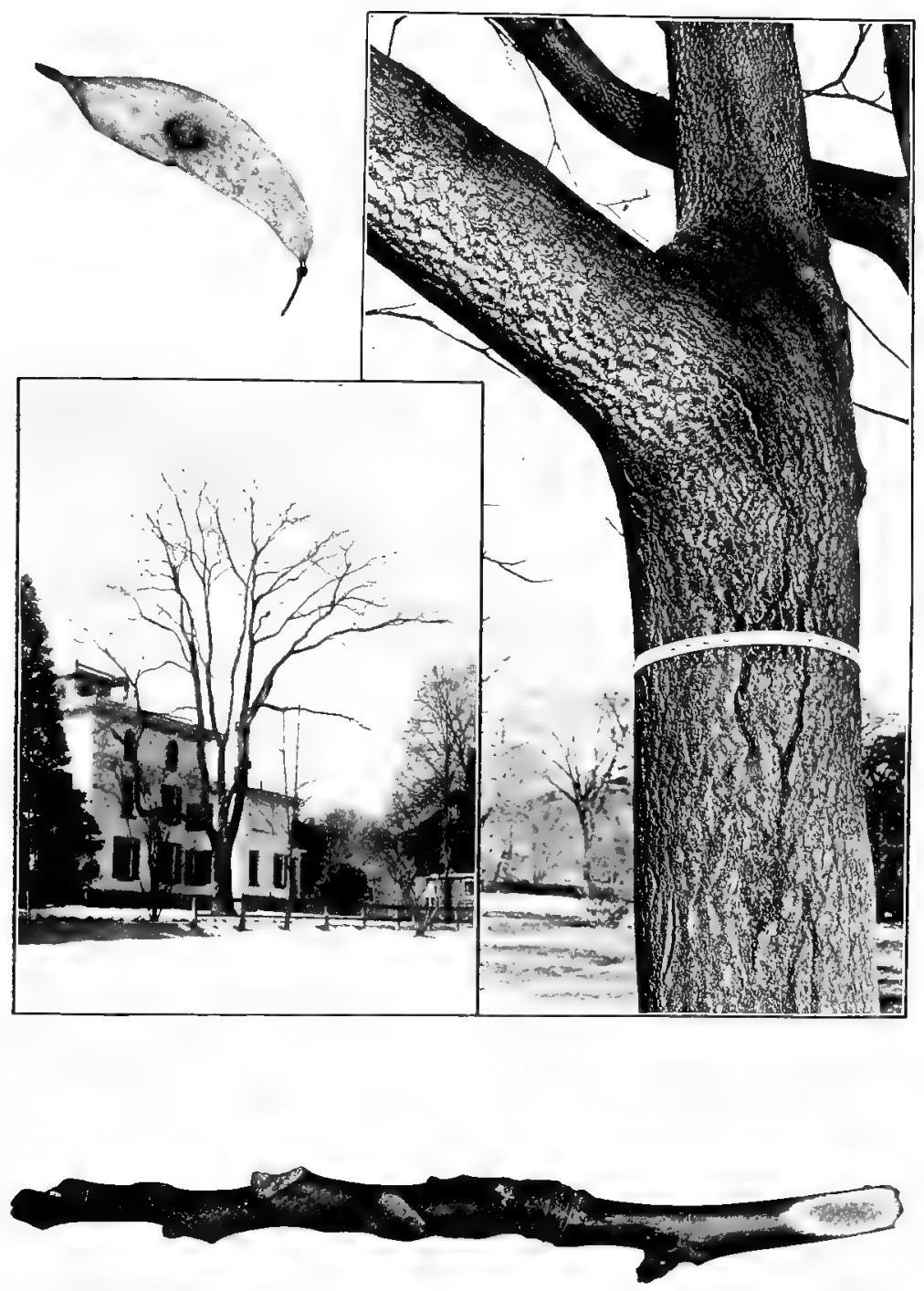


\title{
STAGHORN SUMACH
}

\author{
Rhus typhina L. \\ R. hirta (L.) Sudw. \\ (Lefthand twig and lower habit picture in plate)
}

HIBIT-A shrub or small tree rarely over $25 \mathrm{ft}$. in height with a trunk diameter less than a foot; making a straggling growth with forked branching forming a flat head with conspicuous red frult clusters generally present and stout relvety branchlets; sprouting abundantly from the roots and thus forming broad thickets.

BARk-Thin, dark brown, smooth or in older trees more or less rough-scaly.

TWIGS-Stout, conspicuously covered with long velvety olive brown to almost black hairs, whence the common name from resemblance to a stag's antlers in the "velvet"; the tips often killed back sereral inches by the frost; cut twig exuding a copious white milky juice. LENTICELS-conspicuous except as covered by the hairs, orange colored, becoming laterally enlarged rough dots on older growth. PITH -wide, yellowish-brown.

LEIF-sC.RS-Alternate, more than 2-ranked, deeply T-shaped, almost encircling the bud. STIPULE-SCAIR-absent. BLNDLE-SCARS - scattered or frequently arranged in 3 groups, generally not conspicuous.

BIDs-Terminal buds absent, lateral buds conical, densely coated With long rusty hairs.

FRI IT-In rather compact, erect, cone-like clusters; individual fruits. drupes about $4 \mathrm{~mm}$. in diameter coated with acid-tasting red hairs and enclosing a small bony-covered seed. The conspicuous red fruiting clusters are persistent throughout the winter but, since the species tends to be dioecious, are not borne by all trees.

COMPARISONS-A somewhat smaller form. the Smooth Sumach [Fhus glabra L.]. closely resembles the Staghorn Sumach in habit, twig and fruit characters but the twigs are smooth (except the fruit stalks which may be downy) and generally are covered with a bloom. (See twig on right and upper habit picture in plate.) The Dwarf Sumach. [Rhus copallina L.], is generally smaller in New England than the other sumachs. It has red fruit clusters like the smooth and the Staghorn Sumachs but is distinguished from these two forms by the watery instead of white milky juice, by the leaf-scars which do not surround the bud and by the turpentine flavor to the young twigs. For comparison with the Poison Sumach see latter species.

DISTRIBL TIOX-In widely varying soils and localities, river banks. rocky slopes to an altitude of $2,000^{\circ} \mathrm{ft}$. cellar holps and waste places generally, often forming copses. From Nova Scotia to Lake Huron; south to Georgia; West to Minnesota and Missouri.

IN NET ENGLAND-Common throughout.

WoOD-Light, brittle, soft, coarse-grained, orange-colnred, streaked with green. With thick nearly white sapwood. Pipes for drawing the sap of the sugar Maple are made from the young shoots. The bark especially of the roots is rich in tannin. 

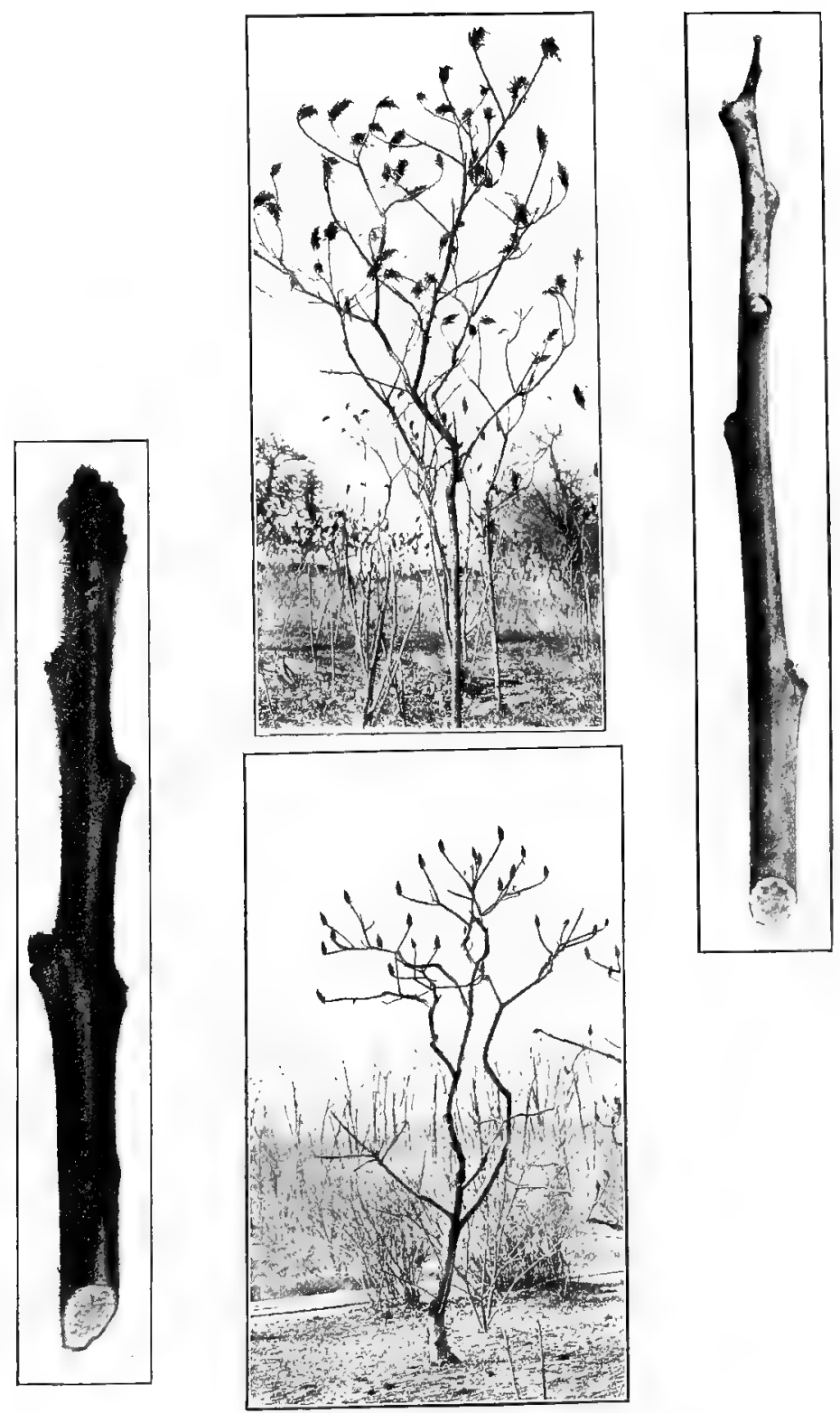

Stagiorn and Smooth Sumach 


\section{POISON SUMACH \\ Poison Dogwood, Poison Elder, Swamp Sumach. Rhus Vernix L. \\ R. venenata DC.}

HABIT-A shrub or small tree 5-20 ft. in height with a trunk diameter reaching 8-10 inches; trunk generally forking near the ground producing an open, rounded, bushy head.

B.IRK-Thin, light gray, smooth or slightly roughened with more or less conspicuous horizontally elongated lenticels.

TwrGs-Stout, brown to orange brown, older growth light gray, smooth, with watery resinous juice turning black on exposure. LENTICELS-numerous, minute, raised dots. PITH-yellowish-brown.

LEIF-SCARS-Alternate, more than 2-ranked, comparatively large, conspicuous, inversely triangular, raised, upper margin straight, slightly depressed or elevated, pointed and projecting. STIPULE-SCARS - bsent. BUNDLE-SCAFS-conspicuous, irregularly scattered in a clused ring or a single curved line.

BCDs-Terminal buds present, small but larger than laterals; shortconical, 3-20 mm. long, purplish. BUD-SCALES-finely downy on the back and margins.

FICIT-A globular, slightly compressed, striate drupe about $5 \mathrm{~mm}$. in diameter. very shiny, ivory white or yellowish-white, generally persistent through the winter in lung pendant clusters. The species is dioecious, however, and therefore some trees do not fruit.

COMP IRISONS-From the other Sumachs the Poison Sumach is dis. tinguished by the presence of a terminal bud, its broad leaf-scars not encirting the bud, with conspicuous generally scattered bunde-scars. The loose clusters of white fruit are distinctive when present. The Poison Sumach is almost entirely confined to swamps or wet places While the other Sumachs grow for the most part in dryer situations. The Poison Sumach resembles its climbing relative the Poison Ivy [ $R h u s$ Toxicodendron L.] in that all parts of the plant at all times of the year contain an oil poisonous to the touch only more actively so. Some indiriduals are more and others less susceptible. A preventive against the poison is thoroughly to wash as soon as possible in strong alcohol or strong soap suds the parts of the body that have come in contact with the plant.

DISTRIBL TION-Low grounds and swamps; occasional on the moist slopes of hills. Infrequent in Ontario; south to northern Florida; west to Minnesuta and Louisiana.

IN NETV ENGLAND-Maine-local and apparently restricted to the southwestern sections; as far north as Chesterville, Franklin county; Termont-infrequent; common throughout the other New England states, especially near the seacoast.

IN CONNECTICUT-Occasional in most districts, becoming frequent near the coast.

WOOD-Light, soft, coarse-gralned, light yellow, streaked wlth brown. with lighter colored sapwood. The juice can be used as a black lustrous durable varnish. 

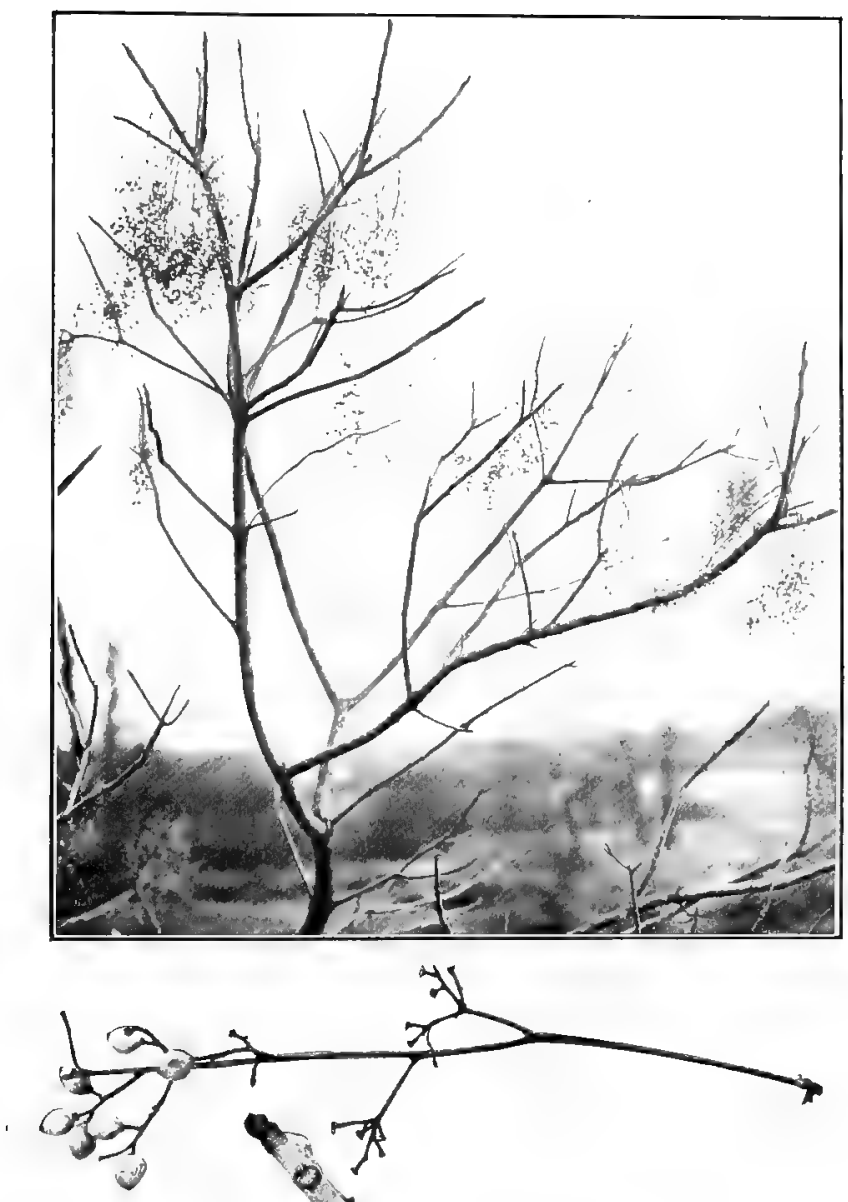


\section{HOLLY \\ American Holly, White Holly. Ilex opaca Ait.}

HIBIT-A shrub or small tree rarely reaching $30 \mathrm{ft}$. In height, with a trunk diameter of 15-18 inches; larger south and west; with slender horizontal drooping or slightly ascending branches furming a compact conical head with spiny evergreen leaves.

B.RK-Light gray, smooth becoming somewhat roughened with age.

TWIGS-Rather slender, grayish to yellowish brown, smooth or more or less downy. LENTICELS-inconsilicuous.

LEIF-SCIRS-Alternate, more than 2-ranked, semi-oval. BUNDLESCAFis-sulitary.

LENVES-Thick, erergreen, elliptical to oborate, spiny-tipped and with few sping leeth or rarely entire, dull yellowish-green above. pale and yellowtr beneath: midrib prominent beneath, with short, stout, slightly fine-downy leaf-stalks, gruoved above. STIPULES-minute, awIshaped, persistent.

IBIDS-Short, blunt, roundish, more or less downy, terminal bud printed.

FHIIT-Persistent through the winter, about the size of a pea, dull red or rarely yelluw berr-like. will four ribbed nutlets. Some trees bear only sterlle flowers and therefore never pruduce fruit.

COMP.ARIsoxs-The American Holly closely resembles the cultivated European Holly [Ilex Aquifolium L.] but the leaves of this latter specits are describcd as glossier, of a deever green color, more wavynargined with whilish iranslucent edges, and the berries as of a deeper red color.

DISTRIBI TION-Generally found in somewhat sheltered situations in sandy loam or in low, moist soil in the ricinity of water. Massachusetts, southrard to Florida; westward to Missouri and the bottom-lands of eastern Texas.

IN NET ENGLAND-Maine-reported on the authority of Gray's Manual, sixth edition. in rarious botanical works but no station is known: New Hampshire and Termont-no station reported; Nassachusetts-occasional from Quincy south ward upon the mainland and the 1sland of Naushon: rare in the peat sivamps of Nantucket; Thode Island common in south Kingston and Little Compton and sparingly found upon Prudence and Conanicut islands in Narragansett Bay.

IN CONNECTICLT-Rare; roadsides and thickets; escaped from cultivation or possibly native.

WOOD-Light, tough, not strong, close-grained, nearly white when first cut, turning brown with age and exposure. with thick rather lighter colored sapwond, ralued and much used in cabinet making, in the Interior finish of houses and in urnery; the branches are much used in Christmas decuratiuns 

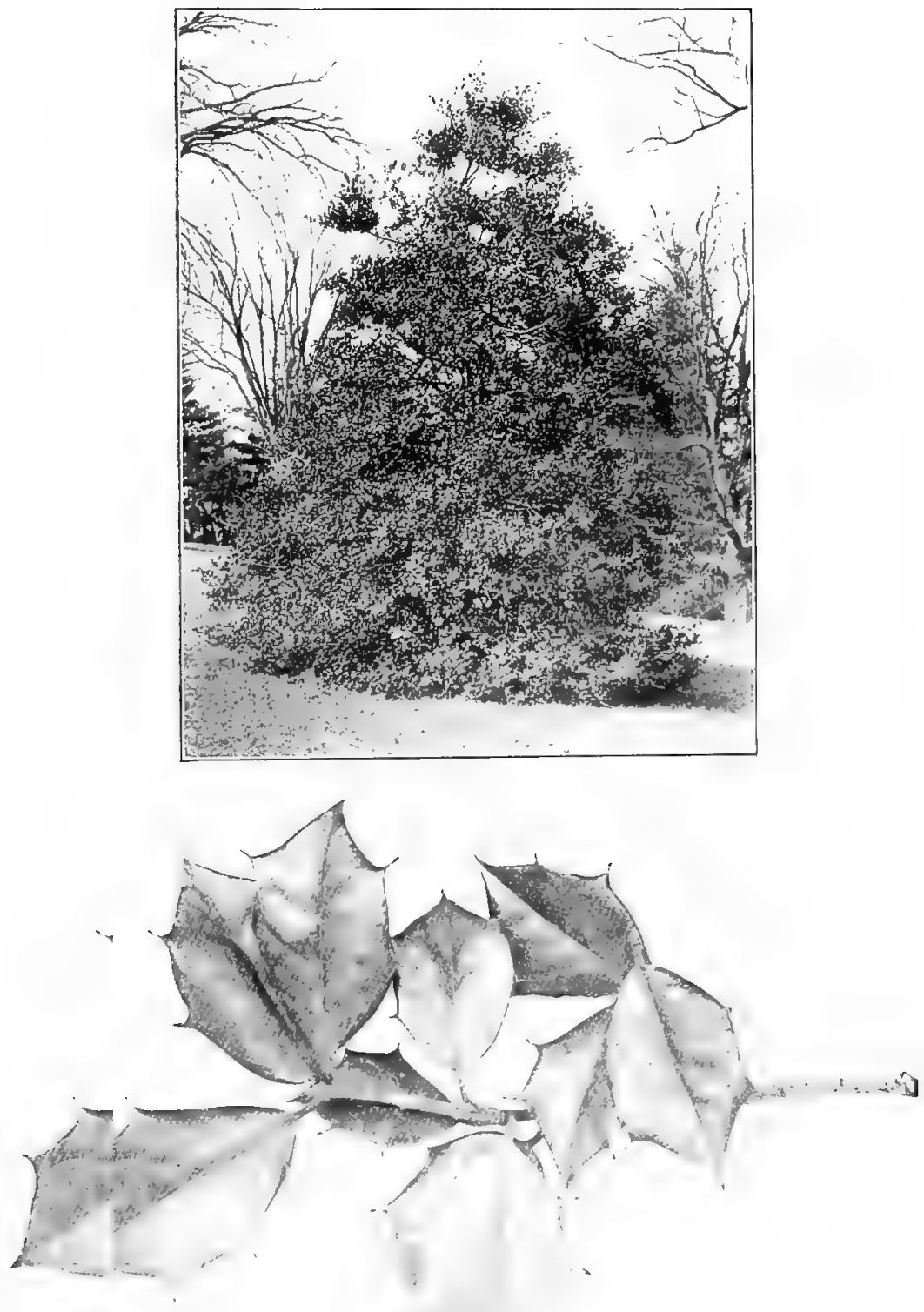

IIOLLY 


\section{STRIPED MAPLE Moosewood, Whistlewood. Acer pennsylvanicum L.}

HIDIT-A shrub or small tree 15-30 ft. high with a short trunk 5-10 Inches in diameter and slender straight branches, forming in northern New England a large part of the underbrush and a favorite food of moose and deer whence the name of Moosewood.

BIRI-Rather thin, reddish-brown or dark green, conspicuously streaked longitudinally with narrow white lines, at length dark gray. often transversely warty.

TWIGS-Stout, smooth, red or green; year's growth marked by two circles formed by scars of the two outer pairs of bud-scales. LENTICELS-inconspicuous. PITH-brown.

LE IF-SCARS-Opposite; wide, broadly V-shaped; their adjacent edges nearly meeting and forming a pair of short stubby teeth separated by a more or less well developed decurrent ridge. BUNDLE-SCARS-3, generally more or less compounded forming often 5 to 7 separate bundle-scars.

BTDS-Distinctly stalked, 6-10 $\mathrm{mm}$. long exclusive of the rather long stalk, tapering to a blunt tip, red, shining, more or less 4-sided; terminal bud larger than appressed lateral buds. BUD-SCALES-the thick, red. single, outer pair only visible, enclosing an inner pair of thick palehaly scales, within which are enclosed one or more pairs of thin green scales.

FRIIT-In long drooping terminal racemes with thin widely spreadIng wings; $2-2.5 \mathrm{~cm}$. long, seed-like portion rather long with a pit-like depression on one side; the elongated racemes from which the fruit has fallen often remaining on tree throughout winter.

COMPARISONs-Easily distinguishable at all times from all other Maples by the striking white streaks in the young bark which appear often as early as the second year (see photograph of twig) and persist even on comparatively old trunks. The large stalked buds are also characteristic. The brown pith of the twig and the one-sided pitting of the seed-like portion of the fruit are characters which distinguish the Bush Maples (i.e. the Mountain and the Striped) from our other species of the genus. Forms of the genus Viburnum. Which are for the most part shrubs, resemble somewhat the Bush Maples but, aside from having drupe-like frults, may generally be easily distinguished by bud characters:-some having naked, others scurfy buds, some with the first pair of scales shorter than the bud and some with the second pair of scales smooth.

DISTRIBCTIOX-Cool, rocky or sandy woods, usually in the shade of other trees. Nova Scotia to Lake Superior; south on shaded mountain slopes and in deep ravines to Georgia; west to Minnesota.

IN NEW ENGLAND-Maine-abundant, especially northward in the forests; New Hampshire and Vermont-common in highland woods: Massachusetts-common in the western and central sections, rare towards the coast; Rihode Island-frequent northward.

IN CONNECTICTT-Rocky woods in rich soll; occasional in the north western part of the state, becoming rare eastward and southward, reaching Ashford, East Haddam, Huntington and Redding.

WoOD-Light, soft, close-grained, light brown with thick lighter colored sapwood of $30-40$ lajers of annual growth. 

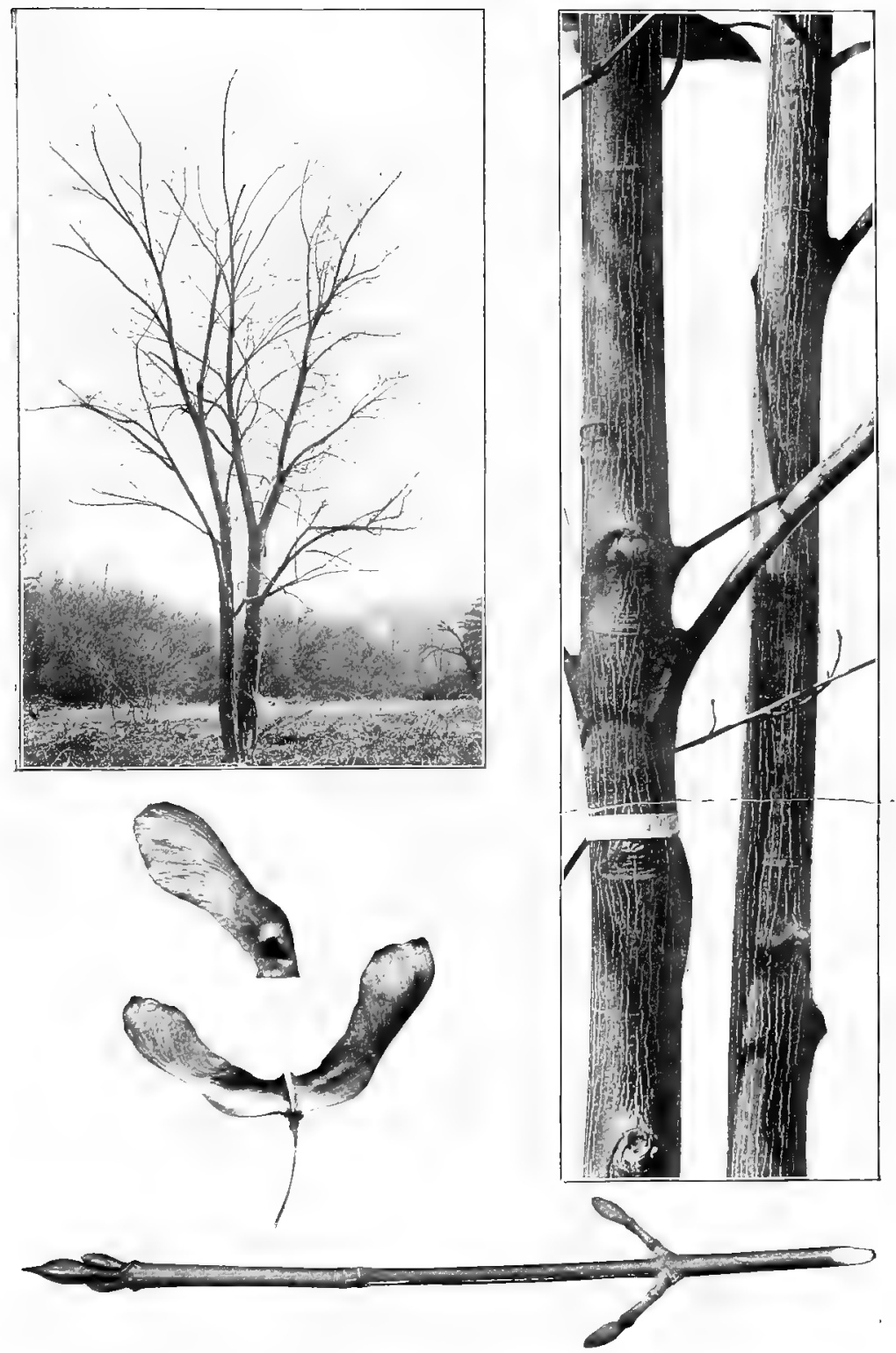

Striped Maple 


\section{MOUNTAIN MAPLE}

\section{Acer spicatum Lam.}

H IBIT-Shrub or small bushy tree up to $25 \mathrm{ft}$. in height with a trunk diameter of 6-8 inches; trunk short, straight, with slender upright branches.

MIRK-Very thin, reddish-brown to dingy-gray, smooth or slightly furrowed.

TwIGS-Slender, bright red to purple on upper side where exposed to the light, yellowish to greenish on shaded under side, color persisting for several years; covered especially toward tip with short appressed grayish hairs, which may persist in scant amount for several years toward upper part of each year's growth. Year's growth marked by $2-3$ circles furned by scars of bud-scales. LENTICELS-fer. inconspicuous. PITH-brown.

LEIF-SCIRS-Opposite, narrow, Tr-shaped, margined by a lighter colored and mure or less raised rim, nearly meeting. BUNDLE-SCARS3 , undirided.

BCDS-Stalked, small, slender, pointed; generally under $6 \mathrm{~mm}$. in length including stalk, re or greenish, covered, especially the terminal buds. With short appressed grayish hairs; terminal bud larger than appressed lateral buds. BLD-SCALES-thick, 2-3 pairs, one or at most 2 pairs visible, the second pair hairy.

FICIT-In drooping racemes with wide more or less spreading wings about $2 \mathrm{~cm}$. or less long, seed-like portion short, with pit-like depressicin on one side.

CoMp.risoxs-Resembles the Striped Maple (which see) in habit, distribution, color of twigs and few scales to the stalked buds. It differs from the Striped Maple in absence of white streaks on young bark and by pale down on twigs and especially on the smaller buds.

DISTIRB TIOX-Noist rocky hillsides usually in the shade of other trees. From Nova Scotia and Newfoundland to Saskatchewan, along mountain ranges to Georgia.

IN NEW EXGLAND-Maine-common, especially northward in the forests; New Hampliire and Termont-common; Massachusetts-rather common in western and central sections, occasional eastward; Rhode Island-occasional northward.

IN CONXECTICCT-Occasional in the northern part of the state, becoming rare southmard, reaching East Haddam, Guilford at Bluff Head, Meriden and Redding.

Woop-Light, soft, close-grained, light brown tinged with red, with thick lighter colored saproor. 

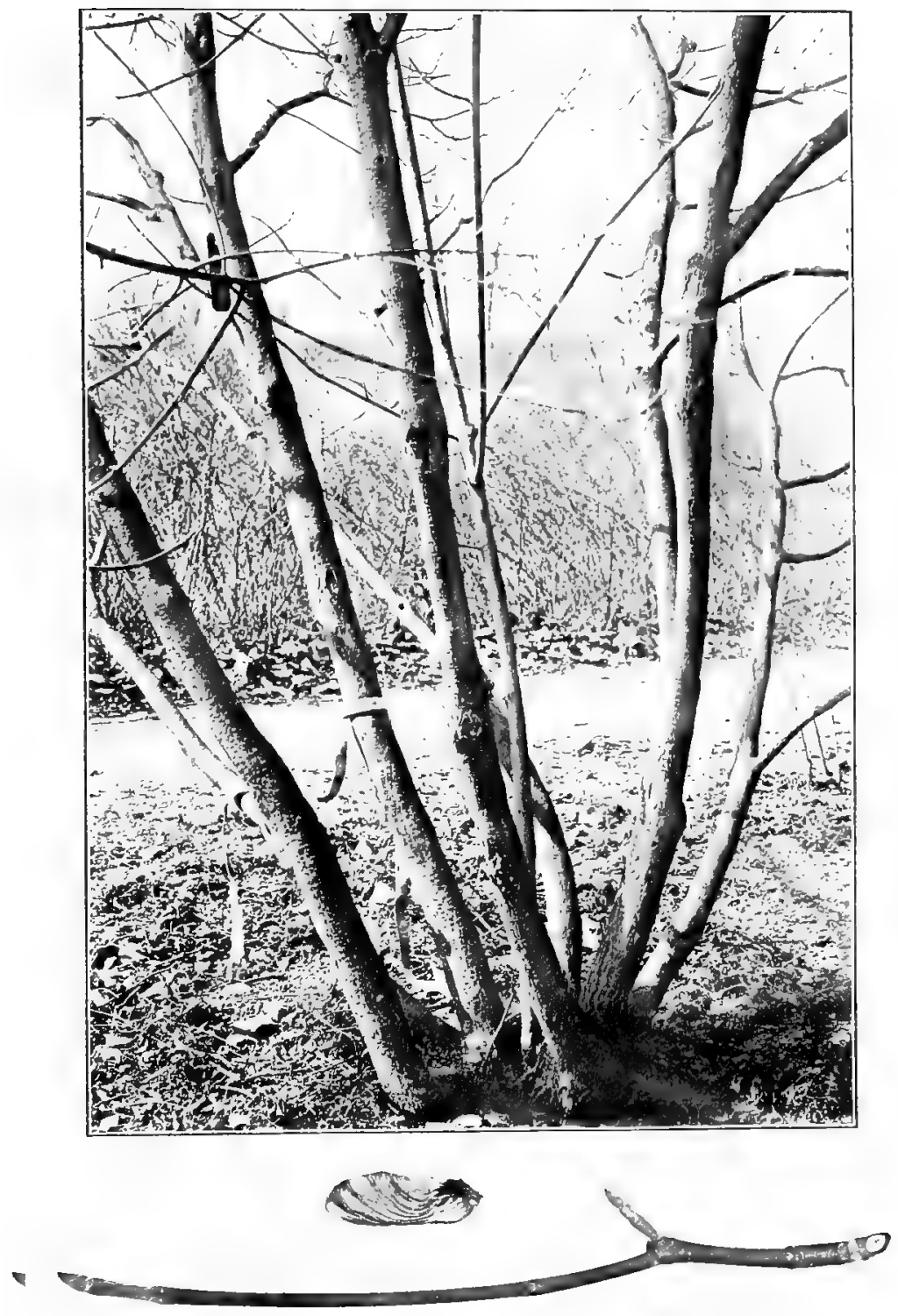

Mountain Maple 


\section{SUGAR MAPLE Rock Maple, Hard Maple. \\ Acer saccharum Marsh.}

A. saccharinum Wang., not L.; A. barbatum Michx.

HABIT-A large tree 50-90 ft. in height, with trunk diameter of $2-5$ ft.; trunk more or less continuous, in the open developing at $8-10 \mathrm{ft}$. from the ground stout, erect branches which form in young trees a broad or narrow egg-shaped head. becoming frequently a broad, roundtopped head when older. Leares sometimes persistent into winter especially on lower branches of joung trees.

BIRK-On young trunks and limbs dark gray, with tinge of buff, close and firm, smooth or slightly fissured, becoming deeply furrowed into long, thick. irregular plates which often curve back along one edge, giring ploughed appearance to the trunk. Some trees are to be found with yellowish-gray, more or less flaky bark. (See upper bark picture).

TWIGS-Slender, shining, reddish-brown to buff tinged with orange. smooth. LENTICELS-numerous, pale, conspicuous. PITH-white.

LEAF-SCARS-Opposite, narrow V-shaped; outer margins of a pair nearly meeting; often pale downiness within leaf-scar. BUNDLESCAFS-3, sometimes compound.

BUDS-Conical to orate, sharp-pointed, reddish-brown, rather downy especially toward tip; terminal bud 4-6 $\mathrm{mm}$. long, about twice as long as appressed lateral buds. BUD-SCALES-overlapping, 4-8 pairs visible, their margins finely hairy.

FR CIT-3-5 cm. long, in short terminal clusters, wings broad, parallel or slightly spreading.

CoMPARISONs-The Sugar Maple is readily distinguished from other maples by its narrow, conical, sharp-pointed, brown buds and by the large number of scales to the bud. The fruit clusters of the Sugar Maple are from terminal buds, those of the Red and the Silver Maple are from lateral buds. The fruiting of the Sugar Maple in consequence causes a noticeable forking of the twigs while it does not interrupt the growth in the Fed and the Silver Maple. Further, fruit stalks and sometimes even the fruits themselves are persistent into winter on the Sugar Maple and are not persistent on the Red and the Silver. The Black Maple [Acer saccharm, var, nigrum (Michx. f.) Britton] is found in the northern part of New England but is too closely related to the Sugar Maple to be considered a distinct species. It has darker buds and bark than the type form.

DISTRIBUTION-Rich woods and rocky slopes, frequently planted by roadsides. Nova Scotia and Newfoundland; westward to Lake of the Woods; south to the Gulf States; west to Minnesota, Nebraska, Kansas and Texas.

IN NEW ENGLAND-Abundant, distributed throughout the woods, often forming in the northern portlons extensive upland forests; attainIng great size in the mountainous portions of New Hampshire and Termont, and in the Connecticut river valley; less frequent toward the seacoast.

IN CONNECTICUT-Frequent or common in northern districts, becoming rare near the coast, except as an escape from cultivation.

woOD-Heavy, hard, strong, close-gralned, tough, with a fine satiny surface susceptible of receiving a good polish, light brown tinged with red, with thin sapwood of 30-40 layers of annual growth; largely used for the interior finish of buildings, especially for floors, in the manufacture of furniture and in turnery, in shipbuilding, shoe-lasts and pegs and largely as fuel. Accidental forms with the grain curled and contorted, known as Curly Maple and Bird's Eye Maple, are common and highly prized in cabinet making. Maple sugar is principally made from the sap of this tree. 

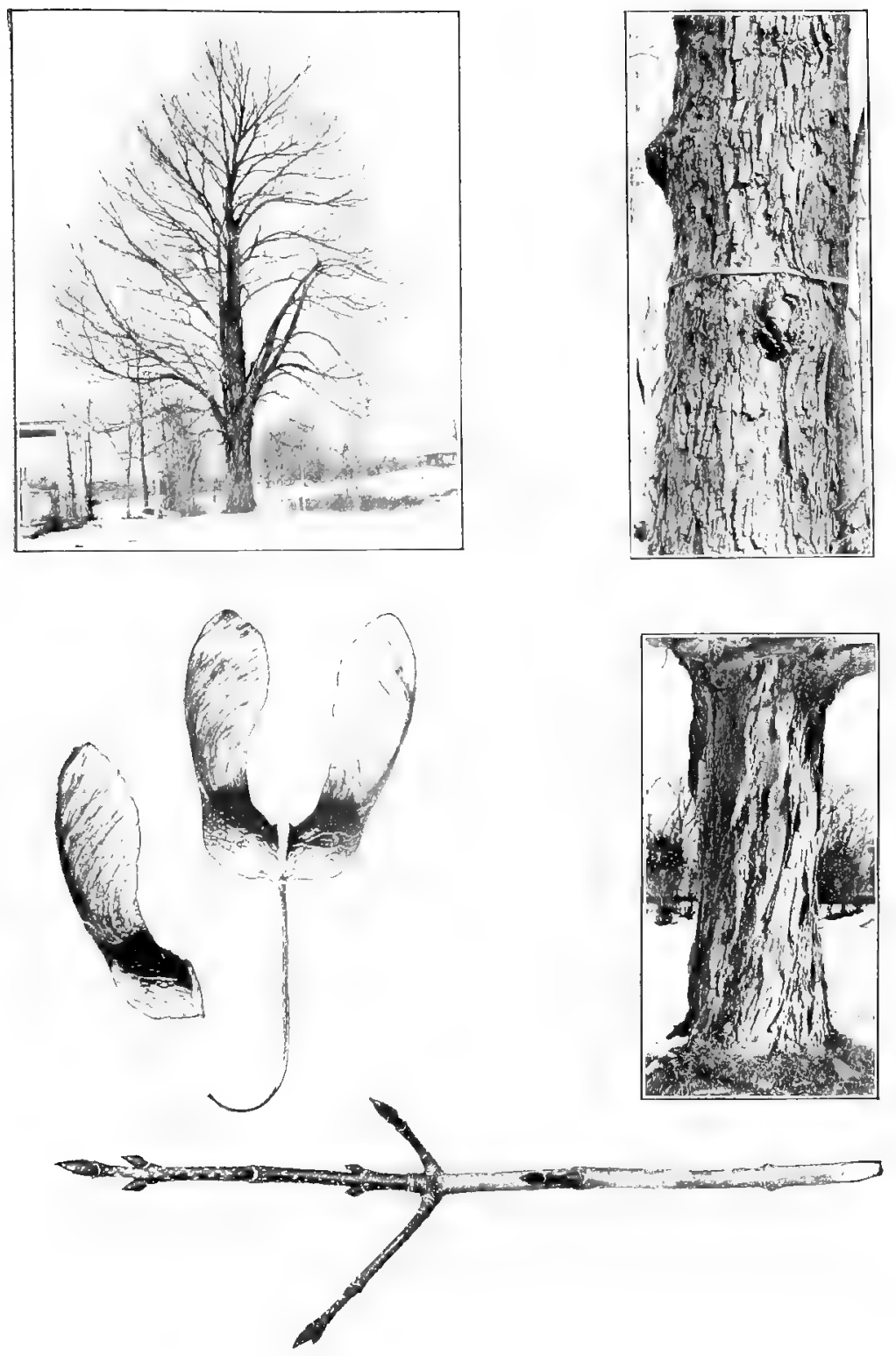

Sugar Maple 


\section{SILVER MAPLE White, River, or Soft Maple.}

Acer saccharinum L.

A. dasycarpum Ehrh.

HIBIT-A good sized tree $50-60$ ft. high with trunk diameter of 2-5 ft.; dividing near the ground into several slightly spreading limbs which bran. i further up. turming a very wide, broad-topled head. Lateral branchlets strongly tend to grow downward and then curve sharply upward at their tips.

BIRI-smooth, gray, with reddish tinge on young trunks and brimlies; on ulder trunks redish-brown more or less furrowed; the surface separating into long thin flakes which become free at the ends and flake off exposing the redder inner layers.

TWICS-Similar to those of Red Maple but with a distinct rank odor when freshly cut or broken.

LEIF-sCIRS-Similar to those of Red Maple.

BIDs-Similar to those of the Red Maple but generally somewhat larger. the flower buds more densely clustered with a larger number of buds in a cluster.

FHI IT-Large, 4-7 cm. long, wings spreading, in lateral clusters, ripening in early spring and therefore difficult to find in winter.

COMPARISONS-The Silver Maple closely resembles the Red Maple in twig characters but can be readily distinguished from the latter by the rank odor of the fresh twigs when broken. The flakiness of the bark of the Silver Maple is also distinctive. The bending down of the branchlets with a sharp upward curve at their tips while much more marked in the Silver Maple occurs to a certain extent in the Red and therefore cannot be depended upon alone as a distinctive character. If the flower buds be dissected out and examined with a hand-lens the immature flowers of the Silver Maple will be found to be surrounded by a culv-like calyx which in the Red Maple is made up of separate dirisions. See under Red Maple for Comparisons with other species.

DINTRIBITIOY-Along river banks and In moist deep-soiled woods, not typically in swamps; often planted for ornament under the name of White Maple. Infrequent from New Brunswick to ottawa, abundant frnm Ottawa throughont Ontario: south to the Gulf states; west to rakota. Nebraska, Kansas, and Indian Territory; attaining its maximum size in the basins of the ohio and its tributaries; rare towards the seacoast throughout the whole range.

IN NEW ENGLAND-Occasional throughout: most common and best developed upon the banks of rivers and lakes at low altitudes.

IN CONNECTICUT-Frequent inland along the larger streams, rare elsewhere.

woOD-Hard, strong, close-grained, easfly worked, rather brittle, pale brown with thick sanwood of $40-i 0$ layers of annul growth: now sometimes used for flonring and in the manufacture of furniture. Sugar is occasionally made from the sap. 

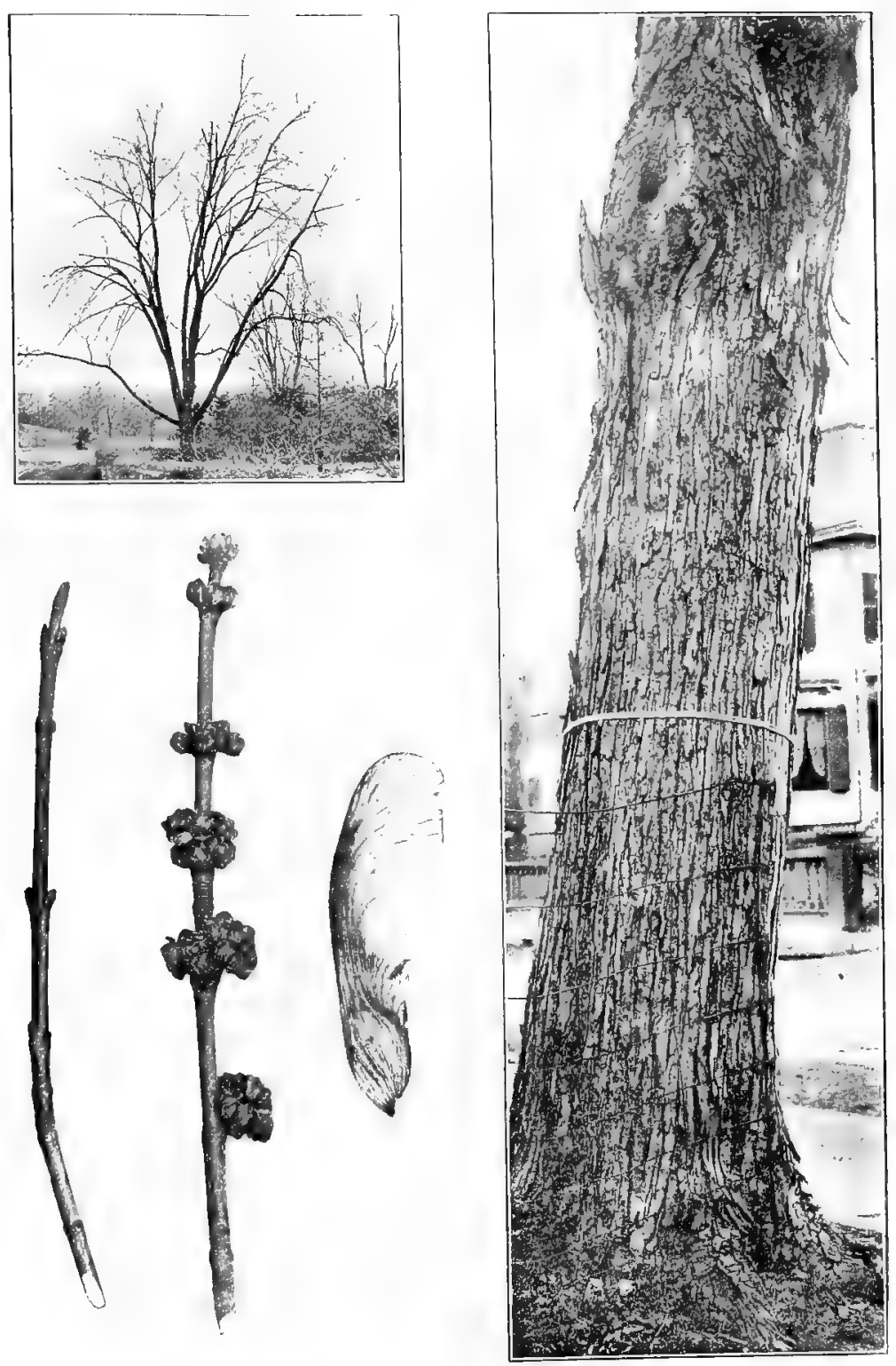

Silver Maple 


\section{RED MAPLE \\ Swamp, Soft or White Maple. \\ Acer rubrum L.}

HA BIT-A medium sized tree, 40-50 ft. high, occasionally in swamps reaching 75 ft. in height, with trunk diameter of $2-4 \mathrm{ft}$; branching low down and forming an oblong, rather compact head, frequently largest at the top but sometimes broad at the base. Branches slender as well as branchlets, the latter showing slight tendency to turn up at their tips; upper branches appearing decidedly gray and often resembling those of the Beech if viewed with the light.

BIRI-Smooth, light gray on young trunks and branches; on older trunks very dark gray, roughened into long ridges, sometimes somewhat shaggy and separating in long plates. (See right hand bark photograph).

TWIGs-Rather slender, bright or dark red, shining; odorless when cut. LENTICELS-numerous, conspicuous. FITH-pinkish toward upper part at least of each year's growth beyond the second.

LEAF-sCARS-Broad, U to V-shaped, adjacent edges notmeeting. BUNDLE-SCARIS-3.

BCDs-Red, blunt-pointed, broadly oval-ovate to spherical in flower buds, generally under $5 \mathrm{~mm}$. long, short-stalked; flower buds numerous, stout, collateral (one on ejther side of smaller axillary bud). BUDSCALES-4 pairs or generally fewer visible with pale hairs on margins, outer pair of scales not over half covering the bud.

FRUIT-Small, generally under $3 \mathrm{~cm}$. long, wings spreading, In lateral clusters, ripening in spring and therefore difficult to find in winter.

COMPARISONS-The Red Maple closely resembles the Silver Maple in the winter condition. See Silver Maple under Comparisons for differences. The Red and the Silver Maple are distinguishable from our other Maples except the Box Elder by presence of collateral buds, and the numerous clusters of these flower buds give a characteristic beaded appearance to the twigs against the sky; from the Striped and Mountain Naples by the larger number of scales exposed in the bud; from the Striped and the Norway and Sycamore Maples by much smaller buds; from the Mountain Maple and the Box Elder by their smooth outer bud: scales; from the Sugar Maple by their red twigs and by their red, blunt buds with few scales. See under Sugar Maple.

DISTRIBUTION-Borders of streams, in low lands, wet woods and swamps or sometimes in dry ground, of rapid growth and a favorite for park planting but usually not adapted to city streets. Nova Scotia to the Lake of the Woods; south to southern Florida; west to Dakota, Nebraska and Texas.

IN NEW ENGLAND-Common throughout from the sea to an altitude of $3,000 \mathrm{ft}$, on Katahdin.

\section{IN CONNECTICUT-Common.}

woOD-Very heavy, close-grained, not strong, light brown often slightly tinged with red, with thick, rather lighter colored sapwood: used in large quantities in the manufacture of chairs and other furniture, in turnery, for wooden-ware and gun-stocks. 

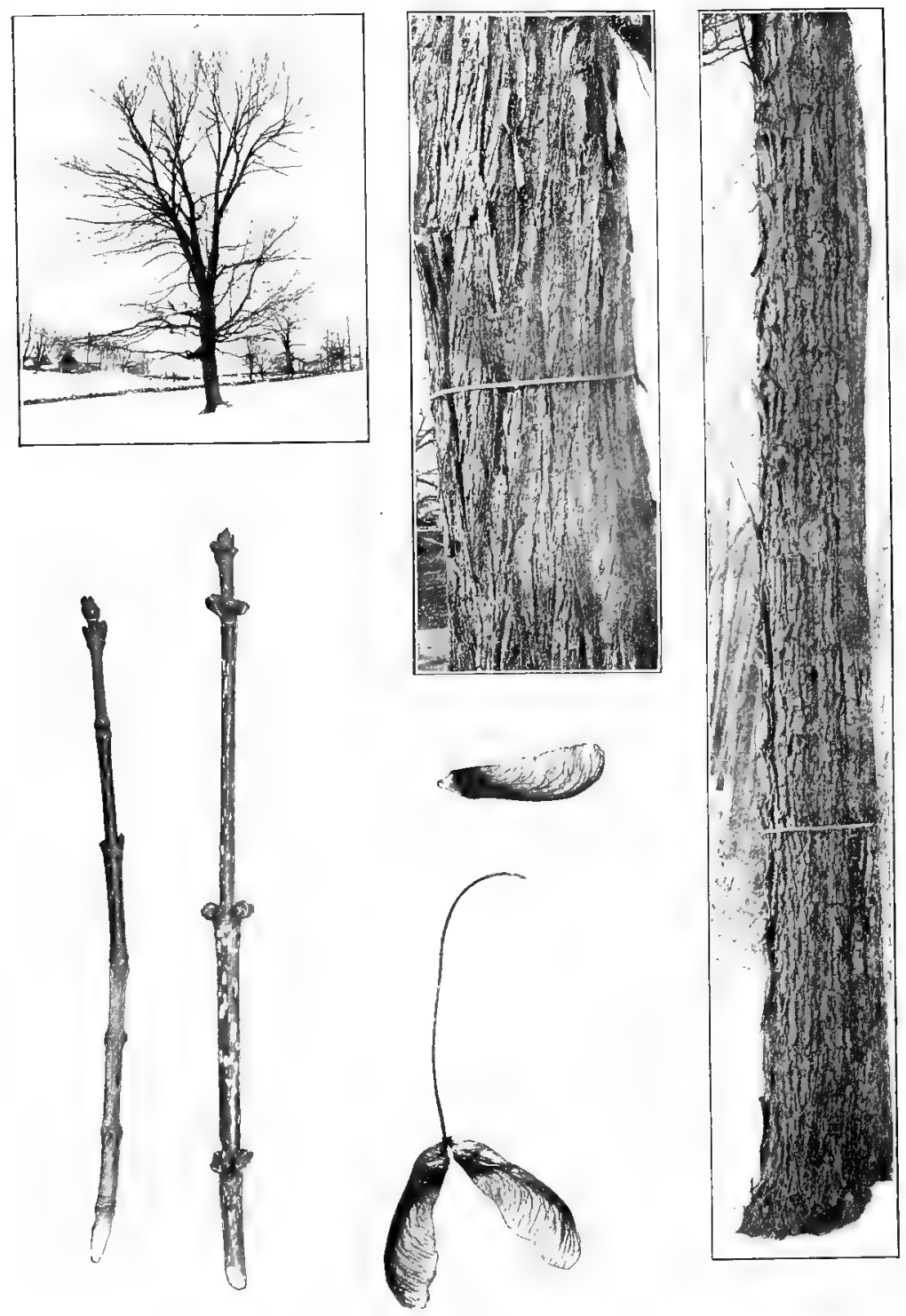

Red Maple 


\section{NORWAY MAPLE Acer platanoides $L$.}

HIBIT-A mediumly large tree reaching in Europe $100 \mathrm{ft}$. in helght, with ruund spreading head.

BIRK-Dark, broken into firm, close, narrow ridges which run together and enclose small diamond-shaped spdces, somewhat resembling bark of White Ash but the ridges and diamond-shaped spaces are finer.

TWIGs-Stout. smooth, shining, brown to greenish or yellowishbrown, branchlets of two or mure years growth and even vigorous season's shoots plainly streaked with fine, irregular, longitudinal cracks in bark.

LEAF-SCIRS-Opposite, narrow $V^{r}$-shaped, half encircling the twig, the adjacent edges of opposite leaf-scars meeting and continued upward into a short touth. BUNDLI-SCARS-3.

BCDS-Completely red or yellowish-green toward the base, sometimes whole bud stroncly tinged with yellowish-green; terminal bud larger than lateral buds, $5-\$ \mathrm{~mm}$. long. more than $1 / 2$ as broad as long, oval to ovate; generally with a pair of comparatively large lateral buds below terminal bud; lateral buds small, appressed. BUD-SCALES-thick. more or less keeled, margin very finely hairy scales to terminal bud generally 5 pairs-2, or at most 3 pairs only showing smooth but enclosing " pairs which are thickly covered with dark rusty-brown hairs; in small buds sometimes 4 pairs smooth and 1 pair hairy.

FRIIT-Generally over $5 \mathrm{~cm}$, long, seed-like portion flattish, with wings diverging in a straight line.

Comp.risovs-The Norway Maple is easily distinguished from the Sycamure Maple by the redness of its buds, the brown hairiness of the inner scales, the ridging of the bark and the divergence of the wings of the fruit; from the native Maples by the large buds and the characteristically ridged bark.

DISTRIBI TIOX-A European form extensirely cultirated as a shade tree being more tolerant of unfavorable city conditions than most other forms. Its low head, however, is a disadvantage for city street planting.

wo00-Moderately heavy, hard, clnse-grained, white or yellowishWhite, fairly durable under cover but of short duration in the open; used In Europe by joiners, for finer wheelwrights' work, for carving, for mathematical instruments and for various other purposes. 

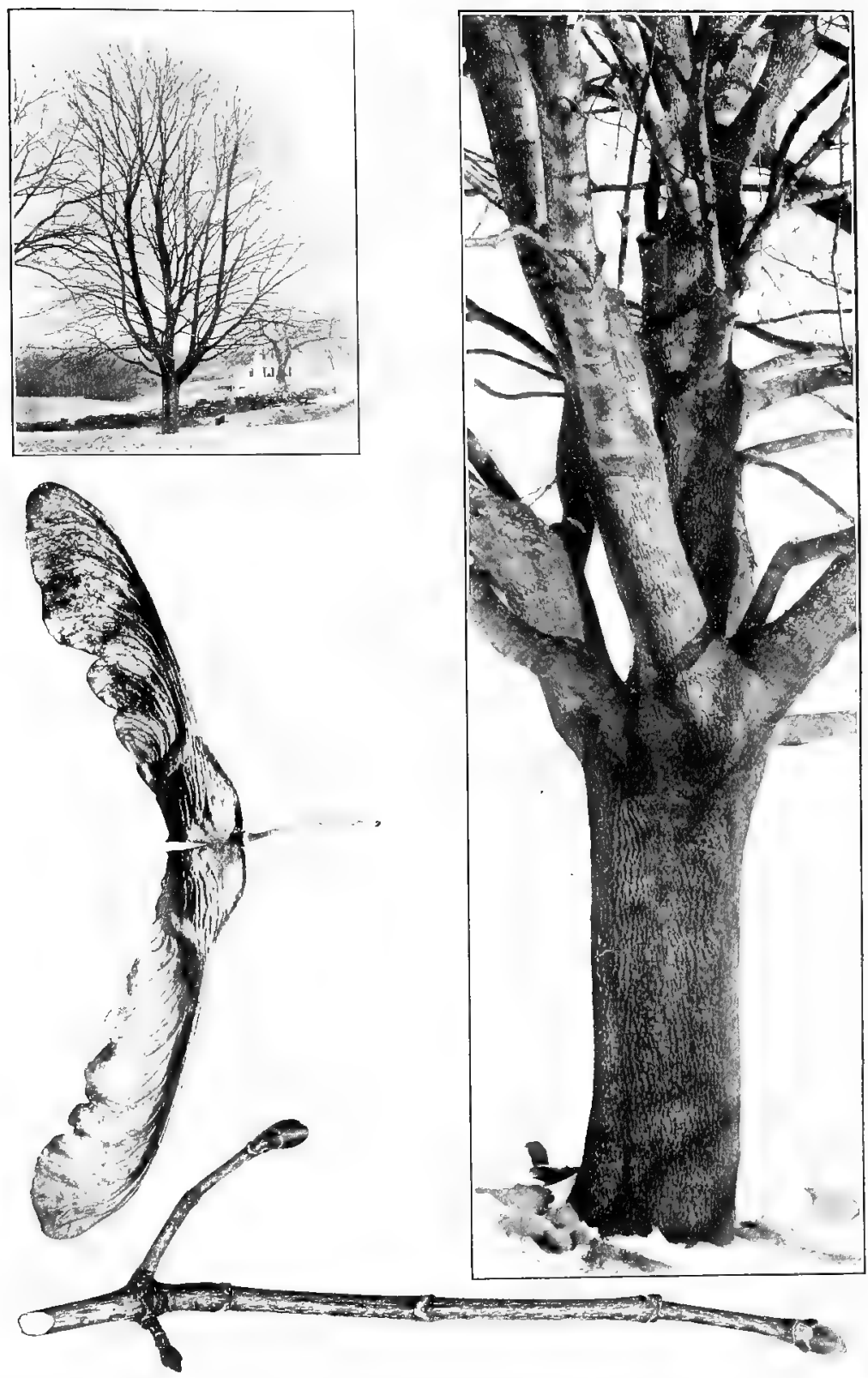

Norway Maple 


\section{SYCAMORE MAPLE}

\section{Acer Pseudo-Platanus L.}

H IBIT-A rather large tree of vigorous growth, reaching in Europe $120 \mathrm{ft}$. in height, with large spreading head.

B.RI-Dark reddish-brown, flaking off in squarish or short oblong scales.

TWIGs-Stout, smooth, shining, yellowish-greenish to brown.

LEIF-SCARS-Opposite, shallow. V-shaped; adjacent edges of opposite leaf-scars not meeting. BUNDLE-SCARS-3 elongated lengthwise with the leaf-scar or compound.

BIDs-Green, sometimes sllghtly reddlsh, terminal bud larger than lateral buds, $7-12 \mathrm{~mm}$. long, broadly oval to ovate to nearly spherical, much more than 1/2 as wide as long; lateral buds divergent. BUD. SCALES-more or less keeled, with dark brown edging, dark polnted apex and finely hairy margin; scales to terminal bud, 6-7 pairs, 3 pairs at least generally visible, the outer scales smooth, the 2 inner scales thickly covered with silvery white hairs.

FRIIT-Generally less than $5 \mathrm{~cm}$. long, seed-like portion nearly spherical. wings making about a right angle resembling fruit of the Sugar Maple.

Comp.risons-Distinguished from the Norway Maple by the green buds, having outer scales with dark margins and white-hairy inner scales and by the flaky bark; from the native Maples by the larger buds and the peculiar bark.

DISTRIBL TION-A European form, cultivated in the United States as a shade tree but less extensively than the Norway Maple.

WoOD-Similar in character to that of the Norway Maple and used for the same purposes. 

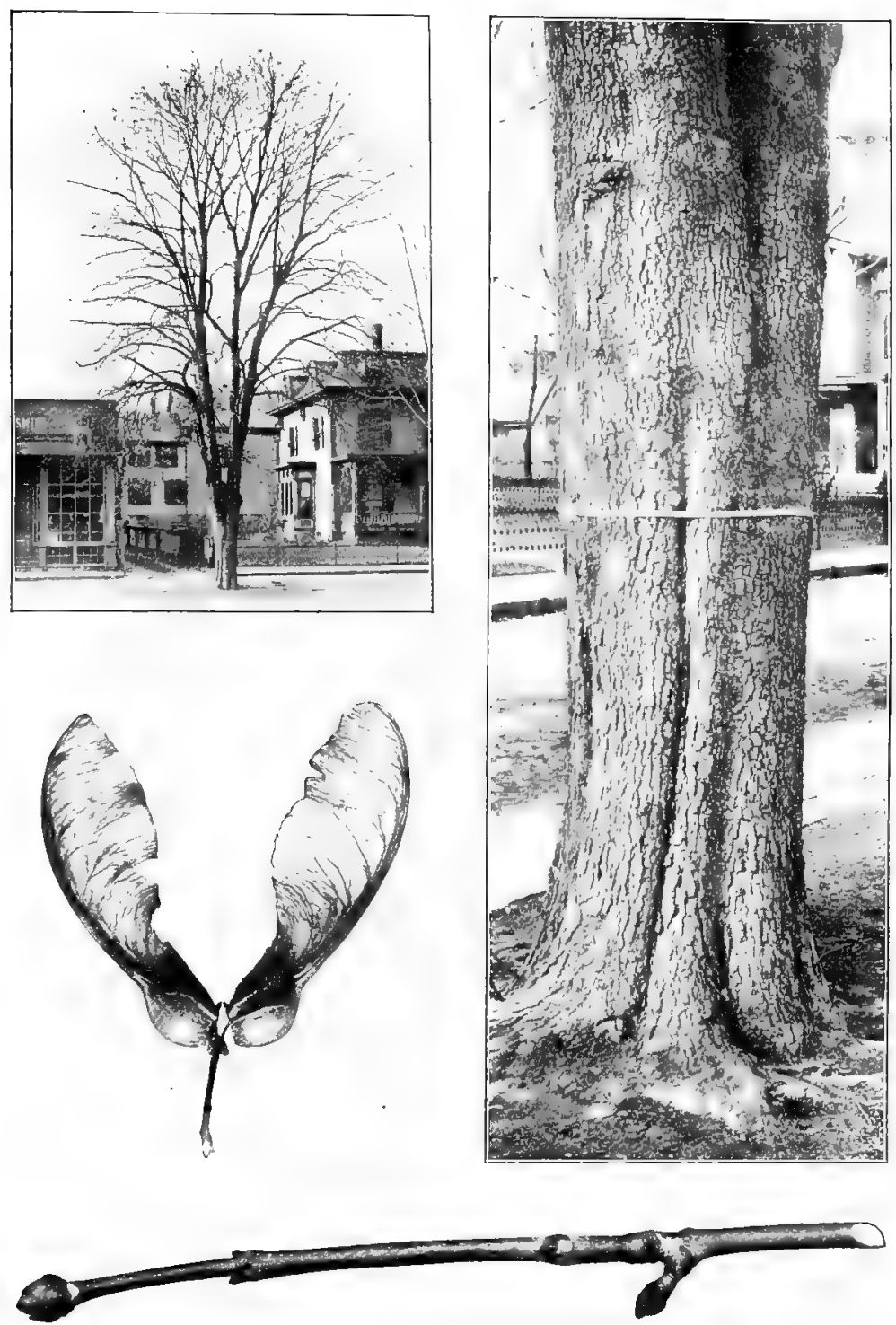

Srcamore Maple 


\section{BOX ELDER Ash-leaved Maple. \\ Acer Negundo L. Negundo aceroides Moench Negundo Negundo Karst.}

H.1BIT-A medium sized tree 40-50 ft. high with a trunk diameter of $1-2$ ft.; diriding low down, sometinies only a few feet from the ground into a number of stout spreading branches, forming a wide head.

B IRI-Pale gray or light brown. broken by rather shallow furrows into marrow, firm, close, irregular flat-topped ridges which are further cracked horizontally; bark of young trunks and branches smooth, with raised buff lenticels, which are horizontally nure or less elongated.

TWIGs-Stout, reddish-purple or green. smooth. polished or often with a whitish bloom which readily rubs off. LEXTICELS-conspicuous, forming somewhat longitudinally elongated, scattered, raised buff dots.

LFAF-SCIRS-Opposite, narrow T-shaped, margined by a lighter colured outer rim, half encircling the twig, the adjacent edges of opposite leaf-scars meeting and prolonged upward into a conspicuous narrow tooth, the inner margin often hairy. BUNDLE-SCARS-large, 3 in number, generally undivided.

BI DS- Short-stalked, red, more or less white-woolly, the terminal buds $6 \mathrm{~mm}$. or less long. rather longer than the appressed lateral buds. BLD-SCALES-outer pair less densely wooly than inner pars. gruwn together at base, entirely enclosing the bud or slightly gaping and exposing next inner pair; outer scales of lateral buds often distended by formation in their axils of stout collateral buds.

FR CIT-3.5-5 cm. long in drooping racemes, wings spreading at a sharp angle, seed-like portion long, fattish; fruit stalks remaining on tree throughout winter. The Box Elder is strictly dioecious, therefore fruit is not borne by all individuals.

COMPARISONS-The stout brightly colored red or green twigs and branchlets often covered with a bloom the first year and the downy buds with generally collateral buds present on some of the twigs, as well as the narrow tooth formed at the junction of adjacent deeply $V^{T}$-shaped leaf-scars render the Box Elder easily distinguishable in the winter condition.

DISTRIBI TION-Banks of streams, lakes and borders of swamps: a rapid grower and often planted as a shade tree, thrives best in moist soil but is tulerant of dry situations. Infrequent from eastern Ontario to Lake of the Woods; abundant from Manitoba westward to the Rocky mountains south of 55 degrees north latitude; south to Florida; west to the Rocky and Wahsatch mountains, reaching its greatest size in the river bottoms of the Ohio and its tributaries.

IN NFW ENGLAND-Maine-along the St. John and its tributaries, especially in the French villages, the commonest roadside tree, brought in from the wild state according to the people there; thoroughly established young trees, originating from planted specimens, in various parts of the state; New Hampshire-occasional along the connecticut, abundant at Walnole; extending northward as far as South Charlestown; Vermont-shores of the Winooski river and of Lake Champlain.

IN CONNECTICLT-Rare or local; apparently native along the Housatonic river from oxford to Salisbury; escaped from cultivation at Putnam, Groton, Southington, Wethersfield and Norwalk.

WooD-Light, soft, close-grained, not strong, creamy white with thick hardy distinguishable sapwood; occasionally manufactured into cheap furniture and sometimes used for the interior finish of houses. for wroden ware, cooperage and paper pulp. Small quantities of maple sugar are occasionally made from this tree. 

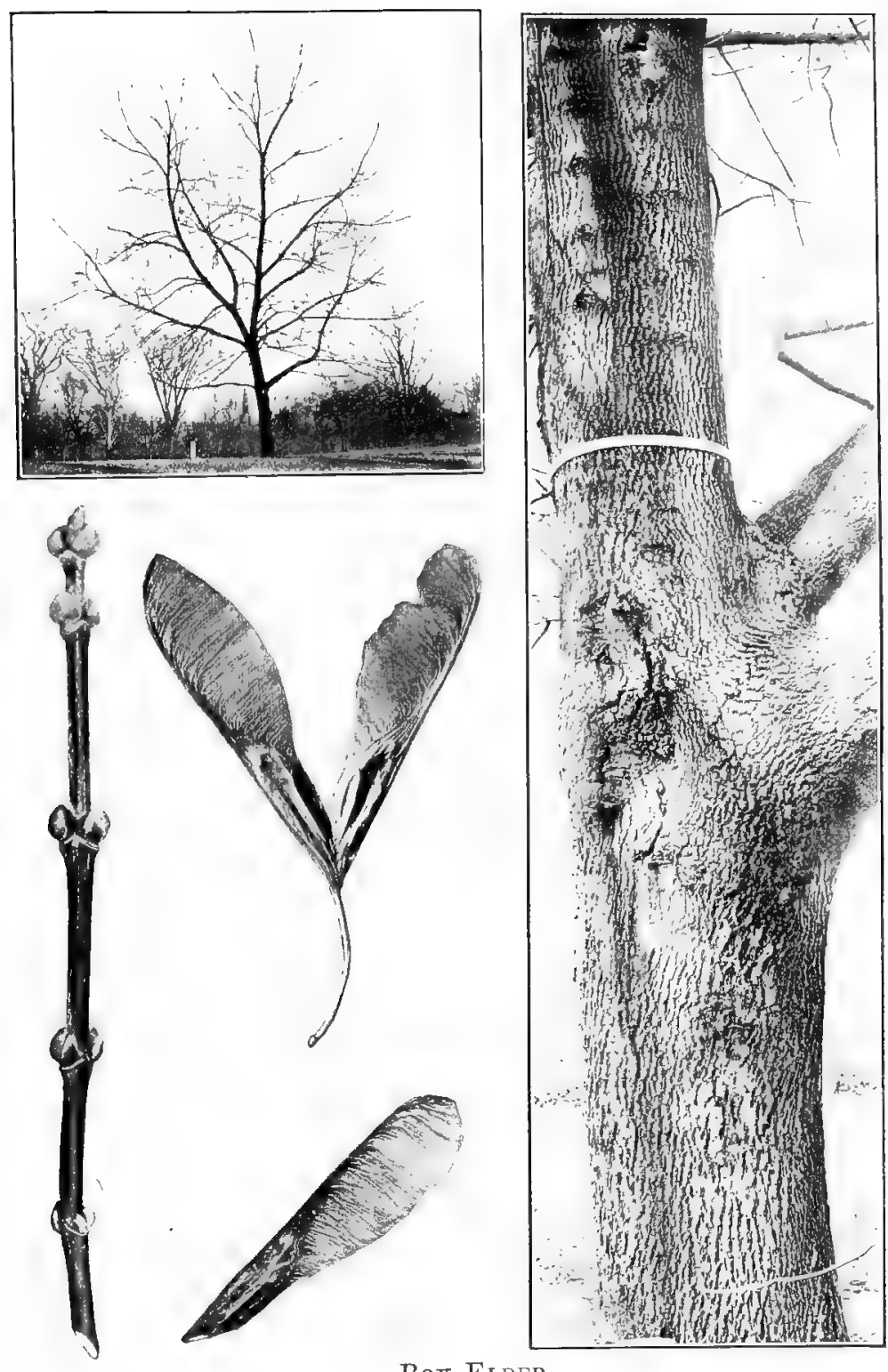

Box Elder 


\section{HORSE-CHESTNUT} Aesculus Hippocastanum L.

H IBIT-A grood sized tree reaching $70 \mathrm{ft}$, in height with a trunk diameter of 2-3 ft.; sometimes with trunk continuous into top of tree but mere frequently dividing soon into a number of large slightly spreading linbs forming an oblong or broadly conical head, in old age with drouping lower branches with upturned tips; spray stiff and coarse with conspicuous terminal buds.

BIRK-Dull brown becoming shallowly fissured into irregular platelike scales somewhat resembling bark of Apple Tree.

TWIGS-Stout, reddish-yellowish to grayish-brown, smooth or slightly fine-downy. SCALE-SCAFS-marking annual growth, distinet, LENTICELS-large, conspicuous, scattered. PITH-wide.

LF IF-SCIRS-Opposite, large, inversely triangular. STIPULESCAFA-alisent. BLNDLE-SCARS-3-9, generally 7, large, conspicuous, in a single curved line.

BI DS-Large, dark reddish-brown, varnished with sticky gum; terminal buds often flower buds, larger than laterals, 1.5 to $3 \mathrm{~cm}$. long: when a flower bud, a terminal scar is left and the twig forks from growth of bud pair below. BUD-SCALES-opposite in 4 rows, about 5 pairs risible in terminal bud, thick with thin margins, the lower pairs more or less keeled and often with abrupt sharp points.

FRIIT-A weak-spined bur, containing the large seeds marked with a large conspicuous scar; not remaining on the tree during winter.

CoMPARISONS-Two western trees with buas free from resinous coating i. e, the Fetid or Ohio Buckeye [Aesculus glabra Willd.] and the Sweet Buckeye [Aesculus octandra Marsh.] are sometimes planted in New England. They belong with the Horse-chestnut to the genus Acsculus which is readily distinguished from other New England genera by the large size of the twigs, buds, opposite leaf-scars and bundlescars.

DISTRIBCTION-A native of southern Asia much planted as an ornamental shade tree in this country and in Europe and naturalized in many places.

wo0D-Light, soft, very close-gralned, whltish, slightly tinged with yellow; in Europe used by carvers and turners. 

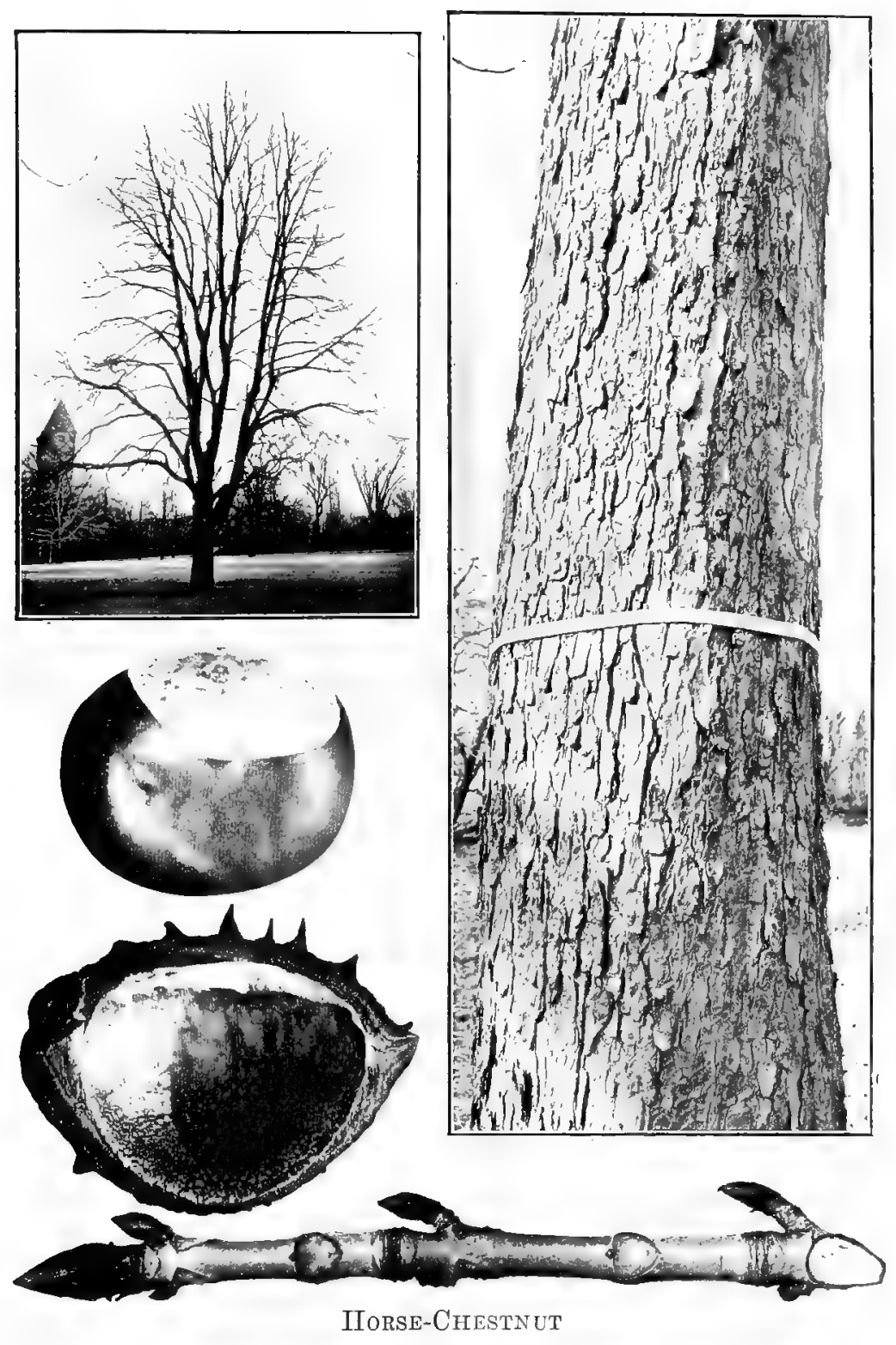


\section{LINDEN \\ Basswood, Lime Whitewood, Beetree. Tilia americana L.}

HABIT-A large tree 50-75 ft., to $100 \mathrm{ft}$ in height in the upper valley of the Connecticut river, with a trunk diameter of $2-4$ ft.; with a straight trunk generally continuous into the top, beset with numerous slender branches, those at the base often strongly drooping, forming a narrow pyramidal head as shown in habit picture or more commonly becoming broadly ovate or round-topped and oblong. [Habit picture is taken from the European Linden, which resembles the American species in habit.]

B.RI-Dark gray, firm but easily cut, in young stems smooth (upper part of smaller trunk in photograph), becoming fissured into long rather narrow flat-topped ridges, divided by characteristically transverse cracks into short blocks (lower bark picture), becoming with age deeply furrowed with broader more rounded ridges (older trunk).

TwIGs-Rather slender, smooth, shining, bright red or greenish or covered with a gray skin; generally zizag, somewhat mucilaginous; fibres in inner bark long, tough, appearing as blunt conical masses in cruss-section of older twig, and in surface sections of the bark as whitish wavy lines enclosing lens-shaped darker masses which show externally as wrinkled depressions of the bark. LENTICELSscattered, dark, oblong.

LEIF-sCARS-Alternate, 2-ranked; large, elevated, semi-oval to elliptical. STIPLLE-SCARS-narrow, often showing bunde-scars. BLNLLE-SCARS-few to many. scattered or in a ring or forming a single curved line, showing as 3 in deep surface section.

BIDS-Terminal bud absent; lateral buds large to medium, ovate, 3-10 mm. long, somewhat flattened, often lopsided, divergent, dark red or sometines green, smooth or slightly downy at apex. BUD-SCALESrarely more than 2-3 visible, thick, rounded at the back, not $2-r a n k e d$ nor in pairs.

FRI IT-About the size of a pea, woody, spherical, singly or in clusters of several with a common stalk attached midway to a leafy bract, sometimes remaining on the tree into the winter.

CoMP IRIsoxs-The American Linden, more commonly known among lumbermen as Basswood differs but slightly in winter or summer condition from the European species [7ilia vulgaris Hayne] which is much cultirated as a street tree. Annther Bassivood [Tilia Michanxii Nutt.] has been reported in New England only from Connecticut, but is rare in this state. The Lindens are sometimes confused with the Elms, but aside from the different habit of growth the Linden has larger, bright colored buds with $2-3$ scales only showing, while the Elms have many scales visible and their bundle-scars are depressed.

DISTRIBITIOV-In rich woods and loamy soils and often cultivated. Southern Canada from New Brunswick to Lake Winnipeg; south along the mountains to Georgia; west to Kansas, Nebraska and Texas.

IN NEW ENGLAND-Throughout, frequent from the sea coast to a)titudes of $1.000 \mathrm{ft}$., rare from $\mathbf{1 , 0 0 0}$ to $2,000 \mathrm{ft}$.

IN CONNECTICUT-Occasional.

woOD-Soft, straight-grained, light brown faintly tinged with red. with thick hardly distinguishable sapwood of 55-65 layers of annual growth, employed in the manufacture of paper-pulp; under the name of Whitewood largely used for woodenware, cheap furniture, the panels of carriages, and for inner soles of shoes. The tough inner bark furnishes fibres for mats, cordage, etc. 


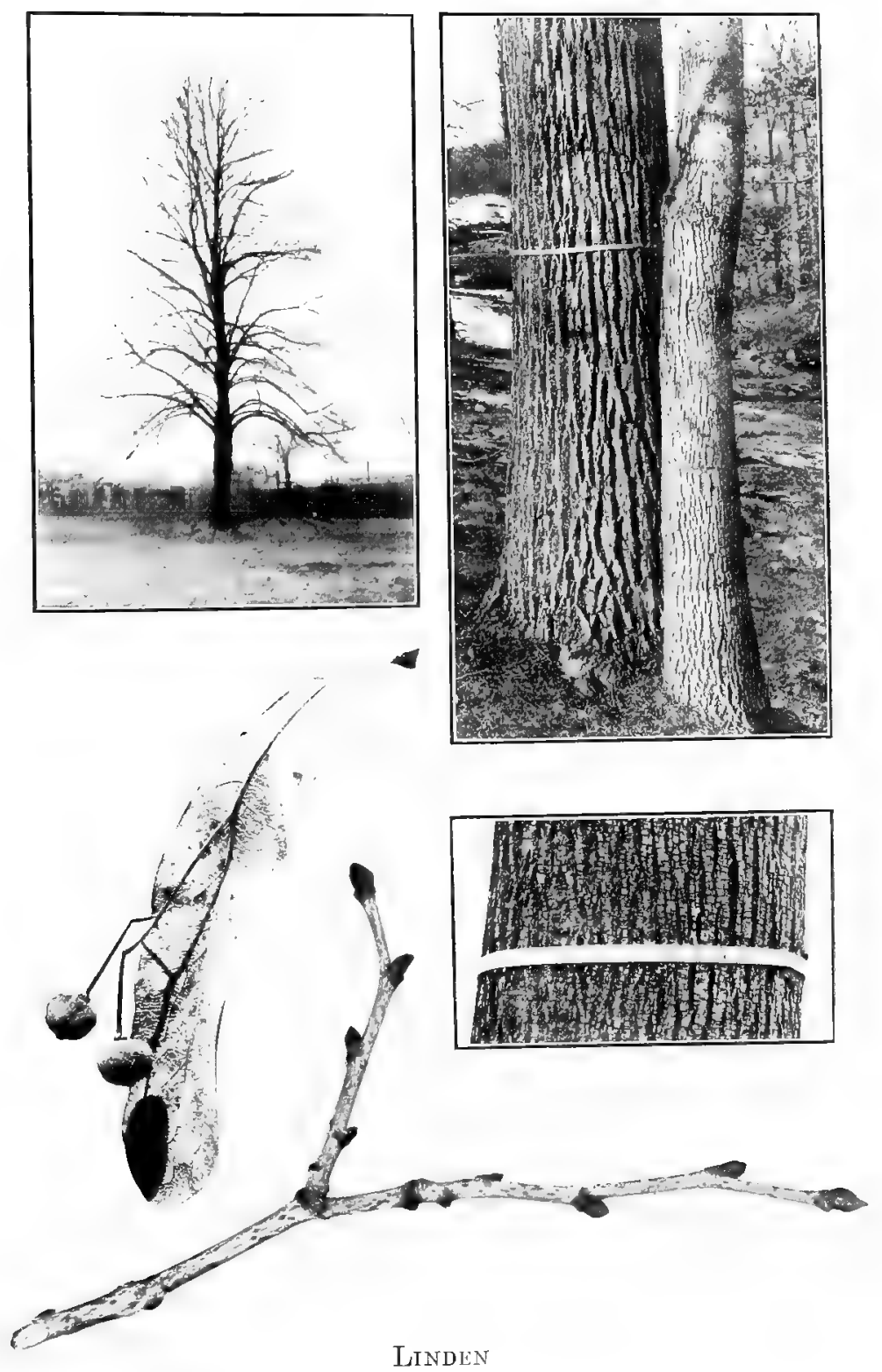




\section{FLOWERING DOGWOOD Boxwood, Dogwood, Flowering Cornel. Cornus florida L.}

HABIT-A small tree 15-30 ft, in height, with a trunk diameter of 6-10 inches; developing a low spreading bushy head with slender upright or spreading branches and divergent sinuously curved branchlets turning upward near the end and bearing on their upper sides clusters of fruiting twigs terminated by large conspicuous erect flower buds.

BARK-Dark brown to blackish, ridged and broken into small 4-sided or rounded plate-like scales, resembling alligator leather in appearance.

TWIGS-Slender, bright red or yellowish-green, smooth or generally appearing more or less mealy from minute closely appressed gray hairs; with bitter taste, LENTICELS-inconspicuous. PITH-gritty, granular.

IEAF-SCARS-Opposite, on twigs of the season raised on bases of leaf-stalks with deep V-shaped notch between, on older growth practically encircling twig. STIPULE-SCARS-absent. BUNDLESCARS-3, in leaf-scars of the season often cuntluent and first seen in section through persistent base of leaf-stalk.

BIDS-Lateral buds minute, covered by persistent bases of leafstalks; terminal leaf-buds flattened-conical, red, generally downy at least at apex, covered by a single pair of opposite pointed scales rounded at back and joined below for 1/s their length; flowering buds very abundant, terminal, large, spherical to inverted flat turnip. shaped, 4-8 mm. broad, covered by two opposite pairs of bud-scales, the first $2-3$ pairs of leaves below the flower buds generally reduced to narrow-pointed scales.

FRUIT-Scarlet, oblong, about $1.5 \mathrm{~cm}$. long, fleshy, with a grooved stone, clustered, ripening in October and generally not remaining on the tree during winter.

Comparisoxs-The Flowering Dogwood differs from its relative the Alternate-leared Dogwood [Comus alternifolia L.] by its opposite leafscars, from the Bush Maples, - the Striped and the Mountain-which it somewhat resembles in twig characters, by its alligator bark, the presence of but a single pair of scales to terminal leaf-bud, by the persistent bases of leaf-stalks covering the lateral buds and by the abundant large flower buds.

DISTRIBL TION-Woodlands, rocky hillsides, moist, gravelly ridges, frequently cultivated as an ornamental tree. Provinces of Quebec and Ontario; south to Florida; west to Minnesota and Texas.

IN NEW ENGLAND-Maine-Fayette Ridge, Kennebec county; New Hampshire-along the Atlantic coast, and very near the Connecticut river, rarely farther north than its junction with the West river; Vermont-southern and southwestern sections, rare; Massachusettsoccasional throughout the state, common in the Connecticut river valley, frequent eastward; Khode Island-common.

IN CONNECTICUT-Occasional, local or frequent.

WOOD-Heavy, hard, strong, close-grained, brown sometimes changing to shades of green and red, with lighter colored sapwood of $30-40$ layers of annual growth; largely used in turnery, for the bearings of machinery, the hubs of small wheels, barrel hoops, the handles of tools and occasionally for engravers' blocks. 

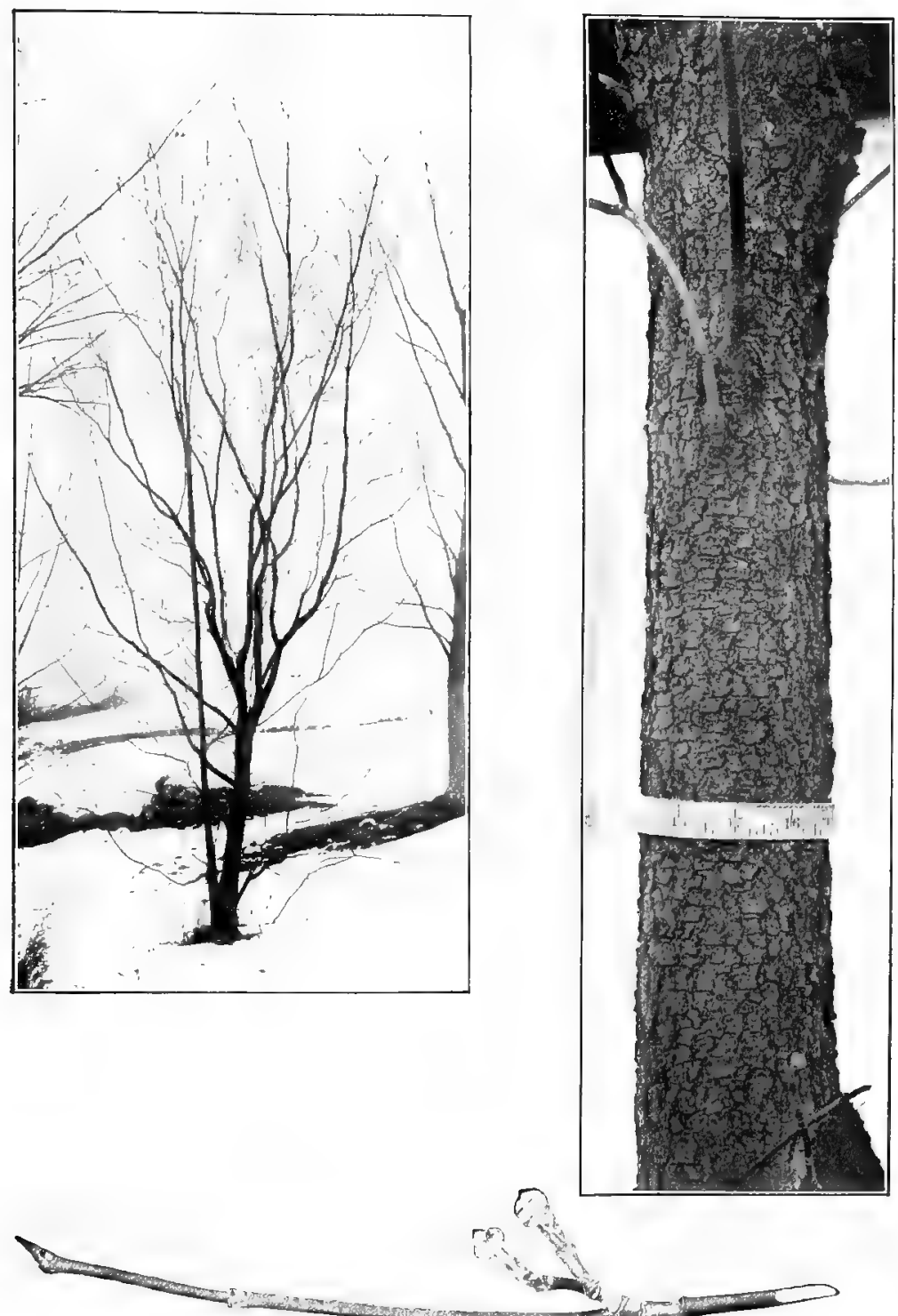

Flowering Dogtwood 


\section{TUPELO \\ Pepperidge, Sour or Black Gum. \\ Nyssa sylvatica Marsh. \\ N. multiflora Wang.}

H A BIT-A tree $20-50 \mathrm{ft}$. in height with trunk diameter of 1-2 $\mathrm{ft}$. or in the forest $60-50 \mathrm{ft}$. high, reaching greater dimensions further south: generally easily recognized from the manner of branching alone, though extremely rariable in outline. The trunk is erect, generally continuous well into the top. lower branches developed low down on trunk, horizontal or declined often to the ground, upper branches horizontal or slightly ascending. with numerous lateral branches and stubby branchlets forming horizontal layers. The branches are slender and exceedingly numerous. more so than in any other of our trees. The head may be short. cylindrical and flat-topped. or low and broader than tall. (see plate lower habit picture) or more commonly as when crowded in the forest, narrow, pyramidal or conical (see plate upper habit picture) or inversely conical and broad and flat at top.

BIRK-on young tree, grayish, flaky, on older trunks darker with deener furrows and ridges broken into somewhat regular hexagonal blocks.

TW Irs-slender, smooth or nearly so, grayish to light reddish-brown, produing numerous short slow growing spurs crowded with leaf-scars on the sides of more rapidly grown shoots. LENTICHLS-scattered, inconspicuous. PITH-with thin transterse woody partitions through the ground-mass, best seen with aid of a hand-lens.

LFIF-SCIRS-Alternate. generally more than 2-ranked. distinct, broadly crescent-shaped. STITULE-SCAFS-absent. BUNDLE-SCARSconspi.uous. 3, simple or slightly compound but in 3 distinct groups, generally depressed, whitish in contrast to reddish-brown of leaf-scar.

BCDS-Ovate, dark reddish-brown. smooth or slightly downy at tip, the lateral buds generally blunt-pointed. divergent, on rigorous shoots slightly raised on a cushion of the bark, sometimes on vigornus shoots developing a superposed accessory bud larger than the axillary one; terminal bud slightly larger than laterals, about $5 \mathrm{~mm}$. InIs. generally sharper pointed. with slightly curved apex. BUD-SCALISS-3-4 visible, broadly ovate, rounded, terminally somewhat keeled and pointed.

FRI IT-A small bluish cirupe ripening in autumn.

COMPIRISONS-Although the outline of the crown differs widely, the numerous slender horizontally layered branches generally render the Tupelo distinguishable at a distance. Its 3 conspicuous bundlescars in connection with the woody partitions in the pith will prevent Its being confused with any other tree.

DISTRIBI TION-In rich. moist soil, in swamps and on the borders of rivers and ponds. Ontario; south to Florida; west to Michigan, Missouri, and Texas.

IN NETV ENGLAND-Majne-Waterville on the Kennebec, the most northern station yet reported; New Hamphire-most common in the Merrimac valley, seldom seen north of the White Mountains: Vermontoccasional; Massacliusetts and Rhode Island-rather common.

IN CONNECTICUT-Frequent.

WoOD-Heary, soft, strong, fine-grained, very tough, difficult to split, not durable. light vellow or nearly white. with think lighter colored saptrond of s0-100 layers of annual growth; used for the hubs of wheels, rollers in glass facturies, ox-jokes, wharf piles and sometimes for the soles of shoes. 

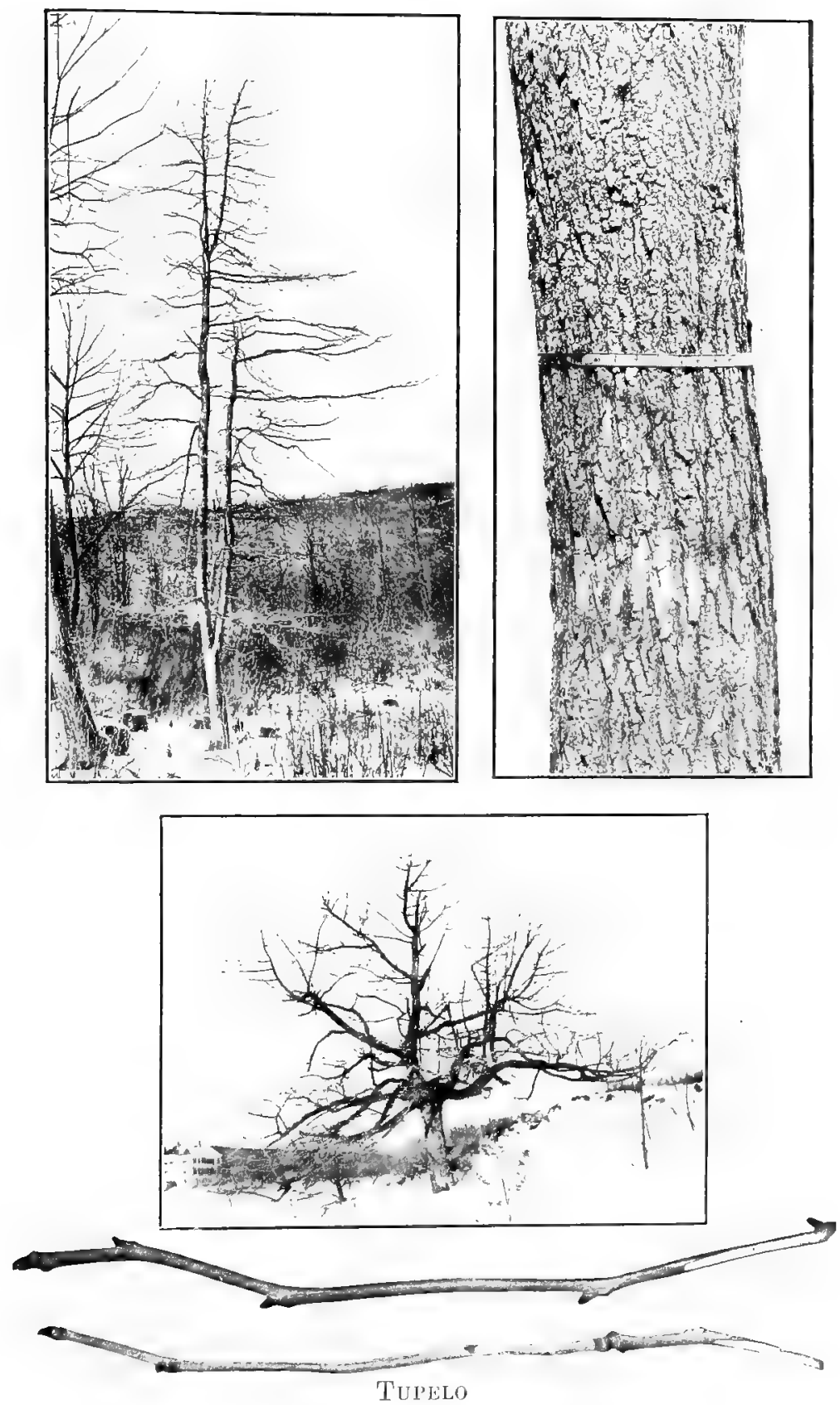


\section{WHITE ASH}

Fraxinus americana $\mathrm{L}$.

HIBIT-In the forests a large tree with straight, tall trunk, free from branches to near the narrow crown, 50-75 ft, in height with trunk diameter of $2-3 \mathrm{ft}$, reaching over $100 \mathrm{ft}$. in height in the Ohio basin; in the open a broader tree with ovate, round-topped or pyramidal to oblong outline, the trunk at times continuous into the crown but generally dividing comparatively low down into a number of slightly spreading limbs with slender spreading branches, the lower more or less drooping and recurved. The coarse twigs are formed at a broad angle approaching a right angle with the branch and this cross-shaped branching seen against the sky is an easy means of identification.

BARK-Grayish-brown, characteristically furrowed with narrow, flattopped, firm, irregular, longitudinal ridges which are transversely broken, more or less confluent and enclosing diamond-shaped hollows; old trunks becoming smoother by scaling off of the ridges.

TWIGS-Stout, smooth and shining, grayish or greenish-brown often with a slight bloom, very brittle, flattened at nodes at right angles to leaf-scars. LENTICELS-large, pale, scattered dots.

LEAF-SCARS-Opposite, large, consplcuous, raised, crescent-shaped to nearly semi-circular but always notched at the top. STIPULE-SCARSabsent. EUNDLE-SCARS-numerous, minute, in a curved line, often indistinct, sometimes more or less confluent.

BUDS-Stout, semi-spherical to broadiy ovate, scurfy, and more or less sllghtly downy, rusty to dark brown to sometimes almost black; on rapidly growing shoots, superposed buds often present; terminal bud larger than the laterals, about $5 \mathrm{~mm}$. or less long, blunt, generally decidedly broader than long. A palr of lateral buds generally present at end of twig nearly on level with terminal bud, their leaf-scars causing terminal swelling of twig. BUD-SCALES-generally broadly ovate, opposite in pairs, $2-3$ pairs visible, those of terminal bud with sharp, abrupt, sometimes deciduous points.

FHIIT-Winged, 2-5 cm. Iong, the seed-bearing portion round in section, marginless below with much longer wing dilating from near the tip, hanging on the tree in clusters into the winter. The Ash is dioeclous and consequently only the female trees ever bear fruit. Since further these do not bear every season, the fruit does not form a very usable winter character for any of the Ashes. The staminate flowers on the male trees are frequently infected by mites and persist through the winter in blackish distorted clusters.

COMPARISONS-The White Ash is hardly to be confused with the few other genera of trees that have opposite leaf-scars. It is distinguished from the other Ashes figured here in that its leaf-scar is generally narrow and deeply concave, further from the Black Ash by Its rough ridged bark and generally rusty and blunter bud-scales and from the Red Ash by its smooth, generally shiny twigs.

DISTRIBITION-RIch or molst woods, fields and pastures near streams. Newfoundland and Nova Scotia to Ontarlo; south to Florida; west to Minnesota, Nebraska, Kansas and Texas.

IN NEW ENGLAND-Maine-very common, often forming large rorest areas; in the other New England states, widely distributed, but seldom occurring in large masses.

IN CONNECTICUT-Frequent.

woon-Heavy, hard, strong, close-gralned, tough and brown with thick lighter colored sapwood: used in large quantity in the manufacture of agricultural implements for the handles of tools, In carriage building. for oars and furniture, and in the interior finish of buildings; the most valuable of the American species as a timber tree. 

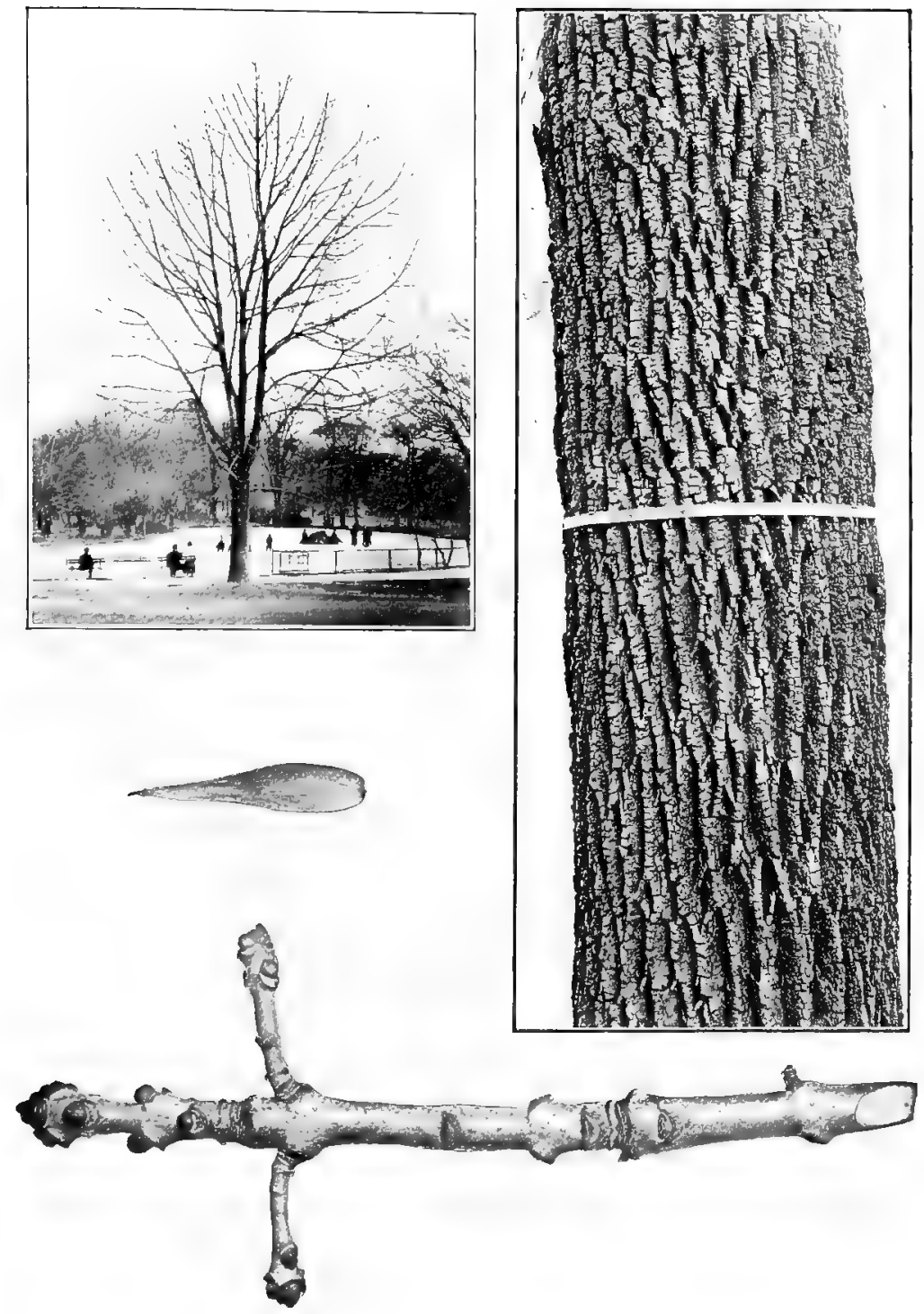

VIIITE Ash 


\section{RED ASH \\ Brown, or River Ash.}

Fraxinus pennsylvanica Marsh.

F. pubescens Lam. ; F. Darlingtonii Britton.

H IBIT-A medium to large-sized tree, $30-70$ ft. in height with a trunk diameter of $1-3 \mathrm{ft}$; in general appearance resembling the White Ash.

RIRK-Similar to that of White Ash but with somewhat shallower furrows.

TWIGs- ore slender than those of White Ash, densely velvetydowny in typical condition but often without down especially in the Green Ash [Fraxinus pennsyluanica, var, lanceolata (Bork.) sarg.].

LFIF-SCIRs-Senicircular, upper margin rarely somewhat depressed.

BLDs-Dark rusty brown smaller and narrower than those of the White Ash, about " pairs of seales visible to terminal bud.

FRI IT-Seed-bearing portion round in section, marginless below with wing extending down its sides.

COMPIRIsoys-The Fed Ash is not distinguished by most people from the Trhite Ash which it closely resembles. The downiness of its twigs which is considered its chief specific character is not constant. The shape of its leaf-scar, in general semi-circular with upper margin not concave, is perhays its best distinguishing character. Further its terminal buds are narrower, showing fewer scales and the twigs are more slender. The smooth-twigged Green Ash [Fraxinus pennsulvanica. var. lanceoluta (Bork.) Sarg.] is considered by the best authorities only a variety of the Red. The Black Ash is best separated by its characteristic scaly bark and generally black buds.

The European Ash [Fraxinus excelsior L.] is frequently cultivated. It has a bark resembling that of the White Ash and has a pair of lateral buds nearly on level with terminal buds; but its leaf-scars are semicircular and its buds jet black.

DISTRIBLTIOX-Fiver banks. swampy lowlands, margins of streams and punds. New Brunswick to Manitoba; south to Florida and Alabama; West to Dakota, Nebraska, IKansas, and Missouri.

IN NETV ENGLAND-Maine-infrequent; New Hampshire-occasionai, extending as far north as Boscawen in the Merrimac valley; Vermont $\rightarrow$ common along Lake Champlain and its tributaries; occasional in other sections; Massachusetts and Rhode Island-sparingly scattered throughout.

IN CONNECTICUT-Frequent.

wooD-Heary, hard, rather strong, brittle, coarse-grained, light brown with thick lighter brown sapwood streaked with yellow; sometimes confounded commercially with the mure valuable wood of the White Ash. 

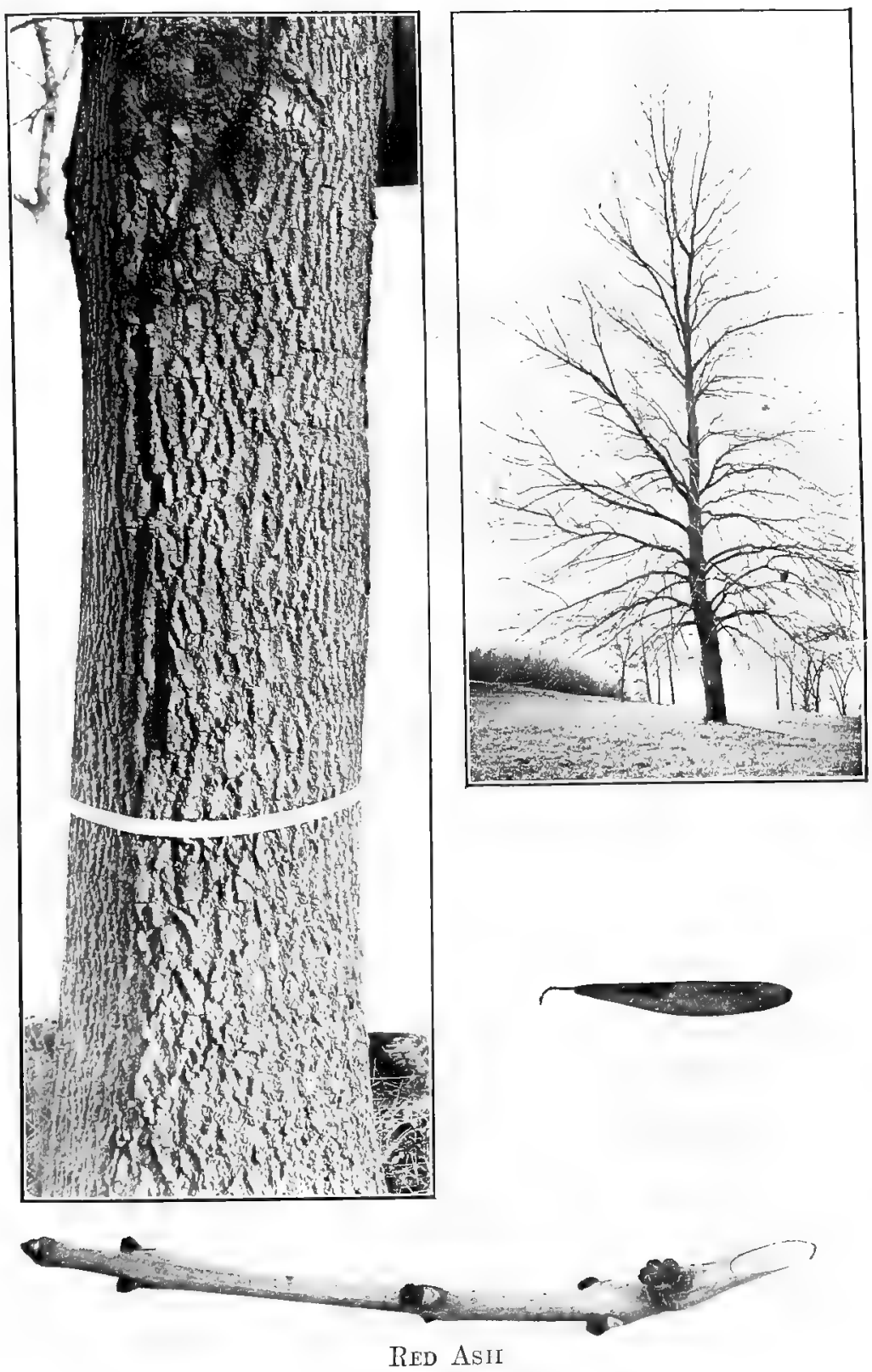


\section{BLACK ASH \\ Hoop, Swamp, Basket or Brown Ash. \\ Fraxinus nigra Marsh. \\ F. sumbucifolia Lam.}

HA BIT-A tall tree 60-80 $\mathrm{ft}$. in height with trunk diameter of 1-2 $\mathrm{ft}$. larger further south; in swamps in company with other trees with tall slender trunk of nearly uniform diameter to point of branching supporting a narrow head; in the open, where it is seldom found, said to have a habit similar to that of the White Ash.

RARK-Ash-gray, slightly tinged with buff, without deep ridges, forming thin scales smoothish on the outside and edges, easily rubbed off and exposing a surface rather sort to the touch suggesting somewhat the feel of asbestos or talcum powder; trunk frequently with knobby excrescences.

Twus-Very stout, similar to those of White Ash but lighter gray and not shiny.

LEAF-SCARS-Opposite, large, consplcuous, circular to seml-circular; the upper margin not concave, often extending upward as a thin flap partially hiding the bud; otherwise resembling the White Ash.

BUDS-Resembling those of White Ash but generally decidediy black though occasionally rusty, terminal bud ovate, pointed, as long as or longer than broad, more or less flattened at right angles to outer pair of scales, last pair of lateral buds generally at some distance from the end giving terminal bud a stalked appearance. BUD-SCALES-of terminal bud broadly keeled and narrower than in White Ash, generally only 1-2 pairs visible.

FRLIT-With broad wing, distinctly notched at apex, surrounding the flattened seed-bearing portion.

COMPARISONS-The Black Ash is easily distinguished from the White by its soft, scaly bark, the even or raised upper margin of its leal-scars, 1ts narrower and generally black buds, and the stalked appearance of its terminal bud. When growing in the swamps beside the White Ash its twigs can be seen to be much stouter and fewer than those of the latter species.

DISTRIHUTION-Wet Woods, river bottoms, and swamps. Antlcost1 through Ontario; south to Delaware and Virginia; west to Arkansas and Missourl.

IN NEW ENGLAND-Maine-common; New Hampshire-south of the White Mountains; Vermont-common; Massachusetts-more common in central and western sections; Rhode Island-infrequent.

\section{IN CONNECTICUT-Occasional.}

WoOD-Heavy, rather soft, not strong, tough, coarse-grained, durable, easily separable into thin layers, dark brown with thin light brown often nearly white sapwood; largely used for the interior finish of houses and cabinet-making, and for fences, barrel hoops and in the manufacture of baskets. 

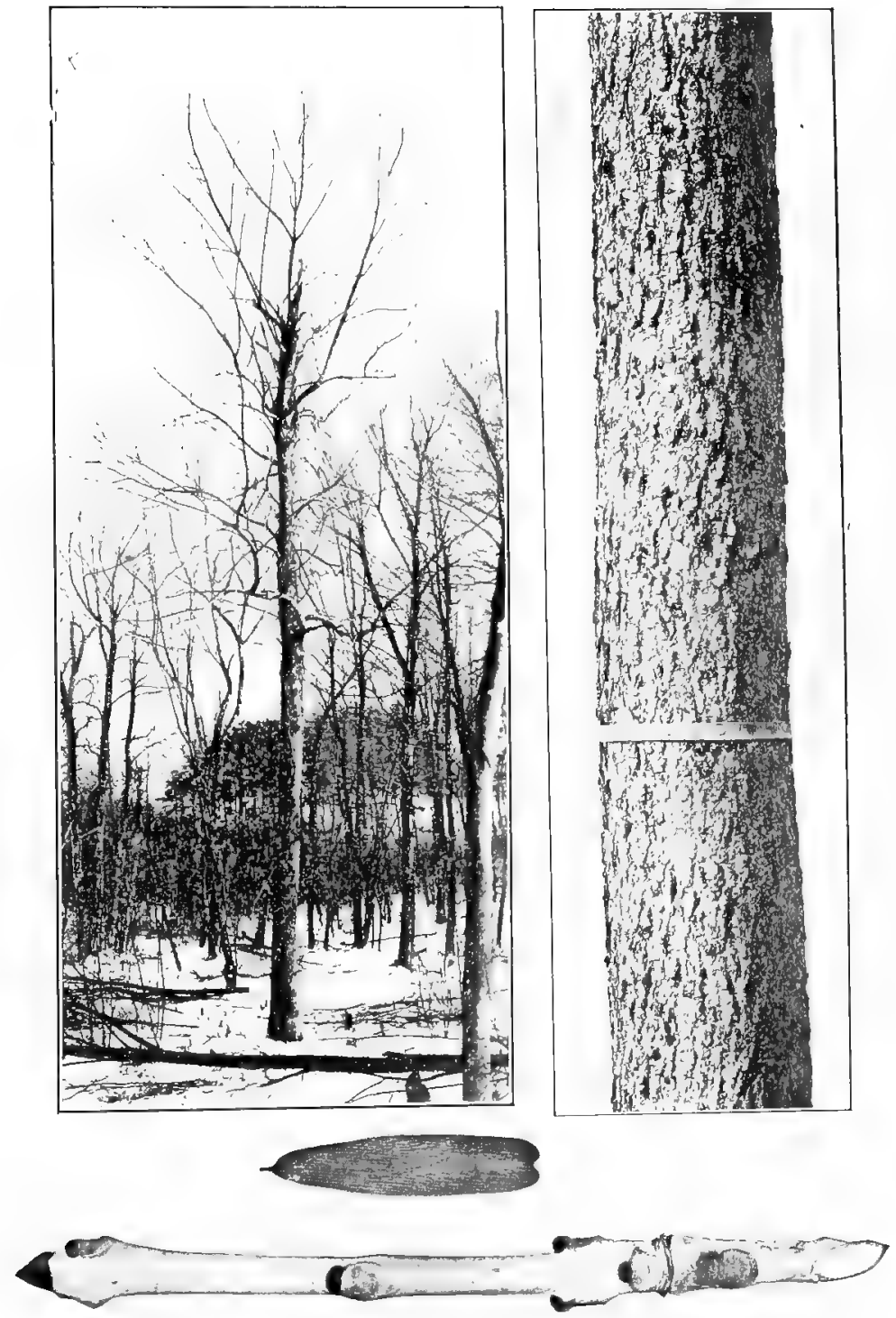

Black AsH 


\section{HARDY CATALPA \\ Cigar Tree, Indian Bean, Western Catalpa. \\ Catalpa speciosa Marder.}

H iniт-A tall tree reaching $100 \mathrm{ft}$. in height and $4 \mathrm{ft}$. in trunk diamenter in the Ohio basin, of smaller dimensions in New England with slender branches, forning a comparatively narrow round-topped head.

PIRK-Reddish to grayish brown, with longitudinal scaly ridges.

TWIGS-Stout, smooth or slightly short-domny, redaish to yellowishbrown, the tips of twigs generally winter killed. LENTICELSconspicuous, rather large and numeruus. PITH-white, wide, occasionally chambered at the nodes.

LFAF-SCIRS-Opposite or more frequently 3 at a node, laro and conspicuous, round to elliptical, with depressed center. STIPULESCAPS-absent. BLADLE-SCAPS-conspicuuls, often raised, forming a closed ring.

13 DS-Terminal bud absent, lateral buds small, semi-spherical, generally under $2 \mathrm{~mm}$, high, BUD-SCALES-brown, loosely overlapping, about 5 or 6 visible.

FRIT-A long cylindrical capsule, $\delta-20$ inches in length, with $n u-$ merous flattened, winged, white-hairy, fringed seeds, persistent on the tree through winter. The photograph of the capsule is reduced to about $2 / 5$ natural size.

COUP.IRISONS-The 3 large circular leaf-scars at a node with complete ring of bundle-soars renders the Catalpa twig easily recognizahle. The long cigar-like fruits that hang on the tree supply a distinetive habit character. A very closely related southern and less hardy species the Common Catalpi [Catalpa biononioides Walt.] was formerly more planted than the Hardy Catalpa. It is a smaller tree with a rather more spreading habit bit is most readily distinguished from the western species at the time of flowering.

DISTRIBLTIOX-Not native in New England but planted as an ornamental shade tree and for timber. It grows native along borders of streanis and ponds and rich often inundated bottom-land; southern Indiana, Illinois, and Missouri south into Kentucky, Tennessee and Arkansas.

WoOD-Light. soft, not strong, coarse-grained, very durable in contact with the soil, light brown with thin nearly white sapwood of 1 or 2 layers of annual growth: largely used for railroad ties, fence posts and ralls and occasionally for furniture and the interior finish of houses. 


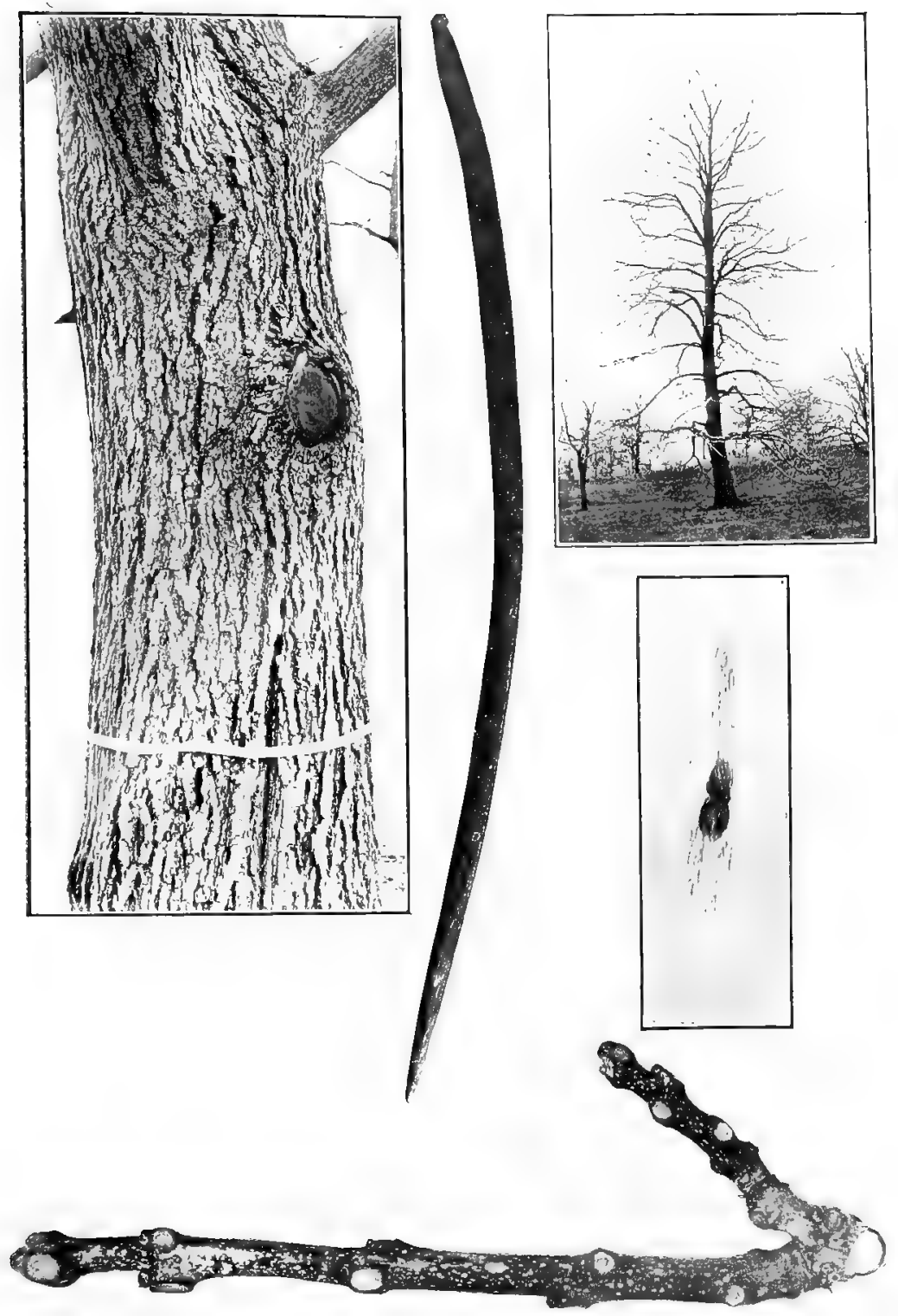

IIARDT CATALPA 


\section{GLOSSARI.}

Accessory buds. Buds at or near the nodes but not in the axil. of two kinds, collateral and superposed.

Acorn. The complete fruit of an Oak consisting of a nut partially enclosed by an involucrate cup.

Alternate. Scattered along the stem; said of leares and scales in distinction from opposite.

Apex. The top, as the tip of the bud.

Appressed. Lying close against the twig, as the buds of the Shad Bush (p.493).

Awl-shaped. Small and tapering to a slender point.

Axil. The angle formed at the upper side of the attachment of the leaf to the stem.

Axillary. In an axil. An axillary bud is the first bud above the leaf or leaf-scar.

Bark. The outer covering of the trink or branch. I'nless otherwise specified, the hearling "Bark" in the descriptions refers to the bark of the trunk.

Berry. A fruit fleshy throughout.

Bloom. The powdery waxy substance easily rubbed off, as the bloom on the twigs of the Box Elder (p.547).

Bract. A more or less modified leaf.

Branch. A secondary division of a trunk.

Branchlet. A small branch.

Bud. An undeveloped branch or fruit cluster with or without a protective covering of scales.

Bud-scales. Reduced leaves covering a bud.

Bundle-scars. Scars of the fibro-vascular buniles which ran up through the leaf-stalk and connected with the veins of the leaf, seen as dots in the leap-scar (fig.4).

Bur. A spiny fruit, as the bur of the Chestnut (p.431).

Buttressed. Said of the trunk when enlarged at the base as frequently is the case in the White Elm (p.461).

Calyx. The outer portion of a flower consisting of a circle of modified leaves usually green in color.

Capsule. A dry fruit which splits at maturity to let out the seeds.

Catkin. A unisexual, elongated, compact cluster of flowers with scaly bracts usually falling away in one piece, as in the Alders (p.427), Birches (p.415-425), etc.

Cell. One of the chambers of the ovary. One of the microscopic structural elements out of which plant tissues are built up.

Chambered. Said of the pith when interrupted by hollow spaces, as in the Butternut (fig.6).

Collateral buts. Accessory buds at the side of the axillary bud as in the Fied Maple (fig.7).

Cone. A fruit such as of the Pines with woory closely overlapping scales.

Confuent. Sait of bundle-scars, when the separate scars are so close together that they appear to form a single scar. 
Conical. Cone-shaped, largest at the base and tapering to the apex.

Crown. The upper mass of branches.

Cup-shaped. Shaped like a cup; deeper than saucer-shaped.

Deciduous. Falling away; said of trees that drop their leaves before winter.

Decurrent. Said of ridges that run down from the leaf-scar.

Deliquescent. Said of a tree with broad spreading habit as the Apple (p.487).

Dioecious. Said of plants such as the Willows and Poplars that have separate male and female individuals.

Divergent. Said of buds that point away from the twig as in the Carolina Poplar (fig.5).

Downy. Covered with fine hairs.

Drupe. A stone-fruit as in the Cherries with the seed enclosed in a stone or pit which is surrounded by a fleshy portion.

Egg-shaped. Shaped like an egg with the broadest part below the middle.

Elliptical. Oblong with regularly rounded ends.

Entire. Margin without indentations.

Epidermis. The outermost layer of cells.

Escape. A plant originally cultivated but now growing like a wild plant.

Evergreen. With green leaves in winter, as the Pines and Holly.

Excurrent. Said of a tree of erect habit of growth, such as the Spruce (p.359) or Poplar (p.395).

Fan-shaped. Shaped like an expanded fan.

Fibro-vascular bundles. The strands containing the elements for the transportation of fluids through the plant. They ultimately connect with the veins of the leaves.

Flaky (bark). With loose scales easily rubbed off.

Flower bud. A bud containing an undeveloped flower or flower cluster.

Fluted. With rounded ridges.

Fruit. The part of a plant containing the seeds.

Gland. A small protuberance, as on the leaves of the Arbor Vitae (p.377).

Habit. The general appearance of the tree as seen at a distance.

Habitat. The place where the tree naturally grows, such as swamps, sandy plains, etc.

Hairy. With long hairs.

Head. The upper portion of a tree.

Heartwood. The dead central portion of the trunk.

Hoary. Grayish-white with a fine close down.

Bybrid. A cross between two species or varieties.

Internode. The portion of the stem between two nodes.

Inversely triangular. Inverted triangular with the apex below.

Involucre. The bracts surrounding the flower cluster.

Juvenile. Youtheul, said of the leaves formed in the early stages of development. 
Feeled. With a central ridge like the keel of a boat.

Fey. A winged fruit.

Lanceolate. Lance-shaped: similar to orate but narroner with outline tapering sratually to the apex.

Lateral bud. A bud produced on the side of a twig.

Leaf bud. A bud containing undereloped leares but not flowers.

Leaf-scar. The scar left by the fall of the leaf (fig.4).

Leaf-stalk. The stem of a leaf.

Lenticels. Corky spots on the surface which admit air to the interior of the twig.

Limbs. The larger branches.

Linear. Long and narrow, several times as long as broad with parallel edges, as the leaves of the Pines.

Lobed. With rounied indentations running $1 / 3$ to $2 \%$ the way from the margin inward.

Longitudinal. Lengthwise.

If dutlary rays. Ray's of tissue extending from the pith toward the bark, best seen in cross section.

Midrib. The central vein of a leaf.

Naked bud. A bud without bud-scales.

Needle. A narrow leaf as in the Pines.

Node. The place on the twig at which one or more leaves mere produced (fig.4).

Nut. A large hard fruit as in the Hickory, Oak and Chestnut.

Nutlet. A small nut.

oblanceolate. Inverted lanceolate.

oblong. Two or three times longer than broad with about uniform diameter.

obovate. Inverted ovate.

opposite (leaves and leaf-scars). With two leaves or leaf-scars opposed at a note.

oval. Broadly ellintical.

ovary. The part of the pistil producing the seeds.

Orate. Egg-shaped, with the broadest part below the midule.

Persistent. Remaining on the tree.

Pistil. The seed-bearing portion of the flower.

Pith. The softer central portion of a twig.

Pod. A dry fruit which splits open at maturity.

Pome. A fruit like the Apnle or Pear.

Pungent. Sharp to the taste.

Pyramidal. Shaped like a pyramid with broadest portion at the base.

Raceme. A simple cluster of stalked flowers arranged along an elongated axis.

Resin-duct. A tube for the conduction of resin seen in the leares of the Pines.

Sapuood. The young living wood outside the heartwood. 
Saucer-shaped. Shaped like a saucer, shallower than cup-shaped.

Scale. A small modifier leaf seen in buds and cones. One of the flakes into which the outer bark often divides.

Scurfy. Covered with small bran-like scales.

Sepal. One of the divisions of the calyx.

Sessile. Without a stalk.

Shrub. A low woody growth, smaller than a tree and generally branching near the base.

Smooth. Not rough nor hairy.

Spray. The aggregate of smaller branches and branchlets.

Spur. A short, slowly-grown branchlet.

Stamens. The pollen-bearing portions of a flower.

Staminate. Having stamens; said of trees bearing only male flowers.

Sterile. Not producing seed.

Stipular. Similar in form or position to stipules.

Stipules. Two small leaf-like borlies located at the base of the leaf-stalk in some species.

stipule-scar. The scar left by the fall of a stipule (fig.5).

Stomata. Breathing pores in Jeaves.

Stone-fruit. A fruit like that of the Cherry. The same as drupe.

Strengthening cells. Thick walled cells present in the leaves of some of the Pines.

Striate. Longitudinally streaked.

Submerged. Covered, as by the bark.

Sucker. A shoot arising from below ground.

Superposed buds. Accessory buds above the auxillary bud, as in the Butternut (fig.6).

Surface-sectioned. Cut parallel to and near the surface.

Teeth.-Small projections along the margin.

Terminal bud. The bud formed at the tip of a twig.

Thorn. A stiff woody sharp-pointed projection.

Top-shaped. Shaped Iike a top with the broadest part above.

Tree. A woody plant, Iarger than a shrub, from which it cannot always be distinguished. Usually defined as a woody growth, unbranched near the base and reaching a height of at least fifteen feet.

Triangular. Shaped like a triangle with the base below.

Trunk. The main stem of a tree.

Twig. A young shoot. Unless otherwise specified, used in the descriptions to denote the growth of the past season only.

Valvate. Said of buds in which the scales meet without overlapping.

Whorl. A cluster of three or more leaves or leaf-scars at a single nole.

Wing. A thin flat appendage.

Woolly. Covered with tangled or matted hairs resembling wool. 


\section{INDEX}

Where the species receives its most extended description, the page number appears in boldface type. Where the species is otherwise mentioned, the page number is printed in ordinary type. Synonyms of both common and scientific names are printed in italics and their page numbers in ordinary type.

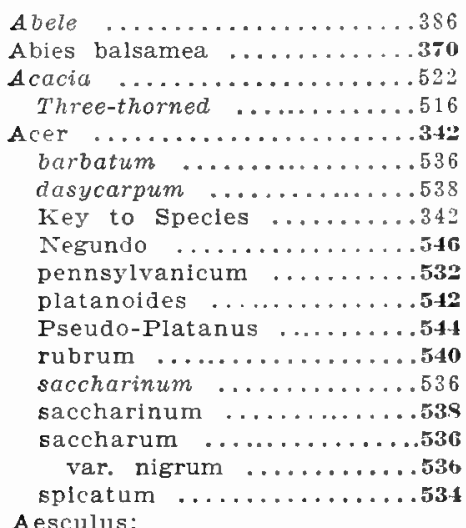

Aesculus:

glabra ...............548

Hippocastanum .........548

octandra ..............548

Allanthus ...........514, 524

glandulosa ............ 524

Alder ..............426, 478

European Black ........426

Hoary ...............426

Smooth .............426

Speckled ............4 426

Alligator-wood ...........480

Alternate-leaved Dogwood ...552

Amelanchier canadensis ....492

Alnus:

incana .............426

rugosa .............428

vulgaris ............420

American Aspen ...........388

Beech ................428

Elm .................460

Holly ..................530

Hornbeam . .318, 325, 410, 412

Larch ..................... . .

Mountain Ash .........488

Plum .............506, 508

var. Gold ...........508

Amygdalus Persica ........512

Apple ................. 316 $321,466,468,484,486,490,548$
Apple, Thorn .............494

Arbor, Vitae ..............376

Ash .....325, 327, 328, 343, 556

American Mountain ......488

Basket ............ 560

Black .... 322, 556, 558, 560

Brown ...........558, 560

European ............55s

European Mountain ......4488

Green ...............558

Hoop . . . . . . . . . 464, 560

Key to Species ..........343

Mountain ............488

Prickly ............5 522

Red .................558

River ..............558

Swamp .............. 560

Western Mountain ......488

White ........319, 322, 327

$328,406,474,542, \mathbf{5 5 6}, 558,560$

Ash-leaved Maple ........546

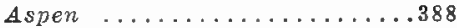

American ..............388

Large-toothed . . .386, 388, 390

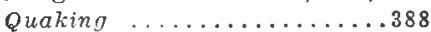

Small-toothed ..............

..... 394, 386, 388, 390, 392

Austrian Pine .............352

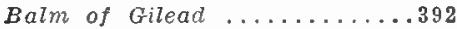

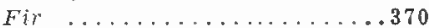

Balsan .............370, 392

Fir .........368, 370, 372

Poplar .........38s, 390, 392

Basket Ash ............560

Rasswood ............550

Bay:

Swamp ...................

Sweet .........341, 470, 472

Bean, Indian ..........562

Bear Oak ...........442, 454

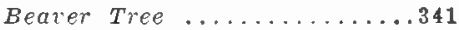

Beech ................ . 318 $321,412,428,492,520,540$

American .............428

Blue ...............412

European ............428

Water ...............412

Beetree ..............550 


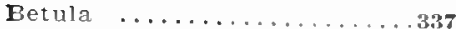

alba ............... 424

var. papyrifera ........42z

Key to Species ....................

lenta ...............414

lutea ...............416

nigra ...............418

papyrifera $\ldots \ldots \ldots \ldots \ldots . \ldots 422$

populifolia ...........420

Big Bud Bickory.............404

Bilsted ...............480

Eirch .......318, 319, 322, $\mathbf{3 3 7}$

Black $317,318,321,414,416,418$

Canoe ................4 422

Cherry ..............414

European Paper .........424

European White ........424

Gray ...............416

Gray ............420, 422

Fey to Species ............337

Old Field .............420

Paper ...318,416,420, 422, 424

Poplar ...............420

Poverty .............4420

Red .............4 416, 418

River ...............418

Silver ................416

Small White ...........4420

Sweet ...............414

White ...........420, 422

Yellow ..318, 414, 416, 418, 422

Bird Cherry ............500

Bird's Eye Maple ...........536

Eitternut ........398,400, 408

Black Ash ...322, 556, 558, 560 Birch 317, 318, 321, 414, 416, 418

Cherry ..............496

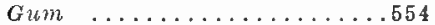

Knot ...............498

Larch . ............. . 356

Locust . . . .......... 522

Maple ..............536

Oak .......318, 446, 450, 452

Oak Group ....319, 325, 338, 452

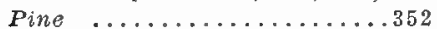

Scrub oak...............454

Spruce ............... 350

$356,358,360,362,370,376$

Walnut ........398, 400, 524

Willow .................384

Blue Beech ............412

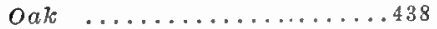

Spruce ........358, 360, $\mathbf{3 6 1}$

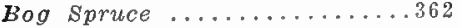

Box Elder ............540, 546

Box White oak ...........444

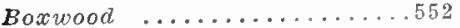

Bristly Locust ............. . .
Broom Hickory .........406

Brown Ash .........558, 560

Buckeye:

Fetid ...............54s

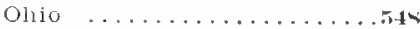

Sweet ..............544

Eur Oak ...........436, 480

Bush Maple..........532, 552

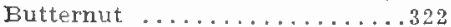
$323,324,398,400,408,524$

Buttonball ..............482

Buttonwood .............482

Cabinet Cherry ..........496

Canada Plum .........506, 508

Canoe Birch .............422

Carolina Popular ...........321

$323,324,388,390,394,396$

Carpinus caroliniana ......412

Carya .................336

alba $\ldots \ldots \ldots \ldots \ldots \ldots \ldots \ldots 402$

alba .................404

amara ...............408

cordiformis ............408

glabra ..............406

Key to Species ..........336

microcarpa ..........4406

ovata ..............4402

porcina ............406

tomentosa ............404

Castanea :

dentata $\ldots \ldots \ldots \ldots \ldots \ldots \ldots 430$

sativa, var. americana.....430

vesca, var. americana.....430

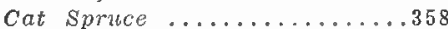

Catalpa .............309, 562

bignonioides $\ldots \ldots \ldots \ldots \ldots \ldots \mathbf{5 6 2}$

Common ..............562

Hardy ..............562

speciosa ............562

Western .............56z

Cedar .........374, 376, 380 Coast White 326, 374, 376, 380 Red ..........374, 378, 340 White .............374, 376

Celtis occidentalis .......464

Cercis canadensis .........518

Chamaecyparis:

sphaeroidea $\ldots \ldots \ldots \ldots \ldots . .374$

thyoides .............37t

Cherry...318, 319, 321, 341, 414 Amarelles .............504

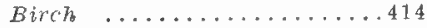
Bird ................500 Black ................496 Black Tartarian .........502 Cabinet .............496 Choke ........496, 498, 504 Early Rıchmoni ........504 
Cherry (Continued)

Elropean Bird ......... 502

Fire .................500

Key to Species ............341

Louis Philippe ..........504

May Duke ............50

Ma $\approx a r d \ldots \ldots \ldots \ldots \ldots . \ldots . . . .502$

Jontmorency ...........504

Morello ..............504

Napoleon .............502

Pie ...............504

Pin ................500

Pigeon .............. . 5110

$R_{u m} \ldots \ldots \ldots \ldots \ldots \ldots 4 . \ldots . \ldots 49$

Sour ...316, 496, 498, 502, 501

Sweet $316,317,496,498 \mathbf{5 0 2}, 504$

Wild Black 496, 498, 500, 504

Wild Fied ......498, 500, 504

Windsor ................502

Chestnut $\ldots \ldots \ldots \ldots \ldots \ldots \ldots \ldots$

$\ldots \ldots .309,319,322,328,430,440$

oak ................440

Oak .......440,442, 414, 446

Chinese Magnolia ......470, 472 Swmach .............524

Chinquapin Oak ...433, 440, 442

Chinquapin Oak ...........442

Choke Cherry .....496, 498, 504

Cigar Tree .............562

Cladrastis lutea .........520

Clammy Locust ..........522

Coast White Cedar ...........

..........326, 374, 376,380

Cockspur Thorn .........494

Coffee Bean ................514

Nut ...............514

Coffee Tree, Kentucky $322, \mathbf{5 1 4}, 524$

Colorado Blue Spruce........364

Common Catalpa ..........562 Juniper ............358, 350

Locust . . . . . . 324, 516, 522

Cork Elm .....456, 460, 462, 480

Cornel, Flowering ..............2

Cornus:

alternifolia $\ldots \ldots \ldots \ldots \ldots \ldots . . .52$

florida .............. . . . . .

Cottonwood ...............394

Crataegus ...............4\$4

Crus-galli ............4!14

pruinosa $\ldots \ldots \ldots \ldots \ldots \ldots . .444$

Cucumber Tree ........470,472

Large-leaved ............340

Cultirated Plums ..........nos

Cupressus, thyoides .........57

Curly Maple ................\$\%

Crilonia vulgaris .......... Ho

Dirreood ..............4t10

Dimerosporiun Collinsil ....492
Dogwood ................552

Alternate-leaved ........552

Flowering ............552

Poison .................528

Double $\$$ pruce .............362

Douglas Fir ..........368, 370

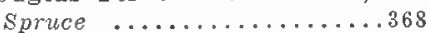

Downy Poplar ............336

Jwarf Chinquapin Oak ........

$\ldots \ldots \ldots \ldots . .432,440,442,454$

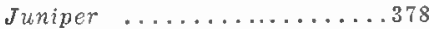

Sumach ..............526

Elder:

Box ................ 546

Poison ...............528

Filkzoood .............472

$\operatorname{Elm} \ldots \ldots \ldots 323,340,438,464,550$

American ............. 460

Cork .....456,460, 462, 480

English ....316, 458, 460, 462

False $\ldots \ldots \ldots \ldots . \ldots 464$

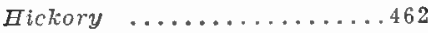

Key to Species ............340

Moose ..............4456

Northern Cork .........4.462

Red ................456

Rock ...............462

Slippery .......456, 460, 462

Water ...............460

White $\ldots 316,456,458,460,462$

Winged .............462

Finglish Elm ..316, 458, 460, 462

European Ash ...........55s

Beech ...............128

Bird Cherry ...........502

Black Alder ...........426

Holly ...............530

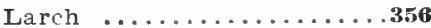

Linden ............. . 550

Mountain Ash ..........4\$8

Paper Birch ...........4424

Plum .................. . . . . . . .

var. Lombard ......... . sok

Weeping Willow .........344

White Birch ..........4 4.4

White Willow ...........344

Evergreens .......316, 321, 329

Fagus:

americana .............428

atropunicea ............428

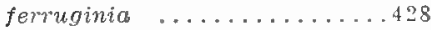

Erandifolia ............428

sylyatica ..............24

F'alse Elm ................464

Fetld Buckeye ...............48

Fir ...............................

Balm of Gilead ..........370

Balsam .........368, 370, 372

Donglas ............348, 370

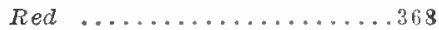


Fir (Continued)

Scotch ..................................

Fire Cherly ...........500

Flowering Cornel .........552

Dogwood .............55*

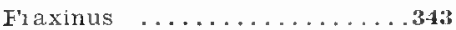
americana ..........328, 5.ti Darlingtonii .............558 excelsior ...............55 Key to Species .........34 nigra ............... . . pennsylvanica ..........5ss rar. lanceolata ........55is pubescens ..............558 sambucifolia ...........560

Gillkgo ............... . 3N" biloba .................

Gleditschia .............516 Gleditsia triacanthus ......516

Golden Osier ..............384

Gopher Wood ............520

Gray Birch ..........1:0, 422 Birch ................. 416 Pine ......................

Green Ash ..............5ss Gum:

Black ................ $55 t$

Red .................480

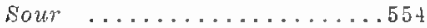

Sweet ...............4\$

Gymnocladus:

canadensis ............514

dioica ...............514

Hackberry . . . . . . . 322, $\mathbf{4 6 4}$

Hackmatack ..............356

Hamamelis virginiana ......47s

Hard Maple ..............536

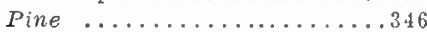

Fardy Catalpa ............562

Haw ................494

Hawthorn .........494, 516

Hazel, Witch ...........47s

Femlock ............370, 372 spruce ................... 372

Hickoria:

atba $\ldots \ldots \ldots \ldots \ldots \ldots \ldots 404$

glabra ................406

minima ...............408

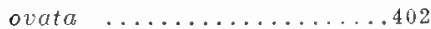

Hickory .............336, 462 Big Bud ............4404

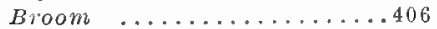

Elm ..............462

Key to Species .........336

Pignut ..............400 Shag-bark ...319, 402, 404, 406 Shell-bark ............402

Small-fruited ........406
Hickory (Continued)

sucmp ............... 118

White-heart .........4.4 404

Houry Alder ...........426

Holly .................530

American .............530

European .............530

White ................530

Floney Locust. . 349, 494, 516, 522 Shucks .............. 516

Hoop Ash ..........46t, 560

Hop Hornbeam ....325, 410,412

Itonueam ............412 American ...31s, 325, 410, 412 Hop ............395, 410, 412

Horse Plum .............506 Fiorse-chestnut

$\ldots \ldots \ldots 319, \quad 320,321,322,5 \pm 5$ Il $\times$ X :

A'puifoliun ........... . 30

opaca .............. 5\$0

Indian bean ............562

Iron oak ................ . . 434

I. onwood ..........4410, 410

Jry, Poison .............52s

Jack Pine ............20, 348

Japanese Plum ............ sos

var. Red June ..........50s

Judas Tree ..............518

Juglans:

cinerea ...............39s

nisra ..............400

Juneberry ..............4492

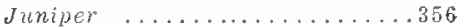

Common ............375, 380

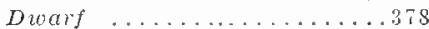

Red ........................

Juniperus:

communis $\ldots \ldots \ldots \ldots . \ldots . . . .38$

var. alpina .............. 38

var. canadensis .........378

var. depressa ...........378

nana .................... 378

virginiana ..............350

Kentucky Coffee Tree $322,514,524$

Key to Genera and Species ...329

Labrador spruce .......................

Lancewood .............492

Larch ............... . . . . . 38 ,

American ...................

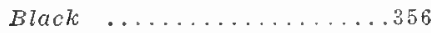

European ................5

Key to Species ..............335

Large-leaved Magnolia ..........

...............340, 470, 475

Cucumber Tree ...........340

Umbrella Tree ...........340

Large-toothed Aspen $356,388,390$

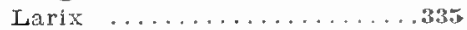

americana $\ldots \ldots \ldots . . .356$ 
Larix (Continued)

decidua ............... 356

europaea ............. 356

Key to Species ............335

laricina .............356

Laurel Magnolia ..........341

Leverwood .............410

Lime ................550

Linden ...........440, 550 European .............5no

Liquidambar ..........480 Styraciflua $\ldots \ldots \ldots \ldots \ldots .480$

Liriodendron Tulipifera ......474

Locust . . . . . . . . . . .522

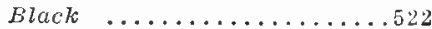

Bristly ..............

Clammy ..............

Common ........324, 516, 522 Honey .....309, 494, 516, 522

Sweet ................ 516

White ................ 522

Yellow ...............522

Lombardy Poplar 388, 390, 394, 396

Maclura pomifera ........494

Magnolia .............310, 474 acuminata $\ldots \ldots \ldots \ldots \ldots .470$ Chinese ...........470, 472 conspicua ............470

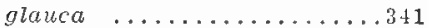
Key to Species ...........340 Laurel ...................341 Large-leaved ....340, 470, 472 macrophylla ............340 Dountain ............4470 tripetala ...........478 Umbrella .............472 virginiana .............. . 341 Mahogany ...............514 Maidenhair Tree .......... 382 Malus Malus ............486 Maple ................342 Ash-leaved ............546

Bird's Eye ............ E3ts

Black ................536

Bush ............. 532, 552

Curly ................536

Hard ................ 536

Key to Species .......... . 342 Mountain ...532, 534, 540, 552 Norway ........540, 542, 544 Tied $323,324,325,536,538,540$

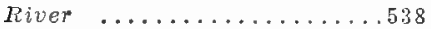
Rock ............... 536 Sllver ......325, 536, 538, 540 Soft .................538 540 Striped .....532, 534, 540, 552 Sugar .....526, 536, 540, 541 Swamp ...............540 Sycamore ......540, 542, 544
Maple (Continued)

White ............538, 540

Mazzard Cherry ...........502

Mockernut ........402,404, 406

Moose Elm .............456

Moosewood ..............532

Morello Cherry ............504

Morus .................340

alba ..............448

Key to Species ...........340

rubra ..............466

Mossy-cup oak ..........436

Mountain Ash ...........488

Magnolia .............470

Maple ......532, 534, 540, 552

Mulberry 322, 324, 325, 340, 468

Key to Species .........340

Red ..............466, 468

Silkworm .............468

White ...........446, 468

Necklace Poplar ...........394

Negundo:

aceroides ............546

Nequndo ..............546

Nettle Tree ............464

Nicker Tree ..............514

Northern Cork Elm .......462

Northern Scrub Pine ........348

Norway Maple .....540, 542, 544

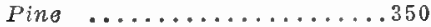

Spruce .............360, 360

\section{Nyssa:}

multiflora $\ldots \ldots \ldots \ldots \ldots \ldots 54$

sylvatica ...........554

Oak ...318, 322,325, 337, 428,430

Bear .............4442, 454

Black ......318,446,450, 452

Black Scrub ............ . 454

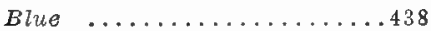

Box White ...........4434

Bur .............436, 480

Chestnut .............440

Chestnut ....440,442, 444, 446

Chinquapin ...........4442

Chinquapin ......432, 440, 442

Dwarf Chinquapin ......... $\ldots \ldots \ldots \ldots \ldots .432,440,442,454$

Iron $\ldots \ldots \ldots \ldots \ldots \ldots . \ldots 44$

Key to Species .............338

Mossy-cup ............436

Over-cup ..............436

Pin .................448

Post ..............432, 434

Red .....430,444, 446, 450, 452

Rack ..................444

Rock Chestnut ..........444

Scarlet ....446,448, 450, 452

Scrub .................442

Scrub Chestnut .........442

Swamp .................448 
Cak (Continued)

Swamp White 316, 432, 438, 442

White ..................... $432,434,436,438,444,446$

Yellow ............440,452

Yellow-bar ced .........4452

Ohio Buckeye ............54s

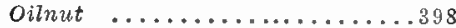

Old-field Birch ...........420

Oriental Sycamore ..........4sz

Osage Orange ...........494

Osier

Golden .................. 844

Ostrya virginiana .......440

Over-cup oak ...........4436

Padus:

serotina .............496

virginiana ...........498

Paper Birch $318,416,420,422,424$

Peach ..............341, 512

Pear 316, 321, 322, 470, 484, 486

Pepperidge ...............554

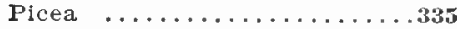

Abies ................360

alba $\ldots \ldots \ldots \ldots \ldots \ldots . . . \ldots 358$

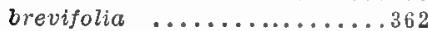

canadensis ..............358

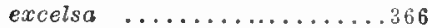

Key to Species ...........335

mariana ................362

var. semiprostrata .......362

Menziessii ..............364

nigra $\ldots \ldots \ldots \ldots \ldots \ldots . . . . .362$

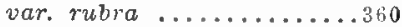

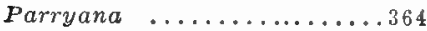

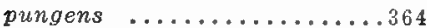

rubens $\ldots \ldots \ldots \ldots \ldots . . . . . .360$

rubra ...............360

Pie Cherry ..............504

Pigeon Cherry ...........500

Pignut ............402,406 Hickory ..............406

Pin Cherry ...............500

Oak ..................448

Pine ............326, 335, 382

Austrian ..........350, 352

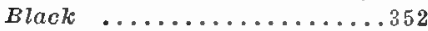

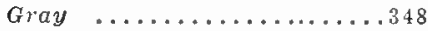

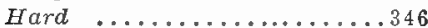

Jack ................326, 348

Key to Species ...................

Northern Scrub .........348

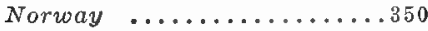

Pitch ........344, 346, 350

Red .......344,346, 350, 352

Scotch ................... 3484

Soft .................. 344

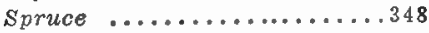

Weymouth ...................
Pine (Continued)

White..344, 346, 350, 354, 370

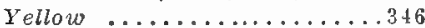

Finus .................335

Banksiana ..............348

divaricata ...............348

Kiey to Species ...........335

Lariclo, var. austriaca ... .352

resinosa ..............350

rigida ....................

Strobus ................34t

sylvestris .............354

Fitch Pine ........344, 346, 350

Plane Tree .............482

F'latanus :

occidentalis ..........482

orientalis ............442

Plowrightia morbosa ........498

Plum ..............341, 498

American .........506, 508

var. Gold ...........508

Canada ..........506, 508

Cultivated ............508

European ............508

var. Lombard ........508

Horse ..............506

Japanese ...............508

var. Fied June ........508

Key to Species ......................

Ked ................506

Wild ...................................

Poison Dogwood ..........528

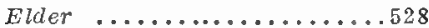

Ivy ................528

Sumach ........318, 526, 528

Poplar 316, 322, 225, 336, 388, 390

Balsam ........388, 390, 392

Bitch ............... 420

Carolina .................

$321,323,324,388,390,394,396$

Downy Poplar ..........336

Key to Species .............336

Lombardy . . . 388, 390, 394, 396

Necklace ................ 394

Silver ..........386, 388, 390

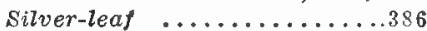

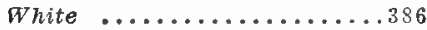

Yellow ..............4474

Popple ..............388, 390

Populus .................336

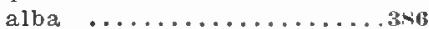

balsamifera ............392

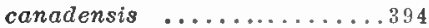

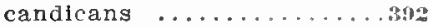

deltoides .................1

dilatata $\ldots \ldots \ldots \ldots . . . . . .396$

fastigiata $\quad \ldots \ldots \ldots \ldots . . .396$

grandidentata ..........390

heterophylla ............336

Key to Species ...........336 
Populus (Continued) monilifera ................394

nigra, var. italica .......306

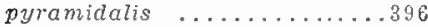
tremuloides ............3ss Post oak ...........432, 431 Poverty Birch ............420

Prunus ......... 315, 311, $500^{\circ}$ anericana .............50s var. nigra ............506 aviun .............. 502 Cerasus ...............504 domestica ...............50s Key to Species . . .......... . 341 nigra ................506 pennsylvanica ..........500 Persica ...............512 serotina .............496 triflora ................50s virginiana ............440s Pseudotsuga:

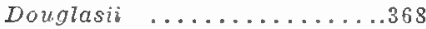

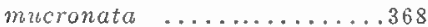

taxifolia ...................

Pyrus:

americana ...........448s

Aucuparia ............4\$8 communis ............444

Cudonio .............490

Malus ..............4\$ 4\$

sitchensis ............48s

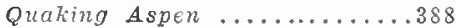

Quercitron ..............452

Quercus .................337

acuminata ..............440

alba .................432

bicolor .............4435

coccinea .............450

var. tinctoria ........45"

ilicifolia ............454

Irey to species ..........33s

macrocarpa ..........446

minor ................434

Muhlenbergii .........440

nana .................454

obtusiloba ............434

palustris ...........445

platanoides ............448

prinoides .............442

var. rufescens ..........412

Prinus ..............444

pumila ..............454

rubra .............4446

stellata $\ldots \ldots \ldots \ldots \ldots . . . .434$

tinctoria ..............452

velutina ............. 458

Quince ...............4.490

Red Ash ..............558

Birch ...........416, 418
Fed Celar ........374, 378, $\mathbf{3 8 0}$ Elm ............... 456

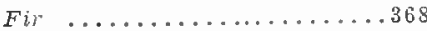

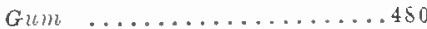

Juniper $\ldots \ldots \ldots \ldots \ldots \ldots \ldots . \ldots 38$

Maple $323,324,325,536,538,540$

Niulberry ..........466, 468

Oak ....430,444,446,450,452

Pine .......344, 346, 350, 352

Plum .................506

Spruce ....358, 360, 362, 370

Redbud ............... 518

Flıus .................311

copallina ............526

glabra ............. 526

hirta .............. 526

Key to Species .................... 341

Toxicodendron ........52s

typhina $\ldots \ldots \ldots \ldots \ldots \ldots \ldots .520$

venenata $\ldots \ldots \ldots \ldots \ldots . \ldots 528$

Vernix ..............528

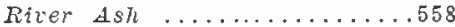

Birch ..............418

Maple ..............538

Robinia:

hispida .............522

Pseudo-Acacia .........522

viscosa .............. 522

Rock Chestnut Oak .......444

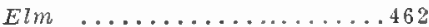

Naple ...............536

$o_{a k} \ldots \ldots \ldots \ldots \ldots \ldots \ldots . \ldots . \ldots . \ldots 44$

Rowan Tree ..............488

Fum Cherry ............496

Salisburia adiantifolia ........38 3

Salix:

alba $\ldots \ldots \ldots \ldots \ldots \ldots \ldots$. $\ldots \ldots 4$

Var. vitellina ........384

babylonica ............384

nigra .....................

vitellina ...............384

Sassafras ...........318, 476

officinale ...........476

Sassafras ..............476

varifolium ...........456

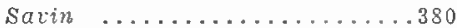

Scarlet Oak ...446,448, 450,4.52

Scotch Fir ...................

Pine ............348, $\mathbf{3 5 4}$

Scrub ouk ..............442

Chestnut Oak ..........442

Service Berry ............492

Tree ................488

Shad Bush .............492

Shadblow .............492

Shag-Eark Hickory ........... $\ldots \ldots \ldots \ldots \ldots$ 319, 402, 404, 406 Shell-bark Hickory ........402

Silkworm Mulberry .......468 
Silcer Birch .......... 116

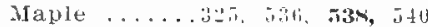
Poplar .........entit, 3st, 390

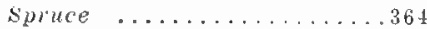
silver-leaf Poplat ..........3\$b skunk spruce ................... slippery Elm ......t5, 460, $46=$ Small White Birch .........420 small-fruited Hickury ..... \$0t Small-toothed Aspen ..........

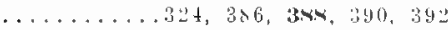
Simouth Alder ............. 120 sumach .............. 521 Soft Hople ........... 538, 540 Pine ..................... sorbus amerienut ...........48s Suur Cherry 316, 496, 4t4, 501, Gum ................. 55 sueckled Alder .............t

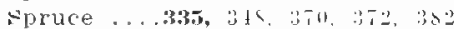
Black ................351 $356,358,361,34 \pm .370,376$

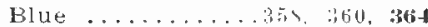

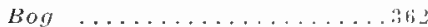
cat ...............

Colorado Blue ...........361

Double ..................36:

Douglas ................364

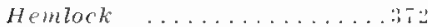

Key to Species ...........395

Labrador ................. 35s

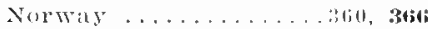

Pine ...............

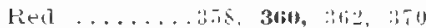

silier .................. . . . .

skink .............358

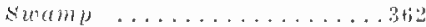

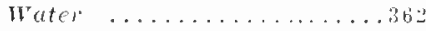

White ..............., 3bit

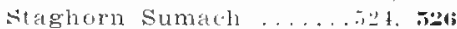

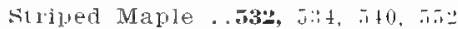
sugar berry .............t6t

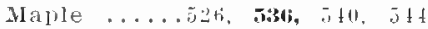
sumach .........341, 526, 5.4 Chinese ...............521

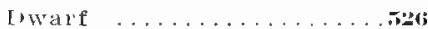
Key to Species ............

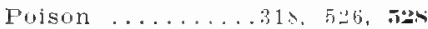
Smooth ............. 52t; sitaghorn .............. swamp .................52s

swemp $A s h \ldots \ldots \ldots \ldots . \ldots . \ldots 1$

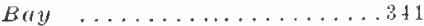

Hickory ..............4ts

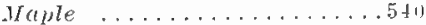

oak .................448

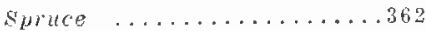

Sumach .............528

White Oak . 316, 432, 438, 442
Sweet Bay .......341, 470,472 Birch ................414

Buckeye ..............54k

Cherry $316,317,496,498,502,504$ Gum ................ tivo

Locust . . .......... . 516

siycamore .......319, 322, 412 Maple .........540,542, 544 Urielital ..............42

Tacamahue ..............392

Tramaruck ................ 6

Thorn .................tyt

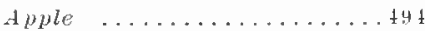

(rockspur .............41)4

Tree .............. 516

Whate ...............494

Thee-thorned Acuria .......516

Thuja occidentalis ..........35;

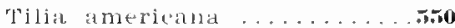

Michauxii ............ . no

vulgaris .......................

Tuothache Trec ...........522

Tree of Heaten .........52t

Tsuga calladensis .........372

'l'ulip Tree ..........472, \$74

Tupelo ......313, 316, 322, 5.74

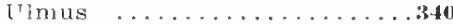

atata ............... 1962

thmerickna ............ \$60

("itmpestris ...........45s

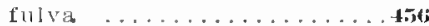

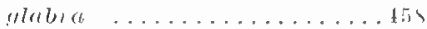

Key to sirecies ............ 34 !l mbescens .............45

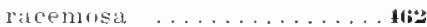

Thomasi ............. 462

Lnibrella Tree .......470, \$7: Large-leded ............. . 340

Viburnum .....................

Tirgilia .................

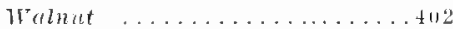

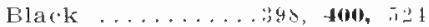
White .................

Il ater Birch .............112 Elm $\ldots \ldots \ldots \ldots \ldots \ldots \ldots+6 \ldots$

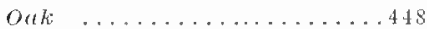

Spruce ................362

Mrstern Cretalpa ..........562 Hountain Ash ............ts

Wermouth Pine ..............44

Whistlewood ............. . . 33

1thite Ash ........313, 322, 327 $328,106,461,542,5016,554$, itill Birch ............4211, 12 Cedre ........... 374, 376 $4 \ln 1 . .316,456,458,460,462$ Holly $\ldots \ldots \ldots \ldots \ldots \ldots \ldots . . .5313$ Locust .............522 waple ...........53s, 540 
White (Continued.)

Irulberry ........446, 46s

$\mathrm{Oak}_{\mathrm{k}} \ldots . . . . . . . . .319$

432, 434, $436,438,444,446$

Oak Group 319, 339, 432, 442, 441

Pine ...344, 346, 350, 354, 370

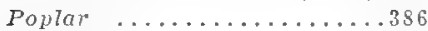

Spruce ................................. 360

thorn ................494

Thalnut ...................

White-heart Hickory .......404

Thitewood ..........474, 550

II il Black Cherry ..........

...........496, 49s, 500,504

Plum ................506

Fed Cherry .....498, 500, 504

Tillow .........................
Tilluw (continuer.)

\begin{tabular}{|c|c|}
\hline Blach & $\ldots \ldots \ldots \ldots \ldots \ldots+\ldots$ \\
\hline Europea & n Weeping .......38-1 \\
\hline Europea & n White ........384 \\
\hline Fellow & $\ldots \ldots \ldots \ldots \ldots \ldots \ldots+\ldots \ldots$ \\
\hline inged $\mathrm{E}$ & $\operatorname{lm} \ldots \ldots \ldots \ldots \ldots 2$ \\
\hline itch $\mathrm{Haz}$ & zel ............47s \\
\hline itches' B & 3rooms $\ldots \ldots \ldots \ldots 492$ \\
\hline ellow Bi & irch $318,414, \mathbf{4 1 6}, 418,422$ \\
\hline Locust & $\ldots \ldots \ldots \ldots \ldots \ldots \ldots \ldots$ \\
\hline oak ... & $\ldots \ldots \ldots \ldots 440,452$ \\
\hline Pine .. & $\ldots \ldots \ldots \ldots \ldots \ldots \ldots \ldots$ \\
\hline Poplar & $\ldots \ldots \ldots \ldots \ldots 44$ \\
\hline Tillor & $\ldots \ldots \ldots \ldots \ldots 3_{4}$ \\
\hline Tood. & $\ldots \ldots \ldots \ldots \ldots \ldots$ \\
\hline & ked oak .......... \\
\hline
\end{tabular}




\section{Publications of the Station AVAILABLE FOR FREE DISTRIBUTION}

The following publications of the Storrs Agricultural Experiment Station are available for distribution, and as long as the supply lasts, will be sent free to residents of Connecticut who desire then.

No. 3t. Discussion of the Anount of Protein Required in the Ration for Dairy Cows.

No. 35. The Camembert Type of Soft Cheese in the United States.

No. 3i. The So-Called "Germicidal Property" of Milk.

No. 39. Pig Feeding Experiments.

No. 40 . Creamery Problems.

No. 11. Spraying Notes, 1901-1905.

No. 42. Quality of Milk Affected by Common Dairy Practices.

No. 43. The Facility of Digestion of Foods a Factor in Feeding.

No. 4.5. The Apple Leaf-Miner.

To. 4t. Directions for Making the Camembert Type of Cheese.

No. 4i. Milking Machines.

No. 48. Comparative Studies with Covered Milk Pails.

Xo. 49. Petroleum Emulsion for the San Jose Scale.

Xn. 54. Proprietary anr Home-Made Miscible Oils for the Control of the San Jose Scale.

Xo. 58. Camembert Cheese Problems in United States.

No. 59. Bacterium Lactis Acidi and Its Sources.

No. 61. Apple Growing in New England. Parts I. and II.

No. 62. Apple Growing in New England. Part III.

No. 63. The Cost of Feeding Heifers.

No. 64. Connecticut Weather Review.

No. 65. Butter Making on The Farm.

No. 66. Apple Growing in New England (Part IV.)

No. 6\%. Water Glass, a Preservative for Eggs.

No. 68. Bacillary White Diarrhea of Young Chicks. (Second Report.)

No. 69. New England Trees in Winter.

\section{REPORTS.}

The Reports of the Storrs Agricultural Experiment Station for 1889, 1890, '9t, '95, (Part III.), '96 (Part II.), '98, '99, 1900, 1901,1905 and 1908-09, are available for free distribution.

Address all requests to the Director of Storrs Agricultural Experiment Station, Storrs, Conn. 


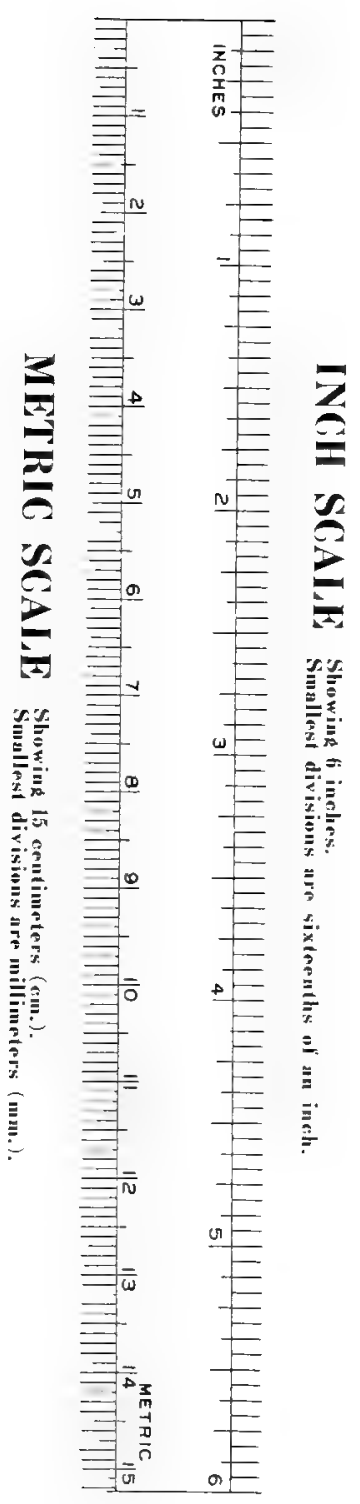









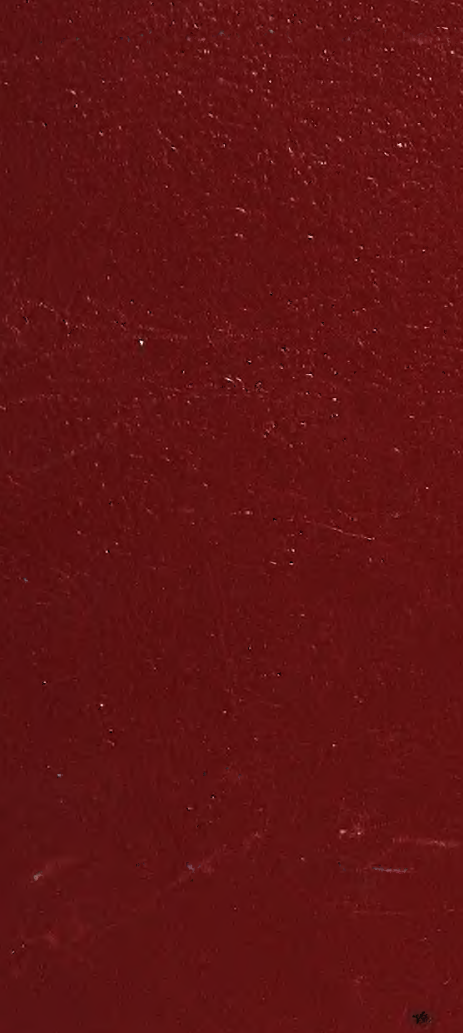

d
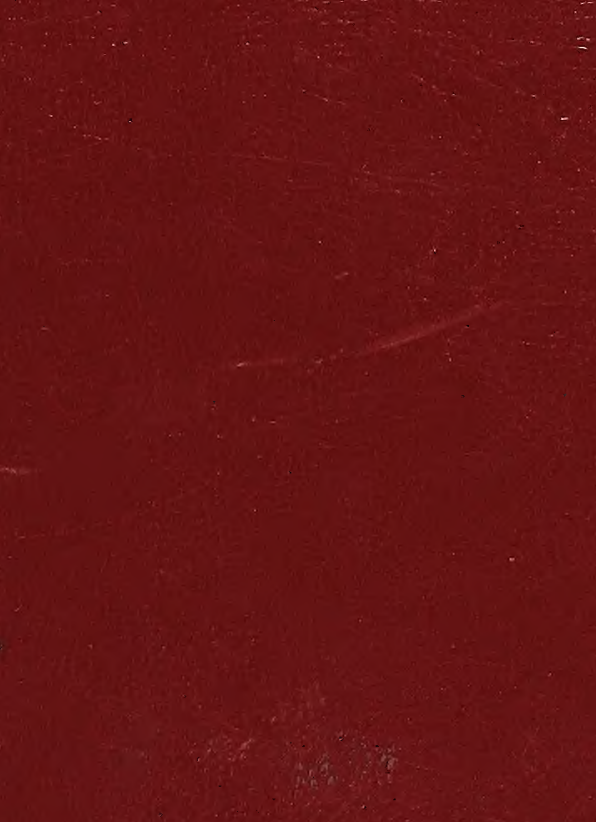

$\because$
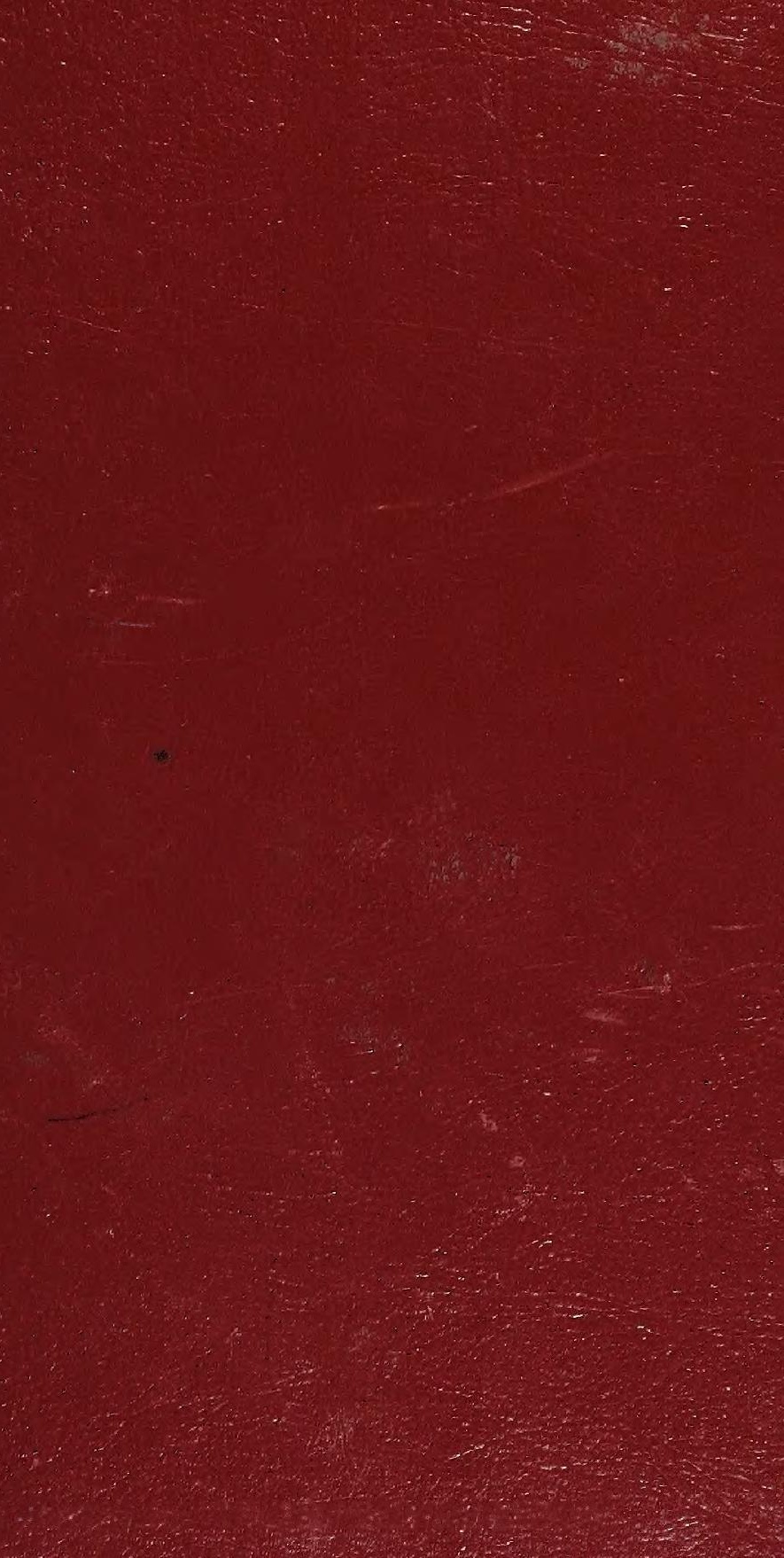